\title{
The \\ Glass Beads \\ of the Prehistoric \\ and Roman Periods \\ in Britain and Ireland
}

\section{Margaret Guido F.S.A.}
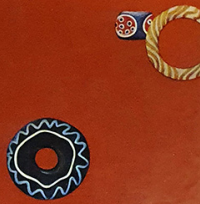

(3)

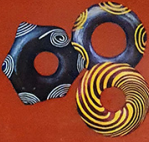

PUBLISHED BY THE SOGIETY OF ANTIQUARIES DISTRIBUTED BY THAMES AND HUDSON LTD 
Reports of the Research Committee of the Society of Antiquaries of London No. XXXV

\section{The Glass Beads of the}

Prehistoric and Roman Periods

in Britain and Ireland

By

MARGARET GUIDO, F.S.A.

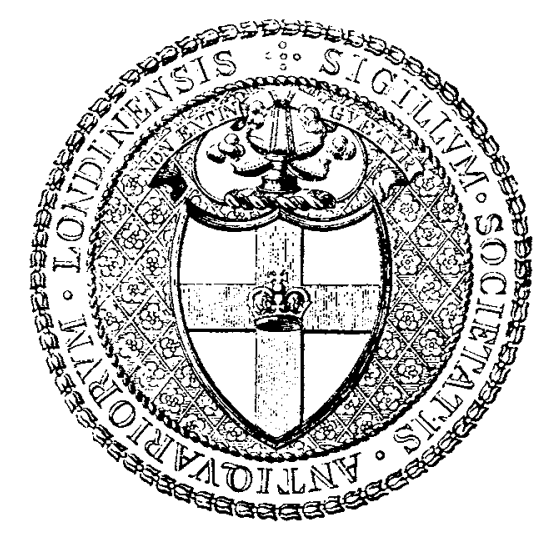

Published by

The Society of Antiquaries of London

Distributed by

Thames and Hudson Ltd.

1978 
(C) The Society of Antiquaries of London, $197^{8}$ ISBN O 500990263

PRINTED IN GREAT BRITAIN BY

THE EASTERN PRESS LIMITED OF LONDON AND READING 


\section{In grateful memory of Tessa Verney Wheeler, F.S.A.}




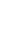




\section{PREFACE}

$I^{1}$ $\mathrm{T}$ is a strange fact that no serious study of ancient European glass beads has as yet been attempted: the reason probably lies in the very daunting size of the subject, the enormous variety of material to be studied and our almost total ignorance about the location of local glass bead factories. Nevertheless a beginning was certainly made in I96o when Dr. Thea Elisabeth Haevernick published her classic study of glass armlets and some varieties of Celtic beads. ${ }^{1}$ This largely Central European study paved the way for what all countries, by subdividing types of beads into meaningful classes, now need to do much more fully, so that a true overall picture can be obtained. At present, owing to the area chosen for her study, the distribution maps published by Dr. Haevernick inevitably show a concentration around the Upper Rhine, Switzerland, Czechoslovakia, and Austria which repeats itself for each class of armlet or bead under discussion, but now, particularly as we know that beads and armlets were produced in workshops both large and small all over Europe, the study needs to be extended both in depth and extent; Britain and Ireland, so conveniently two islands without artificial frontiers, readily present themselves for the first intensive study.

Armlets in the British Isles have already been the subject of some research, ${ }^{2}$ and an interesting outcome of the study was that many were regarded as of native British manufacture. If this was so for armlets, how true might it be for beads? A result of the present study is to draw attention to several areas of Britain in which beads were almost certainly manufactured and certainly distributed.

We need to make a country-by-country analysis, starting with Bronze Age glass beads, on which some notes are published below. So far we only know that during the last millennium B.C., apart from the big production centres in the Near East, Egypt, and the Eastern Mediterranean, large-scale bead production took place also in Northern Italy, ${ }^{3}$ and in Carniola where thousands of beads have been reported from graves at Magdalenska, Gora, Vinica, St. Veit and other sites and subsequently dispersed. ${ }^{4}$ Central Europe, too, particularly perhaps Bohemia, had centres of production and we now know that there were many smaller centres all over the Celtic world (see pp. 29-37), including Britain.

\footnotetext{
1 Haevernick, T. E. (1960). This has recently been supplemented for Czechoslovakia, by Venclovà, N. (1971). The latter publication is especially useful for its illustrations, and there is a short résumé in English.

${ }^{2}$ Kilbride-Jones, H. E. (1938), followed by Stevenson, R. B. K. (1954-6). One of these armlet classes, made apparently in Britain and thought to have been postAgricolan in date, is now known to have been earlier. See Harden, D. B. and Price, J., in Cunliffe, B. (1971 b) and p. 78 , n. 1 , below. See also Stevenson, R. B. K., in Rivet, A. L. F. (ed.) (1966), fig. 3, p. 27, and forthcoming in $G A J$ iv $(1976)$.
}

${ }^{3}$ Red and blue glass for bead-making in the early first millennium B.c. has been reported from Frattesine in Northern Italy not far from the mouth of the river Po. Barfield, L. ( 1971 ), I00.

4 Mahr, A. (ed.) (1934). Over 2,000 beads were discovered in one of the necklaces from St. Veit, and it was written, 'it is really surprising to watch the never-ending variety of beads offered by practically each individual grave'. Most of the beads from the Mecklenburg Collection are either at Harvard or in the Ashmolean Museum at Oxford. 
Some of the La Tène Celtic beads, both on the Continent and in Britain, are of such exquisite craftsmanship that it is surprising to find hardly any reference to them in works concerning Celtic art. For instance, in a recent exhibition of 'Early Celtic Art' ${ }^{5}$ drawn from many parts of Europe, not a single example of this craft was displayed: only one exhibit, and that atypical, showed a group of marble, shale, and amber beads. Again, in discussing Iron Age crafts, Cunliffe (1975) makes no mention of glass. It is time that La Tène glass beads were recognized not only for their artistic qualities but for their chronological and cultural significance as well.

I am grateful to Dr. D. B. Harden not only for first suggesting my undertaking this study, but also for so generously working to improve the text in innumerable details, and to the very many museum curators and private individuals who have co-operated with me by allowing me access to their collections. The resulting Schedules printed at the end of this book (mostly under the old county system) must be incomplete in certain respects, even if every attempt has been made to find all available material, and over I $5^{\circ}$ museums have been visited. But very many beads have been noted only from excavation reports, and it is for this reason that it has been impossible in the majority of cases to be certain of the method by which a bead was made (see pp. 7-8). Where possible, each bead has been drawn and coloured on a card which has been filed in its Group or Class as defined in this study; the resulting corpus will be deposited in the care of the Society of Antiquaries, Burlington House.

The work has been helped by the generous provision of grants from the Central Research Funds of London University and from the Leverhulme Trust, to both of which foundations I am grateful. I am indebted to Mr. George Boon for many stimulating discussions and to Dr. R. G. Newton for having kindly checked through that part of this study concerned with chemical components in glass and for making alterations and improvements to it; to Dr. Michael Avery for discussing his suggested dating of Meare in Somerset in advance of his publication and to very many curators and excavators who have shown me recently discovered and sometimes stratified beads. Lastly I want to thank Mr. Nick Griffiths for his beautiful coloured drawings, reproduced here as pls. I and II, and for his other drawings.

It is necessary to stress that the conclusions reached in the discussion are often relevant only to the British Isles, and should not be applied without due caution to other areas of Europe. It is equally important for the reader to understand my usage of the words Classes and Groups.

I have used the word Class for beads which show identical or similar forms and decoration - or in certain Scottish Classes (see Classes I3 and I4) a divergence of decoration despite which there is no doubt that they really belong to the same Class. These can all be studied for what they can reveal to us both of their cultural and chronological settings, and of the movements of peoples or trade contacts which lay behind their distribution patterns. They are coherent and significant, and are as valid as 'type fossils' as are many bronzes and other small classifiable objects.

In the Groups, on the other hand, I include miscellaneous beads which appear similar only because they have no very notable characteristics; they are therefore not so useful to us as

\footnotetext{
5 See the Catalogue of that title published by the Edinburgh University Press in 1970 for the Arts Council of Great Britain.
} 
coherent Classes can be, and it is also certain that the schedules of Groups often include beads of widely different dates and cultural backgrounds-even post-Roman ones. It would therefore be quite meaningless to study them for what could be gleaned about their archaeological cultures from their distribution. They simply represent a corpus which by more advanced glass analysis (chemical, spectrographic, microprobe tests, ratio of lead isotopes or whatever the method may be) can ultimately be broken down into significant Glasses. 


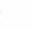




\section{GONTENTS}

Preface $\quad v$

List of Plates xiii

List of Figures $\quad \mathrm{xv}$

Abbreviations and Bibliography xvii

\section{TEGHNIGAL AND ARGHAEOLOGIGAL GONSIDERATIONS \\ PART I. TEGHNICAL CONSIDERATIONS}

The chronological limits of the study 3

The forms and uses of beads and their decoration 4

Methods of manufacture 7

Colours and opacifiers used for glass beads $\quad 8$

A. Translucent glass $\quad 9$

B. Opaque glass $\quad$ I6

\section{PART II. ARGHAEOLOGIGAL CONSIDERATIONS}

The earliest glass beads in Britain $\quad$ I 9

Iron Age and Roman beads of Continental origin or inspiration in Britain

Iron Age beads of British origin or design

Roman beads

Irish beads

\section{DESGRIPTION OF BEAD GLASSES AND GROUPS \\ PART III. BEADS OF CONTINENTAL ORIGIN OR INSPIRATION}

(i) Decorated Classes of the Iron Age

Class I Arras Types I and II

Glass 2 Welwyn Garden City type

Class 3 Large annular beads with eyes (South Harting type)

Class 4 Opaque yellow beads with one or two rows of blue and 
Class 5 Clear colourless annular beads with opaque yellow round the inside of the perforation (Hanging Langford type)

Class 6 Large blue annular beads with marvered white or yellow spirals (Oldbury type) sometimes with swags between the spirals (Colchester type)

Glass 7 Large annular beads with whirl or ray design in contrasting colours (Celtic whirl or ray types)

(ii) Decorated or undecorated groups (both Iron Age and Roman in date)

Group I Large or medium annular beads with streaky or mottled design

Group 2 Miscellaneous spiral-decorated beads

Group 3 Miscellaneous horned beads, some with eyes or spirals

Group 4 Compound-eyed beads with small eyes set in roundels (Garrow Tor type)

Group 5 Miscellaneous wave-decorated beads

Group 6 Undecorated annular beads

Group 7 Undecorated globular beads

Group 8 Exotic beads of Iron Age date

\section{PART IV. IRON AGE BEADS OF BRITISH DESIGN AND ORIGIN}

Class 8 Small opaque yellow annular beads

Class 9 Annular beads decorated with two-colour cables

Class Io Meare spiral beads (colourless with opaque yellow spirals)

Class I I Meare variant beads (colourless with different designs in opaque yellow)

Class I 2 Stud beads

Glass I3 North Scottish spiral-decorated beads

Class I 4 North Scottish decorated annular beads

\section{PART V. ROMAN PERIOD BEADS}

Small segmented beads

Segmented beads enclosing metal foil

Cylinder-shaped beads

Square-sectioned beads (long or cube-shaped)

Long polygonal beads

Prism-shaped beads

Small biconical beads 
Long biconical beads

Long blue biconical or square-sectioned beads with white and red chevron or band

Oblong beads with round section

Miscellaneous undecorated heart- or pear-shaped beads, and oval or round beads with flat section

Boat- or kidney-shaped beads

Small gadrooned beads

Diamond-faceted beads

Glass melon beads

Exotic beads of the Roman period

100

IOI

\section{THE SCHEDULES}

Beads of Continental origin or inspiration

Iron Age beads of British design and origin

INDEX

General Index 



\section{LIST OF PLATES}

(between pages 102 and 103)

I I-IO: beads of Classes $\mathrm{I}-7$ and Groups 2, 4 and 5

II ro-I 7: beads of Groups 5-7 and Classes 8-1 2

Below, $1-5$ : exotic beads of Roman date

III $a-d$ : beads of Classes $3,6,7,9$, I 3 and I4

IV $a$ Late Roman beads from Lankhills Cemetery, Winchester

$b$ Late Roman necklace from Fordington, Dorchester, Dorset 



\section{LIST OF FIGURES}

I Decorative motifs

2 The distribution of second- and early first-millennium B.C. glass beads

3 The Iron Age tribes of Britain: approximate territories

4 Suggested glass bead factories and other sites of importance 32

5 Class I beads: Arras types I and II 45

6 The distribution of Class I beads $\quad 46$

7 Class 2: Welwyn Garden City type $\quad 48$

8 Class 3: South Harting type 49

9 The distribution of Class 3 beads 50

Io Class 4: Findon type 5 I

I I Class 5: Hanging Langford type 52

I 2 The distribution of Class 5 beads 53

13 Class 6: Type A (Oldbury) and Type B (Colchester) 54

I4 The distribution of Class 6 beads

I5 Class 7: Whirl and ray beads 57

I6 The distribution of Class 7 beads $\quad 5^{8}$

I 7 Group I: annular beads with mottled decoration 59

I8 Group 2: miscellancous spiral-decorated beads 60

I9 Group 3: horned beads, some with eyes or spirals 6I

20 Group 4: Garrow Tor type 6I

2 I Group 5: miscellaneous wave-decorated beads $\quad 63$

22 The distribution of Groups 6 and 7 beads 67

23 Group 8: exotic beads of Iron Age date $7 \mathrm{I}$

24 Class 8: small opaque yellow annular beads 73

25 The distribution of Class 8 beads 75

26 Class 9: annular beads and two-coloured cables $\quad 76$

27 The distribution of Class 9 beads 78

28 Class 10: Meare spiral-decorated beads 79

29 The distribution of Class io beads 80

30 Class II: Meare variant beads $8 \mathrm{I}$

3 I The distribution of Class I I beads 83

32 Class I2: stud beads 84

33 Class I3: North Scottish spiral-decorated beads 85

34 The distribution of Class I3 beads 86

35 Class I4: North Scottish decorated annular beads 87

36 The distribution of Class i4 beads 88

37 Forms of Roman beads 92

$3^{8}$ Exotic beads of the Roman period $\quad 98$ 


\section{ABBREVIATIONS AND BIBLIOGRAPHY}

The abbreviations are mainly of journals cited in both the Bibliography and the Schedules. However, certain monographs (e.g., Wheeler, Maiden Castle) are given in an abbreviated form $(M C)$ applicable to the Schedules only; when cited in the text, they appear in a slightly different form (Wheeler, R. E. M. (I943)) for which reference should be made to the Bibliography. 



\section{ABBREVIATIONS}

A Archaeologia.

AA Archaeologia Aeliana.

AANHSC Ayrshire Archaeological and Natural History Society Collections.

$A B$ Archaeologia Belgica.

$A C$ Archaeologia Cambrensis.

ACt Archaeologia Cantiana.

AGC Ayr and Galloway Collections.

AH Archaeologia Hungarica.

A.M. Ashmolean Museum.

An Antiquity.

Anf Antiquaries Fournal.

ANL Archaeological News Letter.

Ar Archaeometry.

Ar7 Archaeological Journal.

$A R$ Archaeological Review. (C.B.A.)

BAF Bedfordshire Archaeological Journal.

$B B C S$ Bulletin of the Board of Celtic Studies.

$B I A L$ Bulletin of the Institute of Archaeology in London.

B.M. British Museum.

BPI Bullettino di Paletnologia italiana.

BRGK Berichte der Römisch-Germanischen Kommission.

Brit Britannia.

BSAC Bulletin de la Société Archéologique Champenoise.

BSPF Bulletin de la Société Préhistorique Française.

CA Current Archaeology.

Cam Hawkes, C. F. G., and Hull, M. R., Camulodunum: First Report on the Excavations at Colchester 19301939. (Reports of the Research Committee of the Society of Antiquaries of London, xiv, I947.)

C.B.A. Council for British Archacology.

CLAJ County Louth Archaeological Journal.

G.M. Cambridge Museum of Archaeology and Ethnology.

EAH Essex Archaeology and History.

FF Forschungen und Fortschritte (Korrespondenzblatt (Nachrichtenblatt) der deutschen Wissenschaft

Ga Gallia. und Technik.)

GAJ Glasgow Archaeological Journal.

GDV Germanische Denkmäler der Völkerwanderungszeit.

Ge Germania.

GECF General Electric Company Journal.

Gl Bulleid, A., and Gray, H. St. George, The Glastonbury Lake Village, i (191 I), ii (1917).

HA Helvetia Archaeologica.

HH Bushe-Fox, J. P., Excavations at Hengistbury Head, Hampshire, 1911-12. (Reports of the Research Committee of the Society of Antiquaries of London, iii, I9I5.) 
FBAA Journal of the British Archaeological Association.

JCNWAAHS Fournal of the Chester and North Wales Architectural, Archaeological and Historical Society.

JDANHS Fournal of the Derbyshire Archaeological and Natural History Society.

JGAHS Journal Galway Archaeological and Historical Society.

JGS Journal of Glass Studies.

JMM Fournal of the Manx Museum.

JNNHSFC Journal of the Northamptonshire Natural History Society Field Club.

JPEK Jahrbuch für prähistorische und ethnographische Kunst (Berlin).

FRAI Fournal of the Royal Anthropological Institute.

JRGZM Jahrbuch des Römisch-Germanischen Zentralmuseums, Mainz.

JRIC Journal of the Royal Institution of Cornwall.

JRS Journal of Roman Studies.

FRSAI Fournal of the Royal Society of Antiquaries of Ireland.

MA Monumenti Antichi (Accademia dei Lincei, Rome).

MAGW Mittheilungen der Anthropologischen Gesellschaft in Wien.

MAn Monmouthshire Antiquary.

MAr Medieval Archaeology.

MC Wheeler, R. E. M. (1943), Maiden Castle, Dorset (Reports of the Research Committee of the Society of Antiquaries of London, xii, I943).

Me i Bulleid, A., and Gray, H. St. George, The Meare Lake Village, i (1948).

$M e$ ii Bulleid, A., and Gray, H. St. George, The Meare Lake Village, ii (I953).

Me iii Cotton, M. A. (ed.), The Meare Lake Village, iii ( 1967 ).

Ne Gurle, J., Newstead: A Roman Frontier Post and Its People. The Fort of Newstead in the Parish of Melrose (I9I I).

N.M.A. National Museum of Antiquities, Edinburgh.

N.M.W. National Museum of Wales, Cardiff.

NS Notizie degli Scavi.

NSFFS North Staffordshire Fournal of Field Studies.

o Oxoniensia.

of Offa.

Os Whiting, W., etc. (I93I), Report on the Excavation of the Roman Cemetery at Ospringe, Kent. (Reports of

$P$ Préhistoire. the Research Committee of the Society of Antiquaries of London, viii, I93I.)

PAI Proceedings of the Archaeological Institute (later Archaeological Journal).

PCAS Proceedings of the Cambridge Antiquarian Society.

PCNHSS Proceeding of the Coventry Natural History and Scientific Society.

PDAS Proceedings of the Devon Archaeological Society.

PDNHAS Proceedings of the Dorset Natural History and Archaeological Society.

PHFCAS Proceedings of the Hampshire Field Club and Archaeological Society.

PNNAS Papers of the Norfolk and Norwich Archaeological Society.

PPS Proceedings of the Prehistoric Society.

PRIA Proceedings of the Royal Irish Academy.

PSANHS Proceedings of the Somerset Archaeological and Natural History Society.

$P S A L$ Proceedings of the Society of Antiquaries of London.

PSAS Proceedings of the Society of Antiquaries of Scotland.

PSIA Proceedings of the Suffolk Institute of Archaeology.

PZ Praehistorische Zeitschrift. 
RA Revue archéologique.

RAECE Revue archéologique de l'Est et du Centre-Est.

R.G.H.M. Royal Commission on Ancient and Historical Monuments (England).

R.G.K. Römisch-Germanische Kommission.

R.G.Z.M. Römisch-Germanisches Zentralmuseum, Mainz.

Rich i-v Bushe-Fox, J. P., Reports on the Excavations of the Roman Fort at Richborough, Kent. (Reports of the Research Committee of the Society of Antiquaries of London vi, 1926, vii, 1928, x, 1932, xvi, 1949 and xxiii, I968.)

SAC Sussex Archaeological Collections.

S.A.L. Society of Antiquaries of London.

SDNQ Somerset and Dorset Notes and Queries.

Sf Société Fersiaise.

SNQ Sussex Notes and Queries.

TBGAS Transactions of the Bristol and Gloucestershire Archaeological Society.

TBNHS Transactions of the Buteshire Natural History Society.

TCW Transactions of the Cumberland and Westmoreland Antiquarian and Archaeological Society.

TDA Transactions of the Devonshire Association.

TDGNHAS Transactions of the Dumfries and Galloway Natural History and Antiquarian Society.

TLAHS Transactions of the Leicestershire Archaeological and Historical Society.

TLSSAHS Transactions of the Lichfield and South Staffordshire Archaeological and Historical Society.

TNDFC Transactions of the Newbury and District Field Club.

TPBAS Transactions and Proceedings of the Birmingham Archaeological Society.

TRIA Transactions of the Royal Irish Academy.

TSAS Transactions of the Shropshire Archaeological Society.

TWNFC Transactions of the Woolhope Naturalists' Field Club.

TZ Trierer Zeitschrift.

UJA Ulster fournal of Archaeology.

Ver Wheeler, R. E. M. and T. V., Verulamium, a Belgic and Two Roman Cities. (Reports of the Research Committee of the Society of Antiquaries of London, xi, 1936.)

VCH Victoria County History.

WAM Wiltshire Archaeological and Natural History Magazine.

WCFC West Cornwall Field Club.

YAJ Torkshire Archaeological Journal. 


\section{BIBLIOGRAPHY}

Abercromby, J. (1912). Bronze Age Pottery of Great Britain and Ireland.

Alcock, L. (1964). Dinas Powys.

- (1973). Arthur's Britain.

Allen, D. F. (r 944$)$. 'The Belgic dynasties of Britain and their coins', $A$ xc, I-46.

— ( $196 \mathrm{I}$ ). 'The origins of coinage in Britain: a re-appraisal', in Frere, S. (ed.) (rg6I), 97-308.

Ammianus Marcellinus. Incerti Auctoris : Epitome de Caesaribus, xli.

ApSimon, A. M. and Greenfield, E. ( I 972). 'The excavations of Bronze Age and Iron Age settlements at Trevisker, St. Eval, Gornwall', $P P S$ xxxviii, 302-8r.

Arbman, H. (1940). Birka I.

- (I940-43). Birka I: Die Gräber.

Atkinson, D. (1930). 'Caistor excavations', $P \mathcal{N N} A S$ xxiv, $93 \mathrm{ff}$.

Avery, M. (1 968). 'Excavations at Meare East, 1966', PSANHS cxii, 2 I-39.

Avery, M., Sutton, J. E. G. and Banks, J. W. (Ig67). 'Rainsborough, Northants., England: Excavations, I 96 I-5', PPS xxxiii, 207-306.

Baillie-Reynolds, P. K. ( $193^{8}$ ). Collected reports of Excavations on the Site of the Roman Fort of Kanovium.

Barfield, L. (197 I). Northern Italy.

Bateson, J. D. and Hedges, R. E. M., (1975), 'The scientific analysis of a group of Roman-age enamelled brooches', $A r$ xvii, pt. 2, particularly p. 182.

Baur, P. V. G. (1938), see Kraeling, C. H. (1938).

Beck, H. C. (I 928$)$. 'Classification and nomenclature of beads and pendants', $A$ lxxvii, I-76.

- (1934). 'Glass before I 500 B.c.', Ancient Egypt and the East (June), 7-2 I.

- (1936). Beads and Magic.

Beck, H. G. and Stone, J. F. S. (1 935). 'Faience beads of the British Bronze Age', $A$ lxxxv, 203-52.

Benadik, B. (I 959). 'sklo v ts keltskom hrobovom inventâri na Slovensku' (Glas im keltischen Grabinventar in der Slowakei) in Acta Universitatis Carolinae, Philosophica et Historica, iii (Prague), 27-224.

—_ (1962). 'Chronologické vztahy keltskych pohrebisk na Slovensku', in Slovenská archeológia, x-2, $371-5$.

Biddle, M. ( 1970 ) in $C A$ xx, 245-6.

- (1972). 'Excavations at Winchester, 1970: Ninth interim report', Anf lii, 93-1 31 .

- (forthcoming), Winchester Studies, iii, parts I and II.

Birley, E. B. (1953). Roman Britain and the Roman Army.

Boisserain, U. P. (ed.) (1955). Historia Romana.

Boon, G. C. (I945). 'The Roman site at Seamills, I 945-46', TBGAS lxvi, $25^{8-95}$.

- (I950). 'The Roman villa in Kingsweston Park. ...', TBGAS lxviii, 5-58.

- (1957). Roman Silchester (extensively revised I 974).

_- (1966). 'Gilt glass beads from Caerleon and elsewhere' in $B B C S$ xxii, pt. I, r $04-9$.

- (I972). Isca. N.M.W.

— (1977), 'Gold-in-Glass beads from the ancient world', Brit viii, r93-207. .

Borlase, W. G. (1872). Naenia Cornubiae. 
xxiv GLASS BEADS OF THE PREHISTORIG AND ROMAN PERIODS

Borlase, W. G. (I879). 'Archaeological discoveries in the parishes of St. Just-in-Penwith and Sennen', FRIC xxi, I90-2 I 2.

Boulanger, Cl. (I902-5) . Le Mobilier Funéraire (Gallo-Romain et Franc) en Picardie et en Artois.

Bowen, E. G. (I954). The Settlements of the Celtic Saints in Wales.

- (1972). Britain and the Western Seaways.

Branigan, K. (I97I). 'Wessex and Mycenae: some evidence reviewed', WAM 1xv, 89-107.

- (1972). 'The Surbo bronzes-some observations', PPS xxxviii, 276-85.

- (1973). 'Gauls in Gloucestershire', TBGAS xcii, 82-95.

Břen, Jiři (rg66). Trisov: A Celtic Oppidum in South Bohemia.

- (1972). 'The present state of research into the problems of Celtic oppida in Central Europe', BIAL $\mathrm{x}, \mathrm{I} 3-22$.

Bretz-Mahler, Denise (I97I). 'La civilisation de La Tène I en Champagne: le facies marnien', Ga supplément xxiii.

Brewster, T. G. M. (I97I). 'The Garton Slack chariot-burial in East Yorkshire', An xlv, 289-92.

Brill, R. H. and Wampler, J. M. (1965), see Young, W. J. (1965) (ed.).

Brizio, E. (r 899). 'Tl sepolcreto gallico di Montefortino presso Arcevia', $M A$ ix, 6 i $7-808$.

Brunton, G. (1930). Qau and Badari III.

- (1937). Mostagedda.

Budge, E. Wallis ( I 907). Account of the Roman Antiquities Preserved at Chesters.

Bulleid, A. (1924). The Lake Villages of Somerset.

Bulleid, A. and Gray, H. St. G. (I I I ). The Glastonbury Lake Village, 2 vols.

(1948). The Meare Lake Village, i.

- (1956). The Meare Lake Village, ii.

(1967). The Meare Lake Village, iii (ed. Cotton, M. A.).

Burley, E. (I955-6). 'A catalogue and survey of the metal-work from Traprain Law', PSAS 1xxxix, I $8 \mathrm{ff}$.

Bushe-Fox, J. P. (I9I5). Hengistbury Head, Hampshire. (S.A.L. Research Report, iii.)

(1949). Excavations at the Roman Fort at Richborough, Kent, iv. (S.A.L. Research Report, xvi.)

Galey, E. R. (1962). Analysis of Ancient Glasses. (Corning Museum of Glass Monographs, i.)

Gallander, G. (IgI I). 'Notice of the discovery of two vessels of clay on the Culbin Sands, ... with a comparison of the Gulbin Sands and the Glenluce Sands and of the relics found on them', PSAS xlv, I $58-8 \mathrm{I}$.

Charleston, R. J. ( 1963 ). 'Glass "cakes" as raw material and articles of commerce', $\mathcal{J} G S \mathrm{v}, 54-67$.

Cheesman, G. L. (I9I4). The Auxilia of the Roman Imperial Army.

Childe, V. G. (1929). The Danube in Prehistory.

Christlein, R. (1966). Das Alamannische Reihengräberfeld von Marktoberdorf in Algäu.

Clarke, G. (1972), in Biddle, M. (1972), 94-8 and forthcoming in Winchester Studies, iii, part II.

Glayton, J. (1880). 'Description of Roman remains discovered near to Procolitia, a station on the Wall of Hadrian', $A A$ viii, I-39.

Clifford, E. M. (I 6 I) Bagendon: A Belgic Oppidum.

Cole, H. (1966), in $7 G S$ viii, $46-7$.

Goles, J. M. (1 959-6o). 'Scottish Late Bronze Age metalwork: typology, distributions and chronology', $P S A S \mathrm{xciii}, \mathrm{I} 6-\mathrm{I} 34$.

Coles, J. M. and Simpson, D. D. A. (eds.) (1962). Studies in Ancient Europe.

Collis, J. R. (197 I). 'Markets and money', in Jesson, M. and Hill, D. (eds.). 
Collis, J. R. (1974). Oppida: the Beginnings of Urbanisation in Temperate Europe (unpublished Cambridge Ph.D. thesis).

Collingwood, R. G. and Wright, R. P. (I965). The Roman Inscriptions of Britain, i.

Corder, P. (1 955). 'The re-organisation of the defences of Romano-British towns in the fourth century', Arf cxii, 20-42.

Gotton, M. A. ( 1967 ), see under Bulleid, A. and Gray, H. St. G. (1967).

Gunliffe, B. (I968) (ed.). Excavations at Richborough, Kent, v. (S.A.L. Research Report, xxiii.)

- (I97 I a). 'Some aspects of hill-forts and their cultural environment', in Jesson, M. and Hill, D. (eds.) (1971).

- (197I b). Excavations at Fishbourne $1966_{-9}$, i and ii. (S.A.L. Research Reports, xxvi-xxvii.)

- (1972). 'The Late Iron Age metalwork from Bulbury, Dorset', Anf lii, 293-308.

- (1974). Iron Age Communities in Britain.

- (1976). Iron Age Sites in Central Southern England. (G.B.A. Research Report, 16).

Cunnington, M. E. (1923). The Early Iron Age Site at All Cannings Cross Farm, Wiltshire.

Curle, A. and Cree, J. (19I 5-24). Reports on Traprain Law in PSAS xlix-lviii.

Gurle, J. (1 9 I I ). Newstead: A Roman Frontier Post and its People.

- (I93 I-2). 'An inventory of objects of Roman and provincial origin found on sites in Scotland not definitely associated with Roman constructions', PSAS lxvi, 277-397.

Daniel, Glyn (1958). 'The chronology of the French collective tombs', PPS xxiv, I-23.

Davis, J. B. and Thurnam, J. (1 865). Crania Britannica.

Déchelette, J. (1904). Les Fouilles du Mont Beuvray de I897-9o.

—- (I914). Manuel d'archéologie préhistorique, celtique et Gallo-Romaine, ii, 3me partie. Second age du fer out époque de la Tène, I 314-27.

De Paor, M. and L. ( $196 \mathrm{I}$ ). Early Christian Ireland. (3rd ed.)

Dewar, H. S. L. and Godwin, H. ( 1963$)$. 'Archaeological discoveries in the raised bogs of the Somerset levels', PPS xxix, especially pp. 39-40.

Diaconu, G. (I965). Tirgşor.

Dudley, D. ( 1968 ). 'Excavations on Nor'nour in the Isles of Scilly, I 962-66', Arf cxxiv, I-64.

Duncan, G. S. ( I 960). Bibliography of Glass. (Society of Glass Technology, Sheffield.)

Ebert, M. (ed.) (1924-9). Reallexikon der Vorgeschichte.

Eck, T. (1891). Les Deux Cimetières Gallo-Romains de Vermand et de Saint-Quentin.

Eogan, G. (1964). 'The Later Bronze Age in Ireland in the light of recent research', PPS xxx, 268-351.

Favret, P.-M. (1927). 'La nécropole Hallstattienne des Jogasses', $R A$ xxvi, 80-1 46.

- ( 1936 ). 'Les nécropoles des Jogasses à Chouilly (Marne)', $P$ v, 24-I I 9.

Feachem, R. W. (I966). 'The hill-forts of Northern Britain', in Rivet, A. L. F. (ed.) (I966), 59-88.

Fell, G. (1936). 'The Hunsbury hill-fort, Northants.', Arf xciii, 57-100.

Foster, I. Ll. and Alcock, L. (ed.) (1968). Culture and Environment.

Fowler, E. (1964). 'Celtic metalwork of the fifth and sixth centuries, A.D.', $\operatorname{Arf}$ cxx, $98-160$.

Fowler, P. J. et al. (1970). Cadbury Congresbury, Somerset. (Dept. Extra-Mural Studies, Bristol Unjversity.) See also $C A$ xxiii (November).

Fox, A. (I96I). 'South-western hill-forts', in Frere, S. (ed.) (196r), 35-6o.

Fox, C. (1923). The Archaeology of the Cambridge Region.

- (1943). The Personality of Britain. (4th ed.)

- (1958). Pattern and Purpose. 
xxvi GLASS BEADS OF THE PREHISTORIG AND ROMAN PERIODS

Frere, S. S. (196r) (ed.). The Prablems of the Iron Age in Southern Britain.

- (1967). Britannia. A History of Roman Britain.

- (1972). Verulamium Excavations, i. (S.A.L. Research Report, xxvii.)

Gillam, J. P. (1958). 'Roman and native A.D. I22-197', in Richmond, I. A. (ed.) (1958), 60-9o.

Goodchild, R. G. (I947). 'The Farley Heath sceptre', Anf xxvii, 83-5 and refs.

Goodchild, R. G. and Kirk, J. R. (r954). 'The Romano-Geltic temple at Woodeaton', $O$ xix, I5-37.

Gozzadini, G. (I87o). L'Antico Necropole a Marzabotto nel Bolognese.

Gray, H. St. G. (I942). 'Glass beads found in a cist burial at Glevedon', PSNAHS lxxxviii, 73-6.

Greenwell, W. (1877). British Barrows.

- (I890). 'Recent researches in barrows in Yorkshire, Wiltshire, Berkshire, etc.', $A$ lii, I-72.

- ( 1906 ). 'Early Iron Age burials in Yorkshire', $A$ lx, $25^{\mathrm{I}-3} 3^{\text {I } 2}$.

Griffith, F. Ll. (1902-7). El Amarna. (Archaeological Survey of Egypt, vols. xiii-xvii.)

Grimes, W. F. (1939-45). Excavations on Defence Sites 1939-45.

- (ed.) (195I). Aspects of Archaeology in Britain and Beyond.

Grinsell, L. V. (197I). 'Somerset barrows (part ii)', PSANHS cxv, 43-1 37.

Guido, M. (forthcoming). 'The glass beads from Lankhills, Winchester', in Biddle, M. (forthcoming).

Hachmann, R. (1976). 'The problem of the Belgae as seen from the Gontinent', BIAL xiii, I I7-37.

Haevernick, T. E. (1 960). Die Glasarmininge und Ringperlen der Mittel- und Spätlatènezeit auf dem Europäischen Festland. (R.G.K.)

- (1972). 'Perlen mit zusammengesetzten Augen', $P Z$ xlvii, Heft I, $78 \mathrm{ff}$.

Haffner, A. ( I 97 I). Das keltisch-römische Gräberfeld von Wederath-Belginum.

Harbison, P. (1970). Guide to the National Monuments of Ireland.

- (1971). 'The Old Irish chariot', $A n$ xlv, I 7 I-7.

Harden, D. B. (I947), see Hawkes, G. F. C. and Hull, M. R. (1947), esp. pp. 306-7.

- (1967), in Stead, I. M. (1967), 14-16.

- (r968). 'Ancient glass I: pre-Roman', $A r f \mathrm{cxxv}, 46-72$.

- (I 969). 'Ancient glass II: Roman', Arf cxxvi, 44-77.

Harden, D. B. and Price, J. (I97 I), in Cunliffe, B. (I97 I b), 3I 7-68, especially 366-7.

Harding, A. and Warren, S. E. (1973). 'Early Bronze Age faience beads from Central Europe', An xlvii, 64-6.

Harding, D. W. (1 970 ). 'The "New" Iron Age', $C A \times x$ (May), 235-40.

- (1972). The Iron Age in the Upper Thames Basin.

- (1 974). The Iron Age in Lowland Britain.

Hawkes, G. F. C. (1959). 'The ABC of the British Iron Age', An xxxiii, I 70-82.

- (196I). 'Gold ear-rings of the Bronze Age, East and West', Folklore, lxxii, 438--74. (I 968 ). 'New thoughts on the Belgae', An xlii, 6-i 6.

Hawkes, C. F. C. and Hull, M. R. (I947). Camulodunum. (S.A.L. Research Report, xiv.)

Hawkes, S. G. (I975). Note in Arf cxxxii.

Hawkes, S. C. and Dunning, G. C. (I96I). 'Soldiers and settlers in Britain, fourth to fifth century', $M A r \mathrm{v}, \mathrm{I}-7 \mathrm{O}$.

Hélèna, P. (1937). Les Origines de Narbonne.

Hencken, H. O'N. (I950). 'Lagore Crannog: An Irish royal residence of the 7 th-1oth centuries A.D.', PRIA liii, I-247.

Henry, F. (1965) (revised ed.). Irish Art in the Early Christian Period to A.D. 800.

Hoare, R. Colt (181 2). Ancient Wiltshire. 
Hodson, F. R. (1962). 'Some pottery from Eastbourne, the 'Marnians' and the pre-Roman Iron Age in Southern Britain', PPS xxviii, I40-55.

- (I964). 'Gultural grouping within the British pre-Roman Iron Age', PPS xxx, 99-1 Io.

Hogg, A. H. A. (I95 I). 'The Votadini', in Grimes, W. F. (ed.) (I95I), 200-20.

- (1957). 'Four Spanish hill-forts', An xxxi, 25-32.

Hughes, M. J. (1972). 'A technical study of opaque red glass of the Iron Age in Britain', PPS xxxviii, 98-107.

Hull, M. R. (1958). Roman Colchester. (S.A.L. Research Report, xx.)

Jacobsthal, P. (1944). Early Celtic Art.

Jesson, M. and Hill, D. (eds.) (197 I). The Iron Age and its Hill Forts

Jope, E. M. (1957). 'A burial group of the first century A.D. near Donaghadee, Co. Down', UJA xx, 7395.

- (1960). Note in $U \mathcal{J} A$ xxiii, 40.

- (I962). Reported in $A n$ xxxvi, 30 .

Keller, E. (197I). Die spätrömischen Grabfunde in Südbayern. (Münchner Beiträge zur Vor- und Frühgeschichte, I4.)

Keller, J. (I965). Das keltische Fürstengrab von Reinheim. (R.G.Z.M.)

Kenney, J. F. (I929). Sources for the Early History of Ireland, i.

Kenyon, K. M. (1948). The Fewry Wall Site, Leicester. (S.A.L. Research Report, xv.)

Kilbride-Jones, H. E. (1938). 'Glass armlets in Britain', PSAS lxxii, 366-95.

Knowles, W. J. (1879). 'Ancient Irish beads and amulets', $\mathcal{F} R S A I \mathrm{xv}, 523 \mathrm{ff}$.

Koehl, W. Z. ( 1882 ). Neue prähistorische Funde aus Worms und Umgebung, i. (Behrens Germ. Denkmäler, i.)

Kraeling, G. H. (ed.) (I938). Gerasa, City of the Decapolis.

Krâmer, W. (1958). 'Manching. Ein Vindelikisches Oppidum an der Donau', in Neue Ausgrabungen in Deutschland.

- ( $196 \mathrm{I}$ et seq.). Various reports in Ge xl et seq.

- (1964). Das keltische Gräberfeld von Nebringen (Kreis Böblingen).

Krämer, W. and Schubert, F. (1970). Die Ausgrabungen in Manching.

Kunkel, O. (196I). 'Zur Frage keltischer Glasindustrie. Nach einer Manchinger Fundgruppe', Ge $\operatorname{xxxix}, 3^{22}$.

La Baume, P. ( 1967$)$. Das fränkische Gräberfeld von Funkersdorf bei Köln.

Laing, Ll. (1975). The Archaeology of Late Celtic Britain and Ireland, c. 400-I 200 A.D.

Leeds, E. T. (I 926). 'Excavations at Chun Castle in Penwith, Cornwall', $A$ lxxvi, 205-40.

Lethbridge, T. G. (I931). 'Recent excavations in Anglo-Saxon cemeteries in Cambridge and Suffolk', $P C A S$ n.s. iii.

Lucas, A. (r959 ed.). Ancient Egyptian Materials and Industries.

McKerrell, H. (I972). 'On the origin of British faience beads, and some aspects of Wessex-Mycenae relationship', PPS xxxviii, 286--30 I.

MacKie, E. W. (I965 a). 'The origin and development of the broch and wheelhouse building cultures of the Scottish Iron Age', PPS xxxi, 93-146.

—_ ( I $_{9} 6$ b). 'Brochs and the Hebridean Iron Age', An xxxix, 266-78. 
xxviii GLASS BEADS OF THE PREHISTORIG AND ROMAN PERIODS

MacKie, E. W. (I969). 'Radio-carbon dates and the Scottish Iron Age', An xliii, I 5-26.

Mahr, A. (ed.) (I934). Prehistoric Grave Material from Carniola. (Catalogue of the Mecklenburg Collection.)

Mallowan, M. E. L. (1966). Nimrud and its Remains, ii. (Appendix III by Axel von Saldern, 623 ff.)

Mann, L. McL. (1905-6). 'Prehistoric beads of coarse vitreous paste', PSAS xl, 396-402.

May, T. (I g04). Warrington's Roman Remains.

- (1922). The Roman Forts of Templebrough, near Rotherham.

- (1930). Catalogue of the Roman Pottery in the Colchester and Essex Museum.

Megaw, J. V. S. (1970). Art of the European Iron Age.

Milne, J. G. (1948). Finds of Greek Coins in the British Isles. (Ashmolean Museum, Oxford.)

Moreau, F. (1892). Album Caranda.

Morel, L. (1898). La Champagne souterraine; matériaux et documents. Ou résultats de trente-cinq années de fouilles archéologiques dans la Marne.

Müller Beck, H. and Ettlinger, E. (1962-63). 'Die Besiedlung der Engehalbinsel in Bern', BRGK xliii-xliv, 107-53.

Müller-Karpe, H. (I959). Beiträge zur Chronologie der Urnenfelder zeit nördlich und südlich der Alpen.

Myres, J. N. L. (1969). Anglo-Saxon Pottery and the Settlements of England.

— (1973). The Anglo-Saxon Cemeteries of Caistor-by-Norwich and Markshall, Norfolk. (S.A.L. Research Report, $\mathrm{xxx}$.)

Neuburg, F. (1949). Glass in Antiquity.

Newton, R. G. (r97 I a). 'A preliminary examination of a suggestion that pieces of strongly coloured glass were articles of trade in the Iron Age in Britain', $A r$ xiii, I I-I 6.

_._ (197 I b). 'Glass trade routes in the Iron Age', in XXth Congress on Glass Studies (Versailles). (British Glass Industry Research Association, Sheffield.)

Newton, R. G. and Renfrew, C. (1970). 'British faience beads reconsidered', An xliv, 199-206.

Nolte, B. (1968). Die Glasgefüsse im Alten Agypten.

O'Kelly, M. J. ( 1962-4). 'Two ring-forts at Garryduff, Co. Cork', PRIA lxiii, I 7-1 25.

Oppenheimer, A. L., Barag, D., Von Saldern, A. and Brill, R. (1970). Glass and Glass-Making in Ancient Mesopotamia.

Ordnance Survey (1956). Map of Roman Britain.

- ( 1962 ). Map of South Britain in the Iron Age.

ORíordáin, S. P. (I 942). 'A large earthen ring-fort at Garranes, Co. Cork', PRIA xlvii, G., 77-I 50.

- (1954). 'Lough Gur excavations', PRIA lvi, C., 297-459.

- (1964). Tara: The Monuments on the Hill. (2nd ed.)

Párduez, M., in $A H \mathrm{xxv}$ and $\mathrm{xxx}$.

Peacock, D. P. S. (1971). 'Roman amphorae in pre-Roman Britain', in Jesson, M. and Hill, D. (eds.) (197I).

Petrie, W. M. F. (I 888). Tanis. (Egypt Exploration Fund.)

- (1902-1907). Archaeological Survey of Egypt, xiii-xvii.

Pič, J. L. (Igo6). Le Hradischt de Stradonitz en Bohême.

Piggott, S. (1952-3). 'Three metal-work hoards of the Roman period', PSAS lxxxvii, I-5o.

- (1953). 'Bronze double-axes in the British Isles', PPS xix, 224-6.

- (I957-8). 'Excavations at Braidwood Fort, Midlothian, and Graig's Quarry, Dirleton, East Lothian', PSAS xci, 6I-77. 
Piggott, S. (1959). 'The carnyx in Early Iron Age Britain', Anf xxxix, 19-32.

(I970). Early Celtic Art. (Arts Council Exhibition Catalogue.)

Pirling, R. (I 966). Das römische-fränkische Gräberfeld von Krefeld-Gellep.

Pitt-Rivers, A. H. L. F. (1887). Excavations in Cranborne Chase, i.

- (1888). Excavations in Cranborne Chase, ii.

- (1892). Excavations in Cranborne Chase, iii.

- (1898). Excavations in Cranborne Chase, iv.

Powell, T. G. E. (1958). The Celts.

Quiggin, A. H. (I949). A Survey of Primitive Money.

Raddatz, K. (1957) . 'Zu den magischen Schwertanhängern des Thorsberger Moorfunders', Of xvi, 8I-4. Radford, G. A. R. (I95I). 'Report on the excavations at Castle Dore', $7 R I C$ n.s. i A (Appendix Volume). Raftery, B. (I969). 'Freestone Hill, Co. Kilkenny: an Iron Age hill-fort and Bronze Age cairn', PRIA lxviii G., I-108.

— (I972 a). 'Irish hill-forts', in Thomas, C. (ed.) (1972), 37-58.

_- (1972 b). 'Some late La Tène glass beads', $7 R S A I$ lii, Part I, I4-I 8.

Ralston, I. and Büchsenschütz, O. ( 1975). 'Late pre-Roman Iron Age forts in Berry', An xlix, 8-18.

Reinecke, S. (I I I ). Altertümer unserer heidnischen Vorzeit, v.

Renfrew, G. (ed.) (1974). British Prehistory: a new outline.

Richmond, I. A. (1954). The Roman Fort at South Shields: A Guide.

- (1956). 'Roman Britain in I955', JRS xlvi.

(ed.) (1958). Roman and Native in North Britain.

Richmond, I. A. and Thompson, E. A. (1 944). 'Roman Britain in I 943 ', $\mathcal{J} R S$ xxxiv.

Riefstahl, E. (1968). Ancient Egyptian Glass and Glazes in the Brooklyn Museum. (Brooklyn Museum, New York.)

Rivet, A. L. F. (ed.) (1966). The Iron Age in Northern Britain.

Rooksby, H. P. (1962), in GECJ xix, No. I, 20-6.

- ( 1964$)$. Physics and Chemistry of Glasses, i.

Rooksby, H. P. and Turner, W. E. S. (1959 and I 96I), see under Turner.

Ross, A. (1967). Pagan Celtic Britain.

Rynne, E. (I96I). 'The introduction of La Tène into Ireland', in Bericht über den Vinternationalen Kongress für Vor- und Frühgeschichte. (Hamburg, 1958.)

Sandars, N. K. (1957). Bronze Age Cultures in France. (1968). Prehistoric Art in Europe.

Sayre, E. V. ( 1963$)$, 'The intentional use of antimony and manganese in ancient glasses', in Advances in Glass Technology. Part 2, ed. Matson, F. R. and Rindone, G. E., pp. 263-82. (Additional Papers from the VIth International Gongress on Glass, Washington, D.C., 1962.)

Schaeffer, F. A. (1926). Les Tertres funéraires préhistoriques dans la Forêt de Haguenau. (i. Les Tumulus de l'Âge du Bronze.)

Schmidt, E. (1924). 'Le cimetière gaulois du Mont de Vraux à la limite des territoires de Juvigny et de Vraux', $B S A C$ (1924), I 5-20.

Seligman, C. G. and Beck, H. G. (1938). 'Far Eastern Glass: some Western origins', in Bull. Museum of Far Eastern Antiquities, $\mathrm{x}$.

Simpson, G. (1964). Britons and the Roman Army, A Study of Wales and the Southern Pennines in the First to Third Centuries. 
Simpson, M. (I968). 'Massive armlets in the North British Iron Age', in Coles, J. M. and Simpson, D. D. A. (eds.), 233-54.

Slade, F. ( $187 \mathrm{I}$ ). Catalogue of the Collection of Glass formed by Felix Slade, with an introduction by A. Nesbitt. Smith, A. G. (I 884). British and Roman Antiquities of North Wiltshire.

Smith, G. Roach (1852). Collectanea Antiqua, ii and iii.

Stanford, S. C. (1972). 'Welsh Border hill-forts', in Thomas, G. (ed.) (1972), 25-36.

- (1974). Croft Ambrey.

Stead, I. M. (1965). The La Tene Cultures of Eastern Yorkshire. (Yorks. Philosophical Society.)

- (1967). 'A La Tène III Burial at Welwyn Garden City', $A$ ci, I-62.

- (1971), in Butler, R. M. (ed.), Soldier and Civilian in Roman Yorkshire.

Steer, K. A. (1958). 'Roman and native in North Britain: the Severan re-organisation', in Richmond, I. A. (ed.), 9I-I I I.

Stevens, C. E. (I966). 'The social and economic aspects of rural settlement', in Thomas, G. (ed.) (1966).

Stevenson, R. B. K. (1 954-5). 'Native bangles and Roman glass', PSAS lxxxviii, 208-21.

Stone, J. F. S. (1940). 'A Round Barrow on Stockbridge Down, Hampshire', Anf xx, 39-5I.

- (I952). 'Report on beads from Knackyboy Gairn, St. Martins, Isles of Scilly', Anf xxxii, $3^{0-4}$.

Stone, J. F. S. and Thomas, L. C. (1956). 'The use and distribution of faience in the Ancient East and prehistoric Europe', PPS xxii, 37-84.

Sulimirski, T. (1970). The Sarmatians.

Thomas, G. (1966). 'The character and origins of Roman Dumnonia', in Thomas, C. (ed.) (1966), $77 \mathrm{ff}$.

- (ed.) (1966). Rural Settlement in Roman Britain. (C.B.A. Research Report.)

- ( I 97 I). Britain and Ireland in Early Christian Times, A.D. 400-800.

- (ed.) (1972). The Iron Age in the Irish Sea Provinces. (C.B.A. Research Report.)

Thompson, F. H. (1965). Roman Cheshire.

Todd, M. (1973). The Coritani.

- (1975). The Northern Barbarians I00 B.C.-A.D. 300.

Tress, H. J. (1962). Glass Technology, iii, 95-106.

Turner, W. E. S. and Rooksby, H. P. (1959). Glastechnische Berichte, Sonderband v. (Intern. Glaskongress $3_{2} \mathrm{~K}$, Heft VIII, I 7-28.)

- (I96I). 'Further historical studies based on x-ray diffraction methods of the reagents employed in making opal and opaque glass', $\mathcal{J} R G Z M$ viii.

Van der Sleen, W. G. N. (1967). A Handbook on Beads. (Journées internationales du Verre, Musée du Verre, Liège.)

Venclovâ, N. (r97I). 'Pravèké Sklo v Čestoslovensku', in Zpravy, xiii. (Annonces de la Société Tchécoslovaque d'Archéologie.)

Viollier, D. (1916). Les sepultures du second âge du fer sur le plateau suisse.

Von Sacken, E. F. ( I 868). Das Gräbfeld von Hallstatt in Oberösterreich.

Wacher, J. (1974). The Towns of Roman Britain.

Wainwright, G.J. (1967). Coygan Camp.

Warne, C. (1 866). The Celtic Tumuit of Dorset.

Webster, G. (1969). The Imperial Roman Army of the First and Second Ceeturies A.D.

Weinberg, G. Davidson (I969). 'Glass manufacture in Hellenistic Rhodes', in Archaiologikon Deltion, xxiv, I $43-5 \mathrm{I}$.

Wedlake, W.J. (1958). Camerton. (Camerton Excavation Glub.) 
Wenham, L. P. (1968). The Romano-British Cemetery at Trentholme Drive, York.

Werner, J. (1956). Beiträge zur Archäologie des Attilla-Reiches. (Bayerische Akademie der Wissenschaften, xxxviii.)

Weyl, W. A. (195I). Coloured Glasses. (Monograph of the Society of Glass Technology.)

Wheeler, R. E. M. (1941). 'Hill-forts of Northern France ...', Anf xxi, 265-70.

- (1943). Maiden Castle, Dorset. (S.A.L. Research Report, xii.)

Wheeler, R. E. M. and Wheeler, T. V. (1936). Verulamium, a Belgic and Two Roman Cities. (S.A.L. Research Report, xi.)

Wilde, W. R. (186I). Catalogue of the Antiquities in the Museum of the Royal Irish Academy.

Willvonseder, K. (I937). 'Die ältesten Glasfunde aus Österreich', in FF xiii, $3 \mathrm{ff}$.

Young, W. J. (ed.) (1965). Application of Science in the Examination of Works of Art. 



\section{TECHNICAL AND \\ ARCHAEOLOGICAL \\ CONSIDERATIONS}




\section{PART I \\ TEGHNIGAL GONSIDERATIONS}

\section{THE GHRONOLOGIGAL LIMITS OF THE STUDY}

$\mathrm{T}$ $\mathrm{HE}$ date covered by this study cannot be exactly defined. The beginning of the term 'Iron Age' in this context must signify the earliest post-Bronze Age beads imported into these islands, but as our archaeological knowledge of the first millennium B.c. deepens it is becoming increasingly clear that, whereas one part of Britain may have been in a retarded and persisting Bronze Age culture, other parts were already in regular contact with the European Hallstatt and La Tène Continental mainland; we must therefore remain open minded as to whether there was ever an interval between what are listed on p. 20-22 as 'Bronze Age' imports and those discussed in this study, though such an interval now seems less probable. We need more close dates and these are now beginning to be provided by radiocarbon analysis and other modern techniques. It is clear that the last five centuries B.C. witnessed an increase of Celtic bead production to a culmination in the first century A.D. when the Roman Conquest temporarily brought it to an end and beads of Roman types came to the fore instead, until they in turn were supplanted by Teutonic types after the Roman evacuation of Britain.

Apart from a brief discussion of Bronze Age beads the dates for this study are therefore very approximately c. 700 B.G.-A.D. 4IO. This period embraces the earliest Iron Age imports from the Continent, and the beads of the pre-Roman and Roman Iron Age (or RomanoBritish period in those parts of Britain occupied by the Romans) and ends with the arrival of numbers of Germanic settlers. The Iron Age cultural divisions ' $A$ ', ' $B$ ', and ' $\mathrm{C}$ ' are hardly used as our knowledge is still too imprecise for this not to be misleading to foreigners. For the same reason I have only hinted at regional cultural sub-divisions. Approximate dating by centuries has seemed less confusing. To keep the dating terminology simple $I$ have used the term Roman Iron Age for parts of Wales and Scotland not occupied by the Romans, and the word Roman is used as distinct from Romano-British only when there is reason to believe that the site in question was preponderantly more Roman than native in culture. Through lack of knowledge, however, there is inevitably a considerable degree of elasticity. This study has been made when excavations have recently shown that our whole concept of the Iron Age needs revision. As D. W. Harding has stressed 'sites which formerly were seen as singleperiod settlements may now be viewed as the product of prolonged or successive occupations, and groups of sites which might hitherto have been assigned to a single historical context may now be regarded as cumulative over a longer period of time'.1

With regard to the terminal date-the end of the Roman period-this too, though more

1 Harding, D. W. (1970). Among recent accounts of the British Iron Age see, inter alios, Harding, D. W. (1974); Hawkes, C. F. C. (r959) and (rg68); Rivet, A. L. F. (ed.) (1962); Hodson, F. R. (1962); Cunliffe, B. (r974); Frere, S. (ed.) (I96I); Thomas, C. (1966); Todd, M. (1975); and Renfrew, C. (ed.) (1974). See also Ordnance Survey Maps, Southern Britain in the Iron Age and Roman Britain. 
precise, must remain hazy within a few decades. We know that non-Roman peoples were already entering Britain before the end of the occupation, and yet that the Roman way of life, and therefore the objects they used, persisted in large areas of Britain after the formal abandonment by Rome in A.D. 4 IO or more significantly perhaps about A.D. 442 when the foederati revolted and brought an end to the Roman way of life. After that date the barbarian incursions began on a large scale and broke up the central imperial power, but it must be borne in mind that for at least half a century before and after that final date, the picture varies from place to place within Britain, some much affected by the new modes, some remote and lingering in an ever more threatened Roman tradition, and some which had never been more than lightly brushed by Roman culture but which were at the same time halted in a state of non-development of their native heritage based on those lingering Bronze Age or Celtic traditions in which they had been isolated by the Roman occupation. Each area must be studied for its local history, and Ireland in particular can be seen to have followed its own insular history (discussed on pp. 39-42). Only time and further study will elucidate these problems. The cultural complexity of the British Isles is clear to all who work here, but must be stressed again for foreign scholars. I must also emphasize that many of the beads here listed in 'Groups' as apart from those in 'Classes' (see p. vi) may prove in time to fall outside the limits of this research.

Yet another difficulty which at present impedes research is the relative lack of adequate description and illustration of Gaulish, Gallo-Roman, Frankish, and other Continental Iron Age beads, and of Roman and non-Roman beads from beyond the frontiers of the Roman Empire, not to mention early Germanic beads, Celtic beads in Italy and Spain, etc. No doubt, therefore, in the course of time not only will some of the beads listed in the present Schedules turn out to have had a Continental origin, but for the same reason many of the beads at present regarded as 'probably Germanic' (or more properly 'non-ContinentalRoman') and therefore excluded from this study should, had they been recognized, have been included within the chronological limits selected for this study. ${ }^{1}$ The very foundations, both archaeological and historical, are not as yet ready for a more definitive study. For this reason, and because relatively few glass beads come from well-dated contexts, and the great majority are from unscientific early excavations, the classification here adopted cannot lay claim to finality.

\section{THE FORMS AND USES OF BEADS AND THEIR DEGORATION}

Here (and it must be emphasized that the following remarks apply only to the British Isles) the nomenclature follows what appears to be a logical system. The suggested classification put forward for a world basis in Canada has not been used, ${ }^{2}$ because with a highly complex system of classification, a badly made bead can very easily be removed from the Class or

1 There are a number of reports on these beads, well
illustrated in colour, e.g., Moreau, F. (1892); Boulanger, C.
$(1902-5)$; Pirling, R. (1966). For Frankish beads see, inter
alios, La Baume, P., Das Frankische Gräberfeld von Junkersdorf
bei Köln, and the forthcoming and very important publica- tion of Schretzheim, near Dillingen, on the Danube, by Koch, U., in $G D V$, forthcoming.

2 Occasional Papers in Archaeology and History, No. I, Canadian Historic Sites (Queens' Printer for Canada, Ottawa, 1970-1). 
type to which reason and experience tell us it more properly belongs. The essential requirements will vary from country to country, or more properly from one cultural or geographical area to another, and as long as students of beads clearly define the nomenclature they have adopted, it will one day be possible for beads from much wider areas to be correlated and classified. For the same reason the classifications proposed by H. C. Beck ${ }^{\mathbf{1}}$ and W. G. N. Van der Sleen ${ }^{2}$ have not been followed.

The forms used in the present study are explained in the text when they relate to undecorated beads. In the Classes, but not the Groups, the characteristics of form, colour, translucency or opacity, and other details are defined, and many Classes are called after a characteristic site where they have been found. This will help to obviate confusion between two apparently comparable but really unrelated Classes. Beck suggested in I 928 that 'to describe a bead fully it is necessary to state its form, perforation, colour, material, and decoration'; by today's standards this is quite inadequate. To these requirements should be added: dimensions, translucency or opacity, method of manufacture (wound, drawn, blown, hand-moulded, etc.), and, where relevant or possible, some kind of analysis. The approximate or exact date of archaeological context in which it was found is equally essential, and its position in relation to a burial may provide a clue as to how it had been used-for not all were on necklaces. Some were arranged in a panel on a child's breast in a grave at the Forum in Rome, ${ }^{3}$ others were used as decorations on ear-rings, ${ }^{4}$ as brooch-runners, ${ }^{5}$ or as hair ornaments. ${ }^{6}$ In some examples, particularly of Class 6 , the beads were used as talismans attached sometimes to the sword hilt. ${ }^{7}$ Others may have been used as finger-rings for the dead: the German Totenringe. ${ }^{8}$ Sometimes, too, metal pins may be decorated with glass beads. ${ }^{9}$ It must not be assumed that the presence of beads necessarily denotes a female burial, for writing in the Catalogue of the Mecklenburg Collection, ${ }^{10}$ Dr. F. de Tompa points out, 'It goes without saying that horse-trappings . . . denote men's graves, and in the latter case this is corroborated by the fact that the tomb also contained ten arrowheads. . . . This grave, moreover, was very rich in glass beads, and it would therefore be rash to assume that the discovery of many beads in a grave denotes it as a female.' In some modern primitive societies the men wear more beads than the women.

\footnotetext{
1 Beck, H. C. (1928), i-75.

${ }^{2}$ Van der Sleen, W. G. N. (1967). This is particularly important for its section on Dutch sixteenth- and seventeenth-century trade beads, sometimes used as currency by explorers like Sir Samuel Baker, and sometimes in exchange for other commodities among backward communities. See also Quiggin, A. H. (r949).

${ }^{3}$ NS (1902), 96-i I and (1903), 1 23-7o.

4 See, e.g., Mahr, A. (ed.) (r 934 ). Grave 56 from Vinica, of mid-La Tène date, produced a pendant in the form of a little human mask with a small blue glass ear-ring. During Roman times this was not a common usage in Britain, but became more so in post-Roman times.

5 Very common on the Continent, but not so in Britain.

${ }^{6}$ Mentioned in the Ulster Cycle and probably reflecting late Iron Age and Roman Iron Age fashions. See the Annals of Ulster, ed. and trans. in 4 vols. by Hennessy, W. M. (Dublin, I887-190I), and K. H. Jackson, The Oldest Irish
}

Tradition: A Window on the Iron Age (1964).

${ }^{7}$ It is interesting to note in this connection that Pliny (NHist xxix, 52-4) refers to a Gaulish leader having been put to death by order of Claudius for wearing an amulet. Such talismans may have commonly been worn round the neck. A few years ago I was myself offered a bead amulet against the evil eye by a young fisherman in the Aeolian Islands off Sicily. I had been photographing his boat.

8 Petrikovits, H. von, Novaesium (Führer d. Rheinisches Landesmuseum in Bonn, 1957), 42, 11 I.

${ }^{9} P P S \times x x$ (1964), I 59 ff. Many Roman references might also be given.

${ }^{10} \mathrm{Mahr}$, A. (ed.) (1934), 6o, concerning a burial at St. Veit near Sittich, Carniola, of the last few centuries B.c. One might also mention a Gaulish tomb at Introbio (Valsassina), in Italy, containing a La Tène II iron sword, etc., and four large beads; $\mathcal{N S}$ (IgI8), 9 I. 
Necklaces are of course particularly valuable for showing at least a partial cultural and chronological overlap for certain bead types; all the more deplorable for the student has been the habit of dealers and even some museum curators who have strung together for convenience beads from more than one site or from different contexts on a long-occupied site, giving a false impression that they are all of one date. It must be remembered, that there are genuine instances of early beads being found and reused on necklaces of later dates.
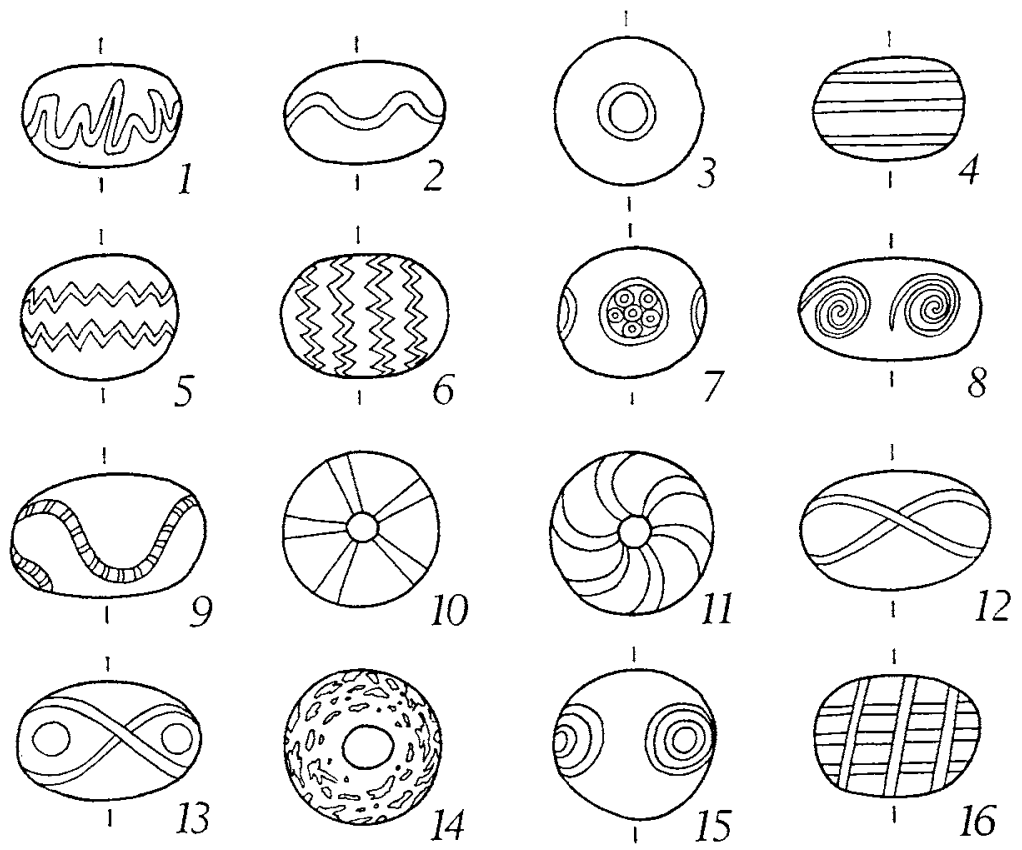

Frg. I : Decorative motifs.

Decoration (see fig. I)

The principal methods of decoration for beads were as follows, but there are, of course, a great many varieties on this theme. The decoration was usually applied and then 'marvered' (rubbed smooth on marble) into the surface while the glass was still warm.

(I) Scrabble: Less well made than the wave bands (2). The applied trail has often snapped and been restarted so that overlapping is found, and in addition the design is more pinched and angular, and the trail of varying thickness. The scrabble is often unmarvered in late or post-Roman examples.

(2) Wave: Generally simply a wavy band of a different colour applied to the circumference of the bead.

(3) 'Eyes': Generally surrounded by a ring or rings different in colour from the body colour of the bead.

(4) Bands: Straight trails applied around the circumference. 
(5) Chevrons in contrasting colour. Note that on the earlier beads this design normally runs at right angles to the perforation. In Irish and post-Roman beads it is parallel to the perforation and is called:

(6) Zig-zag: Vertical chevrons.

(7) Compound eyes: Many small eyes contained in a larger eye.

(8) Spirals: Most commonly white or yellow on a dark ground, or yellow on a colourless ground.

(9) Cables of two twists marvered on a different coloured ground.

(Io) Spoke-like rays in contrasting colour radiating from the perforation.

(I ) Whirls in contrasting colour radiating from the perforation.

(12) Double swag: Figure-of-eight bands crossing on the circumference of the bead.

(13) Double swag with eyes: As (I2) but with spots or eyes in the spaces enclosed by the swags.

(14) Mottled.

(15) Concentric rings.

(16) Criss-cross or network.

Note that the decoration may not have been well marvered or not marvered at all. In such cases the applied trails stand out and are not flush with the bead surface.

\section{METHODS OF MANUFACTURE}

The simplest description of bead-making is given by Van der Sleen ${ }^{1}$ from whose work these short notes are taken. ${ }^{2}$

Glass is made in thick earthenware crucible containers from 2 to $200 \mathrm{lb}$. of mixed pulverized quartz or sand quartz with some lime and soda, potash or nitre, sometimes lead. Generally before heating, iron or copper, manganese or cobalt colouring is added. The ingredients are then thoroughly mixed and heated in one or more firings to a red-hot, viscous state. A 'gathering' of the glass is then drawn out to make a shiny glass rod which quickly solidifies. These rods or canes are then cut down to useful lengths for making the oldest and simplest kind of beads-wound beads.

\section{Wound beads}

The glass cane is melted at one end and folded round a wire. The rest of the rod is cut off and the wire with the glass ring turned and heated till the ring is rounded. In cooling the metal contracts more than the glass and the beads can be pulled off. A tapered bead results from a gradually thinning thread of glass being wound round a wire. If larger beads are needed the cane is wound several times round the metal wire or other core. These resulting beads are then called multiple wound beads.

\footnotetext{
1 Van der Sleen, W. G. N. (1967). See also $7 R A I$ lxxxviii, $203 \mathrm{ff}$. and Neuburg, F. (1949).

${ }^{2}$ See also Riefstahl, E. (1968). This includes a history of
glass-making in Egypt up to the early Roman period.
} 


\section{Drawn beads}

The melted 'gathering' of glass is in this case worked into a gob of funnel shape enclosing a large air-bubble in the glass. This gob (hollow and therefore not a 'cane') is then elongated by drawing. Cut into lengths these rough 'beads' must then have their corners polished off. When still hot, drawn beads can be made into other shapes by pressing them or using small moulds. They can also be bi-coloured-say red with a white core. The first stage is made by pulling out a tube of white glass and then it is 'marvered' or rubbed smooth on marble. This is then rolled over half-molten red glass which adheres to it. Alternatively the white 'bead' can be dipped into a crucible containing molten glass. A drawn tube can also be pinched at regular intervals to be broken off into segments of the required length.

Folded beads

These are flattened glass canes folded round a wire. The line where the melted ends joined is often visible. ${ }^{1}$

\section{Pressed beads}

While still half molten the incipient bead is pressed into hexagonal or square or biconical shapes.

\section{Spiral beads}

The half-molten canes are wound spirally round a wire which, if tapered, would produce tapered segmented beads of the type common on Roman sites.

\section{Blown beads}

Used exceptionally for hollow beads (blown glass was not invented until the first century B.c.). Some large beads were apparently made by blowing them like a vessel, but these are very rare in Britain. The invention made glass-ware much cheaper to produce.

\section{Hand-perforated beads}

Drops of molten glass are perforated with a tool while still hot. This is a very simple form of bead-making and may well have been used by unpractised natives making their own beads in native villages and hill-forts. The perforation is sometimes enlarged by filing, and striations can be seen.

Dr. Haevernick ${ }^{2}$ reproduces a vivid picture of Africans spinning molten glass on two sticks until they are cool and well rounded as annular or ring beads. A characteristic of this type is that the inner circumference of the bead (or armlet) is smooth and tapered.

\section{GOLOURS AND OPAGIFIERS USED FOR GLASS BEADS}

A variety of colours were popular in pre-Roman and Roman times in Britain; the commonest ones in use during the Iron Age were translucent or seemingly opaque blue (a variety of shades but mostly 'cobalt'), opaque yellow, and opaque white (which was reserved for decoration of applied waves, spirals, eyes, and so on). Terracotta red (Pliny's haematinum) and occasionally, but rarely, glass which appears black may also have been in use before

1 Knowles, W. J. (1897), 523 ff.

${ }^{2}$ Haevernick, T. E. (1960), Textafel A, taken from Fro- benius, Und Afrika Sprach, Band 2 (1912). Her work includes full references to bead-manufacturing techniques. 
the Roman conquest. Translucent greenish-blue glass was introduced before the Romans and is discussed below, as is also colourless translucent glass. After the conquest opaque emerald green became increasingly popular for cylinder and polygonal beads (see pp. $95^{-8}$ ).

Glass can be regarded as being composed of a mixture of oxides, the main ones being silica $\left(\mathrm{SiO}_{2}\right)$, rarely less than 60 per cent, lime $(\mathrm{CaO})$, soda $\left(\mathrm{Na}_{2} \mathrm{O}\right)$ and potash $\left(\mathrm{K}_{2} \mathrm{O}\right)$. Alumina $\left(\mathrm{Al}_{2} \mathrm{O}_{3}\right)$ is usually present, derived from clays in the sand. Magnesia (MgO) and iron oxide $\left(\mathrm{Fe}_{2} \mathrm{O}_{3}\right)$ are rarely if ever absent, and traces may be present of the oxides of lead, antimony, barium, etc. The presence of $\mathrm{Al}_{2} \mathrm{O}_{3}$ and $\mathrm{Fe}_{2} \mathrm{O}_{3}$ may well have resulted from the clay crucibles used. ${ }^{1}$

Purple may be obtained by adding manganese; deep blues are generally held to result from cobalt, but this is not invariably the case, and copper without cobalt may give a blue colour, which depends on the composition of the glass itself. 'Probably the colouring power of cobalt minerals was not fully understood in the west in the Iron Age.' 2

Pale blue-green is produced by copper or by iron in the reduced state but not cobalt; reddish amber colour and some browns are probably due to sulphur and/or a carbon compound in combination with iron, but not leaving any trace in spectrographic tests (horse manure has also been known to have been added to produce this colour). White was used almost exclusively for decoration, and yellow was produced by adding lead oxide to produce colorants such as lead antimonate. ${ }^{3}$ Deep greens, browns, and ruby red can be obtained by the addition of copper, and dark bottle-green glass, which does not seem to appear in these islands much before the first century A.D. and which was never commonly used for beads, can be obtained by substituting certain igneous rocks in place of sand.

From earliest glass-making times opacity was achieved through the inclusion of calcium, lead, ${ }^{4}$ or some other antimonate, by adding phosphates or fluorides or by the presence of undissolved silicates. With the discovery of the technique of glass-blowing, now known to have been in the first century B.C., tin oxide, or copper and tin oxides began to replace the earlier opacifying agents. ${ }^{5}$

As Earle R. Caley has pointed out in reference to Roman glass, opacity may be caused by various factors: the presence of stannic oxide or dispersed cuprous oxide, or intense colourization caused by the presence of a high proportion of iron. ${ }^{6}$ It can also be caused simply by insufficient heating to disperse bubbles. (Glass, faience, frit, paste, and other terms are best defined in $M A r \mathrm{xv}, 5$, n. 32 .)

\section{A. TRANSLUCENT GLASS}

\section{GOLOURLESS GLASS}

Colourless glass is known to be deliberately obtained by the addition of either manganese or antimony to the natural greenish-coloured glass, which takes its colour from the iron

1 Weyl, W. A. (195I). Also Tress, H. J. (1962) for ruby glass. There is a valuable discussion in $A$ History of Glassmaking by R. W. Douglas and S. Frank (Foulis and Co., 1970). See also Saleh, S. A., George, A. W. and Helmi, F. $M$. in Studies in Conservation, xvii (1972), 143-72.

2 Jope, E. M. (1957). This contains useful information about glass colouring.
3 Newton, R. G. (rg7r a).

4 Large folded sheets of lead were found in the Hellenistic glass factory in Rhodes.

5 For discussion of lead tin oxide opacifier see Rooksby, H. P. (1962), 20-6, and (1964). See also Turner, W. E. S. and Rooksby, H. P. (1959) and (rg6r).

6 Calcy, E. R. (1962). 
contained in the sand, or any other form of silica which must be its main ingredient. Manganese and antimony can be used either together or separately, and while antimony was utilized at least as far back as the seventh century B.G., manganese was perhaps not used until the first century A.D. and was in constant use after the sixth to fifth century A.D. ${ }^{1}$ Where the colourless glass was produced is not yet clear. Certainly on the Continent it was used by at least the fifth century B.C. or earlier; there are big annular beads and armlets sometimes found in association with La Tène I bronze torcs from which they may have hung $^{2}$ and in the fourth century B.c. the Gauls were using colourless glass, ${ }^{3}$ but this may have reached them as lumps of glass from an area as yet unidentified, but possibly South Russia or in the Eastern Mediterranean. D. B. Harden has pointed out that both Greece and Etruria were on the route to Gaul, and we know that this glass was in use in mainland Greece from the fifth century B.C., and spherical (or 'globular') beads have often been found in Greek grave groups as well as in Etruria and elsewhere.

By La Tène II and possibly before that, both beads and armlets of clear glass were being produced in Central Europe, and their distribution can be studied from the maps prepared by Dr. T. E. Haevernick. ${ }^{5}$ As has already been mentioned, however, areas of France and Spain and the whole of the British Isles play a very marginal part in her study, and this lack, as far as Britain is concerned, can be overcome by looking at the distribution of Classes 5 , Io, and I I, all of which date from at least one or two centuries and maybe more before the Roman conquest.

In Britain the use of colourless glass was to a large extent discontinued during the Roman period for beads, but on the Continent it was probably imported into the west from Egypt and possibly Northern Italy: we do not yet know. Pliny mentions that the first stage of glass was subsequently re-fused in a separate furnace and the product was colourless glass called vitrum purum. This was regarded as the best. In a third fusion the various colorants were added. ${ }^{\circ}$ In Britain the colours may often have been arrived at accidentally by the impurities or trace elements in the raw material. There are kaolin-bearing whitish sands (which would produce almost colourless glass) in Devon and Cornwall, as well as in Derbyshire and Staffordshire, but there is so far no evidence for their exploitation in prehistoric times.

That Meare in Somerset ${ }^{7}$ may have been a distribution centre during the last three or so centuries B.G. for small opaque yellow annular beads (Class 8) and for colourless glass beads often decorated with opaque yellow spirals and other designs (Classes ro and $\mathrm{I} \mathrm{r}$ ) is more than probable, for large quantities of these beads were discovered there, and as yet there do not seem to be any known parallels for them on the Continent (see pp. 32-3). If colourless glass beads of the prehistoric or Roman periods are plotted on a distribution map, it is shown that nearly all the find-spots lie in the western part of Britain, with evidence for movement up

\footnotetext{
${ }^{1}$ Cole, H. (I966), 46-7; Sayre, E. V. (1963). Note that Bontemps (Chemical News, 6 Aug. 1862) proved that manganese was used for window glass at Pompeii to counteract impurities. See also $A$ xlvi (1880), 65-163.

2 Déchelette, J. (1924).

3 e.g., examples in the museums at Épernay, Châlonssur-Marne, Rheims, Soissons, etc.

4 Harden, D. B. ( 1969 ).

5 Haevernick, T. E. (1960). Some of these are so small
}

that they appear to resemble ring-beads somewhat comparable to our Hanging Langford Class (see pp. 51-3) and some were evidently links in chains, or hung from women's torcs as in pre-Roman Gaul.

${ }^{6}$ Caley, E. R. (1962).

${ }^{7}$ Bulleid, A. and Gray, H. St. George (1948 and 1956), followed by Cotton, M. A. (ed.) (1966). See also Avery, M. (1968), 21-39. 
the Bristol Channel and up the Irish Sea to Northern Ireland and to Wigtownshire and the Scottish Isles in the last two or three centuries B.G. During the earlier Roman period some colourless segmented beads in which gold or metal foil was encased between layers of clear glass ${ }^{1}$ were imported from the Near East-probably indirectly-and became more common in the third and fourth centuries. This method was commonly used on the Continent in the Geltic Iron Age. See Haevernick's Group 20, but pre-Roman beads with metal foil do not appear to have reached these islands.

One or two miscellaneous finds of Meare spiral beads (Class Io), which cannot be dated, come from Ireland, but there is a possibility that Ireland (which through nearly all its history went its own individual way) may have seen a renaissance of colourless glass in the fifth century and later, when large quantities of beads were manufactured there, particularly in Antrim where suitable sands are present, specially at Muckish Mount in Donegal. ${ }^{2}$

TRANSLUGENT NATURAL GLASS (German, naturfarbenes)

This glass takes its slightly greenish colour from the iron contained in the sand. It does not seem to have been popular in Britain much before the Roman period, but immediately before and after the conquest, and probably acquired from Gaul, this glass was widely used by the natives, not only for armlets of Types I, II, and III, ${ }^{3}$ some of which were perhaps distributed from Traprain Law (East Lothian) (see pp. 35-6), but also for cable beads (Class 9) whose distribution suggests a certain concentration around the lower Severn and movement up the Irish Sea, and is complementary rather than similar to that of the Type I armlets. Both the beads and the armlets are so far regarded as native British products which were manufactured at some as yet unidentifiable place or places around the first half of the first century A.D. or shortly before. Before that this glass was rare in Britain though plain annular beads of this glass seem more concentrated around Cornwall and the Bristol Channel area than elsewhere. Their place of origin is as yet unknown. This was the type of glass which was more readily available to the native people once the Romans had established military or civil bases from which broken glass bottles and other waste could be pillaged or bartered, ${ }^{4}$ and it is consequently only to be expected that it was used mostly for simply made annular beads throughout Roman times and on into the Saxon period; the peak period of its use seems to have been during the first to early third centuries. ${ }^{5}$ It does not seem to have reached to any noticeable extent beyond the Forth-Glyde area, though a few examples come from the Culbin Sands, nor does it appear in Ireland with one or two rare exceptions in associations which can be proved to be earlier than the renaissance in glass-working after the fifth century.

It is strange that the various types of armlet do not appear to have been common in the Culbin area, especially as at the time of their popularity glass bead-making had become a large industry there (see Classes 13 and I4), although as mentioned above, a bronze snake

\footnotetext{
1 See pp. 93-4.

2 For the problems concerning Ireland, see pp. $39-42$, below.

3 See Preface, footnote 2.

Note, too, the presence of a glass rod $5.5 \mathrm{~cm}$. long from a second- to third-century site at Whitchurch in Somerset;
}

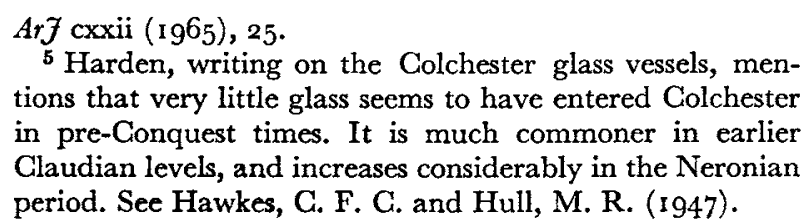

5 Harden, writing on the Colchester glass vessels, mentions that very little glass seems to have entered Colchester in pre-Conquest times. It is much commoner in earlier Claudian levels, and increases considerably in the Neronian period. See Hawkes, C. F. C. and Hull, M. R. (1947). 
armlet with inset blue glass came from the Culbin Sands. May this apparent lack of production of armlets there have been partly due to the natives' difficulty in getting hold of bottle-glass waste from Roman sites? It has been shown in a number of examples that analyses of the armlet glass and bottle-glass reflect similar composition, ${ }^{1}$ and show the same trace elements. Nevertheless it would be carrying the conclusions unwisely far to claim that such was always the case: it remains unproven. Certainly both in some beads and armlets the core was made of the natural green glass and then covered with rarer cobalt or other coloured glass. It is interesting to note that when mechanically aerated this glass becomes milky white in colour, but this variety is extremely rare in British pre-Saxon beads. It may also be noted that among the imported glass gaming-pieces from a Belgic burial at Welwyn Garden City (late first century B.C.) some were of opaque white. ${ }^{2}$

TRANSLUGENT yellow, AND Light GReEN, AMBER-Coloured (REDdish), AND GREENISH-GOLD GLASS

Pale yellow and light green glass (stronger in colour than the 'natural' glass) was preponderantly used for annular beads, and while a number of these have come from Roman towns such as Silchester (Hants) which had a long period of occupation, there are reasons for regarding these beads as being popular among the native Britons rather than the Romans, and a native element is apparent from many of the sites of their discovery. None is so far known to have come from very early Iron Age sites, but some may prove to have been as early as the third to second century B.G. ${ }^{3}$ and to have continued into at least the second century A.D.; in the fourth century, at least at Lankhills cemetery, Winchester, little biconical beads of this yellow glass were present and may have been imported from the Rhineland. (See below, pp. 97-8.)

The difficulty we meet here is that only by testing the glass in some way will it be possible to reduce the various green and yellow beads into more precise Classes. At the moment they represent Groups only. ${ }^{4}$

Two colours can be studied a little more closely: amber-coloured (reddish) and greenishgold.

Translucent amber-coloured glass (reddish) seems to have been unknown in Britain before the first century B.c., and even then was never very popular, although a few small annular beads, almost the only form used for beads in this glass, except for rare cable beads, ${ }^{5}$ linger into the Roman period. In several cases it was used as inlay in native type armlets. ${ }^{6}$ The beads with their fairly concentrated southern distribution-Weston-under-Penyard; Kenchester; Whitcombe, Dorchester; High Rocks, Tunbridge Wells (probably just pre-Roman); Verulamium; Hamworthy; Hunsbury, Northants. (pre-Roman); Bredon, Worcs.; Bath; The Verne, Portland ; ${ }^{7}$ and no doubt a few others - may either have been imported from

\footnotetext{
1 Stevenson, R. B. K. (1954-5), especially $216-21$.

2 Stead, I. M. (1967).

${ }^{3}$ It is to be expected that some green beads may have reached Britain in the last centuries B.c., being already known on the Continent where they were widespread, e.g., light green annular beads from the early Hunsrück-Eifel Culture (about 600-400 B.c.) in Neuwied Museum. Translucent yellow glass seems to have been almost equally early.
}

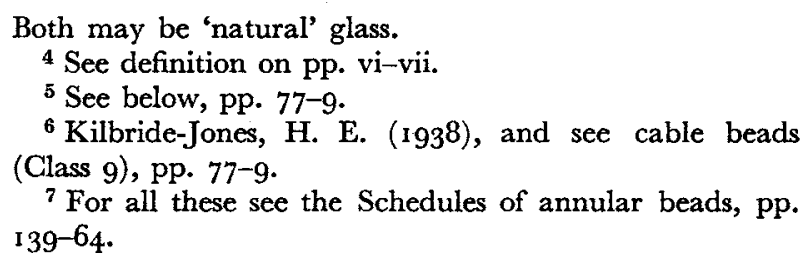


the Continent or made up from lumps of imported glass. Only analysis may one day tell us. It is interesting to find that there are large numbers of amber-coloured beads, both annular and globular, from Irish collections: there are about a hundred examples from the Bell and Grainger collections in Belfast alone. Though their date is unknown, it is quite probable that they are later than the fifth century when glass-working began to be practised on a large scale in Ireland.

Translucent greenish-gold glass. Beads (here called 'Bulbury glass' after a site in Dorset near Poole Harbour (see p. 3o) have such an individual and strong colour, as well as a predominantly southern distribution at about the period (? second century B.c. to second century A.D.) that it is worth regarding them as possible imports. Where they came from we do not yet know (but at least in one case the site where these beads were found produced a Roman or Venetic type of anchor, ${ }^{1}$ and Amorica may have been the source). The sites yielding Bulbury glass ${ }^{2}$ are Silchester, Hants (a Roman town); Verulamium, St. Albans, Herts. (dated ro B.c. to A.D. 40); Portland, Dorset (first century A.D.); Kingscote, Glos. (?first century A.D.); Irchester, Northants. (Iron Age 'B' or early Belgic); Porthmeor, Cornwall (early Roman probably); Bulbury, Dorset (eight examples with mirror, etc., of first century A.D.); St. Mawgan-in-Pyder, Cornwall (? first century B.C. or A.D.); Worthy Down, Hants (? second to first century B.c.); and Whitton Roman villa, Glamorgan (probably first century B.C. or A.D.). Very similar glass comes from Usk, Monmouthshire (dated A.D. 55-6o) ; Prestatyn, Flint (almost certainly Roman period); and Meare, Somerset (probably second to first century B.c.), ${ }^{3}$ as well as from ' Rochester and Alnham,' Northumberland; and Carrawburgh (a bead with a yellow wave decoration from a settlement dating from approximately A.D. $122-383$ ). A large cable bead (Class 9) in this glass came from St. Giles' Hill, Winchester, apparently reused in a later context, and should belong between the first century B.C. to second century A.D. A recent example not yet published comes from Hengistbury Head, Dorset, associated apparently with Dressel IA amphorae of the second to midfirst century B.c. Maybe this glass was distributed from here.

This small group is worthy of being tested to see whether analytically any of these beads are of identical glass, and the non-destructive techniques which have recently become available may well answer a number of such questions.

\section{TRANSLUGENT BLUE GLASS}

Among the earliest imported glass beads in Britain were the small annular beads of cobalt or prussian blue glass (Group 6) beginning around the mid-first millennium B.c. (see fig. 22). Others are of blue, almost translucent cobalt-coloured, glass decorated with blue and white eyes (the type known from the Marnian graves at Arras in Yorkshire, Class I) and from Swallowcliffe and other sites in the south, at present thought to date from about the fifth to fourth century B.C. This cobalt blue (sometimes loosely used here to describe the colour and not necessarily implying the use of cobalt rather than copper) as well as lighter translucent blue continued to be favoured among imported and British Celtic beads (see Classes I, 3, and

1 Cunliffe, B. (1972), 293-308.

2 All in the annular bead Schedules except for one from
Carrawburgh which has a wave decoration.

${ }^{3}$ Nos. G6. EV and G9. 
6) up to the time of the Roman conquest. Then, apart from annular beads with white, or less commonly, yellow waves (Group 5 (A)) which continued right through Roman and Saxon times, they became less used except for simple annular beads and for the small biconical ones (pp. 97-8) and other small beads of non-Celtic origin in the later Roman period. The reason for this is probably twofold: imported beads were probably not any longer being traded to Britain, nor was the glass pot-metal which may have been available in pre-Roman times for manufacture in this country (though its scarcity at Meare is difficult to explain). During the Roman period, as Stevenson has suggested, the common ribbed blue glass melon beads (nearly as common at the mainly second-century Newstead ${ }^{1}$ as the faience ones) may have provided a source for blue beads or armlets made by native craftsmen. For a discussion of glass melon beads see below, p. Ioo.

Many of the small annular blue beads which continue right through the Iron Age and probably through the Roman period as well as the Saxon and Viking periods have no special characteristics, and many of those not found in datable associations, but listed in the Schedules (pp. I 55-62), may well be post-Roman.

As far as the armlets of Scottish northern type are concerned it has already been mentioned that Stevenson ${ }^{2}$ noted that in some instances the cobalt glass had been used extremely sparingly over the ordinary translucent blue-green core-supporting the suggestion made above that cobalt blue glass became increasingly rare after the late first and early second century A.D.

Translucent bright sky-blue glass was much used in the early Roman period.

PURPLE TRANSLUGENT GLASS

This colour was never very commonly used in Britain. Some very thick annular beads of Class 7 appear to be black unless held to a strong light. In its raw state this coloured glass was found at Hengistbury Head near Christchurch, Dorset, ${ }^{3}$ evidently ready for distribution and reuse in the second or first century B.c. Similar glass seems to belong to the first century A.D. or late B.C. at Loughey, Donaghadee in Ireland, ${ }^{4}$ and was used sometimes for large Celtic ray and whirl beads on the Continent. ${ }^{5}$ Its use died out after the beginning of the Roman period in this country.

\section{TRANSLUGENT RED AND CRIMSON GLASS}

This was never common in Britain, and the rare examples were Continental imports, perhaps sometimes reused to decorate native glass armlets. ${ }^{\circ}$ Opaque red glass, particularly terracotta-coloured, was slightly more common, and it is often hard to be sure if the glass was translucent or opaque.

A burial at Clevedon, Somerset (see Group 8), was found with some barrel-shaped and

1 Curle, J. (IgI I).

2 Stevenson, R. B. K. (1954-5).

${ }^{3} H H$. Purple glass also came from a primary context from a broch in Tiree. See MacKie, E. W. (1965 b), 270.

4 Jope, E. M. (1957), 82-4 and (1960), 4 o.

5 Haevernick, T. E. (1960), and one example from Glastonbury. (See Class 7.)
${ }^{6}$ See pp. 35-6. Used either as oblique bands or spots, e.g., Braidwood Fort, Midlothian (PSAS lxxxiii (1948-9), 10); Dod Law, near Wooler, Northumberland (ibid. Ixxxvii (1952-3), 202); Dunagoil Fort, Bute (TBNHS lix (1925)). It is also known from Continental armlets of La Tène III. See Haevernick, T. E. (1960) and, e.g., Krämer, W. (1958), Taf. $\mathrm{I}$, etc. 
apparently hand-moulded colourless glass beads covered with a fine film of crimson translucent glass, ${ }^{1}$ accompanied by beads of yellow opaque glass (Class 8) and one of Class I I. This burial should probably be attributed to the second or first century B.c. The extreme delicacy of this thin glass makes its survival difficult, but it is worth noticing in this context that Warne, excavating in the last century in Dorset at Shapwick, ${ }^{2}$ found what was described as a 'ruby coloured barrel-shaped bead which had evidently undergone the action of fire' in a barrow with a cremation. Three stratified pieces of red glass dated to phase 2 (now thought to belong to the third to second centuries B.c.) came from refuse tips at Meare in Somerset which may have been the glass factory which produced the Glevedon beads.

On the Continent, too, pre-Roman red or crimson glass is uncommon and it may be true to a certain extent as J. L. Pič suggested ${ }^{3}$ that red amber (and one might suggest coral) was preferred by the Celtic peoples. But unrefined carmine-coloured glass was found at Manching which may have been a glass-producing centre. ${ }^{4} \mathrm{O}$. Kunkel also noted semifinished products there. ${ }^{5}$ This glass was represented both in bracelets and beads at Třisov. ${ }^{6}$

Opaque red glass was mostly used in Britain for decoration on Celtic bronze-work such as the Battersea and Witham shields, the brooch from Datchet, and other pieces-sometimes used in a cloisonné technique ${ }^{7-b u t}$ it never reached popularity for beads either during the Iron Age or subsequently.

BEADS WHIGH APPEAR TO BE BLAGK

Beads which appear to be black were never common in Britain before the beginning of the fifth century: they were then imported from Germanic sources and also appear, from their numbers there, to have been manufactured in Ireland as well. In Britain some beads and armlets appear to be black until held to the light when they are shown to be very dark green, brown or purple. In fact with very dark beads it is sometimes impossible to be sure either whether the glass was opaque or translucent, or what was its colour.

A small annular 'black' bead came from the Iron Age village at Meare in Somerset (Taunton Museum, no. G49. EV), ${ }^{8}$ and others from Roman sites such as South Shields, Weston-under-Penyard, and Corbridge. Globular beads of 'black' glass are equally rare; one came from Hunsbury fort (Northants.), perhaps second or first century B.a., and a few came from Roman towns, though during the Roman period jet from Whitby or occasionally shale may have been preferred. The real popularity of 'black' glass, as mentioned above, came at the very end of Roman times, introduced by Germanic peoples, whose beads were frequently decorated in opaque red, yellow or blue (see pl. II, no. 4).

1 Gray, H. St. George (1942), 73-6. (See Group 8, p. 7I.)

2 Warne, C. (1866), 39-4o.

3 Pič, J. L. (Igo6).

4 Krämer, W. (1961).

5 Kunkel, O. (1961), 322.

6 Břeň, J. (1966), 136-7.

\footnotetext{
${ }^{7}$ Fox, C. (1958). What appears to be a red glass stud or half a bead has recently been found at Burton Fleming in an Iron Age cemetery in Yorkshire. (Information from T. C. M. Brewster.)

8 They are known, though rarely, in the Continental Iron Age. See Krämer, W. (1964).
} 


\section{B. OPAQUE GLASS}

YELLOW OPAQUE GLASS

Yellow opaque glass is obtained by the admixture of lead and also antimony and tin. As a ground colour this was extremely popular in Britain for some centuries from about the third century B.C. or earlier, and on the Continent it was frequently used for single or doubletier beads with blue and white eyes (Class 4$).^{1}$ These beads (perhaps Phoenician or Carthaginian) possibly originated somewhere in the Mediterranean area and remained popular for some centuries. They were among the varieties still being produced in the late third to early second century B.c. factory at Rhodes. ${ }^{2}$

In Britain one of the earliest beads made of opaque yellow glass came from All Cannings Cross in Wiltshire, ${ }^{3}$ belonging perhaps to the fifth or fourth century B.c. It has a brown wave around it somewhat like an example from Les Jogasses in France, ${ }^{4}$ probably nearly contemporary. A somewhat similar bead has recently been found at Beckford, Worcestershire with stamped wares (unpublished) and a little later perhaps are some beads from the Queen's Barrow at Arras in Yorkshire, where opaque yellow glass has been used for the wave decoration. ${ }^{5}$ Apparently dating from about the third to second century B.C., though lingering on into the first century A.D., are the small annular beads (Class 8) which appear to have been manufactured, perhaps from imported glass, at Meare in Somerset ${ }^{6}$ and in the Culbin Sands area of Moray (see pp. 34-5). At about the same time the so-called Meare spiral beads (Class Io) and the possibly contemporary or slightly later variants (Class II) were being made at Meare and apparently imitated by the turn of B.G. to A.D. at Culbin (Class I3) where decorated annular beads (Class I4) were also being made. Approximately at the same time some beads of well-known Celtic Continental type decorated with opaque yellow design (Classes 5, 6, and 7) were being imported, some into the main area of Belgic settlement in the south-east, and some further to the west. This glass was also popular for the native armlets now thought to have been made in the first century B.C. to first century A.D. ${ }^{7}$ After the conquest, however, a sharp decline is detected, and it may have been that the native Britons had been cut off from their main source of supply of this variety of glass, whose origin may lie somewhere in Central Europe. Throughout the Roman period this glass seems to have been rare, but was again, of course, very popular in the Migration period. ${ }^{8}$

An attempt has recently been made by Dr. R. G. Newton ${ }^{9}$ to discuss whether opaque yellow glass from several different beads and armlets in the pre-Roman or early Roman Iron Age, if examined by milliprobe X-ray fluorescent spectrometer and neutron activation analysis, could be found to have been made of glass metal from the same source. The results suggested that two of the armlets tested showed that the glass from which they were made

\footnotetext{
1 e.g., from Santa Lucia di Tolmino (about 450-300 B.c.) in Italy ( $N S$ (1930), 426), and from Vraux, Marne, in France, probably fifth century B.C. (in the museum at Châlons-sur-Marne). There are others in St. Germain and in many Continental collections.

2 Weinberg, Gl. Davidson (1969).

3 Cunnington, M. E. (1923).

4 Favret, P.-M. (1936), 24-I 19.

5 Stead, I. M. (1965).

- Bulleid, A. and Gray, H. St. George (1948 and 1956)
}

and especially Cotton, M. A. (ed.) (1967).

${ }^{7}$ See p. $5^{8 .}$

${ }^{8}$ I have examined a number of Frankish beads which might, at first sight, be confused with the Iron Age ones (Class 8), but they are generally less regular, and the tone of yellow more lemon-coloured; they also tend to be more globular in shape. See, for example, Christlein, R. (Ig66).

${ }^{9}$ Newton, R. G. (1971), and also $A r$ xv (1973), 53-7 and $74-6$. 
could have had the same origin, but that a bead of earlier date from Overton in Wiltshire (Class II) had a noticeably lower manganese content and could not have been derived from the same 'stock'. This result was only to be expected. It is hoped that further, and much more extensive, work on these lines will produce more positive results.

\section{OPAQUE RED AND TERRACOTTA-COLOURED GLASS}

This, though not uncommon amongst Gaulish beads and again extremely popular in Frankish and Germanic beads, was never, until the post-Roman period, very much favoured in Britain. Perhaps it may have been technically difficult to make. ${ }^{1}$ One of the pre-Roman annular beads from Meare was a yellow one which had been coated with terracotta-coloured glass paste, suggesting that the latter was rare. As already mentioned in the discussion of translucent red glass, it is not always possible to be quite certain at first glance if some glass was translucent or opaque; if thin enough, however, it can be seen to be translucent. It was in any case never commonly used for beads in Iron Age or Roman times in Britain. It appears in a few exotic Roman beads, perhaps imported from far away parts of the Empire, and it is also found as eyes in beads of Class 3 and as bands or chevrons in the early Germanic beads from the fourth century A.D. and later, when glass paste was more commonly used.

Lead was used as a pigment or as an agent in making red glass but it is not known quite when it was first used. At Tara in Ireland a lump of red 'opaque' glass was discovered in a context thought to date between the first to third century A.D., but so far lead sulphide ore has not been recognized from Ireland and its provenance is therefore unknown. ${ }^{2}$ Since yellow and red may be obtained from the same lead, perhaps some red annular beads (which apart from colour are identical with the Class 8 yellow beads) from Airrieoland Crannog, Ayrshire, may in fact have been intended to be yellow but owing to firing or some accidental or intentional change had become red. Another samian-coloured red drawn bead came from Milking Gap, Northumberland.

Bright sealing-wax-coloured red beads have recently been found in a probably firstcentury A.D. context at Kingscote, Glos. This colour is discussed in Bateson and Hedges (I975).

\section{OPAQUE BLUE GLASS}

(a) Cobalt blue. In its opaque form this glass is very rare until the Roman period and particularly the later part of it when many beads were imported from other parts of the Empire. It was widely used for small segmented beads and long biconical beads, both plain or decorated with red or white bands or chevrons as well as for other smaller forms of Roman beads and polygonal beads. It is also worth noting that the decorated annular beads made in Scotland (Class I4) often employ opaque blue, but whether this was deliberate or accidental

\footnotetext{
1 A recent study of Iron Age opaque red glass has been made, and is valuable for technological data and references. Hughes, M. J. (1972).

2 For Tara, see TRIA xxx (1892-6), 277-93. Dr. Robert Brill is continuing his researches into lead sulphide ores which occur in many deposits in the ancient world. These
}

different deposits in say Spain, Greece, England, etc., produce differing amounts of lead isotopes in galena ores, so that although their exact provenance cannot as yet be identified, at least a geological similarity can be claimed. For example a chip of lead from a first century Roman vase from Caerleon matched the locally mined lead very closely. 
is unknown. In all probability, chance impurities may have given rise to many colours, unsuspected even by the beadmakers themselves, for it is improbable that the craftsmen were so sophisticated that they knew the exact proportions of trace elements required to give the colours they selected.

(b) Sky blue. Most of the beads made of sky blue glass are smallish annular, globular, or occasionally rather larger oblong beads. A rare example from Water Tower Street, Chester, was associated with a coin of Vespasian: it is small and barrel-shaped with a white wave and painted gold band round one end and is almost surely an import. One of the earliest preRoman examples of this glass came from Castle Dore in Cornwall ${ }^{1}$ where the first occupation mainly belonged to the second century B.C., but on the whole the maximum popularity for this colour was reached in the first two or three centuries A.D., and this tallies with the Roman Continental sites as well. This glass was sometimes used in England and abroad for small oblong square-sectioned beads, sometimes threaded on a wire. ${ }^{2}$ Surface finds in a shiny condition should be regarded with suspicion in this country where there was a widespread revival of this glass colour in Victorian and later times, both for bobbin weights for lacemaking and for children's games.

'BLAGK' OPAQUE GLASS

As has been mentioned above, p. I5, it is often difficult to be sure with weathered or thick 'black' glass whether it is really opaque or very thick translucent. The remarks made there may be taken as relevant for opaque glass as well.

OPAQUE DARK BROWNS, PURPLES AND GREENS

Opaque dark browns, purples and greens were particularly common in the Culbin Sands glass used for Classes 13 and 14 and in all probability were accidentally coloured by impurities. Only opaque green was popular in Britain after the Roman conquest, and particularly in the third to fifth century this glass was commonly used for many polygonal beads, small segmented beads, cylinder and cut cylinder beads, and others; originally these may have been poorer imitations of emeralds. Many other opaque colours reappear in quantity with the intrusive beads which began to filter into this country early in Roman times, but especially after the third century when barbarian inroads are attested, and then reached their crescendo during the next centuries. ${ }^{3}$ By the fifth century the Kentish and Thames cemeteries reflect a mixed population of Britons, foederati, and Saxons.

\footnotetext{
1 Radford, C. A. R. (1951).

2 As for instance from Croft Ambry, Herefordshire. Stanford, S. C. (1974).

${ }^{3}$ See $A r 7$ cxx (1963), 134. At Lankhills Cemetery at Winchester, graves with burials containing South German beads and other objects of the fourth century were recently discovered, and the full report by the Winchester Research
}

Unit is forthcoming.

We also know that defences against Saxon raiders were hurriedly adapted at Richborough, Kent, and other sites in the last quarter of the third century when the "Saxon shore forts' were begun by Carausius and Allectus, so some Saxon beads may have come into Britain earlier than we at present suspect. 


\section{PART II}

\section{ARCHAEOLOGIGAL GONSIDERATIONS}

\section{THE EARLIEST GLASS BEADS IN BRITAIN}

$T^{T}$ is now clear that there were sporadic examples of glass beads reaching Britain by the 1 second millennium B.c. and these, if they came by the western sea routes and not direct from the Continent, must take their place alongside, though not perhaps altogether contemporary with, the various other imports from the Eastern Mediterranean characterizing the Wessex Culture in the south (see below). As, however, that culture is still under discussion, with some favouring for it a long and others a short duration, it follows that the dating of some of our glass beads must await the verdict. Beads may be prior to it, some others

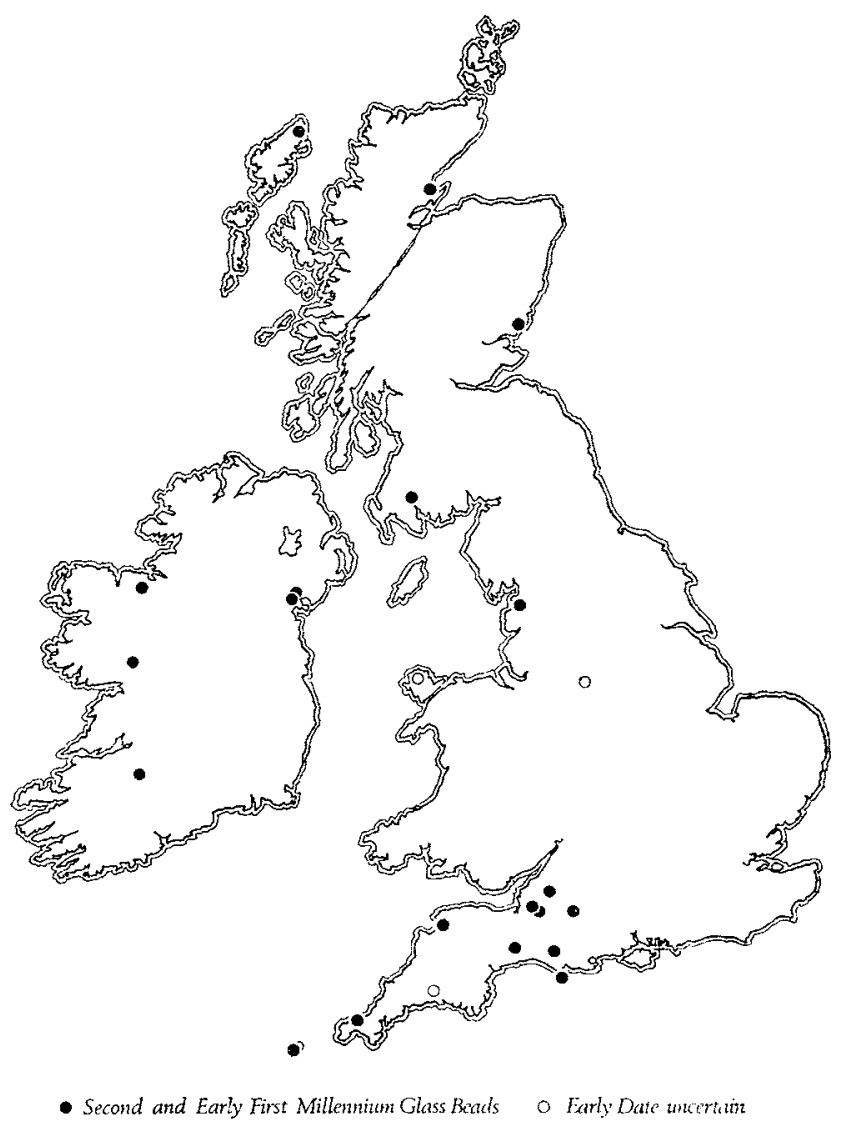

FIG. 2: Distribution of second- and early firstmillennium B.c. glass beads. 
may post-date it, and link, without any identifiable gap, with the earliest Iron Age beads imported by about the sixth century B.c. from the northern Continent.

Not all early beads may have been brought in by trade. The accidental discovery of glass in different places can easily have come about, as pointed out by Renfrew, when sea-weed was used as fuel for smelting copper.

Unfortunately most British examples come from badly documented excavations; no attempt was made in early publications to illustrate beads, and details of many of them and of their associated objects are now lost. Others may exist, but without any known provenance. To make matters even more difficult, many early excavators failed to distinguish between primary and secondary burials. All the same, and despite the occasional confusion between glassy faience and true glass, there are examples which clearly indicate a second-millennium B.c. date, and these fall comfortably into place beside many Continental glass beads, some of which are discussed below.

The glass beads of early date from Britain are as follows:

\section{England}

Boscregan, St. Fust-in-Penwith, Carn Creis (Cornwall). An oblong bead with bands wound around it, once filled with colour now missing. Found with cremations, faience, and shale beads, and a V-bored button under a barrow. Presumably Wessex Culture. (Borlase, W. G. (1879), pl. I6, no. 3.) This sounds like a banded bead of Mediterranean type.

Rillaton, Linkinhorne (Cornwall). 'A few glass beads with a Wessex culture ogival dagger and gold cup.' Possibly faience. Now lost. At least the gold cup, dagger, and beads were apparently secondary in an earlier cairn. (Borlase, W. C. (1872) and $\operatorname{Arf}$ xxiv (1867), 189.)

Thirkel-low, Frith, nr. Buxton (Derbyshire). Again possibly faience. PSAL xv (1893-5), 425 .

Moretonhampstead, Moor Barton Farm (Devon). 'A glass bead, and with it a spearhead [i.e. dagger] of copper and a small amulet of soft stone', the latter perhaps a whetstone. Again possibly Wessex Culture. (Devonshire Barrowes (Devon Association Reports, xxi, 31).) According to R. P. Carrington's notebook in the Devon Record Office at Exeter the beads were 'blue and white'. All the finds were in a stone cist.

St. Alban's Head, Portland (Dorset). Green glass bead 'in form merely a drop of glass pierced through', with a pot which might be Bronze Age. ( $A r f$ vii (I850), 385).

Winterborne St. Martin (Dorset). Bronze Age urn with glass and faience beads. (ApSimon, A. M. and Greenfield, E. (1972), 357).

Stockbridge (Hants). 'A small transparent glass bead of pale bluish colour ... crudely and badly made, having lost its shape whilst being fired.' Originally regarded as intrusive, this bead is probably contemporary with the Middle Bronze Age burial. (PPS iv (1938), 25I and B.M. Registration No. 1939 5-6, 20. See also Stone, J. F. S. (1940).)

Carnforth at Yealand (Lancs.). Found in 1778 in a barrow containing urns with cremated bones. Large blue glass bead $2.5 \mathrm{~cm}$. in diameter. (Baines, E., History of Lancashire, iv ( 1836 ), 581, and $A$ vii (1 785), 4r4.)

Knackyboy Cairn, St. Martin's (Scilly Isles) with a faience star bead. Also found were an irregular greenish-blue, semi-translucent bead, and a large globular blue glass bead. These 
were with a cremation burial with urns, etc., and were thought to belong to the late second millennium B.c. (Stone, J. F. S. (1952).)

Chereton Mendip (Somerset). 'Small opaque blue glass bead, perforated' from cist in cairn with grape cup, amber beads, bronze knife dagger, etc. (Grinsell, L. V. (197I), 99.)

Marksbury (Somerset). Barrow destroyed in about I827. A skeleton was found and 'near its neck a glass bead larger than a walnut'. (Possibly a secondary burial?) (PSAHNS cxv (r97I), 108.)

South Chard, Tatworth (Somerset). Bright greenish-blue globular bead, I $1 \mathrm{~mm}$. in diameter, with a Middle or Late Bronze Age pot, awl, thirty amber beads, etc. Taunton Museum. Thought by Gray to date from the early first millennium B.c. (PSAHNS xcvii (1952), I84-5. See also Anf xviii (1938), and Abercromby, J. (I912), ii, pl. xc I, fig. 433 and pl. cviii, figs. OI4 and P.43.)

Wookey Hole, Cheddar (Somerset). One small opaque blue bead from a Bronze Age barrow. (Balch, H., Wookey Hole (1914), I5o.)

Kingston Deverill (Wiltshire). Objects (lost) included bone tweezers, glass, amber, and jet beads, with cremations in a bowl barrow. (Hoare, R. Colt (1812), i, 75, pl. ix.)

It should be noted that so-called 'yellow glass' beads from Pensthorpe, Norfolk ( $\operatorname{Ar} 7$ vi (1849), 409) and from Barrow Amesbury $\mathrm{G}_{44}$ (in both cases associated with segmented faience beads) are now known to have been calcite. See Stone, J. F. S. (1940), 43-4.

Ireland

Although in some periods of her prehistory Ireland suffered a certain time-lag in comparison with other more advanced parts of the British Isles, during the Early and Middle Bronze Age her richness in gold kept her in communication with Europe via the western sea routes. There is reason to suppose that at least some of the glass beads from Irish contexts go back into the second millennium B.c. Nor should it be forgotten that the Massiliote Periplus quoted by Avienus refers to trade between Ireland and possibly Brittany.

Carnduff (Co. Antrim). Blue bead from a megalith which produced Neolithic ware. (Wood-Martin, W. G., Pagan Ireland (1886), 299.)

Gortnacargy, nr. Bawnboy (Co. Cavan). Small blue glass bead with Irish Late Bronze Age character urn. Possibly first millennium B.c. (PPS xxiv (1958), 212.)

Mullaghmore (Co. Down). From a ritual site with pottery of apparently Bronze Age date. (ÓRiordáin, S. P. (1954), 357.)

Pollacorragune (Co. Galway). In a cist in the top of a tumulus containing a Class I razor. (JGAHS xvii, 48.)

Lough Gur (Co. Limerick), Site C. Small greenish-blue wire-wound bead, apparently from a local Bronze Age context. Technically this bead resembles those from the XVIIIth Dynasty in Egypt, and also some from Southern France. (ORiordán, S. P. (1954), 354-8.) Aghnaskeagh (Co. Louth). Blue glass bead from Bronze Age cairn, with cremations and a pot, apparently primary. (CLAJ viii (1935), fig. 4 , facing p. 245.)

Lough Crew (Co. Meath). One bead of translucent greenish glass. (PSAS $\mathrm{xxx}\left(\mathrm{I} 895^{-6}, 342.\right)$

Two blue glass beads on an amber necklace came from Antrim and are in the Beck Collection, and a similar necklace is in the Murray Collection; both in Cambridge Museum 
of Archaeology and Ethnology. (See Beck, H. C. (1936), I4, pl. I I , and $A$ lxxxv (1936), 212.) Date uncertain.

For the later Irish Bronze Age, see Eogan, G. (1964).

\section{Scotland}

Gilchorn, Arbroath (Forfar). Small irregular, drop-shaped whitish glass bead, partially opalescent, and with signs of a spiral band at one end. (N.M.A., Edinburgh.) Found with a cinerary urn, etc. This bead was compared by Dr. D. B. Harden with XVIIIth Dynasty beads, now in the Ashmolean Museum in Oxford. (PSAS xxv (1890-1), 447-56.)

Glentrool (Kirkcudbrightshire). With a Middle or Late Bronze Age hoard perhaps dating from about the twelfth century в.c. (see discussion below). (PSAS lv (I92 I), 32-3.)

Adabrock (Isle of Lewis). Blue bead about $12 \mathrm{~mm}$. in diameter, now weathered with small greenish spots. With a hoard containing Class II razors. Perhaps about eighth century B.c. (see below). (PSAS xlv (1910-I I) and lvii (1922-3), 33.)

Eddertoun (Ross-shire). Streaked glass bead found in a cairn with what sounds like a cordoned urn, cremation, and a small bronze point. (PSAS v (1862-4), $3 \mathrm{II}^{\mathrm{I}-\mathrm{I} 5 .)}$

\section{Wales}

Llanbabo (Anglesey). This bead might have been faience. From a cairn. (PSAL xix (1902), 50.)

The problems concerning early glass-making and the trade of beads across Europe from factories in the Near East and elsewhere would present a valuable subject for research. At first the products from these early factories may have been bartered or exchanged for Baltic amber, which many scholars now think travelled across the Continent via the eastern end of the Alps to reach the head of the Adriatic somewhere near Aquileia at least by the late third or early second millennium B.c. Research concerned with the earliest glass (as distinct from faience or frit) beads to have found their way across Europe, even to Britain, by this date, is confined to regional, or at best national, lists, but no attempt has as yet been made to draw the information together to obtain an approximate chronological sequence. Nor do we know when glass beads were first made in European factories. Like amber, with its magnetic power, glass beads, particularly when decorated with an eye or spiral, have always been regarded as having magical qualities, and were therefore greatly in demand, and though the earliest beads must have been undecorated, they were presumably prized because of the newly discovered material of which they were made-glass. Subsequently the addition of decoration prompted their supposed efficacy against the 'evil eye' and as such talismans they have been valued right through history from Pliny's description of 'serpent's eggs' among the ancient Gauls, and the 'Druid's eggs' or 'adder's eggs' reported by the seventeeth-century historians of Britain to the amulets superstitiously dangled by car drivers in the Middle East today.

It is not the place here to enter into a detailed discussion of the date of the earliest glass factories in the Near East, but information of basic importance is given in Harden, D. B. (1968), both in the text and footnotes. It is sufficient here to mention that glass had already been discovered by the third millennium B.C., for a fragmentary glass rod in the Berlin Antiquarium bears the insignia of Amenemat III (XIIth Dynasty, 2050-2000 B.C.) and Harden 
cites a lump of dark blue glass, for resmelting, from Abu Shahrain (Eridu) in Mesopotamia, of at least as early a date. Other important sources include Petrie, W. Flinders (I888); Griffith, F. Ll. (I902-7); Axel von Saldern in Mallowan, M. E. L. (I966); Oppenheim, A. L. et al. (I970); Brunton, G. (I930) and (r937); Beck, H. C. (I934); many articles in Iraq, particularly vol. xvi, part I (1954), 83; Reports of the Oxford Excavations at Faras (Nubia) in Liverpool Annals, viii-x; and Nolte, B. (ig68). Oppenheim, A. L., in 7 . Amer. Orient. Soc., xciii (I 973), 259-66, cites linguistic evidence in cuneiform texts, saying that Egyptian glass-workers were using imported glass cakes from Syria.

An article on the spread of gold jewellery across Europe (Hawkes, C. F. C. (I96I)) is also relevant to some of the trade routes followed in the case of glass products, and is valuable for drawing attention to gold penannular ear-rings and hair-rings which reached Bronze Age Ireland from the Eastern Mediterranean.

It is possible that glass beads were being made in European secondary factories by the later second millennium B.c. or at least the early first, and were at first, no doubt, imitations of the imported ones from the Near East. ${ }^{1}$ Dates in the second millennium for Northern European glass beads would once have been considered very early, and, in fact, talking of the finds from a Breton dagger grave (contemporary with the Wessex Culture) at Landivisian (Finistère) in I934, Professor Piggott regarded a glass bead as 'an unexpected and puzzling feature'. ${ }^{2}$

Although some of the British examples, with a notable concentration in south-west England (fig. 2), cannot be closely dated, the evidence of funerary associations suggests that at least the Boscregan (St. Just-in-Penwith), Chewton Mendip, Stockbridge and Kingston Deverill burials belong to some phase of the Wessex Culture of the second millennium, a culture whose duration, as mentioned above, has not yet been determined, ${ }^{3}$ but which drew imports (or models to copy) from both the Eastern Mediterranean and Central Europe. Not far removed in date would be the beads from Gilchorn, Arbroath, in Scotland and Lough Gur in Ireland, both of which are paralleled from XVIIIth Dynasty Egypt (sixteenth to fourteenth century B.c.).

About sixty or more glass beads have come from French megalithic tombs. Daniel, G. (I 958) lists examples from the Dolmen de Pilandes-Costes (or Truan) (Aveyron); Fournes II gallery grave (Aveyron) with fragments of metal and a V-bored button; Grotte de St. Jean d'Alcas (St. Jean de Paul) (Aveyron); Grotte Monier (Var); Grotte de Bringaret (Aude) and the possibly Hallstatt date Romanin ossuary near St. Rémy (Bouches-du-Rhône). Other French examples come from Treille, Mailhac (Aude) where eight small blue glass beads were found with a faience mace-head and degenerate Beaker fragments ${ }^{4}$; while those from the Dolmen à Grailhe (Gard) ${ }^{5}$ were dated by Beck to 2000-I500 B.G. Others are reported by Arnal from Grotte Landric, St. Baulize, and other dolmens in Aveyron, and others include the above-mentioned dagger grave at Landivisian (Finistère), Le Comb Bernard, MagnyLambert (Côte-d'Or); Vinets, Ramperup (Aude), etc., referred to by Sandars, N. K.

\footnotetext{
1 For possible local imitation of faience beads, see p. 34 .

2 Piggott, S., in PPS v (1934), 193.

${ }^{3}$ For the latest discussion of this, see $V C H$ Wiltshire $I$ (ii), 352-7 (1973), Branigan, K. (1970), and Burgess, C. in
}

Renfrew, C. (ed.) (1974)
${ }^{4}$ Ampurias xi (1949), 25
${ }^{5}$ Beck, H. C. (1934), 7. 
(1957) and Schaeffer, F. A. (1926). The majority seem to have been distributed from the Mediterranean coast.

In support of a second millennium date for some glass beads are some barrel-shaped ones, some of glass and some of faience, associated with Mycenaean sherds of L.H. IIIA from La Portella, Salina, in the Lipari Islands. ${ }^{1}$ This date would be slightly earlier than some East Mediterranean imports into Britain, such as the Pelynt sword fragment from Cornwall, thought by Branigan to belong to L.H. IIIB. ${ }^{2}$ but possibly contemporary with the bronze double axes. ${ }^{3}$

As far as the rest of the European mainland is concerned, only a few references can here be suggested, but the time is fast approaching when a coherent study might profitably be made. For Central Europe see Childe, V. G. (1929), Dehn in Germania xxix (1951); Harding, A. (I97 I), 'The Earliest Glass in Europe'; Archeol. Rozhledy xxiii. 2; Godmer Gessner, V., 'Vom Problem der Spätbronzezeitlichen Glasperlen' in Festschrift Reinhold Bosch, 8o-98 (Aarau; also Kuhn in $7 P E K$ (1935), 130, for Egyptian beads in Central Europe). For Germany see Reinecke, S. (I II I). For Holland see Analecta Praehistorica Leidensia, viii (1975), 97 and note references in Butler, J. J. (1969), Nederland in der Bronstijd (Bussum). For Austria see Willvonseder, K. (1937) who gives valuable glass references among many referring to faience. For Czechoslovakia see Venclová, N. (197I) who lists about ten examples from Bohemia but emphasizes the rarity of Middle Bronze Age glass beads in comparison with those of the Late Bronze and Hallstatt periods, Leheckova, E. (1972), Vorgeschichtliche Glasperlen aus Böhmen und Mähren (Annales du $5^{\text {me }}$ Congrès de l'Association Internationale pour l'Histoire du Verre, Prague, 6-I I juillet, 1970, S. $3 \mathrm{I}-4^{\circ}$, Liège) and Moucha, V. (I958), 'Faience and glassy faience beads in the Unétice Culture in Bohemia, Epitymbion Roman Haken (Prague). For Denmark see Brønsted, J., Danmarks Oldtid II (1939), i 18.

A well-documented glass bead from Glentrool in Kirkcudbrightshire may be some centuries later than the earliest glass beads to reach Britain, and may belong to the twelfth to eleventh centuries B.C., approximately contemporary with the Knackyboy beads from the Isles of Scilly. Coles has written: 'The Glentrool hoard [bronzes] has analogous material in Ireland and in Somerset, and is the northern representative of the Ornament horizon in South England, dated mainly by its contacts with Period III in Northern Europe.' 4

Not long after this may be the beads mentioned by Brønsted from Humlum (district of Ringkøbing) in Denmark found with a gold wire arm-ring of about 100o-80o в.c. but by this time glass-works were probably already producing glass in a number of European countries, first perhaps at the head of the Adriatic, and then in Central Europe. A few centuries later, the end of the earlier series in Britain may be marked by the bead from a group at Adabrock in the Isle of Lewis, again discussed by Coles. This group included what appears to have been part of a cross-handle-holder bowl of von Merhart's Class B2b, and other finds which date it approximately to the seventh to sixth centuries B.c., to a period, that is, when north-eastern Scotland, between Moray and Tay, was in direct contact with the north-western German plain (Cole's Adabrock and Tarves phases), and when the Celtic

\footnotetext{
${ }^{1}$ BPI lxv (1956), 61. See also Karo, G., 'Schatz von Tiryns' in Athenische Mitteilungen, lv (1930), I I9-40, especially 125 and 129 ff., fig. 2, pl. iv.
}

\footnotetext{
${ }^{2}$ Branigan, K. (1970) and (1972), especially 282-3.

3 Piggott, S. (1953).

4 Coles, J. M. (1959-60).
} 
world had been opened up to increased Mediterranean trading after the founding of Massilia around 600 B.c.

Enough information, therefore, emerges to permit us to recognize that in Britain no real hiatus intervened to separate the early beads from the later ones discussed in the present study. There was simply and understandably an increasing intensification in their production and trade during the last five centuries B.C.

\section{IRON AGE AND ROMAN BEADS OF CONTINENTAL ORIGIN OR INSPIRATION IN BRITAIN}

THEIR CULTURAL AND GHRONOLOGIGALVALUES, ANDTHEIRMANUFACTURE A ND DISTRIBUTION

During the last five or so centuries which constitute the middle and late Iron Age in Britain, some of the following Classes and Groups of beads were almost certainly imported into England. These will be described in the order here indicated, and will be found on pages $45^{-7}$ I.

(i) DEGORATED GLASSES OF THE IRON AGE

Class I. Small dark blue beads with blue and white eyes ('Arras' type) (pp. 45-8).

Class 2. Large globular beads with white concentric rings ('Welwyn Garden Gity' type) (pp. 48-9).

Class 3. Large annular beads with three coloured eyes set in white ('South Harting' type) (? imported or British made) (pp. 49-50). Almost certainly copied in Britain.

Class 4. Opaque yellow beads with two registers of blue and white eyes ('Findon' type) (pp. 50).

Class 5. Clear colourless annular beads with opaque yellow lining to perforation ('Hanging Langford' type) (pp. $5^{\mathrm{I}}-3$ ). Possibly copied in Britain.

Class 6. Large dark blue annular beads with bosses inlaid with white or yellow spirals ('Oldbury' type) (pp. 53-7).

Class 7. Celtic whirl and ray beads (pp. 57-9). Probably copied in Britain.

Following these Glasses will be the Groups. The reader should be reminded of the division of beads into Classes and Groups stated in the Preface to this study. The Groups below serve here only as a useful corpus which it is hoped will one day be analytically classified.

(ii) Decorated or undegorated groups (both Iron Age and Roman in date)

Group I. Large or medium annular with streaky or mottled design (pp. 59-6o).

Group 2. Miscellaneous spiral decorated beads (p. 6o).

Group 3. Miscellaneous horned beads, some with eyes or spirals (pp. 6o-1).

Group 4. Compound-eyed beads with small eyes set in roundels ('Garrow Tor' type) (pp. 6I-2).

Group 5. Miscellaneous wave-decorated beads (pp. 62-5).

Groups 6 and 7. Undecorated annular and globular beads (pp. 65-7I).

Group 8. Exotic beads of Iron Age date (p. 71 ). 
The cultural and chronological values of beads vary from one to another. Sometimes a given Class may last for several hundred years; at other times one may have been produced and have died out within a span of two or three generations. But beads, being small and attractive, may often have been regarded as precious and curious things which might be handed down as heirlooms or rediscovered many generations after their manufacture and loss, and reused on much later necklaces. It should, in time, be possible to use them, just as one uses metal brooches, etc., to indicate tribal concentrations, folk movements, and commercial contacts, both within Britain itself and in the wider context of Europe.

Among the earliest recognizable imported beads in these islands, apart from some miscellaneous Bronze Age examples (a short list of which is given on pp. 20-2), are perhaps the Arras beads of our Class I, p. 45-8. These, though widespread in the sixth century B.c. and perhaps before in the Mediterranean lands and in Southern Europe, probably reached Britain from the Marne area around the fifth or fourth century B.c. and are found from Wessex to the graves of the Parisi in Yorkshire. Some other Classes not yet closely datable but possibly including the earliest blue beads with white waves (Group 5 (A)) and the opaque yellow beads with two rows of blue and white eyes (Class 4) may also have come in around this time, but only further examples from well-dated contexts will prove the validity of this supposition. We are handicapped, as a glance at any of the Schedules will indicate, by the comparatively few beads from well-dated archaeological deposits: the great mass come from old excavations or chance finds. It is only to be expected that a great many beads came across to England during the last few centuries B.c. but some of the trade may have been from Britain to the Continent once the bead factories had begun production in Britain.

During La Tène II and III there was a partial and slow cultural infiltration from Belgium and elsewhere, though perhaps it was not until the second century в.c. that large numbers of people crossed the channel as invaders, settlers, traders or refugees. The distribution of certain classes of beads may one day be found to tally with that of other finds such as the various coin types studied by $D$. F. Allen. ${ }^{1}$

A great difficulty in Britain lies in the fact that only relatively few Iron Age beads have been found in associated groups, and Professor Piggott's words should be borne in mind: 'Since Iron Age society was socially stratified, distribution maps of domestic things, e.g., pottery, did not necessarily correspond with those of fine metal work, or coins [or perhaps glass beads]. Only in cemeteries would the three come together, and these are still undiscovered.' ${ }^{2}$ As mentioned above, when closer dating is available, it may be possible in conjunction with other finds, such as coins, to connect certain beads with known tribal areas.

Those not familiar with the topography or the local archaeological problems in Britain may be puzzled to see from the maps here published that certain regions never seem to have received beads as trade objects. It is impossible here to attempt more than a very superficial explanation of this phenomenon, but certain facts are worth mentioning. A study still of basic importance is Fox, C. (1943).

In the Iron Age it may reasonably be expected that the areas of Britain most likely to be

${ }^{1}$ Allen, D. F. (196r), following (1944). For the districts of Belgic Gaul occupied by the various tribes see Hawkes, C. F. C. (1968), De Laet, S. J., in Helinium, i (1961) and
Hachmann, R. (1976).

2 Reported in $A n$ xxxiii (1959), 187. 


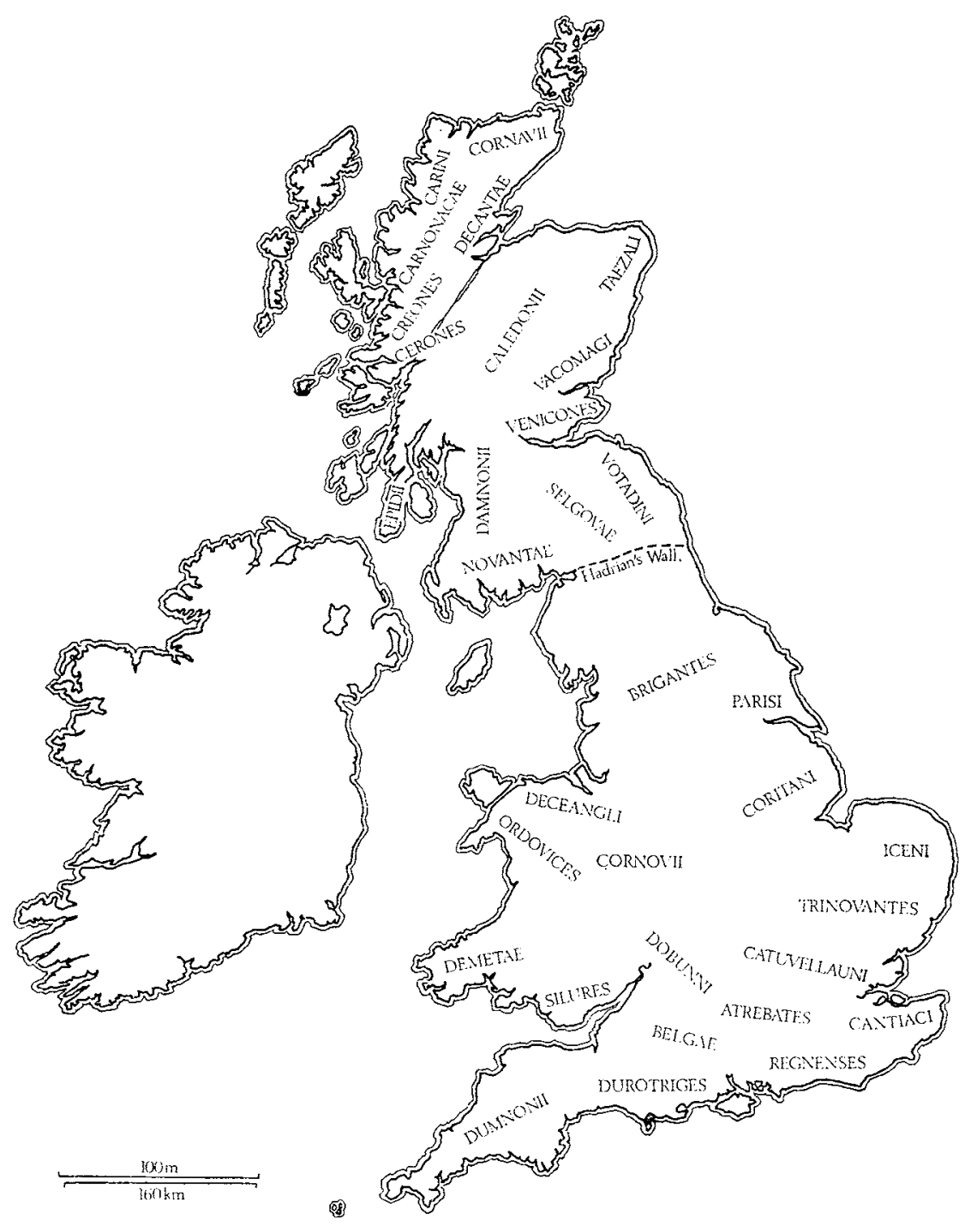

THE IRON AGE TRIBES OF BRITAIN: Approximate territories

FIg. 3: The Iron Age tribes of Britain.

actively trading with or to be settled by small groups of Continental peoples were along the south and south-east seaboards in areas most accessible from the opposite shores. This is clearly demonstrated from the distribution patterns of beads of the third to firstcenturies B.C., when trade activities were at their height and when, especially after the disturbances of the Cimbri and Teutones around roo в.c. and then at the time of Caesar's conquest of Gaul, settlers were presumably crossing the Channel and working their way inland or even sometimes coming up the Bristol Channel. That some of the British natives wished to acquire even greater numbers of beads than reached them from the Continent is shown by the 
presumed bead factory at Meare in Somerset which from about the third to the first century B.c. exported up the Bristol Channel and the Welsh marches as well as up the western seaways, and also by the pre-Agricolan North Scottish and Votadinian bead factories in the Culbin Sands, and perhaps at Traprain Law in East Lothian. (For a description of the local factories, see below, pp. 32-7.) All the same certain blank areas on the maps need to be explained, and the explanation seems to be at least partly an economic one; beads were luxuries which could be bought only when the essential needs had first been satisfied. The inhabitants of areas such as Devon and Cornwall (the Roman Dumnonia ${ }^{1}$ ), trading tin and other commodities especially to the Breton Veneti, had barren uplands to farm and only a relatively narrow coastal fringe: they could not have been rich in certain basic requirements, and the acquisition of these would have had to take priority over luxuries. Even after the Romanization of much of the rest of Britain, Dumnonia remained to a considerable degree unaffected by Roman influences. Much the same would have applied to most of Wales and mid- and northern Scotland, and also, perhaps again for economic reasons, to certain tribal areas such as Brigantia-again poor mountainous land. The territory of the Iceni in Norfolk and Suffolk, much of the centre of which was heavy clay land and perhaps not intensely occupied, lay outside the vigorous trading areas occupied by the Belgae and was moreover suppressed and impoverished by the Romans after the uprising under Boudicca. There are, then, social, economic, and political reasons for the lack of luxuries, and it must be remembered that some of these backward areas may have had nothing to offer in exchange. It must not be forgotten either that certain tribal areas in Britain (e.g., the Coritanian territory around Lincoln and Leicester) remain relatively unexplored archaeologically (see, however, Todd, M. (1973) and (1975)).

Continental politics must also have affected cross-channel trade to southern Britain, and such an explanation has been suggested by Barry Cunliffe to account for the distribution of certain hill-forts in south Britain. ${ }^{2}$ It is noticeable that the earlier beads reaching Britain arrived along the south and western coasts and in the Bristol Channel area, but after the pacification of Gaul in the mid-first century B.c. the trade contacts appear to have shifted eastwards to Kent, Surrey, and Sussex. This was the rich Belgic territory which could afford to import luxuries. It has been suggested that some parts of the south of Britain may have been regarded at this time as hostile territory. ${ }^{3}$

Professor J. Břeň has recently published some notes on Celtic oppida on the Continent. ${ }^{4}$ He regards these as distribution centres for specialized products such as glass, iron, coins, etc. For instance amber imported from the Baltic was perhaps distributed from Staré Hradisko in Moravia, iron objects and unfinished stone sculpture from Havranok, and glass beads, armlets, and other artifacts, from Stradonitz. He makes a plea for the word oppidum to apply only to a fortified Celtic settlement of the first century B.c. concentrating on the manufacture or distribution of some particular commodity: 'the decisive criterion and yardstick is the importance of the oppidum as a manufacturing and industrial centre as seen against the background of the extensive agricultural hinterland.'

1 Thomas, G. (1966). Finds of actual Roman glass, pottery and metalwork are (outside Exeter) startlingly few and far between.

${ }^{2}$ Cunliffe, B., in Jesson, M. and Hill, D. (eds.) (1971).
${ }^{3}$ Peacock, D. P. S., in Jesson, M. and Hill, D. (eds.) (1971).

4 Břeň, J. (1972) with footnotes to recent publications of Central European oppida. 
These conclusions have already received support from J. Collis. ${ }^{1}$ He sees Hengistbury Head in Dorset as a distribution centre for Roman amphorae and late La Tène bronzes, in direct contact with Gentral France, and this evidence is supported by the foreign coins reaching the same centre. ${ }^{2}$ Collis writes: 'In the first century B.c. there was a sudden rise of major marketing centres, each with a network of satellite sites or sub-centres, and a peripheral zone from which it draws its supplies. There is extensive "international" trade between these individual centres, and perhaps foreign traders resident controlling the trade.' It is interesting to note (see p. 30) that Hengistbury may also have been distributing raw glass (see also remarks on pp. $3^{2-3}$ below concerning Meare in Somerset).

Most of the imported beads which are more fully discussed in Part III below are well known from Continental sources, mostly in La Tène II and III, but their immediate point of departure for Britain cannot be ascertained until extensive work has been done in both excavation and collation, particularly in France. The ultimate source for many of the La Tène III Celtic beads, at least, lies in Central Europe, particularly in Switzerland, along the lower course of the river Main, the middle Rhine, and Czechoslovakia. They have above all been found in Celtic oppida such as Manching, Třisov, Stradonitz (in huge quantities, suggesting they were manufactured there), Hockstetter, the Dürrnberg, close to the Hallein salt-mines near Salzburg, Staré Hradisko (an amber-distributing centre), and many other sites. ${ }^{3}$

The closest dating for these oppida seems to come from Třisov (though not all need be strictly contemporary). At Trrisov ${ }^{4}$ the beginning of the settlement, dated by Nauheim type brooches should, Břen wrote, 'not be earlier than the sixties of the first century B.c.', or very little later, and its end is dated from spoon-shaped and Stradonitz brooches (the latter probably ending with the appearance of the so-called 'tongs-shaped' brooches at the close of the first century B.C. or first few years A.D.). At Stradonitz, he points to the sudden end of the oppidum and associates it with the coming of the Marcomanni into Bohemia in the year 9 B.c. or when the Romans occupied the Bavarian Alps. At all events the first century B.c. seems to have been the main period of active life in these oppida, and it follows that many of our imported beads will fit within or at least overlap that chronological horizon. At the same time the disturbed conditions in Gaul would have led to many people crossing to Britain and Ireland. Certainly there was a noticeable intensification in cross-channel contacts during that time. The Roman occupation of Britain immediately after A.D. 43 may have lessened the import or production of native beads, and the few discovered in slightly later contexts must be survivals from pre-Roman days. Thereafter with few exceptions (see pp. 37-9) the imported beads were standard Roman types, and large gaily decorated beads were destined not to reappear until the post-Roman migration period; then Britain received both the Teutonic beads from north-eastern Europe and some Irish beads from the very prolific centres in that country.

No factory has so far been definitely identified in these islands, and the few known glass

\footnotetext{
1 Collis, J. R., in Jesson, M. and Hill, D. (eds.) (1971), and (1974).

${ }^{2}$ Milne, J. G. (1948).

${ }^{3}$ See above, p. 28 . A recent and important paper concerning beads from Czechoslovakia is cited on $\mathrm{p}, 24$.
}

For additions to Haevernick, T. E. (1960) see also Benadik, B. (1959) and (1962). For Manching, see Krämer, W. (1958) and Kunkel, O. (196r), p. 322.

4 Břeň, J. (1966). 
furnaces of Roman date probably produced glass vessels and perhaps window glass rather than beads, like their Continental counterparts at Cologne, and in Normandy during the second century. These British furnaces were at Mancetter (Warwickshire), ${ }^{1}$ Wilderspool Lancs.), ${ }^{2}$ and Caistor-by-Norwich. ${ }^{3}$ Wasters from glass-making in the late second to early third century A.D. have also been found at Colchester, Wroxeter, ${ }^{4}$ and Leicester. ${ }^{5}$ Recently blue glass waste and lumps of raw glass have been found at Castleford, Yorks.

On the European mainland bead factories have not yet been identified, though beads of La Tène date and earlier are so common in Central Europe, around the Upper Rhine in particular, as well as in north Italy and the north of Yugoslavaia (Carniola), that factories will no doubt one day be discovered there. Northern Italy certainly received a new impetus from the eastern Mediterranean (the home of glass-making in Europe) just before and during the Etruscan period. Recently an important late third- to early second-century B.c. bead factory has been identified in Hellenistic Rhodes. ${ }^{6}$

As far as the Iron Age peoples of Britain are concerned, they no doubt at first used imported beads received by various routes, mainly from Europe, brought in by trade or settlers; the origins of many of these beads are fairly accurately known. But there is certainly reason to believe that by La Tène II at least, and during the last three centuries B.C., glass beads were being manufactured here in Britain too-not simply faithful copies of Continental beads, but highly individual both in form and decoration.

Some years ago R. J. Charleston suggested that lumps of glass-metal were probably imported and made up in this country, ${ }^{7}$ and his theory that such a trade was carried on has been supported by the finding of two purple glass armlets and lumps of purple glass in the crude state at Hengistbury Head, near Christchurch, Dorset. ${ }^{8}$ Sir A. Church to whom these were submitted wrote, 'the rough pieces of purple glass shown to me appear to be the so-called "pot-metal" from which, by refusion, etc., various objects may afterwards be fashioned'. Whence this pot-metal was imported, we do not yet know. Charleston's hypothesis is again borne out by the distribution of a particular yellowish-green glass of a very distinctive colour centred round South Dorset and Hampshire, and here called 'Bulbury' type glass from a hill-fort in which beads made of it ${ }^{9}$ were found. Another important article on the subject has been published by R. G. Newton. ${ }^{10}$ The reuse of bits of glass armlets as pendants has also been suggested, ${ }^{11}$ as well as the reuse of Roman pillar-moulded glass. ${ }^{12}$ For the reuse of bottle glass and other broken Roman glass, see above (p. I I). It is also interesting to note that a block of red glass found at Tara in Ireland was submitted for tests and the lead in it was said to have had an Italian origin. ${ }^{13}$

I A recent discovery mentioned by Frere, S. (1967), 290.

2 Thompson, F. H. (1965).

3 Atkinson, D. (1930), 93 ff.

${ }^{4}$ At Wroxeter early Flavian to Antonine glass slag fragments of imported glass for reuse, blobs of melted glass, and open furnaces were all recently discovered. See Brit iv (1973), 287.

5 Wacher, J. (1974), 353.

${ }^{6}$ Weinberg, G. Davidson (1969). See also G. von Merhart in Bonner Jahrbuch (1942), 147.

${ }^{7}$ Charleston, R. J. ( 1963 ). While mainly concerned with the post-medieval period, this paper refers to earlier glass on pp. $5^{8-9}$.

8 Mentioned above, p. $14 . \mathrm{HH}, 63$.

${ }^{9}$ See p. 13, above.

10 Newton, R. G. (I97I).

11 PSAS lxv (I93I), 201. It must be remembered that technologically it is easier to mould glass or turn it into vitreous paste than it would be to make glass from its mineral components.

12 Stevenson, R. B. K. (1954-5), 2 16.

13 Young, W. J. (ed.) (1965) and Charleston, R. J. (1963), note 29 on p. 159 . 
In the publication of the post-Roman site of Dinas Powys in Wales some of the broken glass of Teutonic origin was thought to have been brought to the site for reuse. Fused glass was found there and it was pointed out that 'it is very much easier to reheat existing blocks of glass to make beads, etc., than to manufacture glass from the constituent minerals. It seems clear that the former process was within the technological competence of craftsmen ... whereas the latter was not. This, of course, would explain the fragments of Teutonic or even Oriental glass which have been found on many western sites of this date.' It might also explain the cargoes of waste glass in classical period wrecks in the Mediterranean.

On the Continent instances of the reuse of glass are not infrequent, and it is now thought that some of the great oppida mentioned above for their dating may have been used as distribution centres of glass products and metalwork.

As early as the first part of the first millennium B.c. lumps of blue and red glass appear to have been used at Frattesine in north Italy ${ }^{2}$ - the earliest yet recognized on the European mainland. In the Viking site of Birka ${ }^{3}$ in Scandinavia large quantities of broken glass led to the same conclusion about the reuse of glass waste. There seems then no reason to doubt the existence of this practice.

\section{IRON AGE BEADS OF BRITISH ORIGIN OR DESIGN}

That glass beads were actually made in Britain, even if actual glass-works themselves still elude us, has only become apparent as a result of the present study, when the writer plotted the distribution of Class i 3 beads following a hint made by Graham Callander in I 9 I I when he wrote ${ }^{4}$ : 'I believe that time will show that these beads are more numerous in the northeast than in the South of Scotland.' He was right (see fig. 34), and other evidence points to their manufacture at several other sites.

So far, as mentioned above, only a few presumptive bead factories of Iron Age or early Roman date can be identified in Britain; presumptive in the sense that although no actual glass-working refuse has yet been recognized on any large scale, the distribution of certain bead types is so concentrated in those localities that the evidence points to their having been bead-producing centres. This hypothesis is strengthened by the fact that the beads from these sites are of distinctly individual design, and contrast with those from distribution centres marketing Continental imports.

The British-made beads are as follows:

Class 8. Small opaque yellow annular beads with flattened surfaces (pp. 73-6) perhaps made both at Meare and in the Culbin Sands.

Class 9. Cable beads. Large annular beads decorated with a two-colour twist or cable (pp. 76-9). Probably made, like the comparable armlets, both in England and South Scotland.

Class ro. Meare spiral beads: rather globular colourless translucent beads with fine yellow spirals covering the surface (pp. 79-8r). Made at or near Meare.

${ }^{1}$ Alcock, L. (1964).

2 Barfield, L. (1971).
${ }^{3}$ Arbman, H. (1940-3) i.

${ }^{4}$ Callander, G. (1911), I 78 . 
Class II. Meare variants: related to above group but bearing yellow chevrons, waves, criss-cross, etc. (pp. 8I-4). Also made at or near Meare.

Class 12. Stud beads (p. 84).

Class I3. North Scottish spiral-decorated beads: various colours with yellow spirals (pp. 85-7).

Class I4. North Scottish decorated annular beads: varied colours. Designs often based on rays combined with ladder patterns (pp. 87-9). Both these last Classes were probably made in the Culbin Sands area.

Some of the beads at present relegated to Groups in this study may also have been made in Britain.

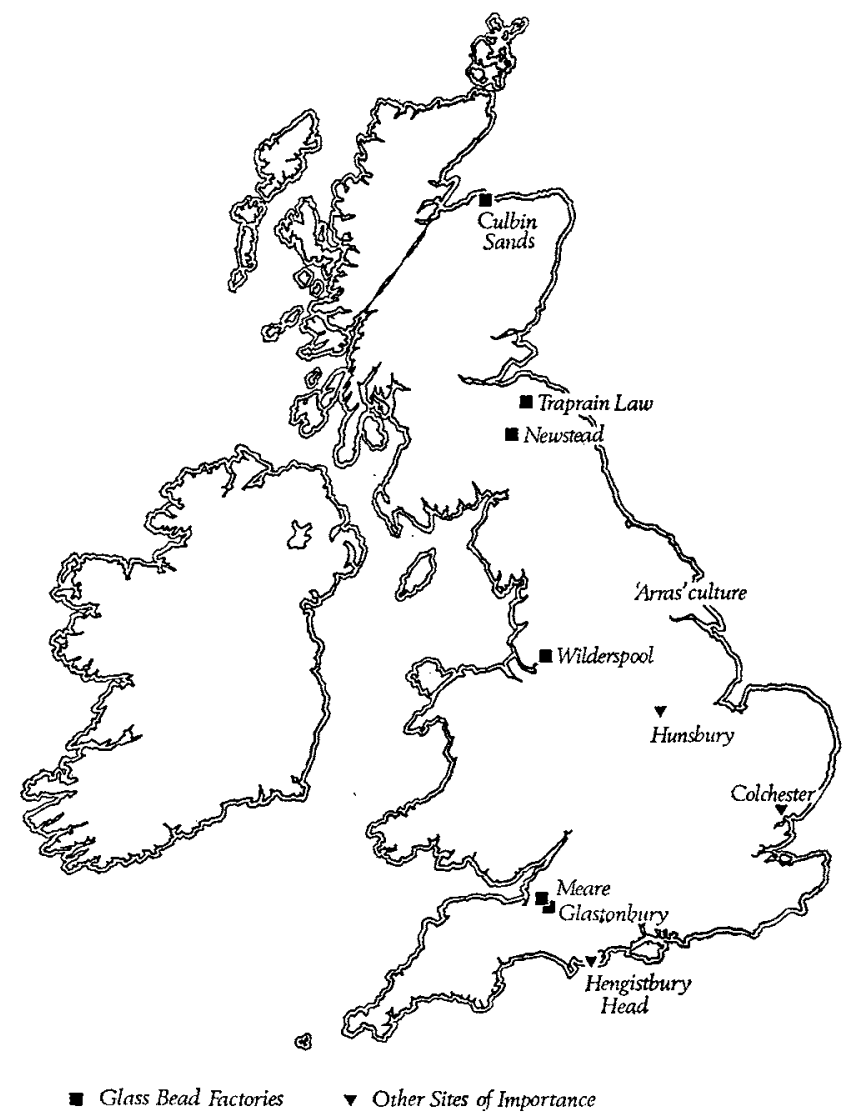

FIG. 4: Suggested glass bead factories and other sites of importance.

The possible factories will now be briefly described:

\section{Meare}

Meare, like nearby Glastonbury, lies on low-lying raised bog-peat in western Somerset, in an area which has experienced variations in its coast-line and height above sea-level, and which is known to have become increasingly water-logged to a maximum degree shortly 
before the Roman conquest. ${ }^{1}$ The western part of the site was excavated over a number of years by Bulleid and Gray $^{2}$ and the three volumes of their report show that the site was particularly rich in finds. Some of the mounds of the eastern group, only a few of which were examined by Bulleid and Gray, have been partly excavated and reinterpreted by Avery. ${ }^{3}$ (All finds from this site, now in the Taunton Museum, are prefixed by the letters EV.)

Briefly Avery's results, kindly given to me before his full publication, reinterpret the character of the stratified deposits in the mounds, and permit a sub-division of phases as follows: the significant ones are Phase 2 (thought to belong to the third century B.c., perhaps even earlier) and Phases 3 and 4 , of the later first century B.c. and the early first century A.D. During some part of the second century B.c., the areas so far excavated were temporarily abandoned, in favour, probably, of other nearby land as yet unidentified.

Phase 2 antedates the decorated ware and La Tène III brooches, and may be contemporary with the La Tène I or II brooches from the site. During this period Meare spiral-decorated beads of Class io and most of the variants of Class i I were being made, as well as some of the small annular beads of Groups 6 and 8. During Phases 3 and 4 small beads, as well as large clear annular beads with yellow waves (Class in (g)), appear to have been made. The numerous other beads cannot yet be assigned to their phases.

The enormous number of beads from Meare can only be explained in one of two ways: either, being not far from the coast, the village could have acted as an emporium or distribution centre for foreign goods, as has been suggested for certain types of oppida, or the beads were actually manufactured in the locality. Whilst there were almost surely some instances of copying Continental beads, the vast majority of them seem to be of purely British design, and their local origin must be regarded as highly probable. One speciality of the factory was the production of translucent colourless glass, often decorated with opaque yellow motifs.

\section{Glastonbury}

This site lies close to Meare and may also have produced beads. Parts of it were excavated by Bulleid and Gray ${ }^{4}$ and, as a result of the new work at Meare, it seems that its earliest phase post-dated Meare Phase 2 and coincided with Phases 3 and 4, and that it was abandoned in the early first century A.D. There are fewer beads from this site, and possibly they were obtained from the nearby Meare factory, but the difference in their character is fairly marked, and local production is very likely.

It is difficult to say what tribal group was occupying the area including Meare and Glastonbury in the last centuries B.c. Perhaps the Durotriges, centred on Wessex, extended into this district, for this is suggested by the distribution of their coins which do, albeit rarely, reach Somerset. ${ }^{5}$ On the other hand it is possible that the Dobunnic territory may have stretched down this far along the south border of the Bristol Channel: their trade relations were noticeably close (see map, fig. 3). The Dumnonii certainly did not reach this part of Somerset, and the extent of Belgic influence is not yet clear. On the whole it seems

\footnotetext{
1 Dewar, H. S. L. and Godwin, H. (1963), and for discussion of flooding, see Williams, M., The Draining of the Somerset Levels (1970).

2 Bulleid, A. and Gray, H. St. George (1948), and Cotton, M. A. (1967).
}

${ }^{3}$ Avery, M. (1968). A fuller report is expected.

${ }^{4}$ Bulleid, A. and Gray, H. St. George (I 9 I I).

${ }^{5}$ Allen, D. F. (196I), Map VII. Map reproduced in Cunliffe, B. (1974), p. 97. 
most likely that the Durotriges, receiving raw glass from Hengistbury Head (which also may have been a factory), and possibly from unidentified harbours on the Somerset coast, had their main factories at these two sites.

\section{Culbin Sands, Moray}

These sand dunes run for miles near the mouth of the Findhorn river in Scotland, and are subject to constant changes in form as the result of strong winds and tides. They cover a land surface occupied in prehistoric and Roman times.

The first suggestion that glass was manufactured in this area was made as long ago as $187 \mathrm{I}$, and among the autograph letters in the Library of the Society of Antiquaries of Scotland in Edinburgh is one from C. Innes to Major Chadwick referring to a bead necklace 'of glass or vitreous paste coloured with oxide of iron', and mentioning 'some curious information from Dr. Gordon of Birnie of the remains of kilns near Elgin where such glass ornaments were manufactured'. Lumps of fused glass of various colours are in the N.M.A. (Nos. BIB 63 and BIB 69).

Perhaps these sandhills may have had a long history for glass- or faience-making. Faience beads of star, quoit or segmented shapes which have a notably Scottish distribution may have been made locally in Scotland, as first suggested by Mann, ${ }^{1}$ as at least fifteen of these came from Culbin where analogous slag is said to have been found. These beads are thought to belong to the mid-second millennium B.C. ${ }^{2}$ But the question of their origin remains uncertain, for a more recent study denies that they were made in Scotland $^{3}$ and repeats the long-held view that they were made in the Near East.

At all events there is no evidence for glass-making in Culbin between this period and about the second or first century B.C. and the first century A.D. At this time the territory of Buchan, Moray and Mar seems to have been inhabited by the Vacomagi and their more easterly neighbours, the Taexali, ${ }^{4}$ both of which tribes may have been merged in a wider Caledonian confederacy by the end of the second century and have been ancestors of the later Picts. It is interesting to note here that the area is characterized by a distinctive, though as yet undated local type of hill-fort, ${ }^{5}$ often unfinished, and possibly hastily constructed at the time of the Agricolan invasion, or at the time of Severus. Were these, perhaps, the same tribesmen as those responsible for the bronze snake-armlet inlaid with blue glass (now in the N.M.A.), and also for the more massive Castle Newe type armlets, the Deskford carnyxbell, ${ }^{6}$ etc.?

Although no glass factory has as yet been identified, the maps make it clear that one must have been producing beads and probably armlets for a hundred years or so, perhaps more, before the Agricolan conquest, when marketing outlets or the possibility of acquiring glass

\footnotetext{
${ }^{1}$ PSAS xl (1905-6), 496-502. See ibid. iv (1860-2), 55 , and for possible glass-making crucibles from the sands, ibid. $\mathrm{xlv}(\mathrm{I} 9 \mathrm{IO}-\mathrm{II}), \mathrm{I} 5^{8-8} \mathrm{I}$. Half-finished beads are recorded in $P S A S$ xxv (1890-I), 508-10.

2 Beck, H. C. and Stone, J. F. S. (1928); Stone, J. F. S. and Thomas, L. C. (1956) and Newton, R. G. and Renfrew, C. (1970).

3 McKerrell, H. (1972). Note that other faience beads
}

came from Stevenston and Glenluce Sands in Ayrshire and Wigtownshire respectively. See, however, Harding, A. and Warren, S. E. (1973), 64-6.

4 Richmond, I. A. (1958) and Steer, K. A. (1958).

${ }^{5}$ Rivet, A. L. F. (ed.) (1966).

${ }^{6}$ See Simpson, M., in Studies in Ancient Europe (Leicester, 1968) and Piggott, S. (1959). 
waste were stopped after the Roman victory at Mons Graupius in A.D. 85. Moreover a number of half-finished beads and glass slag have been discovered there. A Roman glass bottle from Brackenbraes, Turriff, reflects some intercourse between the Taexali and the Romans.

Who these people were and where they had come from is quite obscure. The beads they made were gay, colourful, and highly individual, and their limited distribution (see maps, figs. 34 and 36 ) suggests little outside trade and perhaps only a short period of manufacture. One can, however, detect that these not very competent glass-workers had seen three or four types of bead which they were inspired to copy in their own idiom. They must have seen some Meare spiral beads of Class Io which might have reached them from the west via the Great Glen: these they imitated without being able, or perhaps wanting, to obtain the same translucent, colourless ground. Their own productions, perhaps full of local and fortuitous impurities, were mostly 'black', green, brown or blue, all fairly dark, sometimes opaque, but all with yellow spirals (Class I 3 ). ${ }^{1}$

Another of their designs (Class 14 ), no two of which are identical, shows a combination of the whirl and ray patterns of some Celtic beads (Class 7), albeit in a hardly recognizable form owing to their inferior technique, and the twisted cables (now reduced to a sort of ladder pattern) of Class 9. A certain quantity of small yellow annular beads similar to Class 8 made first at Meare in Phase 2 of the site, but enjoying a long popularity, may also have been produced at Culbin.

Beads from this factory are probably survivals if they post-date the late first century A.D. Glenluce Sands, Wigtownshire

Numbers of beads have also come from these sands. For a discussion of them, see Callander, G. (I9II).

\section{Traprain Law and Nerestead}

The evidence for bead-making at these sites is very tentative. Traprain Law ${ }^{2}$ stands on a high rocky outcrop dominating parts of East Lothian, to the north of the Lammermuirs. It was first inhabited long before the Iron Age, but reoccupied from at least Flavian times as the capital of the Votadini, a tribe whose territory extended down the coastal area between the Tyne and the Forth. It is possibly to be equated with the Curia mentioned by Ptolemy. ${ }^{3}$

This many times fortified settlement was allowed to remain in being throughout the Roman occupation, a fact which argues for some collaboration, and a great number of Roman as well as native objects were found during many seasons of excavations, unfortunately undertaken before scientific methods were adopted.

Local industries thrived at Traprain, and some of the metalwork (e.g., dress-fasteners of certain types $)^{4}$ stems from south-west English cultural traditions. Since, therefore, there were trade contacts between Southern Scotland and the Somerset region it is not surprising to find that the idea of making beads was also adopted in the north, and in fact the actual migration of craftsmen from Meare and Glastonbury cannot be discounted. In a paper

\footnotetext{
1 A 'Pictish' (c. ninth-century) date for these has been recently claimed in $P S A S \mathrm{cv}$ (1972-4), 197-8, but the Groy, Inverness-shire bead is in fact more probably a survival. See also Laing, L1. (1975), $33^{6}$.

2 Gurle, A. O. and Cree, J. (I9I5-24). For more recent
}

reassessments sce Hogg, A. H. A., in Grimes, W. F. (ed.)

(195I), 200-20, and PSAS lxxxix (1955-6), 284.

${ }^{3}$ Richmond, I. A., in Richmond, I. A. (ed.) (1958).

${ }^{4}$ Gillam, J. P., in Richmond, I. A. (ed.) (1958). 
published in I 938 Kilbride-Jones suggested that several types of glass armlets, sometimes decorated with a cable of two-colour twists, seem to have centred on, and perhaps been made at, Traprain Law notably in the first and second centuries A.D. ${ }^{1}$ Fused lumps of coloured glass have indeed been found there, and a number of crucibles containing coloured glass slag. Although exactly similar in technique, so far only one cable bead (Class 9) comes from the large numbers of varied examples from the site and in fact these beads show a notably more southern distribution. Newstead (at the time thought to have been an administrative centre frequented by many natives and one of the frontier posts where traders may have had to present themselves) has produced glass armlets and cable beads, as well as glass melon beads, all of which might have reached there from Traprain, only about forty miles away. But so far the melon beads are rare at Traprain. At least sixty beads have been recovered from Newstead, where the occupation was not a long one. Possibly it had a glass factory, and in Flavian times olive-green glass was not uncommon there.

The idea of the cable motif may have originated at either Glastonbury or Meare, from whose sphere of influence several early and tentative attempts to obtain a twist effect have been found. ${ }^{2}$ A more successful result could have been achieved at Traprain where a busy industrial centre may be envisaged; its cable-decorated products (if indeed they were made there and this is still only surmised) reached up to Moray to inspire the Taexali and Vacomagi to imitate them, even if in a crude way, at their Gulbin Sands factory.

\section{Wilderspool (Lancs.)}

This site in the territory of the Cornovii, ${ }^{3}$ stood beside the Mersey on the outskirts of Warrington, between Chester and Manchester, and seems to have grown up around a ford across the river, as it stands on a deposit of glacial sand among otherwise swampy land; it therefore controlled an important point in the communication system. It was excavated many years ago but unfortunately its true character was not established. Possibly the earliest occupation at Wilderspool was a military one associated perhaps with Agricola's campaigns in the late first century A.D. ${ }^{4}$ but the presence of native beads of both cable (Class 9 ) and Oldbury types (Class 6) hints at an earlier date in that century or even before. By the end of the first century some industries had been begun there, including potteries and, perhaps, a glass bead factory, for the site has produced not only a large number of beads but also lumps of glass slag and a small crucible containing 'black' glass paste. What appears to be an unfinished bead of opaque white glass with red and blue patches was also found. The evidence is presumptive rather than conclusive.

\section{Other sites}

Particularly after the Claudian invasion, glass waste or imported metal was made up at innumerable sites. ${ }^{5}$ The natives in the hill-forts in Wales, Scotland, and elsewhere must

\footnotetext{
${ }^{1}$ Kilbride-Jones, H. E. (1938) followed by Stevenson, R. B. K. (1954-5), and in Rivet, A. L. F. (I 966). For crucibles with plain glass outside and red, yellow, and possibly blue glass inside, see PSAS lvii (1923), 206. A glass rod for beadmaking is mentioned in ibid. 1 (1915-16); it was thought to be first- to second-century in date.

2 See pp." $77-8$, below.
}

${ }^{3}$ See Richmond, I. A. and Foster, I. Ll., in Alcock, L. (ed.) (1968) and Webster, G. (1975).

4 Thompson, F. H. (1965).

5 Note that Strabo (iv.6.3.) wrote that the pre-Roman Britons imported glass utensils, but did not explicitly mention beads. 
frequently have obtained bits of Roman glass, and as already mentioned Stevenson suggested in $1954^{1}$ that a purple and white marbled British type armlet from the hill-fort of Traprain Law, East Lothian, ${ }^{2}$ might have been made from a reworked Roman pillar-moulded bowl from a different level on the same site.

Glass canes for bead-making have been identified from a number of places and may represent the first stage of bead manufacture from reused glass. For some of these sites see Castlehill Fort, Dalry, Ayrshire, ${ }^{3}$ Caerhun, the Roman fort of Kanovium, ${ }^{4}$ the RomanoBritish settlement at Woodyates, ${ }^{5}$ Covesea Cave (Moray), ${ }^{6}$ the native hill-fort of the Votadini at Traprain Law (East Lothian), ${ }^{7}$ and the Romano-British temple at Lamyatt Beacon, Somerset (publication forthcoming), and from Caerwent in Monmouthshire. ${ }^{8}$ What appears to be red vitreous slag came from Airreoland Crannog ${ }^{9}$ in Ayrshire. Large blue melon beads may have been reused by native peoples. A number of these as well as blue glass slag came recently from Castleford, Yorks. (so far unpublished).

\section{ROMAN BEADS}

$$
\text { (see also pp. 91-I02) }
$$

With the Roman occupation, particularly after the mid-second century A.D., the picture alters. The native beads die out and the Romans in Britain never appear to have been much interested in jewellery not made with precious or semi-precious stones: the rest of their repertoire was very limited. It is surprising perhaps to find that the native British taste for variety in form and colour died out at so early a date. But this observation, albeit in another context, had already been made by E. T. Leeds in I933. He wrote: 'It is an incontestable fact ... that from about $25^{\circ}$ to the end of the Roman period, objects other than pottery which exhibit in any degree the influence of Celtic art in their decoration are distinguished by nothing so much as their scarcity.' His words are certainly applicable to beads.

The Roman villas, nearly all of which for climatic or economic reasons lie to the south of a line between the Tees near Middlesbrough and the Dee at Chester, ${ }^{10}$ rarely produce beads other than the small standardized types common to the northern Roman Empire: the finds are nearly all from towns (supply centres, one imagines), such as Cirencester, etc., from Roman military sites, particularly along the Roman Wall, to which they were presumably brought by camp-followers, or from sites such as Cold Kitchen Hill, Wiltshire, ${ }^{11}$ which was in all probability a sacred precinct where offerings might be expected. Recently large numbers of late Roman burials have been discovered at Cirencester (Gloucestershire), and Poundbury, near Dorchester, Dorset, as well as at Lankhills near Winchester, and at least in this last cemetery bracelets and other offerings were sometimes deposited in the graves. There is some evidence to suggest that offerings were not commonly placed with burials

\footnotetext{
${ }^{1}$ Stevenson, R. B. K. (I954), 216, followed by Newton, R. G. (I97I). The latter paper gives some results of microprobe analyses.

2 Curle, A. O. and Cree, J. (1920-1), r53-206.

${ }^{3}$ PSAS liii (1918-19), I23 ff.

4 Baillie-Reynolds, P. K. (1938).

5 Pitt-Rivers, A. H. L. F. (1887), pl. xliv, 23 and 24.
}

6 In the N.M.A., Edinburgh, no. H.M. 2 I 2.

7 PSAS1 (1915), fig. 26, no. I.

${ }^{8}$ Forthcoming in $M A$ 1974 or 1975.

${ }^{9} P S A S$ xxiii (1889), 148 , and $A C C$ vii (1894), 34 .

${ }^{10}$ Stevens, C. E. (I966), I26-7.

$11 W A M$ xliii (1925-7), 180-91, and 327-32. 
for some decades from about A.D. $320-30$, and this may explain the rarity of early fourth century necklaces. ${ }^{1}$ By the latter part of the fourth century, however, at Lankhills ${ }^{2}$ and Cirencester, for instance, the practice of making offerings to the dead was reintroducedperhaps under the influence of incoming central European foederati and craftsmen, who, outside the Roman Empire, had never lost their love of bead necklaces. For more information about non-Roman elements in Roman Britain, see pp. IOI-2.

During the Roman period, and apart from their ornamental use, beads also appear to have been made specifically for use as votive offerings at sacred shrines, wells, and temples. There are, in fact, several such sites some of which have yielded numbers of beads, both of Roman and immediately pre-Roman Celtic types, notably Coventina's Well at Carrawburgh, Northumberland (Procolitia), ${ }^{3}$ Farley Heath ${ }^{4}$ (temple) in Surrey (where the spread of Iron Age coins may have begun in the first century A.D.), Gold Kitchen Hill, Wiltshire (presumed sacred site), ${ }^{5}$ and Lamyatt Beacon (temple) near Bruton in Somerset, ${ }^{6}$ to mention a few of the better known instances.

Coventina's Well contained offerings of many varieties, including over 14,000 coins, pins, glass, potsherds, etc. The pre-Roman and Romano-British temple at Woodeaton (Oxford), ? also produced large numbers of coins, etc., and these facts prompted Anne Ross to write, 'it would seem that a workshop existed on the site, which manufactured articles for dedication in the shrine or shrines'. She adds, what is certainly apposite for the numbers of badly made segmented beads (see below pp. 9I-3) from both Lamyatt Beacon and Cold Kitchen Hill, 'the rather shoddy nature of many rings, bracelets and pins suggests that they were manufactured, not for hard wear but for immediate dedication'. In fact, as the same writer points out, 'markets were an integral part of Geltic religious festivals' ${ }^{8}$

Only presumptive factories for the production of Roman beads have as yet been discovered either in Britain or on the Continent, but the general uniformity of the design of beads leads one to imagine that the demand for them was not extensive and may have been covered by relatively few factories. The richer Roman citizens in the towns on the Continent and certainly in Britain showed little interest in decorated beads, perhaps considered barbarous, and preferred semi-precious stones, and at least by the third and fourth centuries very small glass beads, sometimes threaded on wire as bracelets or necklaces; the poorer people showed even more conservative and humdrum taste. In the early Roman period a few bright and large beads of Celtic type still survived, but by the third century they had almost all disappeared from circulation, and large gaily coloured beads were only reintroduced after the Roman Empire had fallen. Late Roman beads are very small and very common. It is interesting to find the fourth-century historian Trebellius Polio referring to the fashions among late Roman women of wearing numbers of beads (De Gallieno...).

A few definitely Roman types (or types of the Roman period current in the Empire) can be recognized, manufactured both inside and outside the confines of Roman territory and

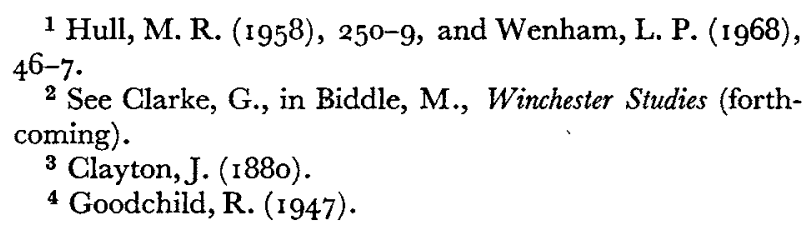

\footnotetext{
${ }^{5}$ WAM xliii (1925-6) $180-9$ I and $327-32$, and ibid. xliv (1928), $13^{8-42 .}$

${ }^{6}$ Information before publication from Mrs. Crystal Bennett and Mr. Roger Leech.

7 Goodchild, R. and Kirk, J. (1954).

8 Ross, Anne (1967), especially 46-8.
} 
large numbers in Egypt, Nubia, etc. (see refs. on p. I02). Sarmatian and other exotic beads can be found in Britain, and the recently discovered fourth- to fifth-century cemetery at Lankhills near Winchester has necklaces which can be paralleled in the Danubian area. Yet others, notably the colourless or 'amber'-coloured reddish glass beads enclosing sheet gold or other metal (see p. 93) came at least originally from more sophisticated glass factories in Egypt or perhaps Syria. It is only to be expected that Roman auxiliaries and their campfollowers brought in beads from the lands of their origin, and that Britons serving overseas in the Roman army would bring back souvenirs from the countries to which they had been posted. ${ }^{1}$ Branigan (1973) has made a strong case for the presence of Gaulish and Germanic people moving across to Britain, particularly to the Gloucestershire-Somerset area, at times of disturbance near the frontier on the Continent between about A.D. $270-300$. They were settlers, and must have left traces of their material equipment as well as their native types of villas, mosaics, etc.

By the third and fourth centuries, as mentioned above, Germanic peoples were coming to England, ${ }^{2}$ but their beads cannot be allocated to their proper origin until we know far more in detail of the Gallo-Roman and non-Roman areas from which beads were obtained. At the moment all that we can do is to try to recognize them as non-Roman. Their floruit in Britain at all events mainly falls outside the limits of the present enquiry, and calls for a separate study. Discussing the Anglo-Saxon cemetery at Caistor-by-Norwich in 1973, J. N. L. Myres writes that the 'culture so closely mirrors that of fourth century Schleswig and Fünen as to imply a fairly direct transference in considerable numbers from Continental Anglia. And certainly from the end of the fourth century, perhaps earlier, there was a considerable body whose direct antecedents were among the less coherent Saxon peoples of the lower Elbe valley and the vast lands extending to the Weser and Ems'. It should be noted, however, that others, e.g. Hawkes, S. C. (rg75), adopt a more cautious view.

\section{IRISH BEADS}

We do not know when beads began to be manufactured in Ireland: but there are several indications to suggest that the period of their real popularity was not earlier than the fifth or sixth century and so falls outside the scope of this book.

Yet there is growing evidence that Continental and British made Iron Age beads reached Ireland before the Roman period began in the rest of the British Isles. The part played by the so-called Irish Sea province has recently been discussed by a number of scholars ${ }^{3}$ and it has been shown by several that the Irish Sea acted as a barrier rather than a bridge between the rest of Britain and Ireland during the Iron Age and Roman periods-even if

\footnotetext{
1 For some notes on the military movements in the Roman period see p. 102. In Eastern Britain there were many Nordic inhabitants for a century before the Adventus Saxomum of A.D. 443-5. See $7 B A A$ (1972).

2 'By the fourth century even inland towns like Winchester were being provided with garrisons of Germanic mercenaries, for the Roman army could no longer protect
}

them.' Biddle, M., in $C A \times x$ (May 1970), 246. Among the many important works concerned with this period see Alcock, L. (1973) ; Hawkes, S. C. and Dunning, G. C. (196r); Corder, P. (1955); Myres, J. N. L., I969) and John Morris, The Age of Arthur: A History of the British Isles from 350-650 (1973).

${ }^{3}$ Thomas, G. (ed.) (1972). 
trade or sporadic settlers brought both Iron Age and Roman objects into Ireland. That this sea bore much traffic can be shown by several pieces of evidence, and these are supported by the distribution of some of the beads discussed in this study. A. H. A. Hogg ${ }^{1}$ has drawn attention to the great diversity in the hill-forts along the west coast of Wales; there is also a connexion between some second-century B.c. to first-century A.D. south-western wide-spaced multivallate hill-forts in Wales and in Devon and Cornwall with undated ones in Iberia, ${ }^{2}$ and such a connexion is emphasized by the 'duck-stamped' pottery and La Tène I fibulae of Iberian type from Cornwall. ${ }^{3}$ Hogg has also noted that 'chevaux-de-frise' defences were common in Iberia, Wales, Scotland, and Ireland. ${ }^{4}$ Barry Raftery ${ }^{5}$ has made an important contribution to Irish studies in isolating two main classes of Irish hill-forts; the wide-spaced multivallate ones (only in certain respects comparable with those described by Aileen Fox, referred to above) which have a notably south and west distribution, and the other classes bordering and inland from the Irish Sea: these have not yet been dated. The distribution of the two classes is almost mutually exclusive. It is possible, therefore, that more Iberian influences may have come into Ireland and also south-west England than are at present recognized, though the vague similarities are far too tenuous to support a serious thesis. ${ }^{6}$ To make matters more difficult there is a serious dearth of dating evidence.

The evidence for La Tène Celts in Ireland is still very meagre, ${ }^{7}$ but it is apparent that, during the few centuries before and after Christ, imported beads occasionally reached Ireland, either directly from the Continent, or indirectly as a result of movements up and down the Irish Sea and from the rest of Britain. Some of the foreign metal objects may reflect immigration movements into Ireland, others may have been copies, made locally, of a few acquired examples. It has been suggested that small groups arriving from overseas could have caused considerable social upheaval, ${ }^{8}$ but on the whole the continuity from the late Bronze Age to the Early Christian period seems to have been largely unbroken. Jope, however, ${ }^{9}$ has pointed out that connexions between British and Irish metal workshops began in the first century A.D. which ultimately produced a continuum in metalwork in the British Isles, and from then onwards Roman provincial styles and techniques pervade much of the Irish work.

Thus present evidence suggests that Ireland may not have had much interest in glass during the Roman occupation of Britain. Perhaps it was the difficulty in obtaining raw glass, combined with the lack of glass technicians, that explains why a site of such regal importance as Tara yielded such small and miserable specimens of beads, acquired in all probability from some area (Wales perhaps) under Roman influence. ${ }^{10}$ By the first century B.c. at least some Gaulish settlers may have established themselves in Ireland and their beads should be searched for. ${ }^{11}$

${ }^{1}$ In Thomas, C. (ed.) (1972).

2 Fox, A. (196r).

${ }^{3}$ Leeds, E. T. (1926-7), 227-38.

4 Hogg, A. H. A. (1957).

${ }^{5}$ Thomas, C. (ed.) (1972).

${ }^{6}$ Kenney, J. F. (1929), passim.

${ }^{7}$ Rynne, E. (1961).

${ }^{8}$ Harbison, P. (1971), 1 $74^{-6}$ and (1970).

${ }^{9}$ Jope, E. M. (1972), 30 .

10 OŔordám, S. P. (1954). Other Roman material might have reached Freestone Hill, Co. Kilkenny. See Raftery, B. (1969), I-108, especially p. 96. The small annular beads of blue and other colours (not examined by me) suggest a Roman date and Romano-British origin, although one decorated bead appears to have come from another, not identified, context. As Alcock writes, curraghloads of raiding Irish gathered treasures from the richer areas of Western Britain. Later, even the young Patrick was kidnapped by them.

11 Powell, T. G. E. (1958), 120. 
In the rest of the British Isles there was a Celtic political resurgence in the fourth to fifth centuries A.D. after 'the shift of power from Roman to native barbarian authorities', ${ }^{1}$ but when this renaissance did begin (and it probably started after St. Patrick's mission in the fifth century), the decorative motifs which emerged were not identical with those of earlier times. As Elizabeth Fowler stresses in another context, we are not dealing with either a survival or a revival so much as a reinterpretation, and this observation seems to be applicable to Ireland. Here a stagnant civilization was increasingly fired by the early Church to produce beautiful things. In her important study, Irish Art in the Early Christian Period to A.D. $800,{ }^{2}$ Françoise Henry writes: "The Christian art which will develop in the framework of the complex and changing circumstances just outlined passes first through a Phase of formation corresponding more or less with the time when Ireland was almost completely isolated from the Continent by pagan England, and so approximately covers the end of the fifth, the sixth and part of the seventh centuries.' Only after this formative period did the real floruit of true Christian art reach its height between $650-800$, and I think that the main output of Irish glass beads may have corresponded with this latter period, even if it began in a more tentative way somewhat earlier. The monasteries grew in size and wealth in the later seventh century and inspired an outburst of craftsmanship. ${ }^{3}$

It is probable therefore that this Irish glass-making renaissance took place at too late a date to be included in the terms of reference of this study. It is possible that the people responsible for the introduction of 'Late Roman B and C Wares' from North Africa, Egypt, the Levant, etc., may have brought with them glass-wares to be imitated, or even skilled Mediterranean glass-workers between about A.D. 500 and 700. Combed and ribbed amphorae came in from the Aegean and Asia Minor a little later; and it is interesting to find that these all seem to have arrived-perhaps together with monastic ideas-direct from the East Mediterranean.

In North Wales (raided by Scotti from Northern Ireland in the late third and fourth centuries), there are no recognizably Irish beads, and this is also so in south-west Wales when the Irish founded Dyfed in about the late fourth century A.D. and in Argyllshire where the Dalriadic Kingdom was founded in the fifth century. We must remember that there was, during Françoise Henry's phase of formation, considerable activity along the western sea routes which alone in the fifth to sixth centuries were able to maintain contact with what remained of Roman civilization in Gaul and the Western Mediterranean, ${ }^{4}$ and Bowen also points out that 'there is archaeological evidence to show that following the withdrawal of Roman control from Britain many Irish immigrants crossed the Irish Sea'. Their influence is particularly well-marked in south-west Wales. The evidence is negative it must be admitted, but if Irish glass-working was thriving in the fourth to fifth centuries it might be reasonable to expect their products to be found in the lands to which they emigrated, particularly in Dyfed in Wales and Dalriada in Scotland. Future evidence may provide an explanation, but at present it is difficult to infer that Irish bead production was significantly

\footnotetext{
${ }^{1}$ Fowler, E. (1964), 134.

${ }^{2}$ London, Methuen. Revised edition, 1965.

3 De Paor, M. and L. (1961) (3rd ed.), 1 I o ff. It must be remembered that the seaways from the Coptic East to
}

Ireland had remained open without serious interference. See also Thomas, C. (1971), and a valuable discussion of beads in Hencken, H. O'N. (1942).

4 Bowen, E. G. (1954). 
active before about the sixth century $;^{1}$ but we sadly lack dated examples. Jewellery, church plate, and the great illuminated manuscripts belong chiefly to the artistic achievements of the seventh to ninth centuries; glass-work may have reached the peak of its technological and artistic ingenuity in Ireland at the same date.

1 Although originally imported from Egypt in Roman times, millefiori glass seems to have been made in Ireland, and possibly Wales as well, during these centuries. For instance the industrial waste at Garranes (fifth-sixth centuries) described by ÓRíordám, S. P. (1942), and at Lagore (later) included crucibles and composite glass rods. See Hencken, H. O’N. (I95I).
For Wales see Alcock, L. (1963), Io-12. There is one piece from Scotland, perhaps of Irish origin, from Luce Bay, Wigtownshire. (Anf 1 (1970), 332-3).

It is interesting to note that some of the beads from the Dalriadic stronghold of Dunadd in Argyllshire were imported Gallo-Roman beads, not, as might have been expected, Irish, unless they were Irish copies. 


\section{DESGRIPTION OF BEAD CLASSES AND GROUPS}




\section{•}




\section{PART III}

\section{BEADS OF GONTINENTAL ORIGIN OR INSPIRATION}

(i) Decorated Classes (Iron Age) (pp. 45-59)

(ii) Decorated or undecorated Groups (Iron Age or Roman dates) (pp. 59-7I)

\section{(i) DEGORATED GLASSES OF THE IRON AGE}

\section{CLASS $I$}

Arras Types I and II (Schedules, pp. I05-7) (pl. I, no. I and figs. 5 and 6)
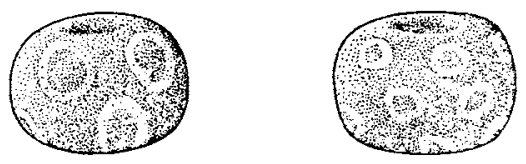

FIG. 5: Arras type beads of Class I: left, Type I; right, Type II. Scale I/I.

The characteristics of these two types are that they are both normally about $12 \mathrm{~mm}$. in diameter and Io $\mathrm{mm}$. in height. They are invariably dark blue, decorated with white rings round blue eyes. In Type I the fewer and larger eyes are defined by white rings marvered into the ground colour of the bead, and these white rings have often fallen out and leave only the circular groove around the eye which is part of the ground of the bead; Type II has many more eyes and they are what have been called 'stratified', i.e., they are made by filling a saucer-like depression first with opaque white and then adding a central blue blob which, overlying the white, appears to be brighter and more translucent than the ground colour.

These are possibly among the earliest Iron Age beads to have found their way to this country, and though their precise dating is still elusive they can be dated approximately to certain Iron Age contexts which will themselves, within a short time, through the use of radio-carbon and other newer dating methods, be much more precisely understood.

Type $I$ is much the less common of the two varieties, and is only present in Britain at Cowlam Barrow $\mathrm{L}$ and Arras (Queen's Barrow, Market Weighton, in Yorkshire) and from a site (Lake, or Winterbourne Stoke in Wiltshire), whose dating will be discussed below.

Type $I I$ is more widespread and shows a distribution (see fig. 6) which extends from the Bristol Channel and Wessex area via the Jurassic Way into Yorkshire.

The 'Arras' culture (the earliest phase of which is known as the Cowlam phase or Phase I) has produced various finds including both Type I and Type II beads and has received considerable 
attention in recent years. ${ }^{1}$ The graves both at Arras itself and at Cowlam and elsewhere in East Yorkshire were excavated in the last century. ${ }^{2}$

The two graves which most concern us here are Grave $L$ at Cowlam and the so-called Queen's Barrow at Arras, characteristic respectively of Phase I and Phase II of the culture.

Grave L at Gowlam produced one Type I bead and some blue beads with white waves, and also two important bronze objects, a brooch paralleled from a Münsingen Ia context in Switzerland, and a bracelet which also has a late Hallstatt or early La Tène analogy from the Continent. A comparable bracelet and brooch were found together in a grave at Yvonand (Switzerland) and are cited by Stead. Switzerland has, it should be noted, also produced Type I beads. ${ }^{3}$

It is not clear yet whether these Cowlam graves and the subsequent ones from Phase II of the Arras culture reflect a direct intrusion from the Marne district of Northern Champagne (for cart or chariot

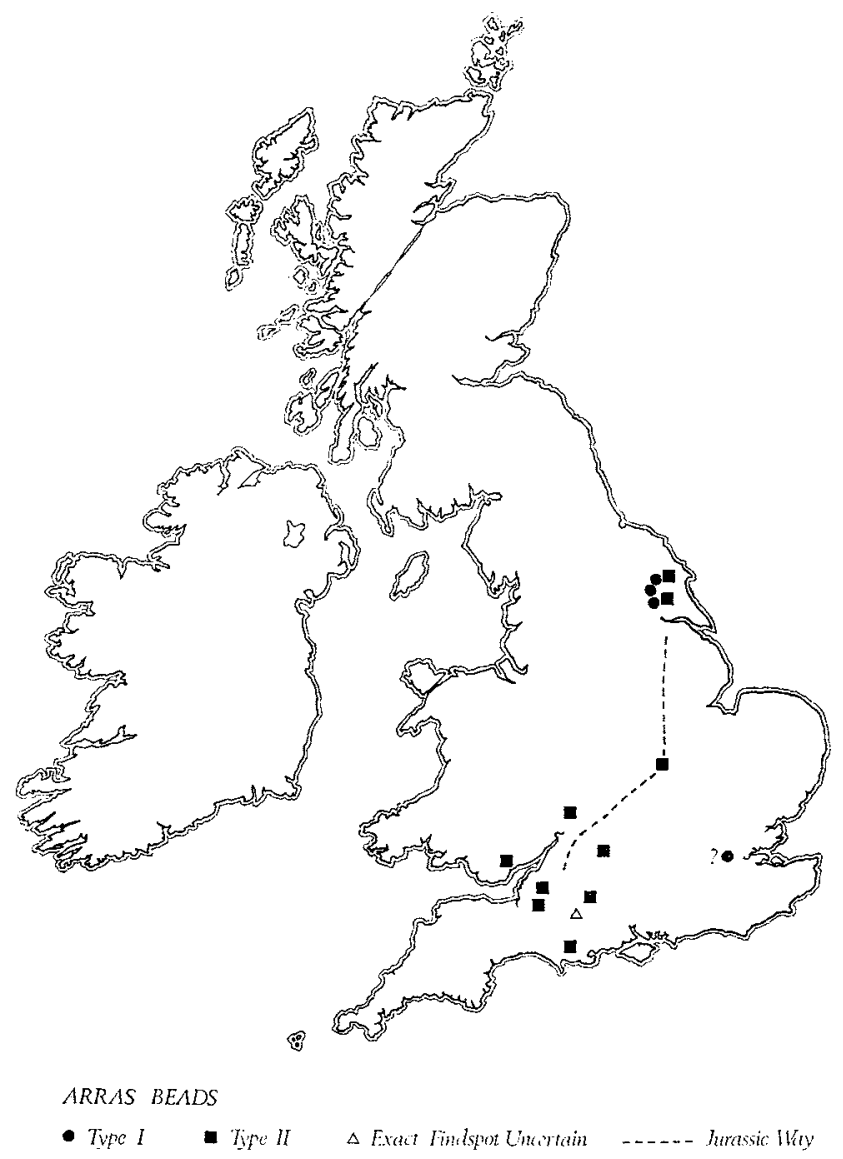

FIG. 6: Distribution of Class I beads.

1 Vital to the discussion is Stead, I. M. (1965) and (1971). Note also Harding, D. W. (1974), 173-6, and Bretz-Mahler, D. (197I). The French Marnian sites still await detailed and full discussion in the light of modern excavations.

2 Many barrows at Arras were excavated as early as 1816 by the Rev. Mr. Stillingfleet; the finds are in the Dept. of
Prehistoric and Romano-British Antiquities in the B.M. One was examined by Greenwell and published in Greenwell, W. (1877), 208-9 and in (189o) and (1906). See also $\operatorname{ArJ}$ xxii (1865), $97-117$ and $241-64$.

${ }^{3}$ Viollier, D. (1916), pl. 22, no. 122. 
burials are also characteristic of both the French and English sites). It has been written, 'while certain resemblance to Champagne is present there are equally clear affiliations with the more southerly La Tène complexes in Burgundy and even Switzerland'. ${ }^{1}$

The second phase of the Arras culture is best represented by the Queen's Barrow, Arras. Here 28 beads of the Cowlam (Type I) variety and 18 of Type II were found, together with 'natural' greenish glass beads with yellow waves and blue beads with white waves. Also present were other finds particularly bronze bracelets of a knobbed type, one of which was also found in one of the Cowlam graves (Barrow LI).

There was therefore an overlap between the Cowlam phase and the rather later Arras or second phase. Chronologically neither is very clearly assignable, but since a number of Type II beads have been found from approximately datable contexts in Britain (see below), the Cowlam phase may have begun around the fifth century or so, and Harding may be right in regarding the Arras culture as part of a Marnian contact which mainly affected southern Britain and which he also tentatively identifies with certain pottery forms. ${ }^{2}$

At least the Type II, and probably the Type I beads as well, originated apparently in the eighth or seventh century in Phoenician lands (there are a number for instance from Bet Shean which were found with a late seventh-century glass amphoriskos, in the museum at Jerusalem). Thence they spread to Corsica, Minorca, Italy, ${ }^{3}$ Yugoslavia, ${ }^{4}$ Czechoslovakia, ${ }^{5}$ and Austria (Hallstatt) ${ }^{6}$ Almost surely they were copied in Central Europe as they occur in the Vosges, Aisne (the Caranda cemetery whose beads are in the museum at Rennes), and others come from a Somme chariot burial (Beck Collection). In Châlons-sur-Marne Museum there are beads of this type in the Bérard Collection; they are also recorded from Marson, Marne (in the British Museum), and from the Mont-de-Vraux cart or chariot burials ${ }^{7}$ as well as from Bergères-les-Vertus and Bussy-le-Château (both Marne). ${ }^{8}$

The Type II beads from Britain include examples from Meare, Somerset(? third to first century B.c.); Swallowcliffe, Wilts. (? fifth to fourth century B.c.); Arras (Queen's Barrow, which also produced the Type I beads referred to above) ${ }^{9}$ (? third century B.c.); Conderton Camp, Bredon, Worcs. (from a late phase of the second main period not yet published but almost certainly third or second century B.c.); Whitton near Barry, Glamorgan (perhaps first century B.G.); Hunsbury, Northants. (? third to first century B.c. hill-fort, strongly influenced by the Yorkshire Iron Age, ${ }^{10}$ and also receiving lead from the south-west); Maiden Castle, Dorset ${ }^{11}$ (an earlier stray found in a deposit of the late second to early first century B.C.). Recently some more beads of this type were discovered at Garton Slack near Driffield, Yorks., with an inhumation burial (perhaps of the third century B.G.) near but not associated with a rich cart burial. ${ }^{12}$

\footnotetext{
1 An xl (1966), 234 .

2 Harding, D. W. (1974), particularly his Chapter 1o, pp. $157 \mathrm{ff}$.

${ }^{3}$ Gozzadini, G. (187o), pl. xv, fig. 1 3 ; others, from Palestrina, dated fourth to second century B.c. are in the Villa Giulia, Rome, and others come from many sites in Etruria as well as from Cumae, etc.

${ }^{4}$ Wissenschaftliche Mitteilungen des Bosnisch-Herzogowinischen Landesmuseums, Band I, Heft A (Sarajevo, 1971). Arras Type

II beads dated from associations to $c$. 250-I IO B.c.

5 Venclová, N. (I97I), fig. iii, I.

${ }^{6}$ Von Sacken, E. F. (1868), pl. xvii, figs. 32, 37.

7 Schmidt, E. (1924), I5-20.

${ }^{8}$ In the museum at St. Germain-en-Laye. Others may be cited from fifth-century graves at Villeneuve-Renneville
}

and Gaurgancon, and from late fifth- to early fourth-century graves at Pierre-Morains, 'Les Champs Écus' (all in the museum at Épernay).

${ }^{9}$ Davis, J. B. and Thurnam, J. (1865). See also the Proceedings of the York meeting of the Archaeological Institute ( 1892 ).

${ }^{10} \operatorname{Arf}$ xciii (1936). In this connexion it is necessary to remember that Hunsbury, lying on the Jurassic Way, also yielded an Arras cart-burial type bridle-bit and two-linked snaffle-bit of Polden Hill type, reflecting southern British and Yorkshire influences passing up and down the route. See ArF cx (1953), 2 I 2-I3.

11 Mistakenly compared with a bead of later type from Newstead, Roxburghshire.

12 Note in $A n$ xlv (1971), 289. Report forthcoming. 
The dating, being somewhat vague, leaves us in doubt whether the beads of Type II at least (and possibly Type I) were first introduced into Yorkshire from the Continent and so through the course of trade found their way down the forest-free Jurassic belt ${ }^{1}$ to Wessex and the Bristol Channel area or whether they first entered the south coast ports and spread northwards.

(A word of warning should be given. A similar but larger bead with Type II affinities was discovered in a Viking grave at Ballinaby, Islay, in the Hebrides ${ }^{2}$ : this is probably a later version of an early design after a long interval, and unlikely to have been a reused early bead.)

\section{CLASS 2}

Welwyn Garden City type beads (Schedules, p. I07) (pl. I, no. 2 and fig. 7)

Perhaps it seems somewhat arbitrary to claim that only two beads can be called a Glass, but nevertheless it is worth drawing attention to them as other comparable beads may turn up in the future.

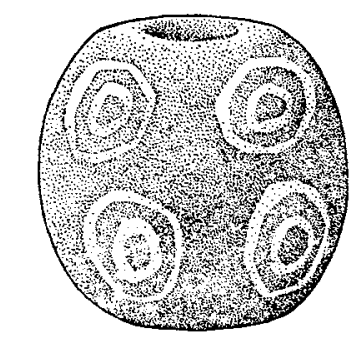

Fig. 7: Class 2: Welwyn

Garden City type. Scale $1 / 1$.

These beads, from Hertfordshire and Sussex, respectively, are rather big, globular beads ${ }^{3}$ made of dark blue glass into which two registers of eyes enclosed by two irregular white circles have been marvered. These 'eyes' are both very much larger and more irregular than those on the Arras Type beads just discussed (pp. 45-8). A small fragment of such a bead might readily be confused with one of the Oldbury type (Class 6 , pp. 53-7, below) if the full development of the globular form and the white rings were incomplete.

Both these beads are relatively closely datable. The Wiggonholt (Pulborough) one, found in a large pit full of Romano-British pottery of the first to second century A.D. and a coin of Vespasian, was only a fragment and almost certainly came from some earlier occupation material. The Welwyn Garden Gity one, of which less than half the bead was included with the burial, is more satisfactorily dated, as it came from a rich late La Tène III grave, one of a group of comparable burials in south-east England, in this instance with grave goods including some Italian imports which place its date within the last quarter of the first century B.c. $;^{4}$ both of these beads of course might have been old and prized when buried.

Where these beads were made is not yet clear, but they belong to a tradition which one would expect to find in northern Italy, where there are a number of large globular beads as distinct from the more numerous annular beads in Central Europe. It is believed that glass bead factories were operating in

\footnotetext{
${ }^{1}$ See Grimes, W. F. in Grimes, W. F. (ed.) (1951), 144-71.

2 PSAS xiv (1879-80), $51 \mathrm{ff}$.

${ }^{3}$ In my opinion the Welwyn Garden City bead was incorrectly restored in the published drawing. It appears to
be globular rather than annular, and to have a rather narrow perforation.
${ }^{4}$ Stead, I. M. (1967), fig. Ioc.


northern Italy and at the head of the Adriatic, ${ }^{1}$ and Beck illustrates a somewhat comparable though earlier small bead from Italy. ${ }^{2}$ It may be significant to note that the Welwyn Garden City bead, buried perhaps as a prized fragment or as a die for a game, came from a cremation in a large rectangular grave without any mound, in which not only the tomb type itself, but also the coloured glass gaming pieces found in it, find their nearest parallels from Montefortino in the Marche, belonging to the Gaulish tribe known as the Senones: these graves were, however, three centuries earlier than the Welwyn Garden City burial. The latter, which is one of a group of eight of the same type, all confined to the southeast of Britain, contained a silver cup and amphorae of Dressel Type $\mathrm{I}^{3}$ of Italian origin. Four other comparable graves are recorded from the Continent and cited by Stead: two from Arras in the Marne and two from Presles-et-Bores (Aisne) but other comparable beads are not yet known to me.

The Welwyn Garden City burial also produced a fragment of a brownish glass armlet with an opaque yellow scrawl around its circumference, and a brown and yellow bead: both are types similar to late Geltic ones from the Continent.

The pottery is characteristic late La Tène III Aylesford-Swarling ware, with some Continental imports.

To sum up: the beads belong to the latter part of the first century B.c., and lingered, at least as survivals, until the Roman conquest. Their possible origin is in Italy or the head of the Adriatic, but this cannot be affirmed with any certainty so far as our present knowledge allows.

\section{CLASS 3}

Large annular beads with eyes of blue or other colours ringed with white (South Harting type) (Schedules, pp. 107-10) (pl. I, no. 3 and II top left, and figs. 8 and 9).

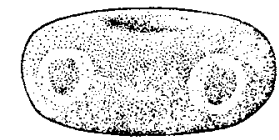

Frg. 8: Class 3: South

Harting type. Scale $\mathrm{I} / \mathrm{r}$.

These are fairly large annular beads with a diameter of approximately $20-30 \mathrm{~mm}$. and a height of about $\mathrm{I}^{-20} \mathrm{~mm}$. Almost invariably they are made of dark blue glass, and they generally have three equidistant eyes, marvered flush with the surface of the bead. These eyes are often of different coloured glass but are always surrounded with an opaque white ring. Occasionally there are only two eyes, and related specimens may have two or more registers of eyes.

These are not Roman beads and certain British examples belong to about the first century B.c. (e.g., Wookey Hole, Somerset), but the majority seem to fall within the early Romano-British period, and it is improbable that many survived into the third century. They are present in England, Wales, and Scotland but not in Ireland.

Continental beads of somewhat similar type are known from the Marne district and elsewhere-e.g., from Recy Voie Chantereine with yellow rings round the eyes found with ring beads whose affinities lie with our Hanging Langford beads (see pp. 51-3). Some smaller examples are also recorded from Gaulish graves but exact parallels are not readily found.

1 See Harden, D. B. (1967).

2 Beck, H. C. (1928), 43, no. A.7.b.

${ }^{3}$ For a discussion of these amphorae and their major concentration in Wessex, and more especially in Trino- vantian territory to the north of the lower Thames around Colchester and Welwyn see Peacock, D. P. S. (1971), I $6 \mathrm{I}-79$. 


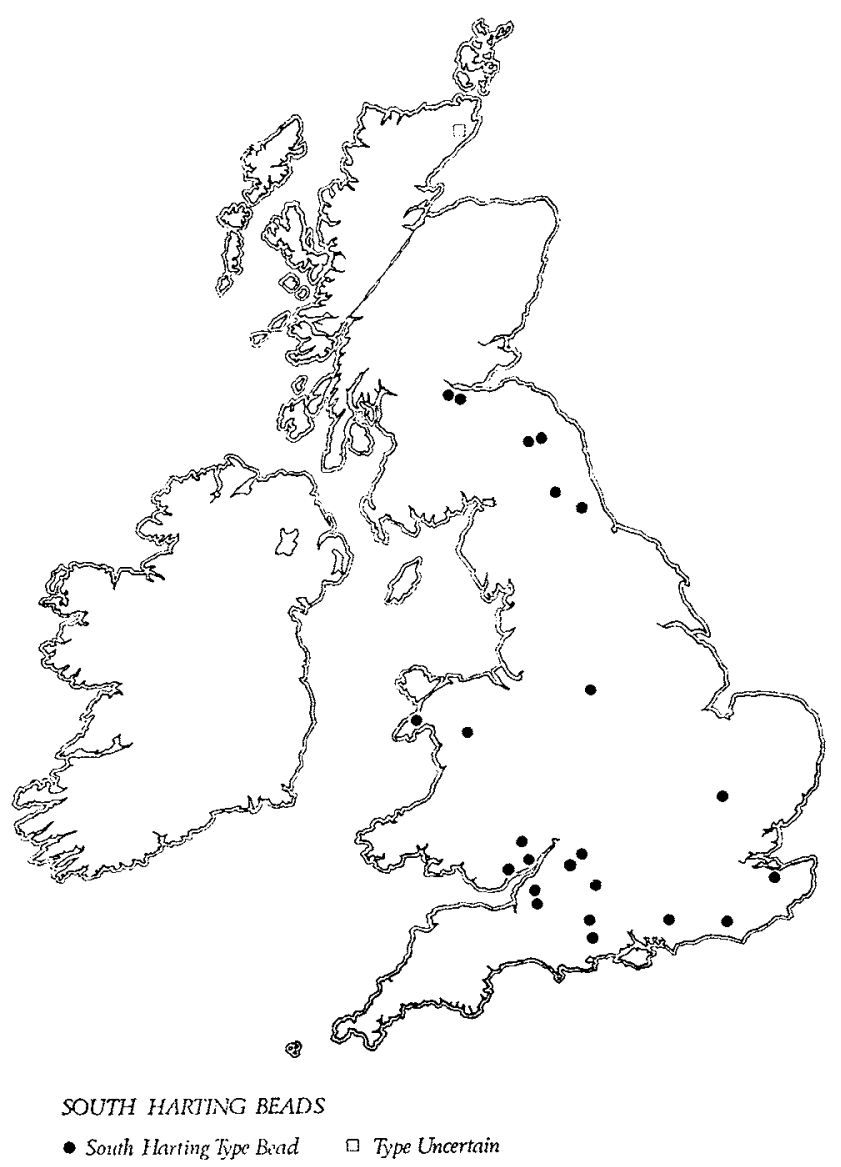

Fig. 9: Distribution of Class 3 beads.

A glance at the distribution map shows that the type is widespread and was carried northwards to early Roman sites in Scotland. It is possible that, as they seem to be commoner in Britain than in France or other parts of the Continent, they were manufactured in this country-but this apparent absence of exact parallels from across the Channel may only reflect our lack of knowledge, particularly of Gaul in the first century B.a.

\section{CLASS 4}

Opaque yellow beads with two superimposed rows of blue and white eyes (Findon type) (Schedules, p. I Io) (pl. I, no. 4 , and fig. 10).

Although a well-defined class on the Continent, only a few of these beads seem to have reached the British Isles, though in various sizes they are very common over the Mediterranean area and parts of Gentral Europe, as are their blue-green counterparts, not recorded from Britain.

In England, unfortunately, both the Woodeaton example and the one without provenance from the Nightingale Gollection were found without associations.

The Findon one, from a ritual site with pottery of Park Brow affinities, is in our present state of 


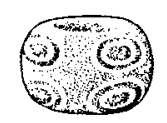

Fig. 1o: Class 4: Findon type. Scale $1 / 1$.

knowledge rather vaguely dated to probably the fourth or third century B.C., and the long period during which these beads were popular on the Continent makes it impossible to be more precise.

In Italy they are common, and are found for instance at Palestrina ${ }^{1}$ in the fourth to second century B.c. (in the Villa Giulia Museum in Rome) and many other sites, including earlier Etruscan tombs. ${ }^{2}$ Nearer to Britain they are known from France with Arras type beads at Vraux ${ }^{3}$ and other Marnian cemeteries, e.g., five or six examples from St. Etienne-au-Temple, and ten from Bergères-les-Vertus. ${ }^{4}$ Others came from Villeneuve Renneville near Epernay (fifth century B.c.) (this was of the almost equally common double variety in which one bead is made with another similar element above it), and from the Nécropole de Pernants (with La Tène I chariot burials, etc.). The latter was found close to, and perhaps originally hung from, a torc on the left shoulder. They are also found at similar dates on Punic sites in the Mediterranean world.

In Bohemia they may have continued in fashion into the second to first century B.c. at Stradonitz. ${ }^{5}$ Others can be quoted from Mladší Doba Zelezná; Tumulus XIII, Grab 36 at Smarje (Sankt Marein); Magdalenska Gora (Slovenia); and from the salt mine site at Hallein (in the Keltenmuseum, Hallein in Austria). In Holland the type is represented in the fourth to third centuries B.c. (in Leiden Museum).

It is impossible at present to try to locate their cultural and chronological range on the Continent, but one thing is fairly certain: their absence in the vast majority of late pre-Roman sites indicates that they were only surviving as rare heirlooms as late as the first century B.c. which may be the date of the one from Stradonitz. Their initial production in the Mediterranean area may go back to the sixth century or even before.

\section{CLASS 5}

Clear colourless annular beads with opaque yellow round the inside of perforation (Hanging Langford type) (Schedules, pp. I I I-I 2) (pl. I, no. 5, and figs. I I and I2).

These annular beads are generally about $20 \mathrm{~mm}$. in diameter and about $6 \mathrm{~mm}$. in height; the straight perforation measures about $10 \mathrm{~mm}$. across. Around the perforation on the inner side of the bead, an irregular and discontinuous band of opaque yellow glass has been applied in such a way that it glows through the clear colourless glass like its prototypes which may have had gold foil enclosed to give the same though more brilliant effect. ${ }^{6}$ It is possible that the smaller 'armlets' (sometimes under $50 \mathrm{~mm}$. in diameter) and the beads were hung from torcs.

Exactly how the opaque yellow was applied is not known, but Déchelette when describing Continental La Tène II armlets decorated in the same technique, says: 'Mon. Viollier estime plutôt que la pâte jaune a été étendue au pinceau une fois le bracelet froid.' An alternative suggestion is that the

\footnotetext{
1 NS (1907), I 44 .

2 Examples of the sixth to fifth centuries B.c. are in the Ashmolean Museum at Oxford, and others come from Staré Vače in Yugoslavia.

${ }^{3}$ Châlons-sur-Marne Museum. See also Bretz-Mahler, D. (1971).

4 St. Germain-en-Laye.
}

\footnotetext{
5 Pič, J. L. (1906). For other Czech ones see Venclová, N. (1971), fig. ii.

6 These are noted by Haevernick, T. E. (1960): Groups I (armlets decorated with enclosed gold foil) and 20 (beads of the same type, which she notes are often found on the Continent in a melted state in cremation graves).
} 


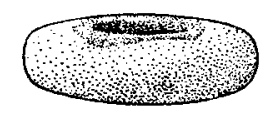

Fig. 11 : Class 5 : Hanging

Langford type. Scale $1 / 1$.

yellow was applied to the mould itself and then fired to the bead when the molten glass was poured in. ${ }^{1}$ The techniques of lining clear glass with opaque yellow first perhaps began to be used for glass vessels and armlets rather than for beads on the Continent, and some early ones, perhaps fourth to third century B.c., have been noted from Montefortino in Italy, ${ }^{2}$ and others are quoted from Monte Rolo San Vito, and from Corroy in the Marne. ${ }^{3}$ In the museum at Mainz there is one from the Rheinhessen, and there are second- to first-century в.c. examples from the Dürrnberg, Hallein, in Austria. ${ }^{4}$

The earliest of the British examples may be around the second century B.c. An armlet of this type comes from Castle Dore in Cornwall, ${ }^{5}$ a site whose first occupation is unlikely to have been much after about I 00 B.c. Another, perhaps of the first century B.c. or early first century A.D., was found at Ballacagen, Isle of Man. ${ }^{6}$ This had a comparable yellow coating inside but also had moulded cable patterns which may mean that it was a local British production (see Class 9 beads). This finds a partial analogy in a badly made armlet from Kintore, Aberdeenshire. ${ }^{7}$ A bead from the hill-fort of Hunsbury, Northamptonshire, also probably belongs to the second to first century B.C.

The two Meare examples may belong, not to the earliest phases of the site, but more probably to the second to first century B.c. (see above, pp. 32-3.)

The hill-fort of Hanging Langford in Wiltshire has not yet been dated, but the finds, while including a La Tène I type fibula, are predominantly Belgic and approximately dated first century B.C. to first century A.D.

Both at Maumbury Rings, Dorchester, Dorset, ${ }^{8}$ and Nor'nour in Scilly the beads come from what may be early Romano-British contexts. The Irish bead could have been traded up the western sea-ways, and the Faversham, Kent, bead was evidently a reused earlier one found in a Saxon context. There are other instances of such reuse. In the British Museum a bead of this Class has been reused in a Frankish necklace from the Rhineland, and in the Ashmolean Museum in Oxford a bead of Oldbury type (Class 6) has been found in a Saxon grave at Ducklington.

The distribution pattern (fig. I2) is unlike that of the other colourless beads with opaque yellow designs which may have been manufactured at or at least distributed from Meare in Somerset, and which do not seem to have Continental analogies. The hypothesis must therefore be that the Hanging Langford Class beads came as imports into the south-west of England, perhaps from northern France or Brittany. They may of course have subsequently been copied in Britain, probably, if anywhere, at Meare.

Continental beads comparable to the British ones are not uncommon. To mention only a few, examples come from Recy Voie Chantereine in the Marne, ${ }^{9}$ found with beads of oppida types such as were found at Stradonitz (second to first century B.C.) and from Manching, of the same date. ${ }^{10}$

1 Viollier, D. (1916).

${ }^{2}$ Brizio, E. (1899).

3 Morel, 1.. (1898), pl.

${ }^{4} M A G W$ (1926), 324-6 and Abb. 2.

5 Radford, C. A. R. (I95I), App. 68-9.

- $\mathcal{} M M$ v, no. 72 .
${ }^{7}$ Kilbride-Jones, H. M. (1938), 305 .

${ }^{8}$ Recently incorrectly compared to a Bulbury-type bead in $A \mathrm{cv}$ (1974-5), 197-8. Incorrectly drawn in fig. 20, no. 10.

9 Châlons-sur-Marne Museum.

10 Krämer, W. and Schubert, F. (1970). 


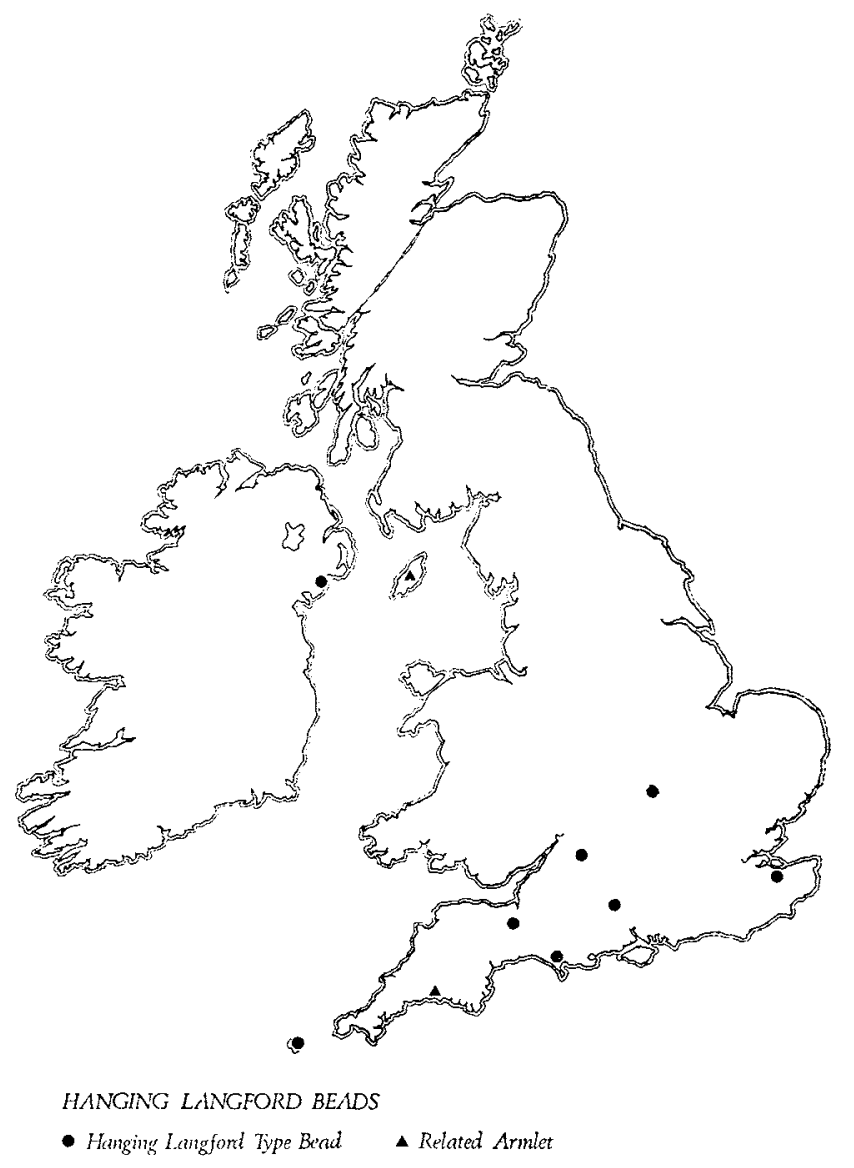

FIG. 12: Distribution of Class 5 beads.

Others come from the Worms district ${ }^{1}$ and from Corseul, Côtes-du-Nord. ${ }^{2}$ Their departure point from the Continent cannot yet be indicated.

It seems convincing that the period of their floruit in Britain lasted from the second century B.c. to the first century A.D., dying out after the Roman conquest.

\section{CLASS 6}

Large blue annular beads with marvered white or yellow spirals (Oldbury type) sometimes with swags between the spirals (Colchester type) (Schedules, pp. I I2-17) (pl. I, no. 6a and b and II, top left and figs. 3 and i4).

Beads which have been called the 'Oldbury' type from the site in Kent where such a bead was discovered and well illustrated, have the following characteristics: they are roughly $25-30 \mathrm{~mm}$. in diameter and rather more annular than globular, about $15^{-20} \mathrm{~mm}$. in height. The perforation, almost invariably cylindrical, is approximately ro $\mathrm{mm}$. wide. The glass (with the few exceptions mentioned below which may not belong to the same period) is dark, almost opaque, blue, appearing to be nearly black sometimes unless held to the light. The ornament generally consists of three, more rarely two,

1 Worms Museum.

2 B.M. Dept. of Prehistoric and Romano-British Antiquities. 
registers of trailed and marvered spirals, carefully made in opaque white, or less commonly yellow glass, round the circumference of the bead often on small bosses (perhaps vestigial 'horns').

A variant of the Oldbury Class is here called the Colchester Glass (B). It is distinguished by having opaque yellow glass double swags running between the spirals.

Both these Glasses belong to a well-known Continental Celtic type which can be ascribed to the last I50 years or so B.G., and they are particularly common during the later first century B.C. This date perfectly well accords with the evidence from the British Isles where quite a number come from datable
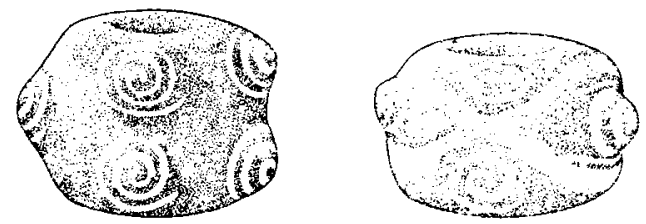

Fig. 13: Class 6: left, Oldbury type (A); right, Colchester type (B). Scale I/I.

contexts. The beads from the Iron Age site of Oldbury itself unfortunately came from a fox's earth from a twice-occupied fort which, though originally thought to be later, has been reconsidered. ${ }^{1}$ It is now thought to belong to the early first century B.c. in its initial phase and to have been refortified about a century later 'by people whose pottery was largely if not predominantly Belgic in character'. The defences of the refortification had an unusual flat-bottomed ditch of a kind well represented in the Seine-Inférieure. ${ }^{2}$ Of about the same date was the Maiden Castle (Dorset) bead, stratified in a deposit of the early first century B.c., and both the Meare and Glastonbury (Somerset) beads should belong to the early first century or so, as the Meare one does not apparently belong to the first phase of that settlement in the third century.

The Breiddin in Montgomeryshire produced a bead which 'could have been associated with a timberbuilt round-house assigned to the first century B.C. to first century A.D.', and another came from the Iron Age fort of South Gadbury in Somerset. Yet another has recently come from Beckford near Tewkesbury, and another from Danebury, Hants, thought to belong to the early first century B.c.

These beads survived into the early Roman period, and on one or two occasions were rediscovered and reused in Saxon times ${ }^{3}$ but they were only survivals by Roman times as their importation was presumably brought to an end with the conquest. However, some dated examples are known. The Colchester bead was possibly pre-conquest in date, belonging, according to Harden, D. B. (I947), to Period III (dating from A.D. 43-8) or IV (from A.D. 48-65). Roman period examples of Oldbury type include the following: Dorchester (Dorset) ${ }^{4}$; Burnt Fen (Cambridge); Yewden (Bucks.); Old Winteringham (Lincs.), probably Glaudian; Chichester (Sussex), with objects of late Antonine date.

The Irish examples are unfortunately almost all without provenance except for one from Dun-namara (Go. Tyrone). These beads may have reached the east coast of Ireland through trade, or have been carried by refugees moving northwards (see below). It is, however, possible that such beads may have been imitated in Ireland once the local glass-workers really developed their skills in a period which appears to fall well outside the scope of this study (see pp. 39-42).

The pattern of distribution (shown in fig. 14) points to a main area of import centred along the south

1 In view of new evidence from Rainsborough Camp, Northants. See PPS xxxiii (1967), $207 \mathrm{ff}$.

Museum).

4 From the Colliton Park villa. See R.C.H.M. Dorset,

${ }^{2}$ Anf xxi (1941), 265-70.

E.g., from a Saxon grave at Ducklington (Ashmolean vol, ii (South-East), pt. 3. 


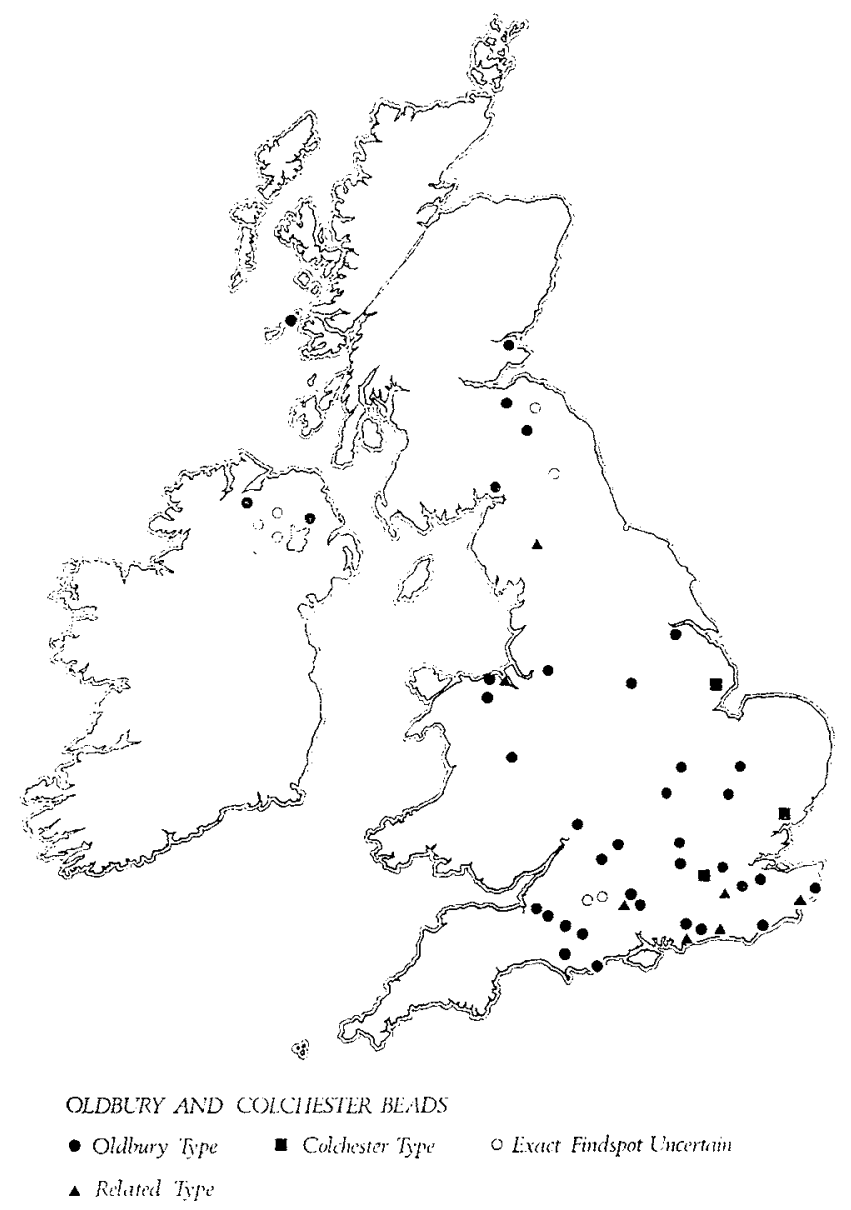

Fig. 14: Distribution of Class 6 beads.

coast, particularly around Kent, Essex, and the Thames estuary, and in Dorset. Some may have come up the Bristol Channel or perhaps reached Somerset and Gloucestershire from the southern counties. From these areas they also spread northwards by both west and east sea routes to reach Northern Ireland and south and west Scotland-perhaps between A.D. 43 and $7 \mathrm{I}$ if not before. Their greatest density is shown to be the area of Belgic settlement or influence in south-east England, and these beads may possibly find a place among the many objects of so-called 'Belgic' type which reached the south of Scotland: cauldrons and cauldron-chains, ${ }^{1}$ certain types of brooches and polychrome enamelling, ${ }^{2}$ a bronze brooch of Type Bii from Graig's Quarry, Dirleton, ${ }^{3}$ loop or ring-ended torcs such as those from Snettisham (Norfolk) and Cairnmuir (Peebles), and the related Castle Newe torcs which are apparently skeuomorphs of the loop-ended variety. ${ }^{4}$

In Treland, it is hard to explain all the examples as coming from ports of call up the western seaways, for as Jope has shown, ${ }^{5}$ a number of other south-east English objects of early first-century A.D. date

\footnotetext{
1 PSAS lxxxvii (1952-3), 17-19, with map.

(1955-6), 135.

4 Anf xxxix (1959), 3 I.

$5 U \mathcal{F A} \times \mathrm{xx}(1957), 85 \cdot 8$.
} 
found their way to Ireland, and their distribution suggests that they were brought by individuals rather than by groups of intending settlers. Alternatively they might have reached Northern Ireland from Scotland, for at that time the two areas shared a common school of metalworking.

Continental analogies for these beads are not difficult to find, and they belong to the last two centuries B.c. and the first few decades of the first century A.D. It is possible that the Oldbury beads resulted from a blending of two earlier bead types, both known in Switzerland and Central Europe in La Tène II. One is an annular blue bead with a single row of white or yellow spirals (see pl. I, no. 6c) and the other a heavy cylindrical blue glass bead with projecting horns surrounded by white rings (see fig. 19, no. 2). Both of these types occur in England but are rare. (See Schedules, pp. I22-4, for the first type.) ${ }^{1}$ The second class is represented so far only from one site in Britain, at Cooling in Kent (see fig. 19) but on the Continent they are noted by inter alios Viollier ${ }^{2}$ from Zollikofen and Berne. The resultant Oldbury type combines the spirals with the horn element which dwindles into bosses or may be entirely flattened.

Whether or not such an ancestry is acceptable, beads of Oldbury or Colchester types are known from Celles-les-Condé (Aisne) found with mostly La Tène II objects, ${ }^{3}$ and others from Loisy-sur-Marne and La Vigne aux Morts (both Marne) are in the museum at Châlons-sur-Marne. Another with yellow spirals came from an inhumation grave a little to the north-west of the oppidum (? of the Vindelici tribe) of Manching in Upper Bavaria. ${ }^{4}$ There is only one fragment which appears to belong to this type from the oppidum of Manching ${ }^{5}$ occupied from the early second century until the later first century B.c. One of Colchester type came from Heppenheim, Rheinhessen, ${ }^{6}$ from a grave (457) with a warrior's iron sword, etc. The importance of this lies in its being, like that from near Manching, a male grave, and there seems little doubt from the position of the finds that the bead was attached to the sword as a talisman (see below). Another Colchester Class bead is in the Speyer Museum, and is very much burnt; apparently both the swags and spirals were yellow. A related bead came from a hillfort at Waldfischbach near Birmisens, South Palatine.

The evidence is therefore consistent in pointing to a date for these beads on the Continent in the last two centuries B.c. and they no doubt lingered in use a little later than the end of the first century B.c. when so many of the oppida were sacked. It is possible that sometimes such beads may have served as a loop for a strap to draw the sword firmly to the scabbard. The use of attaching a bead to the sword is not without precedent, and Joachim Werner showed ${ }^{8}$ that the custom went back to the Sarmatians in the first century B.C. and that during the empire of the Huns it spread to other peoples. He suggested that it reached the British Isles in about A.D. 500, perhaps introduced by Franks. The glass rings were replaced by metal ones after the seventh century A.D. In the light of the evidence from Heppenheim (if the bead was a sword-ring rather than a talisman) the introduction into Northern Europe may have been earlier than the first century B.c. and need not have been of Sarmatian origin. On the whole I find it more convincing to explain the Heppenheim bead as a talisman.

Most of the related spiral beads from Britain can also be matched from Continental sites, but I have not been able to find any analogy for the two colourless examples with yellow spirals, both of which come from collections. It is possible that they are later Irish copies of Oldbury beads, or that, like the

\footnotetext{
1 e.g., Worthing, which had a second-century B.c. parallel from Ludwigshafen, and others from Worms, Manching, etc.

2 Viollier, D. (I916), pl. 32, nos. I I and I2.

${ }^{3} B S P F \mathrm{lv}$, fasc. 1o (1958), 671. Note that from this site came a 'creuset pour perles en bronze', showing that at least some kinds of beads were being made there.

4 Reinecke, S. (I91 I), pl. xiv, no. 230a. One from Grave
}

III (Weber, 1903) was accompanied by a pot, iron sword, spearhead, bronze spiral arm-ring, etc. See also Jacobsthal, P. (1944), pl. 248d and Pič, J. L. (1906), pls. 6, 7 and 8.

${ }^{5}$ Krämer, W. (1958).

${ }^{6}$ Koehl, W. Z. (1882), I S. I6, Abb. 20.

${ }^{7}$ Kindly shown to me in 1965 in advance of publication.

${ }^{8}$ Beiträge zur Archäologie des Attila-Reiches (1956), 26-37. See also $A$ ci (1967) and Raddatz, K. (1957), 81-4. 
many other variants of colourless glass decorated with opaque yellow designs, they were perhaps made at Meare in Somerset. (See Class I I.) It is interesting to note that Ireland also produced the only two colourless examples of Class 7 known from the British Isles (see below).

\section{CLASS 7}

Large annular beads with whirl or ray design in contrasting colours (Celtic whirl and ray types) (Schedules, pp. I I $7-20$ ) (pl. I, no. 7 and II, top right, and figs. I5 and I6).

These two varieties of decoration are generally applied to large annular beads on a blue or purple, brown, or light yellow ground and they may have a straight or rounded hour-glass perforation. The whirls or rays emerge from the perforation (see fig. I5). In addition some of the beads have circumferential bands of a contrasting colour, usually underlying the whirls. For facility of study these beads of Class 7 have been sub-divided into Type (a), blue or purple ground; Type $(b)$, brown or yellowishbrown ground; and Type $(c)$ various other colours. Of the three types Type $(a)$ is the commonest.
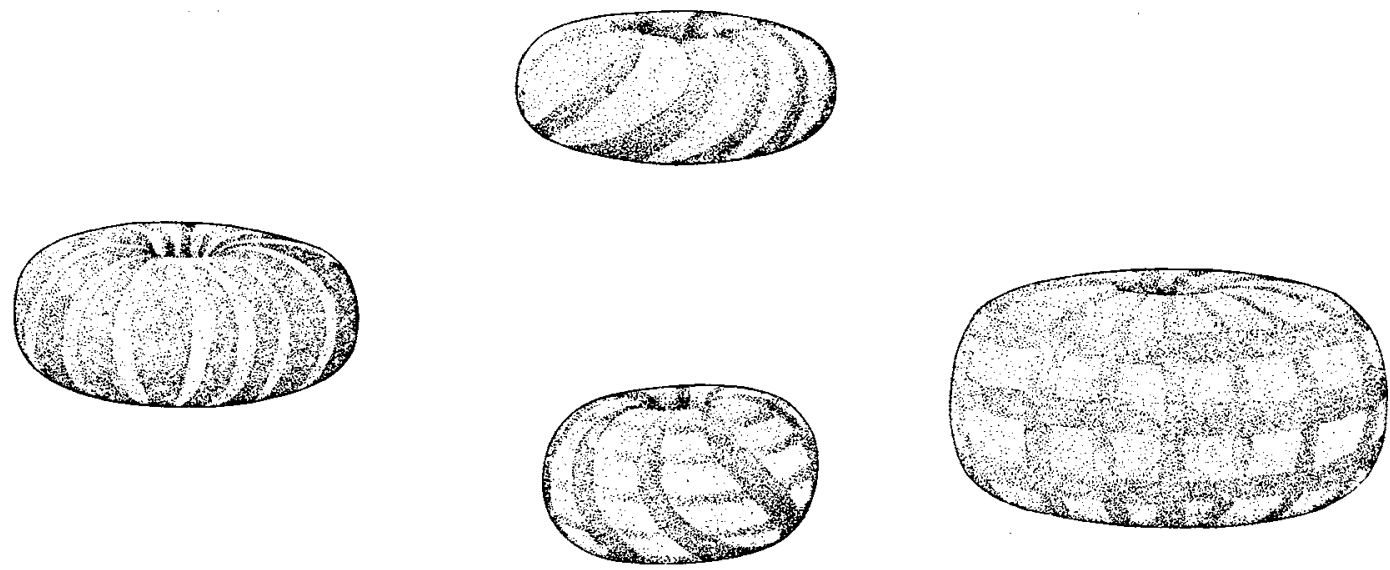

Fig. 15: Class 7: upper, Billericay, Essex-blue and yellow whirls; left, Salisbury Plain, Wilts.'black' with yellow rays; right, Kirkmaiden, Wigtownshire-dark cobalt blue and yellow criss-cross; lower, Colchester, Essex-opaque whitish with purple whirls and light blue bands. Scale $\mathrm{I} / \mathrm{I}$.

TYPE (a)

Several of these have been found in relatively well-dated associations and they can also be paralleled from many Continental Celtic sites. 'The earliest so far dated British example came from a 'rath' at Walesland in Pembrokeshire, and a radio-carbon date of 2 IO-90 B.c. was obtained from its associations; another (? late second century B.c.) has been found at Danebury, Hants; others come from the villages of Meare and Glastonbury in Somerset (one only from each, and both probably late second to first century B.c.). There is little likelihood that these beads were among those manufactured or distributed from Meare. Their importance probably ceased with the Roman occupation of southern Britain. One came from an early Romano-British rubbish pit at Kelvedon in Essex, one from Norsey Wood Camp with Belgic and pre-Belgic pottery and another from first- to early second-century A.D. fort defences at Wick Wood in Wiltshire. Another fragmentary one was stratified A.D. I30-230 at Gaerleon, Monmouthshire: these are survivals, and any examples later than the Claudian conquest can be regarded as such. 
The date of these beads falls within the approximate period I5O B.c. to A.D. 50. Their distribution pattern (see fig. I6) reveals the familiar port of entry up the Bristol Channel, with a scatter up the Irish sea coasts and round the Thames estuary. The Irish evidence is tantalizingly inadequate. At Edenderry (Go. Offaly) the association of one of these beads with some bronze implements must either imply that the bead was accidentally associated with earlier implements, or, less improbably, that the bronzes were types which survived in use into the second to first century B.c. The remaining Irish examples came from collections and are therefore worthless. (Others not included in the Schedules were once in the Pitt-Rivers Museum at Farnham, Dorset (now closed down) marked 'Ireland'.)

TYPE (b)

The three dated examples of this type all support a date in the first century в.c. They come from Hengistbury Head in Dorset, Welwyn Garden City with a Belgic burial (probably last quarter of the first century в.C.), and from Glastonbury Lake Village whose occupation ended not long after this time.

TYPE (c)

Includes beads with green, white or colourless glass. The green and colourless glass examples come from Ireland and are not closely datable; the Colchester bead, with an opaque white ground, pale blue

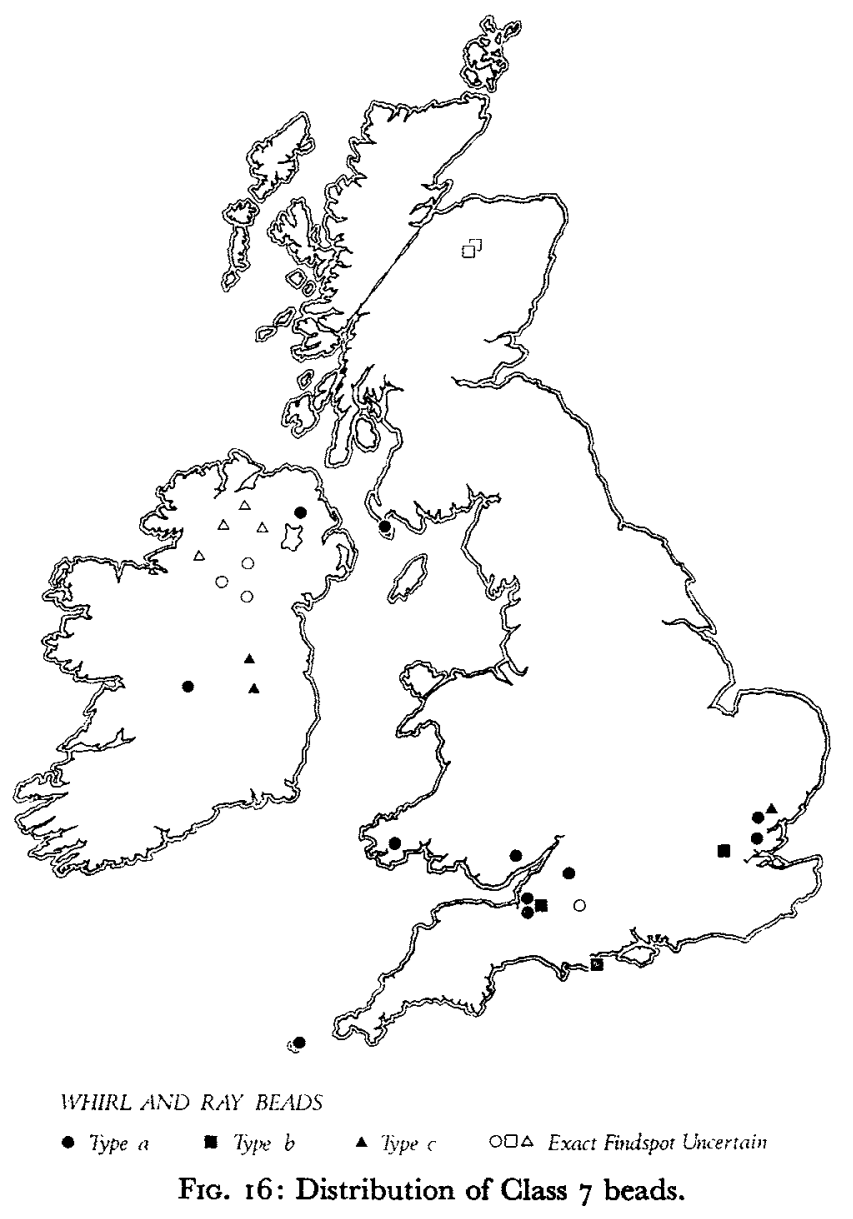


circumferential bands and purple whirls is said to have come from a burial of the mid-first century A.D. and the Seamills one from a Flavian context. The two Irish beads with yellow whirls on colourless glass might have been made at Meare where such a combination of colours was a speciality. But note that two colourless examples of Class 6 also came from Ireland.

Continental parallels for this class are easily found from a wide variety of Celtic oppida in Central Europe, especially from Stradonitz where they may have been made, for over too examples were found there (see p. 29), as well as from Italy, the south and north-west of France, Hungary, Roumania, Poland, Jersey, and elsewhere. ${ }^{1}$ The size is nearly always large and the colours vary considerably, making use of blue, grey, brown, indigo, black, crimson, etc., glass. (Note that somewhat comparable beads also occur in Alamannic sites and care needs to be taken about dating unassociated beads. ${ }^{2}$ )

The British distribution adds to that already plotted by Dr. Haevernick for central Europe and north Italy, and merely emphasizes what we already know, that, either through trade or movements of peoples, these beads arrived on the southern coasts of England in numbers which show a sharp increase during the last century or so B.C. and the early first century A.D. A date around the second to first century B.c. would seem to fit many of the Continental ones, for some of the oppida are thought to have ended their life in the last twenty years of the first century, or a little earlier. The overall picture seems, therefore, to be perfectly consistent. What is not clear, however, is how many of the British ones were copies of Continental prototypes. Their occurrence at the very productive glass-working centres at Glastonbury and Meare, and the fact that the clear glass ones with opaque yellow whirls from Ireland do not seem to have Continental parallels, leaves this question an open one.

\section{(ii) DEGORATED OR UNDEGORATED GROUPS (BOTH IRON AGE AND ROMAN IN DATE)}

\section{GROUP I}

Large or medium annular beads with streaky or mottled design (Schedules, pp. I 2 I-2 fig. I 7)

These beads are common on the Continent and have been catalogued by Dr. Haevernick ( 1960 ) as Group 24 of her study (Ringperlen mit hellgesprenkelter Oberfläche). She emphasizes that the ground colour is usually blue which is spattered with white or yellow dots of varying sizes, and their distribution is not very widespread. She describes them as varying from 22 to $45 \mathrm{~mm}$. in diameter and 9 to $19 \mathrm{~mm}$. in height,

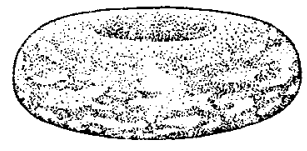

Fig. 17: Group 1: annular mottled beads. Scale $\mathrm{I} / \mathrm{I}$.

\footnotetext{
1 Haevernick, T. E. (1960), passim, and references up to 1959 . Also Déchelette, J. (1904), and others from Corrent, etc. Hélèna, P. (1937) for the oppidum of Montlaurès near Narbonne. For Jersey see $S 7$ xiii (1932). For Trísov (South Bohemia) see Břen̆, J. (1966). For Stradonitz see Pið̌, J. L. (1906), pl. vi; Manching, see Krämer, W. (1958), Haffner,
}

A. (1971), Farbtaf. B., etc.

2 The large criss-cross decorated bead from Kirkmaiden in Wigtownshire can also be closely paralleled from Central Europe. See Pič, J. L. (1906), Tab. VI (for Alamannic beads somewhat resembling Celtic ones, see Garscha, F., Die Alamannen in Südbaden (R. G. K. Berlin, 197o)). 
and she lists 14 examples from Germany, 7 from France, 2 from Switzerland, 2 from Italy, 5 from Austria, and I from Hungary; a much larger number come from Czechoslovakia where they may have been made, for no fewer than twenty-four examples came from the Stradonitz oppidum, previously cited, which is now regarded as the most prolific Gentral European glass centre of the first century B.c. Probably it was from here that the few true examples of this type reached the British Isles, and their probable date, when ascertainable, e.g., Hamworthy (Dorset), Colchester (Essex), Hengistbury Head (Dorset), all probably dating from about 50 B.c. to A.D. 50, shows that they began to be imported very sporadically soon after their manufacture. There are some other examples from Britain which may or may not belong to this group, and some may be local imitations, or survivals into a Roman context. Others may even have an Irish origin, possibly as late as the sixth to ninth century A.D. or so.

All that one can safely say is that some of these beads were imports from the Celtic Continent around

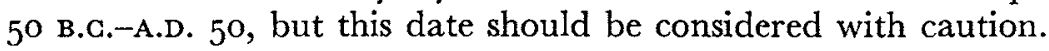

\section{GROUP 2}

Miscellaneous spiral-decorated beads (see also Glasses 6, Io, and I3) (Schedules, pp. I22-4) (pl. I, no. 8 illustrates two examples) (fig. I8)

There is nothing to add here to the information given in the Schedules. Among the beads mentioned there must undoubtedly be some of post-Roman date. They differ widely and seldom have exact
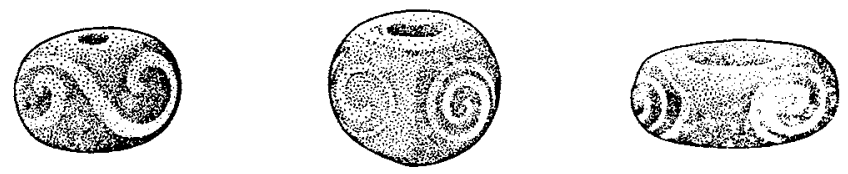

Fig. 18: Group 2-miscellaneous spiral decorated beads (see also Classes 6, 9 (fig. 26, no. 5), 10 and 13, and Groups 3 and 8 ) : left, Meare, Somerset; centre, Traprain Law, E. Lothian; right, Worthing, Sussex. Scale $1 / \mathrm{t}$.

counterparts, or at least they are not recognized. For the time being each newly discovered bead must be dated from its associations and, if exactly similar, from dated beads in these lists. It appears, however, that annular beads, often opaque, and with a spiral around the whole bead's upper and lower surfaces in pale blue or another colour, are of Saxon date; they are, therefore, excluded from these Schedules.

\section{GROUP 3}

Miscellaneous horned beads, some with eyes or spirals (Schedules, pp. 125-6) (fig. 19)

It is clear that these beads do not in any way form a Class: they must have reached Britain in rare instances from as yet unidentified Continental workshops. It is impossible with our limited knowledge of the Continental beads to find exact analogies, and indeed one is tempted to suggest that the natural greenish glass examples must be regarded as datable within the same approximate brackets as have been proposed for the undecorated annular beads of the same glass (second to first century B.c. and throughout the Roman period) and to regard the horns or spirals as a jeu d'esprit on the part of the maker who was availing himself of two well known features: the protruding horn, and the decorative spiral. Thus I should be inclined to date both the Newstead (Roxburghs.) and the Tarporley (Gheshire) beads which are identical-made of natural glass with horns decorated with blue on white spirals-within the early Roman period of the occupation of Newstead which ran from approximately A.D. 80 to I 20. 

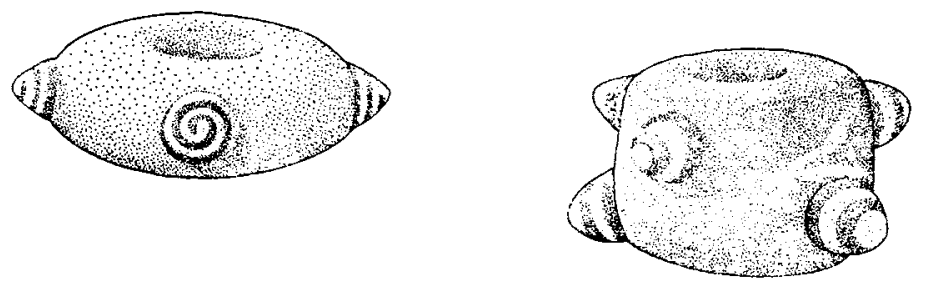

FIG. 19: Group 3-horned beads, some with eyes or spirals (see also Group 8, no. 2 in fig. 23): left, Tarporley, Cheshire; right, Cooling, Kent. Scale $1 / 1$.

The curious bead from Skeffington (Leics.) may also belong to this context. The same date or slightly later might be proposed for the two beads on a blue ground with yellow eyes on horns from Silchester (Hants) and one from Chesters Fort (Northumberland) occupied from about A.D. I22 to 383 . The rest may belong to this roughly defined period with the exception of Lagore and other Irish beads. At Lagore there was almost certainly material derived from earlier occupation close by, for there are other early beads (Meare Class Io, pp. 79-8I). The Hunsbury, Cooling and Donaghadee examples may all be pre-Conquest and horned beads are not uncommon in Continental Celtic beads of La Tène II and III. ${ }^{1}$

The 'black' bead with greenish-yellow horns from Icklingham, like the majority of such dark beads, is likely to belong to the beginning of the Teutonic period.

From the Continent it is not at all rare to find horned beads. ${ }^{2}$ They have always been widely used both in time and space, but are rare in Britain. They certainly continue into the Frankish period. ${ }^{3}$

\section{GROUP 4}

Compound eyed beads with small eyes set in roundels ('Garrow Tor' type) (Schedules, p. I 27) (pl. I, no. 9, and fig. 20)

These beads, which, in the British Isles at least, are not common, are generally slightly more annular than globular and about $15 \mathrm{~mm}$. in diameter. ${ }^{4}$ The classic ground colour is turquoise, but more rarely

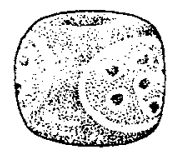

FIG. 20: Group 4-Garrow

Tor type. Scale I/r.

dark blue and into this ground three fairly large mustard-coloured roundels are inset, surrounded by white rings, and with, inside, like eggs in a nest, regularly arranged blue eyes ringed with white. These eyes are stratified as in Arras Type II beads (see p. 45).

${ }^{1}$ See Schedules, p. I 78 . For Donaghadee, see fig. 23 , no. 2.

2 See, for instance, Reinecke, S. (I9I I) v, 236 and 237 , and Taf. 14. Many of much earlier date come from the Eastern Mediterranean.

${ }^{3}$ Examples in the museum at St. Germain (possibly reused beads of Roman date). See also GDV xiii, forthcom- ing, with very valuable coloured plates of beads of sixth- to seventh-century date from Schretzheim on the Danube. Information, in advance of publication, from Dr. Ursula Koch.

${ }^{4}$ On the Continent, on the other hand, they have a tendency to be more globular. 
Three not closely dated English examples come from Girencester ${ }^{1}$ (unstratified), from Silchester (unstratified) ${ }^{2}$ and from an Iron Age hut in the Garrow Tor settlement, ${ }^{3}$ Bodmin Moor, Cornwall. The occupation at Silchester began well before the Roman conquest (there was a La Tène I brooch from the site) and the Garrow Tor huts may go back to the fourth or third century B.c. ${ }^{4}$ In addition to the English beads there are four examples from Ireland which, for reasons of colour or shape, while being closely similar to the English beads, are sufficiently distinct to warn us against a contemporary date. One cannot help feeling that here, as in some other types of bead, the decoration attracted much later Irish glass-workers to copy the pre-Roman Continental and English ones, or at least to use them for free versions of their own invention.

We are now left with the necessity of finding an origin for the English beads, particularly for the earlier one from Garrow Tor.

The well-known and richly accompanied princess's burial from Reinheim (Kr. St. Ingbert) near Saarbrücken ${ }^{5}$ has been attributed to the fourth century B.c., and while the otherwise precisely similar beads from that grave are somewhat larger than their English counterparts, they must undoubtedly have been ancestral to them and perhaps even produced in the same workshop. Similar or related beads also come from the Marne ${ }^{6}$ area and from elsewhere on the Continent, and even from the Near East. ${ }^{7}$

Introduced then into Britain around the fourth to third century B.c., these beads may either have continued to be imported from the Continent until the first century B.c. or thereabouts or, in rare cases, have survived into Roman times, and it seems likely that then, after an interval of some centuries, they were reinterpreted in their own idiom by Irish glass-workers sometime after the fifth century A.D.

\section{GROUP 5}

Miscellaneous wave decorated beads (Schedules, pp r 28-39) (pls. I and II, no. Io a-h, and fig. 2 I)

For convenience of study these are sub-divided as follows:

(A) Translucent blue annular or globular beads with opaque white or yellow wave.

(B) Opaque blue annular or globular beads with blue or purple wave.

(c) Green or natural greenish translucent glass annular beads with white, yellow or blue wave.

(D) 'Black' (dark green or other very dark colours, appearing black).

(i) Annular with white wave.

(ii) Annular with irregular yellow scrawl.

(iii) Annular with various coloured waves.

(iv) Globular with yellow wave.

${ }^{1}$ In the Corinium Museum, Cirencester.

${ }^{2} A$ cii (1959), 53, fig. 8 .

${ }^{3}$ Regarded as one of the earlier Iron Age sites in Cornwall. See Thomas, C. (1966), 75.

${ }^{4}$ Others, of unknown provenance, are in the B.M. (one in the Slade Collection). See Nesbitt (1871), 10, fig. 18 .

${ }^{5}$ Now in the Saarbrücken Museum. See Keller, J. (1955), 13-44, and Megaw, J. V. S. (1970), 76.

${ }^{6}$ Bergères-les-Vertus, Crons (St. Germain Museum, no. I2.012). See Keller, J. (I955 b) 209; Bussy-le-Château (St. Germain, no. I5195); St. Remy sur Bussy, Grave 5 (St. Germain, no. 67839).

7 These were discussed by Seligman, C. G. and Beck,
H. C. (1938), I-64. Haevernick, T. E. (1960) extended her study of these beads (1972) and divided them on a worldwide basis into Classes $A$ (genuine and characteristic beads of the class), $B$ (Italic types with yellow knobs)-the use of knobs (little horns) was common in Italy where the Punic face-bead design may have broken down into a meaningless but still recognizable series of knobs under Celtic influence- $C$ (millefiori beads), and $D$ (beads made from vase glass). Together they cover a very long period of time.

Note also that in a tomb at Aléria in Corsica (Tomb 87) compound beads were dated by a red-figure lekythos to c. 400-375 B.c. (Jehasse, J, and L., La Necropole préromaine d'Aléria, xxx supplément to Gallia (1973), pl. 162). 

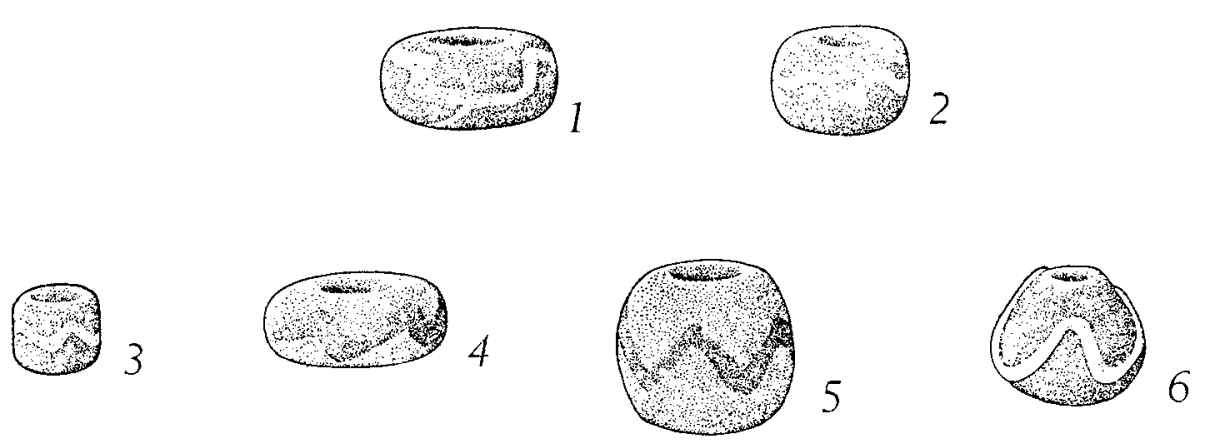

Fra. 21 : Group 5-miscellaneous wave-decorated beads: 1. Caerleon, Mon.-blue with white waves; 2. Almondbury, Yorks.-dark greenish-blue with yellow wave; 3. Meare (East Village), Somerset-translucent green with yellow wave; 4. Glastonbury, Somerset-slaty blue with blue-black wave; 5 . Hamworthy, Dorset-opaque blue with purplish wave; 6. Mildenhall, Wilts.--shiny black with unmarvered yellow wave. Scale $1 / 1$.

(E) Opaque yellow annular beads with coloured wave.

(F) Opaque annular beads with yellow wave.

(G) Translucent 'amber' (reddish-brown) beads with yellow wave.

(H) Translucent colourless beads with yellow wave. (See Class I I, pp. 8I-4.)

(I) Translucent greenish gold with yellow wave.

(A) TRANSLUGENT BLUE ANNULAR OR GLOBULAR BEADS With OPAQUE White or YELLOW WAVE (fig. 2I, no. I)

These beads, almost invariably annular in form, represent such a long-lived type that a distribution map would be meaningless except to emphasize their apparent absence in Ireland and their extreme rarity outside the Roman occupied lowlands of Scotland and Wales. The earliest known from England are those from the Arras (Yorkshire) graves, perhaps attributable to the fourth and third centuries B.C., from the Cowlam Barrow L with Arras Type I bead and from the Queen's Barrow, Arras, with Type II (see pp. 45-8). Not much later we have some examples from Meare in Somerset (about third to first century B.c.) and Longbridge Deverill, Wilts., perhaps third century B.c. Another (c. IOO B.G.) has recently been found at Danebury Camp, Hants. None of these early beads is very strongly coloured in comparison with the rich cobalt blues of the Roman period, but as the same light blues reappear in post-Roman examples, this can hardly be regarded as significant. The 'waves' on these earlier beads are fairly evenly and carefully applied, while during the Roman and post-Roman periods the size of the bead may be larger ( $16 \mathrm{~mm}$. or so in diameter), the colour is stronger, and the occasionally yellow but usually white thread has often been so thinly drawn out during its application that it may have broken more than once and the marvering is less careful. The waves are haphazard and sometimes make bows or knots. This, however, can only be regarded as a reflection of greater or less skill in craftsmanship.

These beads are not common on the Continent, though how widespread they were is not yet known. They occur, for instance, in some graves of the Hunsrïck-Eifel I period (c. $65^{0-500}$ B.c. $)^{1}$ and in the early sixth century B.c. from Fendringen, Switzerland, ${ }^{2}$ and further south and east they may be yet

I $T Z$ xvi-xvii (1941-2), 2 10, fig. 10.

${ }^{2} H A$ v (1971), 2-6. 
earlier. It is, however, quite impossible to date one of these beads visually, for they continued to be used (sometimes as reused Romano-British beads and sometimes newly produced in the Teutonic areas of Northern Europe) into the sixth and seventh centuries. ${ }^{1}$ It follows that some of the many unassociated beads listed in these Schedules may prove, on further evidence, to belong to a period later than the terms of reference for this study.

(B) OPAQUE BLUE ANNULAR OR GLOBULAR BEADS With BLUE OR PURPLE WAVE (Schedules, p. I34) (fig. 2 I, nos. 4 and 5)

For obvious reasons of lack of contrast these two tones of blue were rarely used in combination. Both the two known examples belong in all probability to the second or first century B.c., but this may be fortuitous, though at Meare there was also a bead with light blue spirals on dark blue, likely to belong to the same approximate date.

The concentration of the three examples in the south-west is in agreement with that of many preRoman bead types in Britain.

(c) GREEN OR NATURAL TRANSLUCENT GREENISH GLASS ANNULAR BEADS WiTh WHITE, YELLOW, OR BLUE WAVE (Schedules, pp. I34-5)

These cannot be regarded as other than a miscellaneous collection, each bead from which may be used for comparative purposes with others found in the future, so that one day classes may be distinguished amongst them. They were found at Arras, while the totally colourless glass example from Meare (see pp. 83 and 84 ) is separately classified (Class II). Meare also produced one translucent green bead with yellow wave (fig. $2 \mathrm{I}$, no. 3), and a related but bluer bead came from Almondbury (fig. 2I, no. 2).

(D) VERY DARK GLASS, APPEARING BLAGK

(i) Annular beads with white wave. See remarks in Schedules, pp. 135-7.

(ii) Annular beads with irregular yellow scrawl (Schedules, p. 136). A few undated examples come from Ireland and one from the Roman fort at Segontium in North Wales, where its date is uncertain but it is probably late Roman. It must be remembered that a 'black' annular bead with yellow streaks came from an apparently Roman background at Gaerleon, though this is suspect as it came from old excavations and might be a Teutonic intrusion. For more globular types see (iv) below.

(iii) Annular beads with various coloured waves (Schedules, pp. 136-7). Both terracotta red and light sky-blue were colours which were popularly used during the early migration period, and there is no reason to doubt that on historical grounds some of these Teutonic or Frankish beads began to reach the British Isles during the fourth century (or maybe before). This hypothesis is supported by the few examples from datable contexts likely to fall between A.D. $35^{\circ}-45^{\circ}$ or so. A doubt, however, about the contemporaneity of the 'Northern Ireland' bead must be stressed; not only is it right outside the area in which these beads normally occur, but the wave is bright cobalt blue rather than the very characteristic sky blue of the Frankish beads.

(iv) Globular beads with yellow wave (Schedules, p. 137) (fig. 21, no. 6). These have been separated from the annular beads of similar type only because there is more doubt about the dating of that group. Though these have been claimed as Sarmatian beads of the Roman period there is an apparently slightly

\footnotetext{
${ }^{1}$ See for instance Lethbridge, T. C. (1931), $76 \mathrm{ff}$. It is interesting to note that an example from Cow Down near Buxton, Derbyshire, was described as 'A type common in
}

7 th century graves, probably in this case a toggle for a belt'. (MAr vi-vii $(1962-3), 28$.) 
pre-Roman glass armlet made in a comparable technique and colouring from Hamworthy in Dorset. More evidence is required. The two British examples come from Chesters Fort in Northumberland and Mildenhall in Wiltshire, and according to Sulimirski they may have been Sarmatian imports. ${ }^{1}$

(E) opaque yellow annular beads with coloured wave (Schedules, p. i38)

The frequent use of opaque yellow glass in pre-Roman times has been demonstrated for various classes of beads and armlets, and in fact several of the beads in this group are very closely related to the beads of Class 8 and appear to be identical with them but for the addition of a wave design in another colour, green or blue. In fact they are probably of British manufacture. One came from Meare itself and one from Burton Fleming in Yorkshire, from an Iron Age cemetery. Another (rather more globular and with a slaty blue wave, dated about I00 B.c.) has recently been found at Danebury, Hants. The date of these probably falls between the third and first century B.c. The rather thicker and more globular bead from Beckford in Worcestershire (associated with stamped wares) and one from All Cannings Cross in Wiltshire with a brown wave are slightly different (perhaps marginally earlier), as the latter is closely paralleled from a late Hallstatt period grave (no. 72) at Les Jogasses. ${ }^{2}$ Care should be taken not to confuse these Iron Age beads with some rather similar but rare beads of the Migration period.

(F) Information in Schedules, p. $13^{8}$.

(G) Information in Schedules, pp. I $3^{8-9}$.

(h) translugent colourless beads with yellow wave (see Class i i (G))

(I) TRANSLUGENT GREENish-gold With yellow WAVE (see p. i3, above, for example from Carrawburgh)

\section{GROUP 6}

\section{Undecorated annular beads}

For convenience, the sizes are divided as follows: Large over $30 \mathrm{~mm}$. in diameter; Medium, from I 5 - $30 \mathrm{~mm}$. in diameter; Small, under $15 \mathrm{~mm}$.

(i) Large beads of various colours.

(iia) Medium, and (iib) small natural greenish translucent glass.

(iiia) Medium translucent green, greenish-gold or greenish-brown, and (iiib) small translucent yellow or greenish-gold.

(iva) Medium and (ivb) small blue, translucent or opaque.

(v) Small translucent 'amber' (reddish-brown).

(vi) Small opaque terracotta-coloured.

(vii) Small opaque or translucent sky blue.

(viii) Small opaque. Other colours, but note that yellow beads of this type are separately discussed as Class 8, below.

(ix) Very dark ('black') glass.

(x) Colourless (not scheduled).

1 Sulimirski, T. (1970).

${ }^{2} R A \operatorname{xxvi}(1927)$, II 3. 
(i) LaRge beads of various golours (German, Ringperlen) (Schedules, pp. 139-40)

These were never either made in, or imported on a large scale into, Britain. Those from such Iron Age sites as Worthy Down (Hants), Breedon-on-the-Hill (Leics.), Glastonbury (Somerset) and Congresbury (Somerset) (the last found with a La Tène III brooch) all point to a date within the third to first centuries B.C. In the light of our present knowledge of the type, which is a rare one, they seem to have died out after the Roman conquest, and this suggests that they were imported from the Continent and that the trade was discontinued after that event. Nearly all of them are blue, and they are mostly confined to the southern part of Britain. It seems probable that they belong with the many other large (but undecorated) beads of Continental Celtic origin.

(iia) Medium anNular natural greenish transluaent glass (Schedules, pp. 140-3) (pl. II, no. I I) AND (iib) SMAll ANNular of Similar GLASs (Schedules, pp. 143-5)

These should be considered together with undecorated globular beads (Group 7 (ii), p. 69).

The overwhelming proportion of these beads come from Roman sites and run right through the Roman period. Only a very few are earlier than the conquest, after which a number could have been made from Roman bottle-glass waste or vases imported from Continental sites. The earliest examples come from Glastonbury and Meare in Somerset (? third to first centuries B.c.); from Bury Wood Camp, Colerne in Wiltshire, and Moel Trigarn in Pembrokeshire (of about the same date) and from Trevelgue in Cornwall where the occupation began in the Iron Age but continued through the Roman period. By the first century B.C. or A.D. this glass was also used for probably locally produced cable beads. (See Class 9.)

Some very irregular beads were almost certainly made in hill-forts such as Traprain Law (East Lothian) and Coygan Camp (Carmarthenshire) and these are not easy to distinguish from the numerous and equally roughly made Anglo-Saxon beads from graves such as those at Stanton Harcourt (Oxon.) and Harwell (Berks.) cemeteries of about A.D. $45^{\circ}-55^{\circ}$. Both of these are in the Ashmolean Museum in Oxford.

(iiia) MEDIUM TRANSLUCENT GREEN, GREENISH-GOLD OR GREENISH-BROWN AND (iiib) SMALL TRANSLUCENT YELLOW OR GREENISH-GOLD (see below for 'amber' (reddish-brown)) (Schedules, pp. 145-52)

It has already been pointed out (p. I3) that a concentration of greenish-yellow glass beads in the south from such sites as Worthy Down (Hants) and Bulbury Camp (Dorset), etc., suggests that they may have been made from one or more imported glass ingots of this glass in about the second or first century B.c. None is known to have been associated with Iron Age 'A' wares.

The rest of the beads in this group, where the varieties of greens and yellows are very marked, were also probably imports of around the first century B.c. to first century A.D., but they lingered on sporadically through most of the Roman period. Their pre-Roman distribution is mostly confined to that part of Britain lying to the south of a line from Chester to the Wash; two examples of approximately this date reached Western Scotland (Castle Hill, Dalry, Ayrshire, and Dunagoil Fort, Rothesay, Bute).

(iva) MEdium anNular blue beads translucent or opaque (Schedules, pp. I52-5) ANd (ivb) Small ANnular blue Beads (Schedules, pp. i55-62) (pl. II, no. II and fig. 22)

These two groups can be considered together as their history appears to be similar. They began to be imported in about the sixth century B.c. and are present at several Iron Age 'A' sites of about that date. These are Gussage All Saints, Dorset; All Cannings Cross, Wilts.; Swallowcliffe, Wilts.; Ghalbury Gamp, Dorset; Chinnor, Oxon.; and possibly Grickley Hill, Gloucestershire. Their importation continued throughout the Iron Age, and their distribution in sites of that period strongly suggests 


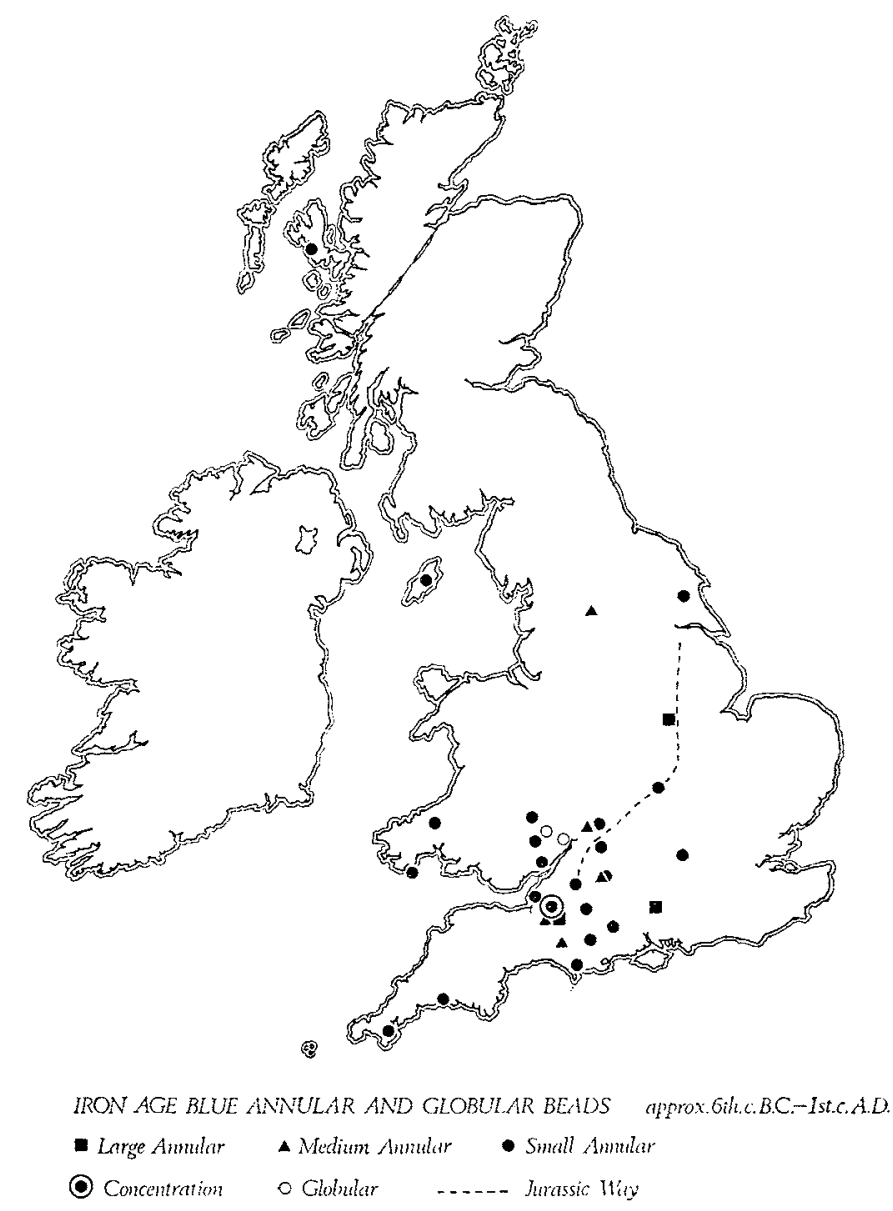

FIG. 22: Distribution of beads of Groups 6 and 7 of known Iron Age date.

a south and south-western entry, possibly up the Bristol Ghannel and the Irish Sea (and possibly that they were made at or distributed from Meare and Glastonbury once these factories had begun production in about the third century B.c.). One or two examples even reached the extreme west of Scotland. In this respect they somewhat resemble the small opaque yellow annular beads of Class 8 which, however, differ from the blue beads in having consistent characteristics which enable them to be considered as a Class rather than a Group, and their period of popularity consequently lasted for a shorter time.

On Roman sites blue annular beads of small and medium size are far from uncommon, but it is noticeable that where they occur a native British element is apparent from the culture. In Ireland ${ }^{1}$ most of these beads appear to belong to the seventh to tenth centuries A.D. (e.g., many from Lagore), but they are common from undated sites; they reached the Kintyre peninsula and a little further into Scotland, and they may perhaps have been worn by the Scotti in the Dalriadic territory of Ulster and Argyllshire. Unfortunately most of the Irish examples come from collections. Fig. 22 shows the distribution of the pre-Roman examples, covering roughly the last five or six centuries B.c. Its significance is

${ }^{1}$ See pp. 39-42, above. 
therefore of limited value-the more so as we do not yet know which were of British and which of Continental manufacture.

In England, too, the type certainly persisted into post-Roman times, but from the dated examples at our disposal it seems possible that these blue beads were in use from about the sixth or fifth centuries B.c. to at least the eighth century A.D.

The Saxon beads of this group, though very common in the seventh-century pagan graves, are generally badly made, rough, and uneven, often with striations around the surface. There are also large quantities of annular blue (but generally opaque) beads from Viking sites such as Birka and Helgö.

These blue beads offer, therefore, very little help for dating purposes.

(v) SMALL TRANSLUCENT 'AMBER' (REDDISH-BROWN) GOLOURED ANNULAR BEADS (Schedules, pp. 162-3)

Small annular beads appear to have been almost the only form in which this glass was made up, and it clearly pre-dated the Roman conquest on certain sites: Hunsbury (Northants.), probably first century B.c.; King Harry's Lane, Verulamium (Herts.), stratified ro B.c. to A.D. 40 ; High Rocks Camp, Tunbridge Wells (Kent), ? first century B.c. Some lasted into the early Roman period, but none, it seems, very late. This glass was also used for a streaky annular bead of La Tène III Celtic type from Hamworthy in Dorset (first century B.c. to first century A.D.) but was evidently never very popular, or else was difficult to obtain, and it was not made into globular or other forms of bead. A small bead of this type but with an abnormally small perforation was found at Mousewold (Dumfriesshire) and this may in every probability be of Irish origin and post-Roman date.

(vi) SMALl opaque terRacotta-coloured BeAds (Schedules, p. I63)

Very rarely made into this shape. Two examples, both pre-Roman, from Croft Ambrey (Herefordshire) and Meare (Somerset), respectively, had this glass applied as a second layer over a yellow or cobalt core, implying that the terracotta glass was not easy to acquire.

(vii) Small opaque or translugent sky blue annular beads (Schedules, p. i6 3 )

These are not a common form and none of them appears to be pre-first century A.D. The Newstead bead is so far the earliest (about A.D. 80-200). For other forms in which this glass was used, see p. 18. On the whole they seem to be early rather than late in the Roman period.

(viii) SMALl OPAQUe ANNULAR Beads of other Golours (Schedules, p. i64)

Very rare. Note that yellow beads of this type are British in origin. See Class 8.

(ix) SMALl 'Black' ANNULAR BEAds (Schedules, p. 164)

As mentioned above it is not always easy to say what is the true colour of this very dark glass. Small annular 'black' beads were certainly known before the Roman conquest, for instance, at Meare (Somerset) perhaps second or first century B.G., and a fragmentary one on a Belgic road at the east entrance of Maiden Castle (Dorset) ; this had a white marvered decoration and is not therefore truly characteristic. A small number of 'black' annular beads of this size have come from Roman sites of long duration and have not, unfortunately, been stratified. Two others, from Scotland, may well be considerably later and be of Irish origin, since in Ireland, again unassociated, there are large numbers from collections. Probably their main floruit in Britain (excluding Ireland) was limited from about the first century B.c. to some time in the Roman period, and their scarcity both on pre-Roman and Roman sites must reflect a very limited attraction for this colour. (It must be remembered that both shale and jet were made into beads in the Roman period.) Teutonic beads of this form are fairly common. 
(x) GOLOURLESS GLASS BEADS

An annular half-bead (diam. $2.3 \mathrm{~mm}$.; ht. $0.6 \mathrm{~mm}$.; perf. diam. $1.5 \mathrm{~mm}$.) came from what appear to have been Iron Age 'B' (? second to first century B.c.) associations at Bury Wood Camp, Colerne, Wiltshire. ${ }^{1}$ It was probably made at Meare. This glass is very rare except at Meare in Somerset. (See pp. 9-II.)

\section{GROUP 7}

Undecorated globular beads (here the term 'globular' applies to beads whose height is more than half their diameter)

The sizes into which the globular beads have been divided are as follows: Large, over $15 \mathrm{~mm}$. in diameter; Medium and Small, under $15 \mathrm{~mm}$. in diameter. (See P1. Il, no. I2.)

(i) Large globular beads in various colours.

(ii) Medium and small globular beads in natural greenish translucent glass.

(iii) Medium and small globular beads in translucent or opaque green glass.

(iv) Medium and small globular beads in cobalt blue translucent or opaque glass.

(v) Medium and small globular beads in sky blue glass, both opaque and translucent.

(vi) Medium and small globular beads in yellow or 'amber' (reddish-brown) translucent or opaque glass.

(vii) Medium and small globular beads in terracotta-coloured, opaque glass (not scheduled).

(viii) Medium and small globular beads in 'black' opaque glass.

(ix) Small beads in bright red opaque glass (not scheduled).

(i) LARGE GLOBULAR BEAds in VARious colours (Schedules, pp. 165-6)

A few globular beads of large size evidently reached the British Isles in the last century or so B.c. but they are only approximately dated from the sites in which they were found. The type was never popular either during the Iron Age or in Roman times. Blue beads of this size were discovered at Glastonbury (? first century B.c.), Bury Wood Camp, Colerne, Wiltshire, with Iron Age 'B' pottery, and from an Iron Age enclosure at Skipton in Yorkshire. A brownish-yellow translucent bead came from Meare (? second to first century B.c.) and others from two undated sites in Scotland. Others have been found unstratified on Roman sites. Nothing can really be said either culturally or chronologically on such little evidence, except that some of them came to Britain before the conquest. They do not represent a coherent group and should be considered together with globular beads of smaller sizes.

(ii) MEDIUM AND SMALL GLOBULAR BEADS IN NATURAL GREENISH TRANSLUGENT GLASS

(Schedules, pp. I66-7)

All examples listed here point to a Roman date and none of them is definitely pre-Roman. About seven examples are vaguely Roman (unstratified) and the more closely dated ones are: Colchester A.D. I50-200; Castle Hill, Whitton, Suffolk (from villa occupied about A.D. I30-290); Barnsley Park Roman villa at Cirencester (occupation second to fourth century); Goygan Camp, Laugharne, Carmarthenshire (late third century). Badly made examples could easily have been made from Roman waste glass in Roman and post-Roman times. As might be expected, they appear to be rare in Ireland though present at Grannack, Ardrahan in Go. Galway. ${ }^{2}$ These are very like those from St. David's Head in Pembrokeshire and probably reflect connexions across the Irish Sea during the early postRoman period in the south.

${ }^{1} W A M$ lviii, lxii and lxiv.

${ }^{2}$ See pp. $39-42$, above 
(iii) MEDIUM AND SMALL TRANSLUGENT OR OPAQUE GREEN GLOBULAR BEADS

(Schedules, pp. 168-9)

The earliest bead of this type seems to be a dark semi-translucent bottle green one from a just preor post-conquest context at Bagendon in Gloucestershire. The remaining ones are only very vaguely dated and probably Roman. A dark green translucent bead came from the Rath of the Synods at Tara in Go. Meath, and this same site produced Roman pottery of the first to third centuries A.D. A pale green translucent bead was found in the aisled round-house of Glettraval in North Uist and was regarded as intrusive from a higher level than that in which it was found: it is probably Roman or even post-Roman, and may possibly belong to (ii) above. Many opaque green beads of this form come from post-Roman contexts and can generally be recognized by their bad workmanship. On the whole opaque green beads tend to be third century or later.

(iv) Medium and SMall blue transluant and opaQueglobular beads (Schedules, pp. $169-72)$.

A common form of bead which not unexpectedly had a very long life. It is possible that some of those listed in the Schedules will one day prove to be later than the Roman period. At present it is difficult to see how such featureless and common beads can be dated unless by some analytical method as yet unknown. They are known from a few native sites of Iron Age date: Bagendon, Gloucestershire (just pre- or post-conquest); Bredon (Gloucestershire-Worcestershire borders)-probably early first century A.D.; Meare, Somerset (second to first century B.c.); Dowles' Brickyard, Worcestershire, from what Miss L. F. Chitty thinks may have been an Iron Age urnfield; Loughey, Donaghadee, Co. Down, from the first-century B.c.-first-century A.D. necklace (see p. 8o); and from a galleried wall-fort at Dun Ardtreck in Skye (first century B.c. to first century A.D.). The rest are probably Roman, and the type continued to be made for many centuries.

(v) Medium and small opaQue and transluaent sky blue globular beads (Schedules, pp. I 72-4)

Here there are very few examples which are not Roman, and this colour of glass was commoner in earlier Roman times. Castle Dore in Cornwall (occupied in the second and first centuries B.c.) produced one such bead, and a roughly contemporary one came from Meare as well.

As mentioned before, dating of stray examples cannot be attempted without analysis since what appears to be this kind of glass is still in use today for toys, and was much used in lace bobbins.

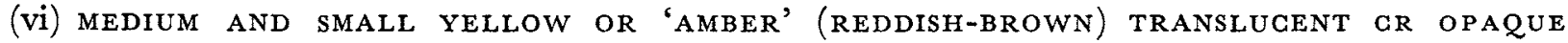
GLOBULAR BeAds ${ }^{1}$ (Schedules, p. I 74)

Very few examples. A few are Roman (amber, translucent yellow). Two earlier beads came from Meare (second to first century B.c.) and one of these is made of the same glass as the opaque annular yellow beads of Class 8 . All that can be said is that like other globular beads they were rare on preRoman sites, and continued occasionally throughout the Roman occupation into post-Roman times.

(vii) OPAQUE TERRAGOTTA-GOLOURED GLOBULAR BEADS (not scheduled)

Several from Meare. Two globular beads fused together, Giog, and Gi33 (I.5 diam.); Gr 34 is another. Perhaps made at Meare. ${ }^{2}$

(viii) MEDIUM AND SMALl 'Black' OPAQUe globular BEADS (Schedules, p. I75)

Here the evidence is equally unsatisfactory as the form was very rarely used. The earliest example so far known from Britain is probably of pre-Roman date (Hunsbury, Northants.), the rest are either

1 See pp. 12 and $16-17$, above for the glass.

${ }^{2}$ Bulleid, A. and Gray, H. St. George (1967). 
Roman or post-Roman. The colour of these beads may be any very dark colour, appearing black. A small late Roman example came from Lankhills Cemetery, Winchester (Necklace 315, Grave 333, a foreign grave dated A.D. $390-410$ ).

(ix) SMALL BRIGHT RED OPAQUE GLOBULAR BEADS (not scheduled)

These are almost unknown in Britain, but recently a number have come from the Roman villa at Kingscote, Glos., with many finds of the first century A.D. In colour they are a bright sealing-wax red.

\section{GROUP 8}

Exotic beads of Iron Age date (Schedules, pp. 176-8 and fig. 23). See also Groups 1-7

Each one of these beads is an original design which may one day be found to have analogies either on the Continent or from one of the British glass-working centres. For the present they are described in the Schedules only, and any known comparable beads are there cited.

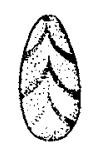

$I$

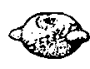

2

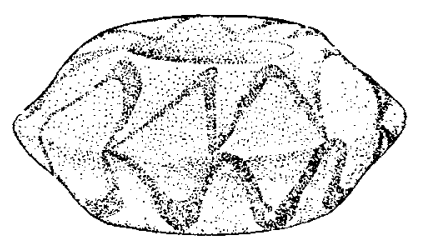

5

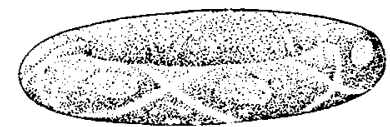

3

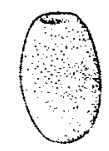

6

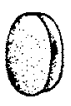

4

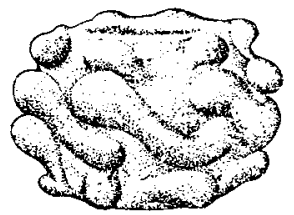

7

Fig. 23: Group 8--Examples of exotic beads of Iron Age date: upper row, I. All Cannings Cross, Wilts. 2. Loughey, Donaghadee, Co. Down (see Group 3). 3. Trevelgue, Cornwall. 4. Badsey, Worcs.; lower row, 5. Hunsbury, Northants.

6. Clevedon, Somerset. 7. Boxford, Berks. Scale $1 / \mathrm{i}$. 


\section{PART IV}

\section{IRON AGE BEADS OF BRITISH DESIGN AND ORIGIN}

THERE are a number of beads which are thought on present evidence (see pp. $3^{\mathrm{I}-7}$ ) 1 to have originated in the British Isles, worked from imported glass by craftsmen who almost certainly came from overseas and who had learnt their complicated and skilled methods of decorating glass beads in Celtic areas of the Continent. It is impossible to establish that this hypothesis is a valid one whilst such large areas of Europe--particularly the south-west-remain unstudied; all we can say is that in the light of present knowledge this seems to be true.

The following Classes of beads are therefore regarded as being of British design and manufacture, and the same must hold good for numbers of other plain or decorated glass beads already discussed but whose origins are as yet uncertain. Note particularly South Harting (Class 3) beads, and the opaque yellow annular beads with coloured waves (Group $5(\mathrm{E})$ ).

$\begin{array}{llc}\text { Class 8 } & \text { Small opaque yellow annular beads with flattened surfaces } & 73 \\ \text { Class 9 } & \text { Annular beads decorated with twisted cables } & 77 \\ \text { Class I0 } & \text { 'Meare spiral' beads } & 79 \\ \text { Class I I } & \text { Meare variant beads } & 8 \mathrm{I} \\ \text { Class I2 } & \text { Stud beads } & 84 \\ \text { Class I3 } & \text { North Scottish spiral-decorated beads } & 85 \\ \text { Class i4 } & \text { North Scottish decorated annular beads } & 87\end{array}$

\section{CLASS 8}

Small opaque yellow annular beads (Schedules, pp. 179-82) (pl. II, no. I3, and figs. 24 and 25)

Unlike the small annular beads of other colours, there are certain features present in these yellow ones which allow them to be regarded as a Class rather than as a Group. Sometimes extremely fine

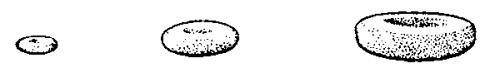

FIG. 24: Class 8-small opaque yellow annular beads. Scale $1 / 1$.

and thin, perhaps when the glass was difficult to acquire, they seldom exceed $12 \mathrm{~mm}$. in diameter and were in all probability graded on necklaces, and sometimes also worn interspersed with other Classes of beads, so providing a useful chronological overlap, even if not complete contemporaneity of life-span. The main characteristics of this Class are the flattened upper and lower surfaces so often present around the perforation (a feature sometimes also noted on Iron Age blue annular beads and due, no doubt, 
to their method of manufacture) and an almost identical rather dull egg-yellow colour, perhaps imitating yellow amber, definitely less lemon-yellow than the superficially somewhat similar annular beads of the post-Roman period.

The initial date for these beads depends on the dating of the following sites, for which the approximate present day dates are in brackets, though these may be altered as more precise methods of dating become available.

In England, Wales, and the Isle of Man dated beads of this Glass come from an early Iron Age fort, Twyn-y-Gaer (Cwmyoy, Monmouthshire), where one example was stratified with 'stamped ware' characteristic of the Welsh marches from about 300-I 50 B.C., and another from the same fort is thought to be a century or more later. ${ }^{1}$ Others come from Castle Dore, Gornwall (c. 200-1 oo B.c.); Ballacagen A, Isle of Man (with Continental La Tène III armlets); Huckhoe Fort, Northumberland (in soil reused in an early Roman hut); Glevedon, Somerset (from a cist burial, on a necklace alternating with barrelshaped crimson beads), and a 'Meare variant' bead (Class II) also ascribed for other reasons to the second century or so B.c. Over fifty examples (including one of two segments) came from Meare, ${ }^{2}$ from Mr. Michael Avery's Phase 2 which is discussed on p. 33. At Conderton Camp, Bredon, Worcs., one was found in a fort with 'stamped pottery'. ${ }^{3}$ Taken together with those from Cwmyoy this emphasizes the evident trade up the Welsh marches. A third to first century B.c. date would also fit the bead of 'stud' type made of this same glass which was found with late Iron Age 'A' wares at Lidbury Camp (Wilts.), though a little second- to first-century B.c. pottery of Glastonbury type and Roman ware also came from this fort (see pp. 84-5). Note that a few small annular beads of this glass, with wave or swag decoration of a colour now lost, have been found in several Iron Age sites and are listed under Group 5 $(\mathrm{E}){ }^{4}$

From Scotland the pre-Roman examples come from a number of brochs, in Iona, Skye, Invernessshire, etc., and from a wheelhouse in South Uist, ${ }^{5}$ and a souterrain and house of late first to early second century A.D. Others came from Aitnock Fort, Dalry, Ayrshire (first to second century A.D.), and eight examples from Howrat Gastle Hill, Dalry, nearby, as well as from Arrieolland Crannog in the same district. Here some glass-working may have taken place, and it is interesting to note that all the last three sites are near to the Stevenston Sands, a good source for suitable glass sand. A galleried wall-fort at Dun Ardtreck in Skye (thought to have been built in the early first century B.c.) produced a necklace including two decorated annular Scottish beads of Class I4 (ascribed-see pp. 87-9-to the late first century B.G. or first century A.D.). At Inverkeilor, Angus, a bead of the class under discussion was found with a Type I glass armlet (see p. 78 ) thought to be of Scottish first-century B.C. or A.D. manufacture.

In the Culbin Sands area around the mouth of the river Findhorn in Moray some 250 beads of this class have been discovered in the sand-dunes, as well as a group of eighty-five other beads. Such a quantity as this, together with other evidence (see pp. 34-5) supports the theory that there was a beadmaking industry there: some also came from the Glenluce Sands in Wigtownshire, but not very many.

One of the most important discoveries for dating purposes is the well-known burial from Loughey, Donaghadee, Co. Down, ${ }^{6}$ in Ireland. The bead here came from a group of objects including among

1 For the latest discussion of this ware see Stanford, S. C. (1970 and 1974). The dating of both the stamped ware and the forts along the Welsh marches is still far from being clearly established.

2 They are conspicuously absent from nearby Glastonbury where the occupation overlapped but started later than that at Meare.

${ }^{3}$ This excavation is still not published. I am grateful to
Mr. Nicholas Thomas for information.

4 See p. 65.

${ }^{5}$ Note that estimated radio-carbon dates now suggest that the semi-brochs and brochs and related buildings may, in some cases, go back to the second century B.c. See MacKie, Euan (1965 a, 1965 b, 1969 and 1975).

${ }^{6}$ Jope, E. M. (1957), 74-95 and (1960), 40. See footnote 2, p. 8 o. 


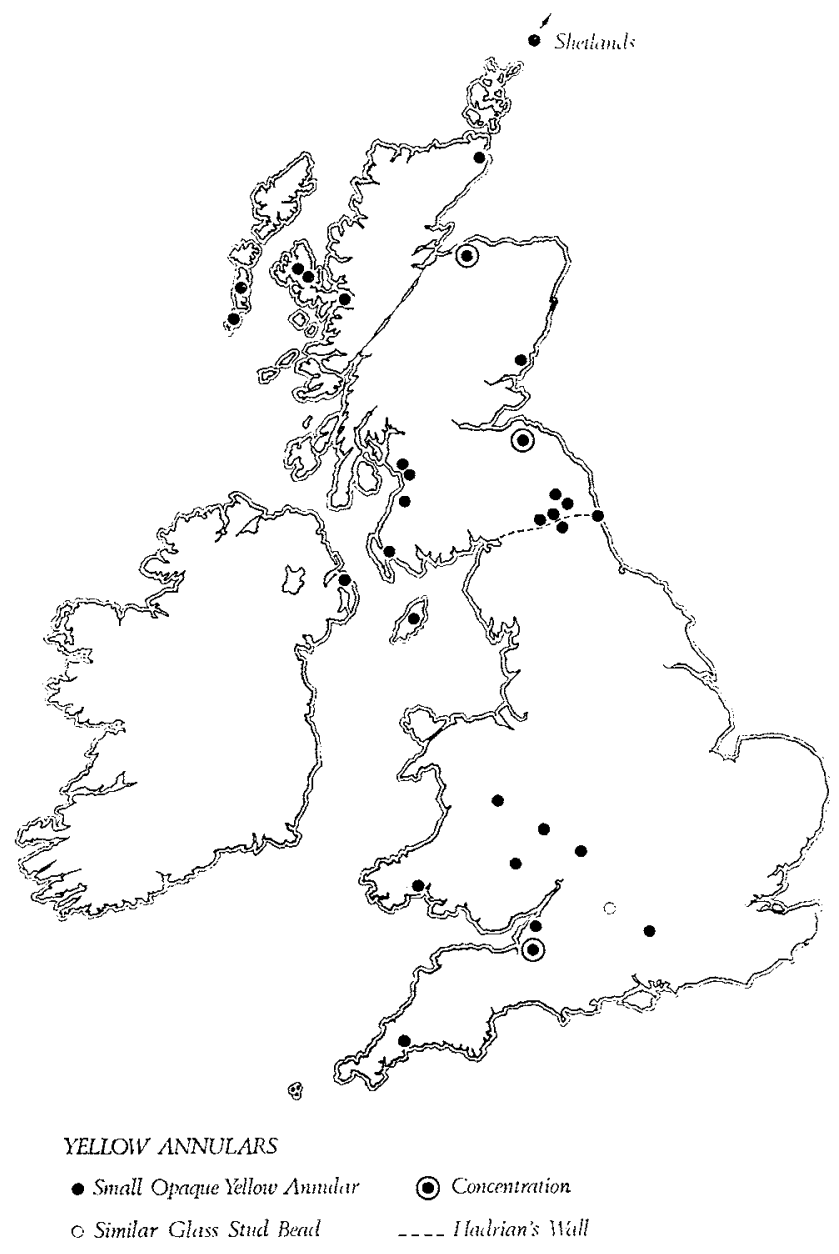

FIG. 25: Distribution of Class 8 beads.

other things a necklace with a number of these yellow beads and a 'Meare spiral' bead of Class io, a small bead with cable decoration mentioned below and a fibula regarded, on Continental evidence, as belonging to the mid-first century B.c. So together all the evidence points to an initial date for these beads in the third to second century B.c. Concentration in both the Meare, Somerset, district and the Culbin Sands area in Moray is very noticeable, but the two centres need not have been strictly contemporary.

As already mentioned above, the Loughey beads include a small annular blue bead decorated with little coloured horns or knobs and a two-colour cable (fig. 23, no. 2) akin to the cable beads of Glass 9, and it is impossible to say whether this bead (for which I have not been able to find any analogies) was produced in Britain, or whether it was imported. The whole necklace could belong to the later first century B.a. on the evidence of the brooch, with the yellow beads and the 'Meare spiral' bead as late survivals.

With regard to the chronology of this class of yellow bead, it seems probable that they were distributed from Meare in the third to second centuries B.C., and the hypothesis, which will again be put 
forward in discussing 'Meare spiral' beads (Class 10) and the North Scottish beads (Classes I 3 and I 4 ) is that, after initially working in the south, some glass craftsmen later migrated northwards and started making similar or related glass beads in the Culbin Sands until the expedition under Agricola put an end to their work, not so much perhaps by violence as by effectively cutting them off from their earlier trade contacts and reducing their living to more backward conditions. Pace D. V. Glarke (in PPS xxxvi, 214-32) the bone dice present in south-west England and again in west Scotland, may reflect the same trade.

A few of these beads come from Roman contexts, mostly first- or second-century as might be expected (e.g., Traprain Law and Castle Hill, Dalry), and one very battered example, perhaps even locally made, came from Coygan Camp in Carmarthenshire, stratified in a late third-century context but thought, surely rightly, by the excavator to have been derived from an earlier phase.

Were the northern beads of this Class made in the Culbin Sands in around the first century B.c. to early first century A.D., or did they come up before this from the southern Iron Age cultures? As we have seen from the evidence, there is nothing to refute MacKie's hypothesis that the broch and wheelhouse complex began earlier than was once thought likely. On bead evidence alone they could have begun around the third or second century B.c. (if the beads came from Meare), or the first century B.c. to first century A.D. if they came from Gulbin. ${ }^{1}$ The distribution map must be studied with care, for we may be dealing with two centres of production, a southern earlier one at Meare, and a northern one beginning a century or even more later.

At all events, to summarize the chronology, these beads began around 250 B.c. and continued to be produced until about A.D. $5^{\text {o. }}$
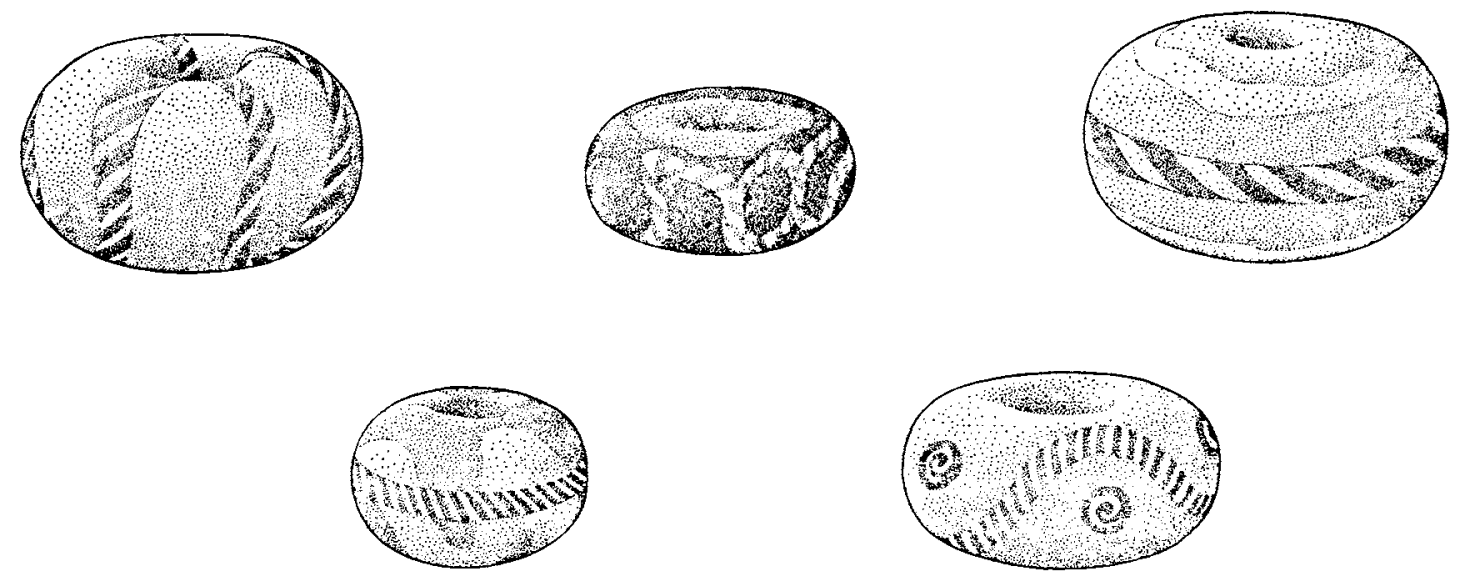

FIG. 26: Class 9-annular beads with two-coloured cables: upper row, t. Tripontium, Warks. Natural greenish glass with red and yellow cable. 2. Moel-y-Gaer, Flints. Natural greenish glass overlaid with inky blue glass and marvered blue and white cable. 3. Wilderspool, Ches. Natural greenish glass. Two white bands and blue and white cable; lower row, 4. Newstead, Roxburghshire. Natural greenish glass with white wave and yellow and white cable 5. Traprain Law, E. Lothian. Natural greenish glass with blue and white cables and white spirals in blue roundels. Scale $1 / 1$.

\footnotetext{
1 The necklace from Dun Ardtreck in Skye included a very small North Scottish decorated annular bead (Class 14). The site, according to radio-carbon dating, might have
}

belonged to the first century B.c., but see footnote , , p. $8_{3}$ below. 
CLASS 9

Annular beads decorated with two-colour twisted cables (Schedules, pp. 182-7) (pls. II, nos. I4 a-c, and III, top right and figs. 26 and 27)

For convenience of study these have been sub-divided according to the ground colour, as follows: (A) natural glass; (B) cobalt blue or purple; (C) brown or golden brown.

All these cable-decorated beads are annular in shape and vary usually between 20 to $30 \mathrm{~mm}$. in diameter, and 10 to $15 \mathrm{~mm}$. in height; the rather wide perforation is almost always cylindrical. In the majority of cases the cable is at least $2 \mathrm{~mm}$. wide and consists of a two-colour twist, rather loosely twisted, and in this respect differing from the somewhat similar but more globular beads with narrow tight twists which are sometimes found on sites of post-Roman date. This, however, is not invariable, for a large Irish toggle bead of unknown date has a wide cable, and can be seen in the Pitt-Rivers Museum in Oxford, and Irish beads of the early Christian period may have twisted cables at each end of long beads.

(A) NATURAL TRANSLUCENT GREENISH GLASS BEADS With COLOURED GABLES

(Schedules, pp. 182-5)

The earliest examples so far discovered in England appear to be those from the Hembury hill-fort in Devon and Meare in Somerset, both thought to belong to about the first century B.c. Of the other stratified or associated examples one was mid-first century A.D., one is A.D. 10-50 and several are vaguely attributed to the Roman period, or sites which begin early; one is Claudian, one Neronian, and one, perhaps the latest, is second-century A.D. In Scotland several come from Roman or RomanoBritish sites, and one comes from a broch, which in all probability points to a first-century A.D. context. In Wales the only dated bead of this type came from Pen Llystyn fort in Caernarvonshire, a fort occupied apparently only from about A.D. 80 to Ioo.

(B) CoBalt BLUe With coloured Gables (Schedules, pp. 185-6)

Here the dates range from Glastonbury, Somerset (probably first century B.c.), and Hembury, Devon (about the same date), to Bagendon, Gloucestershire (stratified A.D. I0-50 or marginally later), and a mainly first- or early second-century A.D. scatter at Windmill Hill, Avebury, Wiltshire. In Scotland the only fairly closely dated example is from an A.D. 80-200 context.

(C) BROWN OR GOLDEN BRoWN With GOlOURED GABles (Schedules, p. i87)

Here again the evidence is consistent, although this ground colour was never so popular as the natural glass or cobalt blue. In England the Leicester bead is probably of the first century A.D.; two were surface finds, and one (Willingham, Cambridgeshire) was associated with a bronze sceptre bearing a portrait thought to represent Antoninus Pius (A.D. 138-6r). None of this Class has been recorded from Scotland and the only Welsh bead of the type came from Caerwent where it was associated with firstcentury pottery and a coin of Nero.

The dating evidence is therefore entirely consistent for these three types, as well as for the related beads. All began to be made in the first century B.C. and died out soon after the end of the first century A.D.

All types are absent from Ireland (see fig. 25) except for a possible example from a collection. There are noticeably few from Scotland north of the Lowlands, and in fact in this respect they contrast strongly with the related Newstead type armlets. The main concentration of cable beads is to the south of a line from Chester to Lincolnshire, and the concentration around the Somerset and Bristol Channel area makes one suspect that there was either a factory or an entrepôt in those parts. It is interesting to note that in four beads (from Meare, Lansdown near Bath, Gharterhouse-on-Mendip and Cirencester) the true twisted cable has been imitated by nicking (and perhaps originally filling with colour?) a marvered trail. These I have called 'tentative' cables, and it may not only be fortuitous that all lie 


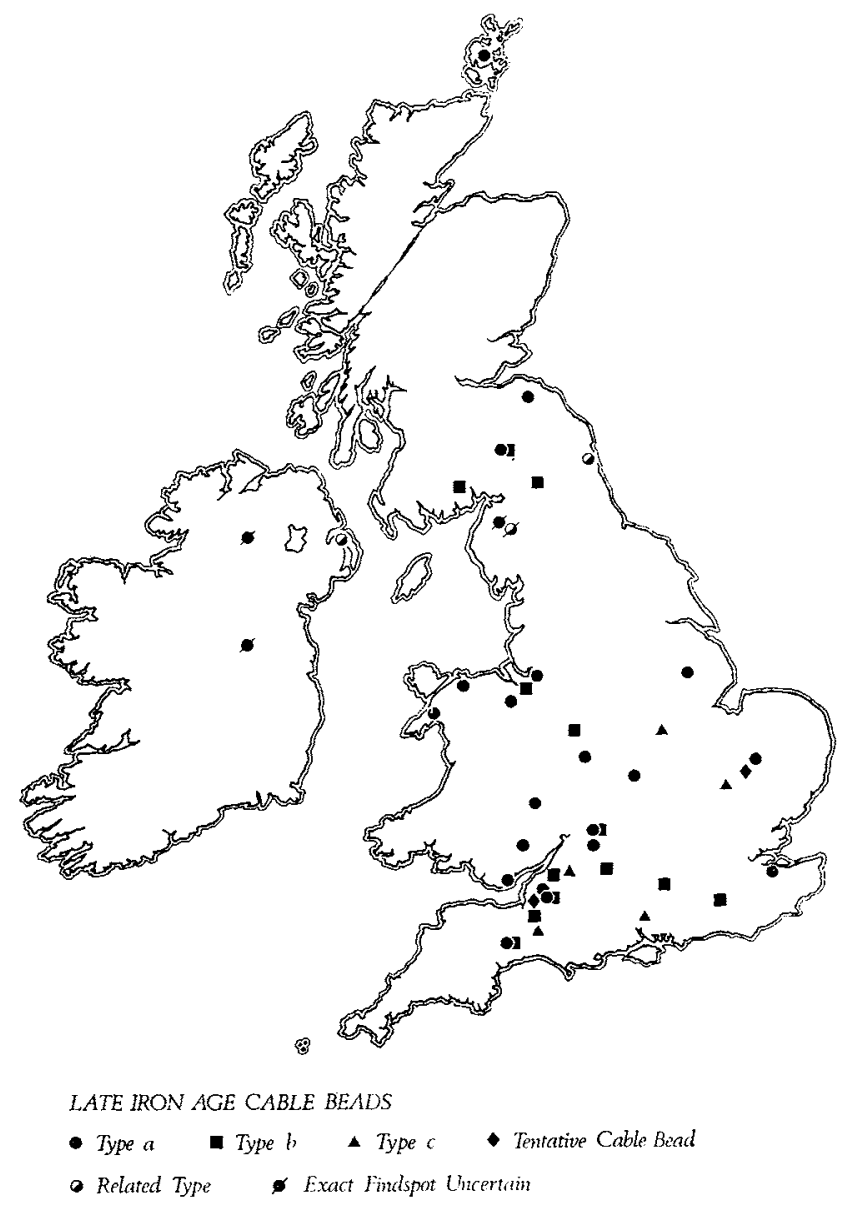

Fig. 27: Distribution of Class 9 beads.

within easy range of the Somerset glass factories of Meare and Glastonbury. Since Glastonbury (rather later to start production of beads than was Meare) produced a true cable twist, it may be that production began there only shortly before the glass-makers moved to the north around the time of the Roman conquest. An increasing number of cable armlets, some quite early in the series, have been discovered in south Britain since Kilbride-Jones regarded them as a Scottish product centred perhaps on Traprain Law. Now we must not only recognize that they began before the late first century A.D. as he suggested, for Harden and Price have recognized a pre-Agricolan one from the Roman palace at Fishbourne, Sussex, ${ }^{1}$ but we must also envisage more than one centre of production. Here a note of warning should be sounded, for it cannot be claimed that all British glass armlets are of local manufacture: a number certainly came in from the Continent, but it is not yet certain how many. The cabled types are different in design, and some of the British monochrome or bichrome ones may be Continental in origin ${ }^{2}$ just like so many bead types; but the cable-decorated ones seem to be native.

The cable decoration is apparently an original one, but it is not impossible that it was inspired from

\footnotetext{
${ }^{1}$ Recently discovered armlets of Class II include one from Cirencester (TBGAS (1971), and one from Bisley, Tunley, Gloucestershire, in the Stroud Museum ( $A R$ (1969)). 2 e.g., $H H$ and Castle Dore, Cornwall (Radford, C. A. R. Others are listed $G A 7$ iv (1976), 53-4. (195I), 68-9), and Hamworthy, Dorset (PDNHAS lvi, pl. iii).
} 
variegated mosaic or millefiori glass patterns which are known from various sites in Britain such as Newstead, Richborough and the Brecon Gaer, and which were common on the Rhine in the early first century A.D. or before. Very much earlier than that a twist decoration had been used in the New Kingdom in Egypt, and in Mesopotamia at several periods. It was also destined to be commonly used in the later Irish string beads of post-fifth-century date.

As a working hypothesis it can be supposed that first the cable beads and some of the armlets were made or distributed in the south of Britain late in the first century B.G. After an interval of half a century or so they were also produced in Scotland, perhaps by people who had learnt their craft in the south and migrated northwards. The cable motif was imperfectly copied in North Scottish beads of Class I4.

Beads from near the Welsh borders were sometimes coated in a second colour before the cable was applied (fig. 26 , centre).

\section{$C L A S S$ Io}

'Meare spiral' beads (Schedules, pp. 187-9) (pl. II, no. 15, and figs. 28 and 29)

These beads are translucent and colourless, usually globular in shape, but some of the spirals were slightly flattened by marvering into a sub-triangular shape. The dimensions of these beads vary from about 9 to $\mathrm{I} 4 \mathrm{~mm}$. in height, and I to $18 \mathrm{~mm}$. in diameter. The perforations are small

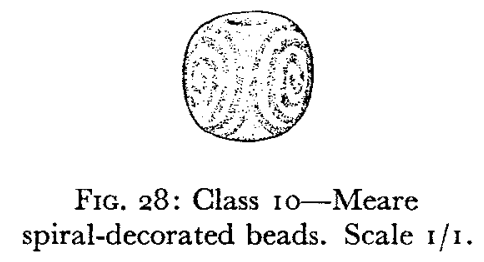

and neatly made. The decoration consists of three carefully wound spirals in opaque yellow glass, occupying almost the whole surface of the bead. These spirals, which are marvered into the body of the bead while warm, are made in the majority of cases with such exquisite precision that one is tempted to think that the very fine examples may have been the product of one man, and most of the rest from the same workshop.

Gontinental analogies, in spite of a fairly extensive search, have not been identified, and it is considered likely that, as such large numbers of them were found at the Iron Age village of Meare in Somerset, they may have been manufactured in that neighbourhood. ${ }^{1}$

The earliest examples of these 'Meare spiral' beads may be those from Meare itself where they were perhaps made during the second phase of the village, antedating the decorated Glastonbury type pottery and La Tène III brooches but contemporary either with the La Tène I or the La Tène II brooches-i.e., in about the third century B.c. From the same cultural context came the chevron beads (Glass I I (a)) and the small opaque yellow annular beads (Glass 8). At Maiden Castle, Dorset, ${ }^{2}$ a spiral-decorated bead was stratified late second or early first century B.c. with what Wheeler has called Bii pottery; with decorated Glastonbury ware (? late second to first century B.c.) from the hill-fort at South Cadbury in Somerset; from the hill-forts of Pen Dinas and Moel Trigarn in West Wales (? third to first centuries B.c.) and from the Culbin Sands in Moray (fused to and presumably therefore

1 See pp. 32-3, above.

${ }^{2} M C, 291-3$ and fig. 98. For revised dating see Frere, S. (1958), 84-92. 


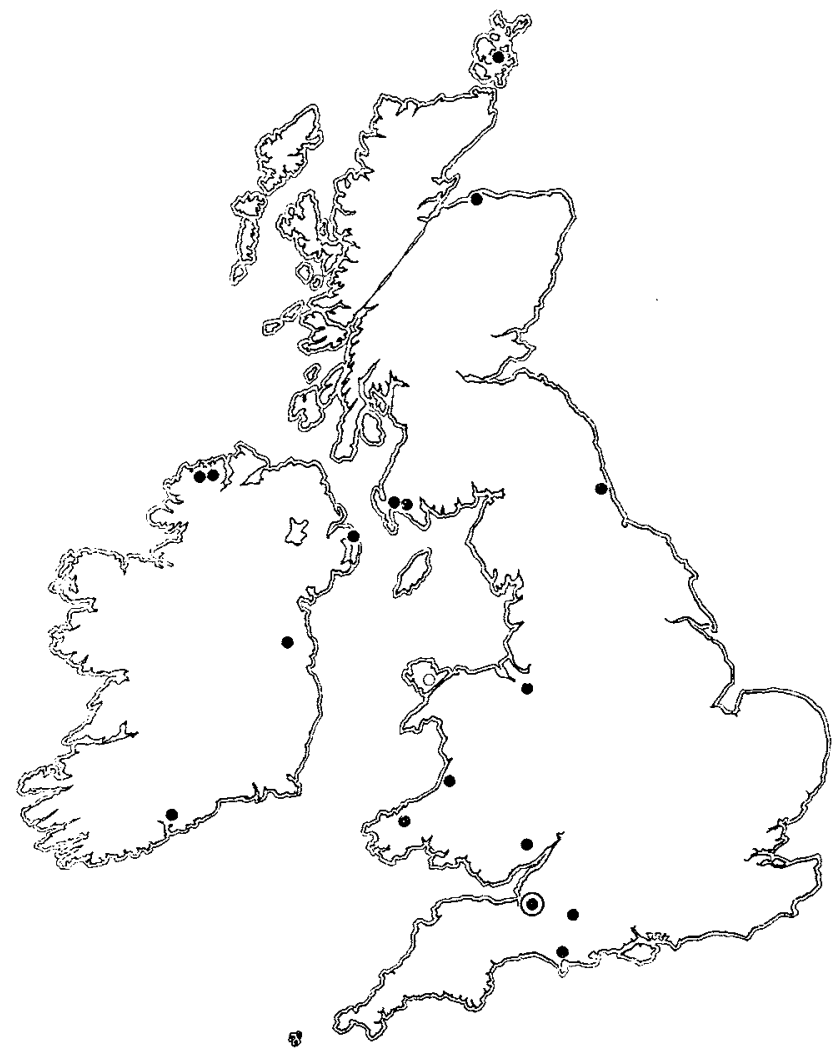

MEARE SPIRALS

- Mecure Spirtl (C) Concentration O Exact Findspot Uncertuin

Fig. 29: Distribution of Class Io beads.

contemporary with an armlet of the first century B.C. or first century A.D. ${ }^{1}$ At Loughey, Donaghadee in Ireland (see p. 75), a bead of 'Meare spiral' type was on a necklace with seventy-one beads of Class 8 , a small horned bead with cable, and sixty-five small blue beads, together with a brooch thought by Jope to be of the mid-first century A.D.- - though possibly a century earlier. ${ }^{2}$

It is interesting to note the long survival of these beads in some instances, and these can only be explained at present as treasured heirlooms perhaps accidentally found and kept. For example, one roughly made example came from South Shields Roman fort, ${ }^{3}$ perhaps not occupied before about

1 This, apparently a true Meare type bead, though possibly a particularly colourless example of a Scottish spiral bead, was fused with part of an armlet of natural greenish glass with longitudinal cables in various colours. (N.M.A., BIB 62.) Note that BIB 6y in the same museum is a clear, colourless blob of molten glass from the same provenance.

${ }^{2}$ Jope, E. M. (1957), 73 ff. and (1960), 40 (note that an unpublished necklace from Meare East also comprised some yellow opaque beads (Class 8) and some spiral decorated ones (Glass ro)). The Nauheim type brooch is now considered to belong to the first half of the first century B.C. See Ralston, I. and Buchsenschutz, O. (1975), I I and Müller Beck, H. and Ettlinger, E. (I962-3), 43-4.

3 Perhaps an heirloom or a very rough imitation. Note that this site also produced a British coin and the tombstone of a Catuvellaunian girl who had married a Palmyrene soldier. 
A.D. I 22, and in Ireland one came from the seventh-century A.D. house at Lagore Crannog, in Co. Meath, ${ }^{1}$ and another from the habitation site of the early Ghristian period at Garryduff, Co. Cork.

One can argue tentatively that the heyday of these beads lies within the approximate date bracket 250 B.C.-A.D. 50 (or they may have finished rather earlier if Belgic domination of Dobunnic territory put an end to native bead production in the first century B.C.). They survived in rare instances into later contexts. At least some of the later craftsmen making these spiral beads may have migrated northwards around the end of the first century в.c. or only a little later, and started production of closely similar but technically inferior beads in the Gulbin Sands district. (See North Scottish spiral beads, Class I3, and pp. 34-5.)

At their best these exquisite beads show 'the peculiar refinement, delicacy and equilibrium' which 'are not altogether what one would expect of men who, though courageous, were also savage, cruel, and often disgusting: for the archaeological refuse, as well as the reports of Classical antiquity, agree in this verdict' ${ }^{2}$

\section{$C L A S S$ I I}

'Meare variant' beads (Schedules, pp. I89-92) (pl. II, a-h, and figs. 30 and $3 \mathrm{I}$ )

These beads, like those of the previous class and those of Class 5 comprise the bulk of the colourless glass beads decorated with opaque yellow designs. Although the decoration of these 'Meare variant' beads is dissimilar, it is clear that they are all closely related among themselves, and were in all probability produced in the same workshops. Their dating may, however, not be exactly contemporary in the sense that, although they may overlap, they may have begun rather earlier or more probably later than the classic type with spirals.
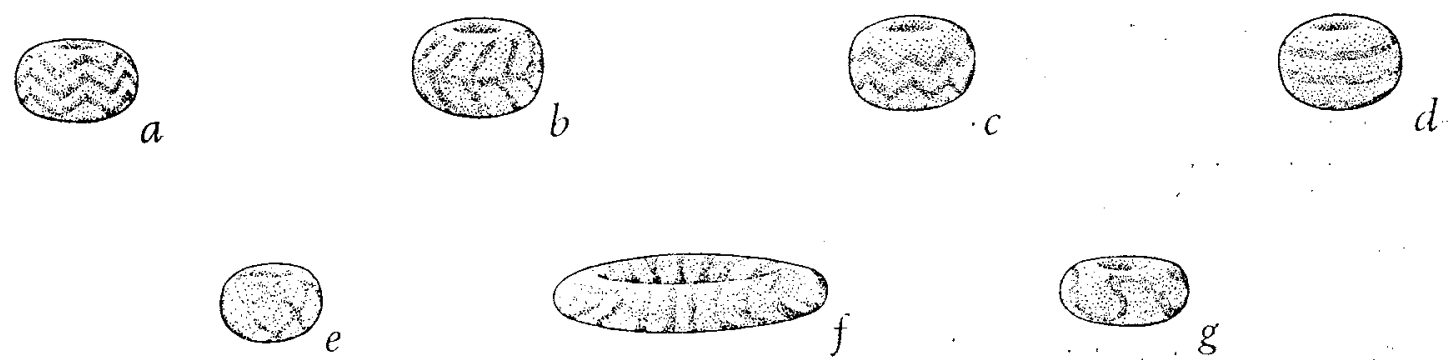

Fig. 30: Class I I-Meare variant beads (see also stud beads, fig. $3^{2}$ ). Scale $1 / 1$.

For ease of study they have been divided into several types, based on their decoration.

Type (a) has multiple chevron lines in opaque yellow, running round the bead at right angles to the perforation in such a way that the whole surface is covered.

Type $(b)$ has a yellow band round the circumference with herring-bone lines radiating from it.

Type $(c)$ has two circumferential chevrons.

Type (d) has several bands running round the bead at right angles to the perforation.

Type $(e)$ has a yellow trellis over the whole bead.

Type $(f)$ has yellow bands down the bead roughly parallel with the perforation.

1 There were several other early-looking beads from Lagore, as well as from the site of Dunshaughlin. See Wilde,
W. R. (1857), 165, I67 and fig. I 23, no. 21 ,

${ }^{2}$ Sandars, N. K. (1968), 226, discussing Celtic art. 
Type $(g)$ has a single wave round the centre.

Type $(h)$ has lines round the bead, overlaid by a looped design running up and down the surface of the bead; with the exception of a few outliers, these beads are almost all grouped round Meare which has produced a number of them.

Type (i) possibly whirl beads of Class 7, Type (c) (pp. 58-9).

Type $(j)$ possibly Irish finds of sub-Oldbury type beads (pp. 56-7).

Type $(k)$ one example only. Decorated with opaque yellow spots.

TYPE (a)

Is the commonest variety, and Meare itself has produced at least twenty-four examples. One comes from Glastonbury, one from a burial at Clevedon (Somerset) on a necklace with small yellow annular beads of Class 8 and some so far unique crimson barrel-shaped beads (see p. 74, fig. 23, no. 6). Others come from not closely dated Iron Age camps at Ham Hill (Somerset) and Caynham (Shropshire). An outlier at Risby Warren (Lincs.) cannot be closely dated. ${ }^{1}$ Michael Avery regards these chevron-decorated beads as contemporary with the spiral-decorated ones of Class io. We must therefore postulate for the present a range of date for the chevron beads from approximately 250 B.c. to about the first century B.c. or so, for there was one example from Glastonbury. If this was a later stray or survival their floruit can be shortened. A note of warning should be given here, for very similar beads also occur in later contexts. ${ }^{2}$

TYPE (b)

These are rarer and their date is less easy to establish. One example came from Meare, and two from Ireland. The Lagore one is too damaged for certain diagnosis, but the site did produce beads which were earlier than the main occupation of the crannog in the seventh century A.D., and may have been discovered at that time on an earlier site nearby; the other one came from a cist-burial in a cemetery with an undated bronze ring at Carrowmore in Co. Sligo. As an example of Type (a) has also been found in a cist-burial, it is probable that the two variants, as might be expected, are related. Evidently Type (b) was rare and cannot be dated precisely, though these and Types (c), (d), and (f), when they occurred at Meare, were regarded by Avery as contemporary with his Phases 3 and 4 of that village (first century B.c. to early first century A.D.). Not all need be so late.

TYPE (c)

Has two circumferential chevrons only. It may or may not be related to the other types. An undated example came from Penzance in Cornwall. The glass is, however, very slightly coloured-not quite as colourless as the Meare ones, and it is not impossible that it may have been an import from Brittany.

TYPE (d)

Only one example, from Meare.

1 The Belgic site at Dragonby is nearby. Anf xxxviii, 43 and refs.

2 Somewhat similar beads, but sometimes with a slightly greenish ground colour, include some from White Fort, Drumarood, Co. Down (latter part of the first millennium A.D.), one large bead from 'Ireland' (Belfast, Benn Collection, 1912-1 72), and Kilmartin, Argyllshire (from top soil of Iron Age and post-Roman fort). Some very similar beads of Dark Age date are made of not quite clear glass, and have the chevrons running parallel to the perforation; two of these come from Co. Antrim (B.M., nos. 92, 4-2r, 17 and

18) and another from 'Ireland' (National Museum, Dublin, 1920-63). Seven related beads came from Garryduff I, Co. Cork, a seventh- to eighth-century site with glass-working evidence. See O'Kelly, M.J. (1962), 69. In rare cases these Irish beads have raised (i.e., unmarvered) decoration. Note a bead from Northern Ireland (B.M., 71.12-10, 34) and one with a trellis pattern like Type (h) (B.M., 1920, II-9, 45). Unmarvered examples also come from Lagore and from Dun Beag, Skye (N.M.A., GA I.105). See PSAS lv (1920-1), 125-6 and fig. 9 . 


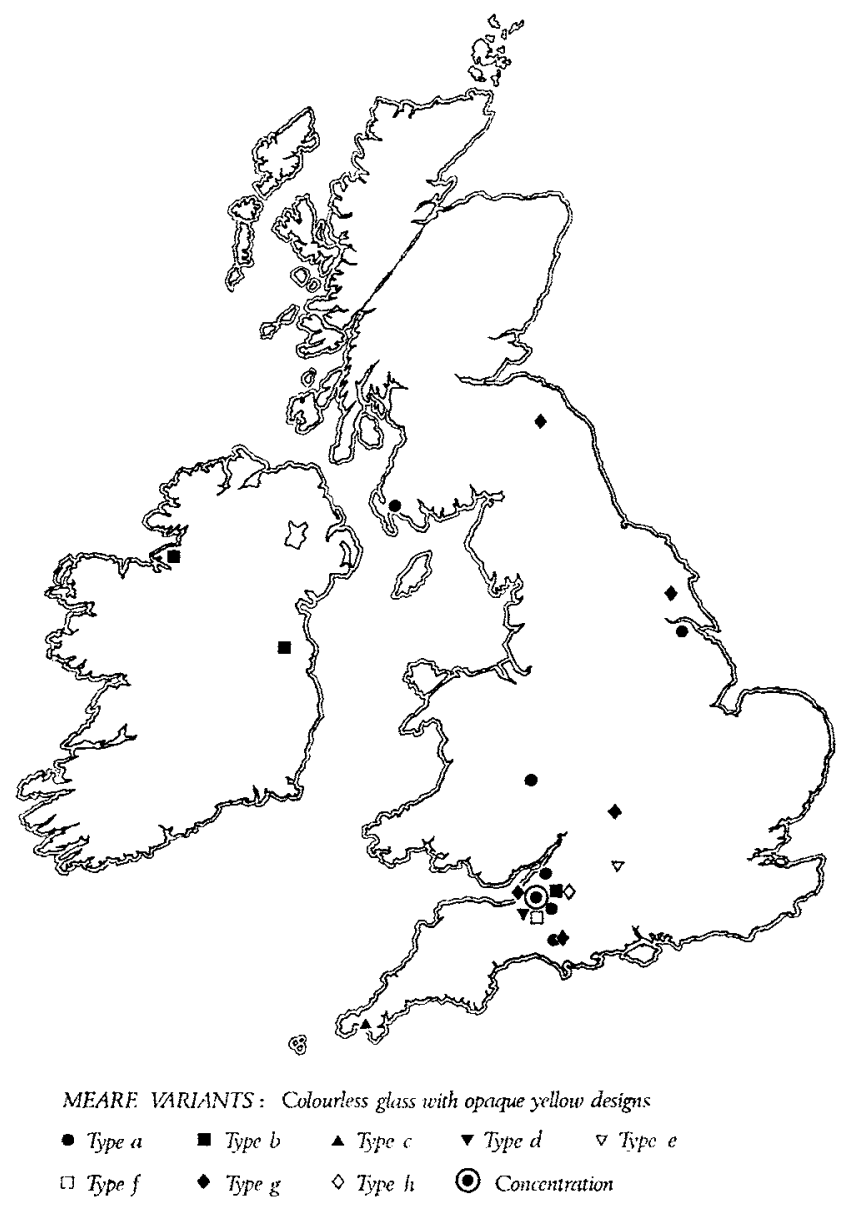

Fig. 31: Distribution of Class 1 I beads.

TYPE (e)

One example only, from an Iron Age site, "from the top of an Iron Age "A" pit' at Overton Down in Wiltshire; not very closely datable but probably second to first century B.c.

TYPE (f)

Half a large annular bead with stripes roughly parallel to the perforation. One example only, from Meare.

TYPE (g), With yellow wave (Schedules, pp. I9I-2)

This type is possibly earlier in origin than the miscellaneous patterns of Types (b), (d) and (f) and the earlier ones are probably the smaller beads about io to $12 \mathrm{~mm}$. in diameter, of which the prototypes (noticeably very slightly coloured whereas the Meare examples are quite colourless) may be those from the Queen's Barrow at Arras in Yorkshire for which a date in about the fourth to third century B.c. has been postulated (see pp. 45-8). It is not yet possible to say whether they were produced in Britain or imported from the Continent. At Meare the several beads decorated with a wave design are annular and of varying sizes, and they fall within the groups tentatively dated by Michael Avery to the first century B.c. to first century A.D., though a very damaged one from Ham Hill may be a little earlier. In 
agreement with the later dating would be both the bead from Newstead, Roxburghshire (the site was occupied in the first to second century A.D. though this bead was a stray found in the area), and the one from Great Chesterford, Cambridgeshire, where the occupation began in the first century B.c. A unique stud-shaped bead decorated on both its elements in this manner may be later than a similar shaped bead found at Lidbury Camp, Enford, Wiltshire, made of the same opaque yellow glass as the small annular beads of Class 8 . At present therefore we can only suggest that the Arras beads are not identical and may be earlier imports, and that the production of beads of truly colourless glass, decorated with yellow waves, only began in Meare Phases 2 to 3 (about the first centuries B.c. or A.D.).

In Northern Ireland there are a number of probably unrelated larger beads, mostly from Co. Antrim and likely to be of later date. It is not yet possible to place these chronologically. ${ }^{1}$

TYPE (h)

Is so far confined to Meare where there was one example only.

TYPES (i) AND (j)

Perhaps restricted to Ireland and made either there at an unknown date, or possibly at Meare in the last two centuries B.c.

TYPE (k)

Only one example of type (k) is known. ${ }^{2}$

\section{$C L A S S$ I 2}

Stud beads (Schedules, p. I92) (pl. II, no. I7, and fig. 32)

These beads consist of two elements, one larger than the other like a modern collar stud. Two examples only are as yet known from Britain and I know of none on the Continent. One is made of clear
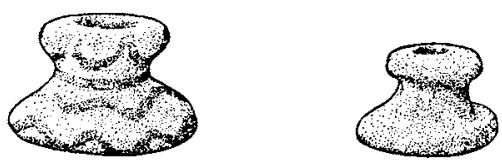

Fig. 32: Class 12-stud beads: left,

Meare, Somerset; right, Lidbury

Camp, Wilts. Scale I/ 1 .

colourless glass decorated with opaque yellow waves (as in Class I I (g), see p. 83). It came from Meare in Somerset where both examples may have been manufactured. The second example made of opaque yellow glass, apparently identical with the glass used for Class 8 annular beads, came from Lidbury Camp, Enford (Wiltshire). It is possible that, as Professor Hawkes has mentioned to me ${ }^{3}$ ' the published material from Lidbury may contain two separate occupations, the later with the re-cut ditch and La Tène III brooch'. The pit in which this stud bead was found could belong to a later occupation than the fairly late 'A' pottery found in it, but on the whole this is improbable, though modern research has

\footnotetext{
1 It is also worth noting that rather similar annular beads with opaque yellow trails are sometimes found in North European Migration Period contexts, but the ground colour is noticeably bluish, and not completely colourless.

2 'Found in Derbyshire' in about I 790. Now strung with
}

other perhaps unassociated beads. (Dept. of Prehistoric and Romano-British Antiquities, B.M.). This is a large annular bead with wide perforation, and five oval spots of opaque yellow around the perimeter. It may belong to a later date.

${ }^{3}$ In a letter of about 1954 . 
done much to point to the danger of trying to draw too much evidence from old and very limited excavation of hill-forts and settlement sites.

The evidence points to both these beads belonging to approximately the third (or second) to first century B.G., and their apparent absence on the Continent need hardly surprise us if we are right in regarding both of them, on their own separate grounds, as of native British manufacture.

\section{CLASS I 3}

North Scottish spiral-decorated beads (Schedules, pp. 193-7) (pl. III bottom left, and figs. 33 and 34 )

These beads are similar in size ( $\mathrm{I}-22 \mathrm{~mm}$. in diameter and Io-1 $8 \mathrm{~mm}$. in height), shape, and pattern to the so-called 'Meare spiral' beads of Glass ro (pp. 79-8I), but they differ in two main aspects: they more generally show a slightly angular shape, probably brought about when the spirals were rather roughly marvered into the bead, and the bead is never colourless but, probably as a result of chance impurities in the sand, may be greenish, brown, dark blue or some other dark colour. The spirals are invariably yellow and the perforations small.
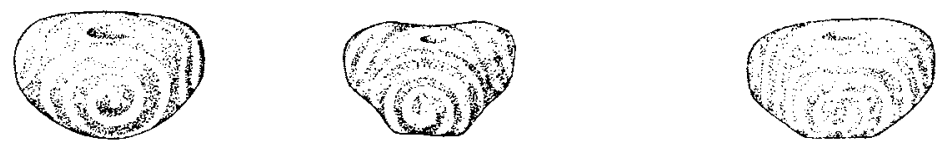

FIG. 33: Class I3-North Scottish spiral-decorated beads: left, Bedlam, Aberdeenshire; centre, Fouhlin, Sutherland; right, 'Aberdeenshire'. Scale $\mathrm{I} / \mathrm{r}$.

Continental beads, which are superficially similar, are more triangular in shape and nearly always on a blue ground. They are known from both north and south of the Alps, ${ }^{1}$ and belong to a period several hundred years earlier than the Scottish ones. Although some derivatives of the Continental series may have found their way to Britain in the last few centuries B.G., the Scottish group seem clearly to be later and to have derived from the 'Meare spiral' beads of Class Io which reached Scotland up the Irish Sea, and which, with the exception of their distinctively colourless ground and greater precision and competence of craftsmanship, resemble the North Scottish beads so closely.

The discovery of a 'Meare spiral' bead fused with a first-century A.D. armlet from Scotland ${ }^{2}$ shows that the Meare beads (even though perhaps mostly belonging to the third- to second-century B.c. phases of that site) were available for local imitation in Scotland in the late first century B.c. or the early first century A.D., and this seems to be the most convincing explanation for the North Scottish group (see pp. 79-80, above). As the map shows (fig. 34), all are concentrated in Aberdeenshire and the neighbouring counties by the Moray Firth, ${ }^{3}$ with the exception of a few outliers which may have been carried by individuals or reached their destinations in the course of trade. This map should be studied in conjunction with fig. 36 showing the distribution of the North Scottish decorated annular beads (Class 14, pp. 87-9), for that group, too, as well perhaps as some of the small opaque yellow annular beads of Class 8 (pp. 73-6), may have been made in the same area. There is little doubt that had the Scottish tribesmen known how to obtain a clear colourless glass like that used for the Meare beads, they might have preferred it, but faced with technical inexperience they seem to have used their

1 Ebert, M. (ed.) (1924-9) xi, Taf. 135.

2 No. BIB 62 in the N.M.A. in Edinburgh. See Schedules of Meare spiral beads, pp. I87-9.
${ }^{3}$ Overlapping the northern part of the area of the souterrains. See Rivet, A. L., F. (ed.) (1g66), 33 . 
own methods in manufacturing beads with local sand, perhaps the Gulbin Sands, containing a variety of impurities. At least eight beads of this type come from the area of the Sands. It is, however, possible that they were sufficiently able craftsmen to obtain the darker colours and to make what suited their own tastes. It is also worth noting that, as noted above (p. 34), a quantity of glass slag, blue, yellow, and green, was found in the Culbin Sands. ${ }^{1}$

The first Scottish imitations were presumably made in the early first century A.D. or only shortly before, and we cannot yet say whether they continued to be made after the Agricolan invasion later in the century. At Gastle Newe a bead of this class came from an earth-house but was not necessarily associated with the bronze armlet of Castle Newe type ${ }^{2}$ of the first century A.D. and with a coin of Nerva (A.D. 96-8) from the same site; two other earth-houses have produced these beads, one at Coldstone (Aberdeenshire) and the other at Fouhlin, Lake Eriboll (Sutherland). Yet others come from brochs at Bowermadden (Gaithness) and Dun Tardhard, Dunvegan (Skye). Occasionally they have been

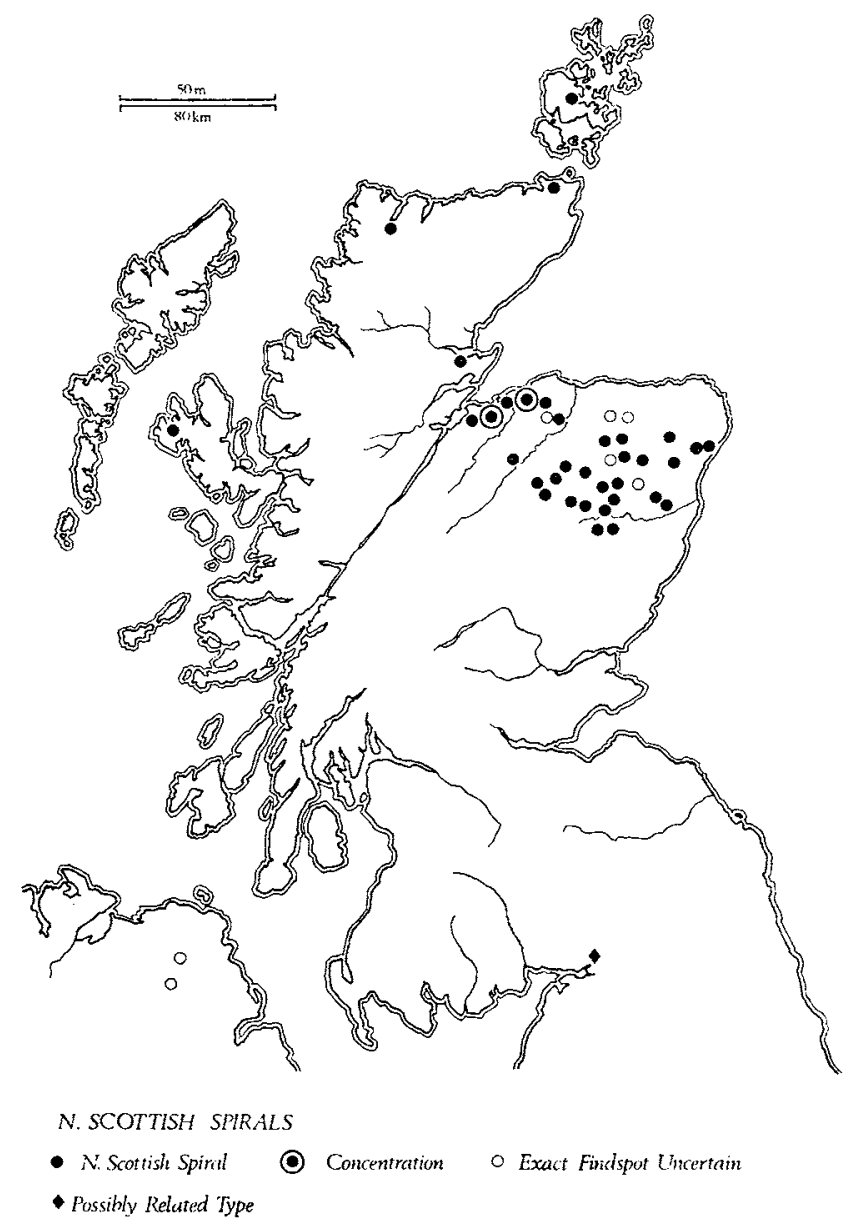

FIG. 34: Distribution of Class I 3 beads.

${ }^{1}$ PSAS xxv (1890-1) and iv (1862), 55, refers to a stone encrusted with glass from a place known as the Old Glass Kiln at Shoggle Burn, Moray. This need not, however, necessarily be ancient glass. See also ibid. ix ( 1871 ).

2 Anf xxxix (1959), 3 r. 
associated with beads of North Scottish decorated annular type (see Glass I4) which are thought to be contemporary and from the same production centre.

With the few outliers in the broch area and in the northern part of Ireland and one find from Netherby (perhaps from the Hadrianic fort there), the overwhelming majority come from Aberdeenshire, Moray, Nairn, and Banffshire, occupied at that time by tribes who were ancestors of the Picts. (See map, fig. 3.) ${ }^{1}$

When these beads ceased to be produced is unclear but it was probably after the Roman victory at Mons Graupius in the late first century A.D. The beads very rarely survived till the late second century, but not, probably, later.

\section{CLASS I4}

North Scottish decorated annular beads (Schedules, pp. 197-200) (pl. III, bottom right and figs. 35 and $3^{6}$ )

Beads belonging to this class differ widely in size, decoration, and colouring, and in fact it was only as a result of close study and an immediately apparent localized distribution that one was able to recognize them as coming from the same workshops. Their sole consistent feature (and even this is not invariable) is their annular form. Otherwise no two beads are identical, and it is only by a certain generic resemblance which they share that they can be isolated as a class, recognizably derived from known antecedents in the Geltic bead repertoire.
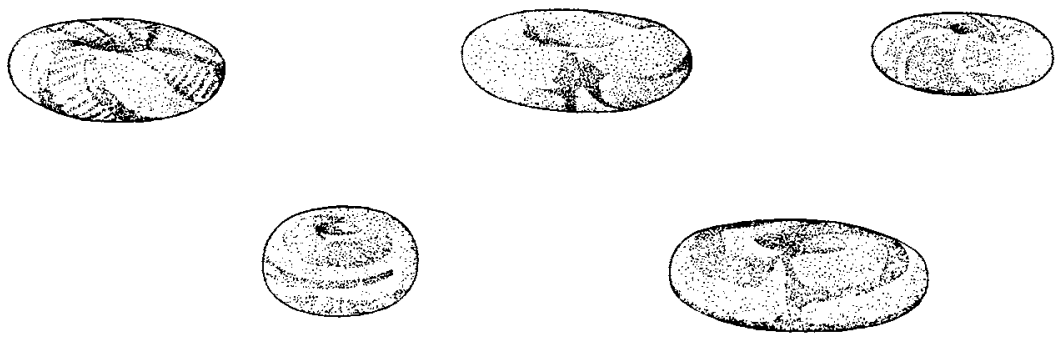

FIG. 35: Class 14-North Scottish decorated annular beads: upper row, I. Aberdeenshire. 2. Clerkley Mill, Morayshire. 3. Culbin Sands, Morayshire; lower row, 4. Kennethmont, Aberdeenshire. 5. Dun Mor Vaul, Tiree. Scale $\mathbf{x} / \mathrm{r}$.

The colours are nearly always opaque and include mostly blues, mauves, and browns; an opaque yellow element is present in almost every example. In size they vary from over $30 \mathrm{~mm}$. in diameter to a few mm., and perforation is sometimes of rounded hour-glass form. A closer look at the patterns with which they are decorated shows that these are derived from two elements: whirls or rays as in the Celtic beads of Glass 7, and ladder patterns which are in effect imitation cables (see Class 9).

It has already been made clear that both these prototypes were available to the glass-workers in north Scotland (see p. 35).

The beads now under discussion will be seen from the map to come from just the same region as the North Scottish spiral decorated beads, and there is little doubt that the annular ones, with their decoration inspired almost certainly from a mixture of two elements, whirl or ray and cables, were being made

1 The bead from Croy (ninth-century) recently cited for dating these beads, in $P S A S \mathrm{cv}\left(197^{2-4)}\right.$, 197-8, is probably

of earlier date but re-used, just as Iron Age beads are sometimes found in Saxon contexts. 
at the same time and in the same area of Moray, a hypothesis substantiated by the absence of known parallels for these beads on the Continent. It is interesting to observe that, as in the case of many glass armlets of British origin, the bead-makers showed a strong propensity for the use of opaque yellow glass.

The evidence for dating the North Scottish spiral beads is satisfactory, and points to the first and second century A.D. The same dating fits the present class. At Cawdor (Nairn) and-less definitelyat Kennethmont (Aberdeenshire) these beads were found in association with North Scottish spiral beads. At Monquhitter (Aberdeenshire) a rather exceptional bead belonging to the first or second century A.D. was found with a Roman intaglio, a native armlet, etc. Necklaces both from the Gulbin Sands and from the galleried wall-fort of Dun Ardtreck (Skye) ${ }^{1}$ include beads of the annular decorated type associated with small annular opaque yellow beads of Class 8 which have been recognized from the same chronological context. At Dun Iardhard (Skye) and at Dun Mor Vaul (Tiree) the decorated class is contemporary with the brochs. It is also worth noting that the far northern Irish examples,

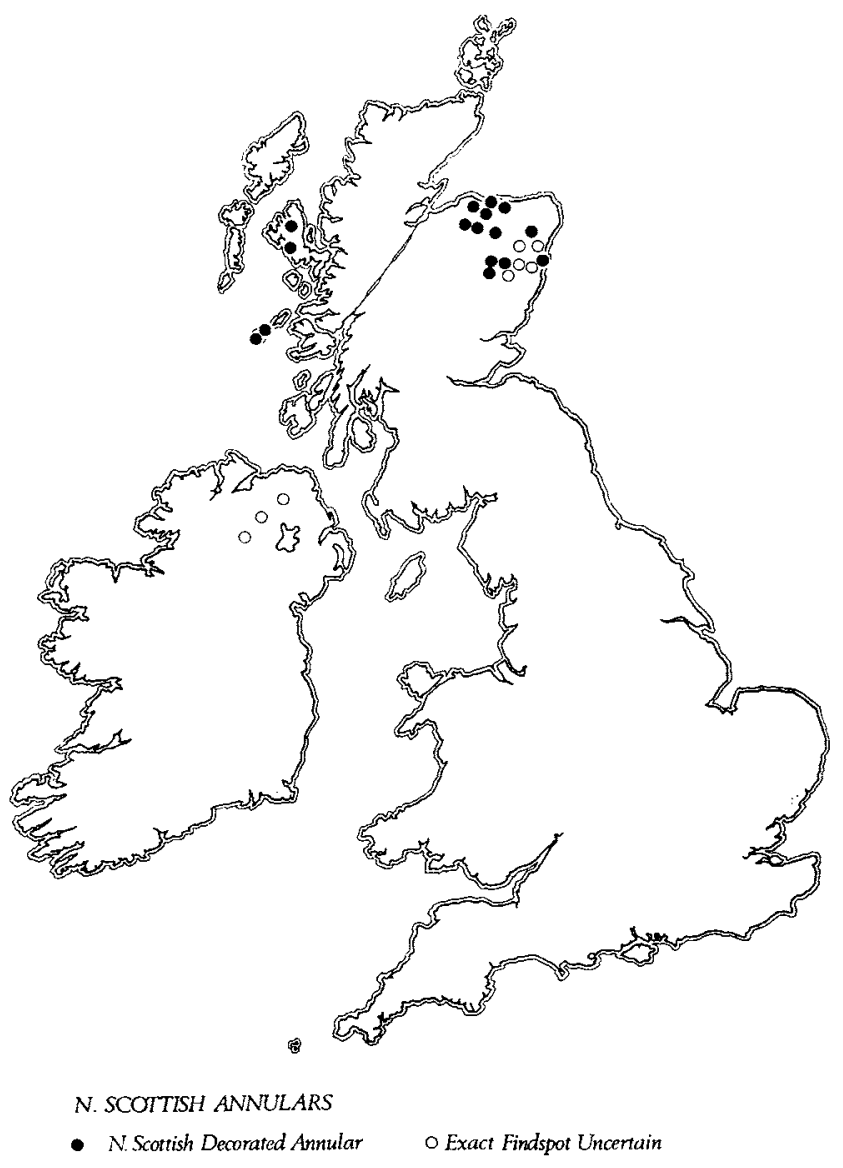

FIG. $3^{6}$ : Distribution of Class 14 beads.

\footnotetext{
${ }^{1}$ It must be remembered that Dun Ardtreck, according to radio-carbon dating may go back to the early first century B.c. but, though possible, it is improbable that the necklace
}

was so early, as nothing else yet supports the beginning of bead production in the Culbin area before the late first century B.C. This assumption may prove to be mistaken. 
some of which make use of an opaque mauve coloured glass like one from Glerkley Hill (Moray), also include what may either be a true imported Celtic whirl bead from Gloughwater, Co. Antrim, or a Scottish imitation of apparently identical glass to that of another bead from the same county, which is definitely of Scottish type (Dublin, nos. I 907.97 and 1908.347, respectively). The few Irish examples certainly do not warrant the suggestion that they were manufactured there, and the notable concentration around northern Aberdeenshire and the Moray Firth should point clearly to their origin. What we do not yet know is from where the Scottish tribesmen obtained their glass. It seems that it can hardly have been imported as waste glass (p. II) as sometimes must have happened further south, closer to established Roman frontier posts.

It is possible that during the early Roman period, the native tribesmen may have satisfied their desire for bright-coloured annular beads by using imported marbled stone or steatite from which to make streaky reddish annular beads. Such beads come from Romano-British sites at Fortingall and Carpow in Perthshire (the latter dated A.D. 209-II), Camelon in Stirlingshire, Newstead in Roxburghshire, Inverness, Parc-croc-rioch in Oronsay, an unidentified site in the Lothians, Rainton near Gatehouse-of-Fleet in Kirkcudbrightshire, and Housesteads and Corbridge in Northumberland and elsewhere. ${ }^{1}$

But where the production of lithomarge beads began and ended is still unknown; it is only suggested here that stone beads of this kind may have locally replaced the glass ones, beginning perhaps soon after Agricola's victory in the north in the late first century.

${ }^{1}$ Listed in $G A \mathcal{J}$ iv (1976), 55-6. Both lithomarge and grey-veined creamy steatite were used. The former probably came from Europe and the latter from Banffshire. Both the Newstead bead and the 'egg' stone from Monquhitter (see p. 88) may belong to the first or second century A.D. 


\section{PART V}

\section{ROMAN PERIOD BEADS ${ }^{1}$}

(pl. IV and fig. 37)

Small segmented beads

PAGE
$9 \mathrm{I}$
$9^{\mathrm{I}}$
93
94
$9^{6}$
$9^{6}$
97
97
$9^{8}$

(a) various colours

(b) enclosing metal foil

Cylinder-shaped beads

Square-sectioned beads, long or cube-shaped

Long polygonal beads

Prism-shaped beads

Small biconical beads

Long biconical beads

Long blue biconical or square-sectioned beads with bands or chevrons in opaque white with a red line in the centre

Oblong beads with round section

Miscellaneous undecorated heart- or pear-shaped beads and oval or round beads with flat section

Boat- or kidney-shaped beads

Small gadrooned beads

Diamond-faceted beads

Glass melon beads

Exotic beads of the Roman period
98

99

99

99

99

99

100

IOI

\section{Small segmented beads}

(a) VARIOUS COLOURS, GENERALLY BUT NOT INVARIABLY OPAQUE (Schedules, pp. 2OI-4)

(fig. 37, nos. I and 2)

Although there are good fossil bone, bone or faience prototypes for this for m of bead, ${ }^{2}$ the origin for the glass ones is more probably simply the result of crimping a hollow rod which could then be broken up into as many segments as required. They did not become popular until Roman times, or shortly before, in Northern Europe and their popularity grew during the late Roman and post-Roman periods.

Several different methods were employed for achieving the required result, and the beads, varying from two to five or six segments, are sometimes only about 0.3 or $0.4 \mathrm{~cm}$. in diameter. The basic requirement was a tube of glass, drawn from a 'gathering' of glass into which a bubble of air had deliberately been introduced; by drawing this out the result was not a solid rod, but a tube which could then be pinched or crimped at roughly regular intervals. Alternatively a thin rod of glass could be wound round and round a wire which was then withdrawn, leaving a tapering bead resulting from the

${ }^{1}$ See also Part III, Groups 6 and 7.

${ }^{2}$ See pp. 37-9, above. 


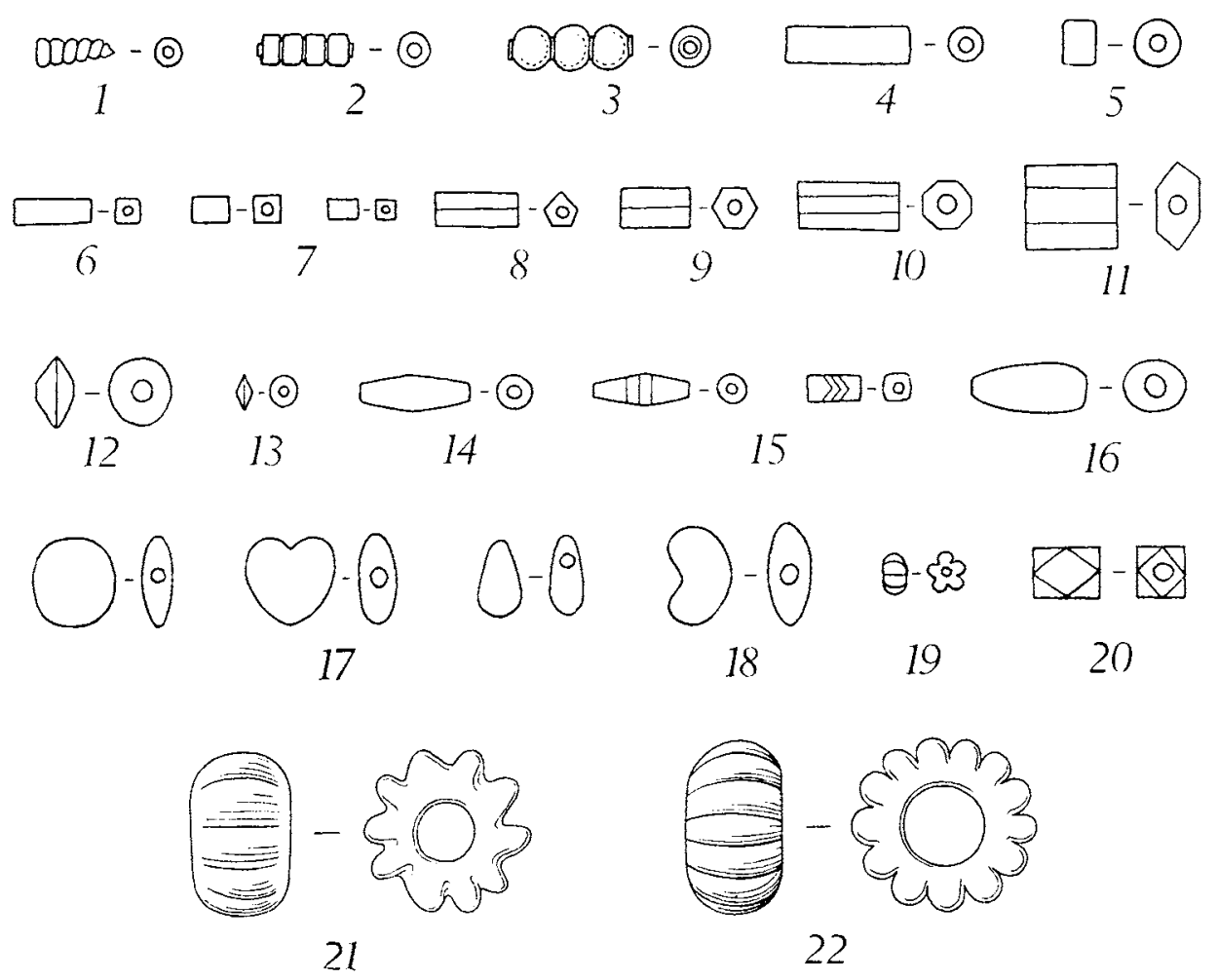

FIG. 37: Forms of Roman beads.

pulling out and consequent thinning of the glass. Such thin rods have been found on a number of British and Continental sites, but it is not always possible to distinguish between those intended for wound segmented beads and those which were designed to form part of an assemblage of rods of different colours to be sliced for millefiori or mosaic glass. Rather larger, hollow segmented beads may have been moulded, or blown, and a fairly common variety (see section (b)) was made with two layers of colourless or amber-coloured glass, often enclosing either gold or white metal foil.

There are very large numbers of these little beads in the Roman world, and they should not be confused with the much larger segmented beads (see below), each globule of which sometimes measures a centimetre or more in diameter; these occur in Viking and other post-Roman contexts.

The commonest colours employed for making the small segmented beads include very dark glass appearing black, opaque terracotta red, yellow, green or blue, and they are often, though not invariably, opaque.

Although they are known from Gallo-Roman contexts in the first century B.c. no such early bead has so far been recognized in Britain. A vast quantity of them come from unstratified Roman sites. One of the earliest is from a second-century context at Godmanchester (Huntingdonshire), and late third- or fourthcentury examples are common: e.g., to mention only a few, from a late fourth-century necklace at Verulamium (St. Albans, Herts.); late third- to fourth-century from the Roman villa at Frocester (Gloucestershire); from late Roman graves at Girencester (Gloucestershire), Lankhills, near Winchester (Hampshire), and Poundbury, Dorchester (Dorset); and from a late Romano-Celtic temple at Lamyatt Beacon (Somerset), where a narrow cane $2 \mathrm{~cm}$. in length, ready perhaps for twisting 
round a wire, was also identified. ${ }^{1}$ The fact that over 400 beads of this type came from Cold Kitchen Hill, Brixton Deverill (Wiltshire), which has also produced an opaque brown rod $\mathrm{I} \cdot 8 \mathrm{~cm}$. in length, makes one wonder whether the beads may have been manufactured near the site of such RomanoCeltic temples. (See p. 38, above.)

This small type of segmented bead, which, not surprisingly, is conspicuously absent from Ireland, did not die out after the Roman withdrawal, but continued to be made well into post-Roman times. Among post-Roman examples there are some from Yeavering (Northumberland) ${ }^{2}$ and from Dalmeny in West Lothian, and they also occur in Teutonic necklaces (sometimes perhaps reused Roman beads), and sixth- and seventh-century examples, often with rather rectangular segments, are frequently discovered in Frankish graves: these are usually made by pinching rather than winding. Noticeably rectangular segments are also present at Lankhills, Winchester, from a fourth-century grave (Grave $33^{6}$ ).

The large examples to which attention was drawn above, sometimes $I$ or even $\mathrm{I} \cdot 5 \mathrm{~cm}$. in diameter and with several segments, are known from Early Christian sites in Ireland, where they are relatively common, ${ }^{3}$ Lundy, etc., and are a common feature in fifth- to eighth-century France, as well as during the Viking period. ${ }^{4}$ Their size and wide perforation distinguish them from Roman examples, and it is also noticeable that many Teutonic and Viking ones have a slight 'collar' where the globular segments were broken off ${ }^{5}$ (also common but less visible on the smaller beads). These large beads may continue, at least in Ireland, into the tenth to eleventh centuries, e.g., at Ballymacash, Co. Antrim. ${ }^{6}$

(b) SEgmented beads Sometimes enclosing Gold or white-metal foll (Schedules, pp. 205-6) (fig. 37, no. 3)

These beads are made with colourless transparent fibrous glass which may enclose either gold or whitemetal foil which glows through the glass to give a pale golden or white colour. In the case of white-metal, it may be sandwiched between two layers of amber-coloured glass which may have been cheaper to produce but which gives a harsher and more glittering result. These beads have already been the subject of a study by G. C. Boon in recent years: it is therefore only necessary to summarize his conclusions and to add any relevant material which has come to light since his paper was published. ${ }^{7}$

As Boon says 'the working procedure was evidently to draw out a tube of glass over a wire core; metal foil was wrapped round this tube and coated with a thin protective layer of glass. The completed ensemble was then threaded upon a narrower wire to be crimped at intervals into the segments which could be broken apart for use as single or multiple units.' As a result of this process it is only to be expected that the broken globules of segments which once belonged to such beads, generally show a thin broken 'collar' at the point of easiest fracture.

There are large quantities of these colourless or amber-coloured segmented beads from Egypt and the Sudan (e.g., Meroe and Faras), and recently a factory of Hellenistic date producing these beads as well as many other varieties has been identified in Rhodes. ${ }^{8}$ Their production began early.

\footnotetext{
1 For similar rods see also Castle Hill and Howrat, Dalry (Ayrshire), in PSAS liii (1918), 123. The recent recognition at Caerwent (no. 1899-igis Ho. V. North) of a long rod intended for this purpose, was published by G. C. Boon in $M A n$ iii, pt. 2 (1972-3), 123, no. 49 and fig. 4. A long 'natural' glass rod, over $5 \mathrm{~cm}$. long, came from Lyons Court Farm, Whitchurch, Somerset, dated to the second or third century A.D. See $A r f$ cxxii (1965), 25.

2 Information from Dr. Brian Hope-Taylor.

${ }^{3}$ See $7 R S A I$ lxiv (1934), 268, and pl. xxix. There are also many from collections. At Garryduff I (Co. Cork) one bead
}

of seventh-eighth-century date measured about $1.6 \mathrm{~cm}$. in diameter; O'Kelly, M. (1963). There was evidence for glass-working on this site. Still larger is a triple example from Letterkeen (Co. Mayo); PRIA liv, I I 3 .

${ }^{4}$ See, e.g., Arbman, H. (r940 and 1943).

5 e.g., a sixth-century bead from Winterbourne Gunner, near Salisbury, WAM lix $\left(19^{6} 4\right), 94$.

${ }^{6}$ Information from Professor E. M. Jope. See also $7 R S A I$ lxiv (1934), 268.

7 Boon, G. C. (1966) and (1977).

${ }^{8}$ Weinberg, G. Davidson (1969). 
In Britain and the Continent they are mainly found in late Roman or post-Roman graves, and, especially in Eastern Europe, in medieval times, but whether these later ones were Roman survivals or were newly manufactured is as yet unsure; the latter hypothesis is more acceptable.

As has been mentioned above their place of origin seems to have been the Near East and Egypt, ${ }^{1}$ but factories producing local imitations may eventually turn up in a variety of other countries. Boon has drawn attention to the fact that colourless glass and gold casing were employed as early as the XVIII Dynasty for decorative purposes, in the tomb of Tutankhamun for example. ${ }^{2}$ How late it continued is at present unknown.

A few beads additional to those published by Boon will be found in the Schedules. Their chronological contexts substantiate his contention that Roman examples in the British Isles fall mainly in the second to fourth centuries and lingered into the seventh century at least (e.g., in the Ashmolean Museum there are fifth- to seventh-century examples from Abingdon, West Stow Heath, and Haslingfield cemeteries).

The few examples in which translucent reddish- or yellow-coloured glass has been used to encase gold foil came from the fourth-century burials at Lankhills, Winchester, and are suspected of having come into the country from east-central Europe: but this theory must be examined in relation to the other finds from the cemetery (publication forthcoming). Certainly non-Roman beads do appear in late Roman burials in Britain (cf. the recently discovered examples from fourth- to fifth-century graves outside Cirencester). There are examples from Roman Egypt in the British Museum. ${ }^{3}$ In view of the very mixed population in Europe around the fourth to fifth centuries these beads (of both types) might arrive in Britain from various Continental sources. They probably continued to be made in Coptic Egypt and were exported along with the other Coptic material found in Germanic, etc., graves (bronze bowls, amethyst beads, etc.), and lingered even into the Viking period. ${ }^{4}$

A warning note about dating and the filling used in these beads results from recent technological analysis. Not all may be comparable and results will have to be awaited. In some instances the filling may not be metal but yellow imitation material.

\section{Cylinder beads}

(a) BLUE (Schedules, pp. 207-8) (fig. 37, no. 4)

These are simple tubular rod beads which may be made either of opaque or translucent glass. The average length-though this varies a lot-is about $15 \mathrm{~mm}$., the width about $4 \mathrm{~mm}$., and the perforation is usually small. (Late Roman examples may be wound beads, smoothed to hide signs of segmentation.)

From the Schedules it can be seen that in Britain they range throughout the Roman period but become commoner after the second century. The later Roman ones often show minute longitudinal striations on

\footnotetext{
1 Although the type is fairly rare in Syria and Palestine, some came from probably Roman tombs at Gerasa. See V. C. Baur in Kraeling, C. H. (ed.) (1938), 546. Dan Barag has excavated one from a second- to fourth-century burial in south Phoenicia (now in Israel), and three others of thirdto fourth-century date came from Hanita in the same region. See also Brunton, G. (I937) (B.M., Egyptian Dept., 62586 of the Roman period and 62592 of Roman or Coptic date; no. 51393 is a Ptolemaic example). Boon, G. C. (Ig66) has also reported examples from South Russia and Bucharest.

Some comparative analyses have been carried out by the Instytut Historii Kulyury MateriaInej (Polska Akademia
}

\author{
Nauk, Warsaw). \\ ${ }^{2}$ Lucas, A. (r 959), 218. \\ 3 Dept. of Greek Antiquities, 1903, 8.13, 16 and 17. See \\ also beads from Faras in the Sudan and in the Ashmolean \\ Museum, Oxford (Liverpool Annals Arch. xii (1925), 98.) For \\ mid-Roman dating see ibid. xi (1924), $144 \mathrm{ff}$. \\ 4 One example came from a late Saxon or Viking context \\ in York; $A$ xcvii (1959), 96. Here Arbman is quoted as \\ writing, 'Some details of the constriction of the ends and \\ centre look very like those of our gold foil beads of the roth \\ century; those of the 9 th were often thicker and generally \\ more regular. .. 'See Arbman, H, (r940 and I943).
}


the surface caused by the drawing out, but not the polishing, of the glass. So far they have not been recorded from pre-Roman sites in Britain, but they clearly last into the post-Roman period and are common, for instance, in sixth- and seventh-century Frankish cemeteries on the Continent.

Apart from one isolated example from the Isle of Man at Close-ny-Chollagh, Scarlett, ${ }^{1}$ all the beads of this type have a very noticeably southern distribution, and it can only be supposed that they were imported from across the Channel, or that they were made in the southern counties at some yet unidentified site.

It is interesting to observe that these beads do not seem to have habitually been cut into short segments as were the comparable opaque green ones described below. An unusual example of clear blue glass with bevelled ends, where it had been knocked off the next bead, seems to be unique in Britain and is thought to have been Coptic or Mediterranean in origin rather than Teutonic. It came from the hill-fort of Dinas Powys near Cardiff (Glamorganshire) occupied into the post-Roman period. ${ }^{2}$

Recently large numbers of small translucent blue cylindrical beads have been recovered from fourthto fifth-century graves at Lankhills cemetery, Winchester, where a mixed Roman and Teutonic population is suspected. ${ }^{3}$

(b) GReEn Gylinder or Gylinder segments (NEARly always opaque) (Schedules, pp. 208-I2) (fig. 57, no. 5)

Everything listed in the Schedules is apparently of the Roman period or immediately before, but it must be noted that the type is not uncommon in Jutish and Anglo-Saxon cemeteries in England, e.g., Chessel Down (Isle of Wight), Stodmarsh (Kent), Sleaford (Lincs.) and Burwell (Cambridgeshire) just to mention a few. ${ }^{4}$ In France they come from a Romano-Belgic cemetery at Villées, as well as from Frankish cemeteries at Samson, Bioul, Éprave, etc., dating from about the fifth to sixth centuries (now in the museums at Namur and St. Germain). Between the third and eighth centuries these beads were widespread and can be seen in Copenhagen and Oslo museums among a great many others.

The earliest examples so far recognized in Britain are perhaps those from a first-century burial at Santon Downham, Suffolk, ${ }^{5}$ and from a 'Belgic' level of the first century B.c. or A.D. at Maiden Gastle in Dorset ${ }^{6}$; they then carry on right through into post-Roman times, reaching their maximum popularity in Britain after the third century.

The same chronology applies to the cut segments, cut at various widths from cylinders of opaque green glass. These are very common in late Roman necklaces from such sites as Lankhills (Winchester), Poundbury near Dorchester (Dorset), Cirencester, etc. A very characteristic late Roman form is about $4 \mathrm{~mm}$. long and $2-3 \mathrm{~mm}$. in diameter.

A necklace largely composed of these came from a fourth-century burial at Cirencester ${ }^{7}$ where the graves are still being excavated on the edge of the town.

\footnotetext{
1 This site also produced two unpierced dumb-bell toggles of post-Roman type, common in Ireland, and one wonders if all three of these beads did not work down from a higher level of occupation. The blue cylinder bead is atypical both in its glass and in the fact that its provenance lies far to the north of the rest of the group. But it is said to have come from a level dated by a La Tène III brooch of Colchester type (current until about A.D. 80). See PPS xxiv (1958), 85 fi. I do not know of other dumb-bell beads or toggles of such an early date, and suspect that the majority
}

of them are post-Roman.

2 Alcock, L. (1964).

${ }^{3}$ For preliminary report see Biddle, M. (1972), 94-8.

Full report forthcoming.

${ }^{4}$ For a discussion of these beads see Hencken, H. O'N.

$(1950-1), 136$.

5 Fox, Cyril (r 923 ).

${ }^{6} M C, 29 \mathrm{I}-3$ and fig. 98 . For redating, see Frere, S. (1958), 84-92.

7 Report forthcoming. 
(c) GYLINDERS IN OTHER GOLOURS (not scheduled)

Gylinder beads which are in colours other than blue or green are rare in Britain. Attention has already been drawn to the long bottle-glass rod of second- to third-century date from Whitchurch (Somerset), ${ }^{1}$ and 'black' glass examples have been found at the Keiss Broch, Caithness ${ }^{2}$ (probably of Roman date), the Roman period site at Cold Kitchen Hill, Brixton Deverill (Wiltshire), now in the Devizes Museum, and Lankhills Cemetery, Winchester.

An opaque terracotta-coloured bead, evidently associated with the Roman site, came from Sea Mills (Somerset) ${ }^{3}$ and another from Ospringe in Kent (with Group 9) on a necklace of late third-century date, now in the Maison Dieu Museum at Ospringe.

A necklace of melon-shaped beads mixed with small cylindrical beads came from a Roman villa at Wiggonholt (Sussex), ${ }^{4}$ but no colour was specified in the report.

Square-sectioned beads (long or cube-shaped) (Schedules, pp. 212-15) (fig. 37, nos. 6 and 7)

The long beads are usually made of bright opaque turquoise blues and greens and appear to be mostly rather late in the Roman period, though it is possible that one example from Templebrough, Rotherham (Yorks.), may be earlier. For the most part they date from the third to fourth centuries.

Another type of smaller section and one slightly tapering end appears to be less common but belongs to the same date. Small cube-shaped beads in translucent blue were found at Lankhills on necklaces which can be dated to the fourth century (Grave 438, later than a coin of A.D. 36 I). Small green opaque beads of square section, but rather longer than cube-shaped, also came from the same grave. They appear to be rare and may have been brought from South Bavaria as they occur in the last third of the fourth century there. ${ }^{5}$ But note that some came from Camerton (Somerset) on a necklace stratified 'before A.D. 284 '. ${ }^{6}$ So the late third to late fourth centuries may be the usual date.

Long polygonal beads (hexagonal, pentagonal or octagonal) (Schedules, pp. 2I $5^{-18}$ ) (fig.37, nos. 8, 9 and Io)

Almost invariably these are light green in colour, and most of them are opaque, and appear to have been made from the same glass as the opaque green cylinder and cut cylinder segments described above. Both types may have been cheap imitations of emeralds. Blue ones are less common and may prove to be mostly post-Roman in date.

From the Schedules it can be seen that the earliest recorded example from Britain - though not on the other side of the Channel-came from the Belgic burial in Essex at Mount Bures, ${ }^{7}$ found with fire-dogs and other objects of Io B.C.-A.D. 50, and two wooden beads of this type from Dorset seem to be only a little later. ${ }^{8}$ From the Conquest onwards the green beads of this type last through the Roman period and were common throughout the Roman world. One very complex example ${ }^{9}$ has a bright yellow core which radiates to each of the five angles and is then covered with translucent green glass: this bead may have been imported from Egypt or some sophisticated area of bead-making, and reached Whitton between the first century B.c. and about A.D. 300 .

It can also be seen from the Schedules that the few rich blue examples, all hexagonal, came from sites with a late or post-Roman occupation: two from the Broch of Dun Beag in Skye, and one from

1 Anf cxxii (1965), 25 .

2 PSAS xliii (rgog), I2.

3 This site, Portus Abonae, dates from the first century and may have survived into the early fourth (Bristol Museum 2220). See Boon, G. C. (1945), 258-95 and (1949) I84-8.

4 SAC Lxviii (1937), 35 .

5 Keller, E. (I97I), Abb. 27, no. 19 and pp. 86 and 92.
6 Information from Mr. W.J. Wedlake.

7 Smith, C. Roach (1852) and Stead, I. M. (1967), I-62.

${ }^{8}$ From Whitcombe, with blue annular beads with a white wave and Samian ware of A.D. 96-1 10. Information from Mrs. G. Aitken.

${ }^{9}$ From the Whitton Roman villa, near Barry, Glamorganshire. 
Jarlshof in Shetland. One came from an evidently Teutonic necklace of the mid- or second half of the fourth century from Lankhills, Winchester, and may be an import from South Bavaria.

Whereas the green beads of these polygonal forms have a long duration, becoming more popular in the later Roman period, the blue ones may have been confined to the late Roman period and have entered Britain with non-Roman people. Only time and more closely dated examples will prove how true this hypothesis may be.

Prism-shaped beads (Hungarian prisma formiga beads) (See schedules of exotic beads of the Roman period below) (fig. 37, no. I I)

These are six-sided with two long sides, flat in section and with angular ends. They are a rare type but have come from Richborough (Kent), ${ }^{1}$ Chesters Fort (Northumberland) and Verulamium (Hertfordshire), the latter being of mixed green and white rather than plain green glass. They are regarded by Professor Sulimirski as being of Sarmatian origin. ${ }^{2}$ I am grateful to Dr. Grace Simpson for the reference to similar prisma formiga beads from Hungary. ${ }^{3}$ The horsemen who introduced these beads are known to have been among the Roman troops sent to this country; over 5,000 of them were brought into Britain in the late second century.

Small biconical beads (Schedules, pp. 2 I 8-2 I) (fig. 37, nos. I2 and I3)

\section{(a) BLUE}

These beads are translucent, medium to dark blue in colour and fall into two main sizes, one slightly larger (measuring between about 5 to $7 \mathrm{~mm}$. in diameter and about the same width or slightly more, and having a small perforation) and another very small and uniform variety.

The Schedules show that those of the first variety are for the most part of late Roman date but they are also known from earlier contexts. At Maiden Castle (Dorset) an example was stratified in a level of A.D. 25-70 and this is less surprising when another comes from the Holcombe villa in Devon, stratified late second century. These beads are also fairly common on the Continent, for instance, on Sarmatian sites, ${ }^{4}$ and in the museum in Mainz there are some from South Russia of the second to third century A.D. Those on another necklace of first- to fourth-century date from Redel (Pomerania) are so sharply cut that they may have been segments from a longer row of beads broken into required lengths. It is clearly impossible to date the rather larger variety of biconical blue bead on its own grounds within the Roman period; this type probably continued into post-Roman times.

On the other hand the very small variety of translucent light blue, among several colours, seems to be consistently late as far as our limited knowledge extends at present. These only measure about $3 \mathrm{~mm}$. in diameter and $2 \mathrm{~mm}$., or even less, thick. They have recently been found at the fourth-century cemetery at Lankhills, Winchester, and can be paralleled from numerous Continental sites. ${ }^{5}$ Like all Roman period beads, we do not yet know where they were made. We can only say that present evidence points to a fourth- to fifth-century date for these very small biconical blue beads. ${ }^{6}$

(b) AND (c) OTHER COLOURS (MOSTLY VERY SMALL)

These appear to be common in the very small form only and are found in quantities from fourthto fifth-century graves at Lankhills and Girencester. Most typical are the opaque green ones made of

1 Rich iv (1949), 239. This site also produced a chalcedony bead (Richborough Museum, no. 28), rather like one from Chesters, Northumberland, thought by Prof. Sulimirski to be Sarmatian.

${ }^{2}$ Sulimirski, T. (1970).

3 See Párduez, in $A H$ xxv (194r), Taf. 24 and 25, and pp. $56 \mathrm{ff}$.

4 Sulimirski, T. (I97o).
5 See, for instance, Keller, E. (r97I): Sjorold, T., The Early Iron Age Settlements of Arctic Norway (Tromso, ig62). For Gaul and the Danubian provinces see Eck, T. ( I $89 \mathrm{I}$ ), 20, 6. For Hungary see Sagrar, B. in Acta Arch. xviii ( 1966 ), 204 ff.

${ }^{6}$ There is also a necklace largely composed of these small beads from Icklingham, Suffolk, in the Ashmolean Museum in Oxford. 
the same glass as the green cylinder beads (see above, p. 95). The translucent yellow ones, some of which may be as early as A.D. 300-40 at Lankhills (Grave I 88), are so far rare-but a few very dark ('black') or amber-coloured ones are also known. We may here be dealing with imports from the Germanic world of the Rhineland (? Alamannic products) but the evidence is too scanty to be certain. Both translucent yellow and opaque green beads of the type, as well as blue ones are dated there by Keller ${ }^{1}$ to the last third of the fourth century in South Bavaria, and they are probably prolific in Northern Germany, Belgium, etc. In Hungary these very small biconical beads come from first- to second-century A.D. Sarmatian graves.

Long biconical beads (Schedules, pp. $22 \mathrm{I}-2$ ) (fig. 37, no. I4)

These are generally about Io $\mathrm{mm}$. in length and $3-4 \mathrm{~mm}$. in maximum width, and are most commonly made of opaque blue glass though other colours, terracotta, turquoise, and bottle green (not yellow) have been recorded from the Continent, and two colourless translucent ones came from a late Roman burial at Poundbury, Dorchester.

Once again the dating is consistently Roman; only one (Bagendon, Gloucestershire) may have slightly antedated the occupation, ${ }^{2}$ but was almost certainly obtained from an area under Roman influence, and in any case the bead is somewhat indeterminate in form. Within the Roman period it is impossible to narrow down the date of their popularity. They were already current by the second century and probably before, and they continued into the third century at least, though their conspicuous absence from the large numbers of fourth-century beads from Lankhills and Girencester suggests that by that date they had gone out of fashion.

These beads reached Northumberland in a few instances but are largely confined to the southern and midland counties. It is not known where they were produced. The majority may prove to belong to the second and third centuries.

Long blue biconical or square-sectioned beads with bands or chevrons in opaque white with a red line in the centre

(Schedules, pp. 222-3) (pl. II, bottom row, no., and fig. 37, no. I5)

These beads are usually rather carelessly made and may sometimes be squarish in section. There may be one or more bands or chevrons. It is improbable that these were made in Britain and they may have been imported from North Africa or the Eastern Mediterranean. The British examples, when stratified, point to a late Roman date, third to fourth century, though it is impossible to be precise about this, as many came from unstratified contexts and may have been earlier. Somewhat similar beads, but larger, and with a straight band rather than a chevron, are occasionally found among Teutonic beads, e.g., Stouting, Sussex. ${ }^{3}$ At least some of these were made by the folding method, as a straight join is visible down one side and the red and white bands do not meet correctly. Possibly some of these are reused Roman beads, but their manufacture persisted well into the post-Roman period. It is interesting to note that a bead similar to the English Roman period beads of this type was found with a possible Libyan burial, ${ }^{4}$ accompanied by a coin of Constantine (A.D. $306-37$ ), a date which accords well with British evidence. ${ }^{5}$

The post-Roman beads tend to be larger than the Roman ones.

\footnotetext{
1 Keller, E. (1971).

2 See Brit vi (1975), 36-6r (V. G. Swan, 'Oare reconsidered'), where it is suggested that the phase previously dated A.D. 50-60 may be A.D. 60-70.

3 These are also rounded in section. There are two from a necklace of about A.D. 600 from Canterbury (Ashmolean Museum, no. 1909-215). The same types come from the Danubian site of Schretzheim, near Dillingen (sixth- to seventh-century) and will be published shortly, probably as
}

vol. I 3 of the GDV by Ursula Koch.

${ }^{4}$ Information from Dr. Cabot Briggs of Harvard University in about 1950 . No further information.

5 Note, however, that their manufacture began earlier in Nubia. A necklace of Ptolemaic date (approx. 304-30 B.c.) including both a little square-sectioned bead of this type and two larger round-sectioned ones came from Faras. See Liverpool Annals Arch., viii-xii (192 I-5) (Dept. Egyptian Antiquities, B.M., no. 51393, referred to on p. 23 above). 
Oblong beads with round section (Schedules, p. 224) (fig. 37, no. 16)

Very few of these are known so far, all opaque sky blue in colour and varying in length from $I \cdot I$ to $\mathrm{I} \cdot 8 \mathrm{~cm}$. On such slender evidence we can only recognize them as being an uncommon type vaguely belonging to the Roman period in Britain.

Miscellaneous undecorated heart- or pear-shaped beads and oval or round beads with flat sections (Schedules, pp. 224-7) (fig. 37, no. I7)

The Schedules show that these vary so much in colour and shape that it is at present impossible to quote useful analogies for them: they are generally, in Britain, of Roman date though some drop- or pear-shaped beads come occasionally from earlier sites. ${ }^{1}$ A rigid classification based on shape would be meaningless as they are often so worn round the perforation or carelessly made that the original shape has been lost. There is a tendency for flat-sectioned round or oval beads to be late Roman in date, and some were present at the big fourth-century cemetery (with Germanic graves also) at Oudenburg. ${ }^{2}$

Boat-shaped beads (German, Perlen in Kahnform) (fig. 37, no. 18) (not scheduled)

These boat- or 'kidney'-shaped beads are not at all common in Britain but one came from a late Roman necklace from Ham Hill, Montacute (Somerset), and another from Grave 199 at Lankhills, Winchester (Hants). The Ham Hill example was made of translucent natural greenish glass, and the Lankhills one of translucent light blue. Both of these were probably imported. The Lankhills grave in question was dated from other contents to c. A.D. $3^{10-} 3^{\circ}$ and similar beads came from graves of the first half of the fourth century at Krefeld-Gellep and other South Bavarian, North Rhenish and Westphalian sites. ${ }^{3}$ Recently another has been identified on a fourth(?)-century necklace in the Golchester and Essex Museum. The find is an old one and the beads may be a miscellaneous collection strung together.

Small gadrooned beads (German, gerippte) (fig. 37, no. 19) (not scheduled)

Only one example of this variety is known to be from Britain, from an unstratified level at Winchester. These are known from South Bavaria and according to Keller ${ }^{4}$ belong to the middle third of the fourth century. Perhaps rather later in date are three small opaque blue examples from Miss Young's Collection in Edinburgh from the Culbin Sands which are like some from Chamberlain's Barn, Leighton Buzzard. 5

Diamond-faceted beads (Schedules, pp. 227-8) (fig. 37, no. 20)

There are a large variety of faceted beads in Europe but only one type appears to be recognizable as a class in Britain during the period at present under review: a cube-shaped translucent blue glass bead, measuring about $6 \mathrm{~mm}$. by $4 \mathrm{~mm}$. with a diamond-shaped facet on the two long sides. These come from late Roman burials at Girencester (Gloucestershire), Lankhills, near Winchester (Hants), Lufton and Lamyatt Beacon in Somerset (the last from the same level as a coin of Constantine II as Caesar (A.D. 330-5) ). At Lankhills a date of about A.D. 350-9o seems likely, and this would accord well with Continental dates quoted by Keller. ${ }^{6}$ At Oudenburg in Belgium beads of this type came from

\footnotetext{
1 Note that heart-shaped beads were made in Hellenistic Rhodes, so that the type was long-lived, but not, apparently, in Britain, where the earliest (more drop-shaped than heartshaped) appear to be Gi3iA and B from Meare in the Taunton Museum.

2 $A B$ (1971), 135 .

${ }^{3}$ See Keller, E. (197I), Abb. 27, no. 13. There are two
}

such beads from late Roman necklaces from Boulogne in the Ashmolean Museum (Evans Collection, nos. 1927.1346 and I347).

4 Keller, E. (1971).

${ }^{5} \operatorname{Arf} \mathrm{cxx}$ (1954). These are of late sixth- or seventhcentury A.D. date.

${ }^{6}$ Keller, E. (1971), 88. 
Grave 67 , dated around A.D. $370-400$. It is interesting to note that both at Lankhills and at Oudenburg Germanic elements were present. ${ }^{1}$

There is good reason to suppose that these particular beads reached Britain from the Rhineland, Poland or the Low Countries, together with other Germanic beads and metal objects. The type was widespread. Moreau ${ }^{2}$ makes it clear that faceted beads of this character were common in fifth- to sixthcentury Gallo-Roman graves in the Aisne district, and they are common too in late Sarmatian graves in Hungary. Their overall dates seem, therefore, to range from the third or fourth century until about the sixth. It should be noted, however, that somewhat similar beads made of opaque blue glass or terracotta paste also appear in Viking graves of A.D. 800-100o but there should be no confusion between these and the late Roman ones.

\section{Glass melon beads (Schedules, pp. 228-30, excluding Ireland) (fig. 35, nos. 2 I and 22)}

It was not my original intention to include glass melon beads in this study for it is well known that, in faience or paste, and perhaps glass too, they were so long-lived that it seemed improbable that extensive work in museums and publications would yield valuable chronological evidence. The Schedules, albeit far from complete, are nevertheless worthy of careful study and give surprising results.

When Hencken ${ }^{3}$ gave his detailed description of beads coming from one site in Britain (in this case Lagore in Ireland), he wrote, 'Melon beads are a long-lived and widespread type that began in pre-Roman times and continued to be common among the Germanic peoples in West and Northern Europe to the Viking Age. They are also fairly common in Treland.' As an overall picture for Europe this statement is true, but it proves to be misleading if applied to glass melon beads in Britain.

Although these beads do begin early on the Continent (for instance they came from a third- to second-century B.c. cart burial at St. Etienne-au-Temple, and from the Beaulieu cemetery at Nogentsur-Aube),${ }^{4}$ as yet no pre-Roman example can be recognized from Britain.

The earliest are Roman, and a study of the Schedules reveals that mostly blue or green glass melon beads come from many Flavian and Antonine sites. But then they die out and do not reappear until postRoman times. As Hencken pointed out, they were popular again among Germanic peoples in the sixth century and later, when they were often made in a rather slap-dash way with nicks rather than true gadroons like the Roman ones. Many of the Germanic ones are made from smoky yellow translucent glass.

So they continue right through into Viking times. One came from a Viking house at Birksay, Orkney, ${ }^{5}$ and they were common at Birka. ${ }^{6}$ Sometimes they were twisted so that the fluting is S-shaped.

A few come from Ireland, some certainly of post fifth-century date, and others perhaps imported from the Roman world. By the tenth-eleventh centuries very small examples were common and numbers of that date have been found at York.

To sum up: the true Roman glass melon beads were imported into Britain from Claudian to Antonine times. They may have been imitated in local factories here, e.g. Castleford (see p. 37), but their chronological range is almost entirely restricted to the first and second centuries. They reappear in numbers in post-Roman times but are less well made and can generally be distinguished from the earlier ones.

One unusual example, decorated with horizontal bands, came from Caerlon and will be found in the Schedules of exotic Roman beads.

${ }^{1} A B(1971), 135$.

2 Moreau, F. (1892).

${ }^{3}$ Hencken, H. O’Neil (1950).

4 Now in the St. Germain Museum, nos. 12720 and
245 16 , respectively.

5 N.M.A., IL 505.

${ }^{6}$ Arbman, H. (1940). 


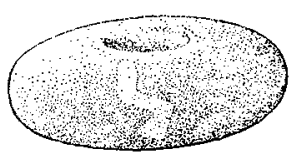

$I$

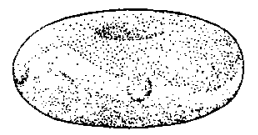

6

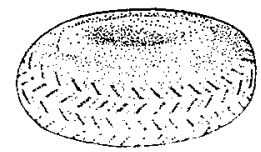

IO

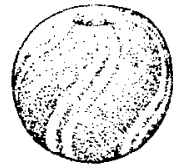

2

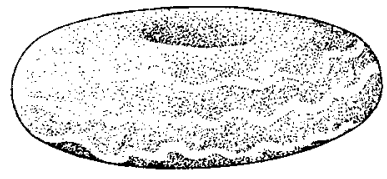

7

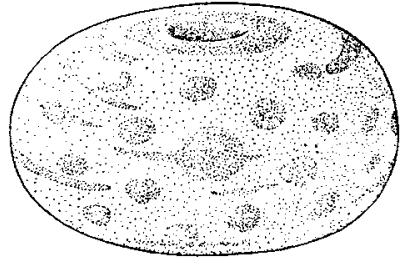

$I I$

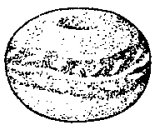

3

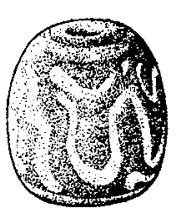

8

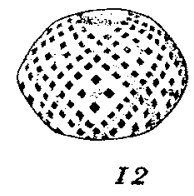

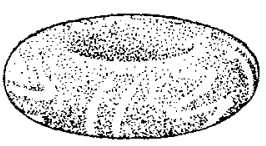

5

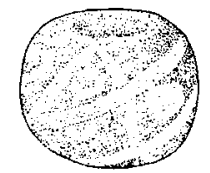

9

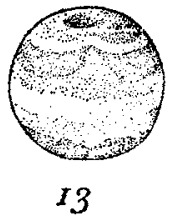

FiG. 38: Examples of exotic beads of the Roman period: upper row, I. Colchester, Essex. 2, 3. Newstead, Roxburghshire. 4. Kenchester, Herefordshire. 5. Colchester, Essex; centre row, 6. Caernarvon (Segontium). 7. Willingham, Cambs. 8. Aldborough, Yorks. 9. Barnsley, Gloucs.; lower row, ro. South Shields, Durham. I 1. Caerleon, Mon. 12. Colchester, Essex. I3. Bromham, Wilts. Scale I/1.

Exotic beads of the Roman period (Schedules, pp. $23^{\mathrm{I}-7}$ ) (pl. II, I-5 and fig. $3^{8}$ )

Very roughly these beads, which for the most part do not resemble either each other or anything else in the recorded repertoire of the British Isles, fall into two main groups. First are the beads which are variations on a native pre-Roman idiom, generally annular beads with free designs, very nonRoman in character; these appear to linger into the Roman period but to die out after about the second century or soon afterwards. Then comes a short period in the third century when only the unimaginative designs of the little standard Roman beads, current in so many districts in or contiguous to the Continental Roman world, predominate. By the early fourth century the native Geltic world was beginning to make itself felt again. Once more decorated and often large beads begin to reach Britain from the European mainland. This time the delight in curvilinear design has been lost, and the very different taste, albeit sometimes derived from the Celtic origin of the Central European tribes, is reflected in the heavy Germanic beads, many of which may have reached first Europe and then Britain from Egypt, exotic treasures carried in the course of trade or of troop movements from one part of the Empire to another by auxiliaries drawn from all over the Empire, and brought to Britain first perhaps by numeri (regiments raised from outside the Empire) and then increasingly by craftsmen and foederati in the fourth century. After this century we are in the dark about the classification of glass beads; Irish glass-working seems to have begun quickly, the true Anglo-Saxon settlement of South and East England intensified, and after that, there was first sporadic raiding and then more extensive settlement by the Vikings. The bridging century, the fifth, is still archaeologically difficult to define. ${ }^{1}$

1 See, for instance, a report on continuing excavations at Mucking, Essex. Here the question is asked, "Were the 
The beads in the Schedules draw attention to some of the non-Roman objects reaching Britain from overseas. As more knowledge accrues, it should be possible before long to identify their places of origin, even if the search will need to be very wide. British auxiliaries were sent to Thracia, Dacia and North Africa; the Roman inscriptions mention soldiers from Spain, Tungria, Pannonia, Raetia, and Batavia. We know that Sarmatian cavalry were serving in Britain in the second century, that Thracians were at Colchester and Cirencester (and Brigantian tribesmen served with the Cohors II Thracum), that the fifth Cohort of Gauls was at South Shields (Durham) in about A.D. 222, and that in 277-8 defeated Burgundian and Vandal tribesmen were sent to Britain. At times Usipii from Germany and contingents from Spain joined the medley as well as a detachment of Tigris boatmen and Alamanni from the Rhineland, large numbers of whose near neighbours, the Marcomanni from Bohemia, had been sent to Britain by Marcus Aurelius. Syrians, too (Cohors I Hamiorum sagittariorum) served on the Wall.

Some of the principal sources of information are listed below, and there the matter must rest. ${ }^{1}$

Among recognizably foreign beads in Britain in the early centuries are the segmented clear glass beads with gold or metal foil enclosed (? Syria and Egypt), ${ }^{2}$ a little gadrooned bead which appears to be Central European, some 'black' globular beads with yellow waves (Sarmatian), boat-shaped beads (? Rhenish), cube-shaped faceted beads (Gallo-Roman and North European), large long 'black' or dark brown slightly biconical beads decorated with roughly applied unmarvered decoration in yellow, white, sky blue or sealing-wax red bands, eyes or chevrons (? Central Europe) acquired perhaps over a century or more from Syria or Egypt by Teutonic peoples, and early (? Teutonic) examples of 'black' annular beads decorated with red or yellow or blue scrabble designs, single or double, swags, etc., which became more common after about A.D. 400 and are noticeably common in Ireland. About all these we know very little, but study of them might throw much light on the archaeology of the suband post-Roman periods. ${ }^{3}$

1 See, inter alios, Collingwood, R. G. and Wright, R. P. (1965); Frere, S. (1967) especially Chapters II and 14 ; Boisserain, U. P. (ed.) (1955); Ammianus Marcellinus, see Incerti Auctoris: Epitome de Caesaribus xli; Simpson, G. (1964); Birley, E. (1953); Webster, Graham (I969); Cheesman, G. L. (I9I5); Richmond, I. A. and Thompson, E. A. (I944 and 1956); Sulimirski, T. (1970); Starr, G. G., Roman Imperial Navy $3^{I}$ B.C.-A.D. $3^{24}$ (Illinois, 2nd ed., I960);
Wacher, J. (1974). For late Roman sites on the Continent see inter alios Diaconu, G. (1965) and Párduez, M.

2 For Roman glass from Syria, etc., see Harden, D. B. (1969), and refs. Also Iraq xi, 2 (1949), I 5 I-9.

3 The most recent general historical and archaeological surveys of the period between A.D. $3^{67}$ and 634 include Alcock, L. (1973), Thomas, C. (1971), and Morris, J., The Age of Arthur ... (1973). See also Laing, L. (1975). 

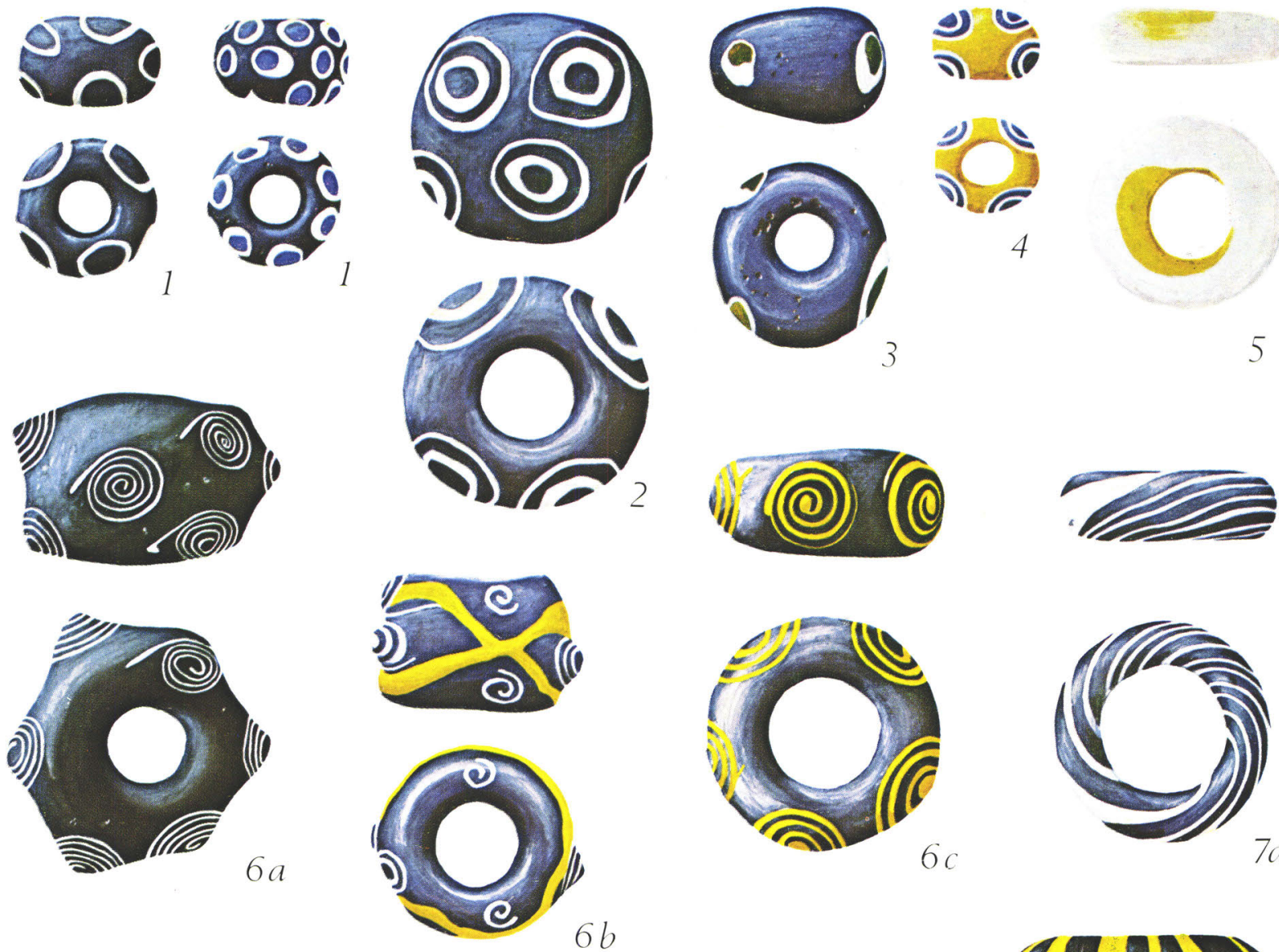

oa

$6 b$
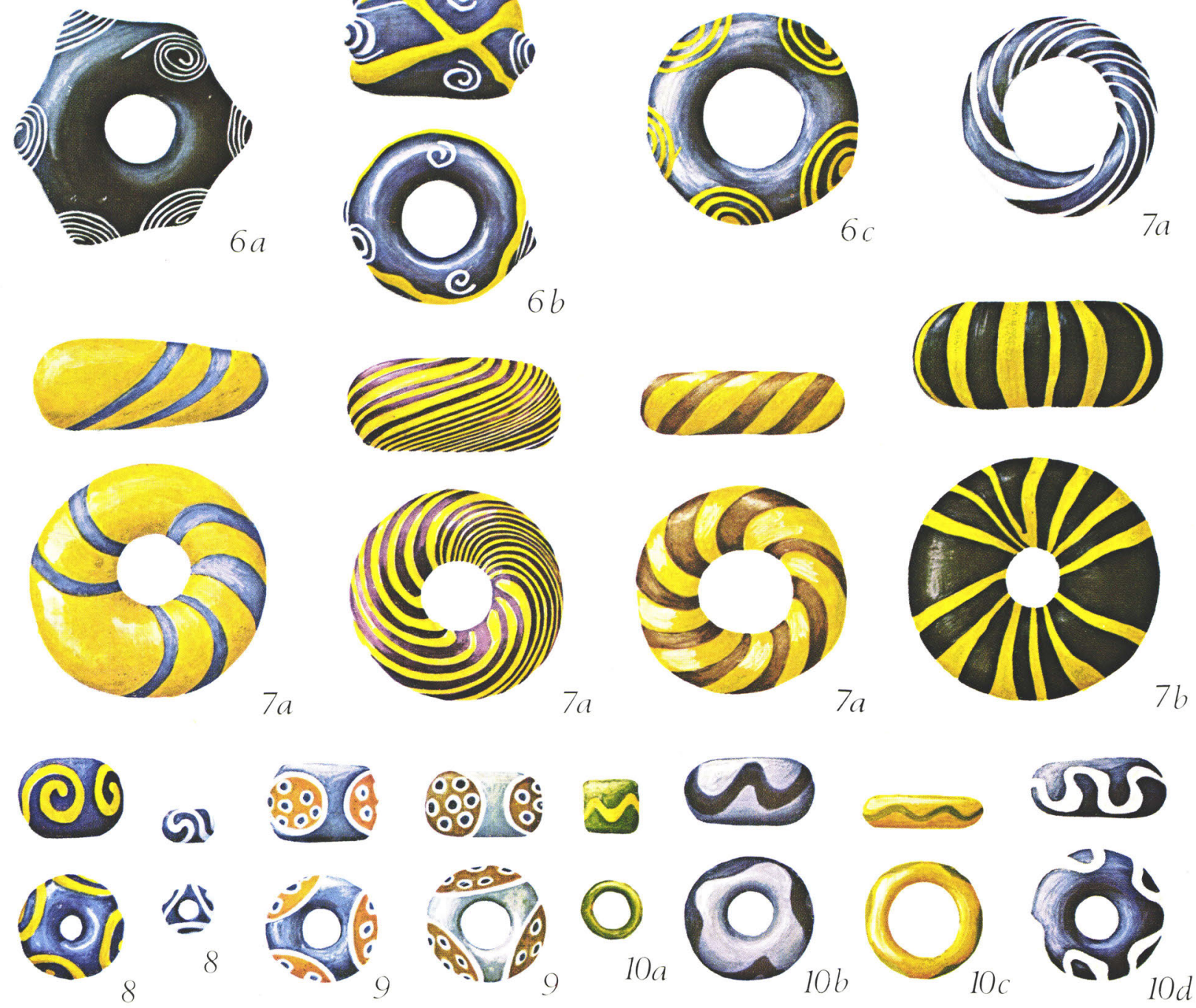

I, Class I: Arras types I and II. 2, Class 2: Welwyn Garden City type 3, Class 3: South Harting type. 4, Class 4: Findon type. 5, Class 5: Hanging Langford type. 6, Class 6: Oldbury type (a), Colchester type $(b)$, and related type $(c)$. 7, Class 7: whirl $(a)$ and ray $(b)$ beads. 8, Group 2: Miscellaneous spiral-decorated beads. 9, Group 4: Garrow Tor type. Io $(a-d$.), Group 5: wave-decorated beads. 

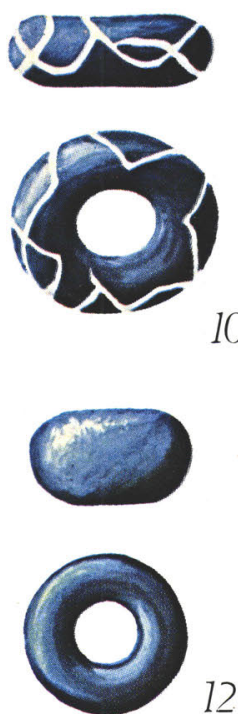

$10 e$
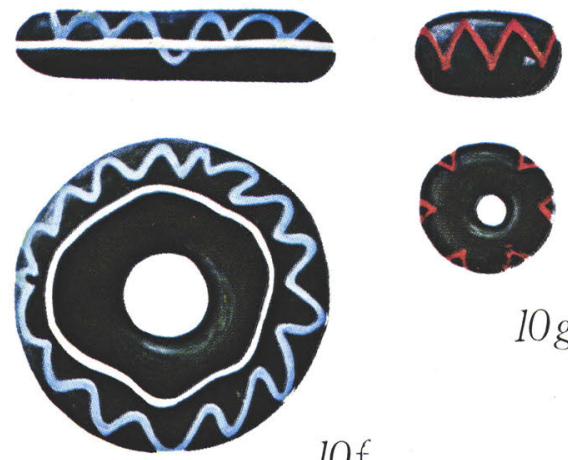

$10 g$

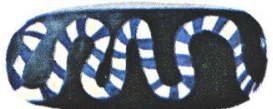

12
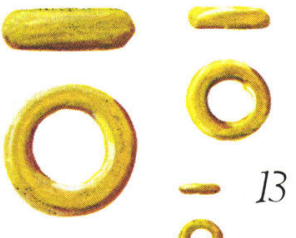

0
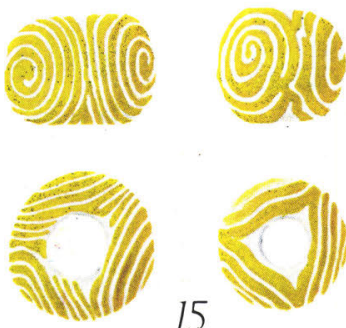

15
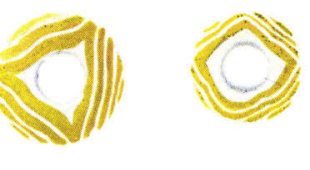

$16 a$
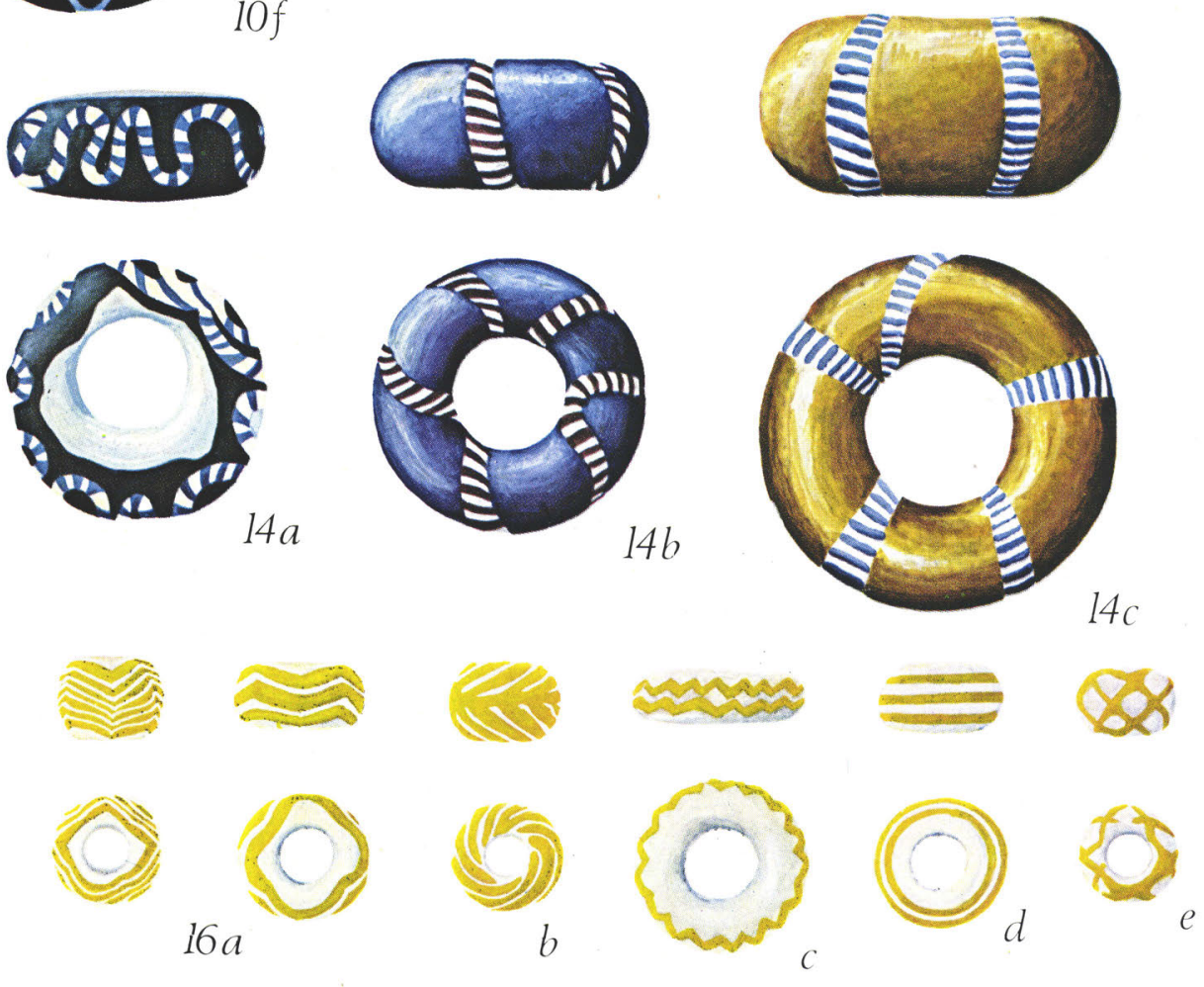

2)) M(C<
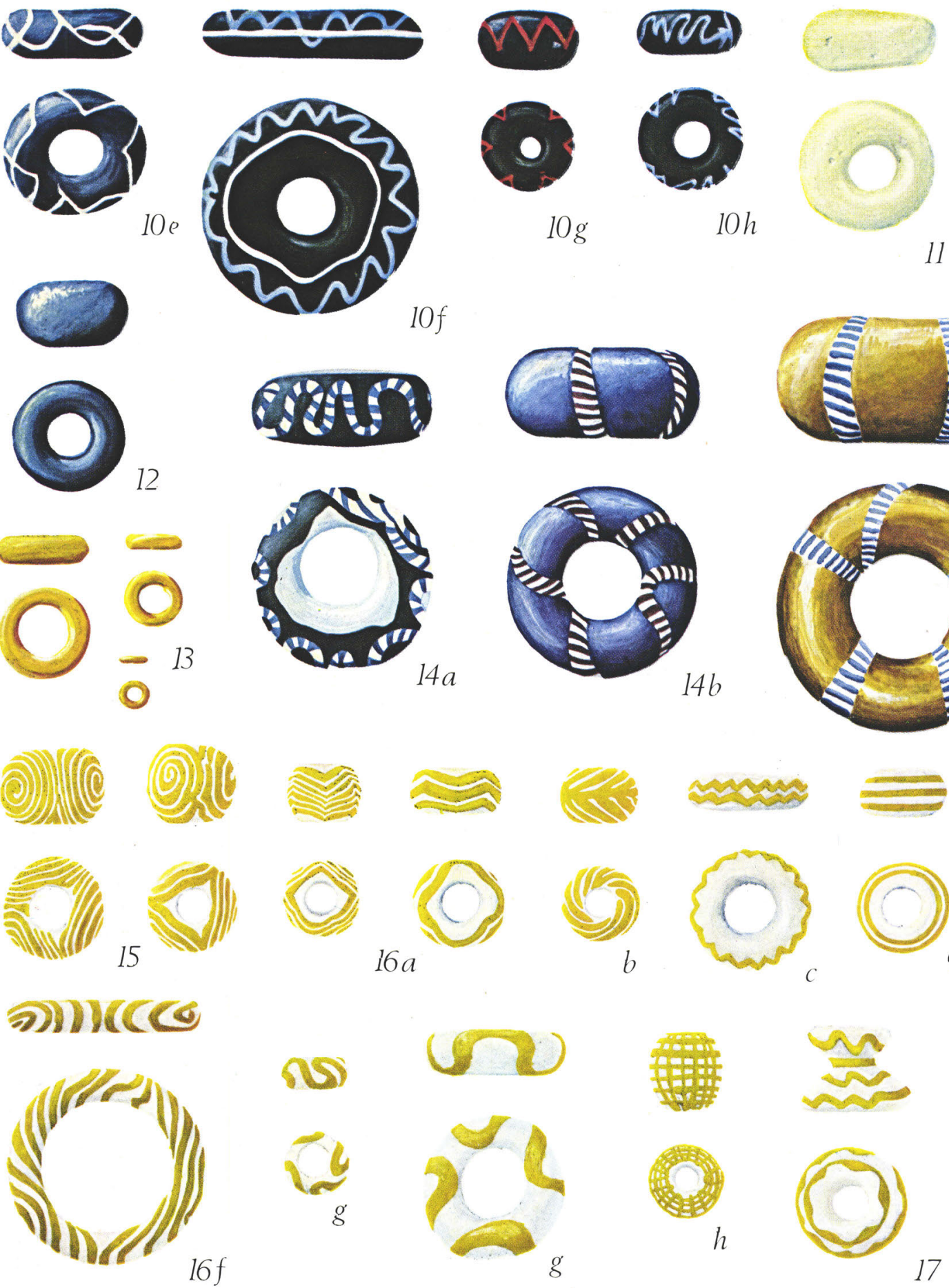

146

$14 c$

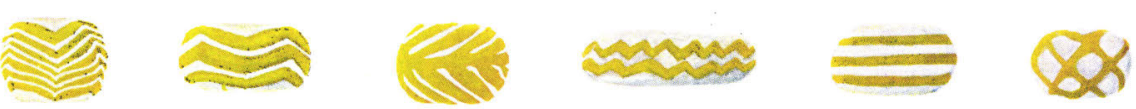

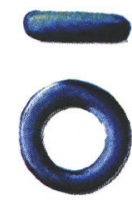

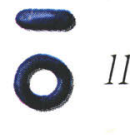




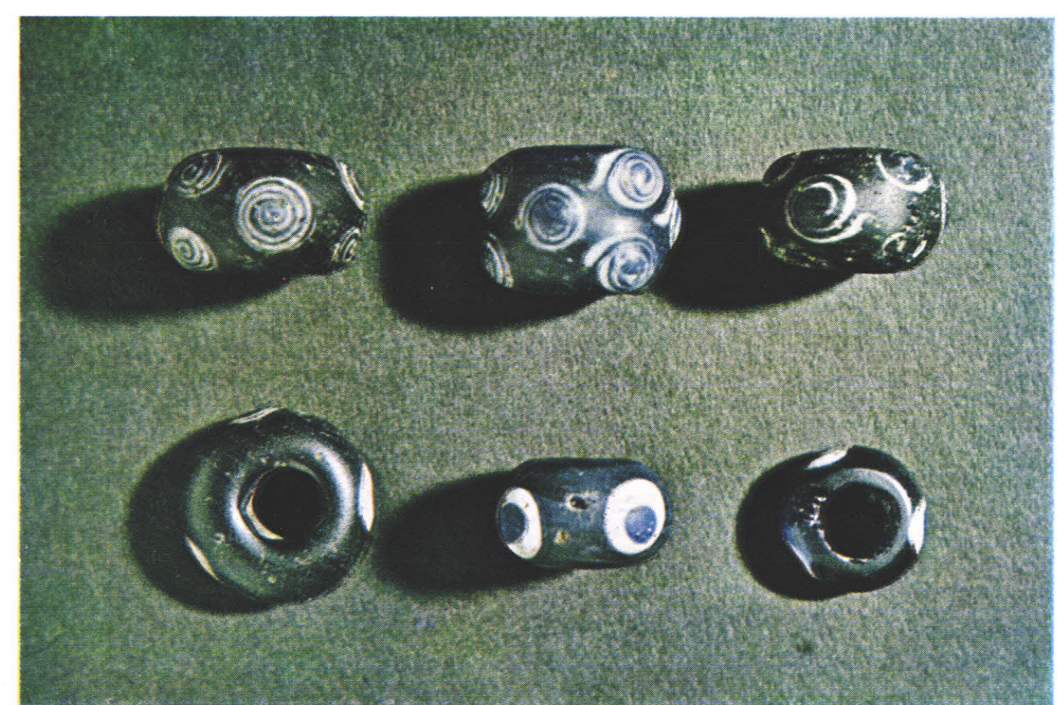

a. Above, Class 6: Oldbury type. Below, Class 3: South Harting type.

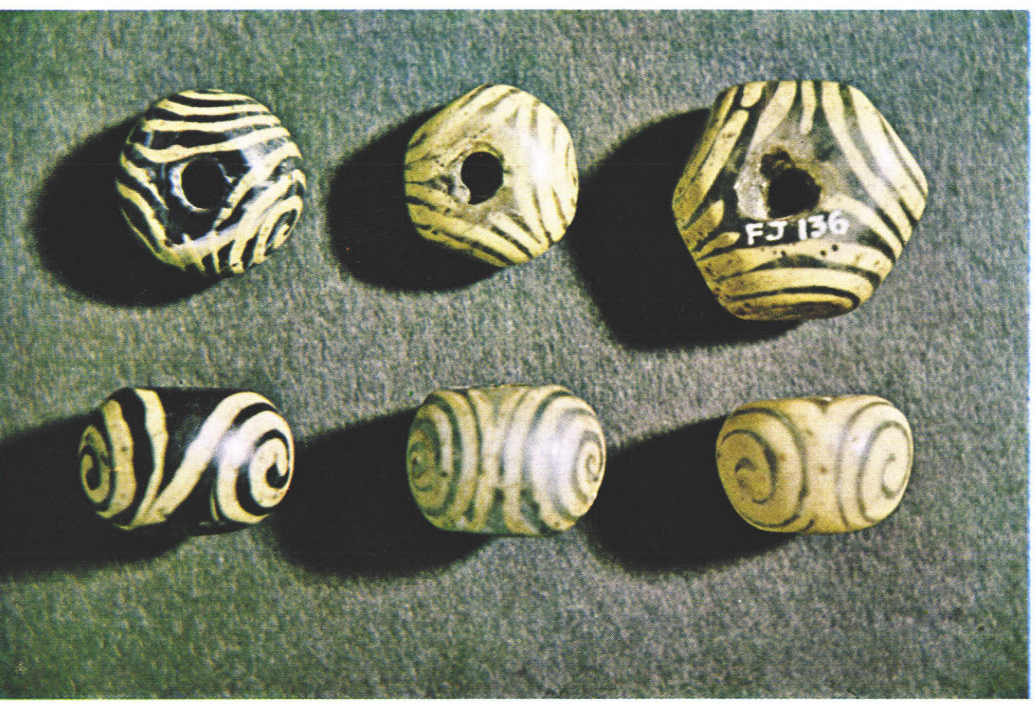

c. Class I3: North Scottish spiral beads.

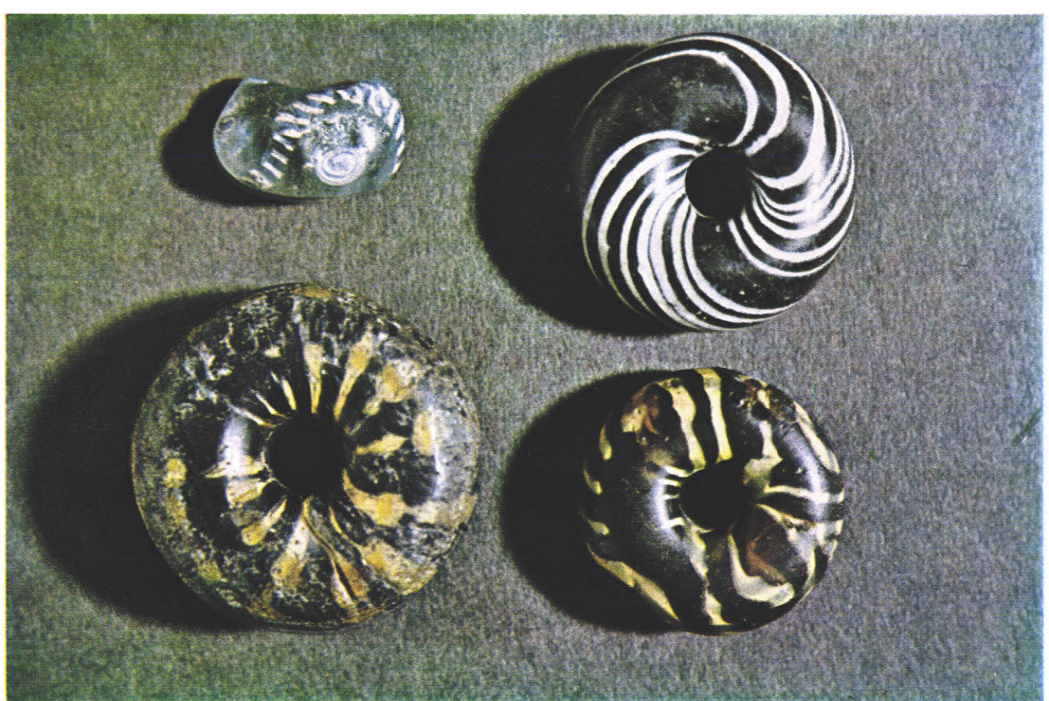

b. Above, Class 9: cable bead (l.) and Class 7: Celtic whirl $\left(r_{\circ}\right)$. Below, Glass 7: Celtic ray

省
ヨ

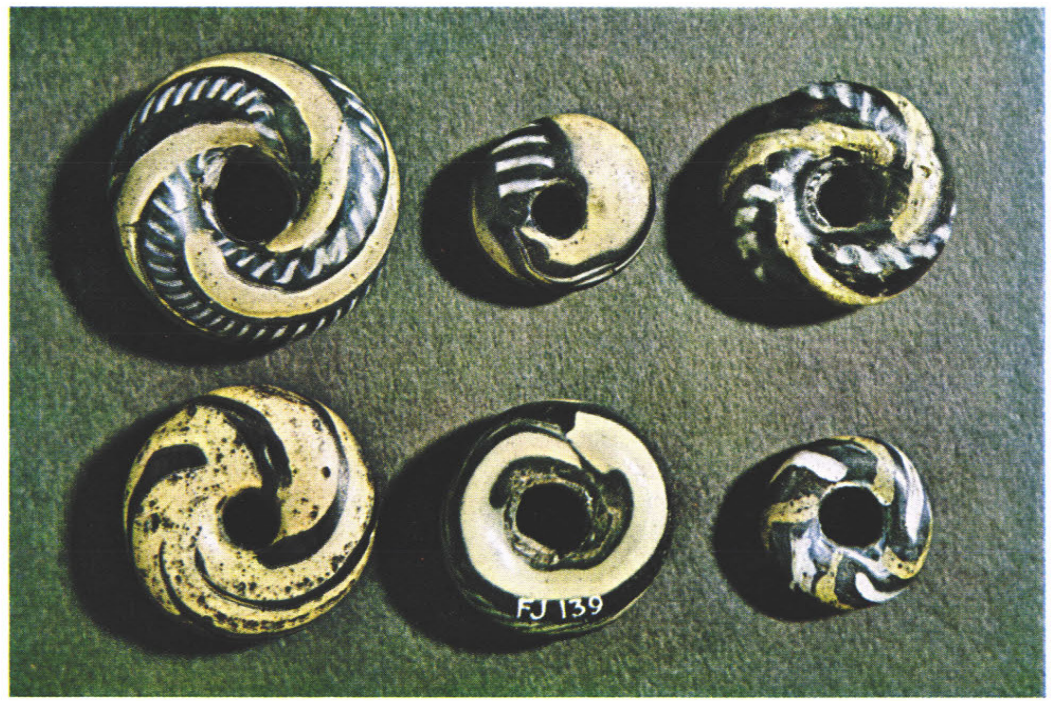

d. Class I4: North Scottish decorated annular beads. 
PLATE IV

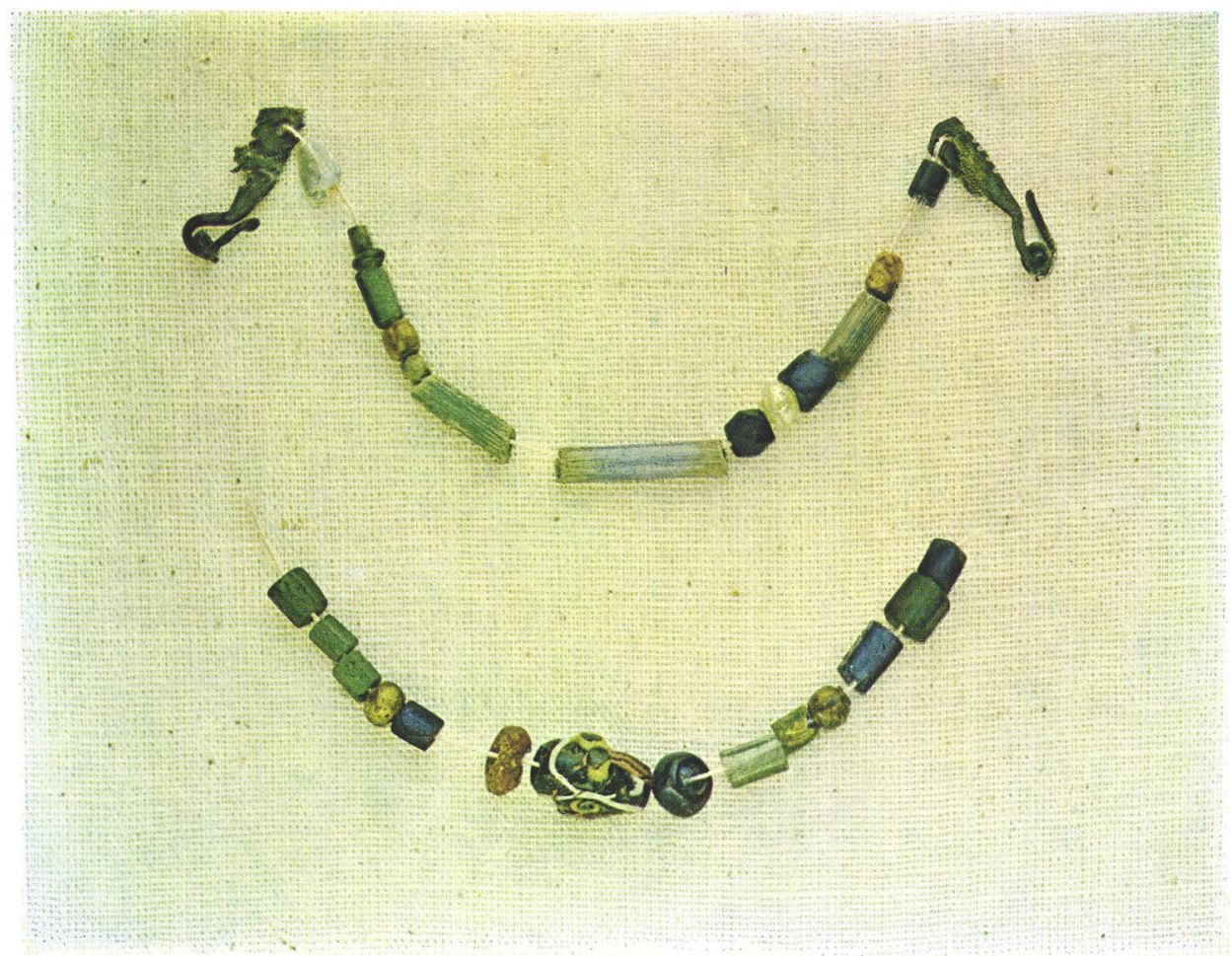

a. Late Roman period necklace from Lankhills cemetery, Winchester (Scale approximately $2 / 3$ ).

(Photograph: Winchester Research Unit).

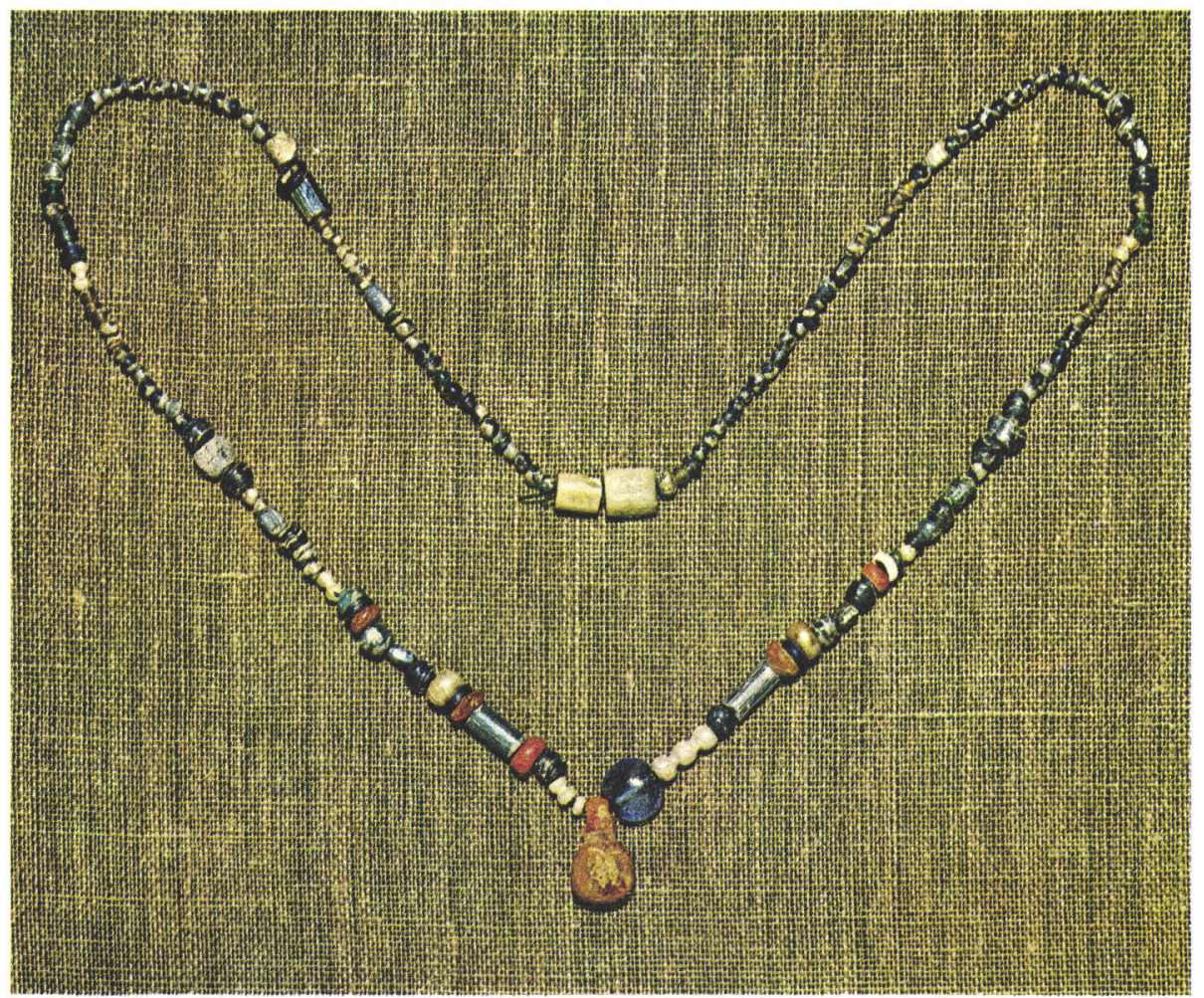

b. Late Roman necklace from Fordington, Dorchester, Dorset (scale 2/3).

(by courlesy of Dorset County Museum) 


\section{THE SGHEDULES}

\section{NOTES}

(i) Most of the references under the column counTy refer to the position before the local government reorganisation of I974.

(ii) Museums. Certain frequently cited museums in the column MUSEUM AND No. are abbreviated as follows:

A.M. Ashmolean Museum, Oxford

B.M. British Museum

C.M. Cambridge Museum of Archaeology and Ethnology

N.M.A. National Museum of Antiquities, Edinburgh

N.M.W. National Museum of Wales, Cardiff

It should also be noted that the Guildhall Museum collections (cited as 'Formerly Guildhall Museum') have now been merged in the Museum of London.

(iii) Publication references. For the identification of references cited under the column PUBLication, see Abbreviations on pp. xix-xxi. 



\title{
BEADS OF GONTINENTAL ORIGIN OR INSPIRATION DEGORATED GLASSES OF THE IRON AGE
}

\author{
GLASS 1
}

ARRAS TYPE I

(Grooved Circles filled with White)

\begin{tabular}{|c|c|c|c|c|c|}
\hline $\begin{array}{l}\text { SITE AND } \\
\text { PARISH }\end{array}$ & COUNTY & MUSEUM \& NO. & $\begin{array}{l}\text { DESCRIPTION AND } \\
\text { APPROX. DIMENSIONS }\end{array}$ & $\begin{array}{l}\text { ASSOCIATIONS AND } \\
\text { REMARKS }\end{array}$ & PUBLICATION \\
\hline \multicolumn{6}{|c|}{ ENGLAND } \\
\hline Londion & Middlesex & $\begin{array}{l}\text { Collection } \\
\text { of the Marquis } \\
\text { Mayeda }\end{array}$ & $\begin{array}{l}\text { Beck's notes say } \\
\text { 'Probably the largest } \\
\text { bead of this sort } \\
\text { known'. No dimen- } \\
\text { sions }\end{array}$ & $\begin{array}{l}\text { Probably this type to } \\
\text { judge from sketch. } \\
\text { 'Dug up near Lon- } \\
\text { don' }\end{array}$ & $\begin{array}{l}\text { Beck's notes, } \\
\text { Cambridge }\end{array}$ \\
\hline $\begin{array}{l}\text { Lake or } \\
\text { Winterbourne } \\
\text { Stoke }\end{array}$ & Wiltshire & Lost & $\begin{array}{l}\text { Dimensions approx. } \\
1 \cdot 3 \mathrm{~cm} \text {. diam. and } \\
1 \cdot 2 \mathrm{~cm} \text {. high. In- } \\
\text { accurate drawing }\end{array}$ & $\begin{array}{l}\text { Not clear from text } \\
\text { if associated with } \\
\text { another bead illus- } \\
\text { trated-of Type II }\end{array}$ & $\begin{array}{l}\text { Smith, A. C. } \\
\text { (1884), p. } 19\end{array}$ \\
\hline $\begin{array}{l}\text { Arras, } \\
\text { Queen's Barrow }\end{array}$ & Yorkshire & $\begin{array}{l}\text { Originally Ioo beads } \\
\text { of various types. Re- } \\
\text { mainder as follows. } \\
\text { Yorkshire Museum } \\
\text { beads not individually } \\
\text { numbered. The B.M. } \\
\text { ones of Type I are: } \\
73.12-19.176 \text { and } \\
\text { I } 77 ; 80.8-2.142 ; \\
91.3^{-27.1} \text { and } 2 ; \\
92.4-21.78\end{array}$ & $\begin{array}{l}\text { White filling mostly } \\
\text { gone, } 3 \text { eyes. Diam. } \\
1 \cdot 5 \mathrm{~cm} . \mathrm{Ht} .1 \cdot 3 \mathrm{~cm} \text {. } \\
27 \text { others similar }\end{array}$ & $\begin{array}{l}\text { From Queen's Bar- } \\
\text { row with I } 8 \text { examples } \\
\text { of Type II, and many } \\
\text { other beads now } \\
\text { scattered with I5 } \\
\text { natural greenish } \\
\text { beads with yellow } \\
\text { wave and } 5 \text { blue } \\
\text { beads with white } \\
\text { wave }\end{array}$ & $\begin{array}{l}\text { Davis, J. B. and } \\
\text { Thurnam, J. } \\
\text { (1865);PAI (1846- } \\
\text { published I } 848 \text { ), } \\
26-32 . \text { For full } \\
\text { details, see } \\
\text { Stead, I. M. } \\
\text { (1965), p. } 59\end{array}$ \\
\hline Cowlam & Yorkshire & B.M. $79.12-9.536$ & $\begin{array}{l}\text { One example. Diam. } \\
2 \mathrm{~cm} . \mathrm{Ht} . \mathrm{I} \cdot 5 \mathrm{~cm} .\end{array}$ & $\begin{array}{l}\text { From Barrow L. } \\
\text { with } 69 \text { blue with } \\
\text { white wave }\end{array}$ & $\begin{array}{l}\text { Greenwell, W. } \\
(\text { I } 877), 208-9, \\
\text { fig. I I } 2 . \text { See also } \\
\text { Stead, I. M. } \\
(\text { I } 965), \text { p. } 59\end{array}$ \\
\hline \multicolumn{6}{|c|}{$\begin{array}{c}\text { ARRAS TYPE II } \\
\text { (Stratified Eyes) }\end{array}$} \\
\hline \multicolumn{6}{|c|}{ ENGLAND } \\
\hline Hatford & Berkshire & A.M. 1942.205 & $\begin{array}{l}\text { Diam. I } \cdot 9 \mathrm{~cm} . \mathrm{Ht} . \\
\mathrm{I} \cdot \mathrm{I} \mathrm{cm} \text {. Straight } \\
\text { perforation } 7 \mathrm{~mm} . \\
\text { wide. Opaque } \\
\text { ground }\end{array}$ & $\begin{array}{l}\text { Near Iron Age } \mathrm{A}_{2} \\
\text { sherds, carinated bowl } \\
\text { of Wessex A type, and } \\
\text { sherd of B type. } \\
\text { But not necessarily } \\
\text { associated }\end{array}$ & $\begin{array}{l}O \text { vii }(194 I-2), \\
\text { IO3n. }\end{array}$ \\
\hline
\end{tabular}




\begin{tabular}{|c|c|c|c|c|c|}
\hline $\begin{array}{l}\text { SITE AND } \\
\text { PARISH }\end{array}$ & COUNTY & MUSEUM \& NO. & $\begin{array}{l}\text { DESGRIPTION AND } \\
\text { APPROX. DIMENSIONS }\end{array}$ & $\begin{array}{c}\text { ASSOCIATIONS AND } \\
\text { REMARKS }\end{array}$ & PUBLICATION \\
\hline ? East & Anglia & $\begin{array}{l}\text { Norwich } \\
\text { Fitch Colln. } 641-2 \text {. } \\
427 \text { and } 649 \cdot 76.94\end{array}$ & $\begin{array}{l}\text { Characteristic of this } \\
\text { class. Diam. } 1 \cdot 3 \mathrm{~cm} \text {. } \\
\text { Ht. } 8 \mathrm{~mm} \text {. }\end{array}$ & $\begin{array}{l}\text { This comes from a } \\
\text { collection and may } \\
\text { not even have been } \\
\text { found locally }\end{array}$ & Not published \\
\hline $\begin{array}{l}\text { Maiden } \\
\text { Castle, } \\
\text { Winterbourne } \\
\text { Monkton }\end{array}$ & Dorset & Dorchester, Dorset & $\begin{array}{l}\text { Diam. I } 8 \mathrm{~cm} . \mathrm{Ht} \text {. } \\
1 \cdot 3 \mathrm{~cm} . \text { Straight } \\
\text { perforation } 8 \mathrm{~mm} . \\
\text { wide }\end{array}$ & $\begin{array}{l}\text { Regarded as probably } \\
\text { an earlier stray in a } \\
\text { deposit including Bii } \\
\text { pottery of 2nd to early } \\
\text { Ist c. B.C. }\end{array}$ & $\begin{array}{l}M C \text {, fig. } 98, \text { no. to, } \\
\text { fragment no. I I }\end{array}$ \\
\hline $\begin{array}{l}\text { Hunsbury, } \\
\text { Hardingstone }\end{array}$ & $\begin{array}{l}\text { Northampton- } \\
\text { shire }\end{array}$ & Lost & $\begin{array}{l}\text { 'A blue glass bead } \\
\text { with white inlaid dots. } \\
\text { Cf. Queen's Barrow \& } \\
\text { Swallowcliffe' }\end{array}$ & $\begin{array}{l}\text { Not stratified. } \\
\text { Occupation until ist c. } \\
\text { B.c. Initial date } \\
\text { perhaps } 4^{\text {th-3rd c. }} \\
\text { B.c. till Ist c. A.D. }\end{array}$ & $\begin{array}{l}\text { Fell, C. }\left(193^{6}\right) \text {, } \\
\text { p. } 69\end{array}$ \\
\hline $\begin{array}{l}\text { Meare, Lake } \\
\text { Village (West) }\end{array}$ & Somerset & Taunton G8 and G6 5 & $\begin{array}{l}\text { G8, diam. I } \cdot 7 \mathrm{~cm} \text {. } \\
\text { Ht. I } 2 \mathrm{~cm} . \text { Perf. } \\
\text { diam. } 6 \mathrm{~mm} . \text { ( } 3 \text { rows } \\
\text { of eyes). } \\
\quad \text { G65, diam. } 1 \cdot 3 \\
\text { cm. Ht. } 9 \mathrm{~mm} \text {. Perf. } \\
\text { diam. } 4 \mathrm{~mm} . \text { ( } 2 \text { rows } \\
\text { of eyes) }\end{array}$ & $\begin{array}{l}\text { Occupation probably } \\
\text { began } 3 \text { rd c. B.c. }\end{array}$ & Me iii \\
\hline Wookey Hole & Somerset & Wells & $\begin{array}{l}\text { Appears to be a } \\
\text { carelessly made } \\
\text { example of this type. } \\
\text { Diam. I } 3 \mathrm{~mm} \text {. Ht. } \\
9 \mathrm{~mm} \text {. Perf. diam. } \\
3 \mathrm{~mm} \text {. }\end{array}$ & $\begin{array}{l}\text { From Hole Ground } \\
\text { above the cave }\end{array}$ & \\
\hline Swallowcliffe & Wiltshire & Devizes & $\begin{array}{l}\text { Diam. } 1 \cdot 4 \mathrm{~cm} . \mathrm{Ht} . \\
9 \mathrm{~mm} . \text { Perf. diam. } \\
5 \mathrm{~mm} .\end{array}$ & $\begin{array}{l}\text { From Iron Age } \\
\text { settlement ? } 5^{\text {th th }} \\
4^{\text {th c. B.c. }}\end{array}$ & $\begin{array}{l}\text { WAM xlii } \\
\left(1925^{-7}\right), 88-9\end{array}$ \\
\hline $\begin{array}{l}\text { No exact } \\
\text { provenance }\end{array}$ & 'Wiltshire' & & $\begin{array}{l}\text { Globular, c. } 1.2 \mathrm{~cm} . \\
\text { high and } 1.3 \mathrm{~cm} \text {. } \\
\text { diam. }\end{array}$ & Old find & $\begin{array}{l}\text { Smith, A. C. } \\
\text { (I } 884), \text { p. I } 9 . \\
\text { Inaccurate } \\
\text { drawing }\end{array}$ \\
\hline $\begin{array}{l}\text { Conderton } \\
\text { Camp, } \\
\text { Conderton }\end{array}$ & $\begin{array}{l}\text { Gloucestershire } \\
\text {-Worcestershire } \\
\text { borders }\end{array}$ & Birmingham & $\begin{array}{l}\text { Diam. I } 4 \mathrm{~cm} . \mathrm{Ht} \text {. } \\
8 \mathrm{~mm} . \text { Perf. diam. } \\
5 \mathrm{~mm} . \text { Opaque } \\
\text { ground }\end{array}$ & $\begin{array}{l}\text { With 'duck' pottery } \\
\text { from and main phase } \\
\text { of the camp }\end{array}$ & $\begin{array}{l}\text { Expected to be } \\
\text { published by } N \text {. } \\
\text { Thomas }\end{array}$ \\
\hline $\begin{array}{l}\text { Arras, Queen's } \\
\text { Barrow }\end{array}$ & Yorkshire & $\begin{array}{l}\text { Originally a necklace } \\
\text { of roo varied beads } \\
\text { of several types, the } \\
\text { remainder are in the } \\
\text { Yorkshire Museum } \\
\text { and the B.M. and } \\
\text { their registration } \\
\text { numbers are given } \\
\text { under Type I }\end{array}$ & I 8 beads of this class & $\begin{array}{l}\text { With a number of } \\
\text { beads including } 28 \\
\text { of Arras Type I }\end{array}$ & $\begin{array}{l}\text { A lx (19o6), } 296 . \\
\text { See also Stead, } \\
\text { I. M. (1965) }\end{array}$ \\
\hline
\end{tabular}




\begin{tabular}{|c|c|c|c|c|c|}
\hline $\begin{array}{l}\text { SITE AND } \\
\text { PARISH }\end{array}$ & COUNTY & MUSEUM \& No. & $\begin{array}{l}\text { DESCRIPTION AND } \\
\text { APPROX. DIMENSIONS }\end{array}$ & $\begin{array}{l}\text { ASSOCLATIONS AND } \\
\text { REMARKS }\end{array}$ & PUBLICATION \\
\hline $\begin{array}{l}\text { Garton } \\
\text { Slack }\end{array}$ & Yorkshire & & $\begin{array}{l}35 \text { beads described as } \\
\text { 'of Arras type' (? } \\
\text { Type II) }\end{array}$ & $\begin{array}{l}\text { With an inhumation } \\
\text { etc., in area of } \\
\text { the chariot burials }\end{array}$ & $\begin{array}{l}\text { Preliminary note } \\
\text { in } A n \times l v(1971) \text {, } \\
289\end{array}$ \\
\hline & & & WALES & & \\
\hline $\begin{array}{l}\text { Whitton, } \\
\text { nr. Barry }\end{array}$ & $\begin{array}{l}\text { Glamorgan- } \\
\text { shire }\end{array}$ & N.M.W. & $\begin{array}{l}\text { Nearly half bead. } \\
\text { Diam. I } 6 \mathrm{~cm} . \mathrm{Ht} . \\
\mathrm{I} \cdot 2 \mathrm{~cm} . \text { Perf. diam. } \\
0 \mathrm{~mm} .\end{array}$ & $\begin{array}{l}\text { Site occupied ist c. } \\
\text { B.C. to about A.D. } 3^{00}\end{array}$ & $\begin{array}{l}\text { Information from } \\
\text { Dr. Michael } \\
\text { Jarrett }\end{array}$ \\
\hline
\end{tabular}

\section{CLASS 2 \\ WELWYN GARDEN GITY TYPE \\ ENGLAND}

Welwyn
Garden City

Wiggonholt, Sussex Pulborough

Worthing Museum, Wig. 64-65 A 186.2.

Fragment, globular -broken remains of 4 eyes. Original height and diameter both about $3 \mathrm{~cm}$. Perf. diam. I cm.
With rich grave goods of last 20 years of Ist c. B.c. This bead is very fragmentary but I do not think the form restored in the publication is correct. It appears to be globular not annular

From large pit full of Romano-British pottery of ist-2nd c. A.D., coin of Vespasian etc.
$A$ ci ( 1967$),$ I 8 , fig. 1o. I think incorrectly restored to an annular shape instead of globular
$S A C$ cxii (1974), fig. 7 , no. 28

\section{CLASS 3}

\section{SOUTH HARTING TYPE}

\section{ENGLAND}

\section{Willingham Cambridge- shire}

Taddington (Old Woman's House)
Dark blue translucent with white rings round blue eyes. Diam. $c$. $3 \cdot 5 \mathrm{~cm}$. Ht. $1 \cdot 9 \mathrm{~cm}$.

Four eyes all blue. Not stratified Diam. $3 \cdot 1 \mathrm{~cm} . \mathrm{Ht}$.

$\mathrm{I} \cdot 7 \mathrm{~cm}$.
Found with a club bearing portrait of Antoninus Pius, and a cable bead, etc.
Derbyshire Buxton
Anf vi (1926), 178 ; JRS xiii (1923), 9 I and xxxix (1949), I9

$7 D A \mathcal{N} H S$ xxxiii (I9II) 


\begin{tabular}{|c|c|c|c|c|c|}
\hline $\begin{array}{l}\text { SITE AND } \\
\text { PARISH }\end{array}$ & COUNTY & MUSEUM \& NO. & $\begin{array}{l}\text { DESCRIPTION AND } \\
\text { APPROX. DIMENSIONS }\end{array}$ & $\begin{array}{l}\text { ASSOCIATIONS AND } \\
\text { REMARKS }\end{array}$ & PUBLICATION \\
\hline $\begin{array}{l}\text { Gussage } \\
\text { Down }\end{array}$ & Dorset & $\begin{array}{l}\text { Dorchester } \\
\text { I } 889.1 .2 \text { I }\end{array}$ & $\begin{array}{l}\text { Blue with one green } \\
\text { and two yellow eyes } \\
\text { ringed with white. } \\
\mathrm{Ht.} 1 \cdot 4 \mathrm{~cm} \text {. Diam. } \\
2 \mathrm{~cm} .\end{array}$ & Wake Smart Colln. & \\
\hline Wimborne? & Dorset & Dorchester & $\begin{array}{l}\text { Blue with white } \\
\text { rings round } 3 \text { red } \\
\text { eyes. Diam. } c \text {. } \\
2 \mathrm{~cm} \text {. }\end{array}$ & $\begin{array}{l}\text { Site called } \\
\text { 'Vindogladia' on label } \\
\text { probably Badbury } \\
\text { Rings }\end{array}$ & \\
\hline $\begin{array}{l}\text { Chester-le- } \\
\text { Street }\end{array}$ & Durham & B.M. 83.7-5.107 & $\begin{array}{l}\text { Almost opaque dark } \\
\text { blue with five cobalt } \\
\text { eyes ringed with } \\
\text { white. Diam. } 3.5 \mathrm{~cm} \text {. } \\
\text { Ht. } 2 \cdot 3 \mathrm{~cm} .\end{array}$ & & \\
\hline Chedworth & $\begin{array}{l}\text { Gloucester- } \\
\text { shire }\end{array}$ & $\begin{array}{l}\text { Chedworth Roman } \\
\text { Villa Museum }\end{array}$ & $\begin{array}{l}\text { Dark blue with } \\
\text { several blue eyes }\end{array}$ & $\begin{array}{l}\text { Said to be 'Early } \\
\text { Iron Age' and } \\
\text { possibly found in a } \\
\text { barrow near the villa }\end{array}$ & $\begin{array}{l}\text { For villa, see } \\
\text { TBGAS lxxviii } \\
\text { (1959), } 5\end{array}$ \\
\hline $\begin{array}{l}\text { Chatham } \\
\text { Lines }\end{array}$ & Kent & ? & $\begin{array}{l}\text { Diam. about } 2.8 \mathrm{~cm} \text {. } \\
\text { Blue with white } \\
\text { rings round orange } \\
\text { centres }\end{array}$ & $\begin{array}{l}\text { Almost certainly an } \\
\text { earlier bead reused } \\
\text { in Saxon Barrow IV }\end{array}$ & $\begin{array}{l}\text { Douglas, J. Nenia } \\
\text { Britannica }\left(1^{6} 7\right) \text {, } \\
\text { pl. } 4, \text { no. } 2\end{array}$ \\
\hline Corbridge & $\begin{array}{l}\text { Northumber- } \\
\text { land }\end{array}$ & $\begin{array}{l}\text { Corstopitum } \\
\text { Museum }\end{array}$ & $\begin{array}{l}\text { Very large a mber } \\
\text { brown with } 3 \text { rows } \\
\text { of blue eyes ringed in } \\
\text { white. Fragmentary. } \\
\text { Diam. } c .4 \cdot 5 \mathrm{~cm} \text {. } \\
\text { Ht.c. } 3.5 \mathrm{~cm} \text {. }\end{array}$ & $\begin{array}{l}\text { Early find from } \\
\text { Corstopitum }\end{array}$ & \\
\hline $\begin{array}{l}\text { Priddy, } \\
\text { East } \\
\text { Harptree }\end{array}$ & Somerset & & $\begin{array}{l}4 \text { beads with white } \\
\text { around brown eyes } \\
\text { on a blue ground }\end{array}$ & $\begin{array}{l}\text { St. Cuthbert's lead } \\
\text { mines? mid-Ist c. } \\
\text { A.D. }\end{array}$ & $A$ Ixxii (191 ), 567 \\
\hline $\begin{array}{l}\text { Wookey } \\
\text { Hole }\end{array}$ & Somerset & Wells & $\begin{array}{l}\text { Blue with white } \\
\text { around brown eyes. } \\
4 \text { others from } \\
\text { woman's skeleton }\end{array}$ & $\begin{array}{l}\text { From so-called } \\
\text { 'Celtic' levels with } \\
\text { Glastonbury pottery } \\
\text { (2nd-Ist c. B.c.?) }\end{array}$ & $A$ lxii (I9I I), 579 \\
\hline Lewes & Sussex & Lewes & $\begin{array}{l}\text { Atypical. Four } \\
\text { depressions for eyes, } \\
\text { now weathered out }\end{array}$ & $\begin{array}{l}\text { From Caburn hill- } \\
\text { fort. This may have } \\
\text { been a post-Roman } \\
\text { bead as suggested } \\
\text { in the report }\end{array}$ & $\begin{array}{l}S A C \text { lxviii ( } 1927) \text {, } \\
\text { I9 }\end{array}$ \\
\hline South Harting & Sussex & $\begin{array}{l}\text { c/o National Trust, } \\
\text { Uppark }\end{array}$ & $\begin{array}{l}\text { Dark blue with white } \\
\text { rings round } 2 \text { green } \\
\text { eyes. Diam. } 2 \cdot 3 \mathrm{~cm} \text {. } \\
\text { Ht. I } \cdot \mathrm{I} \mathrm{cm} .\end{array}$ & $\begin{array}{l}\text { From Romano- } \\
\text { British site near } \\
\text { Harting Beacon }\end{array}$ & Unpublished \\
\hline Atworth & Wiltshire & Devizes & $\begin{array}{l}\text { Half a translucent } \\
\text { cobalt bead with } 2 \\
\text { green eyes and a third } \\
\text { missing. Diam. } 2 \cdot 1 \mathrm{~cm} \text {. } \\
\text { Ht. I I mm. Perf. } \\
\text { diam. } 6 \mathrm{~mm} \text {. }\end{array}$ & Unstratified & $\begin{array}{l}\text { Probably to be } \\
\text { published in } \\
W A M \text { about } 1977\end{array}$ \\
\hline
\end{tabular}




\begin{tabular}{|c|c|c|c|}
\hline $\begin{array}{l}\text { SITE AND } \\
\text { PARISH }\end{array}$ & COUNTY & MUSEUM \& NO. & $\begin{array}{l}\text { DESCRIPTION AND } \\
\text { APPROX. DIMENSIONS }\end{array}$ \\
\hline \multirow[t]{2}{*}{$\begin{array}{l}\text { Below } \\
\text { Barbury } \\
\text { Castle, } \\
\text { Wroughton }\end{array}$} & \multirow[t]{2}{*}{ Wiltshire } & \multirow[t]{2}{*}{ Devizes 479} & $\begin{array}{l}\text { Badly made cobalt } \\
\text { blue with } 2 \text { irregular } \\
\text { green eyes and } \\
\text { I brown eye ringed } \\
\text { in white. } \\
\text { Diam. } 2 \cdot 1 \mathrm{~cm} \text {. Ht. } \\
\text { irreg. } 1 \cdot 4 \mathrm{~cm} \text {. Perf. } \\
\text { diam. } 8 \mathrm{~mm} \text {. }\end{array}$ \\
\hline & & & GOTLAND \\
\hline \multicolumn{2}{|c|}{ 'Probably Scotland' } & N.M.A. FJ82 & $\begin{array}{l}\text { Cobalt with } 3 \text { reddish } \\
\text { eyes ringed in white. } \\
\text { Diam. } 2.5 \mathrm{~cm} . \mathrm{Ht} \text {. } \\
\text { I } \mathrm{cm} .\end{array}$ \\
\hline
\end{tabular}

Wick Caithness C.M., E. A. B. Barnard Gift

Newstead Roxburgh- N.M.A. FRA896 shire

Newstead Roxburgh- N.M.A. shire

Camelon

Fort, Falkirk

Camelon

Fort, Falkirk

Stirlingshire

N.M.A. FI 64

Stirlingshire N.M.A. F 340

Stirlingshire N.M.A. F 164

Nevin
Opaque greenishblack with 3 bright azure eyes

Part of cobalt bead with blue eyes ringed in white. Diam. $3.0 \mathrm{~cm}$. Ht. I $\cdot 7 \mathrm{~cm}$.

Natural translucent greenish glass with one eye striped in yellow and blue, surrounded with ring of yellow. The other eye blue. Diam. c. $3 \mathrm{~cm}$. Ht. I $1 \mathrm{~cm}$.

Cobalt blue. Of the 4 eyes in white rings, 2 are missing and 2 are blue. Diam. $2 \cdot 2 \mathrm{~cm}$. Ht. I $2 \mathrm{~cm}$.

Bright cobalt with 3 blue eyes ringed in white

\section{WALES}

Described as an ox-eyed bead
This is not like the rest of this Class and may belong to a later date

Probably early Roman occupation c. A.D. $80-200$

Probably early Roman occupation c. A.D. $80-200$

This site produced native glass armlets of ist-2nd C. A.D.

This site produced native glass armlets of Ist-2nd C. A.D.

Almost certainly this type. From big fort at Garn Boduan
PSAS $\mathrm{xxxy}$ (I900-I), 329

$P S A S \mathbf{x x x v}$

(1900-I), 329

Arf cxvii (1962), I ff. 


\begin{tabular}{|c|c|c|c|c|c|}
\hline $\begin{array}{l}\text { SITE AND } \\
\text { PARISH }\end{array}$ & COUNTY & MUSEUM \& NO. & $\begin{array}{l}\text { DESCRIPTION AND } \\
\text { APPROX. DIMENSIONS }\end{array}$ & $\begin{array}{l}\text { ASSOCIATIONS AND } \\
\text { REMARKS }\end{array}$ & PUBLICATION \\
\hline $\begin{array}{l}\text { Whitton, } \\
\text { nr. Barry }\end{array}$ & $\begin{array}{l}\text { Glamorgan- } \\
\text { shire }\end{array}$ & ?N.M.W. & $\begin{array}{l}\text { Dark blue, white } \\
\text { rings round bright } \\
\text { blue eyes. Half } \\
\text { another, translucent } \\
\text { cobalt with one } \\
\text { remaining green eye. } \\
\text { Diam. I } 9 \mathrm{~cm} . \mathrm{Ht} \text {. } \\
9 \mathrm{~mm} \text {. Perf. diam. } \\
8 \mathrm{~mm} \text {. }\end{array}$ & $\begin{array}{l}\text { From Roman villa } \\
\text { excavation no. } 65 \\
\text { IX. Site occupied } \\
\text { about ist c. B.C. to } \\
\text { A.D. } 3 \text { oo }\end{array}$ & $\begin{array}{l}\text { Information frm } \\
\text { Dr. Jarrett, Univ. } \\
\text { College of S. } \\
\text { Wales, Cardiff }\end{array}$ \\
\hline Llanuwchllyn & $\begin{array}{l}\text { Merioneth- } \\
\text { shire }\end{array}$ & $\begin{array}{l}\text { Once on loan to } \\
\text { Carmarthenshire } \\
\text { Antiquarian Soc. } \\
\text { Museum }\end{array}$ & $\begin{array}{l}\text { Opaque blue with } 3 \\
\text { eyes (red, dark } \\
\text { green and light green) } \\
\text { in white rings }\end{array}$ & $\begin{array}{l}\text { Found near Castell } \\
\text { Carn Dochan }\end{array}$ & $\begin{array}{l}A C \text { lxxviii (1923), } \\
3 \text { I I }\end{array}$ \\
\hline Abergavenny & $\begin{array}{l}\text { Monmouth- } \\
\text { shire }\end{array}$ & Abergavenny & $\begin{array}{l}\text { One-third of blue } \\
\text { semi-translucent } \\
\text { bead. One eye only } \\
\text { remains, yellowish- } \\
\text { green. Orig. diam. } \\
\mathrm{I} \cdot 7 \mathrm{~cm} . \mathrm{Ht} .8 \mathrm{~mm} \text {. } \\
\text { Perf. diam. } 7 \mathrm{~mm} \text {. }\end{array}$ & $\begin{array}{l}\text { From Flannel Street } \\
\text { (no. FI66). Ist c. } \\
\text { finds from this } \\
\text { Roman site }\end{array}$ & $\begin{array}{l}\text { To be published } \\
\text { in } M A n\end{array}$ \\
\hline Caerleon & $\begin{array}{l}\text { Monmouth- } \\
\text { shire }\end{array}$ & N.M.W. & $\begin{array}{l}\text { Fragment of large } \\
\text { royal blue bead with } \\
\text { one remaining blue } \\
\text { eye. Diam. } 3 \cdot 9 \mathrm{~cm} \text {. } \\
\text { Ht. } 2 \cdot 4 \mathrm{~cm} . \text { Perf. } \\
\text { diam. } 1 \cdot 3 \mathrm{~cm} \text {. }\end{array}$ & $\begin{array}{l}\text { Roman period, } \\
\text { almost certainly late } \\
\text { ist-early and C. A.D. }\end{array}$ & $A C \operatorname{cxix}(1970)$ \\
\hline
\end{tabular}

\section{CLASS 4}

\section{OPAQUE YELLOW BEADS WITH PAIRS OF SUPERIMPOSED BLUE AND WHITE EYES ('FINDON TYPE')}

$\begin{array}{lll}\text { Woodeaton } & \text { Oxfordshire } & \begin{array}{l}\text { A.M. I } 896 \\ R_{159}\end{array} \\ & & \\ \begin{array}{l}\text { Findon } \\ \text { (Muntham } \\ \text { Court) }\end{array} & \text { Sussex } & \text { Worthing } \\ & & \end{array}$

Small bead. Diam. I cm. Ht. $7 \mathrm{~mm}$. Perf. diam. $3 \mathrm{~mm}$. Two tiers of blue and white eyes

Diam. I $3 \mathrm{~cm} . \mathrm{Ht}$. $9 \mathrm{~mm}$. Perf. diam. $6 \mathrm{~mm}$. Two tiers of eyes (fig. 10)
Definitely from Wood- Harding, D. W. eaton, possibly Gordon Collection (1972)

From Iron Age A ritual site, culturally related to Park Brow
$A \mathcal{N L}$ v, no. Io (March 1955), 204-5 and vi, no. 4 (1957). SNQ xiv (1954-7), 196-8, 232-3. See also Frere, S. (ed.) ( $\left.195^{8}\right), 20$

Nightingale Collection. A larger one is illustrated in drawings of 1850 in the Society of Antiquaries of London library, Burlington House, Piccadilly. It has no location but was probably found in England 


\begin{tabular}{|c|c|c|c|c|c|}
\hline $\begin{array}{l}\text { SITE AND } \\
\text { PARISH }\end{array}$ & COUNTY & MUSEUM \& NO. & $\begin{array}{l}\text { DESGRIPTION AND } \\
\text { APPROX. DIMENSIONS }\end{array}$ & $\begin{array}{l}\text { ASSOCIATIONS AND } \\
\text { REMARKS }\end{array}$ & PUBLICATION \\
\hline \multicolumn{6}{|c|}{ CLASS 5} \\
\hline \multicolumn{6}{|c|}{ THE HANGING LANGFORD TYPE } \\
\hline \multicolumn{6}{|c|}{ ENGLAND } \\
\hline $\begin{array}{l}\text { Castle Dore } \\
\text { fort (Fowey) }\end{array}$ & Cornwall & Truro & $\begin{array}{l}\text { No bead of this type } \\
\text { but part of armlet } \\
\text { in identical technique }\end{array}$ & $\begin{array}{l}\text { Occupation from } \\
\text { early 2nd c. B.c. to } \\
\text { c. IоO B.c. }\end{array}$ & $\begin{array}{l}\mathcal{F} R I C \text { n.s. i }(\mathrm{r} 95 \mathrm{r}), \\
68\end{array}$ \\
\hline $\begin{array}{l}\text { Nor'nour, } \\
\text { Scilly }\end{array}$ & Cornwall & St. Mary's, Scilly & $\begin{array}{l}\text { Clear glass with faint } \\
\text { yellow traces inside. } \\
\text { Half only. Diam. } \\
2.2 \mathrm{~cm} . \mathrm{Ht} .6 \mathrm{~mm} \text {. }\end{array}$ & $\begin{array}{l}\text { Site } 1 \text {, Room 2. Site } \\
\text { may begin in pre- } \\
\text { Roman period with } \\
\text { floruit in 2nd c. A.D. } \\
\text { Lasted till late Roman } \\
\text { times }\end{array}$ & $\operatorname{Arf} \mathrm{cxxiv}(1967)$ \\
\hline $\begin{array}{l}\text { Maumbury } \\
\text { Rings, } \\
\text { Dorchester }\end{array}$ & Dorset & Dorchester 273 & $\begin{array}{l}\text { Yellow unevenly } \\
\text { applied. Diam. } \\
2 \mathrm{~cm} . \text { Ht. } 5 \mathrm{~mm} \text {. }\end{array}$ & $\begin{array}{l}\text { With early Romano- } \\
\text { British material. } \\
\text { Incorrectly repub- } \\
\text { lished in } A \text { (1975) }\end{array}$ & $\begin{array}{l}\text { H. St. George } \\
\text { Gray, Excavations } \\
\text { of Maumbury Rings, } \\
\text { Dorchester (1912) }\end{array}$ \\
\hline ? Colchester & Essex & Colchester & No details & $\begin{array}{l}\text { Among collection of } \\
\text { miscellancous beads }\end{array}$ & \\
\hline Cirencester & $\begin{array}{l}\text { Gloucester- } \\
\text { shire }\end{array}$ & Cirencester Cgo8 & $\begin{array}{l}\text { Half bead. Diam. } \\
2.2 \mathrm{~cm} . \mathrm{Ht} .6 \mathrm{~mm} \text {. } \\
\text { Perf. diam. I } \mathrm{I} \mathrm{cm} .\end{array}$ & From Roman town & \\
\hline Faversham & Kent & $\begin{array}{l}\text { C.M., Beck Colln. } \\
\text { I } 659\end{array}$ & $\begin{array}{l}\text { Diam. } 2 \cdot 3 \mathrm{~cm} . \mathrm{Ht} . \\
7 \mathrm{~mm} .\end{array}$ & $\begin{array}{l}\text { Grave XX A ra. Said } \\
\text { to be from Anglo- } \\
\text { Saxon context. If so it is } \\
\text { almost surely an } \\
\text { earlier bead reused }\end{array}$ & \\
\hline $\begin{array}{l}\text { Hunsbury } \\
\text { Iron Age fort, } \\
\text { Hardingstone }\end{array}$ & $\begin{array}{l}\text { Northamp- } \\
\text { tonshire }\end{array}$ & Northampton & $\begin{array}{l}\text { Diam. } 2 \cdot 3 \mathrm{~cm} . \mathrm{Ht} . \\
5 \mathrm{~mm} .\end{array}$ & $\begin{array}{l}\text { Unlikely to be later } \\
\text { than early ist c. } 8 . \mathrm{c} \text {. } \\
\text { Occupation may } \\
\text { have begun in } 4^{\text {th }} \text { c. } \\
\text { B.c. }\end{array}$ & $\begin{array}{l}\text { Fell C. (1936), } \\
\text { p. } 69\end{array}$ \\
\hline $\begin{array}{l}\text { Meare Lake } \\
\text { Village (West } \\
\text { Village) }\end{array}$ & Somerset & $\begin{array}{l}\text { Taunton } \mathrm{G}_{3} \text { and } \\
\mathrm{G}_{74}\end{array}$ & $\begin{array}{l}\text { Two beads. Diams. } \\
25 \text { and } 19 \mathrm{~mm} \text {. }\end{array}$ & $\begin{array}{l}\text { Mound VII in pre- } \\
\text { Roman village of } \\
\text { 3rd-Ist c. B.C. }\end{array}$ & $M e$ iii, 289 \\
\hline $\begin{array}{l}\text { Hanging } \\
\text { Langford } \\
\text { Camp, Steeple } \\
\text { Langford }\end{array}$ & Wiltshire & Salisbury $139 / 39$ & $\begin{array}{l}\text { Half bead only. } \\
\text { Diam. } 2 \cdot 2 \mathrm{~cm} . \mathrm{Ht} \text {. } \\
0 \cdot 7 \mathrm{~cm} . \text { (fig. I } \mathrm{I} \text { ) }\end{array}$ & $\begin{array}{l}\text { Almost all the } \\
\text { pottery is Belgic and } \\
\text { the finds } c \text {. Ist B.C.-- } \\
\text { Ist c. A.D. except for } \\
\text { one La Tène I bronze } \\
\text { fibula }\end{array}$ & Unpublished \\
\hline No prove & nance & A.M. 1836.70 & $\begin{array}{l}\text { Diam. } 2 \cdot 3 \mathrm{~cm} . \mathrm{Ht} \text {. } \\
8 \mathrm{~mm} . \text { Perf. diam. } \\
\text { I } \mathrm{mm} .\end{array}$ & $\begin{array}{l}\text { This comes from a } \\
\text { miscellaneous collec- } \\
\text { tion of beads, some } \\
\text { probably carly Iron } \\
\text { Age and some Irish }\end{array}$ & $\operatorname{Arf} \mathrm{iii}(\mathrm{r} 846), 355$ \\
\hline
\end{tabular}




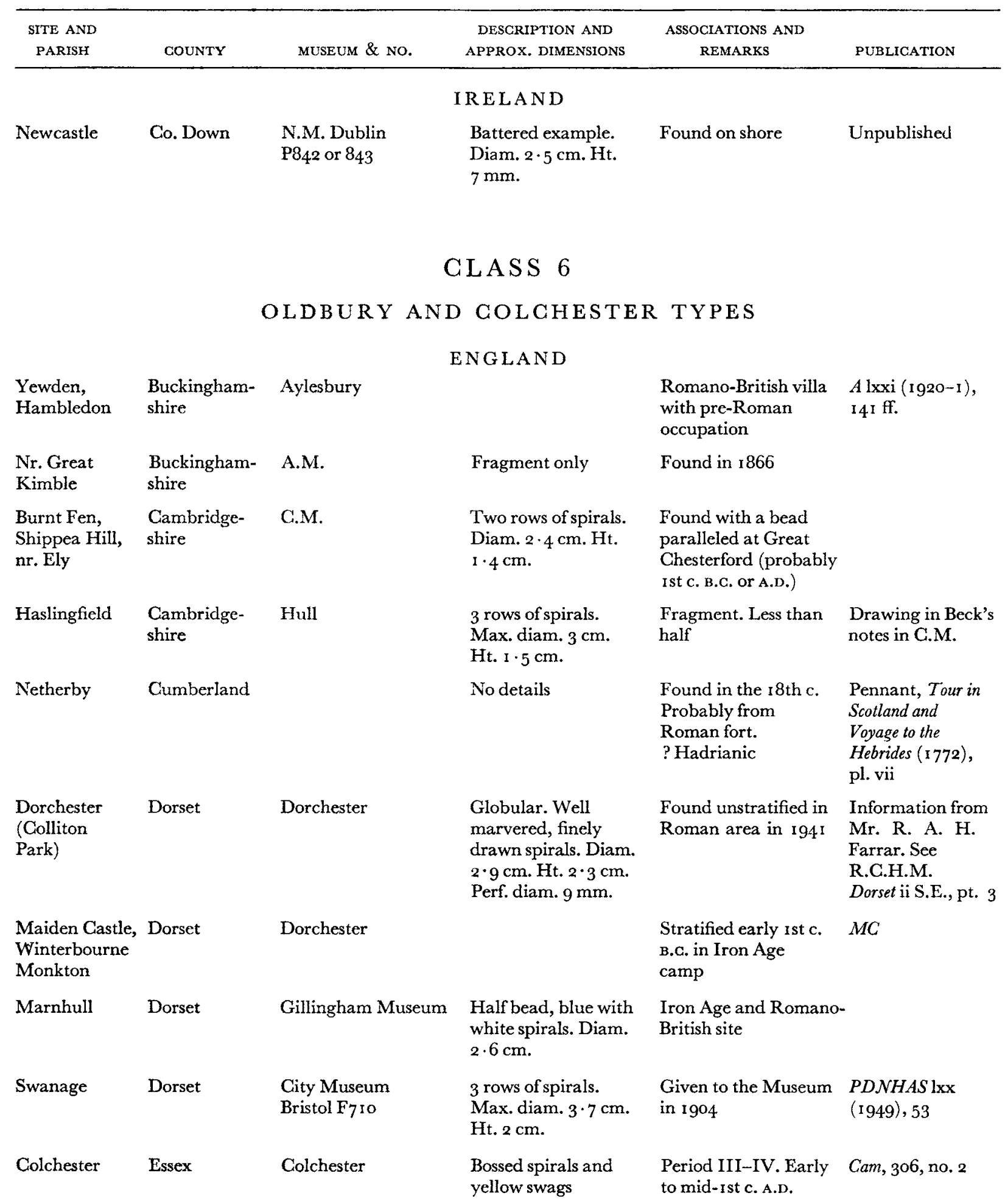




\begin{tabular}{|c|c|c|c|c|c|}
\hline $\begin{array}{l}\text { SITE AND } \\
\text { PARISH }\end{array}$ & COUNTY & MUSEUM \& NO. & $\begin{array}{l}\text { DESGRIPTION AND } \\
\text { APPROX. DIMENSIONS }\end{array}$ & $\begin{array}{l}\text { ASSOCIATIONS AND } \\
\text { REMARKS }\end{array}$ & PUBLICATION \\
\hline $\begin{array}{l}\text { Danebury } \\
\text { Ring, } \\
\text { Nether Wallop }\end{array}$ & Hampshire & & $\begin{array}{l}\text { Fragment with } 3 \\
\text { spirals. Max. diam. } \\
2.8 \mathrm{~cm} . \mathrm{Ht} . \mathrm{I} \cdot 4 \mathrm{~cm} . \\
\text { Perf. diam. } 9 \mathrm{~mm} .\end{array}$ & $\begin{array}{l}\text { From Iron Age fort. } \\
\text { Pit } 463 \text {, layer } 2 . \\
\text { ? Early ist c. B.c. }\end{array}$ & $\begin{array}{l}\text { Information from } \\
\text { Barry Cunliffe }\end{array}$ \\
\hline $\begin{array}{l}\text { Winchester } \\
\text { (Brook Street) }\end{array}$ & Hampshire & Winchester & $\begin{array}{l}\text { Very abraded half } \\
\text { bead with } 3 \text { very } \\
\text { worn spirals. One on } \\
\text { a slight boss. No } \\
\text { flling colour remains. } \\
\text { Diam. } 2 \cdot 4 \mathrm{~cm} . \mathrm{Ht} \text {. } \\
1 \cdot 5 \mathrm{~cm} . \text { Perf. diam. } \\
6 \mathrm{~mm} \text {. }\end{array}$ & $\begin{array}{l}\text { Evidently kept as a } \\
\text { curiosity. From } \\
\text { Roman or post- } \\
\text { Roman pit } 463 \text {. } \\
\text { Found in } 197^{2}\end{array}$ & $\begin{array}{l}\text { Biddle, M. } \\
\text { (forthcoming) }\end{array}$ \\
\hline Hythe & Kent & & & & $\begin{array}{l}A C t \mathrm{xlv}(\mathrm{r} 933) \\
\text { pl. iv }\end{array}$ \\
\hline $\begin{array}{l}\text { Oldbury fort, } \\
\text { Ightham }\end{array}$ & Kent & $\begin{array}{l}\text { Sir Edward Harrison } \\
\text { Colln., Maidstone }\end{array}$ & $\begin{array}{l}\text { Diam. } 3 \cdot 4 \mathrm{~cm} . \mathrm{Ht} . \\
\mathrm{I} \cdot 4 \mathrm{~cm} .\end{array}$ & $\begin{array}{l}\text { From 2-period hill- } \\
\text { fort. Period I early } \\
\text { Ist c. B.c., Period II } \\
\text { redefended about Ioo } \\
\text { years later. This bead } \\
\text { came from a fox earth } \\
\text { below the western } \\
\text { rampart }\end{array}$ & $\begin{array}{l}A C t \mathrm{xlv}(\mathrm{r} 933), \mathrm{I} 5^{8}, \\
\text { and pl. iv, li (r939), } \\
\text { 162, 18o; } A \text { xc } \\
\text { (1944), 165 ff. }\end{array}$ \\
\hline $\begin{array}{l}\text { Romney } \\
\text { Marsh }\end{array}$ & Kent & & $\begin{array}{l}\text { Yellow spirals. Diam. } \\
\text { c. } 2.5 \mathrm{~cm}\end{array}$ & $\begin{array}{l}\text { From Haunted } \\
\text { House Field. Now in } \\
\text { hands of Mr.J. } \\
\text { Sinden, Hope Farm, } \\
\text { St. Mary in the } \\
\text { Marsh, Romney } \\
\text { Marsh, Kent }\end{array}$ & $\begin{array}{l}A C t 1 \text { (1938), I53-4 } \\
\text { with photograph }\end{array}$ \\
\hline Westerham & Kent & B.M. 1928.1 1.5 & $\begin{array}{l}3 \text { rows slightly bossed } \\
\text { spirals. Max. diam. } \\
2.8 \mathrm{~cm} . \mathrm{Ht} . \mathrm{I} \cdot 7 \mathrm{~cm} \text {. }\end{array}$ & & \\
\hline $\begin{array}{l}\text { Wilderspool, } \\
\text { Warrington }\end{array}$ & $\begin{array}{l}\text { Lancashire } \\
\text { Cheshire } \\
\text { border }\end{array}$ & Warrington & $\begin{array}{l}\text { Fragment. Ht. I } 4 \\
\mathrm{~cm} .\end{array}$ & $\begin{array}{l}\text { Roman industrial } \\
\text { site }\end{array}$ & $\begin{array}{l}\text { Thompson, F. H. } \\
(1965) \text {, fig. } 20 \text {, } \\
\text { no. } 22\end{array}$ \\
\hline $\begin{array}{l}\text { Old } \\
\text { Winteringham }\end{array}$ & Lincolnshire & Scunthorpe & $\begin{array}{l}3 \text { rows spirals, slightly } \\
\text { bossed. Max. diam. } \\
3.2 \mathrm{~cm} \text {. Ht. } 2 \mathrm{~cm} \text {. }\end{array}$ & $\begin{array}{l}\text { Probably a Claudian } \\
\text { fort, almost surely } \\
\text { dating between A.D. } \\
47-7 \text { I }\end{array}$ & $\begin{array}{l}\text { To be published } \\
\text { shortly }\end{array}$ \\
\hline Spilsby & Lincolnshire & Lincoln $270-209$ & $\begin{array}{l}\text { Colchester type. } \\
\text { Bossed spirals } \\
\text { between yellow } \\
\text { swags. Max. diam. } \\
2.6 \mathrm{~cm} . \text { Ht. I. } 6 \mathrm{~cm} \text {. } \\
\text { (fig. I3, right) }\end{array}$ & $\begin{array}{l}\text { Originally in Trollope } \\
\text { Colln. and thought } \\
\text { to be Saxon }\end{array}$ & $\begin{array}{l}P S A L, \text { and S., vi } \\
75 ; A r \mathcal{J} \times 1,18 \mathrm{I}\end{array}$ \\
\hline London & Middlesex & $\begin{array}{l}\text { Formerly Guildhall } \\
\text { Museum } 17347\end{array}$ & $\begin{array}{l}\text { Badly made and } \\
\text { fragmentary. Orig. } \\
\text { diam. } c .2 \cdot 6 \mathrm{~cm} . \mathrm{Ht} \text {. } \\
\mathrm{I} \cdot 5 \mathrm{~cm} .\end{array}$ & $\begin{array}{l}\text { Almost surely up-river } \\
\text { from Brentford }\end{array}$ & \\
\hline
\end{tabular}




\begin{tabular}{|c|c|c|c|c|c|}
\hline $\begin{array}{l}\text { SITE AND } \\
\text { PARISH }\end{array}$ & COUNTY & MUSEUM \& NO. & $\begin{array}{l}\text { DESCRIPTION AND } \\
\text { APPROX. DIMENSIONS }\end{array}$ & $\begin{array}{c}\text { ASSOCIATIONS AND } \\
\text { REMARKS }\end{array}$ & PUBLICATION \\
\hline $\begin{array}{l}\text { Hunsbury } \\
\text { fort, } \\
\text { Hardingstone }\end{array}$ & $\begin{array}{l}\text { Northampton- } \\
\text { shire }\end{array}$ & Northampton & $\begin{array}{l}2 \text { with strongly pro- } \\
\text { jecting knobs. One } \\
\text { has one row and } \\
\text { slight collar at each } \\
\text { end. Max. diam. } 2.6 \\
\mathrm{~cm} . \mathrm{Ht} \text {. } .6 \mathrm{~cm} \text {. The } \\
\text { other } 3 \text { rows of spirals: } \\
\text { Max. diam. } 3 \mathrm{~cm} \text {. } \\
\text { Ht. } 1.8 \mathrm{~cm} .\end{array}$ & $\begin{array}{l}\text { From Iron Age hill- } \\
\text { fort. Unlikely to be } \\
\text { much after ist c. B.c. } \\
\text { but occupation seems } \\
\text { to have begun about } \\
4^{\text {th }} \text { c. B.c. }\end{array}$ & $\begin{array}{l}\text { Fell, C. (I936), p. } \\
69 . \text { See also } \\
\mathcal{F} \mathcal{N} \mathcal{N} H S F C \text { xviii } \\
\text { and xix }\end{array}$ \\
\hline
\end{tabular}

$\begin{array}{ll}\text { Weekley, } & \text { Northampton- Northampton } \\ \text { Kettering } & \text { shire }\end{array}$
University Museum Fragment. Two

Newcastle-upon-Tyne slightly bossed spirals 652 (T. Stevens Colln.) no. 22

Broughton $\quad$ Oxfordshire
Poggs

Ducklington Oxfordshire

A.M. $1909 \cdot 489 \mathrm{~b}$

Glastonbury Lake Village

Somerset

Glastonbury $\mathrm{GI}_{1}, \mathrm{G}_{5}$, $\mathrm{G}_{9}$, and $\mathrm{GI}$

$\begin{array}{ll}\text { Meare } & \text { Somerset } \\ \text { Lake Village } & \\ \text { South } & \text { Somerset } \\ \text { Cadbury } & \end{array}$

Richmond Surrey

Formerly Guildhall Museum 33I

Bexley Hill, Sussex slightly
remain

Diam. $1.8 \mathrm{~cm} . \mathrm{Ht}$. I cm.
Ht. I $5 \mathrm{~cm}$. Perf. diam. $7 \mathrm{~mm}$.

Fragments. Gg has 2 rows spirals: Diam. $2 \cdot 5 \mathrm{~cm}$., ht. $\mathrm{I} \cdot 6 \mathrm{~cm}$. Gi, one row spirals: Diam. $2 \cdot 1 \mathrm{~cm}$., ht. I - I cm. G 5 and Gi I fragments

Taunton $\mathrm{G}_{45} \mathrm{EV}$

Half only. Diam. $2 \cdot 4 \mathrm{~cm}$. Ht. $1 \cdot 4 \mathrm{~cm}$.

Fragment with 3 yellow spirals and another smaller with white spiral
Colchester type. White spirals and opaque yellow swags. Diam. $3 \cdot 1 \mathrm{~cm}$.

3 rows slight bosses. Max. diam. $3 \mathrm{~cm}$. Ht. $2 \mathrm{~cm}$.
3 rows bossed spirals. Less than half remains
Coins from this Roman villa range from Vespasian to Valentinian
$\tilde{J} \mathcal{N N H S F C}$ xviii and xix, pl. so and viii, 35
Reused in grave with Saxon spearhead, 2 bronze small long brooches

White spirals on slight Reused in Saxon grave PSAL i (1859-61), bosses. Diam. $2 \cdot 4 \mathrm{~cm}$. (Grave 2) IOO-I

\section{From Lake Village $\quad G l$ ii, pl. lix}

From Lake Village, Me iii 3rd-Ist c. B.C.?

Pre-Roman Iron Age Information from Prof. Leslie Alcock

Given by T. $O$. Barlow I 867 


\begin{tabular}{|c|c|c|c|c|c|}
\hline $\begin{array}{l}\text { SITE AND } \\
\text { PARISH }\end{array}$ & COUNTY & MUSEUM \& NO. & $\begin{array}{c}\text { DESCRIPTION AND } \\
\text { APPROX. DIMENSIONS }\end{array}$ & $\begin{array}{l}\text { ASSOCIATIONS AND } \\
\text { REMARKS }\end{array}$ & PUBLICATION \\
\hline Chichester & Sussex & Chichester & $\begin{array}{l}3 \text { rows of spirals on } \\
\text { bosses. Max. diam. } \\
3 \mathrm{~cm} . \mathrm{Ht} .1 \cdot 7 \mathrm{~cm} . \\
\text { Perf. diam. } 1 \mathrm{~cm} .\end{array}$ & $\begin{array}{l}\text { With a burial dated } \\
\text { by pottery and other } \\
\text { objects to the Late } \\
\text { Antonine period. } \\
\text { (Group 228) }\end{array}$ & $\begin{array}{l}\text { Down, A., and } \\
\text { Rule, M. } \\
\text { Chichester } \\
\text { Excavations, i } \\
\text { (1971) (Chichester } \\
\text { Civic Society } \\
\text { Excavations } \\
\text { Committee) }\end{array}$ \\
\hline $\begin{array}{l}\text { Torberry, } \\
\text { South Harting }\end{array}$ & Sussex & & Small fragment only & Iron Age hill-fort & $\begin{array}{l}\text { Cunliffe, B. } \\
\text { (1976), fig. I } 4 \text {, } \\
\text { no. } 6 \text { and p. } 14\end{array}$ \\
\hline $\begin{array}{l}\text { Brough-under- } \\
\text { Stainmore }\end{array}$ & Westmorland & A.M. $1927.88 \mathrm{I}$ & $\begin{array}{l}\text { Related type. Single } \\
\text { row of spirals. Max. } \\
\text { diam. } 2 \cdot 2 \mathrm{~cm} . \mathrm{Ht} \text {. } \\
1.6 \mathrm{~cm} .\end{array}$ & $\begin{array}{l}\text { Stray find } \mathrm{I} 888 \text {. This } \\
\text { site was probably } \\
\text { Flavian in origin. It } \\
\text { was restored in } c .200 \\
\text { A.D. and by the } 4^{\text {th }} \text { c. } \\
\text { a vicus had grown up } \\
\text { outside }\end{array}$ & \\
\hline Beckford & $\begin{array}{l}\text { Worcester- } \\
\text { shire }\end{array}$ & & $\begin{array}{l}\text { Damaged. Half bead. } \\
3 \text { rows spirals on } \\
\text { bosses. Diam. } 2 \text { I mm. } \\
\text { Ht. } 1.4 \mathrm{~cm} \text {. Perf. } \\
\text { diam. I } \mathrm{cm} .\end{array}$ & $\begin{array}{l}\text { Iron Age site in } \\
\text { course of excavation }\end{array}$ & $\begin{array}{l}\text { Information from } \\
\text { Mr. Britnell }\end{array}$ \\
\hline 'Probably & Wiltshire' & Once at Stourhead & Two beads & & $\begin{array}{l}\text { Thurnam, Ancient } \\
\text { British Barrotes, p. } \\
212, \text { n. } 6 . \text { One may } \\
\text { be the bead } \\
\text { referred to in } \\
\text { Hoare, R. Colt } \\
(1812), \text { i, p. } 176\end{array}$ \\
\hline $\begin{array}{l}\text { Fulwood, nr. } \\
\text { Sheffield }\end{array}$ & Yorkshire & Sheffield & $\begin{array}{l}\text { Very dark, almost } \\
\text { opaque. } 2 \text { or } 3 \text { tiers of } \\
\text { badly made spirals. } \\
\text { Diam. } 2 . \text { I cm. Ht. } \\
\text { I } 8 \mathrm{~cm} \text {. Perf. diam. } \\
\text { I } \mathrm{cm} .\end{array}$ & $\begin{array}{l}\text { Stray find in same } \\
\text { area as Roman pottery }\end{array}$ & $\begin{array}{l}\text { Information from } \\
\text { Mr. Butterworth, } \\
\text { Sheffield Museum }\end{array}$ \\
\hline \multicolumn{2}{|c|}{ 'Probably East England' } & Salisbury $18 a$ & $\begin{array}{l}3 \text { slightly knobbed } \\
\text { rows of spirals. Max. } \\
\text { diam. } 2 \cdot 2 \mathrm{~cm} \text {. Ht. } \\
1 \cdot 5 \mathrm{~cm} .\end{array}$ & $\begin{array}{l}\text { This has no proven- } \\
\text { ance and could } \\
\text { perhaps be one of the } \\
\text { Wilts. beads men- } \\
\text { tioned above }\end{array}$ & \\
\hline
\end{tabular}

\section{RELAND}

$\begin{array}{ll}\text { Sandy Braes } \quad \text { Antrim } & \text { Belfast, Knowles } \\ & \text { Colln. } 638(1924)\end{array}$

'Northern Ireland' Dublin I907.85
3 rows of spirals (not bossed). Max. diam. $3.5 \mathrm{~cm}$. Ht. $2 \cdot 2 \mathrm{~cm}$.

Max. diam. $2 \cdot 4 \mathrm{~cm}$. Ht. I $6 \mathrm{~cm}$.
Site is 8 miles S.E. of Ballymena 


\begin{tabular}{|c|c|c|c|c|c|}
\hline $\begin{array}{l}\text { SITE AND } \\
\text { PARISH }\end{array}$ & COUNTY & MUSEUM \& NO. & $\begin{array}{l}\text { DESCRIPTION AND } \\
\text { APPROX. DIMENSIONS }\end{array}$ & $\begin{array}{l}\text { ASSOCIATIONS AND } \\
\text { REMARKS }\end{array}$ & PUBLICATION \\
\hline 'Northern & Ireland' & Dublin 1920.63 & & & \\
\hline 'Northern & Ireland' & $\begin{array}{l}\text { Belfast, Grainger } \\
\text { Colln. } 24{ }^{1} 4\end{array}$ & $\begin{array}{l}2 \text { rows only flat } \\
\text { spirals }\end{array}$ & & \\
\hline 'Northern & Ireland' & Belfast 2416 & $\begin{array}{l}3 \text { rows of flat spirals. } \\
\text { Diam. } 2.6 \mathrm{~cm} . \mathrm{Ht} \text {. } \\
\mathrm{I} \cdot 6 \mathrm{~cm} .\end{array}$ & & \\
\hline Dun-na-mana & Tyrone & B.M. $90.2 .15 . \mathrm{I} \mathrm{I}$ & $\begin{array}{l}\text { Very dark blue. Well } \\
\text { made spirals. Diam. } \\
2 \cdot 7 \mathrm{~cm} . \mathrm{Ht} .1 \cdot 7 \mathrm{~cm} .\end{array}$ & Found in 1890 & $\begin{array}{l}\mathcal{F} R S A I, 4^{\text {th s., vi }} \\
\left(\mathrm{I} 88_{3}-4\right), 70, \text { fig. } 5\end{array}$ \\
\hline \multicolumn{6}{|c|}{ SGOTLAND } \\
\hline \multirow[t]{2}{*}{ Earlston } & Berwickshire & N.M.A. FJ 103 & $\begin{array}{l}\text { Fragmentary. One } \\
\text { remaining spiral on } \\
\text { pronounced boss. } \\
\text { Max. diam. } 2.6 \mathrm{~cm} \text {. } \\
\mathrm{Ht} .1 .7 \mathrm{~cm} .\end{array}$ & 'Near Earlston' & \\
\hline & $\begin{array}{l}\text { Berwickshire } \\
\text { (probably) }\end{array}$ & N.M.A. FJ112 & $\begin{array}{l}\text { Single row of spirals. } \\
\text { Diam. } 2 \cdot 3 \mathrm{~cm} . \mathrm{Ht} \text {. } \\
\mathrm{I} \cdot 2 \mathrm{~cm} .\end{array}$ & $\begin{array}{l}\text { From Lady John } \\
\text { Scott's Colln. }\end{array}$ & \\
\hline $\begin{array}{l}\text { Arinabost, } \\
\text { Isle of Coll }\end{array}$ & Argyllshire & N.M.A. FJ94 & $\begin{array}{l}\text { Rather squat. Max. } \\
\text { diam. } 2 \cdot 5 \mathrm{~cm} . \mathrm{Ht} \text {. } \\
2.0 \mathrm{~cm} . \text { (fig. } 13 \text {, } \\
\text { left) }\end{array}$ & $\begin{array}{l}\text { From an earth house } \\
2 \text { miles NW. of } \\
\text { Arinagour ( } 1896) \text {. } \\
\text { Said to have been } \\
\text { found with a large } \\
\text { bronze pin with fluted } \\
\text { head, etc. Also part } \\
\text { of a twisted gold } \\
\text { bracelet }\end{array}$ & $\begin{array}{l}\text { Beveridge, } \\
\text { Coll and Tiree, } \mathrm{i}-3 \\
\text { and } P S A S \mathrm{xxxvii} \\
(\mathrm{1} 903), 68\end{array}$ \\
\hline Kilmany & Fife & N.M.A. FJ2I & $\begin{array}{l}\text { Max. diam. } 2 \cdot 4 \mathrm{~cm} \text {. } \\
\text { Ht. I } 6 \mathrm{~cm} .\end{array}$ & $\begin{array}{l}\text { Brighouse Farm, } \\
\text { Logie }\end{array}$ & $\begin{array}{l}P S A S \times \operatorname{xix}(1884-5), \\
133\end{array}$ \\
\hline Gilmerton & Midlothian & N.M.A. FJ99 & $\begin{array}{l}\text { Max. diam. } 2 \cdot 8 \mathrm{~cm} \text {. } \\
\text { Ht. } 1.6 \mathrm{~cm} .\end{array}$ & $\begin{array}{l}\text { Ploughed up in about } \\
\text { r } 909\end{array}$ & $\begin{array}{l}P S A S \text { xliv (1909- } \\
\text { го), } 9\end{array}$ \\
\hline
\end{tabular}

\section{WALES}

The Breiddin Montgomeryshire

Gronant, nr. Flintshire Not yet placed
Blue-black fragment From hill-fort with bossed spiral. Max. diam. $2 \cdot 5 \mathrm{~cm}$. Ht. I $4 \mathrm{~cm}$.

Very fine example without bosses. Diam Perf. diam. $9 \mathrm{~mm}$.
Information from Mr. Christopher Musson

Found 1975 and awaiting publication 


\begin{tabular}{|c|c|c|c|c|c|}
\hline $\begin{array}{l}\text { SITE AND } \\
\text { PARISH }\end{array}$ & COUNTY & MUSEUM \& No. & $\begin{array}{l}\text { DESCRIPTION AND } \\
\text { APPROX, DIMENSIONS }\end{array}$ & $\begin{array}{l}\text { ASSOCIATIONS AND } \\
\text { REMARKS }\end{array}$ & PUBLICATTON \\
\hline \multicolumn{4}{|c|}{ OLDBURY CLASS EXOTIC } & TYPE & \\
\hline \multicolumn{2}{|c|}{ No location } & $\begin{array}{l}\text { Slade Colln., B.M. } \\
7 \text { I.12-10.35 }\end{array}$ & $\begin{array}{l}\text { Except for colour it } \\
\text { resembles the Old- } \\
\text { bury Class. It is made } \\
\text { of clear colourless glass } \\
\text { and the spirals are in } \\
\text { opaque yellow. Diam. } \\
2.7 \mathrm{~cm} \text {. Ht. } 1.7 \mathrm{~cm} \text {. }\end{array}$ & Found in 1871 & \\
\hline \multicolumn{2}{|c|}{ 'Ireland' } & $\begin{array}{l}\text { Bell Colln., N.M.A. } \\
\text { FK2o }\end{array}$ & $\begin{array}{l}\text { Clear glass. } 3 \text { tiers of } \\
\text { protuberances with } \\
\text { white spirals round } \\
\text { amber coloured eyes }\end{array}$ & No details known & \\
\hline $\begin{array}{l}\text { North Bersted, } \\
\text { nr. Felpham }\end{array}$ & Sussex & Sussex & $\begin{array}{l}\text { Half bead. Large } \\
\text { yellow spirals alter- } \\
\text { nating with vertically } \\
\text { placed pairs of white } \\
\text { spirals. Diam. } 2 \cdot 4 \\
\mathrm{~cm} \text {. Ht. I } 4 \mathrm{~cm} . \\
\text { Perf. diam. } 9 \mathrm{~mm} \text {. }\end{array}$ & $\begin{array}{l}\text { Unstratified but } \\
\text { almost certainly } \\
\text { derived from ditch } \\
\text { with 'saucepan' } \\
\text { type pottery or a } \\
\text { Romano-British ditch }\end{array}$ & $\begin{array}{l}\text { Information from } \\
\text { Michael Pitts, } \\
\text { Oving, Chichester, } \\
\text { I975 }\end{array}$ \\
\hline
\end{tabular}

\section{CLASS 7}

LARGE ANNULAR CELTIG BEADS: WHIRL OR RAY TYPE

TYPE (A), BLUE OR PURPLE GROUND WITH WHITE OR YELLOW WHIRLS OR RAYS

\begin{tabular}{|c|c|c|c|c|c|}
\hline \multicolumn{6}{|c|}{ ENGLAND } \\
\hline $\begin{array}{l}\text { Nor'nour, } \\
\text { Scilly }\end{array}$ & Cornwall & St. Mary's, Scilly & $\begin{array}{l}\text { Almost opaque cobalt } \\
\text { with signs of white } \\
\text { rays. Less than half } \\
\text { remains. Diam. } 4 \cdot 1 \\
\mathrm{~cm} . \mathrm{Ht} .1 \cdot 9 \mathrm{~cm} .\end{array}$ & $\begin{array}{l}\text { Site perhaps pre- } \\
\text { Roman in origin but } \\
\text { perhaps lasting to } \\
\text { 4th C. A.D. }\end{array}$ & $\operatorname{Ar} \mathcal{J}$ cxxiv $\left(19^{6} 7\right)$ \\
\hline $\begin{array}{l}\text { Norsey Wood, } \\
\text { Billericay }\end{array}$ & Essex & Chelmsford Br 8.513 & $\begin{array}{l}\text { Opaque blue with } \\
\text { irregular yellow } \\
\text { whirl. Diam. } 3 \cdot 5 \\
\mathrm{~cm} . \text { Ht. } 9 \mathrm{~mm} \text {. } \\
\text { (fig. 15) }\end{array}$ & $\begin{array}{l}\text { Found in the last } \\
\text { century. Many } \\
\text { Belgic and Roman } \\
\text { finds from site }\end{array}$ & 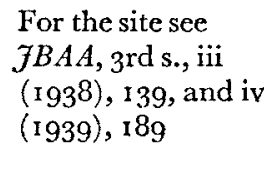 \\
\hline Kelvedon & Essex & $\begin{array}{l}\text { Ipswich? Property } \\
\text { M. R. Campen }\end{array}$ & $\begin{array}{l}\text { Almost opaque with } \\
\text { white whirl. Diam. } \\
2 \cdot 9 \mathrm{~cm} . \mathrm{Ht} \text { I } \cdot \text { I cm. } \\
\text { Perf. diam. I cm. } \\
\text { (fig. I5) }\end{array}$ & $\begin{array}{l}\text { From an early } \\
\text { Romano-British } \\
\text { rubbish pit }\end{array}$ & \\
\hline Glastonbury & Somerset & Glastonbury Gi4 & $\begin{array}{l}\text { Semi-translucent dark } \\
\text { purple with opaque } \\
\text { yellow whirl. Diam. } \\
3 \mathrm{~cm} \text {. Ht. } 1.3 \mathrm{~cm} .\end{array}$ & From Lake Village & $G l$. ii \\
\hline
\end{tabular}




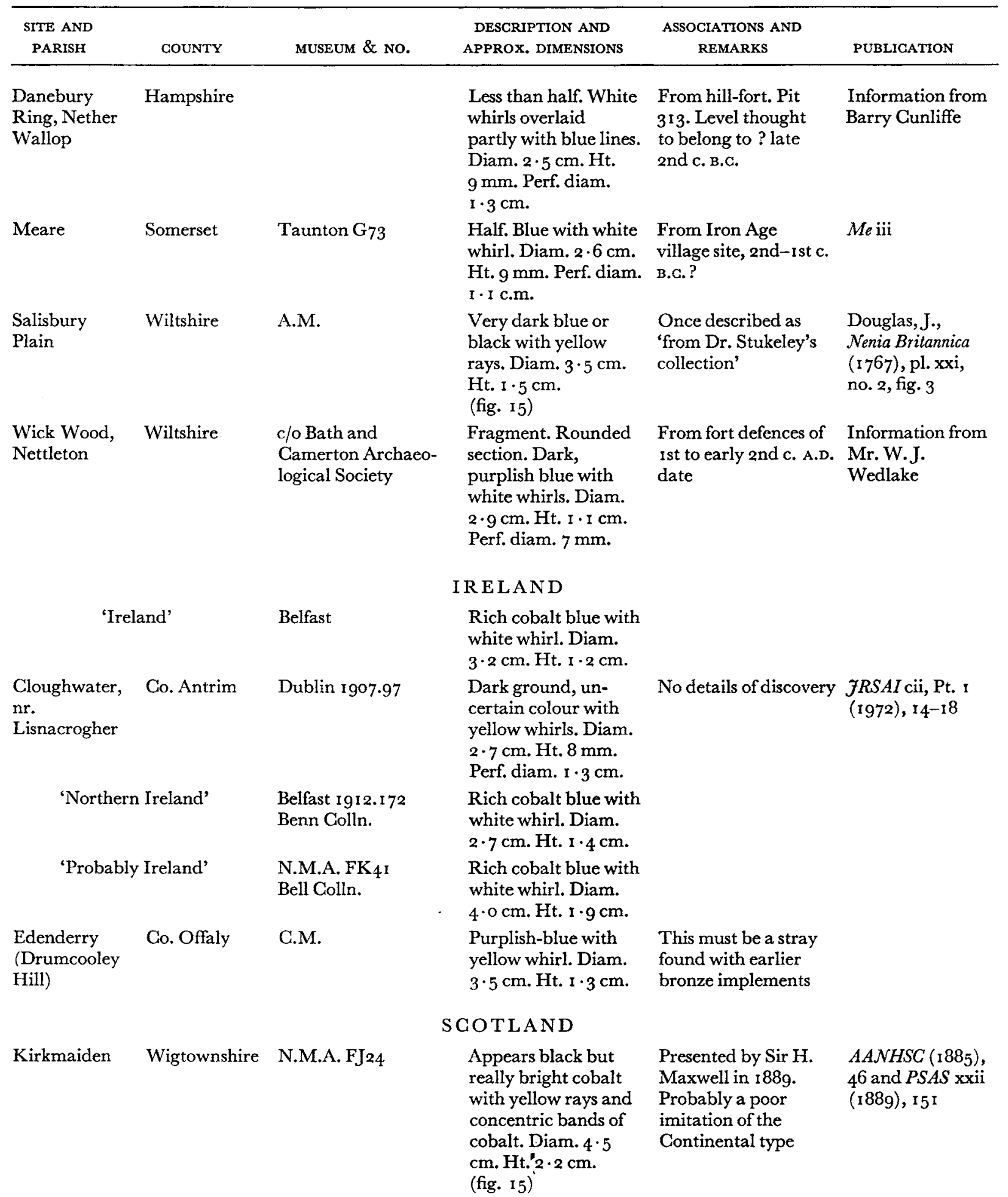




\begin{tabular}{|c|c|c|c|c|c|}
\hline $\begin{array}{l}\text { SITE AND } \\
\text { PARISH }\end{array}$ & COUNTY & MUSEUM \& No. & $\begin{array}{l}\text { DESCRIPTION AND } \\
\text { APPROX. DIMENSIONS }\end{array}$ & $\begin{array}{l}\text { ASSOCIATIONS AND } \\
\text { REMARKS }\end{array}$ & PUBLICATION \\
\hline \multicolumn{6}{|c|}{ WALES } \\
\hline Caerleon & $\begin{array}{l}\text { Monmouth- } \\
\text { shire }\end{array}$ & N.M.W. & $\begin{array}{l}\text { Fragment. Diam. } \\
2 \cdot 9 \mathrm{~cm} . \mathrm{Ht}, \mathrm{I} \cdot 3 \mathrm{~cm} .\end{array}$ & $\begin{array}{l}\text { Stratified A.D. I } 30- \\
230 \text { in excavation to } \\
\text { S.W. of legionary } \\
\text { fortress, in } 1962 \text {. }\end{array}$ & $\begin{array}{l}\text { See Boon, G. C., } \\
I_{\text {sca }}(1972)\end{array}$ \\
\hline $\begin{array}{l}\text { Walesland } \\
\text { Rath }\end{array}$ & $\begin{array}{l}\text { Pembroke- } \\
\text { shire }\end{array}$ & & $\begin{array}{l}\text { Fragment. Blue with } \\
\text { remains of white } \\
\text { whirls }\end{array}$ & $\begin{array}{l}\text { Dated from associa- } \\
\text { tions and radio- } \\
\text { carbon to } 3 \text { rd-2nd c. } \\
\text { B.c. (2 Io } \pm 90 \text { B.c. } \\
\text { (NPL 245)) }\end{array}$ & $\begin{array}{l}\text { Wainwright, G. } \\
\text { 'The excavation } \\
\text { of a fortified } \\
\text { settlement at } \\
\text { Walesland Rath, } \\
\text { Pembrokeshire', } \\
\text { Brit ii (1971), } 4^{8}\end{array}$ \\
\hline \multicolumn{6}{|c|}{ TYPE (B), BROWN OR YELLOWISH-BROWN WITH YELLOW WHIRL } \\
\hline $\begin{array}{l}\text { Hengistbury } \\
\text { Head }\end{array}$ & Dorset & Ghristchurch & $\begin{array}{l}\text { Part only. Diam. } \\
3.7 \mathrm{~cm} . \mathrm{Ht} . \mathrm{I} \cdot 5 \mathrm{~cm} .\end{array}$ & $\begin{array}{l}\text { From Site } 33 . \text { Occu- } \\
\text { pation lasted from } \\
\text { early ist c. B.c. to } \\
\text { Antoninus Pius to } \\
\text { judge from coins only. } \\
\text { Iron Age entrepôt }\end{array}$ & $\begin{array}{l}H H, \text { pl. xxx, no. } \\
20\end{array}$ \\
\hline $\begin{array}{l}\text { Welwyn } \\
\text { Garden City }\end{array}$ & Hertfordshire & B.M. & $\begin{array}{l}\text { Rich bright brown } \\
\text { with yellow inlay. } \\
\text { Fragment only. } \\
\text { Diam. } 3.2 \mathrm{~cm} . \mathrm{Ht} \text {. } \\
\mathrm{I} \cdot 4 \mathrm{~cm} .\end{array}$ & $\begin{array}{l}\text { Probably belongs to } \\
\text { this Class. It came } \\
\text { from a rich grave with } \\
\text { gaming pieces and } \\
\text { imported Italian } \\
\text { objects of the late } \\
\text { Ist c. B.C. }\end{array}$ & $A \operatorname{ci}(\mathrm{r} 967)$, I ff. \\
\hline Glastonbury & Somerset & Glastonbury $\mathrm{G}_{2 \mathrm{I}}$ & $\begin{array}{l}\text { Dark brown with } \\
\text { yellow whirl. Diam. } \\
3 \cdot 4 \mathrm{~cm} \text {. }\end{array}$ & From Lake Village & $G e$ ii \\
\hline
\end{tabular}

\section{SCOTLAND}

Two related beads from 'Scotland' are in the N.M.A.: no. FJ27, dark brownish glass with circumferential bands in yellow and green, diam. $3 \cdot 5 \mathrm{~cm}$., ht. I $8 \mathrm{~cm}$. perf. diam. $8 \mathrm{~mm}$; the other is smaller and paler pinkish-brown (FJ r 34) and may not belong to this Class. 


\begin{tabular}{|c|c|c|c|c|c|}
\hline $\begin{array}{l}\text { SITE AND } \\
\text { PARISH }\end{array}$ & COUNTY & MUSEUM \& NO. & $\begin{array}{l}\text { DESCRIPTION AND } \\
\text { APPROX. DIMENSIONS }\end{array}$ & $\begin{array}{l}\text { ASSOCIATIONS AND } \\
\text { REMARKS }\end{array}$ & PUBlication \\
\hline \multicolumn{6}{|c|}{ TYPE $(\mathrm{C})$, MISCELLANEOUS COLOURS } \\
\hline \multicolumn{6}{|c|}{ ENGLAND } \\
\hline Colchester & Essex & Colchester Group 94 & $\begin{array}{l}\text { Finely made opaque } \\
\text { white with pale blue } \\
\text { circumferential bands } \\
\text { overlaid by purple } \\
\text { rays. Diam. } 2.8 \mathrm{~cm} \text {. } \\
\text { Perf. diam. } 7 \mathrm{~mm} \text {. } \\
\text { (fig. I 5) }\end{array}$ & $\begin{array}{l}\text { Group } 94 \text { is post A.D. } \\
54 \text { as it contained a } \\
\text { coin of Nero and } \\
\text { other objects. The } \\
\text { groups are not re- } \\
\text { garded as reliable as } \\
\text { some are muddled }\end{array}$ & $\begin{array}{l}\text { May, 'T., Catalogue } \\
\text { of the Colchester and } \\
\text { Essex Museum }\end{array}$ \\
\hline Seamills & $\begin{array}{l}\text { Gloucester- } \\
\text { shire }\end{array}$ & N.M.W. & $\begin{array}{l}\text { About one-third } \\
\text { bead. Opaque yellow } \\
\text { core covered in milky } \\
\text { white glass overlaid } \\
\text { with rays and bands } \\
\text { in purple. Diam. } c .3 \cdot 3 \cdot \\
\mathrm{cm} \text {. Ht. } 1 \cdot 3 \mathrm{~cm} \text {. Perf. } \\
\text { diam. } c .9 \mathrm{~mm} \text {. Hour- } \\
\text { glass perforation. }\end{array}$ & $\begin{array}{l}\text { From a Flavian } \\
\text { context. } \\
2\end{array}$ & $\begin{array}{l}\text { Information from } \\
\text { Miss J. Price, } \\
\text { Cardiff } \\
\text { University }\end{array}$ \\
\hline \multicolumn{6}{|c|}{ I R ELAND } \\
\hline \multicolumn{2}{|c|}{ ? Ireland } & A.M. & $\begin{array}{l}\text { Whitish glass with } \\
\text { circumferential bands } \\
\text { and purple rays. } \\
\text { Diam. } 2 \cdot 9 \mathrm{~cm} \text {. Ht. } \\
\mathrm{I} \cdot 3 \mathrm{~cm} . \text { Perf. diam. } \\
4 \mathrm{~mm} \text {. }\end{array}$ & $\begin{array}{l}\text { From a miscellaneous } \\
\text { collection }\end{array}$ & $\begin{array}{l}\operatorname{Arf} \mathrm{iii}(1846), 355 \\
\text { and }\left(\mathrm{I} 8_{3} 6\right), \mathrm{I} 23\end{array}$ \\
\hline Probably & Ireland & $\begin{array}{l}\text { N.M.A. FK 21, 22, } 23 \\
\text { (Bell Colln.) }\end{array}$ & $\begin{array}{l}\text { Ground colour is } \\
\text { green }\end{array}$ & $\begin{array}{l}\text { This and the Den- } \\
\text { hamstown bead } \\
\text { must be from the } \\
\text { same workshop. 'Dug } \\
\text { up in a gravel-pit } \\
\text { with human bones' }\end{array}$ & \\
\hline $\begin{array}{l}\text { Hawkhill, } \\
\text { Kildare }\end{array}$ & Co. Offaly & Dublin $1945 \cdot 323$ & $\begin{array}{l}\text { Almost colourless } \\
\text { ground. Finely made } \\
\text { whirls in yellow. } \\
\text { Diam. over } 3 \mathrm{~cm} \text {. } \\
\text { Slightly hour-glass } \\
\text { perforation }\end{array}$ & $\begin{array}{l}\text { 'Found in a quarry } \\
\text { in hole among débris } \\
\text { and ashes' }\end{array}$ & 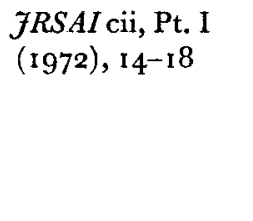 \\
\hline $\begin{array}{l}\text { Denhamstown, } \\
\text { Ardcath }\end{array}$ & Co. Meath & Dublin 1907.79 & $\begin{array}{l}\text { Almost colourless } \\
\text { ground. Finely made } \\
\text { whirls in yellow. } \\
\text { Diam. over } 3 \mathrm{~cm} \text {. } \\
\text { Slightly hour-glass } \\
\text { perforation }\end{array}$ & & Ibid. 14-18 \\
\hline
\end{tabular}




\title{
DEGORATED OR UNDEGORATED GROUPS (BOTH IRON AGE AND ROMAN IN DATE)
}

\author{
GROUP I
}

\section{LARGE OR MEDIUM ANNULAR BEADS WITH STREAKY OR MOTTLED DESIGN}

\begin{tabular}{lccccc}
\hline $\begin{array}{c}\text { SITE AND } \\
\text { PARISH }\end{array}$ & COUNTY & MUSEUM \& NO. & DESCRIPTION AND & ASSOCIATIONS AND \\
\hline
\end{tabular}

Hamworthy Dorset Poole

Hengistbury Dorset Christchurch

Head

Colchester Essex Colchester 99-105

Twyford and

Owslebury

Sittingbourne Kent

Leicester

Leicestershire Leicester

Charterhouse- Somerset on-Mendip

Haughley Suffolk

A.M. 1909.417

Way Colln. Drawings (S.A.I.)

A. C. Pass Colln. Bristol F2083

\section{ENGLAND}

Fragment of large translucent amber glass bead with opaque yellow streaks. Diam. 2.9 $\mathrm{cm}$. Perf. diam. $9 \mathrm{~mm}$.

Bright translucent cobalt with opaque fawn streaks

Large dark translucent cobalt bead with white streaks mostly confined to outer edges. Diam. $3.6 \mathrm{~cm}$. Ht. I $1 \mathrm{~cm}$. Perf. diam. $\mathrm{I} \cdot 2 \mathrm{~cm}$. (fig. I 7 )

Dark blue with yellow Colden Common streaks. Diam.c. 3.1 $\mathrm{cm}$. No other details

Large blue streaks with yellow. No details

Other imported late pre-Roman and Roman beads and a glass armlet from this site

Stray find. From date, probably andIst c. B.c. entrepôt

Now thought to have come from Grave 53 (c. A.D. 25-50). These groups are not completely reliable

Dark blue with yellow From level VI (A.D. streaks. Diam. $2 \cdot 7$ cm. Ht. $\mathrm{I} \cdot 4 \mathrm{~cm}$. Perf. diam. I cm.

Dark greenish-brown

From early Roman lead mines (until around A.D. I 70 imperially controlled)
H. P. Smith, History of Poole, pl. 1, nos. $4^{6}$ and 47

Found by Mr.

May, T. (1930)

Dunkins, Canterbury Congress, $33^{6}$

Kenyon, K. M. (1948), p. 269, fig. 93 , no. 2

VCH Somerset i, 334
Brown with yellow streaks. Diam. $c$. $3 \mathrm{~cm}$. 


\begin{tabular}{|c|c|c|c|c|c|}
\hline $\begin{array}{l}\text { SITE AND } \\
\text { PARISH }\end{array}$ & COUNTY & MUSEUM \& No. & $\begin{array}{l}\text { DESCRIPTION AND } \\
\text { APPROX. DIMENSIONS }\end{array}$ & $\begin{array}{l}\text { ASSOCLATIONS AND } \\
\text { REMARKS }\end{array}$ & PUBLICATION \\
\hline $\begin{array}{l}\text { Wick Wood, } \\
\text { Nettleton }\end{array}$ & Wiltshire & $\begin{array}{l}\text { c/o Bath and Camer- } \\
\text { ton Archaeological } \\
\text { Society }\end{array}$ & $\begin{array}{l}\text { Fragment, dark blue } \\
\text { semi-translucent with } \\
\text { opaque streaks. } \\
\text { Diam. } 2 \mathrm{~cm} . \mathrm{Ht} \text {. } \\
\text { I cm. Perf. diam. } \\
9 \mathrm{~mm} \text {. }\end{array}$ & $\begin{array}{l}\text { Stratified 'post- } \\
\text { Constantinian' }\end{array}$ & $\begin{array}{l}\text { Information from } \\
\text { Mr. W.J. } \\
\text { Wedlake }\end{array}$ \\
\hline
\end{tabular}

\section{IRELAND}

Several unassociated examples. One dark blue with white speckled decoration (diam. $2.3 \mathrm{~cm}$. N.M.A. Bell Colln. $\mathrm{FK}_{44}$ ) is probably from Ireland. Another comes from Shanganagh, Dublin, light green translucent with yellow speckles (diam. $2.2 \mathrm{~cm}$.) and is in C.M. There is nothing to suggest a date for these and they may well be post-6th $c$. in date.

\begin{tabular}{|c|c|c|c|}
\hline \multirow[b]{2}{*}{ 'Stirlingshire?' } & \multicolumn{2}{|c|}{ SGOTLAND } & \\
\hline & Falkirk Museum & $\begin{array}{l}\text { Translucent bottle } \\
\text { glass with yellow } \\
\text { streaks. Diam. } 3 \cdot 3 \\
\text { cm. Ht. } 9 \mathrm{~mm} . \text { Perf. } \\
\text { diam. } 8 \mathrm{~mm} \text {. }\end{array}$ & $\begin{array}{l}\text { Thought to come } \\
\text { from a site producing } \\
\text { Roman pottery. } \\
\text { Given by A. Craig }\end{array}$ \\
\hline
\end{tabular}

Unpublished

\section{$\mathrm{GROUP}_{2}$}

\section{MISGELLANEOUS SPIRAL-DEGORATED BEADS}

(See also Oldbury Class and North Scottish 'Spirals' and Horned Eye with Spirals (Classes 6 and I 3 and Group 3))

\section{ENGLAND}

Hengistbury Dorset B.M.
Head

Ashley Camp, Hampshire Winchester Ashley

Kingscote Gloucestershire
Globular blue with design in white related to spirals. Diam. $1 \cdot 7 \mathrm{~cm}$. Ht. I. $1 \mathrm{~cm}$. Perf. diam. $5 \mathrm{~mm}$.

Half annular bead. Blue with one line of yellow spirals. Related to Oldbury type beads of Class 6

Fragment of small annular bead in blue glass with one white marvered spiral (originally there may have been 3 spirals). Diam. $1 \cdot 2 \mathrm{~cm}$. Ht. $5 \mathrm{~mm}$. Perf. diam. $6 \mathrm{~mm}$.
From fort with Late Iron Age finds Iron Age stray from a site mostly producing later Roman material

Surface find in the Ist C. A.D. area of the Roman villa.
$H H$, pl. xxx, $2 \mathrm{I}$; cf. Reinecke, $\mathrm{S}$. (I9II), v, pl.xiv, figs. 233 and $23^{8}$

Information from Mr. Graham Walker 


\begin{tabular}{|c|c|c|c|c|c|}
\hline $\begin{array}{l}\text { SITE AND } \\
\text { PARISH }\end{array}$ & COUNTY & MUSEUM \& NO. & $\begin{array}{l}\text { DESCRIPTION AND } \\
\text { APPROX. DIMENSIONS }\end{array}$ & $\begin{array}{l}\text { ASSOCLATIONS AND } \\
\text { REMARKS }\end{array}$ & PUBLICATION \\
\hline $\begin{array}{l}\text { Weston- } \\
\text { under- } \\
\text { Penyard, } \\
\text { Bollitree }\end{array}$ & Herefordshire & Gloucester I 734 & $\begin{array}{l}\text { Small dark blue with } \\
3 \text { white spirals - re- } \\
\text { lated to Oldbury } \\
\text { Class. Diam. I cm. } \\
\text { Ht. } 7 \mathrm{~mm} \text {. Perf. } \\
\text { diam. } 5 \mathrm{~mm} \text {. }\end{array}$ & $\begin{array}{l}\text { Early Roman site and } \\
\text { some Belgic coins } \\
\text { from the site as well }\end{array}$ & $\begin{array}{l}\mathcal{J} B A A \text { xxvii }(\mathrm{I} 87 \mathrm{I}) \\
2 \text { I I ff. }\end{array}$ \\
\hline Westerham & Kent & & $\begin{array}{l}\text { One row large yellow } \\
\text { spirals. Diam. } 2 \cdot 3 \mathrm{~cm} \text {. } \\
\mathrm{Ht} .1 \cdot 4 \mathrm{~cm} . \text { Perf. } \\
\text { diam. } \mathrm{I} \mathrm{cm} \text {. }\end{array}$ & $\begin{array}{l}\text { From an Iron Age } \\
\text { hill-fort }\end{array}$ & $\begin{array}{l}\text { Publication } \\
\text { forthcoming after } \\
1971 . \text { Information } \\
\text { from W. Kent } \\
\text { Border Archaeo- } \\
\text { logical Society }\end{array}$ \\
\hline $\begin{array}{l}\text { Corbridge } \\
\text { (near) }\end{array}$ & $\begin{array}{l}\text { Northumber- } \\
\text { land }\end{array}$ & & $\begin{array}{l}\text { Annular bottle-glass } \\
\text { bead 'ornamented } \\
\text { with spots of opaque } \\
\text { blue and white paste } \\
\text { each forming a small } \\
\text { spiral on its surface' }\end{array}$ & $\begin{array}{l}\text { Probably a stray find. } \\
\text { Date unknown. }\end{array}$ & $\operatorname{Arf}$ vii $(1850), 192$ \\
\hline Meare & Somerset & Taunton Gi 5 & $\begin{array}{l}\text { Small globular bead } \\
\text { with light blue spirals } \\
\text { on dark blue. Diam. } \\
6 \mathrm{~mm} . \text { Ht. } 5 \mathrm{~mm} \text {. } \\
\text { Perf. diam. } 2 \mathrm{~mm} \text {. }\end{array}$ & $\begin{array}{l}\text { Occupation mostly } \\
\text { 3rd to ist c. B.c. }\end{array}$ & $M e$ iii ( $\left.\operatorname{Ig67}^{2}\right)$ \\
\hline Meare & Somerset & Taunton $\mathrm{G}_{4} 6$ & $\begin{array}{l}\text { Globular blue with } \\
\text { opaque yellow run- } \\
\text { ning spiral. Diam. } \\
\text { I } 6 \mathrm{~cm} \text {. Ht. I } \cdot \text { I cm. } \\
\text { Perf. diam. very } \\
\text { small (fig. I } 8 \text {, left) }\end{array}$ & $\begin{array}{l}\text { Occupation mostly in } \\
\text { 3rd-Ist c. B.c. }\end{array}$ & $M e \mathrm{iii}\left(\operatorname{Ig}^{67}\right)$ \\
\hline Meare & Somerset & Taunton G68EV & $\begin{array}{l}\text { On necklace with } \\
39 \text { small yellow } \\
\text { opaque annular } \\
\text { beads and } 4 \text { Meare } \\
\text { spiral beads. Light } \\
\text { green triangular with } \\
\text { opaque yellow spirals. } \\
\text { Diam. c. } 8 \mathrm{~mm} \text {. Ht. } \\
6 \mathrm{~mm} \text {. Perf. diam. } \\
3 \mathrm{~mm} \text {. }\end{array}$ & $\begin{array}{l}\text { Evidently contem- } \\
\text { porary with Meare } \\
\text { spiral beads. See } \\
\text { Class Io }\end{array}$ & $M e$ iii ( 1967$)$ \\
\hline Worthing & Sussex & Worthing 4547 & $\begin{array}{l}\text { Annular, semi- } \\
\text { translucent bright } \\
\text { cobalt with } 4 \text { opaque } \\
\text { yellow spirals. ? Re- } \\
\text { lated to Oldbury } \\
\text { Glass. Diam. c. } 2 \mathrm{~cm} \text {. } \\
\text { Ht. irregular c. } 8 \mathrm{~mm} \text {. } \\
\text { Perf. diam. I cm. } \\
\text { (fig. I8, right) }\end{array}$ & $\begin{array}{l}\text { Stray find from Heene } \\
\text { Court, Bath Road, } \\
\text { Worthing in Igr3. A } \\
\text { not uncommon type } \\
\text { on the Continent, } \\
\text { this can be dated } \\
\text { from } 2 \text { nd-rst c. B.c. } \\
\text { sites at Ludwigshafen, } \\
\text { Worms, Manching, } \\
\text { etc. }\end{array}$ & $\begin{array}{l}\text { Mentioned only in } \\
S A C \text { xcviii (1960), } \\
\text { I } 8\end{array}$ \\
\hline
\end{tabular}




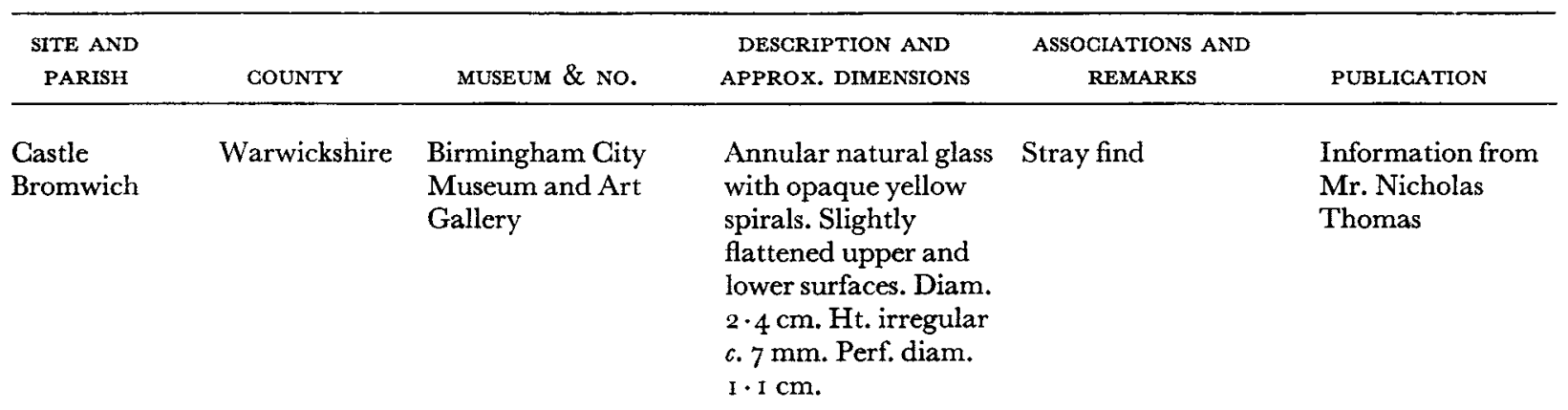

\section{RELAND}

'Ireland' Belfast 623.1924

Traprain Law, East Lothian Prestonkirk

Traprain Law, East Lothian Prestonkirk

Traprain Law, East Lothian Prestonkirk

Castle Island, Wigtownshire Mochrum
Small annular dark cobalt with 3 white spirals like Westonunder-Penyard above. Diam. $1 \cdot 1 \mathrm{~cm} . \mathrm{Ht} .6$ mm. Perf, diam. $4 \mathrm{~mm}$.

\section{SGOTLAND}

N.M.A. 111 .20-376

Rather square globular. Dark blue with four inset lime green roundels containing yellow spirals flattened where spirals. Diam. I $\cdot 5 \mathrm{~cm}$. Ht. I $4 \mathrm{~cm}$. Uneven perforation.

N.M.A. I922.204

Opaque dark blue globular with 3 inlaid white spirals. Diam.

$\mathrm{I} .4 \mathrm{~cm}$. Ht. $\mathrm{I} \mathrm{cm}$.

Perf. diam. $8 \mathrm{~mm}$.

N.M.A. 1924.17 I

See cable beads

Lord David Stuart, Old Place of Mochrum, Port William, Wigtownshire

Globular translucent green with small blue spirals in white roundels. Diam. I 6 cm. Ht. $\mathrm{I} \cdot 5 \mathrm{~cm}$. Perf.
From a collection

Lowest level. Thought to be Late Iron Age or early Roman.

(Reminiscent of gaming pieces from Welwyn Garden City (end ist c. B.c.). See Stead, I. M. ( 1967$)$ )

Probably relates to Oldbury Class

PSAS lvi (1921-2), 227, fig. 24. I diam. $2 \mathrm{~mm}$.
TDGNHAS xxviii ( I $\left.949^{-} 5^{\circ}\right)$
Found with other beads in N.E. building in 1910 . Undated but cf. Welwyn Garden City gaming pieces quoted above and also marbles from Monquhitter (PSAS lxvi, 295) 


\begin{tabular}{ccccc}
\hline $\begin{array}{l}\text { SITE AND } \\
\text { PARISH }\end{array}$ & COUNTY & MUSEUM \& NO. & DESCRIPTION AND & ASSOCIATIONS AND \\
\hline
\end{tabular}

\section{GROUP 3}

MISGELLANEOUS HORNED BEADS (SOME WITH EYES OR SPIRALS)

(See also Classes 6 and 13 and Group 2)

\begin{tabular}{|c|c|c|c|c|}
\hline \multirow[b]{2}{*}{ Tarporley } & \multicolumn{4}{|c|}{ ENGLAND } \\
\hline & Cheshire & G.M. & $\begin{array}{l}\text { Translucent light } \\
\text { bottle glass with } 4 \\
\text { blue horns with white } \\
\text { spirals. Diam. } 3 \cdot 3 \\
\mathrm{~cm} \text {. Ht. } 1 \cdot 2 \mathrm{~cm} . \\
\text { Perf. diam. I } 1 \mathrm{~cm} \text {. } \\
\text { (fig. I9, left) }\end{array}$ & $\begin{array}{l}\text { Found in } 1775 \text {. } \\
\text { Identical to the bead } \\
\text { from Newstead below }\end{array}$ \\
\hline
\end{tabular}

Silchester Hampshire Reading

Cooling Kent Rochester

Fragment. Dark blue semi-translucent with

Occupation ist-5th c. A.D.

yellow and brown horn. Diam. $2 \cdot 4 \mathrm{~cm}$. Ht. $1 \cdot 2 \mathrm{~cm}$. Perf. diam. $8 \mathrm{~mm}$.

$\begin{array}{ll}\begin{array}{l}\text { Hunsbury, } \\ \text { Hardingstone }\end{array} & \begin{array}{l}\text { Northampton- } \\ \text { shire }\end{array} \\ \text { Chesters Fort } & \begin{array}{l}\text { Northumber- Chesters } \\ \text { land }\end{array}\end{array}$

Icklingham Suffolk Bury St. Edmunds
Large blue bead drum-shaped with large very projecting horns surrounded by opaque white rings. Diam. $2 \cdot 5 \mathrm{~cm}$. Ht. $2 \cdot 3 \mathrm{~cm}$. Perf, diam. 8mm. (fig. I9, right)

Translucent bottle glass white swags and 4 opaque white eyes with spirals in light brown translucent glass. Diam. $3 \mathrm{~cm}$. Ht. $\mathrm{I} \cdot 4 \mathrm{~cm}$.

One 'blue with white Iron Age hill-fort knobs' (lost) ? $4^{\text {th-Ist c. B.c. }}$

\author{
This is a Continental Information from \\ La Tène II import Mr. M. Syddell. \\ from a later Romano- To be published \\ British salt panning in $A C t$ \\ site in an Antonine \\ level. Exact parallels \\ from Berne and \\ Zollikofen. See \\ Viollier, D. (1916), \\ pl. $3^{2}$, nos. I I and 12 \\ Mr. M. Syddell.
}

Stray find 1966. Date uncertain

Fell, C. (1936) with refs. to earlier publications

Site occupied about A.D. $122-383$

ery dark blue. Two horned eyes, in blue and yellow. Diam. $3 \mathrm{~cm}$. Ht. $1 \cdot 6 \mathrm{~cm}$. Perf. diam. I $1 \mathrm{~cm}$.

Black ground with green or yellow horns

With a hoard of about Clarke, R., East A.D, 400
For refs., see Collingwood and Richmond, The Archaeology of (revised ed., 1969). See also Boon, G. C. (1957) 


\begin{tabular}{|c|c|c|c|c|c|}
\hline $\begin{array}{l}\text { SITE AND } \\
\text { PARISH }\end{array}$ & COUNTY & MUSEUM \& No. & $\begin{array}{l}\text { DESCRIPTION AND } \\
\text { APPROX. DIMENSIONS }\end{array}$ & $\begin{array}{l}\text { ASSOCIATIONS AND } \\
\text { REMARKS }\end{array}$ & PUBLICATION \\
\hline \multicolumn{6}{|c|}{ IRELAND } \\
\hline $\begin{array}{l}\text { Loughey, } \\
\text { Donaghadee }\end{array}$ & Co. Down & B.M. 62.7-1.19 & $\begin{array}{l}\text { Small blue bead } \\
\text { with yellow and blue } \\
\text { cable and three tiny } \\
\text { opaque yellow horns } \\
\text { (fig. } 23,2 \text { ) }\end{array}$ & $\begin{array}{l}\text { On necklace } \\
\text { including Meare } \\
\text { spirals of Class } 6 . \\
\text { Dated by Nauheim } \\
\text { type brooch, Ist c. } \\
\text { B.C.-Ist c. A.D. }\end{array}$ & $\begin{array}{l}A r 7 \text { xiii }(1856) \text {, } \\
407 \text {, and Jope, } \\
\text { E. M. (1957) } \\
\text { and (r96o) }\end{array}$ \\
\hline $\begin{array}{l}\text { Lagore } \\
\text { Grannog }\end{array}$ & Co. Meath & Dublin $149^{8}$ & $\begin{array}{l}\text { Fragment of blue } \\
\text { bead with bottle glass } \\
\text { eyes with white } \\
\text { opaque spirals }\end{array}$ & $\begin{array}{l}\text { There are some early } \\
\text { beads (Ist c.) from a } \\
\text { mainly } 7^{\text {th }} \mathrm{c} \text {. } \\
\text { occupation }\end{array}$ & $\begin{array}{l}P R I A \text { liii, Section } \\
\mathrm{C}\left(\mathrm{I} 95^{\circ}-\mathrm{I}\right)\end{array}$ \\
\hline \multirow{2}{*}{\multicolumn{2}{|c|}{ 'Ireland' }} & $\begin{array}{l}\text { Benn Colln., Belfast, } \\
\text { 1912:172 }\end{array}$ & $\begin{array}{l}\text { Bottle glass bead with } \\
4 \text { eyes in opaque } \\
\text { white and translucent } \\
\text { blue. Diam. } 2.3 \mathrm{~cm} \text {. } \\
\text { Ht. } 1 \mathrm{~cm} . \text { Perf. } \\
\text { diam. } 6 \mathrm{~mm} .\end{array}$ & No information & \\
\hline & & & \multicolumn{3}{|l|}{ SGOTLAND } \\
\hline Newstead & Roxburghshire & N.M.A. FRA8995 & $\begin{array}{l}\text { Half natural green } \\
\text { glass bead, blue and } \\
\text { white spirals, Diam. } \\
3.3 \mathrm{~cm} \text {. Ht. I } 4 \mathrm{~cm} \text {. } \\
\text { Perf. diam. I } 6 \mathrm{~cm} \text {. }\end{array}$ & $\begin{array}{l}\text { Site occupied about } \\
\text { A.D. } 80-200\end{array}$ & $\mathcal{N}_{e}, 33^{6-7}$ \\
\hline \multirow[t]{2}{*}{ Newstead } & Roxburghshire & N.M.A. FRA398 & $\begin{array}{l}\text { Opaque grey green } \\
\text { with two horned eyes } \\
\text { in yellow in white. } \\
\text { Diam. } 2 \cdot 5 \mathrm{~cm} \text {. }\end{array}$ & & \\
\hline & & & WALES & & \\
\hline Caerleon & $\begin{array}{l}\text { Monmouth- } \\
\text { shire }\end{array}$ & N.M.W. & $\begin{array}{l}\text { Crimson glass with } \\
\text { blue-green clear glass } \\
\text { knobs. Diam. c. } 2 \cdot 3 \\
\text { cm. Ht. } 12 \mathrm{~mm} \text {. } \\
\text { Perf. diam. } 9 \text { mm. }\end{array}$ & $\begin{array}{l}\text { Among miscellaneous } \\
\text { beads. No date. From } \\
\text { Castle Villa }\end{array}$ & $\begin{array}{l}\text { Lee, Catalogue } \\
\text { Museum Caerleon } \\
\text { (1862), pl. xxviii. } \\
\text { See also Arf viii } \\
\text { (1851), 160 }\end{array}$ \\
\hline $\begin{array}{l}\text { Whitton, nr. } \\
\text { Barry }\end{array}$ & $\begin{array}{l}\text { Glamorgan- } \\
\text { shire }\end{array}$ & ?N.M.W. & $\begin{array}{l}\text { Half of big irregular } \\
\text { yellow bead with } \\
\text { large translucent } \\
\text { brown horns } \\
\text { (originally four). Diam. } \\
\text { irregular. Ht. } 1.8 \mathrm{~cm} \text {. }\end{array}$ & $\begin{array}{l}\text { Roman villa site } \\
\text { occupied earlier } c \text {. Ist } \\
\text { c. B.C. to A.D. } 300\end{array}$ & $\begin{array}{l}\text { Information from } \\
\text { Dr. M. Jarrett }\end{array}$ \\
\hline
\end{tabular}




\begin{tabular}{lcccc}
\hline $\begin{array}{l}\text { SITE AND } \\
\text { PARISH }\end{array}$ & COUNTY & MUSEUM \& NO. & DESGRIPTION AND & ASSOGIATIONS AND \\
APPROX. DIMENSIONS & REMARKS & PUBLICATION \\
\hline
\end{tabular}

\section{GROUP 4}

\section{MULTI-EYED WITH SMALL EYES SET IN ROUNDELS \\ ('GARROW TOR' TYPE)}

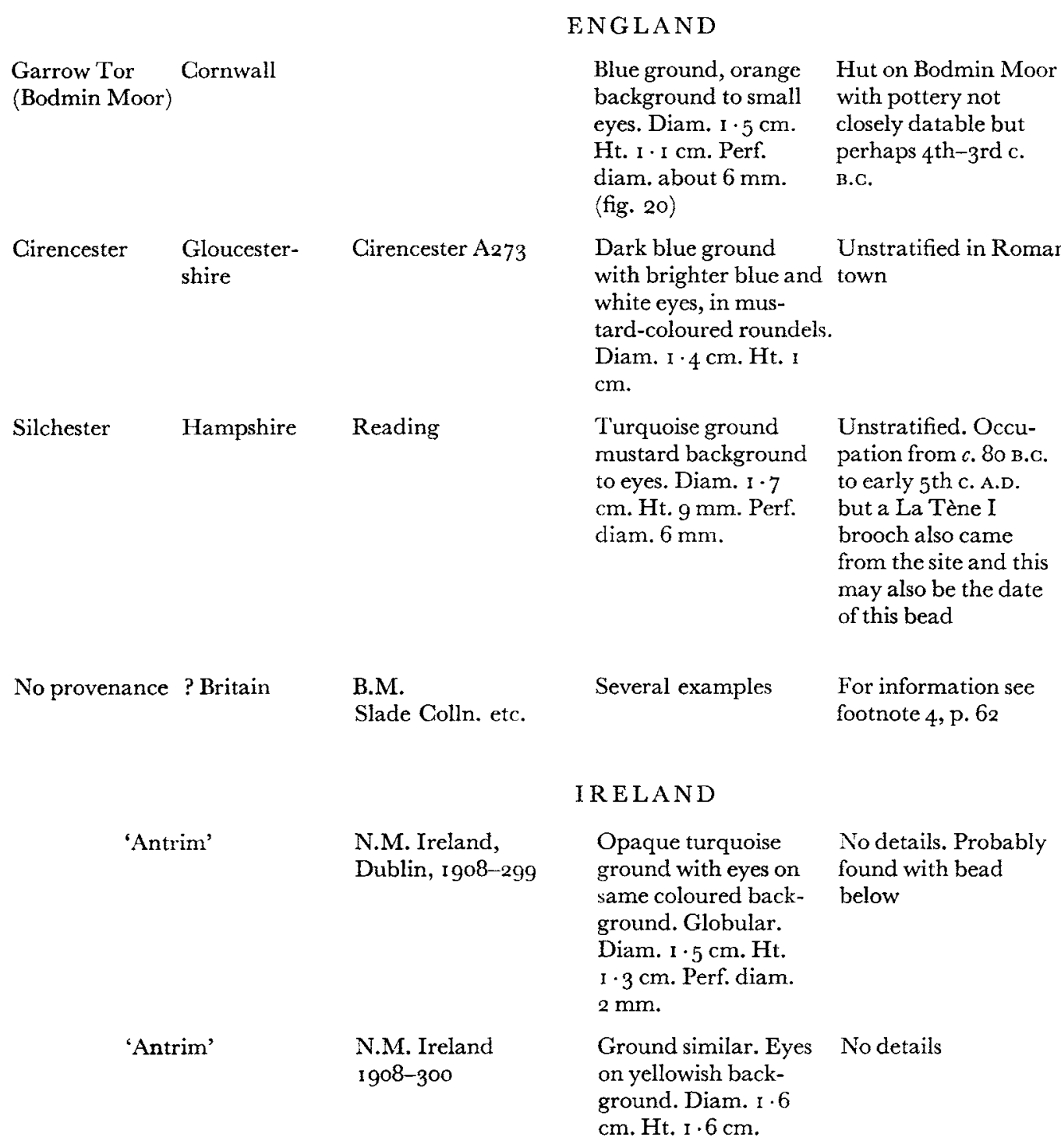

Related but dissimilar beads with eyes in roundels are also in Irish collections. Two annular examples_both with roundels containing 'eyes' are nos. Belfast 1912:173 and (from Antrim). The ground colour of both of them is greenish; they are also differently coloured in the roundels. 


\begin{tabular}{lcccc}
\hline $\begin{array}{l}\text { SITE AND } \\
\text { PARISH }\end{array}$ & COUNTY & MUSEUM \& NO. & $\begin{array}{c}\text { DESCRIPTION AND } \\
\text { APPROX. DIMENSIONS }\end{array}$ & $\begin{array}{c}\text { ASSOCIATIONS AND } \\
\text { REMARKS }\end{array}$ \\
\hline
\end{tabular}

\section{GROUP 5}

WAVE BEADS

(A) TRANSIUCENT BLUE ANNULAR AND GLOBULAR BEADS WITH OPAQUE WHITE OR YELLOW WAVE

\section{ENGLAND}

$\begin{array}{lll}\text { Pangbourne } & \text { Berkshire } & \begin{array}{l}\text { C.M., Beck Colln. } \\ \mathrm{I} 697\end{array} \\ \begin{array}{l}\text { Yewden, } \\ \text { Hambledon }\end{array} & \begin{array}{l}\text { Buckingham- } \\ \text { shire }\end{array} & \begin{array}{l}\text { Hambledon Villa } \\ \text { Museum }\end{array}\end{array}$

Lakenheath Cambridgeshire

G.M., Beck Colln. I 7 I $_{5}$ XLVII A3a

\begin{tabular}{|c|c|c|}
\hline Lakenheath & $\begin{array}{l}\text { Cambridge- } \\
\text { shire }\end{array}$ & ? C.M. \\
\hline $\begin{array}{l}\text { Wilderspool, } \\
\text { Warrington }\end{array}$ & $\begin{array}{l}\text { Cheshire- } \\
\text { Lancashire } \\
\text { borders }\end{array}$ & Warrington 1298 \\
\hline Ashton & Cheshire & Chester gR6 I \\
\hline $\begin{array}{l}\text { Nor' nour, } \\
\text { Scilly }\end{array}$ & Cornwall & St. Mary's, Scilly \\
\hline Probus & Cornwall & Truro \\
\hline
\end{tabular}

Glassonby Cumberland Carlisle 262
(Grayson
Lands
Tumulus)

Semi-translucent blue Stray find. (? Dark with angular upright Ages) wave. Diam. $2 \mathrm{~cm}$. Ht. $8 \mathrm{~mm}$.

Irregular wave of more than one strand on translucent blue. Diam. I. $5 \mathrm{~cm}$. Ht. $8 \mathrm{~mm}$.

\section{Irregular wave} bright cobalt ground semi-translucent. Diam. $1.8 \mathrm{~cm}$. Ht. $6 \mathrm{~mm}$.

Small with regular angular wave. Diam. $\mathrm{I} \cdot 4 \mathrm{~cm}$. Ht. $9 \mathrm{~mm}$.

From mainly Iron Age A site (? 3rd c.

PCAS xlii (1949), B.c.) but with little later scatter

Opaque blue with wide 2 -strand wave. Diam. $\mathrm{I} \cdot 8 \mathrm{~cm}$. Ht. I $\mathrm{cm}$.

Roman site, ? earlier occupation

May, T. (1904); Thompson, F. H. (1965)

Semi-translucent blue with irregular rather flat wave. Diam. I. $8 \mathrm{~cm}$. Ht. $8 \mathrm{~mm}$.

2-strand irregular wave or translucent light blue. Diam. $\mathrm{I} \cdot 4 \mathrm{~cm}$. Ht. $6 \mathrm{~mm}$.

Surface find 5 miles from Chester on line of Watling Street

JCNWAAHS xxxv, Pt. I (I 942) $5^{8}$

Site mainly 2 nd $c$. A.D. but began earlier and lasted till 4 th $\mathrm{c}$.

Arf cxxiv (1967)

White rather angular wave. Fragment. Diam. $2 \cdot 1 \mathrm{~cm}$. Ht. I $\mathrm{cm}$. Perf. diam. $8 \mathrm{~mm}$.

Irregular wave on light blue semitranslucent glass. Diam. $1 \cdot 8 \mathrm{~cm}$. Ht. $9 \mathrm{~mm}$.
From Romano-British Information from camp of Carvossa. Occupation into late Roman or ? early $5^{\text {th }} \mathrm{c}$.

Secondary stray in earlier tumulus. ? Dark Ages
Mr. H. L. Douch

TCW, n.s. i

(IgOI), 295 
THE SCHEDULES: GROUP 5

\begin{tabular}{|c|c|c|c|c|c|}
\hline $\begin{array}{l}\text { SITE AND } \\
\text { PARISH }\end{array}$ & COUNTY & MUSEUM \& NO. & $\begin{array}{l}\text { DESCRIPTION AND } \\
\text { APPROX. DIMENSIONS }\end{array}$ & $\begin{array}{l}\text { ASSOCIATIONS AND } \\
\text { REMARKS }\end{array}$ & PUBLICATION \\
\hline No location & Derbyshire & B.M. & $\begin{array}{l}\text { Bright cobalt with } \\
\text { irregular wave. } \\
\text { Diam. } 2 \mathrm{~cm} . \mathrm{Ht} \text {. } \\
7 \mathrm{~mm} .\end{array}$ & $\begin{array}{l}\text { Found in I } 790 \text { and } \\
\text { now strung with others } \\
\text { from Derbyshire }\end{array}$ & \\
\hline Whitcombe & Dorset & Dorchester & $\begin{array}{l}6 \text { beads. Diams. about } \\
\mathrm{I} .8 \mathrm{~cm} . \text { and perf. } \\
\text { diams. } 8 \mathrm{~mm} \text {. }\end{array}$ & $\begin{array}{l}\text { On necklace with } \\
\text { burial accompanied } \\
\text { by Samian ware of } \\
\text { A.D. } 96-\text { I I o and } 2 \\
\text { wooden beads among } \\
\text { others }\end{array}$ & $\begin{array}{l}\text { Information from } \\
\text { Mrs. Gertrude } \\
\text { Aitken }\end{array}$ \\
\hline Cirencester & $\begin{array}{l}\text { Gloucester- } \\
\text { shire }\end{array}$ & Cirencester Cg22 & $\begin{array}{l}\text { Light blue with? } \\
\text { white wave. Diam. } \\
2 \cdot 2 \mathrm{~cm} . \mathrm{Ht} . \mathrm{I} \cdot \mathrm{I} \mathrm{cm} \text {. } \\
\text { Perf. diam. } 1 \mathrm{~cm} \text {. }\end{array}$ & $\begin{array}{l}\text { Unstratified in Roman } \\
\text { town }\end{array}$ & \\
\hline Fairford & $\begin{array}{l}\text { Gloucester- } \\
\text { shire }\end{array}$ & & & $\begin{array}{l}\text { Stray find. c/o Mrs. } \\
\text { Llewellyn Jones, } \\
\text { Manor Farm }\end{array}$ & \\
\hline Micheldever & Hampshire & B.M. $63.1-20,5$ & $\begin{array}{l}\text { Regular wave. Diam. } \\
\mathrm{I} \cdot 6 \mathrm{~cm} . \mathrm{Ht} . \mathrm{I} \mathrm{cm} .\end{array}$ & $\begin{array}{l}\text { Unstratified from site } \\
\text { producing much } \\
\text { Roman and some } \\
\text { post-Roman material }\end{array}$ & $A r 7$ vi ( 1849$), 399$ \\
\hline Silchester & Hampshire & Reading & $\begin{array}{l}\text { Rich dark cobalt } \\
\text { with regular wave. } \\
\text { Diam. I } 5 \mathrm{~cm} . \mathrm{Ht} \text {. } \\
8 \mathrm{~mm} .\end{array}$ & $\begin{array}{l}\text { Belgic-Roman site } \\
\text { occupied } c . \text { Ist }-5^{\text {th }} \text { c. } \\
\text { A.D. }\end{array}$ & Boon, G. C. (1957) \\
\hline $\begin{array}{l}\text { Weston- } \\
\text { under- } \\
\text { Penyard, } \\
\text { Bollitree }\end{array}$ & $\begin{array}{l}\text { Hereford- } \\
\text { shire }\end{array}$ & Hereford 7630 & $\begin{array}{l}\text { Dark blue with rather } \\
\text { irregular wave. Diam. } \\
1.6 \mathrm{~cm} . \text { Ht. } 6 \mathrm{~mm} \text {. }\end{array}$ & Coin of Cunobelin & $\begin{array}{l}\text { G. H. Jack, } \\
\text { 'Excavations on } \\
\text { the site of } \\
\text { Ariconium', } \\
T W N F C \text { (1923), } \\
\text { pl. 12, fig. } 2\end{array}$ \\
\hline $\begin{array}{l}\text { Weston- } \\
\text { under- } \\
\text { Penyard, } \\
\text { Bollitree }\end{array}$ & $\begin{array}{l}\text { Hereford- } \\
\text { shire }\end{array}$ & Gloucester 1760 & $\begin{array}{l}\text { Semi-translucent } \\
\text { blue with very small } \\
\text { angular wave. Diam. } \\
\text { I } \cdot \text { I cm. Ht. } 6 \mathrm{~mm} \text {. }\end{array}$ & $\begin{array}{l}\text { With many other } \\
\text { early Roman beads } \\
\text { from early Roman } \\
\text { (perhaps pre-Roman) } \\
\text { lead-mining site }\end{array}$ & $\begin{array}{l}7 B A A \text { xxvii }(187 \text { I), } \\
\text { 2 I I ff. }\end{array}$ \\
\hline Northchurch & Hertfordshire & B.M. $93 \cdot 4^{-7}$ & $\begin{array}{l}\text { Translucent light blue } \\
\text { with irregular wave. } \\
\text { Diam. } 1 \cdot 7 \mathrm{~cm} \text {. Ht. } \\
6 \mathrm{~mm} .\end{array}$ & $\begin{array}{l}\text { This site also produced } \\
\text { Dark Ages pin and } \\
\text { brooch but not } \\
\text { necessarily associated }\end{array}$ & \\
\hline Verulamium & Hertfordshire & $\begin{array}{l}\text { Verulamium (St. } \\
\text { Albans) }\end{array}$ & $\begin{array}{l}\text { Blue with white wave. } \\
\text { Diam. I. } 6 \mathrm{~cm} . \mathrm{Ht} \text {. } \\
9 \mathrm{~mm} . \text { Perf. diam. } \\
3 \mathrm{~mm} \text {. }\end{array}$ & Stratified A.D. $155^{-60}$ & $\begin{array}{l}\text { Frere, S. (1972), } \\
\text { fig. } 79, \text { no. } 71\end{array}$ \\
\hline Richborough & Kent & & $\begin{array}{l}\text { Very irregular and } \\
\text { angular wave. Diam. } \\
2 \mathrm{~cm} . \text { Ht. } 9 \mathrm{~mm} \text {. }\end{array}$ & $\begin{array}{l}\text { Pit } 54.2 \text { I feet down } \\
\text { c. A.D. } 400 \text {. Threaded } \\
\text { on bronze wire }\end{array}$ & $\begin{array}{l}\text { Rich iii, } 80, \text { no. } 25 \\
\text { and pl. XI, no. } 25\end{array}$ \\
\hline
\end{tabular}




\begin{tabular}{|c|c|c|c|c|c|}
\hline $\begin{array}{l}\text { SITE AND } \\
\text { PARISH }\end{array}$ & COUNTY & MUSEUM \& NO. & $\begin{array}{c}\text { DESCRIPTION AND } \\
\text { APPROX. DIMENSIONS }\end{array}$ & $\begin{array}{c}\text { ASSOCIATIONS AND } \\
\text { REMARKS }\end{array}$ & PUBLICATION \\
\hline $\begin{array}{l}\text { Risby Warren } \\
\text { (Sandyheath) }\end{array}$ & Lincolnshire & Scunthorpe, RIO4 & $\begin{array}{l}\text { Half, semi-opaque } \\
\text { cobalt with yellow } \\
\text { wave. Diam. I } 8 \mathrm{~cm} \text {. } \\
\text { Ht. } 6 \mathrm{~mm} . \text { Perf. } \\
\text { diam. } 8 \mathrm{~mm} .\end{array}$ & $\begin{array}{l}\text { Found in silt of late } \\
\text { Ist c. A.D. }\end{array}$ & \\
\hline $\begin{array}{l}\text { Walbrook, } \\
\text { London }\end{array}$ & London & $\begin{array}{l}\text { Formerly Guildhall } \\
\text { Museum } 18.642\end{array}$ & $\begin{array}{l}\text { Half light blue bead } \\
\text { with irregular wave. } \\
\text { Diam. } 1 \cdot 7 \mathrm{~cm} . \mathrm{Ht} \text {. } \\
7 \mathrm{~mm} .\end{array}$ & ? Dark Ages & \\
\hline Irchester & $\begin{array}{l}\text { Northampton- } \\
\text { shire }\end{array}$ & & $\begin{array}{l}\text { Thin yellow trail. } \\
\text { Diam. } 2 \cdot 4 \mathrm{~cm} . \mathrm{Ht} \text {. } \\
\text { I } 2 \mathrm{~cm} . \text { Perf. diam. } \\
\text { I } \mathrm{cm} .\end{array}$ & $\begin{array}{l}\text { Unstratified but prob- } \\
\text { ably Roman period }\end{array}$ & $\begin{array}{l}\text { Arf cxxiv (1967), } \\
\text { I I } 9 \text {, fig. } 7, \text { no. } 2\end{array}$ \\
\hline $\begin{array}{l}\text { Great } \\
\text { Chesters }\end{array}$ & $\begin{array}{l}\text { Northumber- } \\
\text { land }\end{array}$ & $\begin{array}{l}\text { Chesters Museum } \\
2506\end{array}$ & $\begin{array}{l}\text { Cobalt blue with } \\
\text { irregular wave. } \\
\text { Diam. I } 7 \mathrm{~cm} . \mathrm{Ht} \text {. } \\
8 \mathrm{~mm} \text {. }\end{array}$ & Roman & \\
\hline $\begin{array}{l}\text { Probably from } \\
\text { Chesters fort }\end{array}$ & $\begin{array}{l}\text { Northumber- } \\
\text { land }\end{array}$ & $\begin{array}{l}\text { Chesters Museum } \\
1361\end{array}$ & $\begin{array}{l}\text { Very dark ground } \\
\text { with greyish white } \\
\text { wave. Diam. } 2 \cdot 1 \mathrm{~cm} \text {. } \\
\text { Ht. I } \mathrm{cm} .\end{array}$ & $\begin{array}{l}\text { Probably between } \\
\text { A.D. I } 22-383 \text { (1 } 9 \text { th c. } \\
\text { find) }\end{array}$ & \\
\hline Wroxeter & Shropshire & $\begin{array}{l}\text { Rowley's House } \\
\text { Museum, } \\
\text { Shrewsbury }\end{array}$ & $\begin{array}{l}\text { Bright cobalt. Diam. } \\
\text { I. } 5 \mathrm{~cm} . \mathrm{Ht} .6 \mathrm{~mm} \text {. } \\
\text { Perf. diam. } 5 \mathrm{~mm} \text {. }\end{array}$ & $\begin{array}{l}\text { From topsoil of } \\
\text { Roman town }\end{array}$ & $\begin{array}{l}\text { Information from } \\
\text { Dr.John } \\
\text { Houghton, } \\
\text { Shrewsbury }\end{array}$ \\
\hline Camerton & Somerset & $\begin{array}{l}\text { Bristol, Skinner } \\
\text { Colln. F } 2313\end{array}$ & $\begin{array}{l}\text { Blue with rather } \\
\text { irregular white wave. } \\
\text { Diam. } 1 \cdot 7 \mathrm{~cm} . \mathrm{Ht} \text {. } \\
8 \mathrm{~mm} .\end{array}$ & $\begin{array}{l}\text { Site produced Saxon } \\
\text { and earlier finds }\end{array}$ & $\begin{array}{l}\text { VCH Somerset } \\
\text { and Wedlake, } \\
\text { W.J. (1958) }\end{array}$ \\
\hline $\begin{array}{l}\text { Charterhouse- } \\
\text { on-Mendip }\end{array}$ & Somerset & ? Beck Colln. C.M. & & $\begin{array}{l}\text { From Roman lead } \\
\text { mines, probably mid- } \\
\text { Ist c. A.D. }\end{array}$ & $\begin{array}{l}\text { See VCH Somerset } \\
\text { for this site }\end{array}$ \\
\hline $\begin{array}{l}\text { Meare Lake } \\
\text { Village }\end{array}$ & Somerset & $\begin{array}{l}\text { Taunton } \mathrm{G}_{3} 8 \text { and } \\
\text { another }\end{array}$ & $\begin{array}{l}\text { One dark opaque } \\
\text { with flattened sur- } \\
\text { faces. : diam. I } 5 \mathrm{~cm} \text {; } \\
\text { ht. } 7 \mathrm{~mm} \text {. ; perf. diam. } \\
4 \mathrm{~mm} . \text { Half another: } \\
\text { diam. I } 7 \mathrm{~cm} . \text {; ht. } \\
4 \mathrm{~mm} . \text { Perf. diam. } \\
\text { I } \mathrm{cm} \text {. }\end{array}$ & $\begin{array}{l}\text { From Lake Village. } \\
\text { At least } \mathrm{G}_{3} 8 \\
\text { resembles the Arras } \\
\text { variety rather than } \\
\text { the Roman period } \\
\text { beads) }\end{array}$ & $M e \mathrm{iii}$ \\
\hline
\end{tabular}




\begin{tabular}{|c|c|c|c|c|c|}
\hline $\begin{array}{l}\text { SITE AND } \\
\text { PARISH }\end{array}$ & COUNTY & MUSEUM \& NO. & $\begin{array}{l}\text { DESGRIPTION AND } \\
\text { APPROX. DIMENSIONS }\end{array}$ & $\begin{array}{l}\text { ASSOCIATIONS AND } \\
\text { REMARKS }\end{array}$ & PUBLICATION \\
\hline $\begin{array}{l}\text { Monkton } \\
\text { Combe }\end{array}$ & Somerset & & $\begin{array}{l}\text { Very battered and } \\
\text { perhaps opaque. } \\
\text { Diam. } 1.7 \mathrm{~cm} .\end{array}$ & & \\
\hline Coddenham & Suffolk & Ipswich & $\begin{array}{l}\text { Battered. Irregular } \\
\text { wave. Diam. I } 4 \mathrm{~cm} \text {. } \\
\text { Ht. } 7 \mathrm{~mm} \text {. Perf. } \\
\text { diam. } 6 \mathrm{~mm} \text {. }\end{array}$ & $\begin{array}{l}\text { Roman site, perhaps } \\
\text { Combretonium }\end{array}$ & \\
\hline $\begin{array}{l}\text { Martlesham } \\
\text { Heath }\end{array}$ & Suffolk & Ipswich & $\begin{array}{l}\text { Identical to one from } \\
\text { Whitton Roman } \\
\text { villa (see below) }\end{array}$ & Chance find & $\begin{array}{l}\text { Information from } \\
\text { Ipswich Museum }\end{array}$ \\
\hline $\begin{array}{l}\text { Whitton } \\
\text { Roman villa }\end{array}$ & Suffolk & Ipswich & $\begin{array}{l}\text { Translucent with } \\
\text { rather irregular wave. } \\
\text { Diam. } 1.5 \mathrm{~cm} . \mathrm{Ht} \text {. } \\
8 \mathrm{~mm} \text {. And another }\end{array}$ & $\begin{array}{l}\text { Villa reputedly } \\
\text { occupied } 2 \text { nd }-4 \text { th c. } \\
\text { A.D. }\end{array}$ & $\begin{array}{l}P S I A \times x i\left(193^{1-3}\right) \text {, } \\
240,249 \text { and } \\
\text { figs. } 16,17\end{array}$ \\
\hline Bagshot Heath & Surrey & & No details & Early find & $A$ vii $(1785)$ \\
\hline $\begin{array}{l}\text { Farley Heath, } \\
\text { Albury }\end{array}$ & Surrey & Guildford & 3 examples & $\begin{array}{l}\text { Romano-Celtic } \\
\text { temple site }\end{array}$ & $\begin{array}{l}\text { Anf xviii (1938) } \\
\text { and } A \text { xxxiv }(1852)\end{array}$ \\
\hline Nr. Rugby & Warwickshire & & $\begin{array}{l}\text { Slightly flattened } \\
\text { around perforation. } \\
\text { Irregular wave on } \\
\text { light blue trans- } \\
\text { lucent ground. Diam. } \\
2 \mathrm{~cm} . \text { Ht. } \mathrm{I} \cdot 3 \mathrm{~cm} \text {. } \\
\text { Perf. diam. } 5 \mathrm{~mm} \text {. }\end{array}$ & $\begin{array}{l}\text { Unstratified in } \\
\text { Roman Tripontium }\end{array}$ & $\begin{array}{l}\text { TPBAS (Nov. } \\
1971)\end{array}$ \\
\hline $\begin{array}{l}\text { Bokerly } \\
\text { Dyke, } \\
\text { Woodyates }\end{array}$ & $\begin{array}{l}\text { Wiltshire- } \\
\text { Dorset borders }\end{array}$ & Salisbury & $\begin{array}{l}\text { Translucent light } \\
\text { blue with yellow } \\
\text { wave. Diam. I } \cdot 7 \mathrm{~cm} \text {. } \\
\text { Ht. I cm. Perf. diam. } \\
6 \mathrm{~mm} \text {. }\end{array}$ & & $\begin{array}{l}\text { Pitt-Rivers, } \\
\text { A. H. L. F. (1888), } \\
\text { p. I } 7 \text { I }\end{array}$ \\
\hline Kennet & Wiltshire & Devizes I 35 & $\begin{array}{l}\text { Opaque slaty blue } \\
\text { with regular wave }\end{array}$ & $\begin{array}{l}\text { Associated with small } \\
\text { schist hone }\end{array}$ & \\
\hline $\begin{array}{l}\text { Longbridge } \\
\text { Deverill } \\
\text { Cow Down }\end{array}$ & Wiltshire & Devizes & $\begin{array}{l}\text { Semi-translucent } \\
\text { with irregular } \\
\text { scrabble. Diam. I } 35 \\
\text { cm. Ht. } 7 \text { mm. } \\
\text { Smaller than usual }\end{array}$ & $\begin{array}{l}\text { Ditch of enclosure. } \\
\text { Probably from Iron } \\
\text { Age 'B', ? } 3 \text { rd c. B.c. }\end{array}$ & $\begin{array}{l}\text { Forthcoming. } \\
\text { Information from } \\
\text { Mrs. Sonia } \\
\text { Hawkes }\end{array}$ \\
\hline Mildenhall & Wiltshire & $\begin{array}{l}\text { c/o Adams, Landulph } \\
\text { Rectory, Saltash, } \\
\text { Cornwall }\end{array}$ & $\begin{array}{l}\text { Half of light trans- } \\
\text { lucent blue bead. } \\
\text { Diam. } 1 \cdot 7 \mathrm{~cm} . \mathrm{Ht} \text {. } \\
8 \mathrm{~mm} .\end{array}$ & $\begin{array}{l}\text { Blackfields Roman } \\
\text { site. This bead found } \\
\text { near site of Saxon } \\
\text { burial }\end{array}$ & \\
\hline $\begin{array}{l}\text { Almondbury } \\
\text { Camp, } \\
\text { Huddersfield }\end{array}$ & Yorkshire & $\begin{array}{l}\text { Tolson Memorial } \\
\text { Museum, Hudders- } \\
\text { field }\end{array}$ & $\begin{array}{l}\text { Squarish, globular, } \\
\text { dark greenish-blue } \\
\text { with cream wave. } \\
\text { Diam. I } \cdot 3 \mathrm{~cm} . \mathrm{Ht} \text {. }\end{array}$ & From Iron Age camp & $\begin{array}{l}\text { Information from } \\
\text { the late Dr. W. J. } \\
\text { Varley }\end{array}$ \\
\hline
\end{tabular}




\begin{tabular}{|c|c|c|c|c|c|}
\hline $\begin{array}{l}\text { SITE AND } \\
\text { PARISH }\end{array}$ & GOUNTY & MUSEUM \& NO. & $\begin{array}{l}\text { DESGRIPTION AND } \\
\text { APPROX. DIMENSIONS }\end{array}$ & $\begin{array}{l}\text { ASSOCIATIONS AND } \\
\text { REMARKS }\end{array}$ & PUBLICATION \\
\hline Arras & Yorkshire & $\begin{array}{l}\text { B.M. } 80.8 .2 . \text { I } 42- \\
\text { I } 44 . \text { For full reference } \\
\text { to museum numbers } \\
\text { see Stead, I. M. } \\
(1965)\end{array}$ & $\begin{array}{l}\text { Small with regular } \\
\text { wave. Diam. } 1 \cdot 2 \mathrm{~cm} \text {. } \\
\text { Ht. } 7 \mathrm{~mm} .\end{array}$ & $\begin{array}{l}\text { From Arras culture } \\
\text { barrow. Found in } \\
1817\end{array}$ & $\begin{array}{l}\text { Stead, I. M. } \\
(1965), \text { pp. } 59-60\end{array}$ \\
\hline Whitby & Yorkshire & Whitby & $\begin{array}{l}\text { Semi-translucent } \\
\text { with irregular wave. } \\
\text { Diam. } 1.6 \mathrm{~cm} . \mathrm{Ht} \text {. } \\
6 \mathrm{~mm} .\end{array}$ & $\begin{array}{l}\text { Found in Knipe Howe } \\
\text { tumulus }\end{array}$ & \\
\hline & & & GOTLAND & & \\
\hline $\begin{array}{l}\text { Haughton- } \\
\text { Alford }\end{array}$ & Aberdeenshire & N.M.A. FJ22 & $\begin{array}{l}\text { Bright, translucent } \\
\text { with rather irregular } \\
\text { wave. Diam. } 2 \cdot 0 \\
\mathrm{~cm} . \text { Ht. } 8 \mathrm{~mm} \text {. }\end{array}$ & & \\
\hline Castle O'er & $\begin{array}{l}\text { Dumfries- } \\
\text { shire }\end{array}$ & Dumfries & $\begin{array}{l}\text { Fragment with } \\
\text { irregular wave. } \\
\text { Diam. I } 3 \mathrm{~cm} . \mathrm{Ht} . \\
6 \mathrm{~mm} .\end{array}$ & $\begin{array}{l}\text { Near the fort. Many } \\
\text { others from this } \\
\text { locality, mostly } \\
\text { melon beads }\end{array}$ & \\
\hline $\begin{array}{l}\text { Traprain Law, } \\
\text { Prestonkirk }\end{array}$ & E. Lothian & N.M.A. V21.342 & $\begin{array}{l}\text { Light, translucent } \\
\text { with irregular wave. } \\
\text { Diam. } 1 \cdot 9 \mathrm{~cm} . \mathrm{Ht} \text {. } \\
8 \mathrm{~mm} .\end{array}$ & From $4^{\text {th }}$ level & $\begin{array}{l}P S A S \mathrm{lv}(\mathrm{I} 920-\mathrm{I}), \\
\mathrm{I} 72\end{array}$ \\
\hline $\begin{array}{l}\text { Traprain Law, } \\
\text { Prestonkirk }\end{array}$ & E. Lothian & N.M.A. 1923.1 43 & $\begin{array}{l}\text { Almost opaque. Flat } \\
\text { facets around } \\
\text { perforation. Diam. } \\
1 \cdot 3 \mathrm{~cm} . \mathrm{Ht} .7 \mathrm{~mm} \text {. }\end{array}$ & & $\begin{array}{l}P S A S \text { lvii (1922- } \\
3), 195\end{array}$ \\
\hline $\begin{array}{l}\text { Castle Haven } \\
\text { Fort, Borgue }\end{array}$ & $\begin{array}{l}\text { Kirkcud- } \\
\text { brightshire }\end{array}$ & $\begin{array}{l}\text { Robertson House, } \\
\text { Castlehaven }\end{array}$ & $\begin{array}{l}\text { Irregular wave. } \\
\text { Diam. } 2 \cdot 0 \mathrm{~cm} .\end{array}$ & $\begin{array}{l}\text { This fort is not closely } \\
\text { datable but a brooch } \\
\text { of Elizabeth Fowler's } \\
\text { 'D } 7 \text { ' type suggests a } \\
\text { slightly post-Roman } \\
\text { date for one phase }\end{array}$ & $\begin{array}{l}P S A S \times l i(1906-7) \\
79\end{array}$ \\
\hline Covesea & Morayshire & N.M.A. HM2o9 & $\begin{array}{l}\text { Bright, semi-translu- } \\
\text { cent }\end{array}$ & $\begin{array}{l}\text { Various finds from the } \\
\text { site include fragments } \\
\text { of imported glass of } \\
\text { the 2nd c. A.D. }\end{array}$ & $\begin{array}{l}P S A S \operatorname{lxv}\left(193^{\circ}-\right. \\
\text { I), I } 77\end{array}$ \\
\hline Newstead & $\begin{array}{l}\text { Roxburgh- } \\
\text { shire }\end{array}$ & $\begin{array}{l}\text { N.M.A. FRA897, } \\
899,901,902 \text { and } \\
\text { from Mr. Mason's } \\
\text { Colln., Selkirk }\end{array}$ & $\begin{array}{l}5 \text { examples. Diams. } \\
2 \cdot 1,2 \cdot 0, \mathrm{I} \cdot 9, \mathrm{I} \cdot 6 \text {, } \\
\text { and } \mathrm{I} \cdot 4 \mathrm{~cm} \text {. }\end{array}$ & $\begin{array}{l}\text { Occupation about } \\
\text { A.D. } 80-200\end{array}$ & $\begin{array}{l}\text { Some in } \mathcal{N e} \text {, pl.xcli, } \\
\text { 1 } 7,19,23,26\end{array}$ \\
\hline \multicolumn{2}{|c|}{ 'Scotland' } & $\begin{array}{l}\text { N.M.A., Duns } \\
\text { Colln. FJ95 }\end{array}$ & $\begin{array}{l}\text { Opaque grey-blue. } \\
\text { Half only. Perforation } \\
\text { small. Diam. } 1 \cdot 5 \\
\mathrm{~cm} \text {. Ht. } 9 \mathrm{~mm} \text {. }\end{array}$ & & \\
\hline
\end{tabular}




\begin{tabular}{|c|c|c|c|c|c|}
\hline $\begin{array}{c}\text { SITE AND } \\
\text { PARISH }\end{array}$ & GOUNTY & MUSEUM \& NO. & $\begin{array}{l}\text { DESCRIPTION AND } \\
\text { APPROX. DIMENSIONS }\end{array}$ & $\begin{array}{l}\text { ASSOCIATIONS AND } \\
\text { REMARKS }\end{array}$ & PUBLICATION \\
\hline \multicolumn{6}{|c|}{ WALES } \\
\hline $\begin{array}{l}\text { Bryn-yr- } \\
\text { Hen-Bobl }\end{array}$ & Anglesey & N.M.W. $37 / 7 / 46$ & $\begin{array}{l}\text { Translucent dark } \\
\text { blue. Diam. } 1 \cdot 7 \mathrm{~cm} \text {. } \\
\text { Ht. } 7 \mathrm{~mm} .\end{array}$ & $\begin{array}{l}\text { Secondary in mega- } \\
\text { lithic tomb }\end{array}$ & $\begin{array}{l}\text { Grimes, W. F., } \\
\text { Prehistory of Wales, } \\
\text { p. } 15^{6} \text { and refs. } \\
\text { p. } 3^{8}\end{array}$ \\
\hline Nevin & $\begin{array}{l}\text { Caernarvon- } \\
\text { shire }\end{array}$ & & $\begin{array}{l}\text { Two examples. One } \\
\text { lighter than the } \\
\text { other, very irregular } \\
\text { scrabble. Diams. } 2 \cdot 0 \\
\text { and } 1 \cdot 7 \mathrm{~cm} \text {. Hts. } 8 \\
\text { and } 5 \mathrm{~mm} \text {. }\end{array}$ & $\begin{array}{l}\text { From Garn Boduan } \\
\text { fort. Thought to be } \\
\text { about A.D. } 600, \text { but } \\
\text { could be earlier }\end{array}$ & $\begin{array}{l}\operatorname{Arf} \text { cxvii }(1962) \\
\text { pl. VI, } 8\end{array}$ \\
\hline Prestatyn & Flintshire & c/o Prestatyn Council & $\begin{array}{l}\text { Light blue with } \\
\text { irregular wave. } \\
\text { Diam. I } 8 \mathrm{~cm} . \mathrm{Ht} \text {. } \\
1 \cdot 1 \mathrm{~cm} . \text { Perf. diam. } \\
5 \mathrm{~mm} .\end{array}$ & $\begin{array}{l}\text { From Roman site. } \\
\text { Many melon beads } \\
\text { but also one thought } \\
\text { to be post-Roman }\end{array}$ & $\begin{array}{l}\text { Ellis Davies, } \\
\text { Prehistoric and } \\
\text { Roman Remains of } \\
\text { Flintshire (1949), } \\
\text { p. } 303 \text {, is very } \\
\text { similar to this bead. } \\
\text { See also } A C \text { (1937) }\end{array}$ \\
\hline $\begin{array}{l}\text { Whitton, } \\
\text { nr. Barry }\end{array}$ & $\begin{array}{l}\text { Glamorgan- } \\
\text { shire }\end{array}$ & N.M.W. & $\begin{array}{l}2 \text { examples. Diams. } \\
\mathrm{I} \cdot 7 \text { and } \mathrm{I} \cdot 6 \mathrm{~cm} \text {. }\end{array}$ & $\begin{array}{l}\text { From Roman villa. } \\
\text { Topsoil occupation } \\
\text { Ist c. B.C.-A.D. } 300\end{array}$ & $\begin{array}{l}\text { Information from } \\
\text { Dr. Jarrett, } \\
\text { University College } \\
\text { of S. Wales, } \\
\text { Cardiff }\end{array}$ \\
\hline Caerleon & $\begin{array}{l}\text { Monmouth- } \\
\text { shire }\end{array}$ & N.M.W. & $\begin{array}{l}\text { Irregular 2-strand } \\
\text { scrabble on trans- } \\
\text { lucent ground. Diam. } \\
\mathrm{I} \cdot 9 \mathrm{~cm} . \mathrm{Ht} .7 \mathrm{~mm} \text {. }\end{array}$ & $\begin{array}{l}\text { 'Near the Castle } \\
\text { mound' }\end{array}$ & $\begin{array}{l}\text { Lee, Catalogue of } \\
\text { the Antiquities of } \\
\text { Caerleon, pl. } \\
\text { XXVIII, fig. } 8\end{array}$ \\
\hline Caerleon & $\begin{array}{l}\text { Monmouth- } \\
\text { shire }\end{array}$ & N.M.W. & $\begin{array}{l}\text { Translucent with 2- } \\
\text { strand irregular } \\
\text { scrabble. Diam. } \\
\text { I } 7 \mathrm{~cm} . \text { Ht. } 8 \mathrm{~mm} \text {. } \\
\text { (fig. } 2 \mathrm{I}, \text { no. I) }\end{array}$ & $\begin{array}{l}\text { Seems to be unre- } \\
\text { corded. Probably } \\
\text { from } 19 \circ 9 \text { excavation }\end{array}$ & \\
\hline Caerleon & $\begin{array}{l}\text { Monmouth- } \\
\text { shire }\end{array}$ & N.M.W. & $\begin{array}{l}\text { Dark with irregular } \\
\text { wave. Diam. I } 9 \mathrm{~cm} \text {. } \\
\text { Ht. } 9 \mathrm{~mm} .\end{array}$ & $\begin{array}{l}\text { From Broadway } \\
\text { drain near legionary } \\
\text { fortress stratified } \\
\text { A.D. } 230-96\end{array}$ & $\begin{array}{l}\text { Ellis Davies, } \\
\text { Prehistoric and } \\
\text { Roman Remains of } \\
\text { Flintshire (1949), } \\
\text { p. } 3 \text { ro, fig. } 127,5 \text {, } \\
\text { is an almost } \\
\text { similar bead. See } \\
\text { also } A C \mathrm{xcii} \\
\text { (1937), 208-32 }\end{array}$ \\
\hline Usk & $\begin{array}{l}\text { Monmouth- } \\
\text { shire }\end{array}$ & N.M.W. & $\begin{array}{l}\text { Globular with irregu- } \\
\text { lar angular wave. } \\
\text { Diam. I } 3 \mathrm{~cm} . \text { Ht. } \\
\text { I } 3 \mathrm{~cm} \text {. Perf. diam. } \\
4 \mathrm{~mm} \text {. Slight flatten- } \\
\text { ing above and below } \\
\text { perforation }\end{array}$ & $\begin{array}{l}\text { Found in } 1968 \\
\text { excavation in Roman } \\
\text { fort occupied A.D. } \\
55^{-60} \text { and again later }\end{array}$ & $\begin{array}{l}\text { Information from } \\
\text { excavator }\end{array}$ \\
\hline
\end{tabular}




\begin{tabular}{cccccc}
\hline $\begin{array}{c}\text { STTE AND } \\
\text { PARISH }\end{array}$ & COUNTY & MUSEUM \& NO. & DESCRIPTION AND & ASSOCIATIONS AND \\
\hline
\end{tabular}

(B) OPAQUE BLUE ANNULAR OR GLOBULAR BEADS WITH BLUE OR PURPLE WAVE

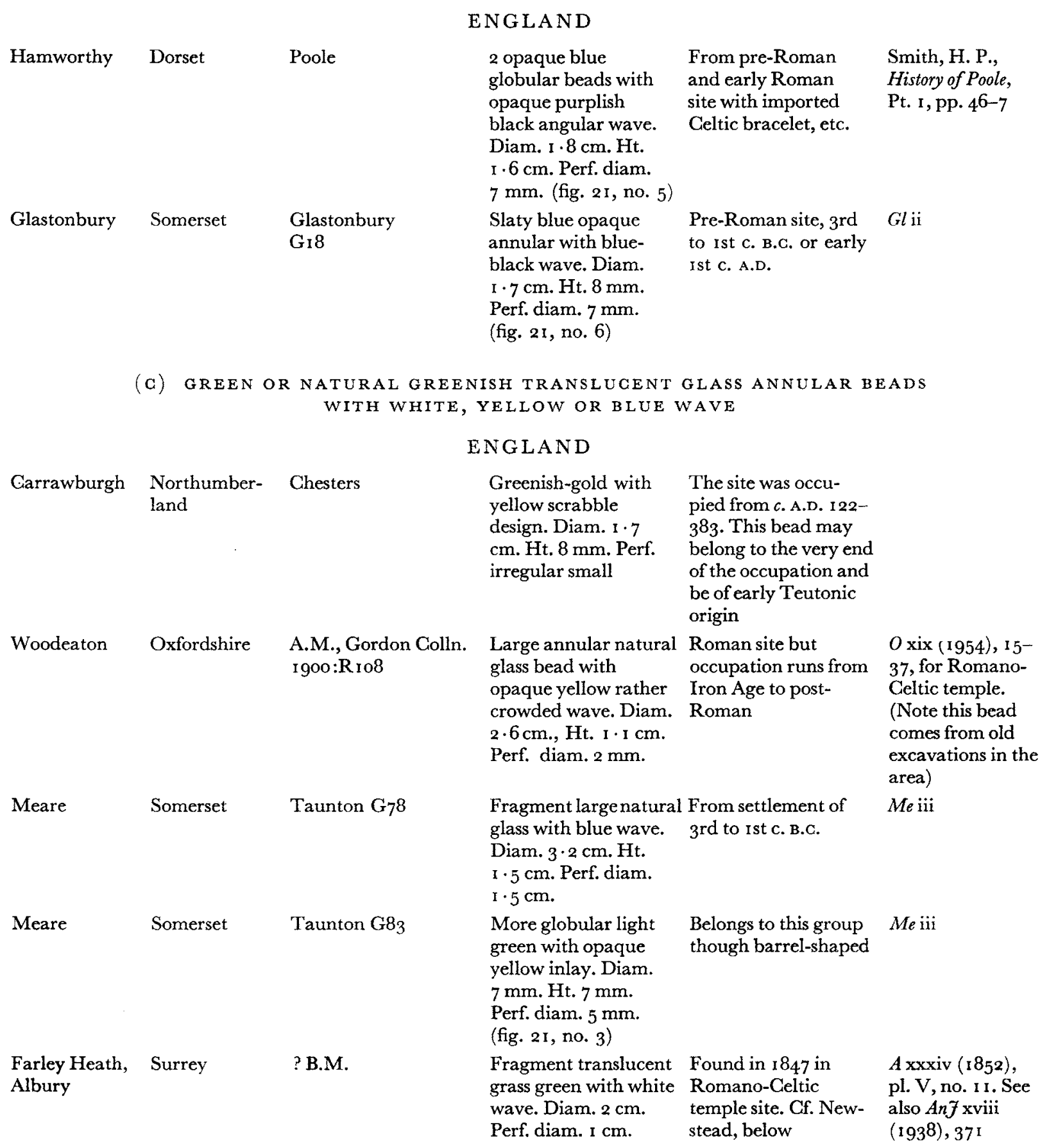




\begin{tabular}{|c|c|c|c|c|c|}
\hline $\begin{array}{l}\text { SITE AND } \\
\text { PARISH }\end{array}$ & COUNTY & MUSEUM \& NO. & $\begin{array}{l}\text { DESCRIPTION AND } \\
\text { APPROX. DIMENSIONS }\end{array}$ & $\begin{array}{l}\text { ASSOCIATIONS AND } \\
\text { REMARKS }\end{array}$ & PUBLIGATION \\
\hline $\begin{array}{l}\text { Queen's } \\
\text { Barrow, } \\
\text { Arras }\end{array}$ & Yorkshire & York & $\begin{array}{l}\text { Annular beads of } \\
\text { almost colourless } \\
\text { clear glass and opaque } \\
\text { yellow wave. Diam. } \\
\text { I } \cdot 2 \mathrm{~cm} . \text { Ht. } 4 \mathrm{~mm} \text {. } \\
\text { Perf. diam. } 6 \mathrm{~mm} \text {. }\end{array}$ & $\begin{array}{l}\text { Iron Age burial, } \\
\text { ? } 4 \text { th-3rd c. B.C. Note } \\
\text { the glass is not so } \\
\text { colourless as the } \\
\text { Meare series. See } \\
\text { Arras beads (Class I) } \\
\text { for relevant discussion }\end{array}$ & $\begin{array}{l}A \mathrm{~lx}(\mathrm{rgo6}) \text {, an } \\
\text { see Stead, I. M } \\
(\mathrm{r} 965)\end{array}$ \\
\hline \multicolumn{6}{|c|}{ SGOTLAND } \\
\hline Newstead & $\begin{array}{l}\text { Roxburgh- } \\
\text { shire }\end{array}$ & N.M.A. FRA903 & $\begin{array}{l}\text { Translucent grass } \\
\text { green with white } \\
\text { wave. Diam. I } 8 \mathrm{~cm} \text {. } \\
\text { Ht. } 8 \mathrm{~mm} . \text { Perf. } \\
\text { diam. } 7 \mathrm{~mm} \text {. }\end{array}$ & $\begin{array}{l}\text { Roman fort occu- } \\
\text { pied c. A.D. } 80-200\end{array}$ & $\mathcal{N} e$, pl. xci \\
\hline $\begin{array}{l}\text { No } \\
\text { provenance }\end{array}$ & 'Wigtonshire' & N.M.A. FJ80 & $\begin{array}{l}\text { Part of translucent } \\
\text { greenish-yellow with } \\
\text { slightly raised yellow } \\
\text { opaque wave. Diam. } \\
2 \cdot \text { I } \mathrm{cm} . \mathrm{Ht} .6 \mathrm{~mm} \text {. } \\
\text { Perf. diam. } 7 \mathrm{~mm} \text {. } \\
\text { W A L E S }\end{array}$ & $\begin{array}{l}\text { Galloway Collns. } \\
\text { I } 898 \text {. Possibly post- } \\
\text { Roman }\end{array}$ & \\
\hline Caerhun & $\begin{array}{l}\text { Caernarvon- } \\
\text { shire }\end{array}$ & $\begin{array}{l}\text { Llandudno, Rapallo } \\
\text { House }\end{array}$ & $\begin{array}{l}\text { Light greeny-blue } \\
\text { with yellow wave. } \\
\text { Diam. } 1.8 \mathrm{~cm} . \text { Ht. } \\
9 \mathrm{~mm} . \text { Perf. diam. } \\
6 \mathrm{~mm} .\end{array}$ & Flavian period fort & $A C \times \mathrm{xci}\left(\mathrm{1} 93^{6}\right)$ \\
\hline \multicolumn{6}{|c|}{$\begin{array}{l}\text { Several come from England, Ireland, and Scotland, e.g., } \\
\text { N.M.A., Bell Golln. nos. FK } 37,38,39 \text { and } 42 . \text { FK } 45 \text {, 'perhaps } \\
\text { Ireland', and in Stranraer Museum, Wigtown (no. I945.326A) } \\
\text { is an example perhaps from the Glenluce Sands. From the Beck } \\
\text { Colln. in Cambridge, nos. } 1320 \mathrm{~J} \text { and } \mathrm{H} \text { and others are said to } \\
\text { have come from Co. Antrim. From England } 2 \text { examples are } \\
\text { from a Saxon necklace from Mildenhall, Wilts. (Devizes Museum } \\
\mathrm{S}_{30} \text { and } 3 \mathrm{I} \text { with saucer brooches) and a similar one, undated, } \\
\text { from Cheverell, Wilts. (Devizes Museum } \mathrm{S}_{3} \text { ). Another from } \\
\text { Faversham, Kent, is in the Beck Colln. at C.M. (no. I677) and } \\
\text { is probably Saxon, as are also one example from Lakenheath in } \\
\text { the same collection and one from Ling Hill, Whitby, in the } \\
\text { Whitby Museum. The general impression is that these black } \\
\text { and white examples may be slightly later than the late } 4 \text { th c. A.D. } \\
\text { when the annular beads with coloured waves seem to have } \\
\text { first reached England from Frankish areas. }\end{array}$} \\
\hline
\end{tabular}


I36 GLASS BEADS OF THE PREHISTORIG AND ROMAN PERIODS

\begin{tabular}{cccccc}
\hline $\begin{array}{c}\text { SITE AND } \\
\text { PARISH }\end{array}$ & COUNTY & MUSEUM \& NO. & DESGRIPTION AND & ASSOCIATIONS AND \\
APPROX. DIMENSIONS & REMARKS \\
\hline
\end{tabular}

(ii) Annular with Irregular Yellow Scrawl

IRELAND

'Northern Ireland' $\quad$ B.M. 71.2-10.54

Several others from Ireland in the British Museum
Half bead. Opaque black with irregular yellow wavy scrawls. Diam. $2 \cdot 5 \mathrm{~cm}$. Ht. $I \cdot I \mathrm{~cm}$.

\section{WA LES}

\begin{tabular}{|c|c|c|c|c|c|}
\hline Caernarvon & $\begin{array}{l}\text { Caernarvon- } \\
\text { shire }\end{array}$ & $\begin{array}{l}\text { Caernarvon, } \\
\text { Segontium Museum }\end{array}$ & $\begin{array}{l}\text { Opaque black with } \\
\text { irregular yellow wavy } \\
\text { scrawls. Diam. c. } 2 \cdot 5 \\
\mathrm{~cm} \text {. }\end{array}$ & $\begin{array}{l}\text { From fort erected in } \\
\text { late ist c. A.D. but } \\
\text { unstratified and prob- } \\
\text { ably later }\end{array}$ & $\begin{array}{l}\text { Wheeler, R. E. M } \\
\text { Segontium and the } \\
\text { Roman Occupation } \\
\text { of Wales (1924), } \\
\text { p. } 169\end{array}$ \\
\hline Caerleon & $\begin{array}{l}\text { Monmouth- } \\
\text { shire }\end{array}$ & N.M.W. CY5O & $\begin{array}{l}\text { Large black bead } \\
\text { with irregular yellow } \\
\text { scrabble. Diam. } 3 \cdot \text { I } \\
\mathrm{cm} . \mathrm{Ht} . \mathrm{I} \cdot 2 \mathrm{~cm} . \text { Perf. } \\
\text { diam. I } 2 \mathrm{~cm} \text {. }\end{array}$ & $\begin{array}{l}\text { From Roman } \\
\text { legionary bath-house } \\
\text { (described in old } \\
\text { catalogue as 'Castle } \\
\text { Villa'). This may be } \\
\text { Roman or a later } \\
\text { stray }\end{array}$ & $\begin{array}{l}\text { Lee, Catalogue of } \\
\text { the Museum at } \\
\text { Caerleon, pl. } \\
\text { XXVIII, fig. } 6 . \\
\text { See } A C \text { (1929) }\end{array}$ \\
\hline \multicolumn{6}{|c|}{ (iii) Annular with Various Coloured Waves } \\
\hline Silchester & Hampshire & Reading & $\begin{array}{l}\text { Half a large flat bead } \\
\text { decorated with white } \\
\text { concentric bands and } \\
\text { light blue wave } \\
\text { between. Diam. } 3.2 \\
\text { cm. Ht. } 7 \mathrm{~mm} \text {. Perf. } \\
\text { diam. } 9 \mathrm{~mm} \text {. }\end{array}$ & $\begin{array}{l}\text { From Atrebatic town } \\
\text { occupied before the } \\
\text { conquest and } \\
\text { throughout Roman } \\
\text { period. Related to a } \\
\text { very similar dark } \\
\text { green bead decorated } \\
\text { in green from } \\
\text { Richborough, Kent }\end{array}$ & $\begin{array}{l}\text { See Boon, G. C. } \\
\text { (1957) and in } A \\
\text { cii }(1969)\end{array}$ \\
\hline Silchester & Hampshire & Reading & $\begin{array}{l}\text { Several other } \\
\text { smaller annular bead } \\
\text { decorated with waves } \\
\text { in light blue, or } \\
\text { yellow or grey }\end{array}$ & $\begin{array}{l}\text { From town occupied } \\
\text { throughout Roman } \\
\text { period }\end{array}$ & $\begin{array}{l}\text { See Boon, G. C. } \\
(1957) \text { and in } A \\
\text { cii }(1969)\end{array}$ \\
\hline Richborough & Kent & Richborough & $\begin{array}{l}\text { Several black beads } \\
\text { with red wave, } \\
\text { double white swag } \\
\text { with blue dots, etc. }\end{array}$ & $\begin{array}{l}\text { Probably these begin } \\
\text { to appear around } \\
\text { A.D. } 400 \text { and may be } \\
\text { Frankish }\end{array}$ & $\begin{array}{l}\text { Some illustrated } \\
\text { in Rich iv, I } 49 \\
\text { pl. iv }\end{array}$ \\
\hline London & London & $\begin{array}{l}\text { Formerly Guildhall } \\
\text { Museum 396I }\end{array}$ & $\begin{array}{l}\text { Sharp angled blue } \\
\text { wave. Diam. } 1 \cdot 5 \mathrm{~cm} \text {. } \\
\text { Ht. } 9 \mathrm{~mm} \text {.'Slightly } \\
\text { hour-glass perforation }\end{array}$ & & \\
\hline
\end{tabular}




\begin{tabular}{|c|c|c|c|c|c|}
\hline $\begin{array}{l}\text { SITE AND } \\
\text { PARISH }\end{array}$ & GOUNTY & MUSEUM \& No. & $\begin{array}{l}\text { DESCRIPTION AND } \\
\text { APPROX. DIMENSIONS }\end{array}$ & $\begin{array}{l}\text { ASSOCIATIONS AND } \\
\text { REMARKS }\end{array}$ & PUBLICATION \\
\hline $\begin{array}{l}\text { Wolstonbury } \\
\text { Hill, } \\
\text { Pycombe }\end{array}$ & Sussex & Lewes & $\begin{array}{l}\text { Azure blue scrabble } \\
\mathrm{cm} . \text { Ht. } 6 \mathrm{~mm} \text {. Perf. } \\
\text { diam. } 5 \mathrm{~mm} \text {. }\end{array}$ & $\begin{array}{l}\text { From floor of hut with } \\
\text { late } 4 \text { th c. A.D. pottery. } \\
\text { This bead was com- } \\
\text { pared by Kendrick to } \\
\text { some from a hoard at } \\
\text { Icklingham dated } c \text {. } \\
\text { A.D. } 400\end{array}$ & $\begin{array}{l}S A C \text { lxxvi (1935), } \\
3^{8, \text { and } i b i d . x c i v} \\
(1956), 70\end{array}$ \\
\hline $\begin{array}{l}\text { Monkton } \\
\text { Downs }\end{array}$ & Wiltshire & Devizes ${ }_{3} \mathbf{I}$ & $\begin{array}{l}\text { Bead comparable to } \\
\text { Wolstonbury, Sussex }\end{array}$ & $\begin{array}{l}\text { With other beads, not } \\
\text { closely datable and } \\
\text { not necessarily } \\
\text { associated }\end{array}$ & \\
\hline $\begin{array}{l}\text { Wick Wood, } \\
\text { Nettleton }\end{array}$ & Wiltshire & & $\begin{array}{l}\text { Badly made with } \\
\text { bright azure wave. } \\
\text { Diam. } 1 \cdot 3 \mathrm{~cm} . \mathrm{Ht} . \\
6 \mathrm{~mm} . \text { Perf. diam. } \\
4 \mathrm{~mm} .\end{array}$ & $\begin{array}{l}\text { Stratified late } 4^{\text {th }} \mathrm{c} \text {. } \\
\text { A.D. }\end{array}$ & $\begin{array}{l}\text { Information from } \\
\text { Mr. W.J. } \\
\text { Wedlake }\end{array}$ \\
\hline $\begin{array}{l}\text { Wick Wood, } \\
\text { Nettleton }\end{array}$ & Wiltshire & & $\begin{array}{l}\text { Another of dark } \\
\text { green with yellow } \\
\text { wave and wide } \\
\text { perforation }\end{array}$ & $\begin{array}{l}\text { Romano-British and } \\
\text { later site }\end{array}$ & $\begin{array}{l}\text { Information from } \\
\text { Mr. W.J. } \\
\text { Wedlake }\end{array}$ \\
\hline
\end{tabular}

\section{RELAND}

$\begin{array}{ll}\text { 'Northern Ireland' } \quad \text { B.M. 71.12.10.48 } & \begin{array}{l}\text { Rather like Wolston- No details } \\ \text { bury but wave is } \\ \text { bright cobalt blue }\end{array}\end{array}$

(iv) Globular Beads with Yellow Wave

\begin{tabular}{|c|c|c|c|c|}
\hline \multirow[b]{2}{*}{ Chesters Fort } & \multicolumn{4}{|c|}{ ENGLAND } \\
\hline & $\begin{array}{l}\text { Northumber- } \\
\text { land }\end{array}$ & Chesters & $\begin{array}{l}\text { Wide pear-shaped } \\
\text { shiny black. Max. } \\
\text { diam. I } 6 \mathrm{~cm} . \mathrm{Ht} \text {. } \\
\mathrm{I} \cdot 5 \mathrm{~cm} \text {. Very small } \\
\text { perforation }\end{array}$ & $\begin{array}{l}\text { May date from A.D. } \\
\text { I } 22-383 \text {; found in } \\
\text { I } 9 \text { th c. (An armlet } \\
\text { from a Roman con- } \\
\text { text at Hamworthy } \\
\text { (in Poole Museum) } \\
\text { is made in identical } \\
\text { manner) }\end{array}$ \\
\hline Mildenhall & Wiltshire & Devizes 129 & $\begin{array}{l}\text { Badly burnt. Max. } \\
\text { diam. I } 5 \mathrm{~cm} \text {. Ht. } \\
\text { I } \cdot 3 \mathrm{~cm} . \text { Small per- } \\
\text { foration (fig. } 2 \mathrm{I} \text {, } \\
\text { no. } 6 \text { ) }\end{array}$ & $\begin{array}{l}\text { Probably from Roman } \\
\text { site. Very similar to } \\
\text { Chesters example } \\
\text { above }\end{array}$ \\
\hline
\end{tabular}




\begin{tabular}{llccc}
\hline $\begin{array}{c}\text { SITE AND } \\
\text { PARISH }\end{array}$ & COUNTY & MUSEUM \& NO. & DESGRIPTION AND & ASSOCIATIONS AND \\
APROX. DIMENSIONS & REMARKS
\end{tabular}

(E) OPAQUE YELLOW ANNULAR BEADS WITH GOLOURED WAVE

Danebury Hampshire

Rings, Nether

Wallop

Meare

Somerset

Taunton Gi35, $\mathrm{G}_{39}, \mathrm{G}_{20}$

All Cannings Wiltshire Devizes

Cross

Beckford Worcester-

shire

Burton Yorkshire

Fleming

Madmarston

Camp,

Swalcliffe

\section{ENGLAND}

More globular than normally. Very abraded and now grey. Originally yellow. Rather straight-sided. Irregular slaty-blue wave. Diam. I. $5 \mathrm{~cm}$. Ht. I. I cm. Perf. diam. $6 \mathrm{~mm}$.

2 examples ( 1 about $1.5 \mathrm{~cm}$. diam.) and have wide perforations and green waves. Ht. c. $5 \mathrm{~mm}$. Another half-bead, smaller, may have had brown wave

Yellow ground with brown wave. Diam. I $-2 \mathrm{~cm}$. Ht. $7 \mathrm{~mm}$. Perf. diam. $2 \mathrm{~mm}$.

Diam. $\mathrm{I} \cdot 4 \mathrm{~cm}$. Ht. $8 \mathrm{~mm}$. Perf. diam. $5 \mathrm{~mm}$. (off-centre). Irregular wave or swag. Filling lost

Small fragment of bead similar to Meare example above. Double wave or swag filling now lost
(F) OPAQUE WHITE ANNULAR BEADS WITH YELLOW WAVE ENGLAND
Oxfordshire A.M.
Hill-fort. From layer thought to date from about IOO B.C.

From Meare preRoman site of 3 rd-1st c. B.c.

Iron Age A site with long occupation

Cunnington, M. E. (1923), pl. 18, no. 15 and P. I 20

Found with duckInformation from stamped and lineartooled wares

From an Iron Age cemetery

Information from Barry Cunliffe

$M e \mathrm{ii}$ W.J. Britnell, Dept. Archaeology, University College, Gardiff

Information from T. C. $\mathrm{M}$. Brewster
Near top of rampart of Middle Iron Age hill-fort reoccupied during $4^{\text {th }} \mathrm{c}$.
$O \mathrm{xxv}(1960), 3^{8}$ and 46 ; fig. 19 , no. 17

(G) TRANSLUGENT 'AMBER' (REDDISH-BROWN) BEADS WITH YELLOW WAVE ENGLAND

Nor' nour, Cornwall St. Mary's, Scilly Scilly

Rust colour probably From a house occuoriginally translucent. pied into late Roman some parts. Diam. $8 \mathrm{~mm}$. Ht. $3 \mathrm{~mm}$. Perf. diam. $4 \mathrm{~mm}$. period. It was a brooch factory in the and C. A.D.
$\operatorname{Arf}$ cxxiv (1967) 
THE SGHEDULES: GROUPS 5 AND 6

\begin{tabular}{llccc}
\hline $\begin{array}{c}\text { SITE AND } \\
\text { PARISH }\end{array}$ & COUNTY & MUSEUM \& NO. & DESCRIPTION AND & ASSOCIATIONS AND \\
\hline
\end{tabular}

\begin{tabular}{|c|c|c|c|c|c|}
\hline \multicolumn{6}{|c|}{ SGOTLAND } \\
\hline $\begin{array}{l}\text { Lochspouts } \\
\text { Crannog, } \\
\text { Maybole }\end{array}$ & Ayrshire & N.M.A. HW2o & $\begin{array}{l}\text { Diam. I } 9 \mathrm{~cm} . \mathrm{Ht} \text {. } \\
1 \mathrm{~cm} . \text { Perf. diam. } \\
8 \mathrm{~mm} .\end{array}$ & $\begin{array}{l}\text { Early Roman period. } \\
\text { Probably Ist-2nd c. } \\
\text { A.D. }\end{array}$ & $\begin{array}{l}P S A S \times v(1880-1), \\
\text { I } 0\end{array}$ \\
\hline
\end{tabular}

\section{GROUP 6}

\section{ANNULAR BEADS}

(i) LARGE BEADS OF VARTOUS COLOURS

\section{ENGLAND}

\begin{tabular}{|c|c|c|c|c|c|}
\hline $\begin{array}{l}\text { Santon } \\
\text { Downham }\end{array}$ & $\begin{array}{l}\text { Cambridge- } \\
\text { shire }\end{array}$ & C.M. & $\begin{array}{l}\text { Half only. Blue. } \\
\text { Diam. } 3 \cdot 2 \mathrm{~cm} . \mathrm{Ht} . \\
9 \mathrm{~mm} . \text { Perf. diam. } \\
\mathrm{I} \cdot 4 \mathrm{~cm} .\end{array}$ & With ist c. A.D. finds & $\begin{array}{l}\text { Fox, C. (1923) } \\
\text { p. } 104\end{array}$ \\
\hline $\begin{array}{l}\text { Nor' nour, } \\
\text { Scilly }\end{array}$ & Cornwall & St. Mary's, Scilly & $\begin{array}{l}\text { Blue. ? fragment of } \\
\text { ring bead. Diam. } c . \\
3 \mathrm{~cm} .\end{array}$ & $\begin{array}{l}\text { Site occupied through- } \\
\text { out Roman period }\end{array}$ & $\operatorname{Arf} \operatorname{cxxiv}(1967)$ \\
\hline $\begin{array}{l}\text { Gussage All } \\
\text { Saints }\end{array}$ & Dorset & & $\begin{array}{l}\text { Fragment. Opaque } \\
\text { green, almost tur- } \\
\text { quoise, ring-bead, } \\
\text { rounded section. } \\
\text { Diam. } 3 \cdot 4 \mathrm{~cm} \text {. Ht. } \\
4 \mathrm{~mm} \text {. Perf. diam. } \\
2.7 \mathrm{~cm} \text {. }\end{array}$ & $\begin{array}{l}\text { This is almost surely } \\
\text { a ring bead for hang- } \\
\text { ing on a torc. Found } \\
\text { with early Iron Age } \\
\text { A pottery and } \\
\text { socketed bone chisels } \\
\text { of All Cannings Cross } \\
\text { type. ? } 5 \text { th-4th c. } \\
\text { B.c. }\end{array}$ & $\begin{array}{l}\text { Information } \\
\text { (in advance of } \\
\text { publication) from } \\
\text { Dr. Geoffrey } \\
\text { Wainwright }\end{array}$ \\
\hline $\begin{array}{l}\text { Worthy } \\
\text { Down, } \\
\text { Winchester }\end{array}$ & Hampshire & Winchester & $\begin{array}{l}\text { Fragment. Blue. } \\
\text { Slight internal nick- } \\
\text { ing probably due to } \\
\text { weathering. Diam. } \\
4 \mathrm{~cm} . \mathrm{Ht} . \mathrm{I} \cdot \mathrm{I} \mathrm{cm} \text {. } \\
\text { Perf. diam. } 2 \mathrm{~cm} \text {. }\end{array}$ & $\begin{array}{l}\text { Pre-Roman site. } \\
\text { Possible analogy in } \\
\text { Déchelette, J. (I9I4) } \\
\text { I } 32 \text { I }\end{array}$ & $\begin{array}{l}\text { PHFCAS x (1929), } \\
\text { 1 } 84\end{array}$ \\
\hline Corbridge & $\begin{array}{l}\text { Northumber- } \\
\text { land }\end{array}$ & Corbridge & $\begin{array}{l}\text { Blue. About } 1 / 3 \\
\text { remains. Diam. } 3 \cdot 4 \\
\mathrm{~cm} . \text { Ht. } 1 \cdot 7 \mathrm{~cm} . \text { Perf. } \\
\text { diam. } 1 \cdot 2 \mathrm{~cm} .\end{array}$ & $\begin{array}{l}\text { This could possibly } \\
\text { be part of a South } \\
\text { Harting Class bead }\end{array}$ & \\
\hline Glastonbury & Somerset & $\begin{array}{l}\text { Glastonbury Museum } \\
\text { G10 }\end{array}$ & $\begin{array}{l}\text { Blue. Diam. } 3 \cdot 1 \mathrm{~cm} \text {. } \\
\text { Ht. } \mathrm{I} \cdot 3 \mathrm{~cm} . \text { Perf. } \\
\text { diam. } 8 \mathrm{~mm} . \text { centre } \\
\text { of rounded section }\end{array}$ & Pre-Roman site & $G l$ ii, Gio \\
\hline $\begin{array}{l}\text { Nyland } \\
\text { (Cheddar } \\
\text { Moor) }\end{array}$ & Somerset & Wells & $\begin{array}{l}\text { Blue. Less than half } \\
\text { remains. Diam. } 3 \cdot 7 \\
\mathrm{~cm} . \text { Ht. } 1 \cdot 3 \mathrm{~cm} \text {. Perf, } \\
\text { diam. } 1 \cdot 2 \mathrm{~cm} .\end{array}$ & $\begin{array}{l}\text { With ist-2nd c. A.D. } \\
\text { Samian, etc. }\end{array}$ & \\
\hline
\end{tabular}


I4O GLASS BEADS OF THE PREHISTORIG AND ROMAN PERIODS

\begin{tabular}{|c|c|c|c|c|c|}
\hline $\begin{array}{l}\text { SITE AND } \\
\text { PARISH }\end{array}$ & COUNTY & MUSEUM \& No. & $\begin{array}{l}\text { DESCRIPTION AND } \\
\text { APPROX. DIMENSIONS }\end{array}$ & $\begin{array}{c}\text { ASSOCIATIONS AND } \\
\text { REMARKS }\end{array}$ & PUBLICATION \\
\hline $\begin{array}{l}\text { Temple- } \\
\text { brough }\end{array}$ & Yorkshire & Rotherham & $\begin{array}{l}\text { Half opaque yellow. } \\
\text { Diam. } 3 \mathrm{~cm} \text {. }\end{array}$ & $\begin{array}{l}\text { Fort of probably } \\
\text { Flavian and } \\
\text { Hadrianic date. } \\
\text { Unscientific excava- } \\
\text { tions }\end{array}$ & May, T. (I922) \\
\hline
\end{tabular}

(iia) NATURAL GREENISH TRANSLUGENT GLASS (MEDIUM SIZE)

\section{ENGLAND}

$\begin{array}{lll}\begin{array}{l}\text { Hambledon, } \\ \text { Yewden }\end{array} & \begin{array}{l}\text { Buckingham- Hambledon } \\ \text { shire }\end{array} \\ \begin{array}{l}\text { Nor' nour, } \\ \text { Scilly }\end{array} & \text { Cornwall } & \text { St. Mary's, Scilly } \\ \begin{array}{l}\text { Porthmeor, } \\ \text { Zennor }\end{array} & \end{array}$

Half only. Diam. 2

\begin{tabular}{|c|c|c|}
\hline $\begin{array}{l}\text { Porth Cressa, } \\
\text { Hughtown, } \\
\text { Scilly }\end{array}$ & Cornwall & \\
\hline Colchester & Essex & Colchester \\
\hline Ongar & Essex & $\begin{array}{l}\text { Hazzledine } \\
\text { Warren Colln. }\end{array}$ \\
\hline Cirencester & $\begin{array}{l}\text { Gloucester- } \\
\text { shire }\end{array}$ & Cirencester B893 \\
\hline Barnwood & $\begin{array}{l}\text { Gloucester- } \\
\text { shire }\end{array}$ & Cheltenham \\
\hline Frocester & $\begin{array}{l}\text { Gloucester- } \\
\text { shire }\end{array}$ & \\
\hline Gloucester & $\begin{array}{l}\text { Gloucester- } \\
\text { shire }\end{array}$ & Gloucester 348 \\
\hline
\end{tabular}
$\mathrm{cm}$. Ht. I cm. Perf. diam. $8 \mathrm{~mm}$.

Half. Rather striated. Diam. $\mathrm{I} .8 \mathrm{~cm}$. Ht. $7 \mathrm{~mm}$. Perf. diam. $9 \mathrm{~mm}$.

Diam. I $7 \mathrm{~cm} . \mathrm{Ht}$ $6 \mathrm{~mm}$. Perf. diam. $4 \mathrm{~mm}$.

Roman villa with
rather earlier Belgic
occupation on site, $c$. A.D. $4^{0-e n d} 4^{\text {th }}$ c.

Occupation of this site Found after the

Irregularly made. Diam. $1 \cdot 7 \mathrm{~cm}$. Ht. I cm. or less. Perf. diam. $5 \mathrm{~mm}$.

2 examples. One: diam. $1 \cdot 7 \mathrm{~cm}$; perf. diam. $7 \mathrm{~mm}$. The other slightly smaller

Diam. $1 \cdot 7 \mathrm{~cm}$. Ht. $1 \cdot 3 \mathrm{~cm}$. Perf. diam. $5 \mathrm{~mm}$.

Diam. I 7 cm. Ht. $8 \mathrm{~mm}$. Perf. diam. $7 \mathrm{~mm}$.

Diam. $1 \cdot 5 \mathrm{~cm}$. Ht. Roman villa $1 \mathrm{~cm}$. Perf. diam. $6 \mathrm{~mm}$.

Badly made with perforation off-centre. Diam. $2 \mathrm{~cm}$. Ht. $1 \mathrm{~cm}$. Perf. diam. $4 \mathrm{~mm}$.

Fragment. Diam. $2.6 \mathrm{~cm}$. Ht. $1.6 \mathrm{~cm}$. Perf. diam. I $1 \mathrm{~cm}$. was mainly 2 nd c. A.D. but also later

With another similar but olive green bead and small blue biconical bead of Roman type from Romano-British village

From cist with brooch and pot probably early Romano-British

From Group 94, dated A.D. 150-200

May, T. (1930), p. 279

Hallsford brickfields. Unassociated

Information from the late Mr. S. H. Warren original report in $\operatorname{Ar} \mathcal{J}$ cxxiv ( 1967 )

Information from the late Miss F. Patchett

$\operatorname{Arf} \operatorname{cxi}(1954)$, I 7

From Roman town

Roman villa

TBGAS lii (1930), $207 \mathrm{ff}$.

From Frocester Court TBGAS lxxxix

Roman villa. Strati- (1970)

fied late $4^{\text {th }}$ C. A.D.

With Roman and Information from post-Roman material Mrs. Bonner 
THE SCHEDULES: GROUP 6

\begin{tabular}{|c|c|c|c|c|c|}
\hline $\begin{array}{l}\text { STTE AND } \\
\text { PARISH }\end{array}$ & COUNTY & MUSEUM \& NO. & $\begin{array}{l}\text { DESGRIPTION AND } \\
\text { APPROX. DIMENSIONS }\end{array}$ & $\begin{array}{l}\text { ASSOCIATIONS AND } \\
\text { REMARKS }\end{array}$ & PUBBLIGATION \\
\hline Silchester & Hampshire & Reading & $\begin{array}{l}2 \text { examples. One } \\
\text { complete: diam. } 2 \\
\text { cm.; ht. } 8 \mathrm{~mm} . ; \text { ir- } \\
\text { regular; perf. diam. } \\
8 \mathrm{~mm} \text {. Another } \\
\text { half slightly larger }\end{array}$ & $\begin{array}{l}\text { Most of the occupa- } \\
\text { tion belongs to the } \\
\text { Roman period }\end{array}$ & $\begin{array}{l}\text { For site, see Boon, } \\
\text { G. C. (1957) }\end{array}$ \\
\hline $\begin{array}{l}\text { Weston- } \\
\text { under- } \\
\text { Penyard, } \\
\text { Bollitree }\end{array}$ & $\begin{array}{l}\text { Hereford- } \\
\text { shire }\end{array}$ & $\begin{array}{l}\text { Gloucester A1 } 754 \\
\text { and } 1074\end{array}$ & $\begin{array}{l}\text { One: diam. I } .8 \mathrm{~cm} . \text {; } \\
\text { ht. } 8 \mathrm{~mm} \text {.; perf. diam. } \\
8 \mathrm{~mm} \text {. Another } \\
\text { similar but smaller } \\
\text { perforation }\end{array}$ & Roman & $\begin{array}{l}\mathcal{J} B A A \text { xxvii (1871), } \\
211\end{array}$ \\
\hline $\begin{array}{l}\text { King's } \\
\text { Langley }\end{array}$ & Hertfordshire & B.M. & $\begin{array}{l}\text { Diam. I } 7 \mathrm{~cm} . \mathrm{Ht} . \\
8 \mathrm{~mm} \text {. Irregular. } \\
\text { Perf. diam. } 6 \mathrm{~mm} .\end{array}$ & $\begin{array}{l}\text { Given by Mr. James } \\
\text { Nantes. Stray find } \\
\text { from Chipperfield }\end{array}$ & \\
\hline Faversham & Kent & $\begin{array}{l}\text { G.M., Beck Golln. } \\
\text { I } 660\end{array}$ & $\begin{array}{l}\text { Diam. I } \cdot 9 \mathrm{~cm} . \mathrm{Ht} \text {. } \\
6 \mathrm{~mm} . \text { Perf. diam. } \\
8 \mathrm{~mm} .\end{array}$ & $\begin{array}{l}\text { ? Anglo-Saxon from } \\
\text { Group XX.A. I.a }\end{array}$ & $\begin{array}{l}\text { H. C. Beck's notes, } \\
\text { Cambridge }\end{array}$ \\
\hline Richborough & Kent & Richborough $133^{\circ}$ & $\begin{array}{l}\text { Series of nicks radiat- } \\
\text { ing from surface. } \\
\text { Diam. I } .5 \mathrm{~cm} . \mathrm{Ht} \text {. } \\
6 \mathrm{~mm} . \text { Perf. diam. } \\
6 \mathrm{~mm} \text {. }\end{array}$ & $\begin{array}{l}\text { Unstratified in } \\
\text { Roman and Saxon } \\
\text { fort }\end{array}$ & Rich iv, p. $25^{8}$ \\
\hline Richborough & Kent & Richborough 3919 & $\begin{array}{l}\text { Slightly pitted with } \\
\text { bubble marks. Diam. } \\
2 \cdot 3 \mathrm{~cm} . \mathrm{Ht} .1 \cdot 3 \mathrm{~cm} \text {. } \\
\text { Perf. diam. } 8 \mathrm{~mm} \text {. }\end{array}$ & $\begin{array}{l}\text { From inner stone fort } \\
\text { ditch middle layer. } \\
\text { Probably } 3 \text { rd or } 4^{\text {th }} \text { c. } \\
\text { A.D. }\end{array}$ & Rich iv, p. 235 \\
\hline Normanby & Lincolnshire & Scunthorpe $\mathbf{R}_{74}$ & $\begin{array}{l}\text { Diam. I } 8 \mathrm{~cm} . \mathrm{Ht} \text {. } \\
8 \mathrm{~mm} . \text { Perf. diam. } \\
8 \mathrm{~mm} .\end{array}$ & $\begin{array}{l}\text { The same site pro- } \\
\text { duced early } 4^{\text {th }} \mathrm{c} \text {. } \\
\text { A.D. ware }\end{array}$ & $\begin{array}{l}\text { Dudley, H., Early } \\
\text { Days in } \mathcal{N} . W . \\
\text { Lincolnshire }\end{array}$ \\
\hline Chesters Fort & $\begin{array}{l}\text { Northumber- } \\
\text { land }\end{array}$ & Chesters & $\begin{array}{l}\text { Flattened surface. } \\
\text { Diam. } 1.9 \mathrm{~cm} . \mathrm{Ht} \text {. } \\
9 \mathrm{~mm} \text {. irregular. } \\
\text { Perf. diam. } 5 \mathrm{~mm} .\end{array}$ & $\begin{array}{l}\text { Found in Igth c. } \\
\text { Probably the site dates } \\
\text { between A.D. I } 22 \text { and } \\
3^{8} 3\end{array}$ & \\
\hline Corbridge & $\begin{array}{l}\text { Northumber- } \\
\text { land }\end{array}$ & Corstopitum & $\begin{array}{l}\text { Almost opaque. } \\
\text { Diam. } 1 \cdot 7 \mathrm{~cm} . \mathrm{Ht} \text {. } \\
7 \mathrm{~mm} . \text { Perf. diam. } \\
5 \mathrm{~mm} .\end{array}$ & $\begin{array}{l}\text { Stray find. Occupa- } \\
\text { tion ist- } 5^{\text {th }} \text { c. A.D. }\end{array}$ & \\
\hline Housesteads & $\begin{array}{l}\text { Northumber- } \\
\text { land }\end{array}$ & $\begin{array}{l}\text { Blackgate Museum, } \\
\text { Newcastle-upon- } \\
\text { Tyne }\end{array}$ & $\begin{array}{l}\text { About: Diam. } 2 \cdot 5 \\
\mathrm{~cm} . ; \text { ht. } 1 \mathrm{~cm} .\end{array}$ & $\begin{array}{l}\text { On a necklace with } \\
\text { cylinder beads and } \\
\text { other Roman types }\end{array}$ & \\
\hline $\begin{array}{l}\text { Brough, } \\
\text { South } \\
\text { Collingham }\end{array}$ & $\begin{array}{l}\text { Nottingham- } \\
\text { shire }\end{array}$ & Newark & $\begin{array}{l}\text { Diam. I. } 6 \mathrm{~cm} . \mathrm{Ht} \text {. } \\
5 \mathrm{~mm} . \text { Perf. diam. } \\
7 \mathrm{~mm} .\end{array}$ & $\begin{array}{l}\text { Stray find. Roman } \\
\text { site }\end{array}$ & \\
\hline Ditchley & Oxfordshire & A.M. $193^{6.367}$ & $\begin{array}{l}\text { Rather irregular. } \\
\text { Diam. } 1 \cdot 7 \mathrm{~cm} . \mathrm{Ht} \text {. } \\
\text { about } 8 \mathrm{~mm} \text {. Perf. } \\
\text { diam. } 6 \mathrm{~mm} \text {. }\end{array}$ & Roman villa & $O \mathrm{i}\left(193^{6}\right), 57$ \\
\hline
\end{tabular}


I42 GLASS BEADS OF THE PREHISTORIG AND ROMAN PERIODS

\begin{tabular}{|c|c|c|c|c|c|}
\hline $\begin{array}{l}\text { SITE AND } \\
\text { PARISH }\end{array}$ & COUNTY & MUSEUM \& NO. & $\begin{array}{l}\text { DESCRIPTION AND } \\
\text { APPROX. DIMENSIONS }\end{array}$ & $\begin{array}{l}\text { ASSOCLATIONS AND } \\
\text { REMARKS }\end{array}$ & PUBLICATION \\
\hline Wroxeter & Shropshire & $\begin{array}{l}\text { Rowley's House } \\
\text { Museum, Shrews- } \\
\text { bury }\end{array}$ & $\begin{array}{l}\text { Irregular. Diam. } \\
1.8 \mathrm{~cm} . \text { Ht. } 8 \mathrm{~mm} . \\
\text { Perf. diam. } 5 \mathrm{~mm} .\end{array}$ & Not stratified & \\
\hline $\begin{array}{l}\text { Kingsdown } \\
\text { Camp, } \\
\text { Bath }\end{array}$ & Somerset & & $\begin{array}{l}\text { Incomplete. Diam. } \\
2 \mathrm{~cm} . \text { Ht. } 8 \mathrm{~mm} \text {. Perf. } \\
\text { diam. } 6 \mathrm{~mm} \text {. }\end{array}$ & $\begin{array}{l}\text { With late Iron Age } \\
\text { and Ist-2nd C. A.D. } \\
\text { Roman finds }\end{array}$ & $\begin{array}{l}\text { Information from } \\
\text { excavator }\end{array}$ \\
\hline Glastonbury & Somerset & Glastonbury $\mathrm{G}_{3}$ & $\begin{array}{l}\text { Half bead. Diam. } \\
2 \mathrm{~cm} . \text { Ht. } 4 \mathrm{~mm} \text {. Perf. } \\
\text { diam. } 1.2 \mathrm{~cm} .\end{array}$ & Late Iron Age site & $G l$ ii \\
\hline Meare & Somerset & Taunton & $\begin{array}{l}\text { Irregular. Diam. I } 9 \\
\mathrm{~cm} . \text { Ht. } 7 \mathrm{~mm} \text {. to } \\
\text { I } \mathrm{cm} \text {. Perf. diam. } \\
6 \mathrm{~mm} . \text { to } 8 \mathrm{~mm} \text {. }\end{array}$ & $\begin{array}{l}\text { From Iron Age site. } \\
\text { ? 3rd to ist c. B.c. }\end{array}$ & $M e \mathrm{iii}$ \\
\hline 'Mendip' & Somerset & $\begin{array}{l}\text { Bristol, A. C. Pass } \\
\text { Colln. F2076 and } \\
\text { F2074 }\end{array}$ & $\begin{array}{l}2 \text { beads. Diam. } \\
1.6 \mathrm{~cm} . \text { and diam. } \\
1.8 \mathrm{~cm} \text {. Rather thick }\end{array}$ & Both stray finds & \\
\hline $\begin{array}{l}\text { Bury Wood } \\
\text { Camp, Colerne }\end{array}$ & Wiltshire & & $\begin{array}{l}\text { Diam. } 2 \cdot 2 \mathrm{~cm} . \mathrm{Ht} . \\
8 \mathrm{~mm} . \text { Perf. diam. } \\
1 \cdot \mathrm{I} \mathrm{cm} .\end{array}$ & $\begin{array}{l}\text { Associated with Iron } \\
\text { Age B ware }\end{array}$ & $\begin{array}{l}\text { Interim reports in } \\
W A M \text { lvii, lxii } \\
\text { and lxiv }\end{array}$ \\
\hline $\begin{array}{l}\text { Broadtown, } \\
\text { Broad Hinton }\end{array}$ & Wiltshire & Devizes $S_{1} 6$ & $\begin{array}{l}\text { Diam. } 2 \cdot 2 \mathrm{~cm} . \mathrm{Ht} . \\
\text { I cm. Perf. diam. } \\
5 \mathrm{~mm} . \text { off-centre }\end{array}$ & $\begin{array}{l}\text { Secondary inhuma- } \\
\text { tion in a barrow with } \\
\text { amber bead and } \\
\text { socketed iron arrow- } \\
\text { head. ? Roman or } \\
\text { Saxon. There is a } \\
\text { Romano-British } \\
\text { cemetery near by }\end{array}$ & $\begin{array}{l}W A M \times 1(1918- \\
19), 353\end{array}$ \\
\hline Catterick & Yorkshire & & $\begin{array}{l}\text { Diam. I } 8 \mathrm{~cm} . \mathrm{Ht} . \\
7 \mathrm{~mm} . \text { Perf. diam. } \\
6 \mathrm{~mm} .\end{array}$ & (Bead 15) Roman & $\begin{array}{l}\text { Information from } \\
\text { Mr.J. Wacher }\end{array}$ \\
\hline Scarborough & Yorkshire & Scarborough $1009 \cdot 3^{8}$ & $\begin{array}{l}\text { Diam. } 2 \mathrm{~cm} . \text { Ht. } \\
8 \mathrm{~mm} . \text { Perf. diam. } \\
8 \mathrm{~mm} .\end{array}$ & $\begin{array}{l}\text { From Roman signal } \\
\text { station occupied } \\
\text { about A.D. } 37^{0}-400\end{array}$ & \\
\hline \multicolumn{6}{|c|}{ SGOTLAND } \\
\hline \multicolumn{2}{|c|}{ Dunbartonshire } & N.M.A. FJ37 & $\begin{array}{l}\text { Diam. } 2 \mathrm{~cm} . \mathrm{Ht} \text {. } \\
\text { I } . \mathrm{cm} . \text { Perf. diam. } \\
7 \mathrm{~mm} .\end{array}$ & $\begin{array}{l}\text { Found by J. John- } \\
\text { stone, } 1849\end{array}$ & \\
\hline Mosspebble & $\begin{array}{l}\text { Dumfries- } \\
\text { shire }\end{array}$ & N.M.A. FJ39 & $\begin{array}{l}\text { Roughly made. Diam. } \\
2 \mathrm{~cm} . \text { Ht. } 9 \mathrm{~mm} \text {. Perf. } \\
\text { diam. } 8 \mathrm{~mm} \text {. }\end{array}$ & $\begin{array}{l}\text { Found by A. H. } \\
\text { Borthwick in I } 869\end{array}$ & \\
\hline Newstead & $\begin{array}{l}\text { Roxburgh- } \\
\text { shire }\end{array}$ & $\begin{array}{l}\text { N.M.A. FRA905 and } \\
906\end{array}$ & $\begin{array}{l}\text { One: Diam. } 2 \cdot 3 \mathrm{~cm} . \\
\text { ht. } 4 \mathrm{~mm} . ; \text { perf. } \\
\text { diam. I } \cdot \text { I cm. } \\
\text { Another, half only, } \\
\text { rather smaller and } \\
\text { thicker }\end{array}$ & $\begin{array}{l}\text { The occupation of } \\
\text { this site lasted from } \\
\text { about A.D. } 80-200\end{array}$ & $\begin{array}{l}\mathcal{N} e, \text { pp. } 33^{6-7} \text { and } \\
P S A S \text { lxxxiv } \\
(1949-50), \text { iff. }\end{array}$ \\
\hline
\end{tabular}




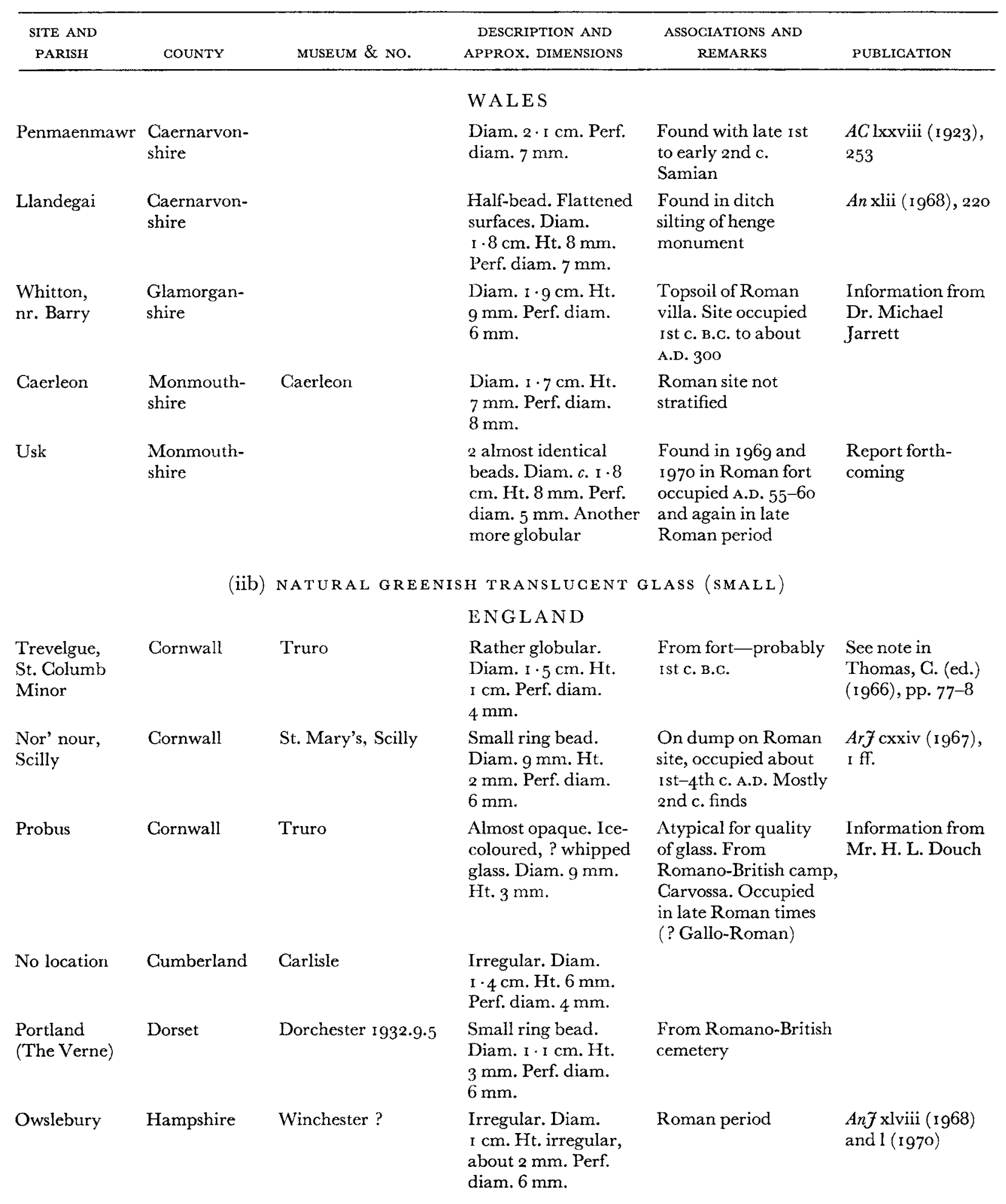


I44 GLASS BEADS OF THE PREHISTORIC AND ROMAN PERIODS

\begin{tabular}{|c|c|c|c|c|c|}
\hline $\begin{array}{l}\text { SITE AND } \\
\text { PARISH }\end{array}$ & COUNTY & MUSEUM \& NO. & $\begin{array}{l}\text { DESCRIPTION AND } \\
\text { APPROX. DIMENSIONS }\end{array}$ & $\begin{array}{l}\text { ASSOCIATIONS AND } \\
\text { REMARKS }\end{array}$ & PUBLICATION \\
\hline Silchester & Hampshire & Reading & $\begin{array}{l}2 \text { examples. One: } \\
\text { diam. I } 4 \text { cm.; ht. } \\
5 \mathrm{~mm} . \text { irregular; } \\
\text { perf. diam. } 1.6 \mathrm{~cm} . \\
\text { Another: diam. } 1 \cdot 3 \\
\mathrm{~cm} . ; \text { ht. } 6 \mathrm{~mm} . \text {; perf. } \\
\text { diam. } 5 \mathrm{~mm} .\end{array}$ & $\begin{array}{l}\text { Site occupied ist c. } \\
\text { B.C. }-5 \text { th C. A.D. }\end{array}$ & \\
\hline Kenchester & $\begin{array}{l}\text { Hereford- } \\
\text { shire }\end{array}$ & Hereford $443^{6}$ & $\begin{array}{l}\text { Upper surface slightly } \\
\text { dished. Diam. } 8 \mathrm{~mm} \text {. } \\
\text { Ht. } 4 \mathrm{~mm} \text {. Perf. diam. } \\
\text { I } \mathrm{mm} \text {. }\end{array}$ & $\begin{array}{l}\text { Occupation until late } \\
4^{\text {th c. A.D. }}\end{array}$ & $\begin{array}{l}T W N F C \text { I } 916 \text { and } \\
193^{6}\end{array}$ \\
\hline $\begin{array}{l}\text { Weston- } \\
\text { under- } \\
\text { Penyard, } \\
\text { Bollitree }\end{array}$ & $\begin{array}{l}\text { Hereford- } \\
\text { shire }\end{array}$ & Gloucester A $75^{2}$ & $\begin{array}{l}\text { Diam. I } \cdot 2 \mathrm{~cm} . \mathrm{Ht} \text {. } \\
5 \mathrm{~mm} . \text { Perf. diam. } \\
5 \mathrm{~mm} .\end{array}$ & Roman & $\begin{array}{l}\mathcal{J B A A} \text { xxvii (I } 87 \mathrm{I}) \\
\text { 2I Iff. }\end{array}$ \\
\hline $\begin{array}{l}\text { Verulamium } \\
\text { (King Harry's } \\
\text { Lane) }\end{array}$ & Hertfordshire & $\begin{array}{l}\text { Verulamium (St. } \\
\text { Albans) }\end{array}$ & $\begin{array}{l}2 \text { beads. Diams. } \\
1 \cdot 3 \text { and } \mathrm{I} \cdot 5 \mathrm{~cm} . \mathrm{Ht} \text {. } \\
4 \mathrm{~mm} \text {. Perf. diam. } \\
8 \mathrm{~mm} \text {. }\end{array}$ & $\begin{array}{l}\text { Necklace on Burial } \\
29 \text { of pre-Roman } \\
\text { Aylesford type. } \\
\text { About 10 B.C.-A.D. } 40\end{array}$ & $\begin{array}{l}\text { Information from } \\
\text { Dr. I. M. Stead, } \\
\text { F.s.A. }\end{array}$ \\
\hline $\begin{array}{l}\text { Godman- } \\
\text { chester }\end{array}$ & $\begin{array}{l}\text { Huntingdon- } \\
\text { shire }\end{array}$ & & $\begin{array}{l}\text { Rather irregular and } \\
\text { almost colourless. } \\
\text { Diam. I } \cdot \mathrm{I} \mathrm{cm} \text {. }\end{array}$ & c. A.D. $150-200$ & $\begin{array}{l}P C A S \operatorname{liv}(1960) \\
83-4\end{array}$ \\
\hline Risby Warren & Lincolnshire & Scunthorpe R I 8 & Several examples & $\begin{array}{l}\text { Mixed Romano- } \\
\text { British and Saxon } \\
\text { occupation material }\end{array}$ & \\
\hline $\begin{array}{l}\text { Great } \\
\text { Chesters }\end{array}$ & $\begin{array}{l}\text { Northumber- } \\
\text { land }\end{array}$ & $\begin{array}{l}\text { University Museum, } \\
\text { Newcastle-upon- } \\
\text { Tyne }\end{array}$ & $\begin{array}{l}2 \text { small examples. } \\
\text { Diam. about } 1 \cdot 2 \mathrm{~cm} \text {. }\end{array}$ & $\begin{array}{l}\text { On necklace with } \\
\text { other Roman beads }\end{array}$ & \\
\hline Bath & Somerset & $\begin{array}{l}\text { Bath Pump Room } \\
\text { Museum }\end{array}$ & $\begin{array}{l}\text { Several small ring } \\
\text { beads about } 8 \mathrm{~mm} \text {. } \\
\text { to I } \mathrm{cm} \text {. in diam. }\end{array}$ & Roman period & $\begin{array}{l}\text { Cunliffe, B., } \\
\text { Roman Bath } \\
\text { Discovered (1971) } \\
\text { and refs. }\end{array}$ \\
\hline $\begin{array}{l}\text { Ham Hill, } \\
\text { Montacute }\end{array}$ & Somerset & Taunton & $\begin{array}{l}\text { Diam. I I cm. Ht. } \\
4 \mathrm{~mm} . \text { irregular. } \\
\text { Perf. diam. } 6 \mathrm{~mm} .\end{array}$ & $\begin{array}{l}\text { Hill-fort with pre- } \\
\text { Roman and Roman } \\
\text { occupation }\end{array}$ & $\begin{array}{l}V C H \text { Somerset i, } 295 \\
\text { and } A \text { xlviii }\end{array}$ \\
\hline $\begin{array}{l}\text { Ham Hill, } \\
\text { Montacute }\end{array}$ & Somerset & Taunton & Another rather larger & $\begin{array}{l}\text { No details of position } \\
\text { of finds }\end{array}$ & $\begin{array}{l}V C H \text { Somerset i, } 295 \\
\text { and } A \text { xlviii }\end{array}$ \\
\hline Hartfield & Sussex & & $\begin{array}{l}\text { Diam. I } \mathrm{cm} . \mathrm{Ht} . \\
\text { irregular } 3 \mathrm{~mm} . \\
\text { Perf. diam. } 6 \mathrm{~mm} .\end{array}$ & $\begin{array}{l}\text { From Garden Hill } \\
\text { Romano-British iron } \\
\text { working site }\end{array}$ & $\begin{array}{l}\text { Information from } \\
\text { Mr. J. H. Money }\end{array}$ \\
\hline Rotherly & Wiltshire & Salisbury & $\begin{array}{l}\text { Rather globular. } \\
\text { Diam. } \cdot 4 \mathrm{~cm} . \mathrm{Ht} \text {. } \\
9 \mathrm{~mm} . \text { Perf. diam. } \\
4 \mathrm{~mm} .\end{array}$ & $\begin{array}{l}\text { Romano-British } \\
\text { village }\end{array}$ & $\begin{array}{l}\text { Pitt-Rivers, } \\
\text { A. H. L. F. (1 } 888) \\
\text { and } A r \mathcal{F} \operatorname{civ}(1947)\end{array}$ \\
\hline $\begin{array}{l}\text { Stockton } \\
\text { Earthworks }\end{array}$ & Wiltshire & Salisbury & $\begin{array}{l}2 \text { examples. One has } \\
\text { diam. } 1 \cdot 4 \mathrm{~cm} \text {; ; ht. } \\
4 \mathrm{~mm} . \text {; perf. diam. } \\
7 \mathrm{~mm} \text {. Another (half): } \\
\text { diam. } 8 \mathrm{~mm} . \text {; perf. } \\
\text { diam. } 6 \mathrm{~mm} \text {. }\end{array}$ & $\begin{array}{l}\text { Belgic and Roman } \\
\text { site }\end{array}$ & $\begin{array}{l}W A M \text { xliii (1897), } \\
3^{89}\end{array}$ \\
\hline
\end{tabular}




\begin{tabular}{|c|c|c|c|c|c|}
\hline $\begin{array}{l}\text { SITE AND } \\
\text { PARISH }\end{array}$ & COUNTY & MUSEUM \& NO. & $\begin{array}{l}\text { DESCRIPTION AND } \\
\text { APPROX. DIMENSIONS }\end{array}$ & $\begin{array}{l}\text { ASSOCIATIONS AND } \\
\text { REMARKS }\end{array}$ & PUBLICATION \\
\hline Catterick & Yorkshire & & $\begin{array}{l}\text { Irregular. Diam. I } 3 \\
\text { cm. Ht. } 4 \mathrm{~mm} \text {. Perf. } \\
\text { diam. } 5 \mathrm{~mm} \text {. Two } \\
\text { others very similar }\end{array}$ & $\begin{array}{l}\text { Beads } 4 \mathrm{I}, 50, \mathrm{i} 3 \text { from } \\
\text { Roman town }\end{array}$ & $\begin{array}{l}\text { Information from } \\
\text { Mr.J. Wacher }\end{array}$ \\
\hline \multicolumn{6}{|c|}{ SCOTLAND } \\
\hline $\begin{array}{l}\text { Traprain Law, } \\
\text { Prestonkirk }\end{array}$ & East Lothian & N.M.A. & $\begin{array}{l}\text { Three clumsily made } \\
\text { examples. Diam. } 8 \\
\text { mm. or smaller }\end{array}$ & Roman period & $\begin{array}{l}\text { For references to } \\
\text { Traprain Law, see } \\
\text { Rivet, A. L. F. } \\
\text { (ed.) (rg66) }\end{array}$ \\
\hline Covesea & Morayshire & N.M.A. HM2 I 4 & $\begin{array}{l}\text { Rather yellower } \\
\text { green than usual }\end{array}$ & $\begin{array}{l}\text { Occupation in early } \\
\text { Roman period. } \\
\text { Fragment of } 2 \text { nd c. A.D. } \\
\text { imported glass from } \\
\text { this site }\end{array}$ & $\begin{array}{l}P S A S \mathrm{lxv}(1931), \\
177\end{array}$ \\
\hline & & & WALES & & \\
\hline Plas Bach & Angelsey & Bangor & $\begin{array}{l}\text { Diam. I } 3 \text { to } \mathrm{I} \cdot 4 \\
\mathrm{~cm} . \mathrm{Ht} .5 \mathrm{~mm} . \\
\text { irregular. Perf. diam. } \\
6 \mathrm{~mm} \text {. Hole worn on } \\
\text { thinner side of bead }\end{array}$ & & $\begin{array}{l}A C, 5^{\text {th }} \text { s., ix } \\
(1892), 243\end{array}$ \\
\hline $\begin{array}{l}\text { Coygan Camp } \\
\text { Laugharne }\end{array}$ & $\begin{array}{l}\text { Carmarthen- } \\
\text { shire }\end{array}$ & & $\begin{array}{l}2, \text { badly made } \\
\text { with irregular } \\
\text { perforation, diam. } \\
\text { about } \mathrm{I} \mathrm{cm} .\end{array}$ & Late 3 rd C. A.D. & $\begin{array}{l}\text { Wainwright, G. J. } \\
\text { (1967) }\end{array}$ \\
\hline $\begin{array}{l}\text { Whitton, } \\
\text { nr. Barry }\end{array}$ & $\begin{array}{l}\text { Glamorgan- } \\
\text { shire }\end{array}$ & & $\begin{array}{l}\text { Diam. I } 5 \mathrm{~cm} . \mathrm{Ht} . \\
9 \mathrm{~mm} . \text { Perf. diam. } \\
5 \mathrm{~mm} .\end{array}$ & $\begin{array}{l}\text { Surface soil in } \\
\text { Roman villa occu- } \\
\text { pied about ist c. B.C. } \\
\text { to A.D. } 300\end{array}$ & $\begin{array}{l}\text { Information from } \\
\text { Dr. M. Jarrett }\end{array}$ \\
\hline $\begin{array}{l}\text { Moel Trigarn } \\
\text { Fort }\end{array}$ & $\begin{array}{l}\text { Pembroke- } \\
\text { shire }\end{array}$ & 'T'enby & $\begin{array}{l}\text { Several examples, } \\
\text { one: Diam. } 1 \cdot 4 \mathrm{~cm} \text {. }\end{array}$ & $\begin{array}{l}\text { One came from same } \\
\text { hut as a Meare spiral } \\
\text { bead (Class?) }\end{array}$ & $A C \mathrm{lv}(\mathrm{I} 900), 206$ \\
\hline
\end{tabular}

(iiia) MEDIUM GREEN, GREENISH-GOLD OR GREENISH-BROWN (TRANSLUCENT IF NOT STATED)

(Note: For natural glass, see Group 6 (iia) and (iib), and, for smaller beads, see Group 6 (v) )

$\begin{array}{ll}\text { Yewden, } & \text { Buckingham- Reading } \\ \text { Hambledon } & \text { shire }\end{array}$

Porthmeor, Cornwall

Zennor

\section{ENGLAND}

Part of ring bead, Roman villa with $\quad A$ lxxi (I920-2I), rich yellowish-green. some earlier occupa- I4I ff. Diam. $1.9 \mathrm{~cm}$. Ht. tion of about A.D. $5 \mathrm{~mm}$. Perf. diam. $\quad 30-400$ I. 2 c.m.

Light greenish-gold. Romano-British Diam. $2 \cdot 2 \mathrm{~cm}$. Ht. village Information from Miss F. Patchett 
I46 GLASS BEADS OF THE PREHISTORIG AND ROMAN PERIODS

\begin{tabular}{|c|c|c|c|c|c|}
\hline $\begin{array}{l}\text { SITE AND } \\
\text { PARISH }\end{array}$ & GOUNTY & MUSEUM \& No. & $\begin{array}{l}\text { DESGRIPTION AND } \\
\text { APPROX. DIMENSIONS }\end{array}$ & $\begin{array}{l}\text { ASSOCIATIONS AND } \\
\text { REMARKS }\end{array}$ & PUBLICATION \\
\hline $\begin{array}{l}\text { St. Mawgan- } \\
\text { in-Pyder }\end{array}$ & Cornwall & Truro & $\begin{array}{l}\text { Greenish-gold. Diam. } \\
2.5 \mathrm{~cm} . \text { Ht. } 7 \mathrm{~mm} \text {. } \\
\text { Perf. diam. } 1.2 \mathrm{~cm} \text {. }\end{array}$ & $\begin{array}{l}\text { This site (Carloggas) } \\
\text { occupied from the } \\
\text { Ist c. B.c. into the } \\
\text { Roman period }\end{array}$ & $\operatorname{Arf}$ cxiii ( $\left.195^{6}\right)$ \\
\hline $\begin{array}{l}\text { Trevelgue, St. } \\
\text { Columb Minor }\end{array}$ & Cornwall & Truro & $\begin{array}{l}\text { Yellow-green. Very } \\
\text { irregular. Diam. I } 6 \\
\mathrm{~cm} \text {. Perf. diam. } \\
9 \mathrm{~mm} \text {. }\end{array}$ & $\begin{array}{l}\text { From hill-fort, per- } \\
\text { haps ist c. B.C. or } \\
\text { earlier }\end{array}$ & $\begin{array}{l}\text { Awaiting publica- } \\
\text { tion. See notes in } \\
\text { Thomas, C. (ed.) } \\
(1966), 77-8\end{array}$ \\
\hline $\begin{array}{l}\text { Cadbury } \\
\text { Castle, } \\
\text { Bickleigh } \\
\text { Bridge }\end{array}$ & Devonshire & & $\begin{array}{l}\text { Dark blue-green. } \\
\text { Diam. I } 4 \mathrm{~cm} . \mathrm{Ht} \text {. } \\
9 \mathrm{~mm} . \text { Perf. diam. } \\
4 \mathrm{~mm} .\end{array}$ & $\begin{array}{l}\text { With } 3 \text { rd c. A.D. } \\
\text { Roman objects in a } \\
\text { well }\end{array}$ & $\begin{array}{l}P D A S \text { lxxxiv } \\
\left(195^{2}\right), \text { IO5-1 }^{-1}\end{array}$ \\
\hline $\begin{array}{l}\text { Bulbury } \\
\text { Camp } \\
\text { (or Belbury), } \\
\text { Lytchett } \\
\text { Minster }\end{array}$ & Dorset & Dorchester I 884.9 .1 I 3 & $\begin{array}{l}8 \text { beads in bright } \\
\text { greenish-gold varying } \\
\text { in diam. from } \mathrm{I} \cdot 2 \text { to } \\
2 \cdot 3 \mathrm{~cm} \text {. }\end{array}$ & $\begin{array}{l}\text { Pre-Roman site with } \\
\text { associated objects. } \\
\text { These beads were } \\
\text { found with a mirror, } \\
\text { etc., of early ist c. } \\
\text { A.D. The camp pro- } \\
\text { duced an iron anchor } \\
\text { of early Roman type. } \\
\text { For this variety of } \\
\text { glass, see p. I3 }\end{array}$ & $\begin{array}{l}A \text { xlviii (1884), } \\
\text { I } 6 \text {, and pl. vi, Io; } \\
\text { illustrated in } A n \mathcal{} \\
\text { lii }(1972), \text { pl. liv }\end{array}$ \\
\hline $\begin{array}{l}\text { Hengistbury } \\
\text { Head }\end{array}$ & Dorset & Southampton? & $\begin{array}{l}\text { Bright greenish-gold } \\
\text { Diam. } 2 \cdot 6 \mathrm{~cm} . \text { Ht. } \\
8 \mathrm{~mm} . \text { Perf. diam. } \\
\mathrm{I} \cdot 3 \mathrm{~cm} .\end{array}$ & $\begin{array}{l}\text { Apparently the same } \\
\text { glass as Bulbury } \\
\text { (Dorset), above. } \\
\text { Associated with } \\
\text { Dressel Type IA am- } \\
\text { phorae of and to mid- } \\
\text { Ist c. B.c. }\end{array}$ & $\begin{array}{l}\text { Information in } \\
\text { advance of } \\
\text { publication from } \\
\text { Dr. D. Peacock }\end{array}$ \\
\hline $\begin{array}{l}\text { Maiden } \\
\text { Castle, } \\
\text { Winterbourne } \\
\text { Monkton }\end{array}$ & Dorset & Dorchester & $\begin{array}{l}\text { Thick annular 'green } \\
\text { vitreous paste'. Diam. } \\
1 \cdot 9 \mathrm{~cm} . \mathrm{Ht} . \mathrm{I} \cdot 4 \mathrm{~cm} \text {. } \\
\text { Perf. diam. } 8 \mathrm{~mm} \text {. }\end{array}$ & $\begin{array}{l}\text { With pottery thought } \\
\text { to belong to early ist } \\
\text { c. B.c. (redated since } \\
\text { the report) }\end{array}$ & $M C, 292$, no. 4 \\
\hline $\begin{array}{l}\text { Portland } \\
\text { (The Verne) }\end{array}$ & Dorset & Dorchester I932.9.4 & $\begin{array}{l}\text { Light green. Diam. } \\
\mathrm{I} \cdot 5 \mathrm{~cm} \text {. Ht. } 4 \mathrm{~mm} \text {. } \\
\text { Perf. diam. } 9 \mathrm{~mm} \text {. }\end{array}$ & $\begin{array}{l}\text { From Romano-British } \\
\text { cemetery }\end{array}$ & \\
\hline Studland & Dorset & & $\begin{array}{l}\text { Said to be similar to } \\
\text { Maiden Castle }\end{array}$ & $\begin{array}{l}\text { From Romano-British } \\
\text { settlement }\end{array}$ & $\begin{array}{l}\text { PDNHAS lxxxvii } \\
(1965), \text { I } 93\end{array}$ \\
\hline Colchester & Essex & Colchester & $\begin{array}{l}2 \text { examples. One } \\
\text { greenish-brown: } \\
\text { diam. } 2 \cdot 2 \mathrm{~cm} \text {; ht. } \\
\text { I } \mathrm{cm} . ; \text { perf. diam. } \\
8 \mathrm{~mm} \text {. Another about } \\
\text { half this size }\end{array}$ & $\begin{array}{l}\text { Found with burial } \\
\text { group } 94 \text { on Roman } \\
\text { site. Dated from } \\
\text { associations } c \text {. } \\
\text { A.D. } 54-68 . \text { Per- } \\
\text { haps made of 'Bul- } \\
\text { bury' glass (see p. I 3). } \\
\text { (These groups are } \\
\text { entirely reliable) }\end{array}$ & $\begin{array}{l}\text { May, T. (I93o), } \\
\text { p. } 279\end{array}$ \\
\hline
\end{tabular}




\begin{tabular}{|c|c|c|c|c|c|}
\hline $\begin{array}{l}\text { SITE AND } \\
\text { PARISH }\end{array}$ & COUNTY & MUSEUM \& NO. & $\begin{array}{c}\text { DESCRIPTION AND } \\
\text { APPROX. DIMENSTONS }\end{array}$ & $\begin{array}{l}\text { ASSOCIATIONS AND } \\
\text { REMARKS }\end{array}$ & PUBLICATION \\
\hline Birdlip & $\begin{array}{l}\text { Gloucester- } \\
\text { shire }\end{array}$ & Cheltenham & $\begin{array}{l}\text { 'Bulbury' glass, } \\
\text { greenish gold. Diam. } \\
2 \cdot 4 \mathrm{~cm} \text {. Ht. irreg. } \\
7 \mathrm{~mm} \text {. Perf. diam. } \\
\text { I } 4 \mathrm{~cm} \text {. }\end{array}$ & $\begin{array}{l}\text { Stray find on slopes } \\
\text { of Birdlip hill }\end{array}$ & \\
\hline Bagendon & $\begin{array}{l}\text { Gloucester- } \\
\text { shire }\end{array}$ & & $\begin{array}{l}\text { Almost clear but } \\
\text { slightly greenish. } \\
\text { About } 1 / 3 \text { missing. } \\
\text { Diam. } 2 \cdot 7 \mathrm{~cm} \text {. Perf. } \\
\text { diam. I } 6 \mathrm{~cm} \text {. }\end{array}$ & $\begin{array}{l}\text { Stratified A.D. 10-50 } \\
\text { on Belgic site }\end{array}$ & $\begin{array}{l}\text { Clifford, E. M. } \\
(\mathrm{I} 96 \mathrm{I})\end{array}$ \\
\hline $\begin{array}{l}\text { Salmonsbury, } \\
\text { Bourton-on- } \\
\text { the-Water }\end{array}$ & $\begin{array}{l}\text { Gloucester- } \\
\text { shire }\end{array}$ & Cheltenham & $\begin{array}{l}\text { Translucent greenish- } \\
\text { gold like Bulbury, } \\
\text { Dorset. Diam. I } 7 \\
\mathrm{~cm} . \text { Ht. } 6 \mathrm{~mm} \text {. Perf. } \\
\text { diam. } 8 \mathrm{~mm} \text {. }\end{array}$ & $\begin{array}{l}\text { From } 2 \text { nd to ist c. } \\
\text { B.c. settlement. } \\
\text { 'Period I : not earlier } \\
\text { than I } 5 \text { o B.c.' }\end{array}$ & $\begin{array}{l}\text { Dunning, G. C., } \\
\text { 'Salmonsbury, } \\
\text { Bourton-on-the- } \\
\text { Water, Glou- } \\
\text { cestershire', in } \\
\text { Harding, D. W. } \\
\text { (ed.), Hillforts } \\
\text { (1976), p. I ro } \\
\text { and fig. } 24,6\end{array}$ \\
\hline Cirencester & $\begin{array}{l}\text { Gloucester- } \\
\text { shire }\end{array}$ & Cirencester Bgo8 & $\begin{array}{l}\text { Bright green. Diam. } \\
\text { I } 8 \mathrm{~cm} . \mathrm{Ht} .6 \mathrm{~mm} \text {. } \\
\text { Perf. diam. } 7 \mathrm{~mm} \text {. }\end{array}$ & $\begin{array}{l}\text { Collection from } \\
\text { Roman town }\end{array}$ & \\
\hline Kingscote & $\begin{array}{l}\text { Gloucester- } \\
\text { shire }\end{array}$ & & $\begin{array}{l}\text { Half bead, bright } \\
\text { greenish-gold. Diam. } \\
\text { c. I } 9 \mathrm{~cm} \text {. Ht. irreg. } \\
5 \mathrm{~mm} \text {. Perf. diam. } \\
\text { I } \cdot \text { I } \mathrm{cm} \text {. }\end{array}$ & $\begin{array}{l}\text { Surface find from } \\
\text { area with ist c. A.D. } \\
\text { objects (? Bulbury } \\
\text { type glass) }\end{array}$ & $\begin{array}{l}\text { Information from } \\
\text { Mr. R. Wichard }\end{array}$ \\
\hline Silchester & Hampshire & Reading & $\begin{array}{l}\text { Yellowish-green. } \\
\text { Diam. I } 8 \mathrm{~cm} . \mathrm{Ht} . \\
9 \mathrm{~mm} . \text { Perf. diam. } \\
7 \mathrm{~mm} .\end{array}$ & $\begin{array}{l}\text { Occupation from late } \\
\text { Iron Age to Roman } \\
\text { period }\end{array}$ & $\begin{array}{l}\text { For site see Boon, } \\
\text { G. C. (1957) }\end{array}$ \\
\hline Silchester & Hampshire & Reading & $\begin{array}{l}\text { Yellowish-green } \\
\text { radiating nicks from } \\
\text { the perforation in one } \\
\text { side. Diam. } 1 \cdot 9 \mathrm{~cm} \text {. } \\
\text { Ht. } 6 \mathrm{~mm} \text {. Perf. diam. } \\
4 \mathrm{~mm} \text {. }\end{array}$ & As above & As above \\
\hline Silchester & Hampshire & Reading & $\begin{array}{l}\text { Dark blue-green with } \\
\text { swirls of iridescence. } \\
\text { Diam. } 2 \mathrm{~cm} . \mathrm{Ht} .9 \mathrm{~mm} \text {. } \\
\text { Perf. diam. } 8 \mathrm{~mm} \text {. }\end{array}$ & As above & As above \\
\hline Worthy Down & Hampshire & Winchester & $\begin{array}{l}\text { Bright greenish-gold. } \\
\text { Diam. } 2 \cdot 4 \mathrm{~cm} . \text { Ht. } \\
7 \mathrm{~mm} \text {. Perf. diam. } \\
\mathrm{r} \cdot 3 \mathrm{~cm} .\end{array}$ & $\begin{array}{l}\text { Upcast from pit in } \\
\text { Iron Age settlement }\end{array}$ & $\begin{array}{l}\text { PHFCAS x (1926- } \\
30), \text { i } 78 \mathrm{ff} \text {. and } \\
\text { fig. } 87\end{array}$ \\
\hline Kenchester & Herefordshire & Hereford & $\begin{array}{l}\text { Half. Translucent } \\
\text { greenish. Diam. I } 6 \\
\mathrm{~cm} . \text { Ht. } 6 \mathrm{~mm} \text {. Perf. } \\
\text { diam. } 6 \mathrm{~mm} .\end{array}$ & $\begin{array}{l}\text { From Roman town } \\
\text { occupied until end of } \\
4^{\text {th } \text { C. A.D. }}\end{array}$ & $\begin{array}{l}\text { For site see } \\
\text { TWNFC I916 and } \\
{ }_{1926} 6\end{array}$ \\
\hline
\end{tabular}




\begin{tabular}{|c|c|c|c|c|c|}
\hline $\begin{array}{l}\text { SITE AND } \\
\text { PARISH }\end{array}$ & GOUNTY & MUSEUM \& NO. & $\begin{array}{l}\text { DESCRIPTION AND } \\
\text { APPROX. DIMENSIONS }\end{array}$ & $\begin{array}{l}\text { ASSOCIATIONS AND } \\
\text { REMARKS }\end{array}$ & PUBLICATION \\
\hline St. Albans & Hertfordshire & Verulamium I4I & $\begin{array}{l}\text { Half bead, medium } \\
\text { green and rather } \\
\text { globular. Diam. I } 5 \\
\mathrm{~cm} . \mathrm{Ht} \text {. I cm. Perf. } \\
\text { diam. } 6 \mathrm{~mm} \text {. }\end{array}$ & $\begin{array}{l}\text { From site of } \\
\text { Verulamitum }\end{array}$ & Ver \\
\hline St. Albans & Hertfordshire & $\begin{array}{l}\text { Verulamium } 1633 . \\
360\end{array}$ & $\begin{array}{l}\text { Greenish-gold. Diam. } \\
2 \cdot 2 \mathrm{~cm} \text {. Ht. irregular } \\
8 \mathrm{~mm} \text {. Perf. diam. } \\
\mathrm{I} \cdot \mathrm{I} \mathrm{cm} .\end{array}$ & & \\
\hline St. Albans & Hertfordshire & Verulamium 33.767 & $\begin{array}{l}\text { Lighter green. Diam. } \\
\text { I. } 8 \mathrm{~cm} . \text { Ht. } 8 \mathrm{~mm} . \\
\text { Perf. diam. } 9 \mathrm{~mm} .\end{array}$ & & Ver, $113-20$ \\
\hline St. Albans & Hertfordshire & Verulamium & $\begin{array}{l}\text { Green, accidentally } \\
\text { streaked with purple. } \\
\text { Diam. I } \cdot 7 \mathrm{~cm} . \mathrm{Ht} \text {. } \\
8 \mathrm{~mm} . \text { Irregular } \\
\text { perforation. }\end{array}$ & Stratified A.D. $105^{-1} 5$ & Frere, S. (1972) \\
\hline Richborough & Kent & $\begin{array}{l}\text { Richborough } 1294 \\
\& 3920\end{array}$ & $\begin{array}{l}\text { Both about } \mathrm{I} \cdot 7 \mathrm{~cm} \text {. } \\
\text { in diam. and } 5 \mathrm{~mm} \text {. } \\
\text { high. Perf. diam. } 9 \\
\text { and } 5 \mathrm{~mm} .\end{array}$ & $\begin{array}{l}\text { Unstratified in Roman } \\
\text { and Saxon fort }\end{array}$ & Rich iv, 259 \\
\hline $\begin{array}{l}\text { Dowgate Hill, } \\
\text { London }\end{array}$ & London & $\begin{array}{l}\text { Formley Guildhall } \\
\text { Museum } 3964\end{array}$ & 2 examples & Old sporadic finds & Unpublished \\
\hline Wallbrook & London & $\begin{array}{l}\text { Formerly Guildhall } \\
\text { Museum I } 8643\end{array}$ & $\begin{array}{l}\text { Semi-translucent. } \\
\text { Diam. } 2 \mathrm{~cm} . \mathrm{Ht} .7 \\
\text { mm. Perf. diam. } 7 \mathrm{~mm} \text {. }\end{array}$ & Dated late ist c. A.D. & \\
\hline Wallbrook & London & $\begin{array}{l}\text { Formerly Guildhall } \\
\text { Museum I } 8643\end{array}$ & $\begin{array}{l}\text { Pale yellowish-green. } \\
\text { Diam. I } .8 \mathrm{~cm} . \mathrm{Ht} . \\
\text { I } \mathrm{cm} . \text { Perf. diam. } \\
7 \mathrm{~mm} \text {. }\end{array}$ & $\begin{array}{l}\text { No details. Could be } \\
\text { classified 'as bottle } \\
\text { glass' }\end{array}$ & \\
\hline $\begin{array}{l}\text { Hunsbury, } \\
\text { Harding- } \\
\text { stone }\end{array}$ & $\begin{array}{l}\text { Northampton- } \\
\text { shire }\end{array}$ & Northampton & $\begin{array}{l}2 \text { large, light green. } \\
\text { Diams. } 2 \cdot 5 \text { and } 2 \cdot 8 \\
\mathrm{~cm} . \mathrm{Ht} .6 \mathrm{~mm} \text {. Perf. } \\
\text { diam. } 1 \cdot 4 \text { and } 1 \cdot 7 \\
\mathrm{~cm} . \text { Two larger and } \\
\text { yellow }\end{array}$ & $\begin{array}{l}\text { From Iron Age fort. } \\
\text { Not stratified. Prob- } \\
\text { ably ist c. B.c. } \\
\text { (Occupation } c .4^{\text {th }} \\
\text { c.-Ist c. B.c. or early } \\
\text { Ist c. A.D.) }\end{array}$ & $\begin{array}{l}\text { Fell, C. (1936), } \\
\text { p. } 69\end{array}$ \\
\hline $\begin{array}{l}\text { Hunsbury, } \\
\text { Harding- } \\
\text { stone }\end{array}$ & $\begin{array}{l}\text { Northampton- } \\
\text { shire }\end{array}$ & Northampton & $\begin{array}{l}\text { Clear yellowish- } \\
\text { brown. Diam. } 2 \cdot 5 \\
\mathrm{~cm} . \mathrm{Ht} .6 \mathrm{~mm} . \text { Perf. } \\
\text { diam. } 1.4 \mathrm{~cm} .\end{array}$ & $\begin{array}{l}\text { From pre-Roman } \\
\text { fort perhaps ist c. } \\
\text { B.c. (Fort occupied } \\
\text { c. } 300 \text { B.c.--early ist c. } \\
\text { A.D.) }\end{array}$ & $\begin{array}{l}\text { Fell, C. (1936), } \\
\text { p. } 69\end{array}$ \\
\hline Irchester & $\begin{array}{l}\text { Northampton- } \\
\text { shire }\end{array}$ & $\begin{array}{l}\text { c/o Dept. of } \\
\text { Environment }\end{array}$ & $\begin{array}{l}\text { Striated round } \\
\text { perimeter. Semi- } \\
\text { translucent. Diam. } \\
2 \mathrm{~cm} . \text { Ht. } 8 \mathrm{~mm} . \\
\text { Perf. diam. } 8 \mathrm{~mm} \text {. }\end{array}$ & $\begin{array}{l}\text { Probably Iron Age } \\
\text { B or early Belgic. } \\
\text { 'Bulbury' type glass }\end{array}$ & $\begin{array}{l}\text { Arf cxxiv (1967), } \\
65\end{array}$ \\
\hline
\end{tabular}




\begin{tabular}{|c|c|c|c|c|c|}
\hline $\begin{array}{l}\text { SITE AND } \\
\text { PARISH }\end{array}$ & COUNTY & MUSEUM \& NO. & $\begin{array}{l}\text { DESGRIPTION AND } \\
\text { APPROX. DIMENSIONS }\end{array}$ & $\begin{array}{l}\text { ASSOCIATIONS AND } \\
\text { REMARKS }\end{array}$ & PUBLICATION \\
\hline Corbridge & $\begin{array}{l}\text { Northumber- } \\
\text { land }\end{array}$ & Corstopitum & $\begin{array}{l}\text { Almost opaque } \\
\text { greenish-brown. } \\
\text { Diam. I } 6 \mathrm{~cm} . \mathrm{Ht} . \\
6 \mathrm{~mm} . \text { Perf. diam. } \\
7 \mathrm{~mm} .\end{array}$ & $\begin{array}{l}\text { Roman site occupied } \\
\text { ist-5th c. A.D. }\end{array}$ & \\
\hline $\begin{array}{l}\text { 'Rochester } \\
\text { and Alnham' }\end{array}$ & $\begin{array}{l}\text { Northumber- } \\
\text { land }\end{array}$ & Chesters Museum & $\begin{array}{l}\text { Greenish-gold. Diam. } \\
2 \mathrm{~cm} . \text { Ht. } 9 \mathrm{~mm} \text {. Perf. } \\
\text { diam. } 7 \mathrm{~mm} \text {. }\end{array}$ & $\begin{array}{l}\text { Almost surely Roman } \\
\text { and same glass as a } \\
\text { bead with yellow } \\
\text { scrabble from } \\
\text { Carrawburgh dated } \\
\text { c. A.D. I } 22-383\end{array}$ & \\
\hline Newark & $\begin{array}{l}\text { Nöttingham- } \\
\text { shire }\end{array}$ & Newark & $\begin{array}{l}\text { Light green. Diam. } \\
\text { about I. } 8 \mathrm{~cm} . \text { Ht. } \\
\text { not seen. Perf. diam. } \\
6 \mathrm{~mm} .\end{array}$ & $\begin{array}{l}\text { Presented by } R \text {. } \\
\text { Woolley }\end{array}$ & \\
\hline $\begin{array}{l}\text { Clungunford, } \\
\text { Brand Hill }\end{array}$ & Shropshire & Clun & $\begin{array}{l}\text { Olive green. Hour- } \\
\text { glass perforation. } \\
\text { Diam. } 2.5 \mathrm{~cm} \text {. Perf. } \\
\text { diam. on surface } \\
8 \mathrm{~mm} \text {. }\end{array}$ & $\begin{array}{l}\text { On Clun-Clee } \\
\text { Ridgeway. Surface } \\
\text { find }\end{array}$ & $\begin{array}{l}\text { Information from } \\
\text { Miss L. F. Chitty }\end{array}$ \\
\hline Glastonbury & Somerset & $\begin{array}{l}\text { Glastonbury Lake } \\
\text { Village Museum } \mathrm{G}_{4}\end{array}$ & $\begin{array}{l}\text { Bright yellowish- } \\
\text { brown. Diam. } 2 \cdot 2 \\
\mathrm{~cm} \text {. Ht. } 6 \mathrm{~mm} . \text { Perf. } \\
\text { diam. } 1 \cdot 4 \mathrm{~cm} .\end{array}$ & $\begin{array}{l}\text { From Lake Village of } \\
\text { pre-Roman Iron Age }\end{array}$ & $G l$ ii \\
\hline Meare & Somerset & Taunton G6EV & $\begin{array}{l}\text { Attached to bronze } \\
\text { ring. Translucent } \\
\text { brownish-yellow. } \\
\text { Diam. I } 9 \mathrm{~cm} \text {. Ht. } \\
6 \mathrm{~mm} \text {. Perf. diam. } \\
9 \mathrm{~mm} \text {. }\end{array}$ & $\begin{array}{l}\text { From East village of } \\
\text { Iron Age site occu- } \\
\text { pied c. 3rd-Ist c. B.c. }\end{array}$ & $M e \mathrm{iii}$ \\
\hline Meare & Somerset & Taunton $\mathrm{G}_{9}$ & $\begin{array}{l}\text { Dark greenish-gold. } \\
\text { Diam. } 2 \mathrm{~cm} . \text { Ht. I } \\
\mathrm{cm} . \text { Perf. diam. } 9 \mathrm{~mm} .\end{array}$ & $\begin{array}{l}\text { From East village of } \\
\text { Iron Age site occu- } \\
\text { pied } c .3^{\mathrm{rd}-\text { Ist c. B.C. }}\end{array}$ & $M e$ iii \\
\hline 'Mendip' & Somerset & $\begin{array}{l}\text { Bristol F2073, } \\
\text { A. C. Pass Colln. }\end{array}$ & $\begin{array}{l}\text { Rather light green. } \\
\text { Diam. } 2 \cdot \mathrm{cm} . \mathrm{Ht} \text {. } \\
7 \mathrm{~mm} . \text { Perf. diam. } \\
8 \mathrm{~mm} .\end{array}$ & $\begin{array}{l}\text { A number of Roman } \\
\text { beads from here }\end{array}$ & \\
\hline Wetton & Staffordshire & Derby $178.12 .{ }^{\prime} 29$ & $\begin{array}{l}\text { Diam. I } 6 \mathrm{~cm} . \mathrm{Ht} . \\
6 \mathrm{~mm} . \text { Perf. diam. } \\
5 \mathrm{~mm} .\end{array}$ & $\begin{array}{l}\text { From 'Thor's Cave' } \\
\text { with Roman objects } \\
\text { of } 2 \text { nd c. A.D. }\end{array}$ & \\
\hline Mildenhall & Wiltshire & Devizes I 26 & $\begin{array}{l}\text { Opaque grey-green } \\
\text { ring-bead. Diam. } \\
2 \cdot 1 \mathrm{~cm} \text {. Perf. diam. } \\
\mathrm{I} \cdot 3 \mathrm{~cm} \text {. }\end{array}$ & $\begin{array}{l}\text { Roman and Saxon } \\
\text { finds from this site }\end{array}$ & \\
\hline Brough & Yorkshire & Hull & $\begin{array}{l}\text { Badly made opaque } \\
\text { greenish-brown. } \\
\text { Diam. I } 7 \mathrm{~cm} . \mathrm{Ht} \text {. } \\
7 \mathrm{~mm} . \text { Perf. diam. } \\
6 \mathrm{~mm} .\end{array}$ & $\begin{array}{l}\text { Roman and Anglian } \\
\text { finds from this site }\end{array}$ & \\
\hline
\end{tabular}


I5O GLASS BEADS OF THE PREHISTORIG AND ROMAN PERIODS

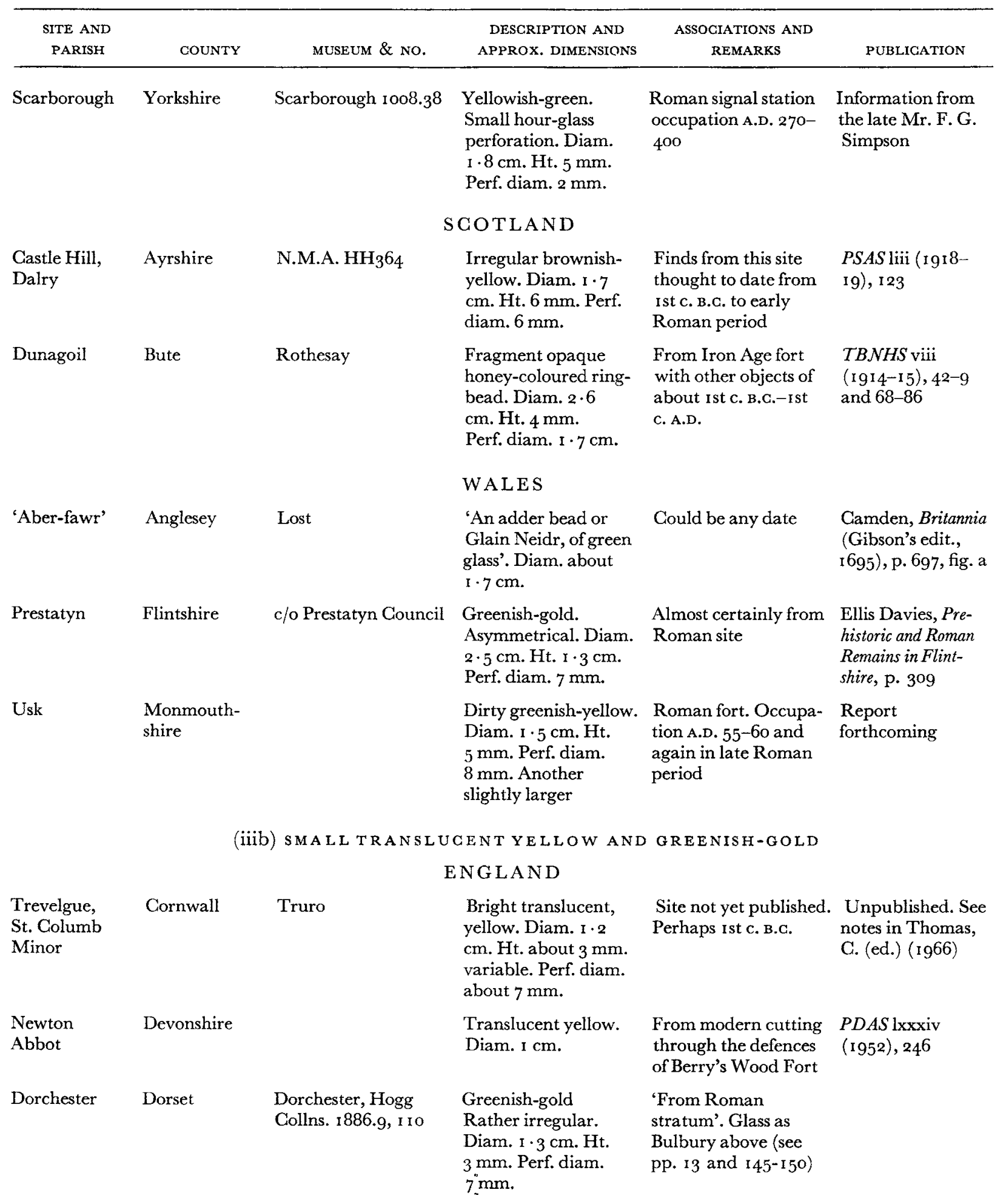




\begin{tabular}{|c|c|c|c|c|c|}
\hline $\begin{array}{l}\text { SITE AND } \\
\text { PARISH }\end{array}$ & COUNTY & MUSEUM \& NO. & $\begin{array}{l}\text { DESCRIPTION AND } \\
\text { APPROX, DIMENSIONS }\end{array}$ & $\begin{array}{l}\text { ASSOCIATIONS AND } \\
\text { REMARKS }\end{array}$ & PUBLICATION \\
\hline $\begin{array}{l}\text { The Verne, } \\
\text { Portland }\end{array}$ & Dorset & $\begin{array}{l}\text { Dorchester } 193^{2.5} \\
6,7\end{array}$ & $\begin{array}{l}\text { Three beads. } \\
\text { Greenish-gold. Diam. } \\
9 \mathrm{~mm} . \text { Ht. } 3 \mathrm{~mm} . \\
\text { Perf. diam. about } \\
4 \mathrm{~mm} .\end{array}$ & $\begin{array}{l}\text { From a Romano- } \\
\text { British cemetery. } \\
\text { Glass appears to be } \\
\text { similar to Bulbury } \\
\text { Camp (see above and } \\
\text { p. I3) }\end{array}$ & \\
\hline $\begin{array}{l}\text { Bredon, } \\
\text { Bredon's } \\
\text { Norton }\end{array}$ & $\begin{array}{l}\text { Gloucester- } \\
\text { shire- } \\
\text { Worcester- } \\
\text { shire } \\
\text { border }\end{array}$ & $\begin{array}{l}\text { Private museum at } \\
\text { Overbury Court }\end{array}$ & $\begin{array}{l}\text { Yellowish. Diam. I } \\
\mathrm{cm} . \text { Ht. } 4 \mathrm{~mm} \text {. Perf. } \\
\text { diam. } 3 \mathrm{~mm} \text {. }\end{array}$ & $\begin{array}{l}\text { Last period of inner } \\
\text { entrance of pre- } \\
\text { Roman hill-fort. } \\
\text { Suggested date early } \\
\text { or mid-ist c. A.D. }\end{array}$ & $\operatorname{Ar} \mathcal{J} \times c v\left(\mathbf{r}^{8} 8\right), 86$ \\
\hline $\begin{array}{l}\text { Winchester, } \\
\text { Lankhills } \\
\text { Cemetery }\end{array}$ & Hampshire & & $\begin{array}{l}\text { Yellow translucent. } \\
\text { Diam. } 4 \mathrm{~mm} \text {. }\end{array}$ & 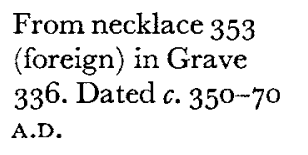 & $\begin{array}{l}\text { Guido, M. } \\
\text { (forthcoming) in } \\
\text { Biddle, M. } \\
\text { (forthcoming) }\end{array}$ \\
\hline $\begin{array}{l}\text { Weston- } \\
\text { under- } \\
\text { Penyard, } \\
\text { Bollitree }\end{array}$ & Herefordshire & Gloucester I $75^{6}$ & $\begin{array}{l}\text { Yellowish-green } \\
\text { slightly biconical. } \\
\text { Diam. I } 2 \mathrm{~cm} . \mathrm{Ht} . \\
3 \mathrm{~mm} . \text { Perf. diam. } \\
6 \mathrm{~mm} .\end{array}$ & From Roman context & $\begin{array}{l}7 B A A \times x v i i \\
(187 \text { I }), 2 \text { I I ff. }\end{array}$ \\
\hline $\begin{array}{l}\text { St. Albans, } \\
\text { King Harry's } \\
\text { Lane }\end{array}$ & Hertfordshire & Verulamium & $\begin{array}{l}2 \text { greenish-gold } \\
\text { beads about } \mathrm{x} \cdot 4 \mathrm{~cm} \text {. } \\
\text { diam. Wide per- } \\
\text { forations }\end{array}$ & $\begin{array}{l}\text { From necklace on } \\
\text { Burial } 29 \text { of Aylesford } \\
\text { type cemetery dated } \\
\text { c. Io B.C.-A.D. } 40 \text {. } \\
\text { This glass is like that } \\
\text { from Bulbury Camp, } \\
\text { Dorset (p. I } 3 \text { ) }\end{array}$ & $\begin{array}{l}\text { Information from } \\
\text { Dr. I. M. Stead }\end{array}$ \\
\hline Dowgate Hill & London & $\begin{array}{l}\text { Formerly Guildhall } \\
\text { Museum } 3964\end{array}$ & $\begin{array}{l}\text { Greenish-yellow. } \\
\text { Diam. I } 4 \mathrm{~cm} . \mathrm{Ht} . \\
4 \mathrm{~mm} \text {. Perf. diam. } \\
5 \mathrm{~mm} .\end{array}$ & Stray find & Unpublished \\
\hline Corbridge & $\begin{array}{l}\text { Northumber- } \\
\text { land }\end{array}$ & $\begin{array}{l}\text { Corstopitum } \\
\text { Museum }\end{array}$ & $\begin{array}{l}\text { Translucent } \\
\text { yellowish-brown. } \\
\text { Diam. } 8 \mathrm{~mm} \text {. Ht. } 2 \\
\text { mm. Perf. diam. } \\
4 \mathrm{~mm} .\end{array}$ & $\begin{array}{l}\text { Roman site occupied } \\
\text { from ist- } 5^{\text {th }} \text { C. A.D. }\end{array}$ & \\
\hline Mendip & Somerset & $\begin{array}{l}\text { A. C. Pass Colln. } \\
\text { Bristol F2075 }\end{array}$ & $\begin{array}{l}\text { Shiny yellowish. } \\
\text { Roughly made, } \\
\text { perhaps coiled. Diam. } \\
\text { I } 2 \text { cm. Ht. irregular. } \\
\text { Small perforation }\end{array}$ & $\begin{array}{l}\text { Stray find with other } \\
\text { Roman beads }\end{array}$ & \\
\hline Baginton & Warwickshire & $\begin{array}{l}\text { Coventry, Herbert } \\
\text { Art Gallery and } \\
\text { Museum }\end{array}$ & $\begin{array}{l}\text { Yellowish-green. } \\
\text { Slightly flattened } \\
\text { around perforation. } \\
\text { Diam. I } 4 \mathrm{~cm} \text {. Ht. } \\
5 \mathrm{~mm} \text {. Perf. diam. } \\
8 \mathrm{~mm} .\end{array}$ & $\begin{array}{l}\text { From The Lunt } \\
\text { Roman fort. (Lower } \\
\text { fill of pit II) }\end{array}$ & $\begin{array}{l}\text { PCNHHS ii, no. } 5 \\
(195 \mathrm{I})\end{array}$ \\
\hline
\end{tabular}


I52 GLASS BEADS OF THE PREHISTORIG AND ROMAN PERIODS

\begin{tabular}{|c|c|c|c|c|c|}
\hline $\begin{array}{l}\text { SITE AND } \\
\text { PARISH }\end{array}$ & COUNTY & MUSEUM \& No. & $\begin{array}{l}\text { DESCRIPTION AND } \\
\text { APPROX. DIMENSIONS }\end{array}$ & $\begin{array}{l}\text { ASSOCIATIONS AND } \\
\text { REMARKS }\end{array}$ & PUBLICATION \\
\hline \multicolumn{6}{|c|}{ SGOTLAND } \\
\hline Mousewald & $\begin{array}{l}\text { Dumfries- } \\
\text { shire }\end{array}$ & N.M.A. FJ 44 & $\begin{array}{l}\text { Rather globular. } \\
\text { Reddish-yellow. } \\
\text { Diam. } 1 \cdot 3 \mathrm{~cm} . \mathrm{Ht} \text {. } \\
6 \mathrm{~mm} \text {. irregular. } \\
\text { Small perforation }\end{array}$ & $\begin{array}{l}\text { Stray find perhaps } \\
\text { unrelated to this series }\end{array}$ & \\
\hline \multirow[t]{2}{*}{ Covesea } & Morayshire & N.M.A. HM2 4 & $\begin{array}{l}\text { Light yellowish- } \\
\text { green. Diam. I. } 2 \mathrm{~cm} \text {. } \\
\text { Ht. } 4 \mathrm{~mm} \text {. Perf. diam. } \\
6 \mathrm{~mm} .\end{array}$ & $\begin{array}{l}\text { 2nd c. A.D. imported } \\
\text { glass from here }\end{array}$ & $\begin{array}{l}P S A S \operatorname{lxv}(1931), \\
177\end{array}$ \\
\hline & & & WALES & & \\
\hline $\begin{array}{l}\text { Whitton, } \\
\text { nr. Barry }\end{array}$ & $\begin{array}{l}\text { Glamorgan- } \\
\text { shire }\end{array}$ & & $\begin{array}{l}\text { Pale greenish-yellow. } \\
\text { Diam. } 9 \mathrm{~mm} \text {. Ht. } \\
2 \mathrm{~mm} \text {. Perf. diam. } \\
5 \mathrm{~mm} .\end{array}$ & $\begin{array}{l}\text { Unstratified in pre- } \\
\text { Roman and Roman } \\
\text { site }\end{array}$ & $\begin{array}{l}\text { Report by Dr. } \\
\text { M. Jarrett } \\
\text { (forthcoming) }\end{array}$ \\
\hline \multirow[t]{3}{*}{$\begin{array}{l}\text { The Breiddin } \\
\text { hill-fort }\end{array}$} & $\begin{array}{l}\text { Montgomery- } \\
\text { shire }\end{array}$ & & $\begin{array}{l}\text { Very pale translucent } \\
\text { yellow. Diam. } 7 \mathrm{~mm} \text {. } \\
\text { Ht. } 3 \mathrm{~mm} \text {. Perf. } \\
\text { diam. } 3 \mathrm{~mm} \text {. One } \\
\text { flattened surface }\end{array}$ & $\begin{array}{l}\text { Unstratified in hill- } \\
\text { fort occupied from } \\
\text { mid-Iron Age to } 4 \text { th } \\
\text { c. A.D. }\end{array}$ & $\begin{array}{l}\text { Information from } \\
\text { Mr. Chris } \\
\text { Musson }\end{array}$ \\
\hline & (iva) & MEDIUM SIZED B & \multirow{2}{*}{\multicolumn{2}{|c|}{ BLUE (TRANSLUGENT IF NOT STATED) }} & \\
\hline & & & & & \\
\hline $\begin{array}{l}\text { Yewden, } \\
\text { Hambledon }\end{array}$ & $\begin{array}{l}\text { Buckingham- } \\
\text { shire }\end{array}$ & Aylesbury & $\begin{array}{l}\text { Medium blue. Stria- } \\
\text { tion in the glass } \\
\text { around the circum- } \\
\text { ference on the sides. } \\
\text { Diam. I } 8 \mathrm{~cm} . \mathrm{Ht} \text {. } \\
6 \mathrm{~mm} \text {. Perf. diam. } \\
8 \mathrm{~mm} \text {. }\end{array}$ & $\begin{array}{l}\text { From Roman villa } \\
\text { occupied throughout } \\
\text { the Roman period }\end{array}$ & $A$ lxxi (1921) \\
\hline $\begin{array}{l}\text { Trelan Bahow, } \\
\text { and } \\
\text { St. Keverne }\end{array}$ & Cornwall & B.M. & $\begin{array}{l}\text { One bright cobalt, } \\
\text { and another greyer. } \\
\text { Both diams. about } \\
2.2 \mathrm{~cm} . \text { Perf. diam. } \\
1 \mathrm{~cm} .\end{array}$ & $\begin{array}{l}\text { With a mirror, etc., } \\
\text { of ist C. A.D. }\end{array}$ & $\begin{array}{l}\text { Hencken, H.O'N., } \\
\text { Archaeology of } \\
\text { Cornwall, p. I } 20 \text { and } \\
\text { Arf xxx (1873), } \\
267\end{array}$ \\
\hline Burnt Fen & $\begin{array}{l}\text { Cambridge- } \\
\text { shire }\end{array}$ & C.M. & $\begin{array}{l}\text { Mixed grey-blue and } \\
\text { greenish-blue, } \\
\text { opaque. Diam. } 2 \cdot 2 \\
\mathrm{~cm} . \mathrm{Ht} .8 \mathrm{~mm} . \text { Perf. } \\
\text { diam. } 8 \mathrm{~mm} \text {. }\end{array}$ & $\begin{array}{l}\text { For similar glass see } \\
\text { Great Chesterford } \\
\text { (below). The same } \\
\text { site produced a bead } \\
\text { of Oldbury type } \\
\text { (Class 6) }\end{array}$ & \\
\hline $\begin{array}{l}\text { Great } \\
\text { Chesterford }\end{array}$ & $\begin{array}{l}\text { Cambridge- } \\
\text { shire }\end{array}$ & C.M. & $\begin{array}{l}\text { Glass as Burnt Fen } \\
\text { above. Diam. } 2 \mathrm{~cm} \text {. } \\
\mathrm{Ht} .8 \mathrm{~mm} . \text { Perf. diam. } \\
7 \mathrm{~mm} \text {. }\end{array}$ & $\begin{array}{l}\text { Probably pre-Roman } \\
\text { or early Roman }\end{array}$ & \\
\hline \multicolumn{2}{|c|}{ Cumberland } & Carlisle & $\begin{array}{l}\text { Medium cobalt. } \\
\text { Diam. I } 7 \mathrm{~cm} . \mathrm{Ht} . \\
5 \mathrm{~mm} \text {. Perf. diam. } \\
9 \mathrm{~mm} \text {. irregular }\end{array}$ & $\begin{array}{l}\text { No evidence of } \\
\text { association }\end{array}$ & \\
\hline
\end{tabular}




\begin{tabular}{|c|c|c|c|c|c|}
\hline $\begin{array}{l}\text { SITE AND } \\
\text { PARISH }\end{array}$ & GOUNTY & MUSEUM \& NO. & $\begin{array}{l}\text { DESCRIPTION AND } \\
\text { APPROX, DIMENSIONS }\end{array}$ & $\begin{array}{l}\text { ASSOCIATIONS AND } \\
\text { REMARKS }\end{array}$ & PUBLICATION \\
\hline Sormerleigh & Dorset & Dorchester I893.2.I I & $\begin{array}{l}\text { Drab grey-blue. } \\
\text { Diam. } 2 \mathrm{~cm} . \mathrm{Ht} . \mathrm{I} \cdot 3 \\
\mathrm{~cm} . \text { Perf. diam. } 9 \mathrm{~mm} \text {. }\end{array}$ & $\begin{array}{l}\text { The rather globular } \\
\text { form of this bead } \\
\text { suggests that it may } \\
\text { belong to the Dark Ages }\end{array}$ & \\
\hline South Shields & Durham & $\begin{array}{l}\text { University Museum, } \\
\text { Newcastle-upon- } \\
\text { Tyne }\end{array}$ & $\begin{array}{l}\text { Rather light blue. } \\
\text { Diam. I } 8 \mathrm{~cm} \text {. Perf. } \\
\text { diam. } 7 \mathrm{~mm} \text {. }\end{array}$ & $\begin{array}{l}\text { From Roman fort } \\
\text { occupied about A.D. } \\
\text { 1 } 22-369\end{array}$ & \\
\hline Cirencester & $\begin{array}{l}\text { Gloucester- } \\
\text { shire }\end{array}$ & Cirencester Bgo8 & $\begin{array}{l}\text { Diam. about I } .8 \mathrm{~cm} \text {. } \\
\text { Ht. } 8 \mathrm{~mm} . \text { Perf. } \\
\text { diam. } 7 \mathrm{~mm} .\end{array}$ & $\begin{array}{l}\text { Roman occupation } \\
\text { Ist-5th c. A.D. }\end{array}$ & \\
\hline Micheldever & Hampshire & B.M. $63 \cdot$ I -20.6 & $\begin{array}{l}\text { Light blue with } \\
\text { bubbly surface. } \\
\text { Diam. } 2 \mathrm{~cm} \text {. Ht. } \\
9 \mathrm{~mm} . \text { irregular. Perf. } \\
\text { diam. } 6 \mathrm{~mm} \text {. }\end{array}$ & $\begin{array}{l}\text { Rather globular in } \\
\text { form. The bead came } \\
\text { from a site which also } \\
\text { produced a Dark Agc } \\
\text { bead and may be of } \\
\text { the same period }\end{array}$ & \\
\hline Silchester & Hampshire & Reading & $\begin{array}{l}\text { Light blue. Diam. } \\
\mathrm{I} \cdot 7 \mathrm{~cm} . \mathrm{Ht} .4 \mathrm{~mm} . \\
\text { Perf. diam. } 9 \mathrm{~mm} .\end{array}$ & $\begin{array}{l}\text { Roman occupation } \\
\text { Ist-5th C. A.D. }\end{array}$ & $\begin{array}{l}\text { For site see Boon, } \\
\text { G. C. (1957) }\end{array}$ \\
\hline $\begin{array}{l}\text { Weston- } \\
\text { under- } \\
\text { Penyard, } \\
\text { Bollitree }\end{array}$ & Herefordshire & Gloucester A 1757 & $\begin{array}{l}\text { Bright dark cobalt. } \\
\text { Diam. } 1 \cdot 9 \mathrm{~cm} . \text { Ht. } \\
5 \mathrm{~mm} . \text { Perf. diam. } \\
8 \mathrm{~mm} .\end{array}$ & $\begin{array}{l}\text { With many other } \\
\text { Roman beads }\end{array}$ & $\begin{array}{l}\mathcal{J B A A} \text { xxvii } \\
(\text { ( } 871), 2 \text { I I ff. }\end{array}$ \\
\hline St. Albans & Hertfordshire & $\begin{array}{l}\text { Verulamium } \\
\text { Museum } 33.275\end{array}$ & $\begin{array}{l}\text { Medium blue. Diam. } \\
\mathrm{I} \cdot 8 \mathrm{~cm} . \text { Ht. } 8 \mathrm{~mm} \text {. } \\
\text { irregular. Perf. } \\
\text { diam. } 9 \mathrm{~mm} .\end{array}$ & & \\
\hline $\begin{array}{l}\text { Breedon-on- } \\
\text { the-Hill }\end{array}$ & Leicestershire & Leicester & $\begin{array}{l}\text { Opaque dark blue. } \\
\text { Straight perforation. } \\
\text { Diam. } c .2 \cdot 5 \mathrm{~cm} \text {. Ht. } \\
\text { I } \mathrm{cm} . \text { Perf. diam. } \mathrm{I} \cdot 2 \\
\mathrm{~cm} .\end{array}$ & $\begin{array}{l}\text { With Iron Age } \\
\text { pottery in a pit }\end{array}$ & $\begin{array}{l}\text { TLAHS xxvi } \\
\text { (r } 950 \text { ), } 39 \text { and } \\
\text { fig. } 7, \text { no. } 3\end{array}$ \\
\hline $\begin{array}{l}\text { Leicester } \\
\text { (Jewry Wall) }\end{array}$ & Leicestershire & Leicester & $\begin{array}{l}\text { Pale blue. Diam. } \\
2 \mathrm{~cm} . \text { Ht. } 7 \mathrm{~mm} . \\
\text { Perf. diam. } 8 \mathrm{~mm} \text {. }\end{array}$ & $\begin{array}{l}\text { From disturbed levels } \\
\text { but a similar bead } \\
\text { was stratified } c \text {. A.D. } \\
\text { I } 80\end{array}$ & $\begin{array}{l}\text { Kenyon, K. M. } \\
\left.\text { (I } 94^{8}\right) \text {, p. } 269 \text {, } \\
\text { fig. } 93 . \text { I }\end{array}$ \\
\hline Risby Warren & Lincolnshire & Scunthorpe Io6 & $\begin{array}{l}\text { Half only. Rather } \\
\text { light cobalt. Diam. } \\
\text { I } 8 \mathrm{~cm} . \mathrm{Ht} .7 \mathrm{~mm} \text {. } \\
\text { Perf. diam. I } \mathrm{cm} .\end{array}$ & $\begin{array}{l}\text { Site produced mostly } \\
\text { Romano-British } \\
\text { finds }\end{array}$ & \\
\hline Corbridge & $\begin{array}{l}\text { Northumber- } \\
\text { land }\end{array}$ & Corstopitum $\mathrm{P}_{5}$ or & $\begin{array}{l}\text { Rather light cobalt. } \\
\text { Diam. } 2 \mathrm{~cm} . \mathrm{Ht} \text {. } \\
8 \mathrm{~mm} \text {. irregular. } \\
\text { Perf. diam. } 7 \mathrm{~mm} \text {. }\end{array}$ & $\begin{array}{l}\text { Occupation through- } \\
\text { out the Roman period }\end{array}$ & \\
\hline $\begin{array}{l}\text { Alchester } \\
\text { (Wendlebury) }\end{array}$ & Oxfordshire & A.M. 1930.603 & $\begin{array}{l}\text { Light translucent } \\
\text { cobalt with striated } \\
\text { surface. Diam. I } 6 \\
\mathrm{~cm} . \mathrm{Ht} .4 \mathrm{~mm} \text {. Perf. } \\
\text { diam. } 7 \mathrm{~mm} \text {. }\end{array}$ & $\begin{array}{l}\text { Roman town occu- } \\
\text { pied throughout } \\
\text { Roman period }\end{array}$ & $\begin{array}{l}\text { For site see } A n f \text { vii } \\
(1927), \text { I } 55-84\end{array}$ \\
\hline
\end{tabular}




\begin{tabular}{|c|c|c|c|c|c|}
\hline $\begin{array}{l}\text { SITE AND } \\
\text { PARISHI }\end{array}$ & COUNTY & MUSEUM \& NO. & $\begin{array}{c}\text { DESCRIPTION AND } \\
\text { APPROX, DIMENSIONS }\end{array}$ & $\begin{array}{l}\text { ASSOCIATIONS AND } \\
\text { REMARKS }\end{array}$ & PUBLICATION \\
\hline Glastonbury & Somerset & Glastonbury $\mathrm{G}_{2}$ & $\begin{array}{l}\text { Fragment. Rich } \\
\text { cobalt. Original } \\
\text { diam. } 2 \cdot \text { I } \mathrm{cm} . \text { Perf. } \\
\text { diam. I } \mathrm{cm} .\end{array}$ & $\begin{array}{l}\text { From Lake Village, } \\
\text { probably and-Ist c. } \\
\text { B.G. or early istc. A.D. }\end{array}$ & $G l \mathrm{ii}$, frontispiece \\
\hline $\begin{array}{l}\text { Ham Hill } \\
\text { (Montacute) }\end{array}$ & Somerset & Taunton & $\begin{array}{l}\text { Smoky grey-blue. } \\
\text { Diam. } 2 \mathrm{~cm} . \text { Perf. } \\
\text { diam. I } 2 \mathrm{~cm} \text {. }\end{array}$ & $\begin{array}{l}\text { From Iron Age hill- } \\
\text { fort with some Roman } \\
\text { occupation }\end{array}$ & $\begin{array}{l}A \text { xlviii ( } 1884), \text { I } 16 . \\
\text { See also } A r 7 \text { cvii } \\
\text { ( } 950), 90\end{array}$ \\
\hline $\begin{array}{l}\text { All Cannings } \\
\text { Cross }\end{array}$ & Wiltshire & Devizes & $\begin{array}{l}\text { Brilliant dark cobalt. } \\
\text { Diam. I } .8 \mathrm{~cm} . \mathrm{Ht} \text {. } \\
6 \mathrm{~mm} . \text { Perf. diam. } \\
9 \mathrm{~mm} .\end{array}$ & $\begin{array}{l}\text { From Iron Age site } \\
\text { with long occupation }\end{array}$ & $\begin{array}{l}\text { Cunnington, M. E. } \\
\text { (1923), p. I } 20 \text { and } \\
\text { pl. I8, fig. I } 6\end{array}$ \\
\hline $\begin{array}{l}\text { Bury Wood } \\
\text { Camp, Colerne }\end{array}$ & Wiltshire & & $\begin{array}{l}\text { Almost opaque. } \\
\text { Irregular. Diam. I } 3 \\
\text { cm. Ht. } 6 \text { mm. Perf. } \\
\text { diam. } 7 \mathrm{~mm} .\end{array}$ & $\begin{array}{l}\text { Associated with Iron } \\
\text { Age 'B' pottery. } \\
\text { ? 2nd-Ist c. B.C. }\end{array}$ & $\begin{array}{l}\text { Interim reports in } \\
W A M \text { lvii, lxii and } \\
\text { lxiv }\end{array}$ \\
\hline $\begin{array}{l}\text { Stockton } \\
\text { Earthworks }\end{array}$ & Wiltshire & Salisbury & $\begin{array}{l}\text { Diam. I } \cdot 7 \mathrm{~cm} . \mathrm{Ht} . \\
9 \mathrm{~mm} . \text { Perf. diam. } \\
6 \mathrm{~mm} .\end{array}$ & $\begin{array}{l}\text { Probably a Belgic } \\
\text { site in origin }\end{array}$ & $\begin{array}{l}W A M \text { xliii ( } 1897 \text { ), } \\
3^{89}\end{array}$ \\
\hline $\begin{array}{l}\text { Briggswath } \\
\text { Whitby }\end{array}$ & Yorkshire & Whitby & $\begin{array}{l}\text { Diam. } 2 \cdot 2 \mathrm{~cm} . \mathrm{Ht} \text {. } \\
\text { I cm. Perf. diam. } \\
6 \mathrm{~mm} .\end{array}$ & $\begin{array}{l}\text { With Romano-British } \\
\text { ware of the late Roman } \\
\text { period found at the } \\
\text { 'Riverside Tea } \\
\text { Gardens' }\end{array}$ & \\
\hline Skipton & Yorkshire & Skipton & $\begin{array}{l}\text { Diam. } 1 \cdot 7 \mathrm{~cm} . \text { Ht. } \\
\text { I. I cm. Perf. diam. } \\
6 \mathrm{~mm} .\end{array}$ & $\begin{array}{l}\text { From an Iron Age } \\
\text { enclosure }\end{array}$ & $\begin{array}{l}\text { Forthcoming, } \\
\text { perhaps in } \\
\mathscr{Y A J}\end{array}$ \\
\hline
\end{tabular}

IRELAND

There are some examples from collections. Mostly about $2 \mathrm{~cm}$. diameter and undated

\section{SGOTLAND}

Traprain Law, East Lothian N.M.A. Prestonkirk
Bright dark cobalt. Diam. I $6 \mathrm{~cm}$. Ht. $4 \mathrm{~mm}$. Perf. diam. $3 \mathrm{~mm}$.
From hill-fort occupied throughout Roman period
For references see Rivet, A. L. F. (ed.) (1966) 


\begin{tabular}{|c|c|c|c|c|c|}
\hline $\begin{array}{l}\text { SITE AND } \\
\text { PARISH }\end{array}$ & COUNTY & MUSEUM \& NO. & $\begin{array}{l}\text { DESGRIPTION AND } \\
\text { APPROX. DIMENSIONS }\end{array}$ & $\begin{array}{l}\text { ASSOCIATIONS AND } \\
\text { REMARKS }\end{array}$ & PUBLICATION \\
\hline Covesea Cave & Morayshire & N.M.A. HM2 13. & $\begin{array}{l}\text { Almost opaque. } \\
\text { Diam. I. } 8 \mathrm{~cm} . \mathrm{Ht} . \\
9 \mathrm{~mm} . \text { Perf. diam. } \\
7 \mathrm{~mm} .\end{array}$ & $\begin{array}{l}\text { Probably Roman } \\
\text { period }\end{array}$ & $\begin{array}{l}P S A S \mathrm{lxv}(\mathrm{I} 93 \mathrm{I}) \\
\mathrm{I} 77\end{array}$ \\
\hline \multirow[t]{2}{*}{ Newstead } & $\begin{array}{l}\text { Roxburgh- } \\
\text { shire }\end{array}$ & $\begin{array}{l}\text { Mr. Mason's Colln., } \\
\text { Selkirk }\end{array}$ & $\begin{array}{l}\text { Rather globular. } \\
\text { Diam. I } \cdot 7 \mathrm{~cm} . \mathrm{Ht} \text {. } \\
\mathrm{I} \cdot \mathrm{I} \mathrm{cm} . \text { Perf. diam. } \\
8 \mathrm{~mm} .\end{array}$ & $\begin{array}{l}\text { Roman site occupied } \\
\text { approx. A.D. } 80-200\end{array}$ & $\mathcal{N} e$ (for site) \\
\hline & & & WALES & & \\
\hline Tythegston & $\begin{array}{l}\text { Glamorgan- } \\
\text { shire }\end{array}$ & & $\begin{array}{l}\text { Very irregular and } \\
\text { perhaps locally made. } \\
\text { Translucent. Diam. } \\
\text { about } 2 \mathrm{~cm} .\end{array}$ & $\begin{array}{l}\text { From defended en- } \\
\text { closure of Cae } \\
\text { Somerhouse. Topsoil. } \\
\text { Site occupied from } \\
\text { late Iron Age to } 4^{\text {th }} \text { c. } \\
\text { A.D. }\end{array}$ & $\begin{array}{l}\text { Information from } \\
\text { Jeffrey Davies, } \\
\text { University Col- } \\
\text { lege, Aberystwyth }\end{array}$ \\
\hline Caerleon & $\begin{array}{l}\text { Monmouth- } \\
\text { shire }\end{array}$ & Caerleon & $\begin{array}{l}\text { Scratched lines } \\
\text { round surface. Diam. } \\
\text { I } 8 \mathrm{~cm} . \mathrm{Ht} . \mathrm{I} \cdot \mathrm{I} \mathrm{cm} . \\
\text { Perf. diam. } 8 \mathrm{~mm} \text {. }\end{array}$ & $\begin{array}{l}\text { No details known. } \\
\text { Probably Roman }\end{array}$ & $\begin{array}{l}A C \operatorname{lxxxiv}(1929), \\
\text { lxxxv (I930), } \\
\text { lxxxvi (1931), } \\
\text { lxxxvii (1932) and } \\
A \text { lxxviii (1928), } \\
\text { r9r }\end{array}$ \\
\hline Sudbrook & $\begin{array}{l}\text { Monmouth- } \\
\text { shire }\end{array}$ & & $\begin{array}{l}\text { Diam. } 1.8 \mathrm{~cm} . \text { Ht. } \\
7 \mathrm{~mm} . \text { Perf. diam. } \\
9 \mathrm{~mm} .\end{array}$ & $\begin{array}{l}\text { Probably Ist c. B.C.- } \\
\text { Ist c. A.D. }\end{array}$ & $A C \mathrm{x} \operatorname{civ}(1939), 75$ \\
\hline \multicolumn{6}{|c|}{ (under $1.5 \mathrm{~cm}$. diam. and translucent if not stated) } \\
\hline $\begin{array}{l}\text { Wilderspool, } \\
\text { Warrington }\end{array}$ & $\begin{array}{l}\text { Cheshire- } \\
\text { Lancashire } \\
\text { borders }\end{array}$ & Warrington 118.08 & $\begin{array}{l}\text { Rather more globular } \\
\text { than most. Diam. } \\
\text { I cm. }\end{array}$ & From Roman site & $\begin{array}{l}\text { For site see May, } \\
\text { T. (1904) and } \\
\text { Thompson, F. H. } \\
\left(19_{5}\right)\end{array}$ \\
\hline $\begin{array}{l}\text { Castle Dore, } \\
\text { Fowey }\end{array}$ & Cornwall & Truro & $\begin{array}{l}2 \text { small beads. Diams. } \\
6 \mathrm{~mm} \text {. and } 8 \mathrm{~mm} . \\
\text { and one lighter in } \\
\text { colour. Diam. } \mathrm{I} \cdot \mathrm{I} \\
\mathrm{cm} .\end{array}$ & $\begin{array}{l}\text { From Iron Age fort, } \\
\text { unstratified, occupied } \\
\text { about } 200 \text { B.C.--Ist c. } \\
\text { A.D. }\end{array}$ & $\begin{array}{l}7 R I C \text { n.s. i } \\
(1946-52), 70, \\
\text { fig. } 8, \text { no. } 5\end{array}$ \\
\hline $\begin{array}{l}\text { Kynance Gate, } \\
\text { Lizard }\end{array}$ & Cornwall & $\begin{array}{l}\text { c/o Lizard Field } \\
\text { Club, Helston }\end{array}$ & $\begin{array}{l}\text { Diam. } 7 \mathrm{~mm} \text {. Another } \\
\text { smaller and greener }\end{array}$ & $\begin{array}{l}\text { From hut in a settle- } \\
\text { ment which produced } \\
\text { Iron Age A and } \\
\text { South-Western B } \\
\text { pottery and con- } \\
\text { tinued into Roman } \\
\text { period }\end{array}$ & \\
\hline
\end{tabular}




\section{${ }^{1} 5^{6}$ GLASS BEADS OF THE PREHISTORIG AND ROMAN PERIODS}

\begin{tabular}{|c|c|c|c|c|c|}
\hline $\begin{array}{l}\text { SITE AND } \\
\text { PARISH }\end{array}$ & COUNTY & MUSEUM \& NO. & $\begin{array}{l}\text { DESCRIPTION AND } \\
\text { APPROX. DIMENSIONS }\end{array}$ & $\begin{array}{l}\text { ASSOCIATIONS AND } \\
\text { REMARKS }\end{array}$ & PUBLICATION \\
\hline $\begin{array}{l}\text { Nor' nour, } \\
\text { Scilly }\end{array}$ & Cornwall & $\begin{array}{l}\text { St. Mary's, } \\
\text { Scilly }\end{array}$ & Diam. $4 \mathrm{~mm}$ & $\begin{array}{l}\text { Roman and just pre- } \\
\text { Roman site. Site I, } \\
\text { Room I. }\end{array}$ & $\begin{array}{l}A r f \operatorname{cxxiv}(1967) \\
\text { I ff. }\end{array}$ \\
\hline $\begin{array}{l}\text { Cadbury } \\
\text { Castle, } \\
\text { Bickleigh } \\
\text { Bridge }\end{array}$ & Devonshire & & $\begin{array}{l}\text { Dark greenish-blue. } \\
\text { Diam. I } 3 \mathrm{~cm} . \mathrm{Ht} \text {. } \\
9 \mathrm{~mm} . \text { Perf. diam. } \\
5 \mathrm{~mm} .\end{array}$ & $\begin{array}{l}\text { Not closely dated in } \\
\text { camp-Iron Age to } \\
\text { Roman occupation }\end{array}$ & $\begin{array}{l}P D A S \text { lxxxiv } \\
\left(195^{2}\right) \\
109-12\end{array}$ \\
\hline 'Derbys & ire' & B.M. & Diam. $9 \mathrm{~mm}$. & $\begin{array}{l}\text { Strung together with } \\
\text { other beads found in } \\
\text { Derbyshire in about } \\
1790 \text { and probably } \\
\text { not associated }\end{array}$ & \\
\hline $\begin{array}{l}\text { Chalbury } \\
\text { Camp, } \\
\text { Bincombe }\end{array}$ & Dorset & Dorchester & $\begin{array}{l}\text { Diam. } 5 \mathrm{~mm} . \text { Ht. } \\
2 \mathrm{~mm} . \text { Perf. diam. } \\
2 \mathrm{~mm} .\end{array}$ & $\begin{array}{l}\text { From hut in Iron Age } \\
\text { A fort associated } \\
\text { with Iron Age A } \\
\text { wares. ? 6th c. B.c. or } \\
\text { little later }\end{array}$ & $\begin{array}{l}\text { Anf xxiii ( } 1943 \text { ), } \\
\text { I } 8 \text { and fig. } 8 \text {, } \\
\text { no. } 53\end{array}$ \\
\hline Dorchester & Dorset & $\begin{array}{l}\text { Dorchester I } 886.9 . \\
\text { I } 3 \text { \& I I I (B. A. } \\
\text { Hogg Colln.) }\end{array}$ & $\begin{array}{l}\text { Diam. I cm. } \\
\text { Another: Diam. } \\
7 \mathrm{~mm} .\end{array}$ & $\begin{array}{l}\text { 'From Roman } \\
\text { stratum' }\end{array}$ & \\
\hline $\begin{array}{l}\text { Colliton Park } \\
\text { Villa, Dor- } \\
\text { chester }\end{array}$ & Dorset & Dorchester & $\begin{array}{l}\text { Thick annular. } \\
\text { Diam. I I cm. Ht. } \\
7 \mathrm{~mm} . \text { Perf. diam. } \\
3 \mathrm{~mm} .\end{array}$ & $\begin{array}{l}\text { From Roman villa } \\
\text { (mostly late). Begun } \\
\text { late 2nd c. A.D. }\end{array}$ & $\begin{array}{l}\text { R.C.H.M. } \\
\text { Dorset ii }\end{array}$ \\
\hline $\begin{array}{l}\text { Gussage All } \\
\text { Saints }\end{array}$ & Dorset & Uncertain & $\begin{array}{l}\text { I whole and I half } \\
\text { bead. Translucent. } \\
\text { Rather irregular. } \\
\text { Both diam. } 1 \cdot 2 \text { or } \\
\text { I } 3 \mathrm{~cm} \text {. Ht. } 5 \text { or } 6 \\
\text { mm. Perf. diam. } 4 \text { or } \\
5 \mathrm{~mm} \text {. }\end{array}$ & $\begin{array}{l}\text { From an early Iron } \\
\text { Age A site with } \\
\text { socketed bone chisels } \\
\text { of All Cannings Cross } \\
\text { type. } 5^{\text {th }}-4^{\text {th }} \text { c. B.c. ? }\end{array}$ & $\begin{array}{l}\text { Information in } \\
\text { advance of } \\
\text { publication by } \\
\text { Dr. Geoffrey } \\
\text { Wainwright }\end{array}$ \\
\hline Portland & Dorset & Dorchester 1932.9.2 & $\begin{array}{l}\text { Opaque very worn } \\
\text { and rather slaty blue. } \\
\text { Diam. } 9 \mathrm{~mm} \text {. }\end{array}$ & $\begin{array}{l}\text { From 'The Verne' } \\
\text { Romano-British } \\
\text { cemetery }\end{array}$ & \\
\hline $\begin{array}{l}\text { Dorchester } \\
\text { (Poundbury } \\
\text { Camp } \\
\text { cemetery) }\end{array}$ & Dorset & Dorchester & $\begin{array}{l}\text { Slightly striated } \\
\text { surface. Diam. } 9 \mathrm{~mm} \text {. } \\
\text { Ht. } 4 \mathrm{~mm} \text {. Perf. diam. } \\
3 \mathrm{~mm} \text {. }\end{array}$ & $\begin{array}{l}\text { Late Roman. Stray } \\
\text { find in cemetery }\end{array}$ & $\begin{array}{l}\text { Information from } \\
\text { Mr. Christopher } \\
\text { Green, 1973 }\end{array}$ \\
\hline $\begin{array}{l}\text { Waddon Hill, } \\
\text { Stoke Abbott }\end{array}$ & Dorset & Bridport & $\begin{array}{l}\text { Half a translucent } \\
\text { blue bead and a } \\
\text { turquoise greenish- } \\
\text { blue about } \mathrm{I} \mathrm{cm} . \text { in } \\
\text { diam. }\end{array}$ & $\begin{array}{l}\text { From a Claudian } \\
\text { fort }\end{array}$ & $\begin{array}{l}\text { Preliminary reports } \\
\text { in } P D \mathcal{N} H A S \text { lxxxii } \\
(1960) \text { and lxxxvi } \\
(1963)\end{array}$ \\
\hline Cirencester & $\begin{array}{l}\text { Gloucester- } \\
\text { shire }\end{array}$ & & $\begin{array}{l}\text { Very small. Diam. } \\
3 \mathrm{~mm} \text {. }\end{array}$ & $\begin{array}{l}\text { Barnsley Park Roman } \\
\text { villa, occupied and- } \\
4^{\text {th }} \text { C. A.D. }\end{array}$ & $\begin{array}{l}\text { Information from } \\
\text { Dr. Graham } \\
\text { Webster }\end{array}$ \\
\hline
\end{tabular}




\begin{tabular}{|c|c|c|c|c|c|}
\hline $\begin{array}{l}\text { SITE AND } \\
\text { PARISH }\end{array}$ & COUNTY & MUSEUM \& NO. & $\begin{array}{l}\text { DESGRIPTION AND } \\
\text { APPROX. DIMENSIONS }\end{array}$ & $\begin{array}{l}\text { ASSOGIATIONS AND } \\
\text { REMARKS }\end{array}$ & PUBLICATION \\
\hline $\begin{array}{l}\text { Bredon, } \\
\text { Bredon's } \\
\text { Norton }\end{array}$ & $\begin{array}{l}\text { Gloucester- } \\
\text { shire--Worces- } \\
\text { tershire borders }\end{array}$ & $\begin{array}{l}\text { Private museum at } \\
\text { Overbury Court }\end{array}$ & $\begin{array}{l}\text { Dark blue, opaque } \\
\text { and rather globular. } \\
\text { Diam. } 1 \cdot 3 \mathrm{~cm} . \mathrm{Ht} \text {. } \\
\mathrm{I} \mathrm{cm} .\end{array}$ & $\begin{array}{l}\text { Probably from the last } \\
\text { period of the inner } \\
\text { entrance. About mid- } \\
\text { Ist C. A.D. }\end{array}$ & $\operatorname{Arfxcv}\left(193^{8}\right)$ \\
\hline $\begin{array}{l}\text { Cirickley Hill, } \\
\text { Coberley }\end{array}$ & $\begin{array}{l}\text { Gloucester- } \\
\text { shire }\end{array}$ & & $\begin{array}{l}\text { Diam. c. } 8 \mathrm{~mm} \text {. } \\
\text { Translucent. Another } \\
\text { with flattened surface }\end{array}$ & $\begin{array}{l}\text { Unstratified from hill- } \\
\text { fort with occupation } \\
\text { apparently before } \\
450 \text { B.c. }\end{array}$ & $\begin{array}{l}\text { Information rom } \\
\text { Mr. Philip Dixon, } \\
1972 \text { and } 1973\end{array}$ \\
\hline Portchester & Hampshire & & $\begin{array}{l}\text { Striated around cir- } \\
\text { cumference. Diam. } \\
9 \mathrm{~mm} . \mathrm{Ht} .3 \mathrm{~mm} \text {. } \\
\text { Perf. diam. } 5 \mathrm{~mm} \text {. }\end{array}$ & $\begin{array}{l}\text { Stratified from late } \\
\text { Roman deposits }\end{array}$ & $\begin{array}{l}\text { Information from } \\
\text { Prof. Barry } \\
\text { Cunliffe }\end{array}$ \\
\hline Silchester & Hampshire & Reading & $\begin{array}{l}\text { Several examples of } \\
\text { varying sizes and } \\
\text { both opaque and } \\
\text { translucent. }\end{array}$ & $\begin{array}{l}\text { Probably pre-Roman } \\
\text { or Roman period }\end{array}$ & \\
\hline $\begin{array}{l}\text { Winchester } \\
\text { (Lankhills } \\
\text { cemetery) }\end{array}$ & Hampshire & & Diam. $8 \mathrm{~mm}$. & $\begin{array}{l}\text { From necklace } 436 \text { in } \\
\text { Grave } 323 . \text { A foreign } \\
\text { grave dated } c \text {. A.D. } \\
35^{0}-70\end{array}$ & $\begin{array}{l}\text { Glark, G. } \\
\text { (forthcoming) } \\
\text { fig. } 86, \mathrm{~g}\end{array}$ \\
\hline $\begin{array}{l}\text { Croft Ambrey } \\
\text { hill-fort, } \\
\text { Lucton }\end{array}$ & Herefordshire & $\begin{array}{l}\text { c/o S.C. Stanford, } \\
\text { Dept. Extra Mural } \\
\text { Studies, Birmingham }\end{array}$ & $\begin{array}{l}\text { One, smaller, has } \\
\text { flattened top and } \\
\text { bottom surfaces. } \\
\text { Diam. } 5 \mathrm{~mm} . \text { The } \\
\text { larger has less } \\
\text { flattening on surfaces. } \\
\text { Diam. } 8 \mathrm{~mm} .\end{array}$ & $\begin{array}{l}\text { The smaller example } \\
\text { provisionally dated } \\
\text { late } 3 \text { rd c. B.c. and } \\
\text { the larger ist c. A.D. }\end{array}$ & $\begin{array}{l}\text { Stanford, S. C. } \\
(1974)\end{array}$ \\
\hline $\begin{array}{l}\text { Weston- } \\
\text { under- } \\
\text { Penyard, } \\
\text { Bollitree }\end{array}$ & Herefordshire & $\begin{array}{l}\text { Gloucester I } 759 \text {, } \\
\text { 1 } 763, \text { I } 764, \text { I } 765 \text { : } \\
\text { I } 766, \text { І } 767\end{array}$ & $\begin{array}{l}\text { Almost all small and } \\
\text { about } 7 \mathrm{~mm} \text {. diam. } \\
\text { One ( } 763 \text { ) is almost } \\
\text { opaque. One ( } 1767) \\
\text { is slightly biconical } \\
\text { and one ( } 1759 \text { ) is } \\
\text { larger, opaque with } \\
\text { diam. } 1.2 \mathrm{~cm} \text {; ht. } \\
9 \mathrm{~mm} .\end{array}$ & Probably ist c. A.D. & $\begin{array}{l}\mathcal{J} B A A \mathrm{xxvii}\left(\mathrm{I} 8_{7} \text { I), }\right. \\
\text { 2 I I ff. }\end{array}$ \\
\hline $\begin{array}{l}\text { Poston Camp, } \\
\text { Vowchurch }\end{array}$ & Herefordshire & Hereford & Diam. about $8 \mathrm{~mm}$. & $\begin{array}{l}\text { From Iron Age camp } \\
\text { occupied Ist C. B.C.- } \\
\text { 2nd C. A.D. }\end{array}$ & $\begin{array}{l}\text { I. E. Anthony, The } \\
\text { Iron Age Camp at } \\
\text { Poston, Hereford- } \\
\text { shire (Woolhope } \\
\text { Club, 1958), and } \\
\text { R.C.H.M. } \\
\text { Herefords. i } \\
\text { (1931), } 245 \text { and ii } \\
\text { (1934), pp. xlvii-ix }\end{array}$ \\
\hline St. Albans & Hertfordshire & $\begin{array}{l}\text { Verulamium } \\
\text { Museum }\end{array}$ & Diam. $6 \mathrm{~mm}$. & $\begin{array}{l}\text { Found in r } 944 \text { in } \\
\text { Room V of Roman } \\
\text { villa }\end{array}$ & \\
\hline
\end{tabular}


I58 GLASS BEADS OF THE PREHISTORIG AND ROMAN PERIODS

\begin{tabular}{|c|c|c|c|c|c|}
\hline $\begin{array}{l}\text { SITE AND } \\
\text { PARISH }\end{array}$ & COUNTY & MUSEUM \& NO. & $\begin{array}{l}\text { DESCRIPTION AND } \\
\text { APPROX. DIMENSIONS }\end{array}$ & $\begin{array}{l}\text { ASSOCIATIONS AND } \\
\text { REMARKS }\end{array}$ & PUBLICATION \\
\hline Ballacagen A & Isle of Man & Douglas, I.o.M. & $\begin{array}{l}\text { Diam. } 6 \mathrm{~mm} \text {. } \\
\text { Another larger, diam. } \\
\text { I } \mathrm{cm} .\end{array}$ & $\begin{array}{l}\text { One from Phase I of } \\
\text { round-house. Prob- } \\
\text { ably and or Ist c. } \\
\text { B.c. Larger one } \\
\text { unstratified }\end{array}$ & $\begin{array}{l}\text { Bersu, G., Three } \\
\text { Iron Age Round } \\
\text { Houses in the Isle of } \\
\text { Man (1977) }\end{array}$ \\
\hline London & London & $\begin{array}{l}\text { Formerly Guildhall } \\
\text { Museum } 3964\end{array}$ & $\begin{array}{l}\text { Diam. I - } 2 \mathrm{~cm} ., \\
\text { irregular shape, } \\
\text { slightly biconical }\end{array}$ & From Dowgate Hill & \\
\hline London & London & $\begin{array}{l}\text { Formerly Guildhall } \\
\text { Museum } 2604\end{array}$ & $\begin{array}{l}\text { Diam. } 1 \cdot 2 \mathrm{~cm} . \text { Wide } \\
\text { perforation }\end{array}$ & No exact location & \\
\hline Chinnor & Oxfordshire & $\begin{array}{l}\text { A.M. I67 and the } \\
\text { other in Aylesbury } \\
\text { Museum on loan }\end{array}$ & $\begin{array}{l}\text { Diam. } 6 \mathrm{~mm} . \\
\text { Another: Diam. } \\
8 \mathrm{~mm} .\end{array}$ & $\begin{array}{l}\text { From Iron Age A } \\
\text { settlement. ? 5th } \\
\text { c. B.c. }\end{array}$ & $\begin{array}{l}\text { Anf xxxi (195I), } \\
\text { I } 46 \text {, fig. Io, no. } 5\end{array}$ \\
\hline Bath & Somerset & $\begin{array}{l}\text { Pump Room and } \\
\text { Museum, Bath }\end{array}$ & $\begin{array}{l}\text { Clear cobalt. Diam. } \\
9 \mathrm{~mm} . \text { Ht. } 2 \mathrm{~mm} \text {. } \\
\text { Perf. diam. } 5 \mathrm{~mm} \text {. }\end{array}$ & $\begin{array}{l}\text { From Roman town } \\
\text { founded late ist c. } \\
\text { A.D. }\end{array}$ & \\
\hline Glastonbury & Somerset & Glastonbury G6, Gi 5 & Various sizes & $\begin{array}{l}\text { From Lake Village. } \\
\text { Occupation beginning } \\
\text { 2nd c. B.c. and ending } \\
\text { in early ist c. A.D. }\end{array}$ & $G l \ddot{\mathrm{ii}}$, frontispiece \\
\hline Meare & Somerset & Taunton & $\begin{array}{l}\text { A number of various } \\
\text { sizes both translucent } \\
\text { and opaque }\end{array}$ & $\begin{array}{l}\text { From Iron Age village. } \\
\text { 3rd-Ist c. B.c.? }\end{array}$ & Me iii \\
\hline 'Mendip' & Somerset & $\begin{array}{l}\text { Bristol F2072 (A. C. } \\
\text { Pass Colln.) }\end{array}$ & $\begin{array}{l}\text { Opaque light blue- } \\
\text { grey. Diam. I. } 2 \mathrm{~cm} .\end{array}$ & $\begin{array}{l}\text { Stray find from site } \\
\text { producing many } \\
\text { Roman finds }\end{array}$ & \\
\hline $\begin{array}{l}\text { Worlebury } \\
\text { hill-fort } \\
\text { (Weston-super- } \\
\text { Mare) }\end{array}$ & Somerset & $\begin{array}{l}\text { (Not in Weston- } \\
\text { super-Mare) }\end{array}$ & $\begin{array}{l}\text { Diam. } 9 \mathrm{~mm} . \mathrm{Ht} . \\
5 \mathrm{~mm} . \text { Perf. diam. } \\
3 \mathrm{~mm} .\end{array}$ & $\begin{array}{l}\text { From a pit in the } \\
\text { hill-fort }\end{array}$ & $\begin{array}{l}\text { Dymond, C.W., } \\
\text { Worlebury (1902), } \\
\text { pl. x, no. I } 5\end{array}$ \\
\hline $\begin{array}{l}\text { Farley Heath, } \\
\text { Albury }\end{array}$ & Surrey & & Diam. I $1 \mathrm{~cm}$. & $\begin{array}{l}\text { Found in } 1847 \text { on site } \\
\text { of a Romano-Celtic } \\
\text { temple }\end{array}$ & $\begin{array}{l}A \operatorname{xxxiv}(185 \mathrm{l}), \mathrm{pl} \\
\mathrm{v}, \text { no. I } 2\end{array}$ \\
\hline Fishbourne & Sussex & $\begin{array}{l}\text { Fishbourne Roman } \\
\text { palace }\end{array}$ & $\begin{array}{l}\text { Half-bead. About } \\
\text { I } \mathrm{cm} \text {. diam. }\end{array}$ & Ist C. A.D. & $F i$ ii, fig. 69, no. 2 \\
\hline Baginton & Warwickshire & & $\begin{array}{l}\text { Diam. I } 1 \mathrm{~cm} . \mathrm{Ht} \text {. } \\
\text { irregular } 2-3 \mathrm{~mm} .\end{array}$ & $\begin{array}{l}\text { From Romano- } \\
\text { British site }\end{array}$ & $\begin{array}{l}\text { PCNHSS ii, no. } 5 \\
\text { (195I) }\end{array}$ \\
\hline $\begin{array}{l}\text { Ryton-on- } \\
\text { Dunsmore }\end{array}$ & Warwickshire & Goventry & $\begin{array}{l}\text { Very thin. Diam. } \\
6 \mathrm{~mm} \text {. Large perfora- } \\
\text { tion }\end{array}$ & Iron Age context & $\begin{array}{l}\operatorname{Arf} \mathrm{cxxi}(1965), \\
\mathrm{I}-22\end{array}$ \\
\hline $\begin{array}{l}\text { All Cannings } \\
\text { Cross }\end{array}$ & Wiltshire & Devizes & $\begin{array}{l}\text { Very worn and grey. } \\
\text { Slight peripheral } \\
\text { groove. Diam. } 8 \mathrm{~mm} \text {. } \\
\text { Perf. diam. } 5 \mathrm{~mm} \text {. }\end{array}$ & $\begin{array}{l}\text { Iron Age settlement } \\
\text { with long occupation }\end{array}$ & $\begin{array}{l}\text { Cunnington, M. E. } \\
\text { (I923), p. I 20, pl. } \\
\text { I8, xvi }\end{array}$ \\
\hline $\begin{array}{l}\text { Cold Kitchen } \\
\text { Hill, Brixton } \\
\text { Deverill }\end{array}$ & Wiltshire & Salisbury & Diam.c. $7 \mathrm{~mm}$. & $\begin{array}{l}\text { Mostly Roman period } \\
\text { finds from this site }\end{array}$ & $\begin{array}{l}W A M \text { xliii } \\
(1925-7), \text { I } 80 \mathrm{ff} . \\
\text { and } 327 \mathrm{ff} ., \text { and } \\
\text { xlviii (1937-9), } \\
185-8\end{array}$ \\
\hline
\end{tabular}




\begin{tabular}{|c|c|c|c|c|c|}
\hline $\begin{array}{l}\text { STTE AND } \\
\text { PARISH }\end{array}$ & COUNTY & MUSEUM \& NO. & $\begin{array}{l}\text { DESGRIPTION AND } \\
\text { APPROX. DIMENSIONS }\end{array}$ & $\begin{array}{l}\text { ASSOCIATIONS AND } \\
\text { REMARKS }\end{array}$ & PUBLICATION \\
\hline $\begin{array}{l}\text { Mancombe } \\
\text { Down, } \\
\text { Warminster }\end{array}$ & Wiltshire & Salisbury & $\begin{array}{l}\text { Diam. I } 3 \mathrm{~cm} . \text { Ht. } \\
6 \mathrm{~mm} . \text { Perf. diam. } \\
4 \mathrm{~mm} .\end{array}$ & $\begin{array}{l}\text { Pre-Roman settle- } \\
\text { ment }\end{array}$ & $\begin{array}{l}W A M \mathrm{~lx}\left(\mathrm{I} 6_{5}\right) \\
53\end{array}$ \\
\hline Swallowcliffe & Wiltshire & Devizes $\mathrm{F}_{3}$ & $\begin{array}{l}\text { Rather globular. } \\
\text { Diam. } 1 \mathrm{~cm} .\end{array}$ & $\begin{array}{l}\text { From Iron Age settle- } \\
\text { ment } c .4^{\text {th }}-3^{\text {rd }} \text { c. } \\
\text { B.c. }\end{array}$ & $\begin{array}{l}W A M \text { xliii } \\
\text { (1925-7), 88-9, } \\
546 \text { and pl. vii }\end{array}$ \\
\hline Swallowcliffe & Wiltshire & Devizes $\mathrm{F}_{4}$ & $\begin{array}{l}\text { Another lighter in } \\
\text { colour very slightly } \\
\text { smaller }\end{array}$ & $\begin{array}{l}\text { Probably } 4 \text { th }-3 \text { rd } c \text {. } \\
\text { B.c. }\end{array}$ & Ibid. \\
\hline Swallowcliffe & Wiltshire & Devizes $\mathrm{F}_{2} \& \mathrm{~F}_{5}$ & Diams. about $\mathrm{I} \cdot 2 \mathrm{~cm}$ & $\begin{array}{l}\text { Probably } 4 \text { th }-3 \text { rd c. } \\
\text { B.c. }\end{array}$ & Ibid. \\
\hline $\begin{array}{l}\text { Wick Wood, } \\
\text { Nettleton }\end{array}$ & Wiltshire & $\begin{array}{l}\text { c/o Bath and Camer- } \\
\text { ton Arch. Soc. }\end{array}$ & $\begin{array}{l}\text { No. } 620 \text { has diam. } \\
3 \mathrm{~mm} \text {. No. } 13 \mathrm{I} \text { is } \\
\text { badly made and } \\
\text { irregular: Diam. } 1 \cdot 1 \\
\mathrm{~cm} \text {. (Half only) }\end{array}$ & $\begin{array}{l}\text { Romano-British and } \\
\text { later. No. I } 3 \text { I I was } \\
\text { post-Roman and No. } \\
620 \text { 'after } 33^{\circ} \text { A.D.' }\end{array}$ & $\begin{array}{l}\text { Wedlake, W.J. } \\
\text { (forthcoming) }\end{array}$ \\
\hline $\begin{array}{l}\text { Wick Wood, } \\
\text { Nettleton }\end{array}$ & Wiltshire & $\begin{array}{l}\text { c/o Bath and Camer- } \\
\text { ton Arch. Soc. }\end{array}$ & $\begin{array}{l}\text { Another light blue: } \\
\text { Diam. } 9 \mathrm{~mm} . \text {; ht. } \\
2 \mathrm{~mm} . \text {; perf. diam. } \\
6 \mathrm{~mm} \text {. }\end{array}$ & $\begin{array}{l}\text { Stratified in post- } \\
\text { Constantinian level }\end{array}$ & $\begin{array}{l}\text { Wedlake, W.J. } \\
\text { (forthcoming) }\end{array}$ \\
\hline $\begin{array}{l}\text { Ogbourne } \\
\text { St. George }\end{array}$ & Wiltshire & Devizes I 32 & $\begin{array}{l}\text { Opaque dark. } \\
\text { Irregular and rather } \\
\text { globular. Diam. } \\
1 \cdot 1 \mathrm{~cm} . \text { Small } \\
\text { perforation }\end{array}$ & Stray find & \\
\hline Rotherley & Wiltshire & Salisbury & Diam. $6 \mathrm{~mm}$. & Romano-British & $\begin{array}{l}\text { Pitt-Rivers, } \\
\text { A. H. L. F. (1888) } \\
\text { and } A r \mathcal{C l v}(1947)\end{array}$ \\
\hline Teffont Evias & Wiltshire & Salisbury $4 / 49$ & $\begin{array}{l}\text { Opaque and very } \\
\text { worn. Diam. } 1 \cdot 3 \mathrm{~cm} \text {. }\end{array}$ & $\begin{array}{l}\text { From a quarry. Stray } \\
\text { find }\end{array}$ & \\
\hline Beckford & Worcestershire & & $\begin{array}{l}\text { Half bead. Translu- } \\
\text { cent. Diam. I } 3 \mathrm{~cm} \text {. } \\
\text { Ht. } 6 \mathrm{~mm} \text {. Perf. diam. } \\
6 \mathrm{~mm} \text {. }\end{array}$ & $\begin{array}{l}\text { Associated with } \\
\text { 'duck' stamped and } \\
\text { linear tooled wares }\end{array}$ & $\begin{array}{l}\text { Information from } \\
\text { W.J. Britnell, } \\
\text { University } \\
\text { College, Cardiff }\end{array}$ \\
\hline $\begin{array}{l}\text { Bredon } \\
\text { (Conderton } \\
\text { Camp) }\end{array}$ & $\begin{array}{l}\text { Worcester- } \\
\text { shire }\end{array}$ & Birmingham & $\begin{array}{l}2 \text { examples. About } \\
6 \text { and } 7 \mathrm{~mm} \text {. in diam. } \\
2 \text { others very fine } \\
\text { in section }\end{array}$ & $\begin{array}{l}\text { Site contemporary } \\
\text { with Meare and } \\
\text { Glastonbury earlier } \\
\text { phase }\end{array}$ & $\begin{array}{l}\text { Forthcoming. } \\
\text { Information from } \\
\text { Mr. N. Thomas }\end{array}$ \\
\hline Burton Fleming & Yorkshire & & $\begin{array}{l}\text { Pale translucent } \\
\text { blue. Diam. } 6 \mathrm{~mm} \text {. } \\
\text { Ht. } 2 \mathrm{~mm} \text {. Perf. diam. } \\
3 \mathrm{~mm} \text {. }\end{array}$ & $\begin{array}{l}\text { From Iron Age } \\
\text { cemetery. ? 3rd- } \\
\text { 2nd c. B.c. }\end{array}$ & $\begin{array}{l}\text { Information from } \\
\text { Dr. Ian Stead }\end{array}$ \\
\hline Doncaster & Yorkshire & & $\begin{array}{l}\text { Dark blue. Diam. } \\
6 \mathrm{~mm} . \mathrm{Ht} .3 \mathrm{~mm} .\end{array}$ & $\begin{array}{l}\text { From Roman site at } \\
\text { Edlington Wood }\end{array}$ & $\begin{array}{l}\text { Grimes, W.F. } \\
\text { (ed.) (195I), } \\
\text { pp. } 9^{0-1}\end{array}$ \\
\hline
\end{tabular}




\begin{tabular}{|c|c|c|c|c|c|}
\hline $\begin{array}{l}\text { SITE AND } \\
\text { PARISH }\end{array}$ & COUNTY & MUSEUM \& NO. & $\begin{array}{l}\text { DESCRIPTION AND } \\
\text { APPROX. DIMENSIONS }\end{array}$ & $\begin{array}{l}\text { ASSOCIATIONS AND } \\
\text { REMARKS }\end{array}$ & PUBLICATION \\
\hline \multicolumn{6}{|c|}{ I RELAND } \\
\hline $\begin{array}{l}\text { Dunshaughlin } \\
\text { crannog, } \\
\text { Lagore }\end{array}$ & Co. Meath & & $\begin{array}{l}\text { Diam. } 8 \mathrm{~mm} \text {. (no. } \\
\text { 8I } 3 \text { ) }\end{array}$ & $\begin{array}{l}\text { One example from } \\
\text { period Ia. This must } \\
\text { be either early like } \\
\text { the Meare spiral bead } \\
\text { from the same site, or } \\
\text { 7th C. A.D. }\end{array}$ & $\begin{array}{l}P R I A \text { liii } \mathrm{C} \\
\left(\mathrm{r} 95^{0}-\mathrm{I}\right), \mathrm{r} 34\end{array}$ \\
\hline Tara & Co. Meath & Dublin & $\begin{array}{l}\text { Bright translucent } \\
\text { cobalt. Diam. } 5 \mathrm{~mm} \text {. } \\
\text { Ht. } 2 \mathrm{~mm} \text {. Perf. diam. } \\
3 \mathrm{~mm} .\end{array}$ & $\begin{array}{l}\text { From the Rath of the } \\
\text { Synods which pro- } \\
\text { duced Roman Ist-3rd } \\
\text { c. A.D. pottery }\end{array}$ & $\begin{array}{l}\text { O Ríordáin, S. P. } \\
\text { (1964) }\end{array}$ \\
\hline \multicolumn{6}{|c|}{ SGOTLAND } \\
\hline Dunadd & Argyllshire & & $\begin{array}{l}\text { Irregularly made and } \\
\text { rather globular. } \\
\text { Diam. } \mathrm{I} \mathrm{cm} \text {. }\end{array}$ & $\begin{array}{l}\text { Stronghold of the } \\
\text { Dalriadic Scots, } \\
7 \text { th-8th c. A.D. or a } \\
\text { little earlier perhaps } \\
\text { initially }\end{array}$ & $\begin{array}{l}P S A S \text { xxxix } \\
(1904-5), 3^{15}\end{array}$ \\
\hline $\begin{array}{l}\text { Kildonan } \\
\text { Fort }\end{array}$ & Argyllshire & & $\begin{array}{l}\text { Diam. } 8 \mathrm{~mm} . \text { half } \\
\text { only }\end{array}$ & $\begin{array}{l}\text { Not very closely } \\
\text { datable but between } \\
\text { 2nd-7th c. A.D. and } \\
\text { perhaps Scottic }\end{array}$ & $\begin{array}{l}P S A S \text { lxxiii } \\
\left(193^{8}-9\right) \text { and lxxvii } \\
(1942-3)\end{array}$ \\
\hline $\begin{array}{l}\text { Ugadale Fort, } \\
\text { Kintyre }\end{array}$ & Argyllshire & ? Glesgow & & Probably 8th c. A.D. & $\begin{array}{l}P S A S \text { lxxxviii } \\
\text { (1954-6), I9 }\end{array}$ \\
\hline $\begin{array}{l}\text { Siccar Point, } \\
\text { Cockburnspath }\end{array}$ & Berwickshire & N.M.A. FJ 126 & Diam. $7 \mathrm{~mm}$. & $\begin{array}{l}\text { From middle of Iron } \\
\text { Age fort }\end{array}$ & $\begin{array}{l}P S A S \text { lxix (1935), } \\
\text { I58 }\end{array}$ \\
\hline Dunagoil Fort & Bute & Rothesay Museum & $\begin{array}{l}3 \text { examples all under } \\
1 \mathrm{~cm} . \text { in diam. } 2 \\
\text { at least are opaque }\end{array}$ & $\begin{array}{l}\text { Probably ist c. B.C.-- } \\
\text { Ist c. A.D. native fort } \\
\text { with some Roman } \\
\text { period occupation }\end{array}$ & $\begin{array}{l}\text { TBNHS viii } \\
\text { (1914-15), 42-9 } \\
\text { and } 68-86\end{array}$ \\
\hline Traprain Law & East Lothian & $\begin{array}{l}\text { N.M.A. nos. 1922.245; } \\
23.172 ; 260, \text { III } \\
20.3^{82, \text { etc. }}\end{array}$ & $\begin{array}{l}\text { Various examples all } \\
\text { small and some } \\
\text { opaque }\end{array}$ & $\begin{array}{l}\text { Native fort occupied } \\
\text { through Roman } \\
\text { period }\end{array}$ & $\begin{array}{l}\text { For site, see refs. in } \\
\text { Rivet, A. L. F. } \\
\text { (ed.) (1966) }\end{array}$ \\
\hline Nr. Coulter & Lanarkshire & $\begin{array}{l}\text { N.M.A. FJ33, Sim } \\
\text { Colln. }\end{array}$ & $\begin{array}{l}\text { Rather light blue. } \\
\text { Diam. I. } 5 \mathrm{~cm} \text {., wide } \\
\text { perforation }\end{array}$ & Stray find & \\
\hline Fendom Sands & Ross-shire & & $\begin{array}{l}\text { About } \frac{3}{4} \text { of bead. } \\
\text { Diam. I I cm., wide } \\
\text { perforation }\end{array}$ & & \\
\hline Bonchester & Roxburghshire & N.M.A. & Diam. $8 \mathrm{~mm}$. & $\begin{array}{l}\text { Probably Roman } \\
\text { period or later. (The } \\
\text { remarks then pub- } \\
\text { lished need not now } \\
\text { hold good for dating) }\end{array}$ & $\begin{array}{l}P S A S \text { Ixxxiv } \\
\left(\text { I } 949^{-50}\right), \text { I } 28\end{array}$ \\
\hline Yair & Selkirkshire & $\begin{array}{l}\text { Mr. Mason's Colln., } \\
\text { Selkirk }\end{array}$ & $\begin{array}{l}\text { Diam. } \mathrm{I} \cdot 2 \mathrm{~cm} \text {., wide } \\
\text { perforation }\end{array}$ & $\begin{array}{l}\text { Stray find by river } \\
\text { bank }\end{array}$ & \\
\hline Gulbin Sands & Morayshire & N.M.A. & $\begin{array}{l}\text { About } 8 \text { examples } \\
\text { various sizes and } \\
\text { blues }\end{array}$ & & \\
\hline
\end{tabular}




\begin{tabular}{|c|c|c|c|c|c|}
\hline $\begin{array}{l}\text { SITE AND } \\
\text { PARISH }\end{array}$ & COUNTY & MUSEUM \& No. & $\begin{array}{l}\text { DESCRIPTION AND } \\
\text { APPROX. DIMENSIONS }\end{array}$ & $\begin{array}{l}\text { ASSOCLATIONS AND } \\
\text { REMARKS }\end{array}$ & PUBLIGATION \\
\hline Culbin Sands & Morayshire & $\begin{array}{l}\text { Miss Young's Colln., } \\
\text { Edinburgh } 1954\end{array}$ & About ro examples & & \\
\hline Nr. Selkirk & Selkirkshire & $\begin{array}{l}\text { Mr. Mason's Colln., } \\
\text { Selkirk }\end{array}$ & $\begin{array}{l}\text { One very fine section. } \\
\text { Diam. } 8 \mathrm{~mm} \text {. and } \\
\text { another more globu- } \\
\text { lar. Diam. } 4 \mathrm{~mm} \text {. }\end{array}$ & & \\
\hline $\begin{array}{l}\text { Dun Ardtreck, } \\
\text { Skye }\end{array}$ & $\begin{array}{l}\text { Inverness- } \\
\text { shire }\end{array}$ & $\begin{array}{l}\text { Hunterian Museum, } \\
\text { Glasgow }\end{array}$ & $\begin{array}{l}\text { Several very small } \\
\text { examples }\end{array}$ & $\begin{array}{l}\text { Probably early ist c. } \\
\text { B.c. From galleried } \\
\text { wall-fort. Small } \\
\text { annular opaque } \\
\text { yellow beads from } \\
\text { the same archaco- } \\
\text { logical horizon }\end{array}$ & $\begin{array}{l}\text { An xxxix (1965) for } \\
\text { preliminary report } \\
\text { and } i b i d . \text { xliii } \\
\text { (1969) for more } \\
\text { accurate dating }\end{array}$ \\
\hline $\begin{array}{l}\text { Glenluce } \\
\text { Sands }\end{array}$ & Wigtownshire & N.M.A. & Several examples & & \\
\hline $\begin{array}{l}\text { Castle Island, } \\
\text { Mochrum }\end{array}$ & Wigtownshire & $\begin{array}{l}\text { c/o Lord David } \\
\text { Stuart, Old Place of } \\
\text { Mochrum, Port } \\
\text { William }\end{array}$ & $\begin{array}{l}2 \text { examples, one } \\
\text { diam. } 6 \mathrm{~mm} \text {., another } \\
\text { diam. } 8 \mathrm{~mm} \text {. }\end{array}$ & $\begin{array}{l}\text { With other beads } \\
\text { including Roman } \\
\text { melon beads and finds } \\
\text { of later date as } \\
\text { well }\end{array}$ & $\begin{array}{l}\text { TDGNHAS xxviii } \\
\left(1949^{-5} \text { ) }\right.\end{array}$ \\
\hline & & & WALES & & \\
\hline $\begin{array}{l}\text { Coygan } \\
\text { Camp, } \\
\text { Lougharne }\end{array}$ & $\begin{array}{l}\text { Carmarthen- } \\
\text { shire }\end{array}$ & & $\begin{array}{l}2 \text { examples, one } \\
\text { flattened surface. } \\
\text { Diam. I cm. One } \\
\text { Diam. } 4 \mathrm{~mm} .\end{array}$ & $\begin{array}{l}\text { Stratified late } 3 \text { rd c. } \\
\text { A.D. }\end{array}$ & $\begin{array}{l}\text { Wainwright, G.J. } \\
(1967)\end{array}$ \\
\hline $\begin{array}{l}\text { Moel } \\
\text { Hiraddug, } \\
\text { Dyserth }\end{array}$ & Flintshire & & $\begin{array}{l}\text { Broken. Diam. I cm. } \\
\text { Ht. } 5 \mathrm{~mm} \text {. Perf. } \\
\text { diam. } 6 \mathrm{~mm} .\end{array}$ & $\begin{array}{l}\text { Topsoil behind inner } \\
\text { rampart of Iron Age } \\
\text { hill-fort }\end{array}$ & $\begin{array}{l}\text { Information from } \\
\text { Jeffrey Davies, } \\
\text { University Coilege, } \\
\text { Aberystwyth }\end{array}$ \\
\hline $\begin{array}{l}\text { Twyn-y-Gaer } \\
\text { hill-fort, } \\
\text { Cwmyoy }\end{array}$ & $\begin{array}{l}\text { Monmouth- } \\
\text { shire }\end{array}$ & $\begin{array}{l}\text { To be either in } \\
\text { N.M.W. or Aber- } \\
\text { gavenny }\end{array}$ & $\begin{array}{l}2 \text { examples, } 7 \mathrm{~mm} \text {. } \\
\text { and half one of } 1 \mathrm{~cm} \text {. } \\
\text { diameter. The } \\
\text { smaller has flattened } \\
\text { upper and lower } \\
\text { surfaces. The half- } \\
\text { bead is badly made } \\
\text { and irregular }\end{array}$ & $\begin{array}{l}\text { The smaller example } \\
\text { came from under the } \\
\text { revetment wall of the } \\
\text { second stone phase of } \\
\text { the east gate. ? 3rd } \\
\text { to ist c. B.c.; the half- } \\
\text { bead, not closely } \\
\text { dated within the same } \\
\text { bracket, came from the } \\
\text { annex fence of the? } \\
\text { first phase }\end{array}$ & $\begin{array}{l}\text { Information from } \\
\text { excavator, L. A. } \\
\text { Probert (see } \\
\text { Boon, G. G. and } \\
\text { Lewis J. M. (eds.), } \\
\text { Welsh Antiquity } \\
\text { (1976), pp. 105- } \\
\text { I9) }\end{array}$ \\
\hline Sudbrook & $\begin{array}{l}\text { Monmouth- } \\
\text { shire }\end{array}$ & & $\begin{array}{l}2 \text { examples. One } \\
\text { small, diam. } 1 \cdot 2 \\
\mathrm{~cm} . \text { ht. } 6 \mathrm{~mm} ., \text { perf. } \\
\text { diam. } 4 \mathrm{~mm} . \text {, and } \\
\text { one medium size } \\
\text { came from this site }\end{array}$ & $\begin{array}{l}\text { One at least should } \\
\text { be native and of Ist } \\
\text { c. B.C.-rst C. A.D. }\end{array}$ & $A C x \operatorname{civ}(1939), 75$ \\
\hline $\begin{array}{l}\text { Caldy Island } \\
\text { (Nanna's } \\
\text { Cave) }\end{array}$ & $\begin{array}{l}\text { Pembroke- } \\
\text { shire }\end{array}$ & & & $\begin{array}{l}\text { Small blue bead with } \\
\text { Romano-British } \\
\text { pottery }\end{array}$ & $\begin{array}{l}A C, 6 \text { th s., xvii } \\
(1917), 73\end{array}$ \\
\hline
\end{tabular}




\begin{tabular}{|c|c|c|c|c|c|}
\hline $\begin{array}{l}\text { SITE AND } \\
\text { PARISH }\end{array}$ & COUNTY & MUSEUM \& NO. & $\begin{array}{l}\text { DESGRIPTION AND } \\
\text { APPROX. DIMENSIONS }\end{array}$ & $\begin{array}{l}\text { ASSOCIATIONS AND } \\
\text { REMARKS }\end{array}$ & PUBLICATION \\
\hline Moel Trigarn & $\begin{array}{l}\text { Pembroke- } \\
\text { shire }\end{array}$ & Tenby & $\begin{array}{l}\text { Flattened upper and } \\
\text { lower surface like } \\
\text { many small annular } \\
\text { beads of opaque } \\
\text { yellow type-diam. } \\
\text { I. I cm. }\end{array}$ & $\begin{array}{l}\text { From hill-fort. The } \\
\text { same fort produced } \\
\text { a bead of Meare } \\
\text { spiral type Class } 6 \\
\text { 3rd-and c. B.c. }\end{array}$ & $\begin{array}{l}A C, 5^{\text {th s., xvii }} \\
\text { ( } 1900), \text { I } 8 g-2 \text { I I }\end{array}$ \\
\hline \multirow{2}{*}{\multicolumn{6}{|c|}{ (v) SMALL:TRANSLUCENT'AMBER' (REDDISH-BROWN) }} \\
\hline & & & & & \\
\hline Whitcombe & Dorset & Dorchester & $\begin{array}{l}\text { Irregular 'amber' } \\
\text { coloured. Diam. } 1 \cdot 5 \\
\text { cm. Ht. } 3 \mathrm{~mm} \text {. Perf. } \\
\text { diam. } 8 \mathrm{~mm} .3 \text { others. } \\
\text { Also fragments of a } \\
\text { very light yellow } \\
\text { one, and two wooden } \\
\text { beads }\end{array}$ & $\begin{array}{l}\text { On necklace dated } \\
\text { A.D. 96- I } 10 \text { from } \\
\text { associated Samian }\end{array}$ & $\begin{array}{l}\text { Information from } \\
\text { Mrs. Aitken }\end{array}$ \\
\hline Silchester & Hampshire & Reading & $\begin{array}{l}\text { Pinkish-brown. Diam. } \\
\text { I. I cm. Ht. } 5 \mathrm{~mm} \text {. } \\
\text { Perf. diam. } 5 \mathrm{~mm} \text {. }\end{array}$ & $\begin{array}{l}\text { Site occupied c. Ist- } \\
5^{\text {th }} \text { C. A.D. }\end{array}$ & \\
\hline $\begin{array}{l}\text { St. Albans } \\
\text { (King Harry's } \\
\text { Lane) }\end{array}$ & Hertfordshire & Verulamium & $\begin{array}{l}\text { One reddish-brown. } \\
\text { Diam. I } 4 \mathrm{~cm} . \mathrm{Ht} . \\
4 \mathrm{~mm} \text {. Perf. diam. } \\
7 \mathrm{~mm} .\end{array}$ & $\begin{array}{l}\text { From necklace on } \\
\text { Burial } 29 \text { of Aylesford } \\
\text { type cemetery dated } \\
\text { c. IO B.C.-A.D. } 40\end{array}$ & $\begin{array}{l}\text { Information from } \\
\text { Dr. I. M. Stead }\end{array}$ \\
\hline Richborough & Kent & Richborough 39,31 & $\begin{array}{l}\text { Several badly shaped } \\
\text { light brownish- } \\
\text { yellow. Diam. about } \\
\text { I cm. }\end{array}$ & $\begin{array}{l}\text { From Roman and } \\
\text { Saxon site }\end{array}$ & $\begin{array}{l}\text { Information from } \\
\text { Mr. G. C. } \\
\text { Dunning }\end{array}$ \\
\hline $\begin{array}{l}\text { Tunbridge } \\
\text { Wells }\end{array}$ & Kent & & $\begin{array}{l}\text { Reddish-brown. } \\
\text { Diam. I cm. Ht. } \\
5 \mathrm{~mm} \text {. Perf. diam. } \\
5 \mathrm{~mm} .\end{array}$ & $\begin{array}{l}\text { From High Rocks } \\
\text { Camp (late Iron Age) } \\
\text { 2nd c. B.C. to Roman } \\
\text { conquest }\end{array}$ & $S A C$ cvi (rg68) \\
\hline Bath & Somerset & $\begin{array}{l}\text { Bath, Roman Baths } \\
\text { Museum }\end{array}$ & $\begin{array}{l}3 \text { similar, reddish- } \\
\text { brown, varying } \\
\text { between diams. } 6 \text { and } \\
9 \mathrm{~mm} \text {. All are small } \\
\text { ring-beads with wic e } \\
\text { perforation }\end{array}$ & $\begin{array}{l}\text { From Roman Bath } \\
\text { site }\end{array}$ & $\begin{array}{l}\text { Cunliffe, B. } \\
\text { Roman Bath Dis- } \\
\text { covered (I97 I) and } \\
\text { refs. }\end{array}$ \\
\hline
\end{tabular}




\begin{tabular}{|c|c|c|c|c|c|}
\hline $\begin{array}{l}\text { SITE AND } \\
\text { PARISH }\end{array}$ & COUNTY & MUSEUM \& NO. & $\begin{array}{l}\text { DESGRIPTION AND } \\
\text { APPROX. DIMENSIONS }\end{array}$ & $\begin{array}{l}\text { ASSOCIATIONS AND } \\
\text { REMARKS }\end{array}$ & PUBLICATION \\
\hline \multicolumn{6}{|c|}{ SCOTLAND } \\
\hline \multirow[t]{2}{*}{ Culbin Sands } & Morayshire & & $\begin{array}{l}\text { Reddish. Appears } \\
\text { very new. Diam. I. } 2 \\
\mathrm{~cm} .\end{array}$ & & \\
\hline & & & WALES & & \\
\hline Caerwent & $\begin{array}{l}\text { Monmouth- } \\
\text { shire }\end{array}$ & Newport D.2.353 & $\begin{array}{l}\text { Brownish-yellow. } \\
\text { Diam. I } 1 \mathrm{~cm} . \\
\text { Perf. diam. } 6 \mathrm{~mm} .\end{array}$ & From Roman site & \\
\hline \multicolumn{6}{|c|}{ (VI) SMALL OPAQUE TERRAGOTTA COLOURED } \\
\hline \multicolumn{6}{|c|}{ ENGLAND } \\
\hline $\begin{array}{l}\text { Croft Ambry, } \\
\text { Lucton }\end{array}$ & Herefordshire & Hereford 223 & $\begin{array}{l}\text { Over a cobalt core. } \\
\text { Diam. } 1 \cdot 4 \mathrm{~cm} . \mathrm{Ht} \text {. } \\
8 \mathrm{~mm} . \text { Perf. diam. } \\
3 \mathrm{~mm} .\end{array}$ & $\begin{array}{l}\text { From hill-fort ? ist c. } \\
\text { A.D. }\end{array}$ & $\begin{array}{l}\text { Stanford, S. C. } \\
(1974)\end{array}$ \\
\hline \multirow[t]{2}{*}{ Meare } & Somerset & Taunton $\mathrm{G} 73$ & $\begin{array}{l}\text { Over a ? yellow core. } \\
\text { Diam. } 8 \mathrm{~mm} . \text { Ht. } \\
3 \mathrm{~mm} . \text { Perf. diam. } \\
4 \mathrm{~mm} .\end{array}$ & $\begin{array}{l}\text { From mound XXVIII } \\
\text { ? 3rd-ist c. B.c. }\end{array}$ & Me iii \\
\hline & & (VII) SMALL OPAQ & UE OR TRANSLUCENT & SKY BLUE & \\
\hline \multicolumn{6}{|c|}{ ENGLAND } \\
\hline Cople & Bedfordshire & $\begin{array}{l}\text { c/o James Dyer, } 45 \\
\text { Ashcroft Rd., Luton, } \\
\text { Beds. }\end{array}$ & $\begin{array}{l}\text { Light blue. Diam. } \\
8 \mathrm{~mm} \text {. Ht. } 5 \mathrm{~mm} \text {. } \\
\text { Perf. diam. } 3 \mathrm{~mm} \text {. }\end{array}$ & $\begin{array}{l}\text { Unstratified mixed } \\
\text { site. Ring ditch of } \\
\text { Iron Age A date } \\
\text { with subsequent } \\
\text { building inside. The } \\
\text { bead almost certainly } \\
\text { belongs to the later } \\
\text { (undated) phase }\end{array}$ & $\begin{array}{l}\text { Information } \\
\text { (1962) from } \\
\text { excavator }\end{array}$ \\
\hline South Shields & Durham & $\begin{array}{l}\text { From University } \\
\text { Museum, Newcastle- } \\
\text { upon-Tyne }\end{array}$ & $\begin{array}{l}\text { Diam. } 7 \mathrm{~mm} . \text { Ht. } 3 \\
\text { mm. Perf. diam. very } \\
\text { small }\end{array}$ & $\begin{array}{l}\text { Fort occupied } 九 \text {. A.D. } \\
\text { 122-369 }\end{array}$ & $\begin{array}{l}\text { See Richmond, } \\
\text { I.A. (1953) }\end{array}$ \\
\hline \multicolumn{6}{|c|}{ IRELAND } \\
\hline Tara & Co. Meath & $\begin{array}{l}\text { Dublin (Tara, no. } \\
\text { I } 32 \text { ) }\end{array}$ & Opaque turquoise & $\begin{array}{l}\text { Rath of the Synods } \\
\text { which produced } \\
\text { Roman pottery of } \\
\text { Ist-3rd C. A.D. }\end{array}$ & $\begin{array}{l}\text { ÓRiordáin, S. P. } \\
(1964)\end{array}$ \\
\hline \multicolumn{6}{|c|}{ SGOTLAND } \\
\hline Newstead & $\begin{array}{l}\text { Roxburgh- } \\
\text { shire }\end{array}$ & $\begin{array}{l}\text { Private hands (Mr. } \\
\text { Mason, Selkirk) }\end{array}$ & $\begin{array}{l}\text { Diam. } 7 \text { mm. Ht. } 2 \\
\text { mm. Perf. diam. very } \\
\text { small }\end{array}$ & $\begin{array}{l}\text { Site occupied } c . \text { A.D. } \\
80-200 . \text { Stray find }\end{array}$ & For site see $\mathcal{N} e$ \\
\hline Selkirk (Nr.) & Selkirkshire & Private hands & $\begin{array}{l}\text { Diam. } 5 \mathrm{~mm} . \mathrm{Ht} .3 \\
\mathrm{~mm} . \text { Perf. diam. } \\
2^{x} \mathrm{~mm} .\end{array}$ & $\begin{array}{l}\text { From Mr. Mason's } \\
\text { Colln., Selkirk. Stray } \\
\text { find }\end{array}$ & \\
\hline
\end{tabular}




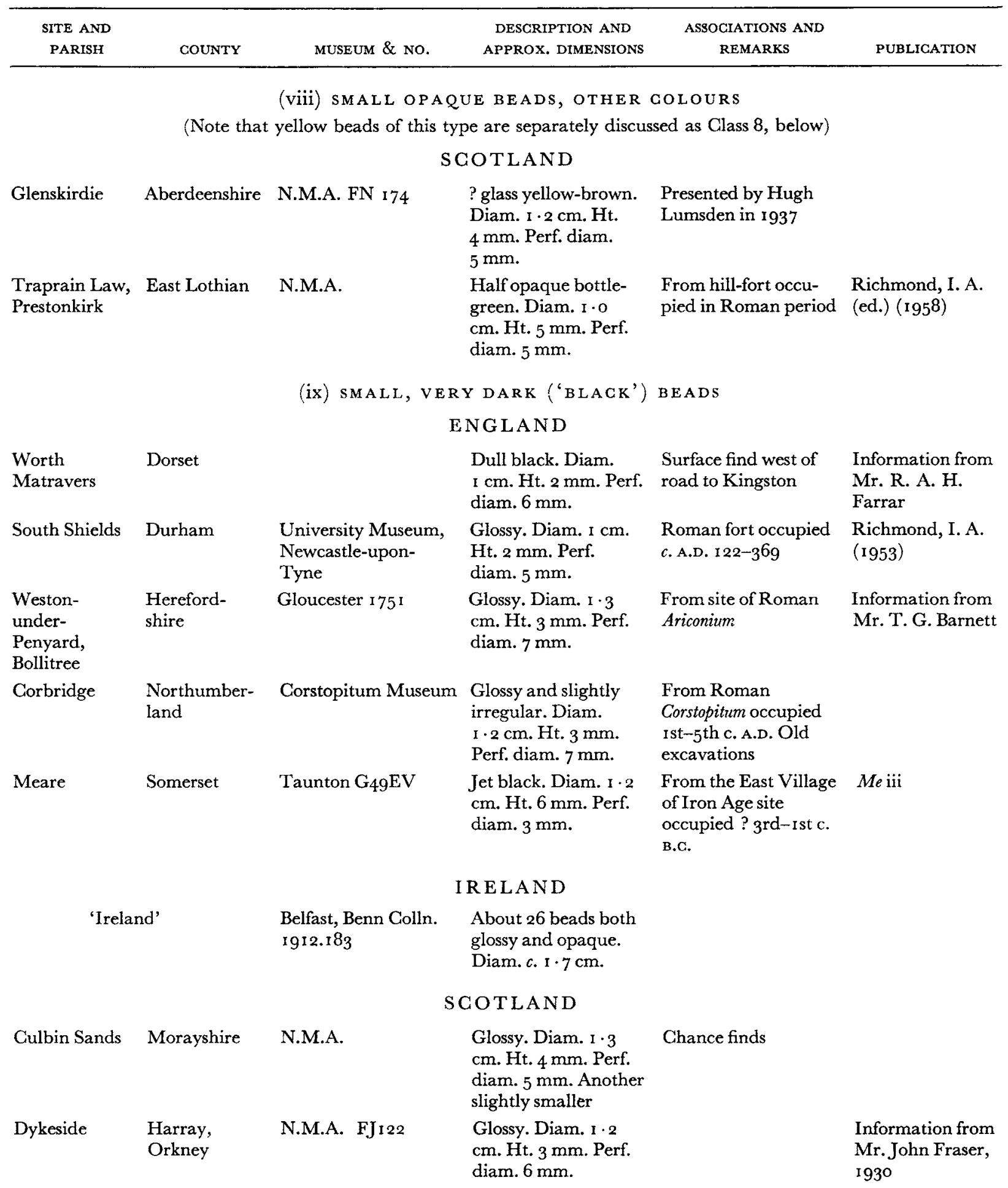




\begin{tabular}{|c|c|c|c|c|c|}
\hline $\begin{array}{l}\text { SITE AND } \\
\text { PARISH }\end{array}$ & COUNTY & MUSEUM \& NO. & $\begin{array}{l}\text { DESCRIPTION AND } \\
\text { APPROX. DIMENSIONS }\end{array}$ & $\begin{array}{l}\text { ASSOCIATIONS AND } \\
\text { REMARKS }\end{array}$ & PUBLICATION \\
\hline \multicolumn{6}{|c|}{ GROUP 7} \\
\hline \multicolumn{6}{|c|}{ UNDEGORATED GLOBULAR BEADS } \\
\hline \multicolumn{6}{|c|}{ (i) LARGE GLOBULAR BEADS IN VARIOUS GOLOURS } \\
\hline \multicolumn{6}{|c|}{ ENGLAND } \\
\hline Hamworthy & Dorset & Poole & $\begin{array}{l}\text { Semi-translucent } \\
\text { bright cobalt. Diam. } \\
1 \cdot 7 \mathrm{~cm} . \mathrm{Ht} . \mathrm{I} \cdot 5 \mathrm{~cm} . \\
\text { Perf. diam. } 6 \mathrm{~mm} .\end{array}$ & $\begin{array}{l}\text { From pre-Roman } \\
\text { and Roman site }\end{array}$ & $\begin{array}{l}\text { H. P. Smith, } \\
\text { History of Poole, } \\
\text { Pt. i, pp. } 46-7\end{array}$ \\
\hline Tuffley & $\begin{array}{l}\text { Gloucester- } \\
\text { shire }\end{array}$ & $\begin{array}{l}\text { Gloucester Museum, } \\
\text { no. } 1028\end{array}$ & $\begin{array}{l}\text { Bright translucent } \\
\text { cobalt. Diam. } 1 \cdot 7 \\
\mathrm{~cm} . \mathrm{Ht} . \mathrm{I} \cdot 5 \mathrm{~cm} . \text { Perf. } \\
\text { diam. } 5 \mathrm{~mm} \text {. }\end{array}$ & $\begin{array}{l}\text { Stray find from Roman } \\
\text { and post-Roman site }\end{array}$ & \\
\hline $\begin{array}{l}\text { Wilderspool, } \\
\text { Warrington }\end{array}$ & $\begin{array}{l}\text { Lancashire- } \\
\text { Cheshire- } \\
\text { border }\end{array}$ & Warrington, no. $5 \mathrm{I}$ & $\begin{array}{l}\text { Bright green. Diam. } \\
\text { I } \cdot 7 \mathrm{~cm} . \mathrm{Ht} . \mathrm{I} \cdot 6 \mathrm{~cm} .\end{array}$ & From Roman site & $\begin{array}{l}\text { For site, see May, } \\
\text { T. (rgo4) and } \\
\text { Thompson, F. H. } \\
\left(\text { I }_{6} \text { ) }\right.\end{array}$ \\
\hline $\begin{array}{l}\text { Rainsborough } \\
\text { Camp, } \\
\text { Newbottle }\end{array}$ & $\begin{array}{l}\text { Northampton- } \\
\text { shire }\end{array}$ & A.M. & $\begin{array}{l}\text { Fragment only. } \\
\text { Diam. } 2 \cdot 5 \mathrm{~cm} . \mathrm{Ht} \text {. } \\
2 \cdot 3 \mathrm{~cm} . \text { Perf. diam. } \\
5 \mathrm{~mm} .\end{array}$ & $\begin{array}{l}\text { From late Iron Age } \\
\text { level, ? 2nd-ist } \\
\text { c. B.C., in Iron Age } \\
\text { fort }\end{array}$ & $\begin{array}{l}P P S \text { xxxiii (1967), } \\
\text { fig. } 28 \text {, no. I } 21\end{array}$ \\
\hline Glastonbury & Somerset & Glastonbury G8 & $\begin{array}{l}\text { Greeny blue opaque } \\
\text { but probably origin- } \\
\text { ally translucent. } \\
\text { Diam. I } 6 \mathrm{~cm} \text {. Ht. } \\
\text { I } 2 \mathrm{~cm} \text {. Perf. diam. } \\
7 \mathrm{~mm} \text {. }\end{array}$ & Pre-Roman & $G l \ddot{\mathrm{ii}}$ \\
\hline Meare & Somerset & Taunton $\mathrm{Gg}_{9}$ & $\begin{array}{l}\text { Translucent brownish- } \\
\text { yellow. Diam. } 2 \mathrm{~cm} \text {. } \\
\text { Ht. I cm. Perf. diam. } \\
7 \mathrm{~mm} \text {. }\end{array}$ & $\begin{array}{l}\text { From East Village of } \\
\text { pre-Roman site }\end{array}$ & $M e$ iii \\
\hline $\begin{array}{l}\text { Bury Wood } \\
\text { Camp, } \\
\text { Colerne }\end{array}$ & Wiltshire & & $\begin{array}{l}\text { Half bead. Translu- } \\
\text { cent. Striated. Diam. } \\
2 \cdot 2 \mathrm{~cm} . \text { Ht. } 1.5 \mathrm{~cm} \text {. } \\
\text { Perf. diam. } 9 \mathrm{~mm} \text {. }\end{array}$ & $\begin{array}{l}\text { From what seem } \\
\text { clearly Iron Age B } \\
\text { associations (2nd-Ist } \\
\text { century B.c.?) }\end{array}$ & $\begin{array}{l}\text { For interim } \\
\text { reports on this site } \\
\text { see } W A M \text { lviii } \\
(196 \mathrm{I}), 40-7 \text { and } \\
\text { I } 85-208 ; \text { lxii } \\
\left(19^{6} 7\right), 1-5 \text {, and } \\
\text { lxiv (1969), } 2 \mathrm{I}-5^{\circ}\end{array}$ \\
\hline Skipton & Yorkshire & Skipton & $\begin{array}{l}\text { Opaque. Blue. Diam. } \\
1.8 \mathrm{~cm} \text {. Ht. irregular } \\
\mathrm{I} \cdot \mathrm{I} \mathrm{cm} . \text { Perf. diam. } \\
6 \mathrm{~mm} .\end{array}$ & $\begin{array}{l}\text { From an Iron Age } \\
\text { enclosure }\end{array}$ & $\begin{array}{l}\text { To be published in } \\
r A \mathcal{F}\end{array}$ \\
\hline
\end{tabular}

\section{RELAND}

Some beads of this form are known from Ireland but from collections 


\begin{tabular}{|c|c|c|c|c|}
\hline $\begin{array}{l}\text { SITE AND } \\
\text { PARISH }\end{array}$ & COUNTY & MUSEUM \& No. & $\begin{array}{l}\text { DESCRIPTION AND } \\
\text { APPROX. DIMENSIONS }\end{array}$ & $\begin{array}{l}\text { ASSOCIATIONS AND } \\
\text { REMARKS }\end{array}$ \\
\hline & \multicolumn{4}{|c|}{ SGOTLAND } \\
\hline & \multicolumn{4}{|c|}{$\begin{array}{l}\text { Two yellowish-brown examples are in the N.M.A. in Edinburgh. They are both } \\
\text { translucent and about } 23 \text { mm. in diameter. They come from Craigsford Mains, } \\
\text { Earlston, Berwickshire (N.M.A. FJ I } 4 \text { 2) and from Birrens, Dumfries (N.M.A. } \\
\text { FP }_{254} \text { ). See for the latter PSAS xxx (1896), 81 ff. }\end{array}$} \\
\hline
\end{tabular}

\begin{tabular}{|c|c|c|c|c|c|}
\hline & & & WALES & & \\
\hline $\begin{array}{l}\text { Moel Trigarn } \\
\text { Fort }\end{array}$ & $\begin{array}{l}\text { Pembroke- } \\
\text { shire }\end{array}$ & Tenby & $\begin{array}{l}\text { Natural glass. } 7 \text { half- } \\
\text { beads about } \mathrm{I} \cdot 8 \mathrm{~cm} \text {. } \\
\text { diam. Ht. } \mathrm{I} \cdot 3 \mathrm{~cm} \text {. } \\
\text { Some of these had } \\
\text { been repaired in } \\
\text { antiquity }\end{array}$ & $\begin{array}{l}\text { Iron Age fort. With a } \\
\text { Meare spiral bead } \\
\text { (Class Io) about } 3^{\text {rd }} \\
\text { to ist c. B.c. }\end{array}$ & $\begin{array}{l}A C, 5^{\text {th s., }} \text { xvii } \\
\text { (1900) }\end{array}$ \\
\hline
\end{tabular}

(ii) MEDIUM AND SMALL GLOBULAR BEADS IN NATURAL GREENISH TRANSLUGENT GLASS

\begin{tabular}{|c|c|c|c|c|c|}
\hline \multirow{2}{*}{$\begin{array}{l}\text { Nor' nour, } \\
\text { Scilly }\end{array}$} & \multicolumn{4}{|c|}{ ENGLAND } & \multirow[b]{2}{*}{$\begin{array}{l}A C, 5^{\text {th }} \text { s., xvii } \\
(1900)\end{array}$} \\
\hline & Cornwall & $\begin{array}{l}\text { St. Mary's, Scilly, } \\
\text { nos. } 114,65\end{array}$ & $\begin{array}{l}2 \text { small beads about } \\
\text { diam. } 7 \mathrm{~mm} \text {. }\end{array}$ & $\begin{array}{l}\text { Most of the occupa- } \\
\text { tion of this site was } \\
\text { Ist-4th c. A.D. }\end{array}$ & \\
\hline $\begin{array}{l}\text { Holcombe } \\
\text { Roman Villa }\end{array}$ & Devonshire & Sidmouth & $\begin{array}{l}\text { Irregularly made. } \\
\text { Diam. } 8 \mathrm{~mm} . \mathrm{Ht} .9 \\
\text { mm. }\end{array}$ & $\begin{array}{l}\text { Unstratified from } \\
\text { Roman villa. The } \\
\text { bronze mirror from } \\
\text { this villa is in the } \\
\text { B.M. }\end{array}$ & $P D A S \mathrm{xxxii}(\mathrm{r} 974)$ \\
\hline Woodyates & Dorset & Salisbury & 2 or 3 small examples & $\begin{array}{l}\text { Early Romano- } \\
\text { British }\end{array}$ & $\begin{array}{l}\text { Pitt-Rivers, } \\
\text { A. H. L. F. (I } 888 \text { ) }\end{array}$ \\
\hline Colchester & Essex & Colchester & $\begin{array}{l}\text { Rather darker than } \\
\text { normal. Diam. } 1 \cdot 5 \\
\mathrm{~cm} . \text { Ht. } 1 \cdot 4 \mathrm{~cm} .\end{array}$ & $\begin{array}{l}\text { From burial group } \\
94 . \text { Apparently with } \\
\text { other beads but the } \\
\text { group has been } \\
\text { confused }\end{array}$ & $\begin{array}{l}\text { May, T. (I93o), } \\
279\end{array}$ \\
\hline Cirencester & $\begin{array}{l}\text { Gloucester- } \\
\text { shire }\end{array}$ & & $\begin{array}{l}\text { Half-bead. Diam. } \\
7 \mathrm{~mm} . \text { Ht. } 5 \mathrm{~mm} . \\
\text { Perf. diam. } 2 \mathrm{~mm} \text {. }\end{array}$ & $\begin{array}{l}\text { From the Roman } \\
\text { villa at Barnsley Park. } \\
\text { Occupation 2nd-4th } \\
\text { C. A.D. }\end{array}$ & $\begin{array}{l}\text { Information from } \\
\text { Dr. G. Webster }\end{array}$ \\
\hline Silchester & Hampshire & Reading & Small beads (several) & $\begin{array}{l}\text { On necklace. Site } \\
\text { occupied throughout } \\
\text { Roman period }\end{array}$ & $\begin{array}{l}\text { For refs. see } \\
\text { Collingwood and } \\
\text { Richmond, The } \\
\text { Archaeology of } \\
\text { Roman Britain (rev. } \\
\text { ed. I969) and } \\
\text { Boon, G. C. (1957) }\end{array}$ \\
\hline Kenchester & Herefordshire & Hereford & $\begin{array}{l}\text { Diam. } 6 \mathrm{~mm} . \mathrm{Ht} \text {. } \\
7 \mathrm{~mm} . \text { Very small } \\
\text { perforation }\end{array}$ & $\begin{array}{l}\text { From Roman town } \\
\text { occupied till c. A.D. } \\
39^{\circ}\end{array}$ & $\begin{array}{l}T W N F C \text { igi } 6 \text { and } \\
1926\end{array}$ \\
\hline
\end{tabular}




\begin{tabular}{|c|c|c|c|c|c|}
\hline $\begin{array}{l}\text { SITE AND } \\
\text { PARISH }\end{array}$ & COUNTY & MUSEUM \& NO. & $\begin{array}{l}\text { DESGRIPTION AND } \\
\text { APPROX. DIMENSIONS }\end{array}$ & $\begin{array}{l}\text { ASSOCIATIONS AND } \\
\text { REMARKS }\end{array}$ & PUBLICATION \\
\hline $\begin{array}{l}\text { Weston- } \\
\text { under- } \\
\text { Penyard, } \\
\text { Bollitree }\end{array}$ & Herefordshire & $\begin{array}{l}\text { Gloucester, nos. } \\
\text { I } 755 \text {, I } 753\end{array}$ & $\begin{array}{l}\text { Almost opaque now } \\
\text { through weathering. } \\
\text { Diam. I } 4 \mathrm{~cm} . \mathrm{Ht} \text {. } \\
\text { I } \mathrm{cm} \text {. Perf. diam. } \\
5 \mathrm{~mm} \text {. Another } \\
\text { smaller }\end{array}$ & $\begin{array}{l}\text { With many early } \\
\text { Roman objects }\end{array}$ & \multirow[t]{2}{*}{$\begin{array}{l}\mathcal{J} B A A \mathrm{xxvii}(\mathrm{I} 87 \mathrm{r}), \\
2 \text { I I ff. }\end{array}$} \\
\hline $\begin{array}{l}\text { Great } \\
\text { Chesters }\end{array}$ & $\begin{array}{l}\text { Northumber- } \\
\text { land }\end{array}$ & $\begin{array}{l}\text { University Muscum, } \\
\text { Newcastle-upon- } \\
\text { Tyne }\end{array}$ & $\begin{array}{l}2 \text { examples about } \\
1 \mathrm{~cm} . \text { in diam. }\end{array}$ & $\begin{array}{l}\text { On Roman necklace. } \\
\text { Early excavations }\end{array}$ & \\
\hline $\begin{array}{l}\text { Castle Hill, } \\
\text { Whitton }\end{array}$ & Suffolk & Ipswich & $\begin{array}{l}\text { A number of small } \\
\text { beads strung on wire } \\
\text { with a flat pendant of } \\
\text { same glass }\end{array}$ & $\begin{array}{l}\text { Roman villa occupied } \\
\text { c. A.D. I } 30-29^{\circ}\end{array}$ & $\begin{array}{l}P S A I \times x i(193 I-3), \\
249 \text { ff. }\end{array}$ \\
\hline \multicolumn{6}{|c|}{ IRELAND } \\
\hline $\begin{array}{l}\text { Grannagh, } \\
\text { Ardrahan }\end{array}$ & Co. Galway & Galway? & $\begin{array}{l}\text { Diameter and height } \\
I \cdot 7 \mathrm{~cm} \text {. ? reused } \\
\text { Roman bottle glass }\end{array}$ & $\begin{array}{l}\text { Very like the St. } \\
\text { David's beads. Prob- } \\
\text { ably first four centuries } \\
\text { A.D. Perhaps pillaged } \\
\text { Roman glass }\end{array}$ & $\begin{array}{l}P R I A \times x \times i i i(1916- \\
17), 508\end{array}$ \\
\hline \multicolumn{6}{|c|}{ WALES } \\
\hline $\begin{array}{l}\text { Coygan } \\
\text { Camp, } \\
\text { Lougharne }\end{array}$ & $\begin{array}{l}\text { Garmarthen- } \\
\text { shire }\end{array}$ & c/o G. Wainwright & $\begin{array}{l}\text { Rather large irregular } \\
\text { and perhaps made of } \\
\text { reused Roman glass }\end{array}$ & Late 3 rd C. A.D. & $\begin{array}{l}\text { Wainwright, G.J. } \\
(1967)\end{array}$ \\
\hline $\begin{array}{l}\text { Merthyr, } \\
\text { Mawr Warren }\end{array}$ & $\begin{array}{l}\text { Glamorgan- } \\
\text { shire }\end{array}$ & N.M.W. $50.466 / 37$ & $\begin{array}{l}\text { Diam. } 9 \text { mm. Ht. } 6 \\
\text { mm. Perf. diam. } 4 \\
\text { mm. }\end{array}$ & $\begin{array}{l}\text { Mixed pre-Roman } \\
\text { and Roman finds }\end{array}$ & $\begin{array}{l}\left.B B C S \text { xiv (I } 95^{2}\right) \\
\text { I } 70-1\end{array}$ \\
\hline $\begin{array}{l}\text { Whitton, } \\
\text { nr. Barry }\end{array}$ & $\begin{array}{l}\text { Glamorgan- } \\
\text { shire }\end{array}$ & N.M.W. & $\begin{array}{l}\text { Diam. } 7 \mathrm{~mm} \text {. Ht. } 6 \\
\text { mm. Very small } \\
\text { perforation }\end{array}$ & $\begin{array}{l}\text { Site of Roman villa. } \\
\text { Occupied ist c. B.C.- } \\
\text { c. A.D. } 3^{00}\end{array}$ & $\begin{array}{l}\text { Information from } \\
\text { Dr. M.Jarrett }\end{array}$ \\
\hline Caerwent & $\begin{array}{l}\text { Monmouth- } \\
\text { shire }\end{array}$ & Newport D2.35 I & $\begin{array}{l}\text { Diam. } 9 \mathrm{~mm} . \mathrm{Ht} . \\
\text { I } \cdot \mathrm{I} \mathrm{cm} . \text { Very small } \\
\text { perforation }\end{array}$ & $\begin{array}{l}\text { From House } 13 \text { of } \\
\text { Roman town }\end{array}$ & $\begin{array}{l}\text { Information from } \\
\text { Dr. G. G. Dunning }\end{array}$ \\
\hline Usk & $\begin{array}{l}\text { Monmouth- } \\
\text { shire }\end{array}$ & & $\begin{array}{l}\text { Diam. } 6 \mathrm{~mm} . \mathrm{Ht} . \\
6 \mathrm{~mm} . \text { Very small } \\
\text { perforation }\end{array}$ & $\begin{array}{l}\text { Roman fort. Main } \\
\text { occupation A.D. } 55^{-} \\
\text {6o but sporadic later } \\
\text { Roman occupation }\end{array}$ & $\begin{array}{l}\text { Information from } \\
\text { excavator }\end{array}$ \\
\hline Moel Trigarn & $\begin{array}{l}\text { Pembroke- } \\
\text { shire }\end{array}$ & Tenby & $\begin{array}{l}\text { Several examples of } \\
\text { varying sizes }\end{array}$ & $\begin{array}{l}\text { From huts in hill-fort } \\
\text { with Iron Age and } \\
\text { later occupation }\end{array}$ & $\begin{array}{l}A C, 5^{\text {th }} \text { s., xvii } \\
\text { (1900) }\end{array}$ \\
\hline $\begin{array}{l}\text { St. David's } \\
\text { Head }\end{array}$ & $\begin{array}{l}\text { Pembroke- } \\
\text { shire }\end{array}$ & Tenby & Several examples & $\begin{array}{l}\text { The beads from this } \\
\text { site look sub- or post- } \\
\text { Roman }\end{array}$ & \\
\hline
\end{tabular}




\begin{tabular}{cccccc}
\hline $\begin{array}{c}\text { SITE AND } \\
\text { PARISH }\end{array}$ & COUNTY & MUSEUM \& NO. & DESCRIPTION AND & ASSOCIATIONS AND \\
APPROX. DIMENSIONS & REMARKS \\
\hline
\end{tabular}

(iii) MEDIUM AND SMALL GLOBULAR BEADS TRANSLUGENT OR OPAQUE GREEN GLASS

\section{ENGLAND}

Nor' nour, Cornwall $\quad$ St. Mary's, Scilly
Scilly
Scilly

Woolley Cornwall
Barrow,
Morwenstow

Dorchester Dorset Dorchester

Dorchester Dorset

Bagendon Gloucester-

Tuffley

Winchester (Lankhills Cemetery)

Lincoln (Flaxengate)

London

'Mendip' Somerset

Shepton Mallet shire

Lincolnshire

London

Gloucester- Gloucester 1030 shire

Dorchester, Hogg's Colln.

Hampshire

Lincoln City and County Museum

Formerly Guildhall Museum I 72 I 5

A. C. Pass Colln., Bristol F209o

Somerset

Shepton Mallet
Mixed opaque green and yellowish glass. Diam. 8 mm. Ht. 8 $\mathrm{mm}$. Small perforation

Bright bottle green. Concave boring. Diam. $6 \mathrm{~mm}$.

Light green opaque. Diam. I $\cdot 2 \mathrm{~cm}$. Ht.

$\mathrm{I} \cdot 2 \mathrm{~cm}$. Small per-

foration

Opaque. Diam. I cm. Probably from the Ht. I I cm. Perf. diam. $3 \mathrm{~mm}$.

Dark bottle green almost opaque.

Diam. $5 \mathrm{~mm}$. Almost opaque.
Diam. $6 \mathrm{~mm}$.

Several beads, green or greenish-yellow, diam. approx. $3 \mathrm{~mm}$.

2 examples

Dark translucent. Diam. $7 \mathrm{~mm}$.

This site produced

In passage dug Roman town

Mid-Ist C. A.D.

Stray find on site producing Roman and post-Roman objects

Necklaces 85,182 , in grave variously A.D. $310-70$ graphically either

Ghance find many Roman finds

Arf cxxiv ( 1967) by tomb robbers in about the late $5^{\text {th }} \mathrm{c}$. A.D., but perhaps not

From Roman stratum R.G.H.M. Dorset

Glifford, E. M. (196r) 215,424 , and 425 , all dated with the period

Both could be stratiRoman or medieval

Translucent squarish. Probably Roman Diam. $5 \mathrm{~mm}$.

Translucent. Diam. $8 \mathrm{~mm}$. Ht. $8 \mathrm{~mm}$. Very small perforation 88

Glarke, G.

(forthcoming), figs. $73, a, 79, a$, $80,1,87$, a, $90, c$

$\mathcal{F R S}$ xxxviii( (1948),

VCH Somerset
Information from Miss D. Dudley

R.C.H.M. Dorset 


\begin{tabular}{|c|c|c|c|c|c|}
\hline $\begin{array}{l}\text { SITE AND } \\
\text { PARISH }\end{array}$ & COUNTY & MUSEUM \& NO. & $\begin{array}{l}\text { DESCRIPTION AND } \\
\text { APPROX. DIMENSIONS }\end{array}$ & $\begin{array}{l}\text { ASSOCIATIONS AND } \\
\text { REMARKS }\end{array}$ & PUBLICATION \\
\hline \multicolumn{6}{|c|}{ I RELAND } \\
\hline Tara & Co. Meath & Dublin & $\begin{array}{l}\text { Well made, translu- } \\
\text { cent dark greenish. } \\
\text { Diam. } 9 \mathrm{~mm} . \text { Ht. } 8 \\
\text { mm. Perf. diam. } \\
2 \mathrm{~mm} \text {. }\end{array}$ & $\begin{array}{l}\text { From the Rath of the } \\
\text { Synods which pro- } \\
\text { duced Ist-3rd c. } \\
\text { Roman pottery (excav. } \\
\text { no. } 204 \text { ). The bead is } \\
\text { probably Roman }\end{array}$ & $\begin{array}{l}\text { ORiordáin, S. P. } \\
\text { (1964) }\end{array}$ \\
\hline Tara & Co. Meath & Dublin & $\begin{array}{l}\text { Smaller and bluer } \\
\text { green }\end{array}$ & Excav. no. 182 & \\
\hline \multicolumn{6}{|c|}{ SGOTLAND } \\
\hline \multicolumn{6}{|c|}{$\begin{array}{l}\text { Two examples from the Culbin Sands (Moray) in N.M.A. in Edinburgh are } \\
\text { undated }\end{array}$} \\
\hline Glettraval & $\begin{array}{l}\text { North Uist } \\
\text { Inverness-shire }\end{array}$ & N.M.A. & $\begin{array}{l}\text { Half bead, described } \\
\text { as pale green trans- } \\
\text { lucent. Diam. } 1 \cdot 4 \\
\mathrm{~cm} \text {. Ht. } \mathrm{I} \cdot 4 \mathrm{~cm} . \\
\text { Perf. diam. } 3 \mathrm{~mm} \text {. }\end{array}$ & $\begin{array}{l}\text { This was found below } \\
\text { the level of the floor in } \\
\text { an aisled round-house } \\
\text { but is thought to have } \\
\text { worked down from a } \\
\text { higher level. It is } \\
\text { probably of early } \\
\text { Roman date }\end{array}$ & $P P S$ xiv (1948), 66 \\
\hline \multicolumn{6}{|c|}{ WALES } \\
\hline \multicolumn{6}{|c|}{$\begin{array}{l}\text { Two very small ones from Laugharne (Goygan Camp) in Wales belong to the } \\
\text { late } 3 \text { rd c. A.D. (Wainwright, G. J. (1967)) }\end{array}$} \\
\hline \multicolumn{6}{|c|}{ (iv) MEDIUM AND SMALL BLUE, TRANSLUGENT OR OPAQUE GLOBULAR BEADS } \\
\hline \multicolumn{6}{|c|}{ ENGLAND } \\
\hline Thatcham & Berkshire & Newbury & $\begin{array}{l}\text { Translucent light } \\
\text { blue. Diam. } 9 \mathrm{~mm} \text {. Ht. } \\
8 \mathrm{~mm} \text {. Perf. diam. } \\
2 \mathrm{~mm} \text {. }\end{array}$ & $\begin{array}{l}\text { Romano-British } \\
\text { settlement }\end{array}$ & $\begin{array}{l}T \mathcal{N D F C} \text { vï (1937), } \\
2 \mathrm{Ig} \mathrm{ff} .\end{array}$ \\
\hline $\begin{array}{l}\text { Santon } \\
\text { Downham }\end{array}$ & $\begin{array}{l}\text { Cambridge- } \\
\text { shire }\end{array}$ & C.M. & $\begin{array}{l}\text { Blue swirled glass. } \\
\text { Diam. I } 44 \mathrm{~cm} . \text { Ht. } \\
9 \mathrm{~mm} . \text { Perf. diam. } \\
3 \mathrm{~mm} .\end{array}$ & With ist c. A.D. hoard & $\begin{array}{l}\text { Fox, C. (1923), } \\
\text { Io4 }\end{array}$ \\
\hline $\begin{array}{l}\text { Nor' nour, } \\
\text { Scilly }\end{array}$ & Cornwall & St. Mary's, Scilly & $\begin{array}{l}\text { Light cobalt blue } \\
\text { translucent and badly } \\
\text { made possibly part of } \\
\text { segmented bead } \\
\text { about } 3 \mathrm{~mm} \text {. diam. }\end{array}$ & $\begin{array}{l}\text { Mostly } 2 \text { nd c. A.D. finds } \\
\text { but others of Roman } \\
\text { period generally }\end{array}$ & $\operatorname{Arf} \operatorname{cxxiv}(1967)$ \\
\hline $\begin{array}{l}\text { St. Mawgan- } \\
\text { in-Pyder }\end{array}$ & Cornwall & Truro & $\begin{array}{l}\text { Rich cobalt, semi- } \\
\text { translucent. Diam. } \\
\text { I } \cdot \text { I cm. Ht. } 9 \mathrm{~mm} . \\
\text { Small perforation }\end{array}$ & $\begin{array}{l}\text { Unstratified in pre- } \\
\text { Roman and early } \\
\text { Roman period settle- } \\
\text { ment (Carloggas) }\end{array}$ & $\operatorname{Arf}$ cxiii (1956) \\
\hline $\begin{array}{l}\text { Fordington, } \\
\text { Dorchester }\end{array}$ & Dorset & Dorchester & $\begin{array}{l}\text { A number of small } \\
\text { examples }\end{array}$ & $\begin{array}{l}\text { From cemetery } \\
\text { mostly } 4^{\text {th }} \text { C. A.D. }\end{array}$ & $\begin{array}{l}\text { Smith, C. Roach } \\
(1852) \text {, iii and } \\
\text { R.C.H.M. Dorset ii }\end{array}$ \\
\hline
\end{tabular}




\begin{tabular}{|c|c|c|c|c|c|}
\hline $\begin{array}{l}\text { SITE AND } \\
\text { PARISH }\end{array}$ & COUNTY & MUSEUM \& No. & $\begin{array}{l}\text { DESCRIPTION AND } \\
\text { APPROX. DIMENSTONS }\end{array}$ & $\begin{array}{l}\text { ASSOCIATIONS AND } \\
\text { REMARKS }\end{array}$ & PUBLICATION \\
\hline Woodcuts & Dorset & Salisbury & $\begin{array}{l}2 \text { examples. Diam. } \\
\text { I } \mathrm{cm} \text {. Diam. } 1 \cdot 4 \mathrm{~cm} .\end{array}$ & $\begin{array}{l}\text { Surface trenching in } \\
\text { Romano-British site }\end{array}$ & $\begin{array}{l}\text { Pitt-Rivers, } \\
\text { A. H. L. F. (1887), } \\
\text { pl. xliv, nos. I I } \\
\text { and I } 2 \text { and } A r \mathcal{J} \\
\operatorname{civ}(1947)\end{array}$ \\
\hline Colchester & Essex & Golchester & $\begin{array}{l}\text { Bright translucent } \\
\text { cobalt. Diam. I } 4 \\
\mathrm{~cm} . \text { Ht. I } 1 \mathrm{~cm} .\end{array}$ & $\begin{array}{l}\text { From group } 94 \text { dated } \\
\text { A.D. I } 50-200 \text {. Group } \\
\text { possibly confused). }\end{array}$ & $\begin{array}{l}\text { May, T. (I930), } \\
279\end{array}$ \\
\hline Bagendon & $\begin{array}{l}\text { Gloucester- } \\
\text { shire }\end{array}$ & & $\begin{array}{l}\text { Semi-translucent } \\
\text { fragment. Diam. I I } \\
\mathrm{cm} . \text { Ht. } 9 \mathrm{~mm} \text {. Perf. } \\
\text { diam. } 3 \mathrm{~mm} .\end{array}$ & $\begin{array}{l}\text { Pre-Roman Belgic of } \\
\text { Ist c. A.D. }\end{array}$ & $\begin{array}{l}\text { Clifford, E. M. } \\
(196 \mathrm{I})\end{array}$ \\
\hline $\begin{array}{l}\text { Bredon, } \\
\text { Bredon's } \\
\text { Norton }\end{array}$ & $\begin{array}{l}\text { Gloucester- } \\
\text { shire-Worces- } \\
\text { tershire borders }\end{array}$ & $\begin{array}{l}\text { Private museum at } \\
\text { Overbury Court }\end{array}$ & $\begin{array}{l}\text { Dark opaque. Diam. } \\
8 \mathrm{~mm} \text {. Ht. } 7 \mathrm{~mm} \text {. }\end{array}$ & $\begin{array}{l}\text { Probably last period } \\
\text { of inner entrance of } \\
\text { hill-fort. Ist c.? B.c. }\end{array}$ & $\begin{array}{l}A r \mathcal{J x C V}\left(193^{8}\right), 86 \\
\text { and fig. I } 2\end{array}$ \\
\hline $\begin{array}{l}\text { Winchester } \\
\text { (Lankhills } \\
\text { Cemetery) }\end{array}$ & Hampshire & & Blue, diam. $6-3 \mathrm{~mm}$. & $\begin{array}{l}\text { Necklaces } 85,215 \\
248,353,425, \text { all } \\
\text { variously dated within } \\
\text { the period A.D. } 3^{10-70}\end{array}$ & $\begin{array}{l}\text { Clarke, G. } \\
\text { (forthcoming) }\end{array}$ \\
\hline $\begin{array}{l}\text { Weston- } \\
\text { under- } \\
\text { Penyard, } \\
\text { Bollitree }\end{array}$ & Herefordshire & Gloucester $175^{8}$ & $\begin{array}{l}\text { Opaque rich cobalt. } \\
\text { Diam. I cm. Ht. } 9 \\
\text { mm. Perf. diam. } \\
2 \mathrm{~mm} .\end{array}$ & $\begin{array}{l}\text { Probably early } \\
\text { Romano-British. } \\
\text { (The site produced an } \\
\text { Oldbury type bead) }\end{array}$ & $\begin{array}{l}\mathcal{J B A A} \text { xxvii (1871), } \\
2 \text { I If. }\end{array}$ \\
\hline $\begin{array}{l}\text { Weston- } \\
\text { under- } \\
\text { Penyard, } \\
\text { Bollitree }\end{array}$ & Herefordshire & $\begin{array}{l}\text { Gloucester I } 749 \text {, } \\
\text { I } 747\end{array}$ & $\begin{array}{l}2 \text { others slightly } \\
\text { smaller }\end{array}$ & $\begin{array}{l}\text { Probably early } \\
\text { Romano-British. } \\
\text { (The site produced an } \\
\text { Oldbury type bead) }\end{array}$ & $\begin{array}{l}7 B A A \text { xxvii ( } 187 \text { г), } \\
\text { 2 г If. }\end{array}$ \\
\hline $\begin{array}{l}\text { Weston- } \\
\text { under- } \\
\text { Penyard, } \\
\text { Bollitree }\end{array}$ & Herefordshire & Gloucester $177^{\circ}$ & $\begin{array}{l}\text { Opaque dull blue. } \\
\text { Diam. } 5 \mathrm{~mm} \text {. Ht. } \\
5 \mathrm{~mm} \text {. Very small } \\
\text { perforation }\end{array}$ & $\begin{array}{l}\text { Probably early } \\
\text { Romano-British. } \\
\text { (The site produced an } \\
\text { Oldbury type bead) }\end{array}$ & $\begin{array}{l}\not{7 B A A} \text { xxvii (I87 I), } \\
2 \text { I I ff. }\end{array}$ \\
\hline St. Albans & Hertfordshire & Verulamium & $\begin{array}{l}\text { One or two on neck- } \\
\text { lace }\end{array}$ & 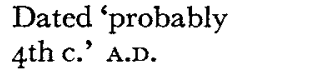 & $\begin{array}{l}V e, p .214 \text { and fig. } \\
47\end{array}$ \\
\hline London & London & $\begin{array}{l}\text { Formerly Guildhall } \\
\text { Museum I } 72 \text { I } 7 / \\
\text { I } 7216,3964\end{array}$ & $\begin{array}{l}\text { Three examples, all } \\
\text { translucent }\end{array}$ & All chance finds & \\
\hline Great Chesters & $\begin{array}{l}\text { Northumber- } \\
\text { land }\end{array}$ & $\begin{array}{l}\text { University Museum, } \\
\text { Newcastle-upon- } \\
\text { Tyne }\end{array}$ & Several & $\begin{array}{l}\text { Roman necklace. Old } \\
\text { excavations }\end{array}$ & \\
\hline Chesters Fort & $\begin{array}{l}\text { Northumber- } \\
\text { land }\end{array}$ & $\begin{array}{l}\text { Chesters Museum } \\
6 \text { I } 4\end{array}$ & Several examples & $\begin{array}{l}\text { Clayton excavation. } \\
\text { Likely date between } \\
\text { A.D. } 122-3^{8} 3\end{array}$ & \\
\hline Brislington & Somerset & Bristol F2318 & $\begin{array}{l}\text { Slightly translucent. } \\
\text { Diam. } 9 \mathrm{~mm} .\end{array}$ & $\begin{array}{l}\text { Roman villa, occu- } \\
\text { pied late } 3 \text { rd to mid- } \\
4^{\text {th }} \text { c. A.D. }\end{array}$ & $\begin{array}{l}\text { TBGAS xxiii } \\
(\mathrm{I} 900) \text { and } \mathrm{xxiv} \\
(\mathrm{I} 90 \mathrm{I})\end{array}$ \\
\hline $\begin{array}{l}\text { Ham Hill } \\
\text { (Montacute) }\end{array}$ & Somerset & Taunton & $\begin{array}{l}\text { Rich dark trans- } \\
\text { lucent. Diam. } 8 \mathrm{~mm} \text {. } \\
\text { Ht. } 8 \mathrm{~mm} \text {. Very small } \\
\text { perforation }\end{array}$ & $\begin{array}{l}\text { Iron Age hill-fort } \\
\text { with later occupation. } \\
\text { Mostly late Iron Age } \\
\text { and Roman }\end{array}$ & $\begin{array}{l}\text { VCH Somerset i, } \\
\text { p. } 295 \text { and } A r f \\
\text { cvii }\left(195^{\circ}\right), 90\end{array}$ \\
\hline
\end{tabular}


THE SGHEDULES: GROUP 7

\begin{tabular}{|c|c|c|c|c|c|}
\hline $\begin{array}{l}\text { SITE AND } \\
\text { PARISH }\end{array}$ & COUNTY & MUSEUM \& NO. & $\begin{array}{l}\text { DESGRIPTION AND } \\
\text { APPROX. DIMENSIONS }\end{array}$ & $\begin{array}{l}\text { ASSOCIATIONS AND } \\
\text { REMARKS }\end{array}$ & PUBLICATION \\
\hline Meare & Somerset & Taunton $\mathrm{G}_{\mathrm{I}}$ & $\begin{array}{l}\text { Rich dark cobalt. } \\
\text { Slightly mottled and } \\
\text { opaque. Diam. } 9 \\
\text { mm. Ht. } 8 \mathrm{~mm} . \text { Perf. } \\
\text { diam. } 3 \mathrm{~mm} .\end{array}$ & $\begin{array}{l}\text { From pre-Roman } \\
\text { settlement. ? 3rd-Ist. } \\
\text { c. B.c. }\end{array}$ & $M e \mathrm{iii}$ \\
\hline Whitton & Suffolk & Ipswich & $\begin{array}{l}\text { Several mounted on } \\
\text { bronze rings. Diam. } \\
6 \mathrm{~mm} \text {. }\end{array}$ & $\begin{array}{l}\text { Roman villa (Castle } \\
\text { Hill) occupied } c \text {. A.D. } \\
\text { I } 30-290\end{array}$ & $\begin{array}{l}P S I A \text { xxi }\left(193^{I}-3\right), \\
249 \mathrm{ff} .\end{array}$ \\
\hline $\begin{array}{l}\text { Cold Kitchen } \\
\text { Hill, Brixton } \\
\text { Deverill }\end{array}$ & Wiltshire & Devizes & $\begin{array}{l}\text { Almost opaque. } \\
\text { Diam. } 1 \mathrm{~cm} . \mathrm{Ht} .8 \\
\text { mm. }\end{array}$ & $\begin{array}{l}\text { Hundreds of late } \\
\text { Roman period beads } \\
\text { came from this hill. } \\
\text { ? Romano-Celtic } \\
\text { temple here. Site } \\
\text { probably deserted by } \\
\text { mid-4th c. A.D. }\end{array}$ & $\begin{array}{l}W A M \times \operatorname{xliii}\left(19^{25-}\right. \\
\text { 7), , } 83 \mathrm{ff} .\end{array}$ \\
\hline $\begin{array}{l}\text { Stockton } \\
\text { Earthworks }\end{array}$ & Wiltshire & Salisbury & \multirow{3}{*}{$\begin{array}{l}\text { Light cobalt, trans- } \\
\text { lucent. Diam. } 4 \mathrm{~mm} \text {. } \\
\text { Several small beads }\end{array}$} & Belgic-Roman & $\begin{array}{l}W A M \times \text { xliii (1925- } \\
\text { 7) }\end{array}$ \\
\hline $\begin{array}{l}\text { Wick Wood, } \\
\text { Nettleton }\end{array}$ & Wiltshire & $\begin{array}{l}\text { c/o Bath and Camer- } \\
\text { ton Arch. Soc. }\end{array}$ & & $\begin{array}{l}\text { Roman necklace } \\
\text { 'before A.D. } 284 \text { ' }\end{array}$ & $\begin{array}{l}\text { Information from } \\
\text { Mr. W.J. } \\
\text { Wedlake }\end{array}$ \\
\hline $\begin{array}{l}\text { Dowles } \\
\text { Brickyard }\end{array}$ & $\begin{array}{l}\text { Worcester- } \\
\text { shire }\end{array}$ & $\begin{array}{l}\text { Once in Bewdley } \\
\text { Institute }\end{array}$ & & $\begin{array}{l}\text { Two beads from what } \\
\text { seems to have been an } \\
\text { early Iron Age urn- } \\
\text { field. Sherds in } \\
\text { Kidderminster } \\
\text { Museum }\end{array}$ & $\begin{array}{l}\text { Information from } \\
\text { Miss L. F. Chitty }\end{array}$ \\
\hline Catterick & Yorkshire & & $\begin{array}{l}\text { Small cobalt blue, } \\
\text { opaque }\end{array}$ & Roman site & $\begin{array}{l}\text { Information from } \\
\text { Mr.J. Wacher }\end{array}$ \\
\hline Seamer & Yorkshire & Scarborough & $\begin{array}{l}\text { Deep translucent } \\
\text { cobalt. Diam. I } 5 \\
\text { cm. Ht. } 9 \mathrm{~mm} . \text { Perf. } \\
\text { diam. } 4 \mathrm{~mm} \text {. }\end{array}$ & $\begin{array}{l}\text { From Roman site. } \\
\text { Found with rusticated } \\
\text { ware of } c . \mathrm{A} . \mathrm{D} .90^{-} \\
\text {I I o in ditch of } \\
\text { enclosure }\end{array}$ & $\begin{array}{l}\text { For site see } 7 R S \\
\text { xxxviii }(1948), 86 \\
\text { and } Y A \mathcal{F x x v i i} \\
(1950), 420-8\end{array}$ \\
\hline \multicolumn{6}{|c|}{ I RELAND } \\
\hline $\begin{array}{l}\text { Loughey, } \\
\text { Donaghadee }\end{array}$ & Co. Down & $\begin{array}{l}\text { B.M. } \\
62.7-1.19\end{array}$ & $\begin{array}{l}\text { A number of small } \\
\text { globular beads }\end{array}$ & $\begin{array}{l}\text { Necklace including } \\
\text { Meare spiral beads, } \\
\text { etc., dated by brooch } \\
\text { to ist c. B.C. or A.D. }\end{array}$ & $\begin{array}{l}U \mathcal{J} A \times x(1957), 74 \\
-95 \text { and } A r \mathcal{J} \times 1 i i \\
(1856), 407\end{array}$ \\
\hline
\end{tabular}

A number come from the Lagore Crannog and several from the Rath of the Synods, Tara. Ist-3rd c. A.D. A number of milky-blue opalescent beads from the Benn Colln., Belfast. Date unknown. The type persisted throughout the postRoman period and is found on Teutonic necklaces-generally rather striated on the surfaces (unpolished).

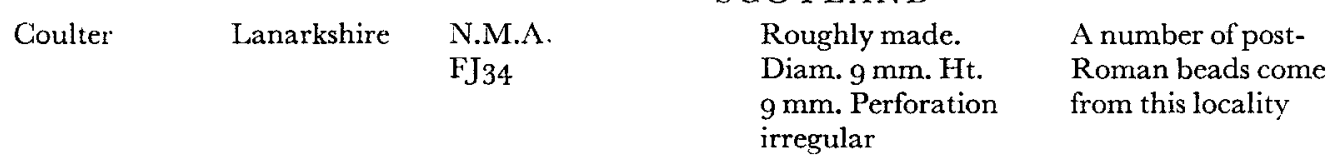

\section{SGOTLAND} irregular 


\section{I72 GLASS BEADS OF THE PREHISTORIG AND ROMAN PERIODS}

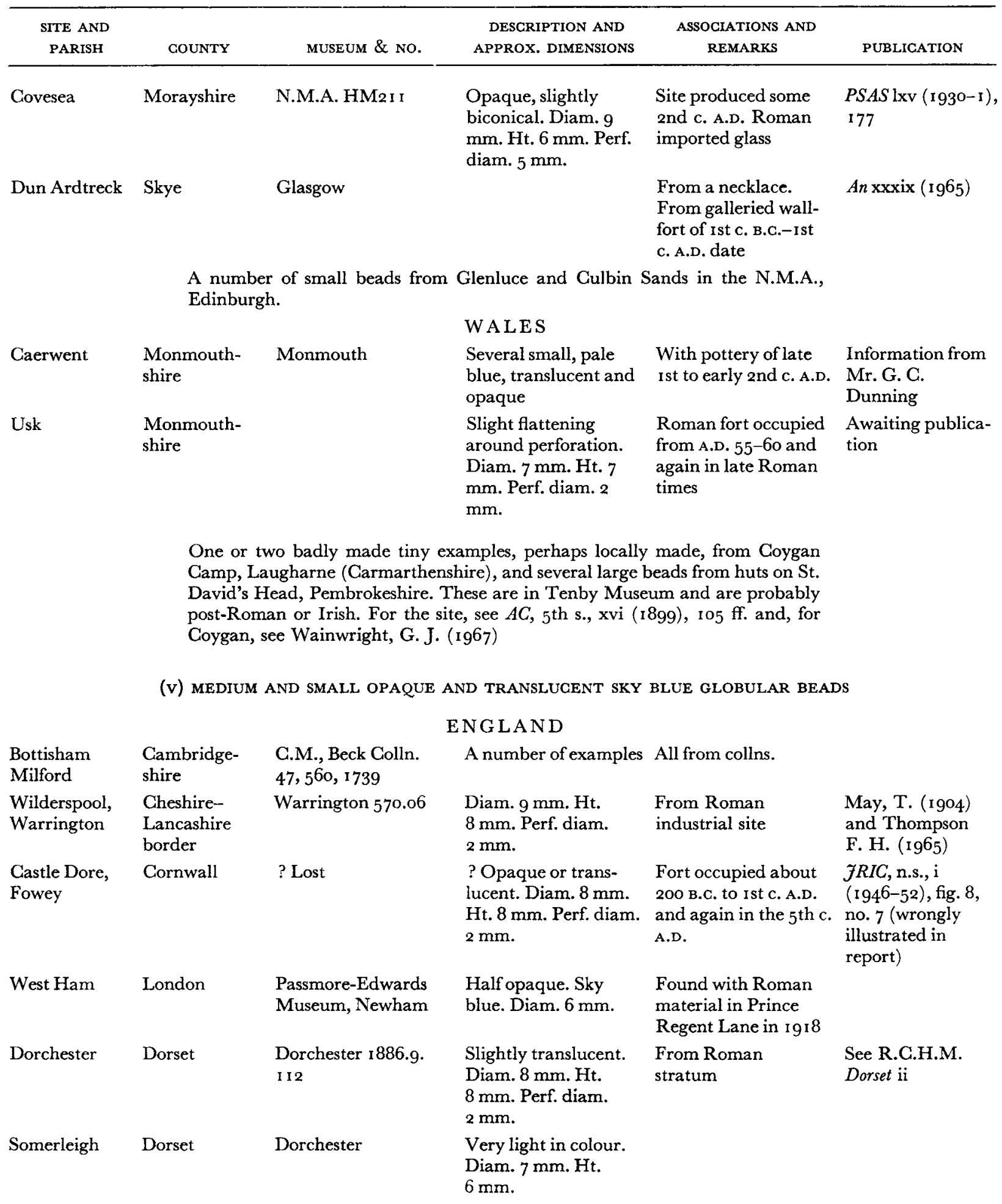




\begin{tabular}{|c|c|c|c|c|c|}
\hline $\begin{array}{l}\text { SITE AND } \\
\text { PARISH }\end{array}$ & COUNTY & MUSEUM \& NO. & $\begin{array}{l}\text { DESCRIPTION AND } \\
\text { APPROX. DIMENSIONS }\end{array}$ & $\begin{array}{c}\text { ASSOCLATIONS AND } \\
\text { REMARKS }\end{array}$ & PUBLIGATION \\
\hline Sydling & Dorset & Dorchester & $\begin{array}{l}\text { Slightly translucent. } \\
\text { Diam. } 8 \mathrm{~mm} . \text { Ht. } \\
8 \mathrm{~mm} . \text { Perf. diam. } \\
2 \mathrm{~mm} .\end{array}$ & & \\
\hline South Shields & Durham & $\begin{array}{l}\text { University Museum, } \\
\text { Newcastle-upon- } \\
\text { Tyne }\end{array}$ & $\begin{array}{l}\text { Diam. I cm. Ht. } \\
6 \mathrm{~mm} \text {. Perf. diam. } \\
2 \mathrm{~mm} .\end{array}$ & $\begin{array}{l}\text { From Roman site } \\
\text { occupied c. A.D. I } 22- \\
3^{69}\end{array}$ & $\begin{array}{l}\text { Richmond, I. A. } \\
\text { (I954) and } f R S \\
\text { lvii (1967) }\end{array}$ \\
\hline Cirencester & $\begin{array}{l}\text { Gloucester- } \\
\text { shire }\end{array}$ & Girencester & Many examples & $\begin{array}{l}\text { Unstratified in } \\
\text { Roman town occu- } \\
\text { pied from ist to } 5^{\text {th }} \mathrm{c.} \\
\text { A.D. or later }\end{array}$ & $\begin{array}{l}\text { Anf xlix ( } 1969 \text { ), } \\
222 \text { and earlier } \\
\text { reports }\end{array}$ \\
\hline Kingscote & Gloucestershire & & $\begin{array}{l}\text { A number of pale } \\
\text { opaque or bright } \\
\text { translucent beads } \\
\text { about } \mathrm{I} \mathrm{cm} \text {. diam. }\end{array}$ & $\begin{array}{l}\text { From surface of area } \\
\text { of Roman site pro- } \\
\text { ducing ist c. A.D. } \\
\text { finds }\end{array}$ & $\begin{array}{l}\text { Information from } \\
\text { Messrs. Graham } \\
\text { Walker and Ted } \\
\text { Swain }\end{array}$ \\
\hline Silchester & Hampshire & Reading & $\begin{array}{l}\text { Half only. Diam. } \\
\mathrm{I} \cdot 1 \mathrm{~cm} . \mathrm{Ht} .8 \mathrm{~mm} . \\
\text { Perf. diam. } 3 \mathrm{~mm} .\end{array}$ & $\begin{array}{l}\text { Occupation through- } \\
\text { out Roman period }\end{array}$ & $\begin{array}{l}\text { For refs. see } \\
\text { Collingwood and } \\
\text { Richmond, The } \\
\text { Archaeology of } \\
\text { Roman Britain (rev. } \\
\text { ed. 1969) }\end{array}$ \\
\hline Kenchester & Herefordshire & Hereford & $\begin{array}{l}\text { Diam. } 8 \mathrm{~mm} . \text { Ht. } \\
6 \mathrm{~mm} . \text { Very small } \\
\text { perforation }\end{array}$ & $\begin{array}{l}\text { Site occupied almost } \\
\text { throughout Roman } \\
\text { period }\end{array}$ & $\begin{array}{l}T W N F C \text { I } 916 \text { and } \\
1926\end{array}$ \\
\hline $\begin{array}{l}\text { Weston- } \\
\text { under- } \\
\text { Penyard, } \\
\text { Bollitree }\end{array}$ & Herefordshire & $\begin{array}{l}\text { Gloucester I } 74^{0-} \\
\text { I } 74^{8}\end{array}$ & Various examples & $\begin{array}{l}\text { From Roman site of } \\
\text { Ariconium }\end{array}$ & $\begin{array}{l}7 B A A \text { xxvii }(1871), \\
2 \text { I Iff. }\end{array}$ \\
\hline Richborough & Kent & Richborough 2 I $4^{\circ}$ & $\begin{array}{l}\text { Diam. } 9 \mathrm{~mm} . \mathrm{Ht} . \\
9 \mathrm{~mm} . \text { Perf. diam. } \\
2 \mathrm{~mm} .\end{array}$ & $\begin{array}{l}\text { Topsoil in Roman } \\
\text { fort road }\end{array}$ & Rich iv, p. 242 \\
\hline $\begin{array}{l}\text { High Rocks } \\
\text { Camp, Tun- } \\
\text { bridge Wells }\end{array}$ & Kent & & $\begin{array}{l}\text { Diam. } 8 \mathrm{~mm} . \mathrm{Ht} . \\
7 \mathrm{~mm} . \text { Perf. diam. } \\
4 \mathrm{~mm} .\end{array}$ & $\begin{array}{l}\text { Surface find in High } \\
\text { Rocks Iron Age } \\
\text { Camp. Originally Iron } \\
\text { Age B, refortified } \\
\text { later with flat- } \\
\text { bottomed ditch of } \\
\text { Fécamp type }\end{array}$ & $\begin{array}{l}S A C \text { cvi (1968), } \\
\text { I } 5^{8}\end{array}$ \\
\hline Hampstead & London & C.M., Beck Colln. & About $1 \mathrm{~cm}$. diam. & & \\
\hline Meare & Somerset & Taunton $\mathrm{G}_{24}$ & $\begin{array}{l}\text { Pale sky blue. Diam. } \\
\text { and ht. } 8 \mathrm{~mm} \text {. Small } \\
\text { perforation }\end{array}$ & $\begin{array}{l}\text { From Iron Age settle- } \\
\text { ment, 3rd c. B.c. to } \\
\text { Ist c. A.D. occupation }\end{array}$ & $M e$ iii \\
\hline Lakenheath & Suffolk & C.M., Beck Colln. & $\begin{array}{l}\text { A number of various } \\
\text { sizes and shapes }\end{array}$ & & \\
\hline Amesbury & Wiltshire & $\begin{array}{l}\text { C.M., Beck Colln. } \\
2553\end{array}$ & $\begin{array}{l}\text { Diam. I cm. Ht. } \\
8 \mathrm{~mm} . \text { Perf. diam. } \\
3 \mathrm{~mm} .\end{array}$ & $\begin{array}{l}\text { From 'Vespasian's' } \\
\text { Camp. Iron Age but } \\
\text { not verified by } \\
\text { excavation }\end{array}$ & \\
\hline
\end{tabular}




\section{I74 GLASS BEADS OF THE PREHISTORIG AND ROMAN PERIODS}

\begin{tabular}{|c|c|c|c|c|c|}
\hline $\begin{array}{l}\text { SITE AND } \\
\text { PARISH }\end{array}$ & COUNTY & MUSEUM \& NO. & $\begin{array}{l}\text { DESGRIPTION AND } \\
\text { APPROX. DIMENSIONS }\end{array}$ & $\begin{array}{l}\text { ASSOCIATIONS AND } \\
\text { REMARKS }\end{array}$ & PUBLIGATION \\
\hline $\begin{array}{l}\text { Salisbury } \\
\text { Plain }\end{array}$ & Wiltshire & $\begin{array}{l}\text { C.M., Beck Colln. } \\
\text { I } 73^{8}\end{array}$ & $\begin{array}{l}\text { Diam. I cm. Ht. } \\
\text { I cm. Perf. diam. } \\
3 \mathrm{~mm} .\end{array}$ & $\begin{array}{l}\text { Found '3 miles from } \\
\text { Stonehenge towards } \\
\text { Devizes' }\end{array}$ & \\
\hline \multirow[t]{3}{*}{ Templebrough } & Yorkshire & Rotherham & $\begin{array}{l}\text { A number, both } \\
\text { translucent and } \\
\text { opaque }\end{array}$ & $\begin{array}{l}\text { Unstratified from fort } \\
\text { thought to be } \\
\text { Flavian and } \\
\text { Hadrianic }\end{array}$ & $\begin{array}{l}\text { See May, 'T. } \\
(1922)\end{array}$ \\
\hline & \multicolumn{4}{|c|}{ SGOTLAND } & \\
\hline & \multicolumn{4}{|c|}{$\begin{array}{l}\text { Fragment from Glenluce, Wigton, in Stranraer Museum } \\
\text { (no. } 343^{A} \text { ) and another in N.M.A. }\end{array}$} & \\
\hline \multicolumn{2}{|l|}{ (vi) } & $\begin{array}{r}\text { SMALL GLOBULAR } \\
\text { TRANS }\end{array}$ & $\begin{array}{l}\text { BEADS: YELLOW OR } \\
\text { LUCENT OR OPAQUE }\end{array}$ & \multicolumn{2}{|c|}{ 'AMBER' (REDDISH-BROWN) } \\
\hline
\end{tabular}

\section{ENGLAND}

Nor' nour, Cornwall St. Mary's, Scilly
Scilly

$\begin{array}{lll}\text { Gloucester } & \begin{array}{l}\text { Gloucester- } \\ \text { shire }\end{array} & \begin{array}{l}\text { Gloucester Museum } \\ 1289\end{array} \\ \text { Gloucester } & \begin{array}{l}\text { Gloucester- } \\ \text { shire }\end{array} & \begin{array}{l}\text { Gloucester Museum } \\ 1287\end{array}\end{array}$

St. Albans Hertfordshire Verulamium Museum 232

Wilderspool, Lancashire- Warrington Museum Warrington Cheshire 1299 border

Meare Somerset Taunton G82

Meare

Somerset

Taunton $\mathrm{G}_{44}$

Dinas Powys

Glamorgan-
shire

N.M.W.
Translucent yellowfawn. Diam. $5 \mathrm{~mm}$. Ht. $5 \mathrm{~mm}$. Perf. diam. I mm.

Yellow-green. Diam. $5 \mathrm{~mm}$. Ht. $3 \mathrm{~mm}$. Very small perforation Bright orange. Diam. $9 \mathrm{~mm}$. Ht. $6 \mathrm{~mm}$. Perf. diam. $4 \mathrm{~mm}$. Like the small opaque

\section{WA LES} fragment. Roman or
Bright, clear reddishyellow. Diam. I 4 cm. Ht. I. $3 \mathrm{~cm}$. Perf. diam. $2 \mathrm{~mm}$. yellow annular beads of Class 8. Diam. I. I cm. Ht. $8 \mathrm{~mm}$. Perf. diam. $3 \mathrm{~mm}$.

Smaller. Opaque lemon yellow

From Mound XVII in pre-Roman site

One pale yellow

From late Roman necklace

Probably Roman

From Mound XIII in pre-Roman site

? Teutonic. Diam.

I $5 \mathrm{~cm}$. mainly Roman

objects
The site produced
Me iii
$\operatorname{Arf~cxxiv~(1967)~}$

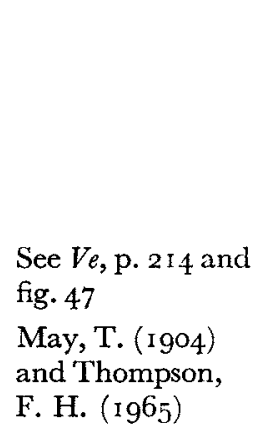




\begin{tabular}{|c|c|c|c|c|c|}
\hline $\begin{array}{l}\text { SITE AND } \\
\text { PARISH }\end{array}$ & COUNTY & MUSEUM \& No. & $\begin{array}{l}\text { DESCRIPTION AND } \\
\text { APPROX. DIMESNIONS }\end{array}$ & $\begin{array}{l}\text { ASSOCIATIONS AND } \\
\text { REMARKS }\end{array}$ & PUBLIGATION \\
\hline \multicolumn{6}{|c|}{$\begin{array}{c}\text { (Viii) MEDIUM AND SMALL 'BLAGK' OPAQUE BEADS } \\
\text { ENGLAND }\end{array}$} \\
\hline $\begin{array}{l}\text { Weston- } \\
\text { under- } \\
\text { Penyard, } \\
\text { Bollitree }\end{array}$ & Herefordshire & Gloucester $175^{\circ}$ & $\begin{array}{l}\text { Bright shiny 'black'. } \\
\text { Diam. I } 3 \mathrm{~cm} . \text { Ht. } \\
\mathrm{I} \cdot 2 \mathrm{~cm} . \text { Perf. diam. } \\
2 \mathrm{~mm} .\end{array}$ & $\begin{array}{l}\text { Site produced early } \\
\text { Roman and later } \\
\text { beads }\end{array}$ & $\begin{array}{l}\exists B A A \mathrm{xxvii}(187 \mathrm{I}), \\
\text { 2I Iff. }\end{array}$ \\
\hline $\begin{array}{l}\text { Hunsbury } \\
\text { Hill-Fort, } \\
\text { Hardingstone }\end{array}$ & $\begin{array}{l}\text { Northamp- } \\
\text { tonshire }\end{array}$ & Northampton & $\begin{array}{l}\text { Dull blackish. Diam. } \\
2 \cdot 2 \mathrm{~cm} . \mathrm{Ht} . \mathrm{I} \cdot 4 \mathrm{~cm} \text {. } \\
\text { Perf. diam. } 6 \mathrm{~mm} \text {. }\end{array}$ & $\begin{array}{l}\text { From pre-Roman } \\
\text { fort. ? } 4 \text { th c. B.c. to } \\
\text { early ist c. A.D. }\end{array}$ & $\begin{array}{l}\text { Fell, C. }(1936), \mathrm{p} . \\
68 \text { and } \mathcal{J N N H S F C} \\
\text { xviii and xix }\end{array}$ \\
\hline Yockleton & $\begin{array}{l}\text { Worcester- } \\
\text { shire }\end{array}$ & $\begin{array}{l}\text { c/o Miss L. F. Chitty, } \\
\text { F.S.A. }\end{array}$ & $\begin{array}{l}\text { Diam. I } 1 \mathrm{~cm} . \mathrm{Ht} \text {. } \\
9 \mathrm{~mm} . \text { Perf. diam. } \\
2 \mathrm{~mm} \text {. }\end{array}$ & $\begin{array}{l}\text { Found in Moor Field } \\
\text { with I } 8 \text { th c. pottery } \\
\text { on line of probable } \\
\text { Roman road }\end{array}$ & $\begin{array}{l}\text { Information from } \\
\text { Miss L. F. Chitty }\end{array}$ \\
\hline
\end{tabular}

\section{IRELAND}

Nothing from a definitely pre-Roman or early Christian period. A number of examples in the Dublin and Belfast museums from collections. It is clear that black glass was commonly made in Ireland but it is not possible yet to date the beads.

\section{SGOTLAND}

Coulter Seat, Aberdeenshire N.M.A. FJ $40,4 \mathrm{I}$

Udney

Birrens

Dun Beag Skye
Two examples.

Diams. $1 \cdot 2 \mathrm{~cm}$. approx.

Diam. I. I cm. Ht. $8 \mathrm{~mm}$.

Glossy slightly barrel shaped. Diam. I 3 cm. Ht. $1 \cdot 3 \mathrm{~cm}$. Perf. diam. $5 \mathrm{~mm}$.
Antonine fort. Constructed A.D. 158

PSAS xxx (1895 6), $8 \mathrm{I}$ and $\mathrm{lxxii}$ (1937-8), 270

From brooch with post-Roman occupation PSAS Iv (1920-1), IIO

\section{WALES}

One from a mixed R.B. and later site at Laugharne (Carmarthenshire) and two from hut sites on St. David's Head, (Pembrokeshire), probably Roman period or post-Roman, in Tenby Museum. 


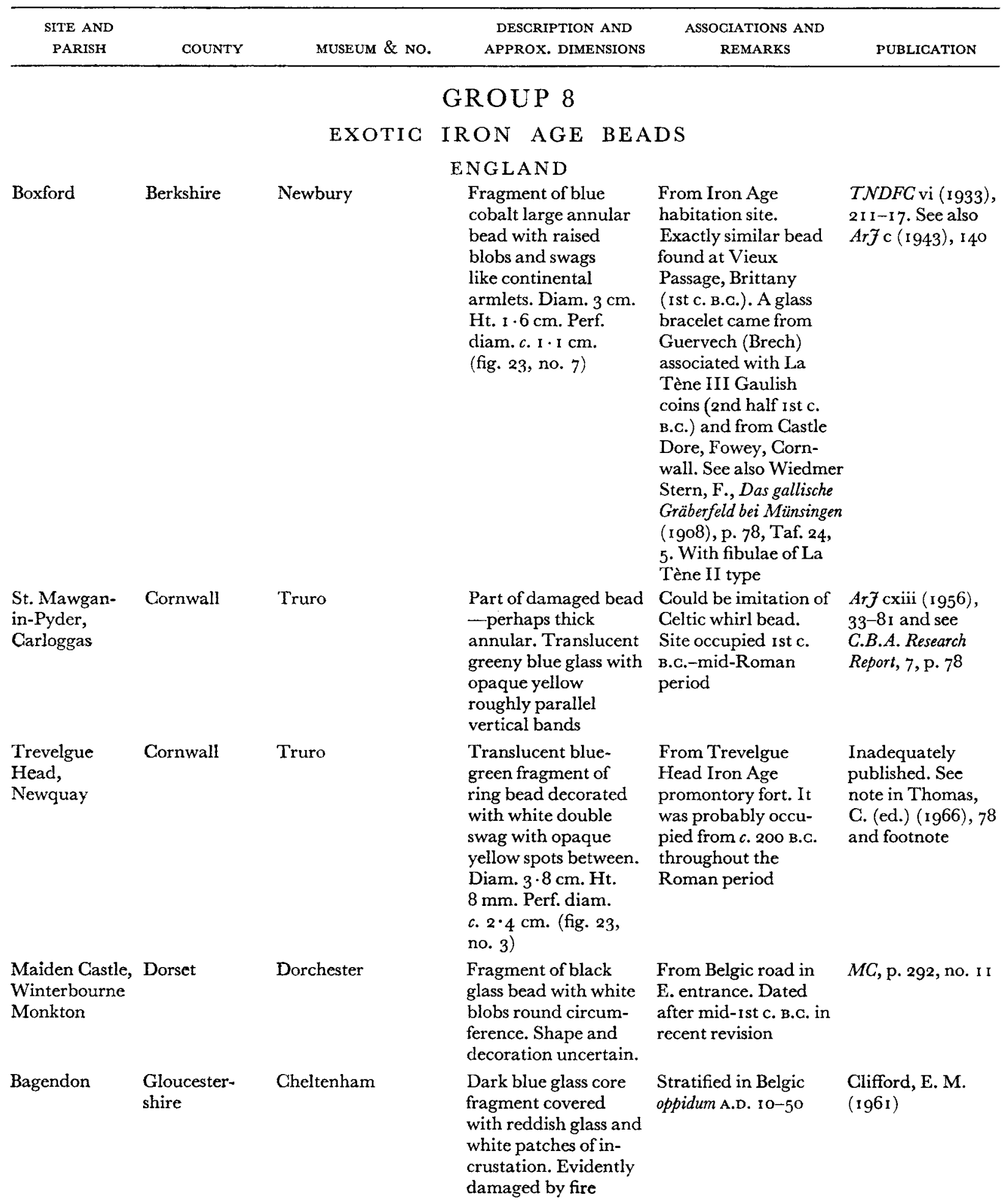




\begin{tabular}{|c|c|c|c|c|c|}
\hline $\begin{array}{l}\text { SITE AND } \\
\text { PARISH }\end{array}$ & COUNTY & MUSEUM \& NO. & $\begin{array}{l}\text { DESGRIPTION AND } \\
\text { APPROX. DIMENSIONS }\end{array}$ & $\begin{array}{l}\text { ASSOCIATIONS AND } \\
\text { REMARKS }\end{array}$ & PUBLICATION \\
\hline $\begin{array}{l}\text { Hunsbury, } \\
\text { Hardingstone }\end{array}$ & $\begin{array}{l}\text { Northamp- } \\
\text { tonshire }\end{array}$ & Northampton & $\begin{array}{l}\text { Large part of bottle } \\
\text { glass biconical bead } \\
\text { with raised running } \\
\text { swags of translucent } \\
\text { blue glass above and } \\
\text { below carination. } \\
\text { Diam. } 4 \mathrm{~cm} \text {. Ht. } \\
\text { I } 9 \mathrm{~cm} \text {. Perf. diam. } \\
\text { I. } 9 \mathrm{~cm} \text {. (fig. } 23 \text {, } \\
\text { no. } 5 \text { ) }\end{array}$ & $\begin{array}{l}\text { Unstratified in } \\
\text { Roman hill-fort. } \\
\text { Perhaps occupied } \\
\text { 2nd-Ist c. B.c. }\end{array}$ & $\begin{array}{l}\text { Fell, C. (1936), } \\
\text { pp. } 68-9 \text { and } \\
\text { fig. } 3, \text { no. } 7\end{array}$ \\
\hline $\begin{array}{l}\text { Shakenoak, } \\
\text { Wilcote }\end{array}$ & Oxfordshire & & $\begin{array}{l}\text { Large blue, white, } \\
\text { green, red and } \\
\text { yellow mixed glass } \\
\text { annular bead frag- } \\
\text { ment. Diam. } 1.8 \mathrm{~cm} \text {. } \\
\text { Perf. diam. } 8 \mathrm{~mm} \text {. }\end{array}$ & $\begin{array}{l}\text { Certainly native. } \\
\text { Perhaps reusing } \\
\text { Roman glass }\end{array}$ & $\begin{array}{l}\text { Brodribb, A. C. } \\
\text { C., Hands, A. R. } \\
\text { and Walker, } \\
\text { D. R., Excavations } \\
\text { at Shakenoak ii } \\
(197 \mathrm{I}) \text {, 105 }\end{array}$ \\
\hline Clevedon & Somerset & Taunton & $\begin{array}{l}8 \text { barrel-shaped very } \\
\text { thin clear glass } \\
\text { beads, coated in } \\
\text { red glass. Hand } \\
\text { moulded, and of } \\
\text { varying sizes. About } \\
\mathrm{I} \cdot 3 \mathrm{~cm} \text {. long and } \\
7 \mathrm{~mm} \text {. diam. at end } \\
\text { and } \cdot 1 \mathrm{~cm} . \text { at } \\
\text { centre (fig. } 23, \text { no. } 6 \text { ) }\end{array}$ & $\begin{array}{l}\text { Necklace of these } \\
\text { beads and Io small } \\
\text { annular beads of } \\
\text { Class } 8 \text { and one of } \\
\text { Meare Class i I with a } \\
\text { burial }\end{array}$ & $\begin{array}{l}\text { PSANHS lxxxviii } \\
\text { (I } 942), 73 \cdot \text { A } \\
\text { possibly similar } \\
\text { bead was found at } \\
\text { Shapwick, Dorset. } \\
\text { See Warne, C. } \\
\text { (1866), 39-40. } \\
\text { Another necklace } \\
\text { of these beads is } \\
\text { said to have come } \\
\text { from Meare }\end{array}$ \\
\hline Meare & Somerset & Taunton $\mathrm{G}_{25}$ & $\begin{array}{l}\text { Small blue opaque } \\
\text { pulley-shaped bead } \\
\text { exactly like Badsey } \\
\text { (Worcester) example } \\
\text { below }\end{array}$ & $\begin{array}{l}\text { From site occupied } \\
3^{\text {rd-Ist c. B.c. }}\end{array}$ & $M e \mathrm{iii}$ \\
\hline $\begin{array}{l}\text { All Cannings } \\
\text { Cross }\end{array}$ & Wiltshire & Devizes & $\begin{array}{l}\text { Long rather drop- } \\
\text { shaped bead of } \\
\text { yellowish-green } \\
\text { translucent glass with } \\
\text { dark blue chevrons. } \\
\text { Or the dark blue may } \\
\text { be the ground colour. } \\
\text { Length } 1 \cdot 2 \mathrm{~cm} \text {. Width } \\
5 \text { mm. Very small } \\
\text { diameter perforation } \\
\text { (fig. } 23 \text {, no. I) }\end{array}$ & $\begin{array}{l}\text { From Iron Age } \\
\text { settlement with long } \\
\text { occupation }\end{array}$ & $\begin{array}{l}\text { Cunnington, } \\
\text { M. E. (1923), } \\
\text { pl. 19, no. } 9 \text { and } \\
\text { p. I } 22\end{array}$ \\
\hline Badsey & $\begin{array}{l}\text { Worcester- } \\
\text { shire }\end{array}$ & $\begin{array}{l}\text { c/o Miss L. F. Chitty } \\
\text { or Worcester } \\
\text { Museum }\end{array}$ & $\begin{array}{l}\text { Small, pale blue } \\
\text { opaque pulley- } \\
\text { shaped bead } \\
\text { (fig. } 23, \text { no. } 4 \text { ) }\end{array}$ & $\begin{array}{l}\text { There is 'duck' } \\
\text { stamped ware, etc., } \\
\text { from Badsey but not } \\
\text { associated. Exactly } \\
\text { like Meare specimen } \\
\text { G25 }\end{array}$ & $\begin{array}{l}\text { See for site } A \mathcal{N} L \\
\text { (October 1949), } 88\end{array}$ \\
\hline
\end{tabular}


I78 GLASS BEADS OF THE PREHISTORIG AND ROMAN PERIODS

\begin{tabular}{|c|c|c|c|c|c|}
\hline $\begin{array}{l}\text { SITE AND } \\
\text { PARISH }\end{array}$ & COUNTY & MUSEUM \& No. & $\begin{array}{l}\text { DESCRIPTION AND } \\
\text { APPROX. DIMENSIONS }\end{array}$ & $\begin{array}{l}\text { ASSOCIATIONS AND } \\
\text { REMARKS }\end{array}$ & PUBLICATION \\
\hline $\begin{array}{l}\text { Burton } \\
\text { Fleming }\end{array}$ & Yorkshire & & $\begin{array}{l}\text { Half annular yellow } \\
\text { opaque glass, like } \\
\text { Class } 8 \text { but with } \\
\text { crossing swags (once } \\
\text { coloured). Diam. I } \\
\text { cm. Ht. } 4 \mathrm{~mm} \text {. Perf. } \\
\text { diam. } 5 \mathrm{~mm} \text {. }\end{array}$ & $\begin{array}{l}\text { With objects of ? 3rd-- } \\
\text { 2nd c. B.c. in Iron Age } \\
\text { cemetery }\end{array}$ & $\begin{array}{l}\text { Information from } \\
\text { Dr. Ian Stead }\end{array}$ \\
\hline & & & IRELAND & & \\
\hline $\begin{array}{l}\text { Loughey, } \\
\text { Donaghadee }\end{array}$ & Co. Down & & $\begin{array}{l}\text { For details } \\
\text { p. } 126\end{array}$ & & \\
\hline
\end{tabular}




\title{
IRON AGE BEADS OF BRITISH DESIGN AND ORIGIN
}

\author{
CLASS 8
}

SMALL OPAQUE YELLOW ANNULAR BEADS

\begin{tabular}{|c|c|c|c|c|c|}
\hline $\begin{array}{l}\text { SITE AND } \\
\text { PARISH }\end{array}$ & COUNTY & MUSEUM \& NO. & $\begin{array}{l}\text { DESCRIPTION AND } \\
\text { APPROX. DIMENSIONS }\end{array}$ & $\begin{array}{l}\text { ASSOCIATIONS AND } \\
\text { REMARKS }\end{array}$ & PUBLICATION \\
\hline \multicolumn{6}{|c|}{ ENGLAND } \\
\hline $\begin{array}{l}\text { Castle Dore, } \\
\text { Fowey }\end{array}$ & Cornwall & Truro & Diam. $9 \mathrm{~mm}$. & $\begin{array}{l}\text { From Iron Age camp, } \\
\text { unstratified. Occupa- } \\
\text { tion } c .200-50 \text { B.c. } \\
\text { and post-Roman }\end{array}$ & $\begin{array}{l}7 R I C, \text { n.s., i } \\
(1946-52), 69, \\
\text { fig. } 8, \text { no. } 3\end{array}$ \\
\hline $\begin{array}{l}\text { Maiden Castle, } \\
\text { Winterbourne } \\
\text { Monkton }\end{array}$ & Dorset & Dorchester & & $\begin{array}{l}\text { From Iron Age A } \\
\text { level of hill-fort }\end{array}$ & $\begin{array}{l}M C, \text { p. } 291 \text { and } \\
\text { fig. } 98, \text { no. } 1\end{array}$ \\
\hline South Shields & Durham & $\begin{array}{l}\text { University Museum, } \\
\text { Newcastle-upon- } \\
\text { Tyne }\end{array}$ & $\begin{array}{l}2 \text { examples with } \\
\text { flattened surface, one } \\
\text { diam. } 8 \mathrm{~mm} \text {. and } \\
\text { another smaller }\end{array}$ & $\begin{array}{l}\text { Fort occupied } c . \text { A.D. } \\
\text { I } 22 \text { to } 4 \text { th } c \text {. }\end{array}$ & \\
\hline Silchester & Hampshire & Reading & Diam. $6 \mathrm{~mm}$. & $\begin{array}{l}\text { Site occupied ist c. } \\
\text { B.C. }-5 \text { th C. A.D. }\end{array}$ & $\begin{array}{l}\text { Boon, G. G. (1957) } \\
\text { and } A \text { cii (1969) }\end{array}$ \\
\hline Kenchester & Herefordshire & & & $\begin{array}{l}\text { Unstratified in } \\
\text { Roman town founded } \\
\text { 2nd half of Ist c. A.D. } \\
\text { and occupied till late } \\
\text { Roman period }\end{array}$ & $\begin{array}{l}\text { Jack, G. H. \& } \\
\text { Hayter, A. G. K. } \\
\text { Excavations on } \\
\text { the site of the } \\
\text { Romano-British } \\
\text { Tozen of Magna } \\
\text { (Kenchester) } \\
\text { (1916), pl. } 45, \text { no. } 3 \\
\text { and TWNHFG } \\
\text { 1958 and } 196 \mathrm{I}\end{array}$ \\
\hline Ballacagen A & Isle of Man & Douglas & $\begin{array}{l}\text { 1 } 2 \text { beads graduated. } \\
\text { All characteristically } \\
\text { flattened around } \\
\text { perforation }\end{array}$ & $\begin{array}{l}\text { From same horizon } \\
\text { as armlets of } 2 \text { nd- } \\
\text { Ist c. B.c. Continental } \\
\text { type Phase I of Celtic } \\
\text { round-house }\end{array}$ & $\begin{array}{l}\text { Bersu, G., Three } \\
\text { Iron Age Round } \\
\text { Houses in the Isle of } \\
\text { Man (1977) }\end{array}$ \\
\hline $\begin{array}{l}\text { Bolham } \\
\text { (Huckhoe } \\
\text { Fort) }\end{array}$ & $\begin{array}{l}\text { Northumber- } \\
\text { land }\end{array}$ & $\begin{array}{l}\text { c/o G. Jobey, F.s.A. } \\
\text { Newcastle-upon- } \\
\text { Tyne }\end{array}$ & $\begin{array}{l}\text { Rather flattened } \\
\text { surface. Diam. } 3 \mathrm{~mm} .\end{array}$ & $\begin{array}{l}\text { From reused soil in } \\
\text { wall of hut of early } \\
\text { Roman date }\end{array}$ & $\begin{array}{l}A A, 4^{\text {th }} \text { s., xxxvii } \\
\text { (1959) }\end{array}$ \\
\hline Corbridge & $\begin{array}{l}\text { Northumber- } \\
\text { land }\end{array}$ & $\begin{array}{l}\text { Corstopitum } \\
\text { Museum, } 4325\end{array}$ & Diam. I cm. & $\begin{array}{l}\text { Occupation ist }-5 \text { th } c . \\
\text { A.D. }\end{array}$ & \\
\hline $\begin{array}{l}\text { Halton } \\
\text { Chesters }\end{array}$ & $\begin{array}{l}\text { Northumber- } \\
\text { land }\end{array}$ & $\begin{array}{l}\text { University Museum, } \\
\text { Newcastle-upon- } \\
\text { Tyne, I } 956.202\end{array}$ & $\begin{array}{l}\text { Flattened surface. } \\
\text { Diam. I } \cdot \text { I } \mathrm{cm} . \mathrm{Ht} \text {. } \\
3 \mathrm{~mm} \text {. Perf. diam. } \\
3 \mathrm{~mm} .\end{array}$ & $\begin{array}{l}\text { Fort on } \\
\text { Hadrian's Wall }\end{array}$ & \\
\hline Housesteads & $\begin{array}{l}\text { Northumber- } \\
\text { land }\end{array}$ & $\begin{array}{l}\text { University Museum, } \\
\text { Newcastle-upon- } \\
\text { Tyne }\end{array}$ & Diam. $8 \mathrm{~mm}$. & & \\
\hline
\end{tabular}




\begin{tabular}{|c|c|c|c|c|c|}
\hline $\begin{array}{l}\text { SITE AND } \\
\text { PARISH }\end{array}$ & COUNTY & MUSEUM \& NO. & $\begin{array}{l}\text { DESCRIPTION AND } \\
\text { APPROX. DIMENSIONS }\end{array}$ & $\begin{array}{l}\text { ASSOCIATIONS AND } \\
\text { REMARKS }\end{array}$ & PUBLICATION \\
\hline $\begin{array}{l}\text { 'Rochester } \\
\text { and Alnham' }\end{array}$ & $\begin{array}{l}\text { Northumber- } \\
\text { land }\end{array}$ & $\begin{array}{l}\text { Chesters Museum } \\
\text { I } 708 \text { or } 3801\end{array}$ & Diam. $1 \mathrm{~cm}$. & \multicolumn{2}{|l|}{$\begin{array}{l}\text { One of the two } \\
\text { Roman sites, unstratified }\end{array}$} \\
\hline Wroxeter & Shropshire & $\begin{array}{l}\text { Rowley's House } \\
\text { Museum, Shrewsbury }\end{array}$ & No details & \multicolumn{2}{|l|}{$\begin{array}{l}\text { Not examined, but } \\
\text { may belong to this } \\
\text { Glass. From Roman } \\
\text { site }\end{array}$} \\
\hline Clevedon & Somerset & Taunton & Diam. $6 \mathrm{~mm}$. & $\begin{array}{l}\text { Io on a necklace with } \\
\text { an inhumation } \\
\text { burial in a cist. Some } \\
\text { barrel-shaped, pink- } \\
\text { covered beads and one } \\
\text { Meare chevron type, } \\
\text { (Class I I a) }\end{array}$ & $\begin{array}{l}P S A \mathcal{N} H S \text { lxxxviii } \\
(\mathrm{I} 942), 73\end{array}$ \\
\hline Meare (East) & Somerset & & $\begin{array}{l}\text { Necklace of these } \\
\text { beads and Meare } \\
\text { spirals of Class Io }\end{array}$ & \multicolumn{2}{|l|}{$\begin{array}{l}\text { Unpublished by H. St. } \\
\text { George Gray }\end{array}$} \\
\hline Meare & Somerset & $\begin{array}{l}\text { Taunton G68EV and } \\
\text { others }\end{array}$ & $\begin{array}{l}\text { Over } 50 \text { examples } \\
\text { from West Village. } \\
\text { Mostly under I cm. in } \\
\text { diam. and with } \\
\text { flattened surfaces. One } \\
\text { necklace of } 39 \text { beads. } \\
\text { One example of } 2 \\
\text { segments }\end{array}$ & $\begin{array}{l}\text { From pre-Roman site } \\
\text { ? 2nd c. B.C. }\end{array}$ & $M e$ iii, pp. $288_{5}-6$ \\
\hline $\begin{array}{l}\text { Conderton } \\
\text { Camp, } \\
\text { Conderton }\end{array}$ & $\begin{array}{l}\text { Worcester- } \\
\text { shire }\end{array}$ & Birmingham & $\begin{array}{l}\text { Slightly flattened } \\
\text { surface. Diam. } 9 \mathrm{~mm} \text {. }\end{array}$ & $\begin{array}{l}\text { From early phase of } \\
\text { fort } 3 \text { rd-2nd c. B.c. ? }\end{array}$ & $\begin{array}{l}\text { Report forth- } \\
\text { coming. Informa- } \\
\text { tion from Mr. N. } \\
\text { Thomas }\end{array}$ \\
\hline \multicolumn{6}{|c|}{ I RELAND } \\
\hline $\begin{array}{l}\text { Loughey, } \\
\text { Donaghadee }\end{array}$ & Co. Down & B.M. 62.7.I.19 & $\begin{array}{l}\text { Number of very small } \\
\text { examples }\end{array}$ & $\begin{array}{l}\text { Burial of ist c. B.c. or } \\
\text { A.D. together with } \\
\text { fibula and Meare } \\
\text { spiral beads and a } \\
\text { bead of group } 3 \\
\text { (see fig. } 23, \text { no. 2) }\end{array}$ & $\begin{array}{l}U \mathcal{J A} A \mathrm{xx}(\mathrm{I} 957) \\
74-95\end{array}$ \\
\hline \multicolumn{6}{|c|}{ SGOTLAND } \\
\hline Inverkeilor & Angus & & Diam. $4 \mathrm{~mm}$. & $\begin{array}{l}\text { From promontory } \\
\text { fort of West Mains of } \\
\text { Ethie in same stratum } \\
\text { as Type I glass armlet }\end{array}$ & $\begin{array}{l}\text { Information from } \\
\text { Abertay Arch. } \\
\text { Soc. }\end{array}$ \\
\hline $\begin{array}{l}\text { Aitnock Fort, } \\
\text { Dalry }\end{array}$ & Ayrshire & & & $\begin{array}{l}\text { With objects of ist or } \\
\text { 2nd c. A.D. }\end{array}$ & $\begin{array}{l}P S A S \text { liii ( I9 19), } \\
\text { I } 32\end{array}$ \\
\hline $\begin{array}{l}\text { Arrieolland } \\
\text { Crannog }\end{array}$ & Ayrshire & N.M.A. & $\begin{array}{l}\text { Identical but reddish } \\
\text { and perhaps burnt }\end{array}$ & & $\begin{array}{l}P S A S \times x i i i(\text { I } 888- \\
9), 228 \text { and } A G C \mathrm{v} \\
(1885), 113\end{array}$ \\
\hline $\begin{array}{l}\text { Howrat Castle } \\
\text { Rock, Dalry }\end{array}$ & Ayrshire & $\begin{array}{l}\text { N.M.A. } \mathrm{HH}_{3} 66 \text { to } \\
373\end{array}$ & $\begin{array}{l}8 \text { beads of varying } \\
\text { sizes }\end{array}$ & $\begin{array}{l}\text { Greenish-yellow glass } \\
\text { was cast in this fort }\end{array}$ & $\begin{array}{l}\text { PSAS liii (1919), } \\
123\end{array}$ \\
\hline
\end{tabular}




\begin{tabular}{|c|c|c|c|c|c|}
\hline $\begin{array}{l}\text { SITE AND } \\
\text { PARISH }\end{array}$ & COUNTY & MUSEUM \& NO. & $\begin{array}{l}\text { DESCRIPTION AND } \\
\text { APPROX. DIMENSIONS }\end{array}$ & $\begin{array}{c}\text { ASSOCIATIONS AND } \\
\text { REMARKS }\end{array}$ & PUBLICATION \\
\hline $\begin{array}{l}\text { Lochspouts } \\
\text { Crannog, } \\
\text { Maybole }\end{array}$ & Ayrshire & N.M.A. HW 19 & $\begin{array}{l}\text { Flattened surface. } \\
\text { Diam. I cm. }\end{array}$ & $\begin{array}{l}\text { Early Roman period } \\
\text { crannog }\end{array}$ & $\begin{array}{l}P S A S \times \mathrm{xv}(188 \mathrm{o}-\mathrm{I}) \text {, } \\
\text { 1 Io and } A G C \mathrm{iij} \\
(1882), 15 \text { and fig. } \\
16\end{array}$ \\
\hline Allasdale & Barra & N.M.A. & $\begin{array}{l}3 \text { examples of varying } \\
\text { size }\end{array}$ & $\begin{array}{l}\text { One from upper } \\
\text { chamber of soutterain } \\
\text { and others from a } \\
\text { house of late Ist or } \\
\text { early 2nd c. A.D. }\end{array}$ & $\begin{array}{l}\text { PSAS lxxxviii } \\
\left(195^{2-3}\right), 104\end{array}$ \\
\hline $\begin{array}{l}\text { Freswick } \\
\text { Links, } \\
\text { Canisbay }\end{array}$ & Caithness & N.M.A. FJi $4 \mathrm{I}$ & $\begin{array}{l}\text { Slightly flattened } \\
\text { surface. Diam. } 5 \mathrm{~mm} \text {. }\end{array}$ & & $\begin{array}{l}P S A S \times x \times v \\
(1900-1), 143\end{array}$ \\
\hline $\begin{array}{l}\text { Culbin Sands, } \\
\text { Elgin }\end{array}$ & Morayshire & $\begin{array}{l}\text { N.M.A. acquired } \\
\text { about } 85 \text { beads }\end{array}$ & Slightly varied in size & $\begin{array}{l}\text { Over } 25 \text { o found at the } \\
\text { base of one of the } \\
\text { sandhills }\end{array}$ & $\begin{array}{l}P S A S \times \times v(1890- \\
1), 510\end{array}$ \\
\hline $\begin{array}{l}\text { Dun Troddan } \\
\text { Broch, Glenelg }\end{array}$ & Inverness-shire & N.M.A. GAII 25 & $\begin{array}{l}\text { Slightly flattened } \\
\text { surface. Diam. } 9 \mathrm{~mm} \text {. }\end{array}$ & From the broch & $\begin{array}{l}P S A S \operatorname{lv}(1920-1), \\
92\end{array}$ \\
\hline $\begin{array}{l}\text { Dun Bhuirg, } \\
\text { Iona }\end{array}$ & Argyllshire & & $\begin{array}{l}2 \text { examples not } \\
\text { examined }\end{array}$ & $\begin{array}{l}\text { From small dun with } \\
\text { broch-type pottery }\end{array}$ & $\begin{array}{l}\text { Noted in } P S A S \\
\text { xxvi (1960), } 34^{8}\end{array}$ \\
\hline $\begin{array}{l}\text { Traprain Law, } \\
\text { Prestonkirk }\end{array}$ & East Lothian & N.M.A. & $\begin{array}{l}\text { Several examples of } \\
\text { varying sizes }\end{array}$ & $\begin{array}{l}\text { Mostly said to have } \\
\text { come from earlier } \\
\text { levels of native fort } \\
\text { occupied through the } \\
\text { Roman period }\end{array}$ & $\begin{array}{l}P S A S \operatorname{lv}(1920-1) \\
198\end{array}$ \\
\hline Clickhimin & Shetland & & Not seen & From pre-broch level & $\begin{array}{l}\text { Hamilton, J. R. C. } \\
\text { Excavations at } \\
\text { Clickhimin in } \\
\text { Shetland (H.M.S.O. } \\
\text { I968) }\end{array}$ \\
\hline Fetlar & Shetland & N.M.A. FJ123 & $\begin{array}{l}\text { Slightly flattened } \\
\text { surface. Diam. } 8 \mathrm{~mm} \text {. }\end{array}$ & & \\
\hline $\begin{array}{l}\text { Dun an } \\
\text { Iardhard } \\
\text { Broch, } \\
\text { Skye }\end{array}$ & Inverness-shire & N.M.A. & Diam. $\mathrm{I} \cdot \mathrm{I} \mathrm{cm}$. & $\begin{array}{l}\text { Apparently in central } \\
\text { hearth of broch }\end{array}$ & $\begin{array}{l}P S A S \text { xlix (19 } 4^{-} \\
15), 65^{-6} \text { and fig. } \\
10,7\end{array}$ \\
\hline $\begin{array}{l}\text { Dun Ardtreck, } \\
\text { Skye }\end{array}$ & Inverness-shire & $\begin{array}{l}\text { Hunterian Museum, } \\
\text { Glasgow, } \mathrm{SF}_{7} 6,97\end{array}$ & $\begin{array}{l}8 \text { or } 9 \text { very small } \\
\text { examples }\end{array}$ & $\begin{array}{l}\text { Probably from a } \\
\text { necklace in galleried } \\
\text { wall fort with } 2 \text { small } \\
\text { decorated Scottish } \\
\text { annular beads (see } \\
\text { Class } 14 \text { ) }\end{array}$ & $A n \operatorname{xxxix}(1965)$ \\
\hline $\begin{array}{l}\text { Dun Mor } \\
\text { Vaul, } \\
\text { Tiree }\end{array}$ & Argyllshire & $\begin{array}{l}\text { Hunterian Museum, } \\
\text { Glasgow, nos. } 409 \\
34^{8}, 390,341,250 \\
416,278 \text { of report }\end{array}$ & $\begin{array}{l}\text { Several of varying } \\
\text { sizes, from very small } \\
\text { to diam. } 9 \mathrm{~mm} .\end{array}$ & From broch & $\begin{array}{l}\text { MacKie, E. W. } \\
\text { (I975) }\end{array}$ \\
\hline $\begin{array}{l}\text { Drimore, } \\
\text { South Uist }\end{array}$ & Inverness-shire & & $\begin{array}{l}2 \text { examples, one } \\
\text { diam. } 1 \mathrm{~cm} \text {. }\end{array}$ & $\begin{array}{l}\text { In sand on floor of } \\
\text { wheel-house at } A \\
\text { Cheardach Mhor and } \\
\text { another unstratified }\end{array}$ & $\begin{array}{l}P S A S \times c i i i\left(1959^{-}\right. \\
60), 150\end{array}$ \\
\hline
\end{tabular}




\begin{tabular}{|c|c|c|c|c|c|}
\hline $\begin{array}{l}\text { SITE AND } \\
\text { PARISH }\end{array}$ & COUNTY & MUSEUM \& NO. & $\begin{array}{l}\text { DESCRIPTION AND } \\
\text { APPROX. DIMENSIONS }\end{array}$ & $\begin{array}{l}\text { ASSOCIATIONS AND } \\
\text { REMARKS }\end{array}$ & PUBLIGATION \\
\hline $\begin{array}{l}\text { Glenluce } \\
\text { Sands }\end{array}$ & Wigtownshire & $\begin{array}{l}\text { Edinburgh and } \\
\text { Stranraer }\end{array}$ & $\begin{array}{l}\text { Mostly small. About } \\
\text { 8-1o examples }\end{array}$ & $\begin{array}{l}\text { Chance finds in } \\
\text { sandhills }\end{array}$ & \\
\hline & & & WALES & & \\
\hline $\begin{array}{l}\text { Coygan } \\
\text { Camp, } \\
\text { Laugharne }\end{array}$ & $\begin{array}{l}\text { Carmarthen- } \\
\text { shire }\end{array}$ & Ministry of Works & $\begin{array}{l}\text { Very battered. This } \\
\text { may be a local } \\
\text { imitation of the type }\end{array}$ & $\begin{array}{l}\text { Stratified late } 3 \text { rd } c \text {. } \\
\text { A.D. but possibly } \\
\text { earlier }\end{array}$ & $\begin{array}{l}\text { Wainwright, G. J. } \\
(1967) \text {, fig. } 49 \text {, } \\
\text { no. } 5\end{array}$ \\
\hline Ffestiniog & $\begin{array}{l}\text { Merioneth- } \\
\text { shire }\end{array}$ & $\begin{array}{l}\text { c/o Gwynedd Arch. } \\
\text { Trust }\end{array}$ & $\begin{array}{l}\text { Slightly oval. Diam. } \\
\text { c. } 9 \mathrm{~mm} . \mathrm{Ht} .4 \mathrm{~mm} .\end{array}$ & $\begin{array}{l}\text { With piece of and c. } \\
\text { A.D. olla }\end{array}$ & Forthcoming \\
\hline $\begin{array}{l}\text { Twyn-y-gaer } \\
\text { Fort, } \\
\text { Cwmyoy }\end{array}$ & $\begin{array}{l}\text { Monmouth- } \\
\text { shire }\end{array}$ & $\begin{array}{l}\text { Destined for N.M.W. } \\
\text { Abergavenny }\end{array}$ & $\begin{array}{l}\text { Two small examples, } \\
\text { very finely made with } \\
\text { flattened surfaces. } \\
\text { Diams. } 6 \mathrm{~mm} \text {. and } \\
5 \mathrm{~mm} \text {. Large perfora- } \\
\text { tions }\end{array}$ & $\begin{array}{l}\text { Smaller one was } \\
\text { stratified with } \\
\text { stamped pottery of } \\
\text { about } 3 \text { rd c. B.c. and } \\
\text { and the other maybe } \\
\text { Ist c. B.c. }\end{array}$ & $\begin{array}{l}\text { Information from } \\
\text { A. Probert, F.s.A. }\end{array}$ \\
\hline The Breiddin & $\begin{array}{l}\text { Montgomery- } \\
\text { shire }\end{array}$ & & $\begin{array}{l}\text { Flattened surfaces. } \\
\text { Diam. } 9 \mathrm{~mm} . \text { Ht. } \\
3 \mathrm{~mm} . \text { Perf. diam. } \\
5 \mathrm{~mm} .\end{array}$ & $\begin{array}{l}\text { Found near bead of } \\
\text { Oldbury type (Class } \\
6 \text { ) but not stratified } \\
\text { in fort occupied into } \\
\text { Roman period }\end{array}$ & $\begin{array}{l}\text { Information from } \\
\text { C. Musson }\end{array}$ \\
\hline
\end{tabular}

\section{CLASS 9}

\section{ANNULAR BEADS DEGORATED WITH TWO-COLOUR TWISTED GABLES}

\begin{tabular}{|c|c|c|c|}
\hline $\begin{array}{l}\text { Wilderspool, } \\
\text { Warrington }\end{array}$ & $\begin{array}{l}\text { Cheshire- } \\
\text { Lancashire } \\
\text { border }\end{array}$ & Warrington 1294 & $\begin{array}{l}\text { Cable round maxi- } \\
\text { mum diam. and white } \\
\text { girth-ring above and } \\
\text { below (fig. } 26, \text { no. } 3 \text { ) }\end{array}$ \\
\hline $\begin{array}{l}\text { No } \\
\text { provenance }\end{array}$ & 'Cumberland' & Carlisle & $\begin{array}{l}\text { Cable in yellow and } \\
\text { natural glass. Diam. } \\
2.6 \mathrm{~cm} \text {. Ht. } 1 \cdot 1 \mathrm{~cm} \text {. } \\
\text { Perf. diam. } 7 \mathrm{~mm} \text {. }\end{array}$ \\
\hline $\begin{array}{l}\text { Hembury } \\
\text { Fort, } \\
\text { Payhembury }\end{array}$ & Devonshire & Exeter 827 & $\begin{array}{l}\text { Fragment. Diam. } \\
3 \cdot 2 \mathrm{~cm} . \mathrm{Ht} . \mathrm{I} \cdot 3 \mathrm{~cm} .\end{array}$ \\
\hline South Shields & Durham & $\begin{array}{l}\text { South Shields } \\
\text { Museum }\end{array}$ & $\begin{array}{l}\text { Very fine. White } \\
\text { circumferential } \\
\text { bands containing } \\
\text { blue and red twists } \\
\text { (see Roman exotic } \\
\text { beads). (Perhaps an } \\
\text { imported bead from } \\
\text { the Near East) }\end{array}$ \\
\hline
\end{tabular}

\author{
Roman site \\ May, T. (1904) \\ and Thompson, \\ F. H. (1965), \\ fig. 20 , no. 20
}

From the date of the $P D A S$ ii, pt. 3,164 fortification. Occupied and and ist c. B.C. until A.D. $65^{-70}$

Occupation about A.D. I 22 to the $4^{\text {th }}$ century A.D.

$A A \times \mathbf{x i}($ 934), 8I102. See also $7 R S$ lvii (1967) 


\begin{tabular}{|c|c|c|c|c|c|}
\hline $\begin{array}{l}\text { SITE AND } \\
\text { PARISH }\end{array}$ & COUNTY & MUSEUM \& NO. & $\begin{array}{l}\text { DESCRIPTION AND } \\
\text { APPROX. DIMENSIONS }\end{array}$ & $\begin{array}{l}\text { ASSOCIATIONS AND } \\
\text { REMARKS }\end{array}$ & PUBLICATION \\
\hline Bagendon & $\begin{array}{l}\text { Gloucester- } \\
\text { shire }\end{array}$ & & Fragment only & $\begin{array}{l}\text { From Belgic site } \\
\text { stratified A.D. I0-50 }\end{array}$ & $\begin{array}{l}\text { Clifford, E. M. } \\
\text { (196I), p. 20I }\end{array}$ \\
\hline Cirencester & $\begin{array}{l}\text { Gloucester- } \\
\text { shire }\end{array}$ & Cirencester Cgog & $\begin{array}{l}\text { Half bead. Indistinct, } \\
\text { partly greenish cable. } \\
\text { Diam. } 2.8 \mathrm{~cm} . \mathrm{Ht} \text {. } \\
\text { I } 4 \mathrm{~cm} . \text { Perf. diam. } \\
\text { I } \mathrm{cm} .\end{array}$ & $\begin{array}{l}\text { Unstratified in } \\
\text { Roman town occu- } \\
\text { pied from ist C. A.D. }\end{array}$ & $\begin{array}{l}\text { Information from } \\
\text { excavator }\end{array}$ \\
\hline Kingscote & Gloucestershire & & $\begin{array}{l}3 \text { examples, all with } \\
\text { blue and white } \\
\text { cables. Diam. } c .3 \mathrm{~cm} .\end{array}$ & $\begin{array}{l}\text { Surface finds from } \\
\text { area mainly of ist } c \text {. } \\
\text { A.D. date }\end{array}$ & $\begin{array}{l}\text { Awaiting } \\
\text { publication }\end{array}$ \\
\hline Silchester & Hampshire & Reading & $\begin{array}{l}\text { Translucent light } \\
\text { blue. Diam. } 3 \mathrm{~cm} . \\
\text { Ht. } .8 \mathrm{~cm} .\end{array}$ & $\begin{array}{l}\text { Occupation ist C. } \\
\text { B.C. }-5^{\text {th C. A.D. }}\end{array}$ & $\begin{array}{l}\text { Boon, G. C. (1957) } \\
\text { and in } A \text { cii (1969) }\end{array}$ \\
\hline Kenchester & Herefordshire & Hereford $605^{8}$ & $\begin{array}{l}\text { Fragment only. Diam. } \\
3.3 \mathrm{~cm} . \mathrm{Ht} .1 .4 \mathrm{~cm}\end{array}$ & $\begin{array}{l}\text { Approximate date of } \\
\text { this Roman town } \\
\text { A.D. } 69-392\end{array}$ & $\begin{array}{l}\text { Jack, G. H. \& } \\
\text { Hayter, A. G. K } \\
\text { Excavations on the } \\
\text { Site of Magna } \\
\text { (Kenchester) (1916), } \\
\text { fig. } 26\end{array}$ \\
\hline Strood & Kent & $\begin{array}{l}\text { Humphrey Wickham } \\
\text { Colln. }\end{array}$ & $\begin{array}{l}\text { Bottle glass ground } \\
\text { with yellow and green } \\
\text { cable }\end{array}$ & $\begin{array}{l}\text { From Roman graves } \\
\text { ranging in date from } \\
\text { Claudius to Gratian }\end{array}$ & $\begin{array}{l}\text { Roach Smith, C. } \\
\text { (1 } 848) \text {, i, pl. ii, pp. } \\
\text { I } 7 \text { ff. }\end{array}$ \\
\hline Lincoln & Lincolnshire & $\begin{array}{l}\text { City and County } \\
\text { Museum, Lincoln }\end{array}$ & $\begin{array}{l}\text { Armlet (not a bead) } \\
\text { but in identical tech- } \\
\text { nique }\end{array}$ & Glaudian & $\operatorname{ArJ}$ ciii $(1946), 27$ \\
\hline $\begin{array}{l}\text { Charterhouse- } \\
\text { on-Mendip }\end{array}$ & Somerset & Bristol F2084 & $\begin{array}{l}\text { Fragment. Blue and } \\
\text { white cable. Diam. } \\
2.9 \mathrm{~cm} . \mathrm{Ht} . \mathrm{I} \cdot 8 \mathrm{~cm} \text {. } \\
\text { Perf. diam. I. } 2 \mathrm{~cm} .\end{array}$ & $\begin{array}{l}\text { Lead mines beginning } \\
\text { Ist c. A.D. A lead } \\
\text { 'pig' of A.D. } 49 \text { was } \\
\text { recovered. } \\
\text { After A.D. } 70 \text { the } \\
\text { mines ceased to be } \\
\text { under Imperial control } \\
\text { but continued in use }\end{array}$ & VCH Somerset i \\
\hline Meare & Somerset & Taunton G. $7^{8}$ & $\begin{array}{l}\text { Fragment of bead of } \\
3 \mathrm{~cm} \text {. diam. with } \\
\text { blue-filled nicking } \\
\text { to give cable effect }\end{array}$ & $\begin{array}{l}\text { Meare village } \\
\text { occupied } c .25^{\circ} \text { B.C.- } \\
\text { A.D. } 20\end{array}$ & $M e$ iii \\
\hline Wall & Staffordshire & Birmingham & $\begin{array}{l}\text { White and dark red } \\
\text { cable }\end{array}$ & Neronian level & TLSSAHS viii, 13 \\
\hline $\begin{array}{l}\text { Santon } \\
\text { Downham }\end{array}$ & Suffolk & C.M. & $\begin{array}{l}\text { Almost colourless } \\
\text { fragment with blue } \\
\text { and white cable. } \\
\text { Diam. } 3 \cdot 2 \mathrm{~cm} \text {. Ht. } \\
9 \mathrm{~mm} \text {. Perf. diam. } \\
2 \mathrm{~mm} \text {. }\end{array}$ & $\begin{array}{l}\text { From Beck's note- } \\
\text { books this bead was } \\
\text { found with the } \\
\text { important ist c. A.D. } \\
\text { hoard. This included } \\
\text { much bronze-work } \\
\text { and fragments of } \\
\text { bluish-green glass-- } \\
\text { perhaps part of an } \\
\text { armlet }\end{array}$ & $\begin{array}{l}P C A S \text { xiii }(1908-9) \text {, } \\
{ }_{15} 6\end{array}$ \\
\hline
\end{tabular}




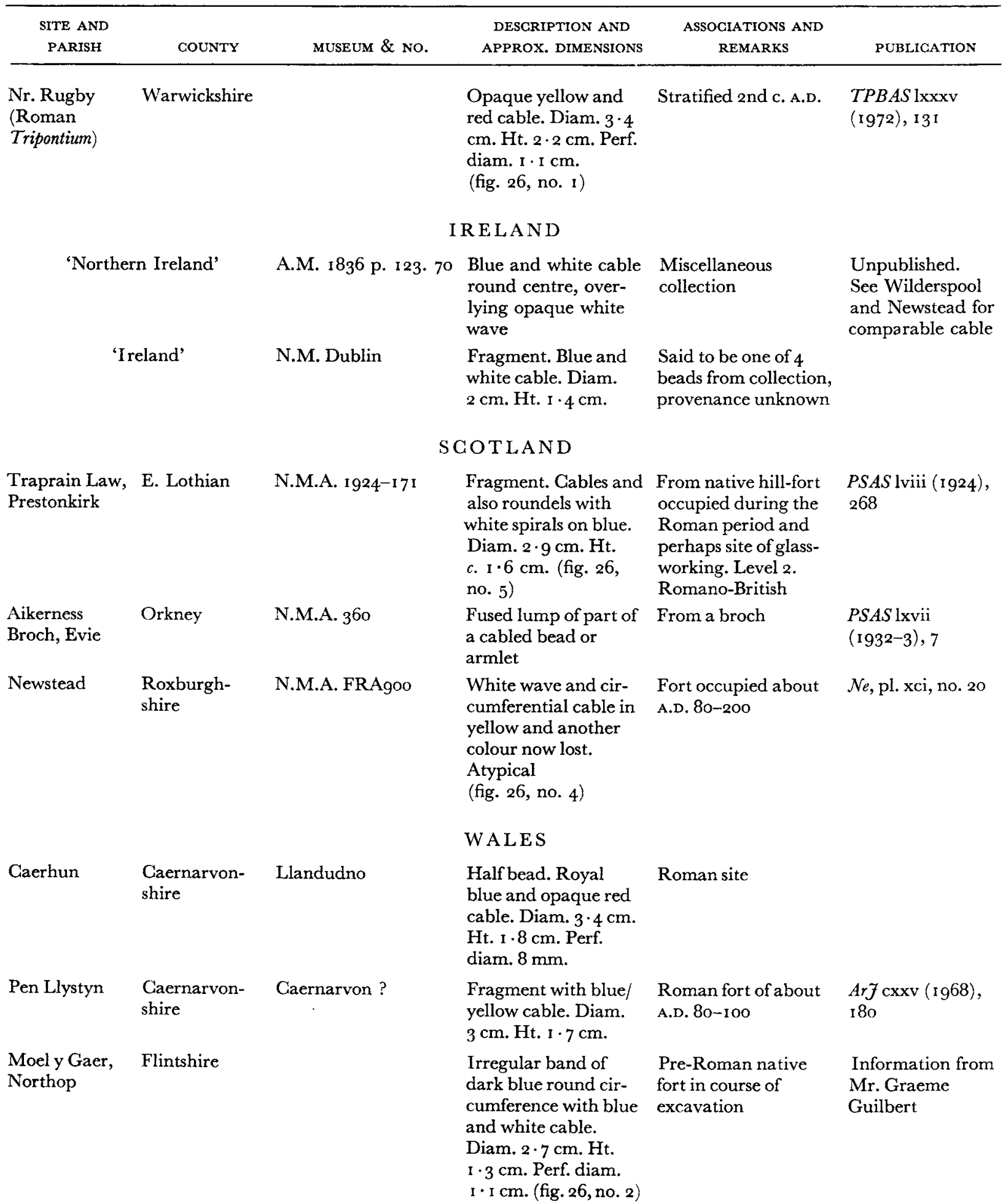




\begin{tabular}{|c|c|c|c|c|c|}
\hline $\begin{array}{l}\text { SITE AND } \\
\text { PARISH }\end{array}$ & COUNTY & MUSEUM \& NO. & $\begin{array}{c}\text { DESCRIPTION AND } \\
\text { APPROX. DIMENSIONS }\end{array}$ & $\begin{array}{l}\text { ASSOCIATIONS AND } \\
\text { REMARKS }\end{array}$ & PUBLICATION \\
\hline Cardiff & $\begin{array}{l}\text { Glamorgan- } \\
\text { shire }\end{array}$ & N.M.W. & $\begin{array}{l}\text { Wide opaque yellow } \\
\text { band round circum- } \\
\text { ference. Opaque red } \\
\text { and white cable. } \\
\text { Diam. } 2.6 \mathrm{~cm} . \mathrm{Ht} \text {. } \\
\text { I } \mathrm{cm} . \text { Perf. diam. } \\
9 \mathrm{~mm} \text {. }\end{array}$ & $\begin{array}{l}\text { Unassociated find } \\
\text { behind Queen Street. } \\
\text { Found about I } 9 \text { Io }\end{array}$ & $\begin{array}{l}\text { Information from } \\
\text { Mr. George Boon }\end{array}$ \\
\hline Caerleon & $\begin{array}{l}\text { Monmouth- } \\
\text { shire }\end{array}$ & Caerleon $63.228 B$ G6 & $\begin{array}{l}\text { Greenish-blue ground } \\
\text { with brown and } \\
\text { yellow cable. } \\
\text { Fragment. Diam. } \\
3 \mathrm{~cm} . \mathrm{Ht} . \mathrm{I} \cdot 5 \mathrm{~cm} \text {. }\end{array}$ & $\begin{array}{l}\text { Building in legionary } \\
\text { fortress. Antonine }\end{array}$ & Boon, G. C. (1972) \\
\hline Usk & $\begin{array}{l}\text { Monmouth- } \\
\text { shire }\end{array}$ & & $\begin{array}{l}\text { Fragment. Translu- } \\
\text { cent blue and opaque } \\
\text { white cable. Diam. } \\
3.3 \mathrm{~cm} . \mathrm{Ht} \text {. } 1.6 \mathrm{~cm} \text {. } \\
\text { Perf. diam. I } 6 \mathrm{~cm} \text {. }\end{array}$ & $\begin{array}{l}\text { Found in } 1967 \text { in } \\
\text { Roman fort occu- } \\
\text { pied in A.D. } 55^{-60} \text { and } \\
\text { again in later Roman } \\
\text { period }\end{array}$ & $\begin{array}{l}\text { Information from } \\
\text { the excavator }\end{array}$ \\
\hline & & (b) $\mathrm{COBALT}$ BLUE & WITH COLOURED & CABLES & \\
\hline \multicolumn{6}{|c|}{ ENGLAND } \\
\hline Fordham & $\begin{array}{l}\text { Cambridge- } \\
\text { shire }\end{array}$ & A.M. Igog-3 I9 & $\begin{array}{l}\text { Purple } / \text { white cable. } \\
\text { Diam. } 2 \cdot 2 \mathrm{~cm} . \mathrm{Ht} \text {. } \\
\mathrm{I} \cdot 4 \mathrm{~cm} .\end{array}$ & & \\
\hline Hilbre Island & Cheshire & & $\begin{array}{l}\text { Yellow and green } \\
\text { cable }\end{array}$ & $\begin{array}{l}\text { Found in } 1893 . \text { Sur- } \\
\text { face find }\end{array}$ & $\begin{array}{l}\text { Thompson } \\
\text { Watkin, W. (1886) } \\
\text { RomanCheshire, p. } \\
280\end{array}$ \\
\hline $\begin{array}{l}\text { Hembury } \\
\text { Fort, } \\
\text { Payhembury }\end{array}$ & Devonshire & Exeter 497 & $\begin{array}{l}\text { Yellow-brown and } \\
\text { white cable with } \\
\text { patch of pale green } \\
\text { blue glass. } \\
\text { Fragment. Diam. } \\
2 \cdot 4 \mathrm{~cm} \text {. Ht. } 1 \cdot 5 \mathrm{~cm} \text {. }\end{array}$ & $\begin{array}{l}\text { Hill-fort probably } 2 \text { nd } \\
\text { c. B.c. to } c \text {. A.D. } 70\end{array}$ & $\begin{array}{l}P D A S \text { ii }(\mathrm{r} 933-6), \\
\text { I67 }\end{array}$ \\
\hline Bagendon & $\begin{array}{l}\text { Gloucester- } \\
\text { shire }\end{array}$ & & $\begin{array}{l}\text { Blue/yellow cable. } \\
\text { Fragment. Ht. I } \cdot 9 \\
\mathrm{~cm} \text {. Another fragment } \\
\text { with green/yellow } \\
\text { cable }\end{array}$ & $\begin{array}{l}\text { Belgic oppidum. Strati- } \\
\text { fied A.D. } 10-50\end{array}$ & $\begin{array}{l}\text { Clifford, E. M. } \\
\text { (Ig6I), p. } 201 \text {, } \\
\text { fig. } 4^{2} \text {, no. } 5\end{array}$ \\
\hline Silchester & Hampshire & Reading & $\begin{array}{l}\text { Dark purple/white } \\
\text { cable. Fragment. } \\
\text { Diam. } 2 \cdot 9 \mathrm{~cm} . \mathrm{Ht} \text {. } \\
\text { I } 3 \mathrm{~cm} . \text { Another } \\
\text { fragment with blue } \\
\text { and white cable. }\end{array}$ & $\begin{array}{l}\text { Occupation ist c. } \\
\text { B.c. }-5 \text { th c. A.D. }\end{array}$ & $\begin{array}{l}\text { Boon, G. C. (1957) } \\
\text { and in } A \text { cii (1969) }\end{array}$ \\
\hline $\begin{array}{l}\text { Barcombe } \\
\text { Hill, } \\
\text { Chesterholm }\end{array}$ & $\begin{array}{l}\text { Northumber- } \\
\text { land }\end{array}$ & $\begin{array}{l}\text { University Museum, } \\
\text { Newcastle-upon- } \\
\text { Tyne, } 1947.1\end{array}$ & $\begin{array}{l}\text { White and brownish- } \\
\text { mauve cable. Diam. } \\
2 \cdot 1 \mathrm{~cm} . \mathrm{Ht} .1 \mathrm{~cm} \text {. } \\
\text { Perf. diam. } 9 \mathrm{~mm} \text {. }\end{array}$ & $\begin{array}{l}\text { No details. This hill } \\
\text { overlooks the fort of } \\
\text { Vindolanda on } \\
\text { Hadrian's Wall }\end{array}$ & $\begin{array}{l}\text { Information from } \\
\text { Dr. D. J. Smith }\end{array}$ \\
\hline
\end{tabular}




\begin{tabular}{|c|c|c|c|c|c|}
\hline $\begin{array}{l}\text { SITE AND } \\
\text { PARISH }\end{array}$ & GOUNTY & MUSEUM \& NO. & $\begin{array}{l}\text { DESCRIPTION AND } \\
\text { APPROX. DIMENSIONS }\end{array}$ & $\begin{array}{l}\text { ASSOCIATIONS AND } \\
\text { REMARKS }\end{array}$ & PUBLIGATION \\
\hline Camerton & Somerset & & $\begin{array}{l}\text { Blue with green cable. } \\
\text { Diam. } \mathrm{I} \cdot 6 \mathrm{~cm} \text {. } \\
\text { Smaller than most of } \\
\text { this Class }\end{array}$ & $\begin{array}{l}\text { Surface find, possibly } \\
\text { unrelated to the rest } \\
\text { of this Class }\end{array}$ & $\begin{array}{l}\text { Wedlake, W.J. } \\
\text { (I } 95^{8)} \text {, fig. } 57 \text {, } \\
\text { no. } 8\end{array}$ \\
\hline $\begin{array}{l}\text { Charterhouse- } \\
\text { on-Mendip }\end{array}$ & Somerset & $\begin{array}{l}\text { Bristol F2085 (A. C. } \\
\text { Pass Colln.) }\end{array}$ & $\begin{array}{l}\text { Cable is yellow with } \\
\text { another colour not } \\
\text { distinguishable. } \\
\text { Fragment. Diam. } \\
2.5 \mathrm{~cm} \text {. Ht. } 1 \cdot 1 \mathrm{~cm} \text {. }\end{array}$ & $\begin{array}{l}\text { From Roman (and } \\
\text { perhaps pre-Roman) } \\
\text { lead mines in use } \\
\text { around A.D. } 4^{\circ}-5^{\circ} \\
\text { and later }\end{array}$ & VCH Somerset i \\
\hline Glastonbury & Somerset & Glastonbury Gi 2 & $\begin{array}{l}\text { Fragment. Translu- } \\
\text { cent blue and white } \\
\text { cable }\end{array}$ & $\begin{array}{l}\text { Iron Age village site } \\
\text { begun about I } 50 \text { B.c. } \\
\text { abandoned before } \\
\text { Roman period about } \\
60 \text { B.C. }\end{array}$ & $\begin{array}{l}\text { Glii, pl. lix, Gi } 2 . \\
\text { See also PSANHS } \\
\text { cxii (1968), } 2 \text { i }\end{array}$ \\
\hline Meare & Somerset & Taunton $\mathrm{G}_{78} 8$ & $\begin{array}{l}\text { Large fragment with } \\
\text { tentative 'cable' in- } \\
\text { cised. Diam. } 2 \cdot 8 \mathrm{~cm} \text {. } \\
\text { Ht. I } 1 \mathrm{~cm} . \text { Perf. } \\
\text { diam. I } 3 \mathrm{~cm} \text {. }\end{array}$ & $\begin{array}{l}\text { Occupation } 3^{\text {rd }} \text { to Ist } \\
\text { c. B.c. }\end{array}$ & $M e$ iii \\
\hline $\begin{array}{l}\text { Seamills, nr. } \\
\text { Bristol }\end{array}$ & Somerset & B.M. 91.3 .276 & $\begin{array}{l}\text { Cable is yellow } \\
\text { twisted with dark } \\
\text { blue or brown. Diam. } \\
3 \mathrm{~cm} \text {. }\end{array}$ & $\begin{array}{l}\text { From Roman port of } \\
\text { Portus Abonae, of } \\
\text { Claudian and later } \\
\text { date }\end{array}$ & $\begin{array}{l}\text { Not published. } \\
\text { For site see } \\
\text { TBGAS lxviii } \\
\text { (1949), 184 }\end{array}$ \\
\hline Hales & Staffordshire & $\begin{array}{l}\text { Newcastle-under- } \\
\text { Lyme }\end{array}$ & $\begin{array}{l}\text { Fragment. Mauve } \\
\text { and white cable. } \\
\text { Diam. } 2 \cdot 4 \mathrm{~cm} . \text { Ht. } \\
\text { I } \cdot 6 \mathrm{~cm} . \text { Perf. diam. } \\
9 \mathrm{~mm} .\end{array}$ & $\begin{array}{l}\text { Unstratified in } \\
\text { Roman villa first } \\
\text { occupied in Ist c. } \\
\text { A.D. }\end{array}$ & $\begin{array}{l}\text { Information from } \\
\text { Mr. F. H. } \\
\text { Goodyear. See } \\
\text { NSfFC ix (1 } 969 \text { ), } \\
\text { I I } 5\end{array}$ \\
\hline Southwater & Sussex & & $\begin{array}{l}\text { Fragment. Cable of } 2 \\
\text { yellow and I white } \\
\text { twist. Diam. } 2 \cdot 4 \mathrm{~cm} \text {. } \\
\text { Perf. diam. I cm. }\end{array}$ & $\begin{array}{l}\text { Gasual find in } \\
\text { ploughed field }\end{array}$ & $\begin{array}{l}\text { Information from } \\
\text { Miss D. Standing, } \\
\text { Horsham }\end{array}$ \\
\hline Avebury & Wiltshire & Avebury & $\begin{array}{l}\text { Cable is white with } \\
\text { another colour now } \\
\text { indistinguishable. } \\
\text { Fragment. Diam. } \\
3.2 \mathrm{~cm} . \mathrm{Ht} .1 \cdot 6 \mathrm{~cm} \text {. } \\
\text { Perf. diam. I } 1 \mathrm{~cm} \text {. } \\
\text { S COTLAND }\end{array}$ & $\begin{array}{l}\text { From R.-B. scatter } \\
\text { mostly late ist-early } \\
\text { 2nd c. A.D. from Neo- } \\
\text { lithic site of Windmill } \\
\text { Hill }\end{array}$ & $\begin{array}{l}\text { Smith, I. (ed.), } \\
\text { Windmill Hill and } \\
\text { Avebury (Oxford } \\
\text { I965), p. I } 74\end{array}$ \\
\hline Crossmichael & $\begin{array}{l}\text { Kirkcud- } \\
\text { brightshire }\end{array}$ & N.M.A. FJ I 24 & $\begin{array}{l}\text { Atypical. Imitation } \\
\text { cable of two twisted } \\
\text { yellow threads. Diam. } \\
2 \mathrm{~cm} \text {. Ht. I } 2 \mathrm{~cm} \text {. }\end{array}$ & $\begin{array}{l}\text { Found with a Roman } \\
\text { melon bead }\end{array}$ & $\begin{array}{l}P S A S \text { lxvii } \\
\left(193^{2}-3\right), 3^{14}\end{array}$ \\
\hline Newstead & $\begin{array}{l}\text { Roxburgh- } \\
\text { shire }\end{array}$ & $\begin{array}{l}\text { Mr. Mason's } \\
\text { Colln., Selkirk }\end{array}$ & $\begin{array}{l}\text { Fragment with } \\
\text { yellow and green } \\
\text { cable. Diam. } 1 \cdot 8 \mathrm{~cm} \text {. } \\
\text { Ht. } \mathrm{I} \cdot \mathrm{I} \mathrm{cm} .\end{array}$ & $\begin{array}{l}\text { Unassociated find un- } \\
\text { related to main } \\
\text { excavations. Roman } \\
\text { site occupied } c . \text { A.D. } \\
80-200\end{array}$ & For site see $\mathcal{N} e$ \\
\hline
\end{tabular}




\begin{tabular}{cccccc}
\hline $\begin{array}{c}\text { SITE AND } \\
\text { PARISH }\end{array}$ & COUNTY & MUSEUM \& NO. & DESCRIPTION AND & ASSOCIATIONS AND & APPROX. DIMENSIONS \\
\hline
\end{tabular}

(c) BROWN OR GOLDEN BROWN WITH GOLOURED GABLES

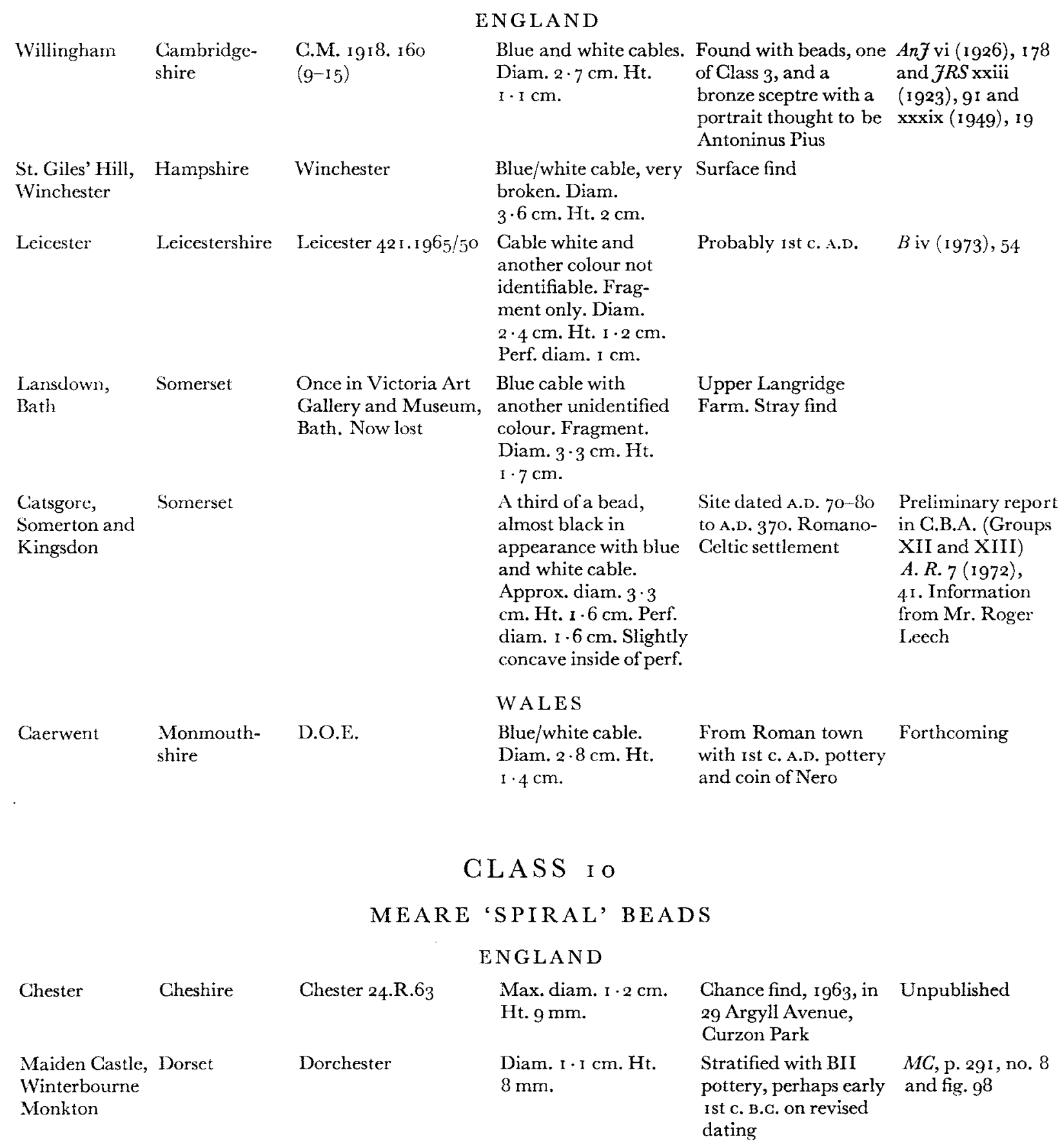




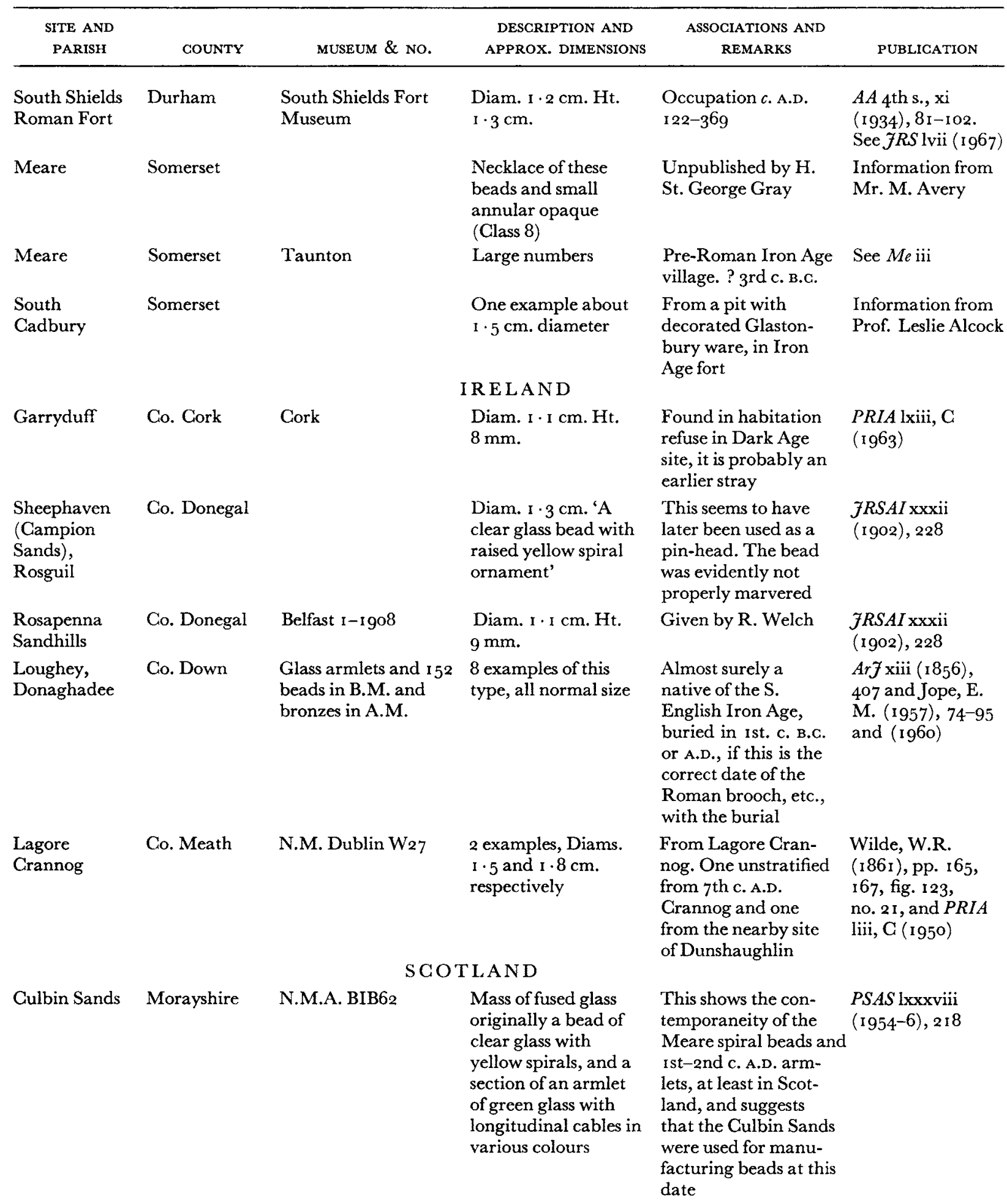




\begin{tabular}{|c|c|c|c|c|c|}
\hline $\begin{array}{l}\text { SITE AND } \\
\text { PARISH }\end{array}$ & COUNTY & MUSEUM \& NO. & $\begin{array}{l}\text { DESCRIPTION AND } \\
\text { APPROX. DIMENSIONS }\end{array}$ & $\begin{array}{l}\text { ASSOCIATIONS AND } \\
\text { REMARKS }\end{array}$ & PUBLICATION \\
\hline 'Orkney' & Orkney & & & $\begin{array}{l}\text { Said to be identical to } \\
\text { example from Caer- } \\
\text { went. Both are } \\
\text { atypical }\end{array}$ & $\begin{array}{l}\text { Waring, J. B., } \\
\text { Rude Stone } \\
\text { Monuments in } \\
\text { Orkney (1870), pl. } \\
53, \text { fig. } 5 \mathrm{a}\end{array}$ \\
\hline $\begin{array}{l}\text { Glenluce } \\
\text { Sands }\end{array}$ & Wigtownshire & N.M.A. & $\begin{array}{l}2 \text { examples both } c \text {. } \\
1 \cdot 3 \mathrm{~cm} \text {. diam. Ht. } \\
\text { I } \cdot 2 \mathrm{~cm} \text {. One very fine. } \\
\text { The other coarser with } \\
\text { flattened facets }\end{array}$ & Stray finds & Unpublished \\
\hline & & & WALES & & \\
\hline Anglesey & Anglesey & B.M. & $\begin{array}{l}\text { Diam. } 1 \cdot 8 \mathrm{~cm} . \mathrm{Ht} . \\
\mathrm{I} \cdot 3 \mathrm{~cm} .\end{array}$ & No information & Unpublished \\
\hline $\begin{array}{l}\text { Pen Dinas } \\
\text { (native fort), } \\
\text { Aberystwyth }\end{array}$ & Cardiganshire & & $\begin{array}{l}\text { Globular. Diam. I } 22 \\
\mathrm{~cm} .\end{array}$ & $\begin{array}{l}\text { Occupation layer in } \\
\text { native fort, perhaps } \\
\text { colonized from Welsh } \\
\text { marches }\end{array}$ & $\begin{array}{l}A n f \times x v(1935), 66 \\
\text { and } A C \text { cxii }(1963) \text {, } \\
\text { I52 }\end{array}$ \\
\hline Caerwent & $\begin{array}{l}\text { Monmouth- } \\
\text { shire }\end{array}$ & Caerwent Museum & $\begin{array}{l}\text { More triangular and } \\
\text { flatter than normal in } \\
\text { section. }\end{array}$ & $\begin{array}{l}\text { Said to be identical to } \\
\text { one from Orkney }\end{array}$ & $\begin{array}{l}A \text { lxxx }\left(193^{\circ}\right), 39 \\
\text { fig. } 2 \text { and } 24^{\circ}\end{array}$ \\
\hline $\begin{array}{l}\text { Moel Trigarn } \\
\text { (Iron Age fort) }\end{array}$ & $\begin{array}{l}\text { Pembroke- } \\
\text { shire }\end{array}$ & Tenby & $\begin{array}{l}\text { Diam. I. } 8 \mathrm{~cm} . \mathrm{Ht} . \\
2.4 \mathrm{~cm} .\end{array}$ & $\begin{array}{l}\text { With late Iron Age } \\
\text { objects in Hut } 2 \mathrm{I}\end{array}$ & $\begin{array}{l}A C, 5^{\text {th s., }} \text { xvii } \\
(1900), 189 \mathrm{ff} \text {. and } \\
203, \text { fig. } 6\end{array}$ \\
\hline
\end{tabular}

\section{GLASS I I}

'MEARE VARIANT' BEADS

(Clear glass with opaque yellow decoration) See also Classes 5,10 , and 12 TYPE (a): MULTIPLE GHEVRONS

\section{ENGLAND}

Risby Warren Lincolnshire Scunthorpe R18

Caynham Shropshire

Camp, nr.

Ludlow

Glevedon
Somerset

Taunton
Diam. I 2 cm. Ht. $7 \mathrm{~mm}$. Perf. diam. $5 \mathrm{~mm}$.

Diam. I $2 \mathrm{~cm}$. Ht. $6 \mathrm{~mm}$. Perf. diam. $5 \mathrm{~mm}$.

Rather straight sides. With red barrelDiam. I. I cm. Ht. $9 \mathrm{~mm}$. Perf. diam. $2 \mathrm{~mm}$.
Site produced mixed finds mostly RomanSaxon but Belgic site of Dragonby is very near

Iron Age hill-fort

shaped beads and small opaque yellow annular beads of Class 8 from urn in inhumation burial in a cist
TSAS lviii (1966), 99 and fig. 22

PSANHS lxxxviii (1942), $73 \mathrm{ff}$. 


\begin{tabular}{|c|c|c|c|c|c|}
\hline $\begin{array}{l}\text { SITE AND } \\
\text { PARISH }\end{array}$ & COUNTY & MUSEUM \& NO. & $\begin{array}{l}\text { DESCRIPTION AND } \\
\text { APPROX. DIMENSIONS }\end{array}$ & $\begin{array}{l}\text { ASSOCLATIONS AND } \\
\text { REMARKS }\end{array}$ & PUBLICATION \\
\hline $\begin{array}{l}\text { Ham Hill, } \\
\text { Montacute }\end{array}$ & Somerset & Taunton & $\begin{array}{l}\text { Half a bead. Diam. } \\
\text { I } 6 \mathrm{~cm} . \mathrm{Ht} . \mathrm{I} \cdot 3 \mathrm{~cm} \text {. } \\
\text { Perf. diam. } 5 \mathrm{~mm} \text {. } \\
\text { Another, very dam- } \\
\text { aged, seems to be very } \\
\text { similar but probably } \\
\text { Type }(\mathrm{g})\end{array}$ & $\begin{array}{l}\text { From late Iron Age } \\
\text { hill-fort. Just below } \\
\text { rampart and near the } \\
\text { old turf line. The } \\
\text { second is unstratified }\end{array}$ & $\begin{array}{l}\text { PSANHS lxxxviii } \\
(1942), 73 \mathrm{ff} \text { and } \\
\text { Arf cvii (1950), } 90\end{array}$ \\
\hline Glastonbury & Somerset & $\begin{array}{l}\text { Glastonbury Lake } \\
\text { Village Museum G22 }\end{array}$ & $\begin{array}{l}\text { Diam. I I cm. Ht. } \\
\text { I cm. }\end{array}$ & $\begin{array}{l}\text { From pre-Roman } \\
\text { village site of about } \\
\text { I } 50 \text { B.c. Abandoned } \\
\text { c. } 60 \text { B.c. }\end{array}$ & $G l$ ii \\
\hline Meare & Somerset & Taunton & $\begin{array}{l}\text { Over } 2 \text { dozen } \\
\text { examples }\end{array}$ & $\begin{array}{l}\text { From pre-Roman } \\
\text { village site. } 3^{\text {rd-1st c. }} \\
\text { B.c. ? }\end{array}$ & $M e$ iii \\
\hline \multicolumn{6}{|c|}{ SGOTLAND } \\
\hline $\begin{array}{l}\text { Glenluce } \\
\text { Sands }\end{array}$ & Wigtownshire & & No details & $\begin{array}{l}\text { Two of these beads } \\
\text { are referred to by } \\
\text { Bulleid and Gray in } \\
G l \text { ii, } 358, \text { n. } 2\end{array}$ & \\
\hline TYPE & (b) : YELLOW & CIRGUMFERENTIAI & BANDS WITH RADI & IATING HERRING-B & ONE LINE \\
\hline \multicolumn{6}{|c|}{ ENGLAND } \\
\hline Meare & Somerset & Taunton Gi4 & $\begin{array}{l}\text { Diam. I } \cdot \text { I cm. Ht. } \\
8 \mathrm{~mm} . \text { Perf. diam. } \\
4 \mathrm{~mm} \text {. One herring- } \\
\text { bone design separated } \\
\text { by circumferential } \\
\text { type }\end{array}$ & $\begin{array}{l}\text { Pre-Roman village } \\
\text { site }\end{array}$ & $M e \mathrm{iii}$ \\
\hline \multicolumn{6}{|c|}{ IRELAND } \\
\hline Carrowmore & Co. Sligo & Dublin $W_{4} K^{\circ}$ & $\begin{array}{l}\text { Diam. } 6 \mathrm{~mm} . \mathrm{Ht} .5 \\
\text { mm. Perf. diam. } \\
3 \mathrm{~mm} . \text { One herring- } \\
\text { bone design separated } \\
\text { by circumferential } \\
\text { type }\end{array}$ & $\begin{array}{l}\text { From cist burials in } \\
\text { a cemetery with } \\
\text { bronze ring }\end{array}$ & $\begin{array}{l}\text { Wood-Martin, } \\
\text { W. G., The Lake } \\
\text { Dwellings of } \\
\text { Ireland (Dublin, } \\
\text { r886) }\end{array}$ \\
\hline $\begin{array}{l}\text { Lagore } \\
\text { Crannog }\end{array}$ & Co. Meath & Dublin 1202 & $\begin{array}{l}\text { Another somewhat } \\
\text { similar but not } \\
\text { identical and very } \\
\text { damaged. The } \\
\text { decoration is not } \\
\text { herring-bone but } \\
\text { parallel lines each side } \\
\text { of central band }\end{array}$ & $\begin{array}{l}\text { Mainly } 7 \text { th c. A.D. but } \\
\text { some much earlier } \\
\text { beads. Note that this } \\
\text { bead is atypical of the } \\
\text { Iron Age series and is } \\
\text { likely to be later }\end{array}$ & $\begin{array}{l}\text { PRIA liii, } \mathrm{C} \\
\left(\mathrm{I} 95^{\circ-\mathrm{I})}\right.\end{array}$ \\
\hline
\end{tabular}




\begin{tabular}{|c|c|c|c|c|c|}
\hline $\begin{array}{l}\text { SITE AND } \\
\text { PARISH }\end{array}$ & COUNTY & MUSEUM \& NO. & $\begin{array}{l}\text { DESCRIPTION AND } \\
\text { APPROX. DIMENSIONS }\end{array}$ & $\begin{array}{c}\text { ASSOCIATIONS AND } \\
\text { REMARKS }\end{array}$ & PUBLICATION \\
\hline \multicolumn{6}{|c|}{ TYPE (c): TWO GIRGUMFERENTIAL GHEVRONS } \\
\hline St. Buryan & Cornwall & Penzance & $\begin{array}{l}\text { Annular bead with } \\
\text { almost clear glass } \\
\text { with } 2 \text { yellow opaque } \\
\text { chevrons. Diam. } \\
\text { about } 2 \mathrm{~cm} .\end{array}$ & $\begin{array}{l}\text { In neighbourhood of } \\
\text { circle and [Bronze } \\
\text { Age] barrows at } \\
\text { Boscawen-un }\end{array}$ & \\
\hline TY PE & (d): SEVER & GIRGUMFERENTI & $\begin{array}{l}\text { AL BANDS AT RIGH? } \\
\text { ENGLAND }\end{array}$ & - ANGLES TO PERFC & ORATION \\
\hline Meare & Somerset & $\begin{array}{l}\text { Taunton G2gEV and } \\
\text { another }\end{array}$ & $\begin{array}{l}\text { Diam. I I cm. Ht. } \\
9 \mathrm{~mm} . \text { Perf. diam. } \\
4 \mathrm{~mm} .\end{array}$ & $\begin{array}{l}\text { From mound XXI } \\
\text { and another from } \\
\text { recent excavations }\end{array}$ & $\begin{array}{l}\text { Me iii and } \\
\text { information from } \\
\text { Mr. Michael } \\
\text { Avery }\end{array}$ \\
\hline \multicolumn{6}{|c|}{ TYPE (e): YELLOW OVERALL TRELLIS } \\
\hline $\begin{array}{l}\text { West Overton } \\
\text { Down }\end{array}$ & Wiltshire & & $\begin{array}{l}\text { Diam. I cm. Ht. } 7 \\
\text { mm. Perf. diam. } \\
5 \mathrm{~mm} .\end{array}$ & $\begin{array}{l}\text { From Iron Age site, } \\
\text { Site XI, top of Iron } \\
\text { Age A pit }\end{array}$ & $\begin{array}{l}\text { WAM lxii ( } 1967 \text { ). } \\
\text { Preliminary report } \\
\text { in } C A \text { I } 6 \text { (Sept. } \\
\text { I } 969 \text { ) }\end{array}$ \\
\hline & TYPE $(f$ & YELLOW BANDS R & $\begin{array}{l}\text { OUGHLY PARALLEI } \\
\text { ENGLAND }\end{array}$ & L TO PERFORATION & \\
\hline Meare & Somerset & Taunton $\mathrm{G} 84$ & $\begin{array}{l}\text { Half of a flat large } \\
\text { annular ring bead. } \\
\text { Diam. } 2.9 \mathrm{~cm} . \mathrm{Ht} \text {. } \\
6 \mathrm{~mm} . \text { Perf. diam. } \\
2 \mathrm{~cm} .\end{array}$ & $\begin{array}{l}\text { From Meare East, } \\
\text { XIII Iron Age village }\end{array}$ & $M e$ iii \\
\hline \multicolumn{6}{|c|}{$\begin{array}{c}\text { TYPE (g): SINGLE WAVEROUND CENTRE } \\
\text { ENGLAND }\end{array}$} \\
\hline $\begin{array}{l}\text { Great } \\
\text { Chesterford }\end{array}$ & $\begin{array}{l}\text { Cambridge- } \\
\text { shire }\end{array}$ & C.M. & $\begin{array}{l}\text { Diam. } 2 \cdot \mathrm{I} \mathrm{cm} . \mathrm{Ht} . \\
9 \mathrm{~mm} . \text { Perf. diam. } \\
\mathrm{I} \cdot 4 \mathrm{~cm} .\end{array}$ & $\begin{array}{l}\text { From a site produc- } \\
\text { ing finds from ist c. } \\
\text { B.c. to end of Roman } \\
\text { period }\end{array}$ & \\
\hline $\begin{array}{l}\text { Madmarston } \\
\text { Camp, } \\
\text { Swalecliffe }\end{array}$ & Oxfordshire & A.M. 1969.165 & $\begin{array}{l}\text { Tinge of bluish-green } \\
\text { in yellow waves. } \\
\text { Diam. } 2 \cdot 5 \mathrm{~cm} . \mathrm{Ht} \text {. } \\
6 \mathrm{~mm} . \text { Perf. diam. } \\
1 \mathrm{~cm} .\end{array}$ & $\begin{array}{l}\text { Iron Age camp with } \\
\text { post-Roman occupa- } \\
\text { tion }\end{array}$ & $O \mathrm{xxv}(\mathrm{r} 960)$ \\
\hline $\begin{array}{l}\text { Ham Hill, } \\
\text { Montacute }\end{array}$ & Somerset & Taunton $\mathrm{HHG}_{5}$ & $\begin{array}{l}\text { Fragment. Very } \\
\text { damaged. Appears to } \\
\text { be a wave rather } \\
\text { than chevron }\end{array}$ & $\begin{array}{l}\text { From near the turf } \\
\text { line below late Iron } \\
\text { Age rampart }\end{array}$ & $\begin{array}{l}P S A N H S \text { lxxxviii } \\
(1942), 73 \mathrm{ff} .\end{array}$ \\
\hline Meare & Somerset & Taunton $\mathrm{G}_{4} \mathrm{EV}$ & $\begin{array}{l}\text { A stud bead. For } \\
\text { details, see p. } 84\end{array}$ & $\begin{array}{l}\text { From Iron Age village } \\
\text { site }\end{array}$ & Me iii \\
\hline
\end{tabular}




\begin{tabular}{|c|c|c|c|c|c|}
\hline $\begin{array}{l}\text { SITE AND } \\
\text { PARISH }\end{array}$ & COUNTY & MUSEUM \& NO. & $\begin{array}{l}\text { DESGRIPTION AND } \\
\text { APPROX. DIMENSIONS }\end{array}$ & $\begin{array}{l}\text { ASSOCLATIONS AND } \\
\text { REMARKS }\end{array}$ & PUBLICATION \\
\hline \multirow[t]{4}{*}{ Meare } & Somerset & Taunton $\mathrm{G}_{33}, 34,5^{2}$ & $\begin{array}{l}\text { Annular beads of } \\
\text { various sizes }\end{array}$ & $\begin{array}{l}\text { From Iron Age village } \\
\text { site }\end{array}$ & $M e$ iii \\
\hline & \multicolumn{5}{|c|}{ I RELAND } \\
\hline & \multicolumn{5}{|c|}{$\begin{array}{l}\text { Note that a number of larger colourless glass annular } \\
\text { beads with yellow wave come from Northern Ireland, } \\
\text { particularly Co. Antrim. The date of these is still not } \\
\text { yet known }\end{array}$} \\
\hline & \multicolumn{4}{|c|}{ SCOTLAND } & \\
\hline \multirow[t]{3}{*}{ Nr. Newstead } & $\begin{array}{l}\text { Roxburgh- } \\
\text { shire }\end{array}$ & $\begin{array}{l}\text { Mr. Mason's Colln., } \\
\text { Selkirk }\end{array}$ & One chevron & $\begin{array}{l}\text { In fields near New- } \\
\text { stead occupied ist- } \\
\text { 2nd C. A.D. }\end{array}$ & $\begin{array}{l}\text { Information from } \\
\text { Mr. R. B. K. } \\
\text { Stevenson }\end{array}$ \\
\hline & \multirow{2}{*}{\multicolumn{4}{|c|}{$\begin{array}{r}\text { TYPE }(\mathrm{h}) \text { : CIRCUMFERENTIAL BANDS OVE } \\
\text { ENGLAND }\end{array}$}} & \multirow[b]{3}{*}{$M e \dddot{i i l}\left(\mathrm{Ig}^{6} 7\right)$} \\
\hline & & & & & \\
\hline Meare & Somerset & $\begin{array}{l}\text { Taunton G69, Gi14, } \\
\text { Gi20 }\end{array}$ & $\begin{array}{l}\text { Barrel-shaped about } \\
1 \mathrm{~cm} \text {. diam. }\end{array}$ & From Iron Age village & \\
\hline
\end{tabular}

\section{GLASS I 2}

\section{STUD BEADS}

Meare Somerset Taunton $\mathrm{G}_{4} \mathrm{EV}$

\section{ENGLAND}

Clear glass decorated with opaque yellow

From pre-Roman village. (For technical waves. Diam. of larger affinities, see Class II) end $1.8 \mathrm{~cm}$; at smaller end $1 \cdot 3 \mathrm{~cm}$. Length $\mathrm{I} \cdot 3 \mathrm{~cm}$. Perf. diam. $6 \mathrm{~mm}$. (fig. 32 , no. I)

Lidbury Wiltshire Devizes

Diam. at larger end $\mathrm{I} \cdot 5 \mathrm{~cm}$. and at smaller end $8 \mathrm{~mm}$. The bead is made of opaque yellow glass and $\mathrm{I} \mathrm{cm}$. in height (fig. 32 , no. 2)

This came from a pit associated with late Iron Age A pottery. On current dating this is thought to be $3^{\text {rd }}$ to 2 nd c. B.c. and it is improbable that the bead is later. The glass resembles small annular opaque yellow beads (see Class 8). (A bead of this glass in two segments also came from Meare. ? 3rd-2nd c. B.c.)
$M e \mathrm{iii}$ (1966)

$W A M \mathrm{xl}$ (I9I7), $33-4$ and pl, ix, no. 12 


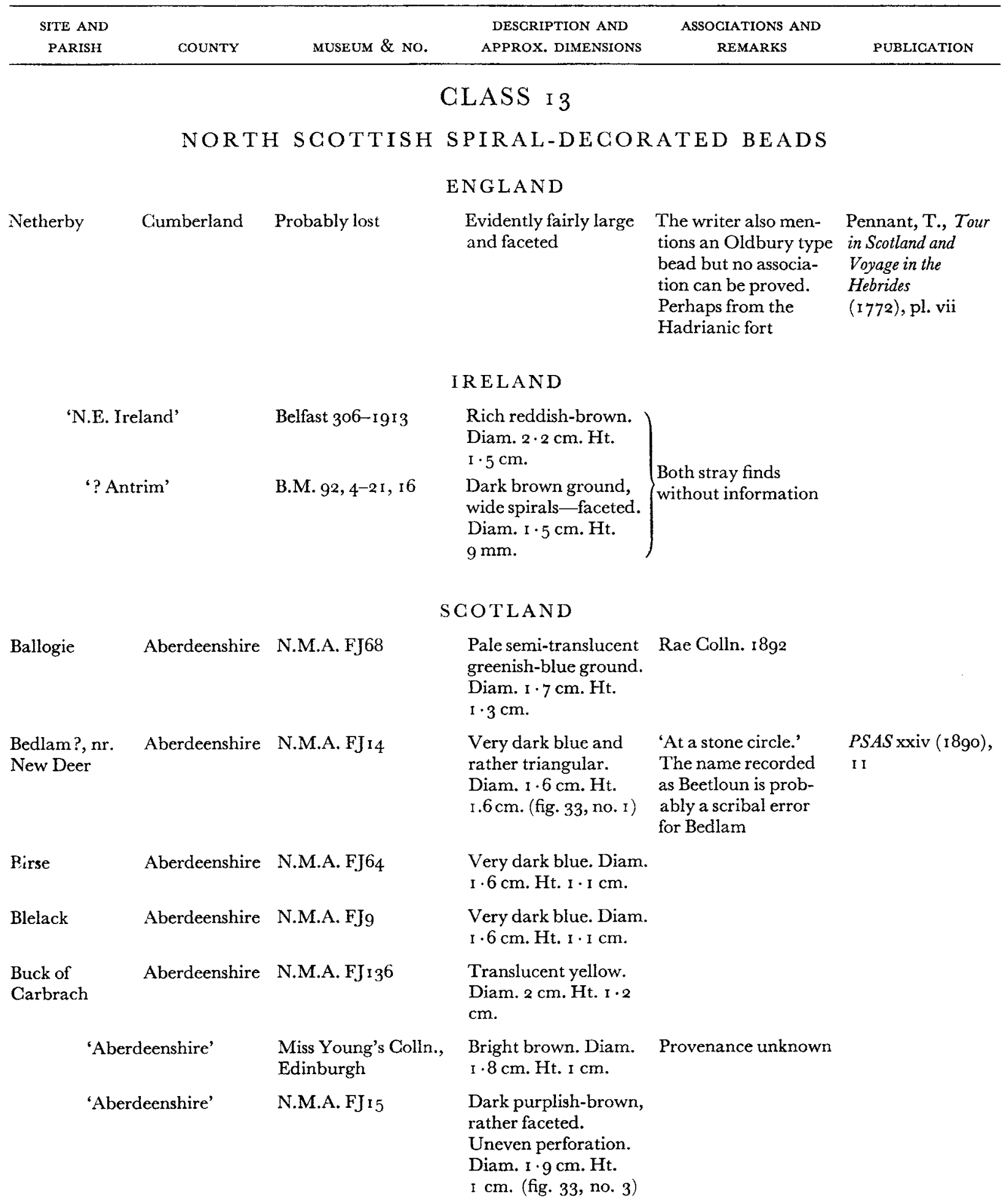




\section{I94 GLASS BEADS OF THE PREHISTORIG AND ROMAN PERIODS}

\begin{tabular}{|c|c|c|c|c|c|}
\hline $\begin{array}{l}\text { SITE AND } \\
\text { PARISH }\end{array}$ & COUNTY & MUSEUM \& NO. & $\begin{array}{l}\text { DESCRIPTION AND } \\
\text { APPROX. DIMENSIONS }\end{array}$ & $\begin{array}{l}\text { ASSOCIATIONS AND } \\
\text { REMARKS }\end{array}$ & PUBLICATION \\
\hline Castle Newe & Aberdeenshire & $\begin{array}{l}\text { Banff Institution } \\
\text { Museum }\end{array}$ & & $\begin{array}{l}\text { From earth-house } \\
\text { associated with hut. } \\
\text { Finds included coin } \\
\text { of Nerva (A.D. } 96-8 \text { ) } \\
\text { and bronze armlet of } \\
\text { Castle Newe type }\end{array}$ & $\begin{array}{l}\text { PSAS xxii (r887- } \\
\text { 8), } 369 ; \text { Simpson, } \\
\text { W. D., Province of } \\
\text { Mar (1943), p. } 74 ; \\
\text { Anderson, J. } \\
\text { Scotland in Pagan } \\
\text { Times (I } 886 \text { ), pp. } \\
\text { 141-3 }\end{array}$ \\
\hline Clova & Aberdeenshire & N.M.A.FJi3 & $\begin{array}{l}\text { Almost opaque } \\
\text { yellowish-green. } \\
\text { Diam. } 1 \cdot 6 \mathrm{~cm} . \mathrm{Ht} \text {. } \\
\mathrm{I} \cdot 2 \mathrm{~cm} .\end{array}$ & $\begin{array}{l}\text { Found with bronze } \\
\text { implements, no } \\
\text { details }\end{array}$ & $\begin{array}{l}P S A S \mathrm{xxiv}(\mathrm{I} 890), \\
\text { II }\end{array}$ \\
\hline Coldstone & Aberdeenshire & N.M.A. FJ 7,8 & $\begin{array}{l}\text { One bright semi- } \\
\text { translucent brown. } \\
\text { Diam. } 2 \mathrm{~cm} . \mathrm{Ht} \text {. } \\
\text { I } \cdot 8 \mathrm{~cm} \text {. One pale } \\
\text { yellow, translucent. } \\
\text { Diam. } .5 \mathrm{~cm} . \mathrm{Ht} \text {. } \\
\text { I } \cdot \mathrm{I} \mathrm{cm} .\end{array}$ & $\begin{array}{l}\text { 'From near a Pict's } \\
\text { house' (earth-house) }\end{array}$ & $\begin{array}{l}P S A S \text { vii }(1866-8), \\
3^{8} 5\end{array}$ \\
\hline Cromar & Aberdeenshire & N.M.A. & $\begin{array}{l}\text { 'A circular bead of } \\
\text { vitreous paste } \\
\text { enamelled on the sides } \\
\text { with } 3 \text { sets of spiral } \\
\text { convolutions' }\end{array}$ & & $\begin{array}{l}P S A S \text { vii (1 } 866-8) \\
320\end{array}$ \\
\hline $\begin{array}{l}\text { Callievar Hill, } \\
\text { Cushie }\end{array}$ & Aberdeenshire & N.M.A. FJi38 & & & $\begin{array}{l}\text { Mentioned in } \\
P S A S \mathrm{cV}(\mathrm{I} 972-4), \\
\mathrm{I} 98\end{array}$ \\
\hline Ellon & Aberdeenshire & $\begin{array}{l}\text { C.M. Given by Mr. } \\
\text { Cosmo Gordon of } \\
\text { Insch }\end{array}$ & $\begin{array}{l}\text { Very dark opaque } \\
\text { blue. Half only. Diam. } \\
1.4 \mathrm{~cm} . \text { Ht. } 8 \mathrm{~mm} \text {. }\end{array}$ & $\begin{array}{l}\text { Stray find at Lady- } \\
\text { mire Fen, I } \frac{1}{4} \text { miles } \\
\text { E.S.E. of Ellon } \\
\text { (noted by Beck) }\end{array}$ & \\
\hline $\begin{array}{l}\text { Glenbuchat } \\
\text { Hill }\end{array}$ & Aberdeenshire & N.M.A. FJ 137 & $\begin{array}{l}\text { Very dark ground, } \\
\text { slightly faceted. Diam. } \\
1.6 \mathrm{~cm} . \mathrm{Ht} . \mathrm{I} \cdot 3 \mathrm{~cm} \text {. }\end{array}$ & $\begin{array}{l}\text { Found by Captain } \\
\text { Hugh Lumsden in } \\
\text { I } 937\end{array}$ & \\
\hline Kennethmont & Aberdeenshire & $\begin{array}{l}\text { Broughton House, } \\
\text { Kirkcudbright, on } \\
\text { loan to N.M.A. }\end{array}$ & $\begin{array}{l}\text { Dark cobalt ground. } \\
\text { Diam. } 1.5 \mathrm{~cm} . \mathrm{Ht} \text {. } \\
\mathrm{I} \mathrm{cm} .\end{array}$ & $\begin{array}{l}\text { Found in digging } \\
\text { foundations for bridge } \\
\text { over the Bogie. } \\
\text { Apparently associa- } \\
\text { tion with bead of } \\
\text { Scottish decorated } \\
\text { annular type }\end{array}$ & Unpublished \\
\hline Kildrummy & Aberdeenshire & $\begin{array}{l}\text { King's Coll. Museum, } \\
\text { Aberdeen }\end{array}$ & $\begin{array}{l}\text { ' } 2 \text { small beads of } \\
\text { vitreous paste striped } \\
\text { with yellow' }\end{array}$ & & $\begin{array}{l}P S A S \times x i i \text { ( } 1888), \\
357\end{array}$ \\
\hline Kinnord & Aberdeenshire & N.M.A. FJ69 & $\begin{array}{l}\text { Dark blue ground, } \\
\text { rather faceted. Diam. } \\
\text { I } 5 \mathrm{~cm} . \mathrm{Ht} .1 \mathrm{~cm} \text {. }\end{array}$ & & \\
\hline Midmar & Aberdeenshire & N.M.A. FJ67 & $\begin{array}{l}\text { Purplish-brown and } \\
\text { rather triangular. } \\
\text { Diam. } 1.6 \mathrm{~cm} . \mathrm{Ht} \text {. } \\
\text { I } \mathrm{cm} .\end{array}$ & & \\
\hline
\end{tabular}




\begin{tabular}{|c|c|c|c|c|c|}
\hline $\begin{array}{l}\text { SITE AND } \\
\text { PARISH }\end{array}$ & COUNTY & MUSEUM \& NO. & $\begin{array}{l}\text { DESCRIPTION AND } \\
\text { APPROX. DIMENSIONS }\end{array}$ & $\begin{array}{l}\text { ASSOCIATIONS AND } \\
\text { REMARKS }\end{array}$ & PUBLICATION \\
\hline Rhynie & Aberdeenshire & $\begin{array}{l}\text { c/o Mr. Alex. Shand, } \\
\text { Longcroft, Rhynie }\end{array}$ & $\begin{array}{l}\text { Very dark ground, } \\
\text { slightly hexagonal. } \\
\text { Diam. } \mathrm{I} \cdot 7 \mathrm{~cm} .\end{array}$ & & $\begin{array}{l}P S A S \mathrm{lxix}(1935) \\
454\end{array}$ \\
\hline Slains & Aberdeenshire & N.M.A. FJ ro & $\begin{array}{l}\text { Very dark opaque? } \\
\text { with flattened } \\
\text { facets. Diam. } 1 \cdot 5 \mathrm{~cm} \text {. } \\
\text { Ht. } 1 \cdot 4 \mathrm{~cm} .\end{array}$ & Unassociated find & $\begin{array}{l}P S A S \text { I }(x 873-4), \\
699\end{array}$ \\
\hline Strathdon & Aberdeenshire & $\begin{array}{l}\text { N.M.A. FJ66, Rae } \\
\text { Colln. } 1892\end{array}$ & $\begin{array}{l}\text { Light yellow. } \\
\text { Flattened spirals. } \\
\text { Diam. I } \cdot 5 \mathrm{~cm} . \mathrm{Ht} \text {. } \\
\text { I } \mathrm{cm} .\end{array}$ & $\begin{array}{l}\text { It is possible that this } \\
\text { came from Castle } \\
\text { Newe which is also in } \\
\text { Strathdon }\end{array}$ & \\
\hline Tough & Aberdeenshire & N.M.A. FJ65 & $\begin{array}{l}\text { Opaque brownish } \\
\text { ground. Diam. } 1.4 \mathrm{~cm} \text {. } \\
\text { Ht. } 9 \mathrm{~mm} \text {. }\end{array}$ & & \\
\hline $\begin{array}{l}\text { Balmerion } \\
\text { Farm, } \\
\text { Glenrinnes }\end{array}$ & Banffshire & N.M.A. FJ 6 & $\begin{array}{l}\text { Translucent yellowish- } \\
\text { green. Diam. } 1 \cdot 3 \mathrm{~cm} \text {. } \\
\text { Ht. } 9 \mathrm{~mm} \text {. }\end{array}$ & $\begin{array}{l}\text { This is almost as } \\
\text { colourless as a Meare } \\
\text { spiral bead but is } \\
\text { more roughly made }\end{array}$ & \\
\hline$?$ & Banffshire & N.M.A. & $\begin{array}{l}\text { 'One round bead with } \\
\text { yellow spirals' }\end{array}$ & & $P S A S \times x v(1890), 8$ \\
\hline$?$ & Banffshire & $\begin{array}{l}\text { Banff Institution } \\
\text { Museum }\end{array}$ & $\begin{array}{l}\text { 'Two beads of } \\
\text { vitreous paste striped } \\
\text { with yellow' }\end{array}$ & & $\begin{array}{l}P S A S \times x i i(1888), \\
3^{69}\end{array}$ \\
\hline Bowermadden & Caithness & N.M.A. GA92 & $\begin{array}{l}\text { 'Blue vitreous paste } \\
\text { enamelled with } \\
\text { yellow spirals, tri- } \\
\text { angularly compressed' }\end{array}$ & From the broch & $\begin{array}{l}\text { Anderson, J., } \\
\text { Scotland in Pagan } \\
\text { Times (1886), p. } \\
233 \text { and } P S A S \text { ix } \\
(1873), 247\end{array}$ \\
\hline Groy & Inverness-shire & N.M.A. & $\begin{array}{l}\text { Rather triangular. } \\
\text { Blue core covered } \\
\text { with opaque brown } \\
\text { with yellow spirals }\end{array}$ & $\begin{array}{l}\text { Probably a survival } \\
\text { of this class found } \\
\text { with } 9^{\text {th }} \text { c. A.D. } \\
\text { coins, etc. }\end{array}$ & $\begin{array}{l}P S A S \times x(1886) \\
93 \text { and } 96\end{array}$ \\
\hline $\begin{array}{l}\text { Dun an } \\
\text { Iardhard, } \\
\text { Dunvegan, Skye }\end{array}$ & Inverness-shire & N.M.A. GA1003 & $\begin{array}{l}\text { Fawn ground. Diam. } \\
\text { I. I cm. Ht. } 9 \mathrm{~mm} .\end{array}$ & From the broch & $\begin{array}{l}\text { PSAS xlix (1914- } \\
\text { 15), } 65 \text { and fig. Io, } \\
\text { no. I }\end{array}$ \\
\hline Burghead & Morayshire & N.M.A. FJ5 6 & $\begin{array}{l}2 \text { with dark blue } \\
\text { ground. One, diam. } \\
\text { I } 5 \mathrm{~cm} ., \text { ht. } 5 \mathrm{~mm} \text {. } \\
\text { One, diam. I } .9 \mathrm{~cm} \text {. } \\
\text { ht. } 1.2 \mathrm{~cm} .\end{array}$ & $\begin{array}{l}\text { Found in i } 890 \text { in the } \\
\text { rampart material of } \\
\text { the post-Roman fort }\end{array}$ & $\begin{array}{l}P S A S \text { xxiv }(1890), \\
379 \text { and } \times x v \\
(1890-1), 68 \\
\text { and Small, A., } \\
\text { in Scottish Arch. } \\
\text { Forum i (1969), } \\
6 \mathrm{I}-8\end{array}$ \\
\hline Culbin Sands & Morayshire & & $\begin{array}{l}\text { Half-bead of brown } \\
\text { glass. Diam. } 1.5 \mathrm{~cm} .\end{array}$ & & $\begin{array}{l}\text { PSAS liv (1919- } \\
\text { 20), I } 5\end{array}$ \\
\hline
\end{tabular}




\begin{tabular}{|c|c|c|c|c|c|}
\hline $\begin{array}{l}\text { SITE AND } \\
\text { PARISH }\end{array}$ & COUNTY & MUSEUM \& NO. & $\begin{array}{l}\text { DESCRIPTION AND } \\
\text { APPROX. DIMENSIONS }\end{array}$ & $\begin{array}{l}\text { ASSOCIATIONS AND } \\
\text { REMARKS }\end{array}$ & PUBLIGATION \\
\hline Culbin Sands & Morayshire & $\begin{array}{l}\text { Miss Young's Colln., } \\
\text { Edinburgh }\end{array}$ & $\begin{array}{l}2 \text { half-beads, one dark } \\
\text { translucent cobalt } \\
\text { and the other darker } \\
\text { and smaller }\end{array}$ & & \\
\hline Culbin Sands & Morayshire & N.M.A. & $\begin{array}{l}\text { Remains of at least } 5 \\
\text { or } 6 \text { specimens, all } \\
\text { broken }\end{array}$ & $\begin{array}{l}\text { One published in } \\
P S A S \mathrm{xxv}(\mathrm{I} 890-9 \mathrm{I}) \\
509, \text { has translucent } \\
\text { pale blue glass tips } \\
\text { and may be later. All } \\
\text { stray finds }\end{array}$ & \\
\hline Keith & Morayshire & Elgin & Bluish ground & & $\begin{array}{l}P S A S \text { xxii (1888), } \\
343\end{array}$ \\
\hline Orton & Morayshire & Elgin & $\begin{array}{l}\text { Translucent blue- } \\
\text { green. Diam. } 1 \cdot 7 \mathrm{~cm} . \\
\text { Ht. } 1 \cdot 2 \mathrm{~cm} . \text { Perf. } \\
\text { diam. } 7 \mathrm{~mm} \text {. }\end{array}$ & $\begin{array}{l}\text { Found at Dykeside, } \\
\text { Orton, in } 1970\end{array}$ & Unpublished \\
\hline $\begin{array}{l}\text { 'Pitcroy' } \\
\text { probably } \\
\text { Pitchroy, nr. } \\
\text { Ballindalloch }\end{array}$ & Morayshire & & $\begin{array}{l}\text { 'Bead of bluish glass } \\
\text { enamelled with yellow } \\
\text { spirals' }\end{array}$ & $\begin{array}{l}\text { 'Found on the hill of } \\
\text { Pitcroy' }\end{array}$ & $\begin{array}{l}P S A S \text { xxviii } \\
(1893-4), 62\end{array}$ \\
\hline Cawdor & Nairnshire & & $\begin{array}{l}2 \text { blue beads. Diam. } \\
1.5 \mathrm{~cm} . \mathrm{Ht} .1 \mathrm{~cm} \text {. }\end{array}$ & $\begin{array}{l}\text { One is rather more } \\
\text { faceted than the other }\end{array}$ & $\begin{array}{l}P S A S \text { xix (1885), } \\
\text { I } 33\end{array}$ \\
\hline Cawdor & Nairnshire & $\begin{array}{l}\text { N.M.A. FJ } \mathrm{I}-4 \text { and } \\
\text { others }\end{array}$ & $\begin{array}{l}2 \text { dark blue ground, } \\
\text { one green, one light } \\
\text { greenish-yellow } \\
\text { translucent, one } \\
\text { blue-green bottle } \\
\text { glass. All normal size }\end{array}$ & $\begin{array}{l}\text { 'Near Cawdor' in a } \\
\text { ditch apparently with } \\
2 \text { beads of Scottish } \\
\text { decorated annular } \\
\text { type (Class } 14 \text { ) }\end{array}$ & $\begin{array}{l}\text { Probably the } \\
\text { beads referred to } \\
\text { in } P S A S \mathrm{v} \text { (1864), } \\
300 \text { and } 313\end{array}$ \\
\hline $\begin{array}{l}\text { Nairn } \\
\text { (unprovenanced }\end{array}$ & Nairnshire & N.M.A. FJI I & $\begin{array}{l}\text { Dark brown semi- } \\
\text { translucent. Diam. } \\
\mathrm{I} \cdot 6 \mathrm{~cm} . \mathrm{Ht} . \mathrm{I} \cdot \mathrm{I} \mathrm{cm} .\end{array}$ & & \\
\hline Evie & Orkney & $\begin{array}{l}\text { J. W. Cursiter } \\
\text { Colln., Kirkwall }\end{array}$ & $\begin{array}{l}\text { Smaller but similar } \\
\text { to bead from Slains }\end{array}$ & & $\begin{array}{l}P S A S \text { xix (1885), } \\
\text { I } 39\end{array}$ \\
\hline$?$ & Orkney & & $\begin{array}{l}\text { White with yellow } \\
\text { spirals and plain ring } \\
\text { round perforation }\end{array}$ & $\begin{array}{l}\text { This may or may not } \\
\text { belong to this Class }\end{array}$ & $\begin{array}{l}\text { Waring, J. B., } \\
\text { Rude Stone } \\
\text { Monuments in } \\
\text { Orkney (London, } \\
\text { 1870), pl. 53, fig. 9; } \\
\text { Alxxx (1930), 240 }\end{array}$ \\
\hline Eddertoun & Ross-shire & N.M.A. EQ45 & $\begin{array}{l}\text { Very dark opaque } \\
\text { blue. The spirals are } \\
\text { white and a yellow } \\
\text { patch is over some } \\
\text { and under others. } \\
\text { Diam. } 1 \cdot 5 \mathrm{~cm} \text {. Ht. } \\
1 \mathrm{~cm} .\end{array}$ & $\begin{array}{l}\text { This is not typical and } \\
\text { may not belong to this } \\
\text { Class. It was found in } \\
\text { a cist with a cremation } \\
\text { and thought to be con- } \\
\text { temporary with a food } \\
\text { vessel or cordoned urn } \\
\text { of very degenerate } \\
\text { type }\end{array}$ & $\begin{array}{l}P S A S \text { V }(1864), 3 \text { I } \\
\text { ff. }\end{array}$ \\
\hline
\end{tabular}


THE SGHEDULES: GLASSES I 3 AND I4

\begin{tabular}{cccccc}
\hline $\begin{array}{c}\text { SITE AND } \\
\text { PARISH }\end{array}$ & COUNTY & MUSEUM \& NO. & $\begin{array}{c}\text { DESCRIPTION AND } \\
\text { APPROX. DIMENSIONS }\end{array}$ & $\begin{array}{c}\text { ASSOCIATIONS AND } \\
\text { REMARKS }\end{array}$ & PUBLICATION \\
\hline
\end{tabular}

Loch Eriboll, Sutherland Fouhlin

'Scotland'
Hunterian Museum, Glasgow, NC40554I

N.M.A. FJi 2,84
Translucent almost From a hut-circle colourless with facets. associated with an Diam. $\mathrm{I} \cdot 5 \mathrm{~cm}$. Ht. earth-house $9 \mathrm{~mm}$. (fig. 33 , no. 2)

2 examples. One semi-translucent bluish and one dark opaque-almost black. Both are typical in size
Forthcoming

\section{GLASS I 4}

NORTH SGOTTISH DEGORATED ANNULAR BEADS

'Derbyshire'

B.M.

'Ireland' (probably the north)

'Probably Ireland'

'Antrim'

'Aberdeenshire'

\section{Belfast 2412}

N.M.A., Bell Colln., $\mathrm{FK}_{40}$

N.M. Ireland, Dublin, I 908.347

\section{ENGLAND}

Translucent blue ground with patches of translucent green and opaque yellow whirls. Diam. 2 I cm. Perf. diam. $4 \mathrm{~mm}$. this Class

\section{RELAND}

Dark blue whirls on whitish ground or vice-versa. Purplish bands round circumference. Diam. $3 \cdot 2 \mathrm{~cm}$. Ht. $1 \cdot 6 \mathrm{~cm}$.

Opaque greyish with opaque white whirls and a patch of greenish-yellow round interior of perforation. Diam. $2.5 \mathrm{~cm}$. Ht. $\mathrm{I} \cdot 4 \mathrm{~cm}$. Perf. diam. $7 \mathrm{~mm}$.

Dark ground with yellow whirls alternating with yellow and brown ladder whirls. Diam. $2 \cdot 7 \mathrm{~cm}$. Ht. $\mathrm{I} \cdot \mathrm{I} \mathrm{cm}$. Perf. diam. $5 \mathrm{~mm}$.

\section{SCOTLAND}

N.M.A., Rae Colln., Badly made. Brown FJ70
Found in 1790 . Unlike the majority of beads in this Class the ground is translucent. It may not belong to

Probably belongs to this Class

May well belong to this Class

Similar glass, apparently, as the whirl bead from Cloughwater, Antrim

(Dublin, I907.97)

From colln. No details
Diam. $\mathrm{I} \cdot 7 \mathrm{~cm}$. $\mathrm{Ht}$. $5 \mathrm{~mm}$. Small perforation 
I98 GLASS BEADS OF THE PREHISTORIG AND ROMAN PERIODS

\begin{tabular}{|c|c|c|c|c|c|}
\hline $\begin{array}{l}\text { SITE AND } \\
\text { PARISH }\end{array}$ & COUNTY & MUSEUM \& NO. & $\begin{array}{l}\text { DESCRIPTION AND } \\
\text { APPROX. DIMENSIONS }\end{array}$ & $\begin{array}{l}\text { ASSOCIATIONS AND } \\
\text { REMARKS }\end{array}$ & PUBLICATION \\
\hline \multicolumn{2}{|c|}{ 'Aberdeenshire' } & N.M.A. FJ 72 & $\begin{array}{l}\text { Badly made. Dark } \\
\text { opaque brownish } \\
\text { with brown } / \text { white } \\
\text { ladder and yellow } \\
\text { bands. Diam. I. } 8 \mathrm{~cm} \text {. } \\
\text { Ht. } 7 \mathrm{~mm} \text {. Small } \\
\text { perforation }\end{array}$ & $\begin{array}{l}\text { From colln. No } \\
\text { details }\end{array}$ & \\
\hline \multicolumn{2}{|c|}{ 'Aberdeenshire' } & $\begin{array}{l}\text { N.M.A., Rae Colln., } \\
\text { FJ73 }\end{array}$ & $\begin{array}{l}\text { Brown with wide } \\
\text { yellow whirls. Diam. } \\
2.5 \mathrm{~cm} . \mathrm{Ht} .9 \mathrm{~mm} \text {. } \\
\text { Perf. diam. } 5 \mathrm{~mm} \text {. }\end{array}$ & & \\
\hline \multicolumn{2}{|c|}{ 'Aberdeenshire' } & $\begin{array}{l}\text { N.M.A., Rae Colln., } \\
\text { FJ7 I }\end{array}$ & $\begin{array}{l}\text { Opaque dark slaty } \\
\text { blue with yellow and } \\
\text { white whirls. Diam. } \\
1 \cdot 7 \mathrm{~cm} . \text { Ht. } 7 \mathrm{~mm} \text {. } \\
\text { Perf. diam. } 4 \mathrm{~mm} \text {. } \\
\text { (fig. } 35, \text { no. I) }\end{array}$ & No details & \\
\hline \multicolumn{2}{|c|}{ 'Aberdeenshire' } & N.M.A. FJ I I 8 & $\begin{array}{l}\text { Whirled bands in } \\
\text { yellow edged with } \\
\text { brown. Intervening } \\
\text { whirls in dark and } \\
\text { light blue ladder } \\
\text { pattern. Diam. } 2.4 \mathrm{~cm} \text {. } \\
\text { Ht. } 8 \mathrm{~mm} \text {. Perf. diam. } \\
7 \mathrm{~mm} \text {. }\end{array}$ & 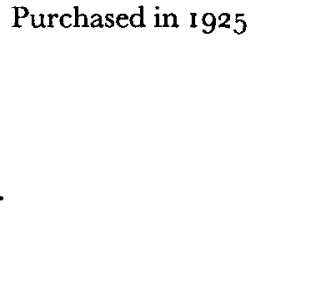 & \\
\hline Kennethmont & Aberdeenshire & $\begin{array}{l}\text { On loan to N.M.A. } \\
\text { from Broughton } \\
\text { House, Kirkcud- } \\
\text { brights. }\end{array}$ & $\begin{array}{l}\text { Clear glass with } \\
\text { opaque yellow and } \\
\text { brown bands. Diam. } \\
\text { I } 6 \mathrm{~cm} \text {. Ht. I } \mathrm{cm} \text {. } \\
\text { Perf. diam. } 4 \mathrm{~mm} \text {. } \\
\text { (fig. } 35 \text {, no. } 4 \text { ) }\end{array}$ & $\begin{array}{l}\text { Found with a North } \\
\text { Scottish spiral bead } \\
\text { when digging bridge } \\
\text { foundations at } \\
\text { Smithston. Apparently } \\
\text { associated }\end{array}$ & \\
\hline $\begin{array}{l}\text { Lickleyhead, } \\
\text { Premnay }\end{array}$ & Aberdeenshire & N.M.A. FJ 39 & $\begin{array}{l}\text { Opaque yellow with } \\
\text { girth bands of dark } \\
\text { brown bordering grey } \\
\text { and white ladder. } \\
\text { Diam. } 2 \cdot 3 \mathrm{~cm} . \mathrm{Ht} \text {. } \\
8 \mathrm{~mm} . \text { Perf. diam. } \\
7 \mathrm{~mm} \text {. }\end{array}$ & Presented in 1937 & \\
\hline $\begin{array}{l}\text { Cairnhill, } \\
\text { Monquhitter }\end{array}$ & Aberdeenshire & ? colln., EQ330 & $\begin{array}{l}\text { Very large rich dark } \\
\text { brown with super- } \\
\text { ficial white streaks. } \\
\text { Semi-translucent. One } \\
\text { side flattened and } \\
\text { smooth. Diam. } 5.5 \mathrm{~cm} \text {. }\end{array}$ & $\begin{array}{l}\text { Found with a North } \\
\text { Scottish spiral bead, } \\
\text { armlet, etc. Probably } \\
\text { Ist-2nd c. A.D. Found } \\
\text { I } 894\end{array}$ & \\
\hline $\begin{array}{l}\text { Udney } \\
\text { (Cloister Seat) }\end{array}$ & Aberdeenshire & N.M.A. FJ20 & $\begin{array}{l}\text { Dark brown whirled } \\
\text { with yellow. Frag- } \\
\text { ment only. Diam. } \\
2.3 \mathrm{~cm} . \text { Ht. } 8 \mathrm{~mm} \text {. } \\
\text { Small perf. }\end{array}$ & $\begin{array}{l}\text { Found with FJig and } \\
\text { other beads, } 2 \text { black } \\
\text { and one whitish.? } \\
\text { Associated }\end{array}$ & $\begin{array}{l}P S A S \text { xxiv }(1890) \text {, } \\
\text { II }\end{array}$ \\
\hline
\end{tabular}




\begin{tabular}{|c|c|c|c|c|c|}
\hline $\begin{array}{l}\text { SITE AND } \\
\text { PARISH }\end{array}$ & COUNTY & MUSEUM \& NO. & $\begin{array}{l}\text { DESCRIPTION AND } \\
\text { APPROX. DIMENSIONS }\end{array}$ & $\begin{array}{l}\text { ASSOCIATIONS AND } \\
\text { REMARKS }\end{array}$ & PUBLICATION \\
\hline Udney & Aberdeenshire & N.M.A. FJ 9 & $\begin{array}{l}\text { Grey opaque ground } \\
\text { with slaty green } \\
\text { whirls. Diam. } 2 \cdot 2 \\
\text { cm. Ht. } 9 \mathrm{~mm} \text {. Perf. } \\
\text { diam. } 5 \mathrm{~mm} \text {. }\end{array}$ & $\begin{array}{l}\text { Found with FJ20, } \\
\text { above, and other } \\
\text { beads. ? Associated }\end{array}$ & $\begin{array}{l}P S A S \times x i v\left(189^{\circ}\right), \\
\text { I I }\end{array}$ \\
\hline $\begin{array}{l}\text { Dun Mor } \\
\text { Vaul, Tiree }\end{array}$ & Argyllshire & $\begin{array}{l}\text { Hunterian Museum, } \\
\text { Glasgow, } \mathrm{SF}_{167}\end{array}$ & $\begin{array}{l}\text { Fragment only. } \\
\text { Opaque blue with } \\
\text { yellow inlay. Diam. } \\
\text { c. } 2.5 \mathrm{~cm} \text {. }\end{array}$ & $\begin{array}{l}\text { Could be part of a } \\
\text { bead or armlet. From } \\
\text { a broch }\end{array}$ & $\begin{array}{l}\text { MacKie, E. W. } \\
(1975)\end{array}$ \\
\hline $\begin{array}{l}\text { Dun Mor } \\
\text { Vaul, Tiree }\end{array}$ & Argyllshire & $\begin{array}{l}\text { Hunterian Museum, } \\
\text { Glasgow, } \mathrm{SF}_{410}\end{array}$ & $\begin{array}{l}\text { Brownish-purple with } \\
\text { opaque yellow inlay. } \\
\text { Diam. } 2.5 \mathrm{~cm} \text {. Ht. I } \\
\mathrm{cm} \text {. Perf. diam. } 8 \mathrm{~mm} \text {. } \\
\text { (fig. } 35 \text {, no. 5) }\end{array}$ & $\begin{array}{l}\text { Probably dates from } \\
\text { the construction of the } \\
\text { broch or very soon } \\
\text { after. Radio-carbon } \\
\text { dating suggests second } \\
\text { part of ist c. B.C. for } \\
\text { this phase }\end{array}$ & $\begin{array}{l}\text { MacKie, E. W. } \\
(1975)\end{array}$ \\
\hline Glerkley Hill & Morayshire & $\begin{array}{l}\text { Miss Young's Colln., } \\
\text { Edinburgh }\end{array}$ & $\begin{array}{l}\text { Opaque yellow with } \\
\text { purplish-blue inlay. } \\
\text { Diam. } 2 \cdot 2 \mathrm{~cm} . \mathrm{Ht} \text {. } \\
9 \mathrm{~mm} \text {. Irregular } \\
\text { perforation } \\
\text { (fig. } 35, \text { no. } 2 \text { ) }\end{array}$ & From a cairn & \\
\hline Gulbin Sands & Morayshire & N.M.A. & $\begin{array}{l}\text { Half only. Opaque } \\
\text { dark blue with streaks } \\
\text { of yellow and green. } \\
\text { Diam. I } 5 \mathrm{~cm} \text {. Small } \\
\text { perforation }\end{array}$ & & \\
\hline Culbin Sands & Morayshire & N.M.A. & $\begin{array}{l}\text { Fragment. Opaque } \\
\text { yellow with broad } \\
\text { dark green and white } \\
\text { ladder bordered in } \\
\text { brown. Diam. } 2 \cdot 4 \mathrm{~cm} \text {. } \\
\text { Ht. } 7 \mathrm{~mm} \text {. }\end{array}$ & & \\
\hline Gulbin Sands & Morayshire & N.M.A. B. I.424 & $\begin{array}{l}\text { Fragment. Trans- } \\
\text { lucent light blue-green } \\
\text { with whirls in yellow } \\
\text { and white. Diam. } c \text {. } \\
2.7 \mathrm{~cm} . \mathrm{Ht} .7 \mathrm{~mm} \text {. }\end{array}$ & & \\
\hline Culbin Sands & Morayshire & $\begin{array}{l}\text { Miss Young's Colln., } \\
\text { Edinburgh }\end{array}$ & $\begin{array}{l}\text { Green ground streaked } \\
\text { with yellow and white } \\
\text { whirls. Diam. I } 8 \\
\mathrm{~cm} . \text { Ht. } 6 \text { mm. Very } \\
\text { small perforation } \\
\text { (fig. } 35, \text { no. } 3 \text { ) }\end{array}$ & & \\
\hline Culbin Sands & Morayshire & & $\begin{array}{l}\text { Amber brown with } \\
\text { yellow and opaque } \\
\text { white ladder design } \\
\text { round part of cir- } \\
\text { cumference. Diam. } \\
\text { I. I cm. Ht. } 3 \mathrm{~mm} \text {. }\end{array}$ & $\begin{array}{l}\text { Found on a necklace } \\
\text { with small annular } \\
\text { opaque yellow beads } \\
\text { of Class } 8\end{array}$ & \\
\hline
\end{tabular}




\begin{tabular}{|c|c|c|c|c|c|}
\hline $\begin{array}{l}\text { SITE AND } \\
\text { PARISH }\end{array}$ & COUNTY & MUSEUM \& NO. & $\begin{array}{l}\text { DESGRIPTION AND } \\
\text { APPROX. DIMENSIONS }\end{array}$ & $\begin{array}{l}\text { ASSOCIATIONS AND } \\
\text { REMARKS }\end{array}$ & PUBLICATION \\
\hline $\begin{array}{l}\text { Cawdor } \\
\text { Castle }\end{array}$ & Nairnshire & N.M.A. FJ I 7 & $\begin{array}{l}\text { Opaque yellow } \\
\text { whirled with blue } \\
\text { and white ladders } \\
\text { outlined in brown. } \\
\text { Diam. } 2 \cdot 2 \text { cm. Ht. } \\
9 \mathrm{~mm} \text {. Perf. diam. } \\
4 \mathrm{~mm} \text {. }\end{array}$ & $\begin{array}{l}\text { Almost certainly one } \\
\text { of the } 6 \text { beads } \\
\text { exhibited in } 1864 \text {. } \\
\text { Found in digging a } \\
\text { ditch. Some were } \\
\text { North Scottish spiral } \\
\text { beads of Class } 13 \\
\text { (FJ I-4) }\end{array}$ & $\begin{array}{l}P S A S \text { v (1862-4), } \\
\text { 3 } 3\end{array}$ \\
\hline \multirow[t]{2}{*}{$\begin{array}{l}\text { Cawdor } \\
\text { Castle }\end{array}$} & Nairnshire & N.M.A. FJ 18 & $\begin{array}{l}\text { Large bead of opaque } \\
\text { yellow whirled with } \\
\text { blue and white ladders } \\
\text { edged in darker blue. } \\
\text { Diam. } 3 \mathrm{~cm} . \mathrm{Ht} \text {. I } \mathrm{cm} \text {. } \\
\text { Perf. diam. } 9 \mathrm{~mm} .\end{array}$ & As above & As above \\
\hline & and' & N.M.A. FJ83 & $\begin{array}{l}\text { Dark brown with } \\
\text { yellow streak and thin } \\
\text { light blue line. Diam. } \\
\text { I. } 6 \mathrm{~cm} . \mathrm{Ht} .4 \mathrm{~mm} \text {. } \\
\text { Perf. diam. } 5 \mathrm{~mm} \text {. }\end{array}$ & Purchased in Igoo & \\
\hline $\begin{array}{l}\text { Dun Ardtreck, } \\
\text { Bracadale, } \\
\text { Skye }\end{array}$ & Inverness-shire & $\begin{array}{l}\text { Hunterian Museum, } \\
\text { Glasgow }\end{array}$ & $\begin{array}{l}2 \text { small annular beads } \\
\text { with traces of yellow. } \\
\text { Diam. } 4 \mathrm{~mm} \text {. Ht. I } \\
\text { mm. }\end{array}$ & $\begin{array}{l}\text { Probably related to } \\
\text { this Class, though } \\
\text { smaller. These beads } \\
\text { were found with some } \\
\text { small annular opaque } \\
\text { yellow ones in a } \\
\text { galleried wall-fort, } \\
\text { thought to have been } \\
\text { built in the early ist c. } \\
\text { B.c. }\end{array}$ & $\begin{array}{l}\text { An xxxix (1965). } \\
\text { For radio-carbon } \\
\text { dating, see } A n \\
\text { xliii }(1969), 23\end{array}$ \\
\hline \multirow[t]{2}{*}{$\begin{array}{l}\text { Dun an } \\
\text { Iardhard, } \\
\text { Dunvegan, } \\
\text { Skye }\end{array}$} & Inverness-shire & N.M.A. GA1007 & $\begin{array}{l}\text { Half. Dark opaque } \\
\text { core with streaks of } \\
\text { yellow and blue. } \\
\text { Diam. } 2 \cdot 2 \mathrm{~cm} . \mathrm{Ht} \text {. } \\
9 \mathrm{~mm} \text {. Irregular } \\
\text { perforation }\end{array}$ & $\begin{array}{l}\text { This bead and a small } \\
\text { opaque yellow annu- } \\
\text { lar bead were found } \\
\text { separately from the } \\
\text { Dark Ages beads from } \\
\text { this broch }\end{array}$ & $\begin{array}{l}P S A S \times \operatorname{lix}(1914- \\
\text { I5), 7-70 }\end{array}$ \\
\hline & nshire' & N.M.A. FJ26 & $\begin{array}{l}\text { Globular. Opaque } \\
\text { yellow with circum- } \\
\text { ferential ladder } \\
\text { patterns in brown and } \\
\text { yellow outlined in } \\
\text { brown. Diam. } 2 \cdot 3 \\
\mathrm{~cm} \text {. Ht. } \mathrm{I} \cdot 8 \mathrm{~cm} . \\
\text { Perf. diam. } 0.6 \mathrm{~cm} \text {. }\end{array}$ & $\begin{array}{l}\text { Possibly not of this } \\
\text { Class, as it is globular } \\
\text { not annular. Given by } \\
\text { Sir H. E. Maxwell in } \\
\text { I } 889\end{array}$ & \\
\hline $\begin{array}{l}\text { Dowalton } \\
\text { Loch }\end{array}$ & Wigtownshire & N.M.A. HU 33 & $\begin{array}{l}\text { Blue and white coil } \\
\text { on surface and blob of } \\
\text { opaque yellow at } \\
\text { perforation. Evidently } \\
\text { related to this Class. } \\
\text { Diam. I } 2 \mathrm{~cm} \text {. Ht. } \\
5 \mathrm{~mm} \text {. Perf. diam. } \\
5 \mathrm{~mm} \text {. }\end{array}$ & $\begin{array}{l}\text { From site of Roman } \\
\text { period crannog }\end{array}$ & $\begin{array}{l}P S A S \text { vi }(1866) \text {, } \\
\text { I } 4 \mathrm{ff} .\end{array}$ \\
\hline
\end{tabular}




\section{ROMAN PERIOD BEADS}

\section{(SEE ALSO UNDEGORATED ANNULAR AND GLOBULAR BEADS, GROUPS 6 and 7 ) SMALL SEGMENTED BEADS}

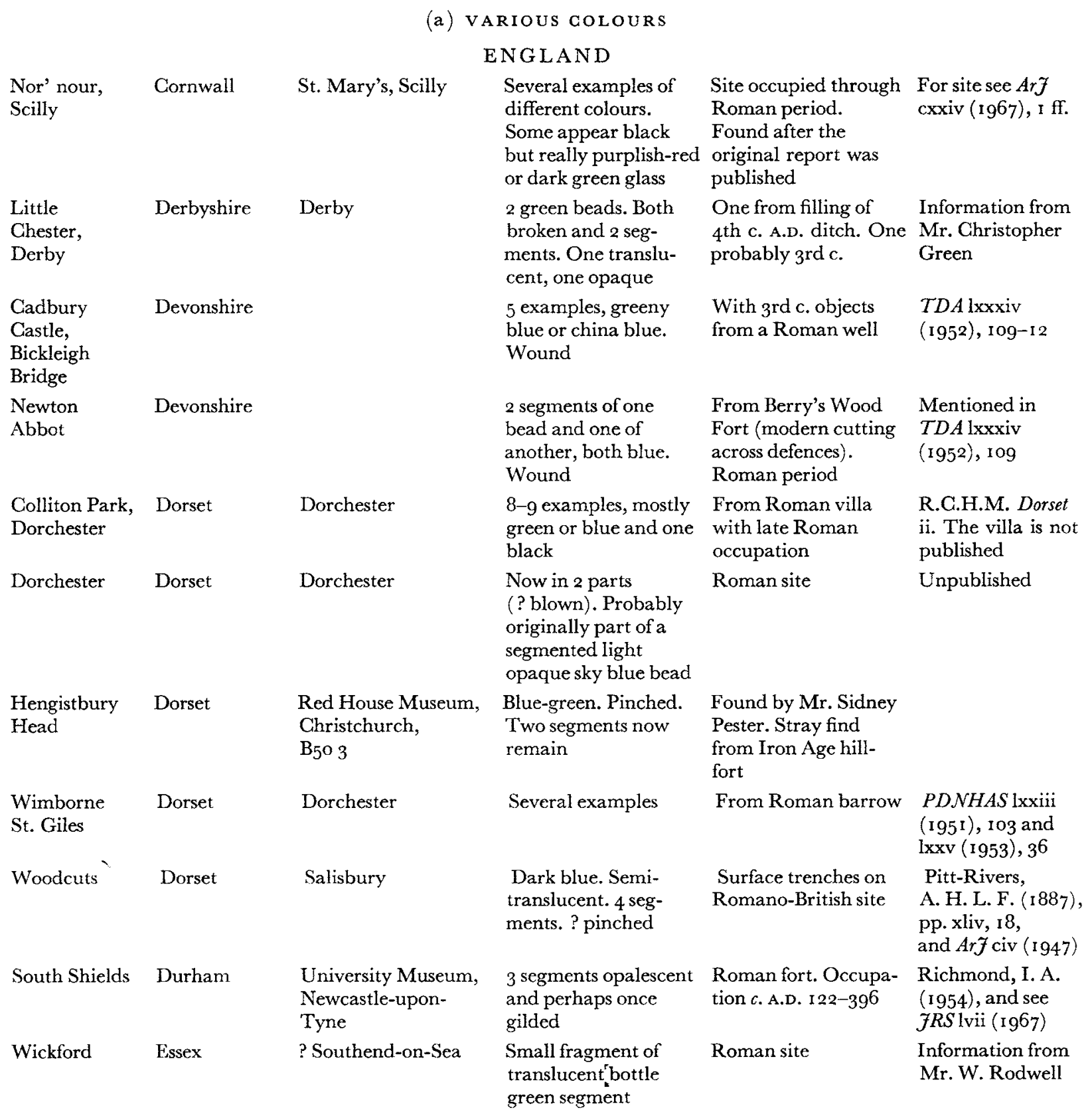




\begin{tabular}{|c|c|c|c|c|c|}
\hline $\begin{array}{l}\text { SrTE AND } \\
\text { PARISH }\end{array}$ & COUNTY & MUSEUM \& No. & $\begin{array}{l}\text { DESCRIPTION AND } \\
\text { APPROX. DIMENSIONS }\end{array}$ & $\begin{array}{l}\text { ASSOCIATION AND } \\
\text { REMARKS }\end{array}$ & PUBLICATION \\
\hline $\begin{array}{l}\text { Cirencester, } \\
\text { Barnsley Park }\end{array}$ & $\begin{array}{l}\text { Gloucester- } \\
\text { shire }\end{array}$ & Cirencester & $\begin{array}{l}\text { Four wound green } \\
\text { examples and several } \\
\text { others in blue, } \\
\text { turquoise blue, etc. }\end{array}$ & $\begin{array}{l}\text { From Roman villa } \\
\text { mainly early } 2 \text { nd to } \\
4^{\text {th }} \text { c. A.D. }\end{array}$ & $\begin{array}{l}\text { Information from } \\
\text { Dr. G. Webster }\end{array}$ \\
\hline Frocester & $\begin{array}{l}\text { Gloucester- } \\
\text { shire }\end{array}$ & & $\begin{array}{l}\text { Fragments of blue } \\
\text { and green segments } \\
\text { of about } 8 \text { beads }\end{array}$ & $\begin{array}{l}\text { Stratified late } 3 \text { rd } \\
\text { and late } 4^{\text {th }} \text { C. A.D. in } \\
\text { Roman villa at } \\
\text { Frocester Court }\end{array}$ & $\begin{array}{l}T B G A S \text { lxxxix } \\
(1970)\end{array}$ \\
\hline Portchester & Hampshire & & $\begin{array}{l}\text { Remains of } 5 \text { or } 6 \\
\text { beads green or } \\
\text { greenish-blue }\end{array}$ & $\begin{array}{l}\text { From late Roman } \\
\text { strata }\end{array}$ & $\begin{array}{l}\text { Information from } \\
\text { Prof. Barry } \\
\text { Cunliffe. } \\
\text { See } A n \mathcal{J} \text { xlix } \\
(1969), 62\end{array}$ \\
\hline $\begin{array}{l}\text { Lankhills } \\
\text { Cemetery, } \\
\text { Winchester }\end{array}$ & Hampshire & & $\begin{array}{l}\text { Over soo rectangular } \\
\text { sections of originally } \\
\text { segmented beads, in } \\
\text { green or blue glass }\end{array}$ & $\begin{array}{l}\text { Necklace } 364 \text {, from } \\
\text { Grave } 33^{6, \text { dated } c .} \\
\text { A.D. } 350-70 . \text { The } \\
\text { grave is intrusive, and } \\
\text { the beads are unusual }\end{array}$ & $\begin{array}{l}\text { Clarke, G. } \\
\text { (forthcoming), } \\
\text { fig. } 90\end{array}$ \\
\hline $\begin{array}{l}\text { Weston- } \\
\text { under- } \\
\text { Penyard, } \\
\text { Bollitree }\end{array}$ & Herefordshire & Gloucester I $77^{2}$ & $\begin{array}{l}\text { Several green and } \\
\text { blue examples }\end{array}$ & $\begin{array}{l}\text { From necklace of } \\
\text { Roman period }\end{array}$ & $\begin{array}{l}\mathcal{J} B A A \mathrm{xxvii} \\
(\mathrm{I} 87 \mathrm{1}), 2 \text { I I ff. }\end{array}$ \\
\hline St. Albans & Hertfordshire & Verulamium 30.15 & $\begin{array}{l}\text { Greeny blue. } 3 \text { seg- } \\
\text { ments and others }\end{array}$ & Roman period & \\
\hline St. Albans & Hertfordshire & Verulamium & $\begin{array}{l}2 \text { small silvery } \\
\text { segments }\end{array}$ & $\begin{array}{l}\text { From late Roman } \\
\text { necklace, probably } \\
\text { 4th c. A.D. }\end{array}$ & $V e$, p. 214, fig. 47 \\
\hline $\begin{array}{l}\text { Godman- } \\
\text { chester }\end{array}$ & $\begin{array}{l}\text { Huntingdon- } \\
\text { shire }\end{array}$ & & 2 segments & $\begin{array}{l}\text { Second half of } 2 \text { nd } c \text {. } \\
\text { A.D. }\end{array}$ & $P C A S$ liv (196o) \\
\hline Lympne & Kent & & $\begin{array}{l}\text { Light blue. } 4 \text { seg- } \\
\text { ments }\end{array}$ & Roman & $\begin{array}{l}\text { Smith, G. Roach, } \\
\text { Excavations on the } \\
\text { Site of the } \\
\text { Roman Castrum at } \\
\text { Lymne (London } \\
1852 \text { ), pl. viii, } \\
\text { no. 10 }\end{array}$ \\
\hline $\begin{array}{l}\text { Dowgate Hill, } \\
\text { London }\end{array}$ & London & $\begin{array}{l}\text { Formerly Guildhall } \\
\text { Museum } 3964\end{array}$ & $\begin{array}{l}2 \text { segments of clear } \\
\text { glass }\end{array}$ & & \\
\hline Carrawburgh & $\begin{array}{l}\text { Northumber- } \\
\text { land }\end{array}$ & Chesters & $\begin{array}{l}\text { Bottle green, irregu- } \\
\text { lar boring. } 4 \text { seg- } \\
\text { ments }\end{array}$ & $\begin{array}{l}\text { I } 9 \text { th c. find. Site dated } \\
\text { A.D. I } 22-3^{8} 3\end{array}$ & \\
\hline $\begin{array}{l}\text { Chesters } \\
\text { Fort }\end{array}$ & $\begin{array}{l}\text { Northumber- } \\
\text { land }\end{array}$ & $\begin{array}{l}\text { Chesters Museum } \\
{ }_{1362}\end{array}$ & $\begin{array}{l}\text { One segment broken } \\
\text { off and several others. } \\
\text { Green wound }\end{array}$ & $\begin{array}{l}\text { I } 9 \text { th c. find. Site } \\
\text { dated A.D. } 122-383\end{array}$ & \\
\hline $\begin{array}{l}\text { Great } \\
\text { Chesters }\end{array}$ & $\begin{array}{l}\text { Northumber- } \\
\text { land }\end{array}$ & $\begin{array}{l}\text { University Museum, } \\
\text { Newcastle-upon- } \\
\text { Tyne }\end{array}$ & $\begin{array}{l}2 \text { segments of bottle } \\
\text { green glass }\end{array}$ & Roman & \\
\hline Housesteads & $\begin{array}{l}\text { Northumber- } \\
\text { land }\end{array}$ & $\begin{array}{l}\text { University Museum, } \\
\text { Newcastle-upon-Tyne }\end{array}$ & $\begin{array}{l}\text { One greeny blue } \\
\text { translucent }\end{array}$ & Roman Wall fort & \\
\hline
\end{tabular}


THE SGHEDULES : ROMAN PERIOD

\begin{tabular}{|c|c|c|c|c|c|}
\hline $\begin{array}{l}\text { SITE AND } \\
\text { PARISH }\end{array}$ & COUNTY & MUSEUM \& NO. & $\begin{array}{l}\text { DESCRIPTION AND } \\
\text { APPROX. DIMENSIONS }\end{array}$ & $\begin{array}{l}\text { ASSOCIATIONS AND } \\
\text { REMARKS }\end{array}$ & PUBLICATION \\
\hline $\begin{array}{l}\text { Old } \\
\text { Yeavering }\end{array}$ & $\begin{array}{l}\text { Northumber- } \\
\text { land }\end{array}$ & & $\begin{array}{l}2 \text { examples blue- } \\
\text { green glass probably } \\
\text { pinched. Translucent }\end{array}$ & Post-Roman & $\begin{array}{l}\text { Information from } \\
\text { Dr. Brian Hope } \\
\text { Taylor }\end{array}$ \\
\hline $\begin{array}{l}\text { East } \\
\text { Markham }\end{array}$ & $\begin{array}{l}\text { Nottingham- } \\
\text { shire }\end{array}$ & Private hands & $\begin{array}{l}3 \text { segments. Trans- } \\
\text { lucent bottle green. } \\
\text { Pinched }\end{array}$ & $\begin{array}{l}\text { Found in } 1950 \text { with } \\
\text { Romano-British } \\
\text { pottery }\end{array}$ & $\begin{array}{l}\text { Information from } \\
\text { finder }\end{array}$ \\
\hline Brislington & Somerset & Bristol F2320-2325 & $\begin{array}{l}\text { Several examples, } \\
\text { green, black and } \\
\text { terracotta-coloured. } \\
\text { One has iron wire } \\
\text { through it. Wound }\end{array}$ & Roman villa & $\begin{array}{l}\text { TBGAS xxiii } \\
(\mathrm{I} 900) \text { and } \mathrm{xxiv} \\
(\mathrm{I} 90 \mathrm{I})\end{array}$ \\
\hline Camerton & Somerset & $\begin{array}{l}\text { Bristol F2317 } \\
\text { (Skinner Colln.) }\end{array}$ & $\begin{array}{l}\text { Opaque bright tur- } \\
\text { quoise-coloured. } 5 \\
\text { segments. Tapered }\end{array}$ & & $\begin{array}{l}\text { For site see VCH } \\
\text { Somerset and } \\
\text { Wedlake, W.J. } \\
\left(195^{8)}\right.\end{array}$ \\
\hline $\begin{array}{l}\text { Ham Hill, } \\
\text { Montacute }\end{array}$ & Somerset & Taunton & $\begin{array}{l}\text { A number of } \\
\text { examples, bottle } \\
\text { green, light blue and } \\
\text { black. Wound }\end{array}$ & $\begin{array}{l}\text { Iron Age. Site occu- } \\
\text { pied through Roman } \\
\text { period }\end{array}$ & $\begin{array}{l}\text { For site see } V C H \\
\text { Somerset i, p. } 295\end{array}$ \\
\hline $\begin{array}{l}\text { Lamyatt } \\
\text { Beacon, } \\
\text { Lamyatt }\end{array}$ & Somerset & Mr. Jones's Colln. & $\begin{array}{l}\text { Many small examples, } \\
\text { pinched or wound. } \\
\text { Mostly green but a } \\
\text { few black. One fine } \\
\text { rod ready for use }\end{array}$ & $\begin{array}{l}\text { About } 30-40 \text { different } \\
\text { coloured segments. } \\
\text { From Romano- } \\
\text { Celtic temple at } \\
\text { Lamyatt Beacon, } \\
\text { probably built about } \\
\text { A.D. } 300 \text {. (Beads may } \\
\text { have been made } \\
\text { here) }\end{array}$ & $\begin{array}{l}\text { Information from } \\
\text { Mrs. C. Bennett } \\
\text { and Mr. Roger } \\
\text { Leech }\end{array}$ \\
\hline $\begin{array}{l}\text { South } \\
\text { Cadbury }\end{array}$ & Somerset & & $\begin{array}{l}4 \text { segments, translu- } \\
\text { cent green, probably } \\
\text { wound }\end{array}$ & $\begin{array}{l}\text { Unstratified in Iron } \\
\text { Age to post-Roman } \\
\text { hill-fort }\end{array}$ & $\begin{array}{l}\text { Information from } \\
\text { Dr. Leslie Alcock }\end{array}$ \\
\hline Whitchurch & Somerset & & $\begin{array}{l}\text { One very small blue } \\
\text { bead of } 2 \text { segments }\end{array}$ & $\begin{array}{l}\text { From Lyons Court } \\
\text { Farm. Possibly 2nd- } \\
\text { 3rd c. }\end{array}$ & $\begin{array}{l}A r \hat{f} \text { cxxii }(1965) \\
25\end{array}$ \\
\hline $\begin{array}{l}\text { Worlebury, } \\
\text { Weston- } \\
\text { super-Mare }\end{array}$ & Somerset & Weston-super-Mare & $\begin{array}{l}\text { Several, mostly red- } \\
\text { brown and green } \\
\text { beads, and badly } \\
\text { made }\end{array}$ & $\begin{array}{l}\text { Iron Age fort occu- } \\
\text { pied into the Roman } \\
\text { period. These beads } \\
\text { found in surface soil }\end{array}$ & $\begin{array}{l}\text { Dymond, C. W., } \\
\text { Worlebury (Bristol, } \\
\text { I902), pl. x, I } 6\end{array}$ \\
\hline Atworth & Wiltshire & Devizes & $\begin{array}{l}\text { Several small } \\
\text { examples }\end{array}$ & $\begin{array}{l}\text { Roman villa site. } \\
\text { From late Roman } \\
\text { spread. Not closely } \\
\text { stratified in I } 974 \\
\text { excavations }\end{array}$ & $\begin{array}{l}\text { Information from } \\
\text { excavator }\end{array}$ \\
\hline
\end{tabular}




\begin{tabular}{|c|c|c|c|c|c|}
\hline $\begin{array}{l}\text { SITE AND } \\
\text { PARISH }\end{array}$ & COUNTY & MUSEUM \& No. & $\begin{array}{l}\text { DESCRIPTION AND } \\
\text { APPROX. DIMENSIONS }\end{array}$ & $\begin{array}{l}\text { ASSOCIATIONS AND } \\
\text { REMARKS }\end{array}$ & PUBLICATION \\
\hline $\begin{array}{l}\text { Brixton } \\
\text { Deverill (Cold } \\
\text { Kitchen Hill) }\end{array}$ & Wiltshire & $\begin{array}{l}\text { Salisbury and } \\
\text { Devizes }\end{array}$ & $\begin{array}{l}\text { Over } 400 \text { different } \\
\text { colours }\end{array}$ & $\begin{array}{l}\text { Mostly Romano- } \\
\text { British finds from } \\
\text { this site. Perhaps a } \\
\text { Romano-Celtic } \\
\text { temple here with } \\
\text { beads made locally. } \\
\text { Probably deserted by } \\
\text { mid-4th c. A.D. }\end{array}$ & $\begin{array}{l}W A M \times \text { xliii }(1925- \\
7), 83 \text { ff. }\end{array}$ \\
\hline $\begin{array}{l}\text { Wick Wood, } \\
\text { Nettleton }\end{array}$ & Wiltshire & $\begin{array}{l}\text { c/o Bath and } \\
\text { Camerton Arch. } \\
\text { Soc. }\end{array}$ & $\begin{array}{l}\text { Bottle green, trans- } \\
\text { lucent. } 4 \text { segments }\end{array}$ & $\begin{array}{l}\text { Stratified 'before } \\
\text { A.D. } 284 \text { ' }\end{array}$ & $\begin{array}{l}\text { Wedlake, W.J. } \\
\text { (1958) }\end{array}$ \\
\hline $\begin{array}{l}\text { Stockton } \\
\text { Earthworks }\end{array}$ & Wiltshire & Salisbury & $\begin{array}{l}\text { Several, opaque blue } \\
\text { or green }\end{array}$ & $\begin{array}{l}\text { Native and early } \\
\text { Roman }\end{array}$ & $\begin{array}{l}W A M \text { xliii } \\
\left(1925^{-7}\right)\end{array}$ \\
\hline Catterick & Yorkshire & c/o D.O.E. & $\begin{array}{l}\text { One segment bottle } \\
\text { green (? blown) and } \\
5 \text { segments of } \\
\text { another, wound }\end{array}$ & & $\begin{array}{l}\text { Information from } \\
\text { Mr.J. Wacher }\end{array}$ \\
\hline \multicolumn{6}{|c|}{ SGOTLAND } \\
\hline $\begin{array}{l}\text { Lochlee } \\
\text { Crannog }\end{array}$ & Ayrshire & & 2 segments & $\begin{array}{l}\text { Sub-Roman and } \\
\text { post-Roman site }\end{array}$ & $\begin{array}{l}P S A S \text { xiii ( } 1879) \\
239\end{array}$ \\
\hline Skewalton & Ayrshire & & $\begin{array}{l}\text { Blue and green } \\
\text { examples, wound }\end{array}$ & & $\begin{array}{l}\text { Smith, J., Prehistoric } \\
\text { Man in Ayrshire } \\
\text { (1895), p. I1 } 6, \\
\text { figs. } 2 \text { I } 4 \text { and } 215\end{array}$ \\
\hline $\begin{array}{l}\text { Traprain Law, } \\
\text { Prestonkirk }\end{array}$ & E. Lothian & N.M.A. & $\begin{array}{l}\text { Several examples. } \\
\text { Semi-translucent } \\
\text { blue. Wound. One } \\
\text { possibly pinched }\end{array}$ & $\begin{array}{l}\text { Probably from Roman } \\
\text { period occupation }\end{array}$ & $\begin{array}{l}\text { See A. H. A. } \\
\text { Hogg in Grimes, } \\
\text { W. F. (ed.) (1951) }\end{array}$ \\
\hline Dalmeny & W. Lothian & N.M.A. & $\begin{array}{l}\text { Green and blue } \\
\text { examples. Several } \\
\text { examples }\end{array}$ & $\begin{array}{l}\text { From E.-W. } \\
\text { orientated graves } \\
\text { perhaps } 6 \text { th c. A.D. }\end{array}$ & $\begin{array}{l}P S A S \times \operatorname{lix}\left(1914^{-}\right. \\
15), 271\end{array}$ \\
\hline Culbin Sands & Morayshire & $\begin{array}{l}\text { Miss Young's Colln., } \\
\text { Edinburgh }\end{array}$ & $\begin{array}{l}\text { One opaque yellow } \\
\text { and one blue, } 3 \\
\text { segments, larger } \\
\text { than usual }\end{array}$ & $\begin{array}{l}\text { Chance finds undated } \\
\text { and almost certainly } \\
\text { post-Roman }\end{array}$ & \\
\hline Culbin Sands & Morayshire & N.M.A. & $\begin{array}{l}\text { Semi-translucent } \\
\text { blue. } 2 \text { segments. } \\
\text { ? blown }\end{array}$ & Ghance find & \\
\hline $\begin{array}{l}\text { Struan, } \\
\text { Skye }\end{array}$ & Inverness-shire & N.M.A. GArog4 & & $\begin{array}{l}\text { From Dun Beag } \\
\text { broch occupied in } \\
\text { Roman and post- } \\
\text { Roman periods }\end{array}$ & PSAS lv $(1920-1)$ \\
\hline
\end{tabular}

WALES

Bottle green, 3 segments. Pinched
Excavated in 1970 in fort occupied from A.D. $55-60$ and again in $3^{\text {rd }-4}$ th $c$.
Information from excavator 


\begin{tabular}{|c|c|c|c|c|c|}
\hline $\begin{array}{l}\text { SITE AND } \\
\text { PARISH }\end{array}$ & COUNTY & MUSEUM \& No. & $\begin{array}{l}\text { DESCRIPTION AND } \\
\text { APPROX. DIMENSIONS }\end{array}$ & $\begin{array}{l}\text { ASSOCIATIONS AND } \\
\text { REMARKS }\end{array}$ & PUBLICATION \\
\hline \multicolumn{6}{|c|}{ (b) SEGMENTED BEADS ENGLOSING METAL FOIL } \\
\hline \multicolumn{6}{|c|}{ ENGLAND } \\
\hline Fordington & Dorset & Dorchester 1846.2 .15 & $\begin{array}{l}3 \text { segments on } \\
\text { necklace }\end{array}$ & $\begin{array}{l}\text { From mainly } 3^{\text {rd- }} \\
4^{\text {th c. A.D. Roman }} \\
\text { cemetery }\end{array}$ & $\begin{array}{l}\text { See Roach Smith, } \\
\text { C. }(1852), \mathrm{iii}, \\
\text { pl. ix and p. } 33 \\
\text { and see R.C.H.M. } \\
\text { Dorset ii }\end{array}$ \\
\hline ? Colchester & Essex & Colchester & $\begin{array}{l}\text { Ten examples from } \\
\text { unknown site }\end{array}$ & Probably Roman & $\begin{array}{l}\text { Baldwin Brown, } \\
\text { G., Arts in Early } \\
\text { England (1915), } \\
\text { p. } 433, \text { pl. } 106 \\
\text { and p. } 409, \mathrm{pl} .5\end{array}$ \\
\hline $\begin{array}{l}\text { Burn Ground, } \\
\text { Hampnett }\end{array}$ & $\begin{array}{l}\text { Gloucester- } \\
\text { shire }\end{array}$ & & & & $\begin{array}{l}\text { Grimes, W. F. } \\
(1939-45), \text { I } 21\end{array}$ \\
\hline Cirencester & $\begin{array}{l}\text { Gloucester- } \\
\text { shire }\end{array}$ & $\begin{array}{l}\text { Corinium Museum, } \\
\text { Cirencester }\end{array}$ & $\begin{array}{l}2 \text { segments of } \\
\text { originally larger bead }\end{array}$ & $\begin{array}{l}\text { From late Roman } \\
\text { graves outside the } \\
\text { town. ? } 4^{\text {th }} \text { C. A.D. }\end{array}$ & $\begin{array}{l}\text { Publication } \\
\text { forthcoming }\end{array}$ \\
\hline Lydney & $\begin{array}{l}\text { Hereford- } \\
\text { shire }\end{array}$ & $\begin{array}{l}\text { Private museum at } \\
\text { Lydney Park }\end{array}$ & $\begin{array}{l}2 \text { examples, one } 5^{-} \\
\text {segmented }\end{array}$ & $\begin{array}{l}\text { Presumably from the } \\
\text { Roman temple to } \\
\text { Nodens. Late } 4^{\text {th }} \text { c. } \\
\text { A.D.? }\end{array}$ & $\begin{array}{l}\text { Wheeler, R. E. M., } \\
\text { Excavations in } \\
\text { Lydney Park, } \\
\text { Gloucestershire } \\
\left(193^{2}\right)\end{array}$ \\
\hline Rockbourne & Hampshire & $\begin{array}{l}\text { Rockbourne Villa } \\
\text { Museum }\end{array}$ & $\begin{array}{l}\text { Striated and broken } \\
\text { off at each end. } \\
\text { Possibly once } \\
\text { gilded }\end{array}$ & $\begin{array}{l}\text { From villa occupied } \\
\text { through Roman } \\
\text { period }\end{array}$ & $\begin{array}{l}\text { Information from } \\
\text { the late Mr. A. T. } \\
\text { Morley Hewitt; see } \\
\text { Roman Villa Report, } \\
\text { 197I (privately } \\
\text { printed) }\end{array}$ \\
\hline $\begin{array}{l}\text { Winchester, } \\
\text { Lankhills } \\
\text { Cernetery }\end{array}$ & Hampshire & & $\begin{array}{l}\text { Various examples } \\
\text { both in clear and } \\
\text { amber coloured glass. } \\
\text { Gold or silver foil } \\
\text { enclosed }\end{array}$ & $\begin{array}{l}\text { Necklaces } 85,215 \text {, } \\
3^{6} 3,43^{6} \text {, and } 443 \text {, all } \\
\text { in graves variously } \\
\text { dated within the } \\
\text { period A.D. } 3^{10-} 70\end{array}$ & $\begin{array}{l}\text { Clarke, G. } \\
\text { (forthcoming) } \\
\text { and George Boon } \\
\text { in } 7 G S \times \text { xii ( } 1975 \text { ) }\end{array}$ \\
\hline $\begin{array}{l}\text { Winchester, } \\
\text { Wolvesey Palace }\end{array}$ & $e^{\text {Humpshire }}$ & & Incomplete example & Unitratified & $\begin{array}{l}\text { Information from } \\
\text { Mr. M. Biddle }\end{array}$ \\
\hline $\begin{array}{l}\text { Weston- } \\
\text { under- } \\
\text { Penyard, } \\
\text { Bollitree }\end{array}$ & $\begin{array}{l}\text { Hereford- } \\
\text { shire }\end{array}$ & Gloucester $1772 \mathrm{~A}$ & One small segment & $\begin{array}{l}\text { With Roman beads } \\
\text { on necklace }\end{array}$ & $\begin{array}{l}7 B A A \text { xxvii (1871), } \\
2 \text { I I ff. }\end{array}$ \\
\hline Baldock & Hertfordshire & & Necklace of 4 I beads & $\begin{array}{l}\text { From Burial Group } \\
89 \text { dated from } \\
\text { associated pottery to } \\
\text { A.D. } 160-190\end{array}$ & $\begin{array}{l}\text { Arflxxxyiii } \\
\left(193^{2}\right), 278\end{array}$ \\
\hline St. Albans & Hertfordshire & Verulamium & $\begin{array}{l}\text { One gilded and one } \\
\text { double white-metal } \\
\text { foil segment }\end{array}$ & $\begin{array}{l}\text { Thought to be } 4^{\text {th }} \mathrm{c} \text {. } \\
\text { A.D. from a necklace } \\
\text { of } 55 \text { mixed beads }\end{array}$ & $\begin{array}{l}V e, \text { p. } 214 \text { and } \\
\text { fig. } 47\end{array}$ \\
\hline
\end{tabular}




\begin{tabular}{|c|c|c|c|c|c|}
\hline $\begin{array}{l}\text { SITE AND } \\
\text { PARISH }\end{array}$ & COUNTY & MUSEUM \& No. & $\begin{array}{l}\text { DESGRIPTION AND } \\
\text { APPROX. DIMENSIONS }\end{array}$ & $\begin{array}{l}\text { ASSOCIATIONS AND } \\
\text { REMARKS }\end{array}$ & PUBLICATION \\
\hline $\begin{array}{l}\text { Bardon Mill } \\
\text { (Vindolanda) }\end{array}$ & $\begin{array}{l}\text { Northumber- } \\
\text { land }\end{array}$ & & $\begin{array}{l}3 \text { globular, perhaps } \\
\text { originally all one } \\
\text { bead }\end{array}$ & $\begin{array}{l}\text { Stratified late } 3 \text { rd- } \\
4^{\text {th c. A.D. }}\end{array}$ & $\begin{array}{l}\text { Information from } \\
\text { Mr. R. E. Birley }\end{array}$ \\
\hline Carrawburgh & $\begin{array}{l}\text { Northumber- } \\
\text { land }\end{array}$ & $\begin{array}{l}\text { Chesters } 614 \text { and } \\
\text { Box } 65\end{array}$ & $\begin{array}{l}\text { About } 20 \text { beads all } \\
\text { probably originally } \\
\text { gilt and perhaps on a } \\
\text { necklace }\end{array}$ & $\begin{array}{l}\text { From 'Coventina's } \\
\text { Well'. 19th c. find, } \\
\text { approximate date } \\
\text { A.D. } 120-3^{8} 3\end{array}$ & $\begin{array}{l}\text { Budge, pp. E. } \\
\text { Wallis, (1907), } 65 \text {, } \\
169,393\end{array}$ \\
\hline Chesters & $\begin{array}{l}\text { Northumber- } \\
\text { land }\end{array}$ & Chesters 614 & $\begin{array}{l}\text { Several beads like } \\
\text { those from Coven- } \\
\text { tina's Well (see } \\
\text { above) }\end{array}$ & $\begin{array}{l}\text { Site occupied about } \\
\text { A.D. I } 22-383\end{array}$ & \\
\hline Wroxeter & Shropshire & $\begin{array}{l}\text { Rowley's House } \\
\text { Museum, Shrews- } \\
\text { bury, Di I } 7\end{array}$ & Io gilded beads & $\begin{array}{l}\text { From the Forum with } \\
\text { late Roman beads. } \\
\text { Perhaps } 4^{\text {th }} \text { C. A.D. }\end{array}$ & Unpublished \\
\hline $\begin{array}{l}\text { Hales Roman } \\
\text { Villa }\end{array}$ & Staffordshire & & One example & $\begin{array}{l}\text { From Roman } \\
\text { context }\end{array}$ & $\begin{array}{l}\text { Information from } \\
\text { Mr. F. H. } \\
\text { Goodyear }\end{array}$ \\
\hline $\begin{array}{l}\text { Farley Heath, } \\
\text { Albury }\end{array}$ & Surrey & Guildford & $\begin{array}{l}\text { One clear bead with } \\
\text { gold foil enclosed }\end{array}$ & $\begin{array}{l}\text { Found in excavations } \\
\text { of } 184^{8-9} \text {. Romano- } \\
\text { Celtic temple }\end{array}$ & $\begin{array}{l}A \mathrm{xxxiv}\left(\mathrm{I} 85^{2}\right) \text { and } \\
A n f \times \operatorname{xviii}\left(193^{8}\right), \\
39^{\mathrm{I}}\end{array}$ \\
\hline Milnthorpe & Westmorland & & 2 segments & $\begin{array}{l}\text { On necklace not } \\
\text { closely datable. From } \\
\text { Dog Hole, Haver- } \\
\text { back. ? Ritual shaft } \\
\text { burial }\end{array}$ & $\begin{array}{l}\text { Information from } \\
\text { Mr. K. P. Bland, } \\
\text { Milnthorpe }\end{array}$ \\
\hline \multicolumn{6}{|c|}{ SCOTLAND } \\
\hline Newstead & $\begin{array}{l}\text { Roxburgh- } \\
\text { shire }\end{array}$ & N.M.A. & $\begin{array}{l}3 \text { or } 4 \text { broken seg- } \\
\text { ments }\end{array}$ & $\begin{array}{l}\text { Site occupied about } \\
\text { A.D. } 80-200 \text {. Prob- } \\
\text { ably second half of } \\
\text { and c. }\end{array}$ & $\mathcal{N} e$ \\
\hline \multicolumn{6}{|c|}{ WALES } \\
\hline $\begin{array}{l}\text { Coygan Camp, } \\
\text { Laugharne }\end{array}$ & $\begin{array}{l}\text { Carmarthen- } \\
\text { shire }\end{array}$ & & $\begin{array}{l}\text { One light grey } \\
\text { almost opaque glass } \\
\text { seems to be a segment }\end{array}$ & Late 3 rd C. A.D. & $\begin{array}{l}\text { Wainwright, G.J. } \\
\text { (I967) }\end{array}$ \\
\hline $\begin{array}{l}\text { Castell } \\
\text { Coch Fort }\end{array}$ & $\begin{array}{l}\text { Glamorgan- } \\
\text { shire }\end{array}$ & N.M.W. & I I beads & Roman date & $\begin{array}{l}\text { Found in } 1955-7 . \\
\text { Information from } \\
\text { G. C. Boon }\end{array}$ \\
\hline $\begin{array}{l}\text { Dinas Powys } \\
\text { (Cardiff) }\end{array}$ & $\begin{array}{l}\text { Glamorgan- } \\
\text { shire }\end{array}$ & N.M.W. & $\begin{array}{l}\text { Wire wound with } \\
\text { 'knocked' ends }\end{array}$ & $\begin{array}{l}\text { Roman or, according } \\
\text { to Harden, Coptic. } \\
\text { Unstratified in hill- } \\
\text { fort with Roman and } \\
\text { Dark Age occupation }\end{array}$ & $\begin{array}{l}\text { Alcock, L. (1964), } \\
\text { p. I } 86, \text { fig. } 41 \text {, } \\
\text { no. } 5\end{array}$ \\
\hline Caerleon & $\begin{array}{l}\text { Monmouth- } \\
\text { shire }\end{array}$ & N.M.W. & $\begin{array}{l}\text { Part of a segmented } \\
\text { bead }\end{array}$ & $\begin{array}{l}\text { From clearing of a } \\
\text { Roman drain }\end{array}$ & Boon, G. C. (1966) \\
\hline Caerleon & $\begin{array}{l}\text { Monmouth- } \\
\text { shire }\end{array}$ & N.M.W. & Another, smaller & $\begin{array}{l}\text { Stratified A.D. I } 30- \\
23^{\circ}\end{array}$ & Boon, G. C. (1966) \\
\hline
\end{tabular}




\begin{tabular}{ccccc}
\hline $\begin{array}{c}\text { SITE AND } \\
\text { PARISII }\end{array}$ & COUNTY & MUSEUM \& No. & DESCRIPTION AND & ASSOCIATIONS AND \\
APPROX. DIMENSIONS & REMARKS & PUBLICATION \\
\hline
\end{tabular}

\section{GYLINDER-SHAPED AND GUT SEGMENTS BEADS}

(a) BLUE GYLINDERS

\section{ENGLAND}

\begin{tabular}{|c|c|c|c|c|c|}
\hline $\begin{array}{l}\text { Nor' nour, } \\
\text { Scilly }\end{array}$ & Cornwall & St. Mary's, Scilly & $\begin{array}{l}\text { Translucent cobalt. } \\
\text { Diam. } 4 \mathrm{~mm} \text {. Length } \\
2 \cdot \text { I cm. }\end{array}$ & $\begin{array}{l}\text { Occupation through- } \\
\text { out Roman period }\end{array}$ & Arf cxxiv ( 1967$)$ \\
\hline $\begin{array}{l}\text { Cadbury } \\
\text { Castle, } \\
\text { Bickleigh } \\
\text { Bridge }\end{array}$ & Devonshire & $\begin{array}{l}\text { Temporarily at } \\
\text { Farsdon House, } \\
\text { Cadbury }\end{array}$ & $\begin{array}{l}2 \text { examples, both } \\
\text { dark blue. Lengths } \\
1.5 \text { and } 1.9 \mathrm{~cm} \text {. }\end{array}$ & $\begin{array}{l}\text { From a well thought } \\
\text { to belong to } 3 \text { rd } \mathrm{c} \text {. } \\
\text { A.D. }\end{array}$ & $\begin{array}{l}\text { PDAS lxxxiv } \\
(1952), 109\end{array}$ \\
\hline Fordington & Dorset & Dorchester I 846.2 .15 & $\begin{array}{l}\text { Opaque. Diam. } 4 \\
\text { mm. Length } c .1 \mathrm{~cm} .\end{array}$ & $\begin{array}{l}\text { Roman cometery. } \\
\text { Perhaps } 3 \text { rd or } 4 \text { th } c \text {. } \\
\text { A.D. }\end{array}$ & $\begin{array}{l}P S A L \text { ii }(\mathrm{I} 853) \\
\text { I } 40^{-1} \text { and } \\
\text { R.C.H.M. Dorset } \\
\text { ii }\end{array}$ \\
\hline Woodyates & Dorset & Salisbury & $\begin{array}{l}\text { Light blue, semi- } \\
\text { translucent with } \\
\text { longitudinal stria- } \\
\text { tions. Diam. } 3 \mathrm{~mm} \text {. } \\
\text { Length } 2 \mathrm{~cm} \text {. }\end{array}$ & $\begin{array}{l}\text { Romano-British } \\
\text { settlement }\end{array}$ & $\begin{array}{l}\text { Pitt-Rivers, } \\
\text { A. H. L. F. ( } 1892 \text { ) } \\
\text { and see } A r 7 \text { civ } \\
\text { ( } 1947 \text { ) }\end{array}$ \\
\hline Cirencester & $\begin{array}{l}\text { Gloucester- } \\
\text { shire }\end{array}$ & & $\begin{array}{l}\text { Light translucent. } \\
\text { Diam. } 4 \mathrm{~mm} . \\
\text { Length } 2 \cdot 5 \mathrm{~cm} .\end{array}$ & $\begin{array}{l}\text { From Barnsley Park } \\
\text { Roman villa, } \\
\text { occupied } 2 \text { nd }-4 \text { th c. } \\
\text { A.D. }\end{array}$ & $\begin{array}{l}\text { Information from } \\
\text { Dr. Graham } \\
\text { Vebster }\end{array}$ \\
\hline Frocester & $\begin{array}{l}\text { Gloucester- } \\
\text { shire }\end{array}$ & & $\begin{array}{l}\text { Diam. } 4 \mathrm{~mm} \\
\text { Length } 1.8 \mathrm{~cm} .\end{array}$ & $\begin{array}{l}\text { From Roman villa } \\
\text { stratified 'post A.D } \\
275 \text { ' }\end{array}$ & $\begin{array}{l}\text { TBGAS lxxxix } \\
(1970)\end{array}$ \\
\hline $\begin{array}{l}\text { Rockbourne } \\
\text { West Park } \\
\text { Roman Villa }\end{array}$ & Hampshire & Fordingbridge & $\begin{array}{l}\text { A number of trans- } \\
\text { lucent glass and vary- } \\
\text { ing sizes }\end{array}$ & $\begin{array}{l}\text { None of these was } \\
\text { stratified. The villa } \\
\text { was occupied through- } \\
\text { out the Roman period } \\
\text { and into Saxon times }\end{array}$ & $\begin{array}{l}\text { Information from } \\
\text { the late Mr. A. } \mathrm{T} \text {. } \\
\text { Morley Hewitt }\end{array}$ \\
\hline $\begin{array}{l}\text { Winchester, } \\
\text { Lankhills } \\
\text { Cemetery }\end{array}$ & Hampshire & & $\begin{array}{l}\text { A number of trans- } \\
\text { lucent glass and } \\
\text { varying sizes }\end{array}$ & $\begin{array}{l}\text { Necklaces } 182,2 \text { I } 5, \\
248,3 \text { I } 5,399 \text {, and } \\
443, \text { all from graves } \\
\text { variously dated } \\
\text { within the period } \\
\text { A.D. } 310-4 \text { Io }\end{array}$ & $\begin{array}{l}\text { Clarke, G. } \\
\text { (forthcoming) }\end{array}$ \\
\hline Silchester & Hampshire & Reading & 'Long blue cylinder' & $\begin{array}{l}\text { On necklace not } \\
\text { stratified }\end{array}$ & $\begin{array}{l}\text { Boon, G. C. (I957) } \\
\text { and in } A \text { cii (1969) }\end{array}$ \\
\hline St. Albans & Hertfordshire & Verularnium & $\begin{array}{l}\text { Opaque sky blue } \\
\text { (and others). Diam. }\end{array}$ & $\begin{array}{l}\text { On necklace of prob- } \\
\text { able } 4 \text { th c. date }\end{array}$ & $\begin{array}{l}V_{\ell}, \text { figs. } 214,47 \\
a-g\end{array}$ \\
\hline
\end{tabular}




\begin{tabular}{|c|c|c|c|c|c|}
\hline $\begin{array}{l}\text { SITE AND } \\
\text { PARISH }\end{array}$ & COUNTY & MUSEUM \& No. & $\begin{array}{l}\text { DESGRIPTION AND } \\
\text { APPROX. DIMENSIONS }\end{array}$ & $\begin{array}{l}\text { ASSOCIATIONS AND } \\
\text { REMARKS }\end{array}$ & PUBLICATION \\
\hline $\begin{array}{l}\text { Close ny } \\
\text { Chollagh, } \\
\text { Scarlett }\end{array}$ & Isle of Man & & $\begin{array}{l}\text { Has light greenish } \\
\text { streaks. Diam. } 0 \cdot 4 \\
\text { cm. Length } \mathrm{I} \cdot 4 \mathrm{~cm} \text {. }\end{array}$ & $\begin{array}{l}\text { Iron Age fort occu- } \\
\text { pied into Roman } \\
\text { period. Bead came } \\
\text { from midden material } \\
\text { together with a Col- } \\
\text { chester type La Tène } \\
\text { III brooch. Late Ist } \\
\text { c. A.D.? unless midden } \\
\text { material was of mixed } \\
\text { date }\end{array}$ & $\begin{array}{l}P P S \text { xxiv }\left(195^{8}\right) \\
94^{-5}\end{array}$ \\
\hline Woodeaton & Oxfordshire & A.M. & $\begin{array}{l}\text { Light translucent } \\
\text { blue. Diam. } 5 \mathrm{~mm} \text {. } \\
\text { Length } 2.2 \mathrm{~cm} \text {. }\end{array}$ & $\begin{array}{l}\text { From Romano-Celtic } \\
\text { temple-occupation } \\
\text { from late Iron Age to } \\
\text { post-Roman }\end{array}$ & $O \operatorname{xix}(1954), 15$ \\
\hline Brislington & Somerset & Bristol F2319 & $\begin{array}{l}\text { Opaque. Diam. } 4 \\
\text { mm. Length } 2 \mathrm{~mm} \text {. }\end{array}$ & From Roman villa & $\begin{array}{l}T B G A S \text { xxiii } \\
\text { (I } 900), 289 \text { and } \\
\text { xxiv (I gor), } 283\end{array}$ \\
\hline 'Mendip' & Somerset & $\begin{array}{l}\text { Bristol F2o86 (A. C. } \\
\text { Pass Colln.) }\end{array}$ & $\begin{array}{l}\text { Opaque. Diam. } 3 \\
\text { mm. Length } \mathrm{I} \cdot 7 \mathrm{~cm} \text {. }\end{array}$ & Stray find & \\
\hline $\begin{array}{l}\text { Sea Mills, } \\
\text { Bristol }\end{array}$ & Somerset & Bristol F2221 & $\begin{array}{l}\text { Opaque. Diam. } 5 \\
\text { mm. Length } \mathrm{I} \cdot 2 \mathrm{~cm} \text {. }\end{array}$ & $\begin{array}{l}\text { Roman fort at Portus } \\
\text { Abonae, Claudian and } \\
\text { later (possibly from a } \\
\text { Ist c. A.D. storehouse) }\end{array}$ & $\begin{array}{l}T B G A S \text { lxviii } \\
(\text { I } 949), \text { I } 84\end{array}$ \\
\hline Whitton & Suffolk & Ipswich & $\begin{array}{l}\text { Length } \mathrm{I} \cdot 8 \mathrm{~cm} \text {. } \\
\text { Semi-translucent }\end{array}$ & $\begin{array}{l}\text { From Roman villa } \\
\text { dated A.D. } 13^{\circ-290}\end{array}$ & $\begin{array}{l}P S I A \times x i(193 \mathrm{I}-3), \\
240 \mathrm{ff} .\end{array}$ \\
\hline \multicolumn{6}{|c|}{ SGOTLAND } \\
\hline $\begin{array}{l}\text { Traprain Law, } \\
\text { Prestonkirk }\end{array}$ & E. Lothian & $\begin{array}{l}\text { N.M.A. Excav. no. } \\
\text { III } 20223\end{array}$ & $\begin{array}{l}\text { Broken fragment } \\
\text { translucent }\end{array}$ & $\begin{array}{l}\text { Occupation through- } \\
\text { out Roman period }\end{array}$ & $\begin{array}{l}\text { See Hogg, A. H. A. } \\
\text { (I } 95 \text { I) }\end{array}$ \\
\hline
\end{tabular}

WA LES

Caernarvon Caernarvon- Segontium Museum, shire Caernarvon
Royal blue. Diam. $5 \mathrm{~mm}$. Length $2 \mathrm{~cm}$. Another smaller and less regular
Unstratified from

Roman fort
Unpublished. Information from G. C. Boon

(b) GREEN GYLINDERS (for Segments, see below, pp. 2 I I-12)

\section{ENGLAND}

Calcot or Bedfordshire Henxworth

Santon

Downham
Cambridgeshire
' 6 long glass beads of
green colour'

With Samian ware from Roman burials

C.M.
Stukeley, W. Itinerarium Curiosum (1 776), p. 78

Opaque green. Diam. With rich ist c. A.D. Fox, C. (1923) $4 \mathrm{~mm}$. Length $8 \mathrm{~mm}$. burial

passim 


\begin{tabular}{|c|c|c|c|c|c|}
\hline $\begin{array}{l}\text { SITE AND } \\
\text { PARISH }\end{array}$ & COUNTY & MUSEUM \& NO. & $\begin{array}{l}\text { DESCRIPTION AND } \\
\text { APPROX. DIMENSIONS }\end{array}$ & $\begin{array}{c}\text { ASSOCLATIONS AND } \\
\text { REMARKS }\end{array}$ & PUBLICATION \\
\hline $\begin{array}{l}\text { Nor' nour, } \\
\text { Scilly }\end{array}$ & Cornwall & $\begin{array}{l}\text { St. Mary's, } \\
\text { Scilly }\end{array}$ & $\begin{array}{l}\text { Probably broken at } \\
\text { one end. Opaque } \\
\text { yellow-green. Diam. } \\
3 \text { mm. Length I cm. } \\
\text { And another frag- } \\
\text { ment, bright bottle } \\
\text { green }\end{array}$ & $\begin{array}{l}\text { Site } 1 \text {, Room. } 2 . \text { Site } \\
\text { occupied for most of } \\
\text { Roman period. } \\
\text { Information from } \\
\text { Miss Dudley } 1962 . \\
\text { Second example } \\
\text { probably with } 2 \text { nd c. } \\
\text { A.D. coins from later } \\
\text { excavation }\end{array}$ & $\operatorname{Arf}$ cxxiv (1967) \\
\hline $\begin{array}{l}\text { Little Chester, } \\
\text { Derby }\end{array}$ & Derbyshire & Derby & $\begin{array}{l}\text { Translucent bottle } \\
\text { glass. Length } c . \mathrm{I} \cdot 2 \\
\mathrm{~cm} .\end{array}$ & $\begin{array}{l}\text { From late Roman } \\
\text { site. Unstratified }\end{array}$ & $\begin{array}{l}\text { Information from } \\
\text { Mr. Christopher } \\
\text { Green }\end{array}$ \\
\hline Woodcuts & Dorset & Salisbury & $\begin{array}{l}2 \text { specimens, one } \\
\text { broken in half } \\
\text { longitudinally. } \\
\text { Diams. } 3 \text { and } 5 \mathrm{~mm} \text {. } \\
\text { Lengths } 2 \text { and } 2 \cdot 2 \\
\mathrm{~cm} \text {. Both translucent }\end{array}$ & $\begin{array}{l}\text { From Romano- } \\
\text { British settlement }\end{array}$ & $\begin{array}{l}\text { Pitt-Rivers, } \\
\text { A. H. L. S. ( } 1887) \\
\text { and } A r \mathcal{J} \operatorname{civ}(\text { I } 947)\end{array}$ \\
\hline $\begin{array}{l}\text { Colliton Park } \\
\text { Villa, } \\
\text { Dorchester }\end{array}$ & Dorset & Dorchester & $\begin{array}{l}\text { Several examples. } \\
\text { Two in translucent } \\
\text { sea-green glass. } \\
\text { Lengths I and } 2 \mathrm{~cm} \text {. } \\
\text { Diams. } 2 \text { and } 5 \mathrm{~mm} \text {. }\end{array}$ & $\begin{array}{l}\text { From Roman villa } \\
\text { late } 2 \text { nd c. A.D. with } \\
\text { subsequent additions }\end{array}$ & $\begin{array}{l}\text { R.G.H.M. Dorset } \\
\text { ii }\end{array}$ \\
\hline $\begin{array}{l}\text { Maiden Castle, } \\
\text { Winterbourne } \\
\text { Monkton }\end{array}$ & Dorset & Dorchester & Blue-green & $\begin{array}{l}\text { From 'Belgic' level, } \\
\text { now redated post } \\
\text { 50 B.C. }\end{array}$ & $M C$ \\
\hline $\begin{array}{l}\text { Poundbury, } \\
\text { nr. Dorchester }\end{array}$ & Dorset & Dorchester & $\begin{array}{l}\text { Necklace of } 78 \text { of } \\
\text { these with } 3 \text { small } \\
\text { square-sectioned blue } \\
\text { beads }\end{array}$ & $\begin{array}{l}\text { From late Roman } \\
\text { grave }\end{array}$ & $\begin{array}{l}\text { Information from } \\
\text { Mr. C.J.S. Green }\end{array}$ \\
\hline $\begin{array}{l}\text { South } \\
\text { Shields }\end{array}$ & Durham & $\begin{array}{l}\text { South Shields and } \\
\text { University Museum, } \\
\text { Newcastle-upon- } \\
\text { Tyne }\end{array}$ & $\begin{array}{l}3 \text { or } 4 \text { examples of } \\
\text { various dimensions }\end{array}$ & $\begin{array}{l}\text { From Roman fort } \\
\text { occupied A.D. } 122- \\
3^{69}\end{array}$ & $\begin{array}{l}7 R S \text { lvii (1967) } \\
\text { and Richmond, } \\
\text { I. A. (I954) }\end{array}$ \\
\hline Cirencester & $\begin{array}{l}\text { Gloucester- } \\
\text { shire }\end{array}$ & & $\begin{array}{l}\text { One translucent sea- } \\
\text { green. Length } 2 \mathrm{~cm} \text {. } \\
\text { Another bottle green, } \\
\text { length } 7 \mathrm{~mm} \text {. }\end{array}$ & $\begin{array}{l}\text { From Barnsley Park } \\
\text { Roman villa occu- } \\
\text { pied } 2 \text { nd }-4^{\text {th }} \text { c. A.D. }\end{array}$ & $\begin{array}{l}\text { Information from } \\
\text { Dr. Graham } \\
\text { Webster }\end{array}$ \\
\hline Cirencester & $\begin{array}{l}\text { Gloucester- } \\
\text { shire }\end{array}$ & Bgo6 & Several segments & $\begin{array}{l}\text { Unstratified in } \\
\text { Roman town }\end{array}$ & \\
\hline Portchester & Hampshire & & $\begin{array}{l}\text { Two rather greenish- } \\
\text { blue. One I cm. long } \\
\text { and another slightly } \\
\text { larger }\end{array}$ & $\begin{array}{l}\text { Both from late } \\
\text { Roman levels }\end{array}$ & $\begin{array}{l}\text { Information from } \\
\text { Prof. Barry } \\
\text { Cunliffe }\end{array}$ \\
\hline $\begin{array}{l}\text { Rockbourne } \\
\text { West Park } \\
\text { Roman Villa }\end{array}$ & Hampshire & Fordingbridge & $\begin{array}{l}2 \text { light green beads. } \\
\text { Diams. } 3 \mathrm{~m} \text {. } \\
\text { Lengths } \mathrm{x} \cdot 5 \text { and } \\
2 \cdot 1 \mathrm{~cm} \text {. }\end{array}$ & $\begin{array}{l}\text { Roman villa occu- } \\
\text { pied throughout } \\
\text { Roman and into } \\
\text { Saxon times }\end{array}$ & $\begin{array}{l}\text { Information from } \\
\text { the late Mr. A. T. } \\
\text { Morley Hewitt }\end{array}$ \\
\hline
\end{tabular}




\begin{tabular}{|c|c|c|c|c|c|}
\hline $\begin{array}{l}\text { SITE AND } \\
\text { PARISH }\end{array}$ & COUNTY & MUSEUM \& NO. & $\begin{array}{c}\text { DESCRIPTION AND } \\
\text { APPROX. DIMENSIONS }\end{array}$ & $\begin{array}{l}\text { ASSOCIATIONS AND } \\
\text { REMARKS }\end{array}$ & PUBLICATION \\
\hline $\begin{array}{l}\text { Rockbourne } \\
\text { West Park } \\
\text { Roman Villa }\end{array}$ & Hampshire & Fordingbridge & $\begin{array}{l}\text { Roughly wound and } \\
\text { opaque dark green }\end{array}$ & $\begin{array}{l}\text { Thought to be } \\
\text { Constantine }\end{array}$ & $\begin{array}{l}\text { Information from } \\
\text { the late Mr. A. T. } \\
\text { Morley Hewitt }\end{array}$ \\
\hline $\begin{array}{l}\text { Winchester, } \\
\text { Lankhills } \\
\text { Cemetery }\end{array}$ & Hampshire & & $\begin{array}{l}\text { A number of translu- } \\
\text { cent and opaque } \\
\text { glass, and of various } \\
\text { sizes }\end{array}$ & $\begin{array}{l}\text { Necklaces } 85,140, \\
215,248,269,3 \text { I } 5, \\
363,399,443, \text { and } 583, \\
\text { all from graves } \\
\text { variously dated } \\
\text { within the period } \\
\text { A.D. } 3 \text { I0-4 IO }\end{array}$ & $\begin{array}{l}\text { Clarke, G. } \\
\text { (forthcoming) }\end{array}$ \\
\hline Kenchester & Herefordshire & Hereford $605^{8}$ & $\begin{array}{l}\text { Semi-translucent, one } \\
\text { end broken. Diam. } \\
6 \mathrm{~mm} \text {. Length } \mathrm{I} \cdot 5 \\
\mathrm{~cm} .\end{array}$ & $\begin{array}{l}\text { The occupation of } \\
\text { this Roman town is } \\
\text { thought to have } \\
\text { ended about A.D. } 390\end{array}$ & $\begin{array}{l}T W \mathcal{T} F C\left(\operatorname{Ig}^{16}\right) \\
\text { and }(1926)\end{array}$ \\
\hline St. Albans & Hertfordshire & Verulamium 30.209 & $\begin{array}{l}\text { Diam. } 5 \mathrm{~mm} \text {. Length } \\
\mathrm{I} \mathrm{cm} .\end{array}$ & $\begin{array}{l}\text { Site A. Building 2, } \\
\text { Room 2, Level } 2\end{array}$ & $\begin{array}{l}\text { See Anthony, Ilid, } \\
\text { Verulamium (1970) }\end{array}$ \\
\hline St. Albans & Hertfordshire & Verulamium 33.192 & $\begin{array}{l}\text { Oval in section. Max. } \\
\text { diam. } 4 \mathrm{~mm} \text {. Length } \\
2 \cdot 3 \mathrm{~cm} \text {. }\end{array}$ & & \\
\hline St. Albans & Hertfordshire & Verulamium 33.700 & $\begin{array}{l}\text { Another example on } \\
\text { its original wire, } \\
\text { opaque. Diam. } 3 \mathrm{~mm} \text {. } \\
\text { Length } 5 \mathrm{~mm} \text {. }\end{array}$ & & \\
\hline $\begin{array}{l}\text { Richborough, } \\
\text { Ash }\end{array}$ & Kent & Richborough 4623 & $\begin{array}{l}\text { Bright bluish-green, } \\
\text { semi-translucent. } \\
\text { Diam. } 4 \text { mm. Length } \\
\text { I.2 cm. }\end{array}$ & & $\begin{array}{l}\text { Information from } \\
\text { Dr. G. C. Dunning }\end{array}$ \\
\hline Manton & Lincolnshire & Scunthorpe & $\begin{array}{l}\text { Diam. } 4 \text { mm. Length } \\
\mathrm{I} \cdot 2 \mathrm{~cm} \text {. Broken }\end{array}$ & $\begin{array}{l}\text { Hut sites. Occupa- } \\
\text { tion throughout } \\
\text { Roman and into } \\
\text { Saxon period }\end{array}$ & $\begin{array}{l}\text { Information from } \\
\text { Mr. R. H. } \\
\text { Arrand }\end{array}$ \\
\hline $\begin{array}{l}\text { Chesters } \\
\text { Fort }\end{array}$ & $\begin{array}{l}\text { Northumber- } \\
\text { land }\end{array}$ & Chesters $278_{3}$ & $\begin{array}{l}2 \text { examples. Both } \\
\text { opaque and of usual } \\
\text { dimensions but } \\
\text { broken }\end{array}$ & $\begin{array}{l}\text { Probably dates from } \\
\text { between A.D. 1 } 22- \\
3^{8} 3\end{array}$ & $\begin{array}{l}\text { Information from } \\
\text { Dr. G. Simpson }\end{array}$ \\
\hline $\begin{array}{l}\text { Great } \\
\text { Chesters }\end{array}$ & $\begin{array}{l}\text { Northumber- } \\
\text { land }\end{array}$ & $\begin{array}{l}\text { University Museum, } \\
\text { Newcastle-upon- } \\
\text { Tyne }\end{array}$ & $\begin{array}{l}\text { Bottle green translu- } \\
\text { cent. Length } c \cdot \mathrm{I} \cdot 2 \\
\mathrm{~cm} \text {. }\end{array}$ & From Roman Aesica & \\
\hline Housesteads & $\begin{array}{l}\text { Northumber- } \\
\text { land }\end{array}$ & $\begin{array}{l}\text { University Museum, } \\
\text { Newcastle-upon- } \\
\text { Tyne }\end{array}$ & $\begin{array}{l}\text { Translucent bottle } \\
\text { green, one } 2 \mathrm{~cm} \text {. long } \\
\text { and three others }\end{array}$ & $\begin{array}{l}\text { From Roman site of } \\
\text { Borcovicium }\end{array}$ & \\
\hline $\begin{array}{l}\text { Bradley Hill, } \\
\text { Somerton }\end{array}$ & Somerset & & $\begin{array}{l}\text { Broken almost } \\
\text { opaque green, } \\
\text { striated. Existing } \\
\text { length } \mathrm{I} \cdot 7 \mathrm{~cm} \text {. Diam. } \\
5 \mathrm{~mm} \text {. Perf. diam. } \\
\text { I } \mathrm{mm} \text {. }\end{array}$ & $\begin{array}{l}\text { From homestead of } \\
4^{\text {th }-5^{\text {th }} \text { c. date }}\end{array}$ & $\begin{array}{l}\text { Preliminary report } \\
\text { in C.B.A. } \\
\text { Groups XII and } \\
\text { XIII, Arch. Rev. } 7 \\
\left(197^{2}\right), 39^{-4 I}\end{array}$ \\
\hline $\begin{array}{l}\text { Lamyatt } \\
\text { Beacon }\end{array}$ & Somerset & & $\begin{array}{l}\text { Light bottle green, } \\
\text { translucent. Length } \\
8 \mathrm{~mm} \text {. }\end{array}$ & $\begin{array}{l}\text { From Romano- } \\
\text { Celtic temple of } \\
\text { 2nd-4th c. A.D. }\end{array}$ & $\begin{array}{l}\text { Information from } \\
\text { Mrs. Crystal } \\
\text { Bennett }\end{array}$ \\
\hline
\end{tabular}




\begin{tabular}{|c|c|c|c|c|c|}
\hline $\begin{array}{l}\text { SITE AND } \\
\text { PARISH }\end{array}$ & COUNTY & MUSEUM \& NO. & $\begin{array}{l}\text { DESCRIPTION AND } \\
\text { APPROX. DIMENSIONS }\end{array}$ & $\begin{array}{l}\text { ASSOCIATIONS AND } \\
\text { REMARKS }\end{array}$ & PUBLICATION \\
\hline Hepworth & Suffolk & Ipswich 959.143 & $\begin{array}{l}\text { Semi-translucent. } \\
\text { Length } 2 \cdot 2 \mathrm{~cm} \text {. }\end{array}$ & Roman & $\begin{array}{l}\text { Information from } \\
\text { Ipswich Museum }\end{array}$ \\
\hline $\begin{array}{l}\text { Overton } \\
\text { Down }\end{array}$ & Wiltshire & & $\begin{array}{l}\text { One opaque. Length } \\
6 \mathrm{~mm} .2 \text { others }\end{array}$ & $\begin{array}{l}\text { From site XII, late } \\
\text { Roman }\end{array}$ & $\begin{array}{l}\text { WAM Ixii }(1967) \text {, } \\
\text { I } 6 \mathrm{ff} .\end{array}$ \\
\hline Catterick & Yorkshire & & $\begin{array}{l}\text { One rather flattened } \\
\text { cylinder and one } \\
\text { segment }\end{array}$ & Roman & $\begin{array}{l}\text { Information from } \\
\text { Mr.J. Wacher }\end{array}$ \\
\hline & & & I RELAND & & \\
\hline \multirow[t]{2}{*}{$\begin{array}{l}\text { Lagore } \\
\text { Crannog, } \\
\text { Dunshaughlin }\end{array}$} & Go. Meath & & $\begin{array}{l}\text { Diam. } 4 \mathrm{~mm} \text {. Length } \\
2.3 \mathrm{~cm} .\end{array}$ & $\begin{array}{l}\text { Unstratified, in post- } \\
\text { Roman site which } \\
\text { yielded pre-Roman } \\
\text { beads as well. This } \\
\text { example could be } \\
\text { early Roman or post- } \\
\text { Roman }\end{array}$ & $\begin{array}{l}\text { PRIA liii G } \\
(1950-1), 136\end{array}$ \\
\hline & & & $\triangle G O T L A N D$ & & \\
\hline $\begin{array}{l}\text { Traprain Law, } \\
\text { Prestonkirk }\end{array}$ & E. Lothian & N.M.A. & $\begin{array}{l}\text { Small opaque green } \\
\text { and two similar found } \\
\text { in second level in } \\
\text { igi5 }\end{array}$ & Roman period & $\begin{array}{l}P S A S \text { liv } \\
\left(19^{1} 9^{-20}\right), 89\end{array}$ \\
\hline \multirow[t]{3}{*}{ Newstead } & $\begin{array}{l}\text { Roxburgh- } \\
\text { shire }\end{array}$ & N.M.A. FRAgo7 & $\begin{array}{l}\text { Diam. } 3 \mathrm{~mm} \text {. Length } \\
9 \mathrm{~mm} .\end{array}$ & $\begin{array}{l}\text { Occupation about } \\
\text { A.D. } 80-200\end{array}$ & $\mathcal{N} e$ \\
\hline & & $\begin{array}{r}\text { SEGMENTS } \\
(\text { Opaq }\end{array}$ & $\begin{array}{l}\text { OF CYLIN DER } \\
\text { te or translucent green) }\end{array}$ & $\mathrm{BEADS}$ & \\
\hline & & & ENGLAND & & \\
\hline $\begin{array}{l}\text { Wood Farm, } \\
\text { Haversham }\end{array}$ & $\begin{array}{l}\text { Buckingham- } \\
\text { shire }\end{array}$ & Aylesbury & $\begin{array}{l}\text { Diam. and length } \\
4 \mathrm{~mm} \text {. }\end{array}$ & Roman site & \\
\hline $\begin{array}{l}\text { Poundbury } \\
\text { Camp, } \\
\text { Dorchester }\end{array}$ & Dorset & Dorchester & $\begin{array}{l}\text { Necklace with } 3 \text { cube } \\
\text { shaped beads and } 78 \\
\text { cut green segments }\end{array}$ & $\begin{array}{l}\text { In a } 4^{\text {th }} \text { c. A.D. } \\
\text { Christian cemetery }\end{array}$ & $\begin{array}{l}\text { Information from } \\
\text { Mr. Christopher } \\
\text { Green, } 1973\end{array}$ \\
\hline $\begin{array}{l}\text { Cirencester } \\
\text { (Watermoor } \\
\text { Cemetery) }\end{array}$ & $\begin{array}{l}\text { Gloucester- } \\
\text { shire }\end{array}$ & Gloucester 539-4I & $\begin{array}{l}\text { Opaque. Diam. } 5 \\
\text { mm. }\end{array}$ & $\begin{array}{l}\text { Roman and post- } \\
\text { Roman }\end{array}$ & $\begin{array}{l}A n \bar{f} \operatorname{xlix}(1969) \\
222 \text { and earlier } \\
\text { reports }\end{array}$ \\
\hline Cirencester & $\begin{array}{l}\text { Gloucester- } \\
\text { shire }\end{array}$ & Girencester Bgor & $\begin{array}{l}\text { On a wire with } 2 \\
\text { melon beads }\end{array}$ & From Roman town & $\begin{array}{l}\text { Anj xlix (1969), } \\
222 \text { and earlier } \\
\text { reports }\end{array}$ \\
\hline Frocester & $\begin{array}{l}\text { Gloucester- } \\
\text { shire }\end{array}$ & & $\begin{array}{l}\text { Semi-translucent } \\
\text { green. Diam. } 4 \mathrm{~mm} .\end{array}$ & $\begin{array}{l}\text { Unstratified but post- } \\
\text { A.D. } 275\end{array}$ & $\begin{array}{l}\text { TBGAS lxxxix } \\
(1970)\end{array}$ \\
\hline Silchester & Hampshire & Reading & Small segment & Necklace. Not dated & $\begin{array}{l}\text { See Boon, G. C. } \\
(1957) \text { and in } A \text { cii } \\
(1969)\end{array}$ \\
\hline $\begin{array}{l}\text { Winchester, } \\
\text { Lankhills } \\
\text { Cemetery }\end{array}$ & & Hampshire & $\begin{array}{l}\text { Many, listed above } \\
\text { under blue and green } \\
\text { glass cylinder beads }\end{array}$ & & $\begin{array}{l}\text { Clarke, G. } \\
\text { (forthcoming) }\end{array}$ \\
\hline
\end{tabular}




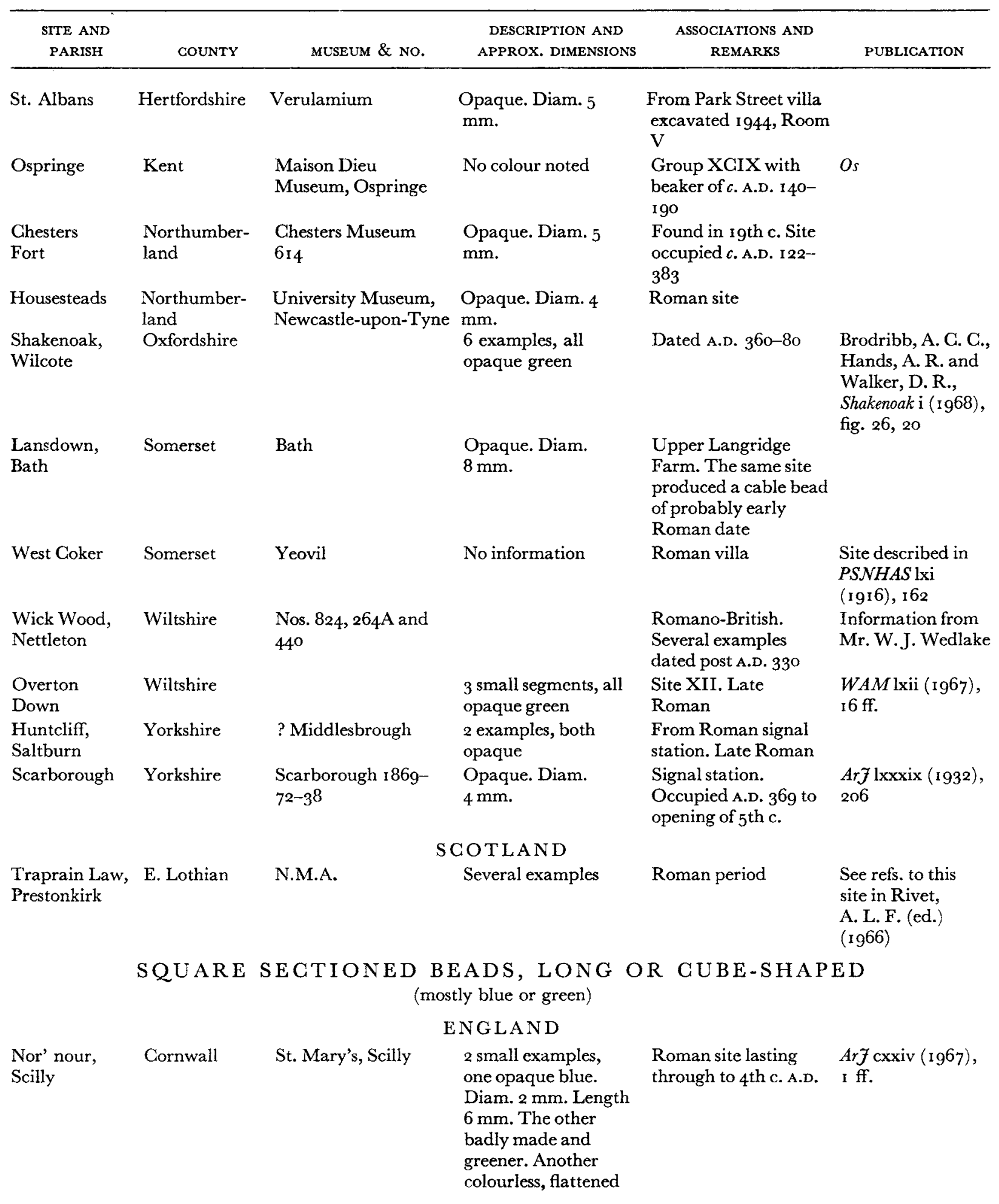




\begin{tabular}{|c|c|c|c|c|c|}
\hline $\begin{array}{l}\text { SITE AND } \\
\text { PARISH }\end{array}$ & COUNTY & MUSEUM \& NO. & $\begin{array}{l}\text { DESCRIPTION AND } \\
\text { APPROX. DIMENSIONS }\end{array}$ & $\begin{array}{c}\text { ASSOCIATIONS AND } \\
\text { REMARKS }\end{array}$ & PUBLICATION \\
\hline Probus & Cornwall & Truro & $\begin{array}{l}\text { Bottle glass. Length } \\
\text { I } 8 \mathrm{~cm} \text {. Width } 4 \mathrm{~mm} .\end{array}$ & 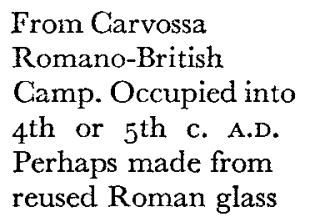 & $\begin{array}{l}\text { Information from } \\
\text { Mr.H.L. Douch }\end{array}$ \\
\hline $\begin{array}{l}\text { Little Chester, } \\
\text { Derby }\end{array}$ & Derbyshire & Derby & $\begin{array}{l}\text { Opaque blue. } \\
\text { Length } 7 \mathrm{~mm} \text {. Diam. } \\
3 \mathrm{~mm} \text {. }\end{array}$ & $\begin{array}{l}\text { From bottom of } 4 \text { th } \mathrm{c} \text {. } \\
\text { A.D. ditch }\end{array}$ & $\begin{array}{l}\text { Information from } \\
\text { Mr. Christopher } \\
\text { Green }\end{array}$ \\
\hline $\begin{array}{l}\text { Colliton Park, } \\
\text { Dorchester }\end{array}$ & Dorset & Dorchester & $\begin{array}{l}\text { One opaque blue, } \\
\text { length } 5 \mathrm{~mm} \text {. One } \\
\text { striated translucent } \\
\text { sea-green, length } \\
2 \cdot 1 \mathrm{~cm} \text {. Another small } \\
\text { with one end only } \\
\text { square in section }\end{array}$ & $\begin{array}{l}\text { From Roman villa. } \\
\text { Mostly late occupa- } \\
\text { tion, but begun in } \\
\text { late 2nd c. A.D. }\end{array}$ & $\begin{array}{l}\text { R.G.H.M. Dorset } \\
\text { ii }\end{array}$ \\
\hline $\begin{array}{l}\text { Poundbury } \\
\text { Camp, } \\
\text { Dorchester }\end{array}$ & Dorset & Dorchester & $\begin{array}{l}3 \text { cube-shaped beads, } \\
\text { translucent } \\
\text { cobalt }\end{array}$ & $\begin{array}{l}\text { On necklace in } 4^{\text {th }} \mathrm{c} \text {. } \\
\text { A.D. Christian } \\
\text { cemetery with } 7^{8} \\
\text { segments of } \\
\text { opaque grcen } \\
\text { cylinder beads }\end{array}$ & $\begin{array}{l}\text { Information from } \\
\text { Mr. Christopher } \\
\text { Green, I } 973\end{array}$ \\
\hline South Shields & Durham & $\begin{array}{l}\text { South Shields } \\
\text { Museum }\end{array}$ & $\begin{array}{l}\text { Blue iridescent. } \\
\text { Diam. } 4 \mathrm{~mm} \text {. Length } \\
2.6 \mathrm{~cm} .\end{array}$ & $\begin{array}{l}\text { Roman fort. Occupa- } \\
\text { tion c. A.D. } 122-369\end{array}$ & $\begin{array}{l}\text { Richmond, I. A. } \\
\text { (1954) }\end{array}$ \\
\hline Frocester & $\begin{array}{l}\text { Gloucester- } \\
\text { shire }\end{array}$ & & $\begin{array}{l}3 \text { examples of diff- } \\
\text { erent sizes. Two have } \\
\text { rounded section at } \\
\text { one end }\end{array}$ & $\begin{array}{l}\text { Stratified late } 3 \text { rd- } \\
\text { late } 4^{\text {th c. A.D. in }} \\
\text { Roman villa }\end{array}$ & $\begin{array}{l}T B G A S \mathrm{lxxxix} \\
(1970)\end{array}$ \\
\hline $\begin{array}{l}\text { Kingscote } \\
\text { Roman Villa }\end{array}$ & Gloucestershire & & $\begin{array}{l}2 \text { or more small } \\
\text { blue examples }\end{array}$ & $\begin{array}{l}\text { Surface finds from } \\
\text { late Roman area of } \\
\text { settlement }\end{array}$ & $\begin{array}{l}\text { Information from } \\
\text { Mr. Graham } \\
\text { Walker }\end{array}$ \\
\hline $\begin{array}{l}\text { Rockbourne } \\
\text { West Park } \\
\text { Villa }\end{array}$ & Hampshire & $\begin{array}{l}\text { Rockbourne Roman } \\
\text { Villa Museum }\end{array}$ & $\begin{array}{l}\text { Several small chips, } \\
\text { blue opaque }\end{array}$ & $\begin{array}{l}\text { From villa occupied } \\
\text { throughout Roman } \\
\text { period }\end{array}$ & $\begin{array}{l}\text { Information from } \\
\text { the late Mr. A. T. } \\
\text { Morley Hewitt }\end{array}$ \\
\hline $\begin{array}{l}\text { Winchester, } \\
\text { Lankhills } \\
\text { Cemetery }\end{array}$ & Hampshire & Winchester & $\begin{array}{l}\text { Various small } \\
\text { examples of necklaces }\end{array}$ & $\begin{array}{l}\text { Necklaces } 363,560 \text {, } \\
\text { and } 5^{8} 3 \text {, all in graves } \\
\text { variously dated to } \\
\text { G. A.D. } 35^{0-80}\end{array}$ & $\begin{array}{l}\text { Clarke, G. } \\
\text { (forthcoming), } \\
\text { figs. 9o, d, } 9^{8}, \mathrm{c}, \mathrm{b}\end{array}$ \\
\hline $\begin{array}{l}\text { Groft Ambrey, } \\
\text { Groft }\end{array}$ & Herefordshire & Hereford & $\begin{array}{l}\text { Necklace with small } \\
\text { sky-blue beads on } \\
\text { wire }\end{array}$ & $\begin{array}{l}\text { Iron Age hill-fort } \\
\text { with later occupation. } \\
\text { This find is probably } \\
\text { Roman }\end{array}$ & $\begin{array}{l}\text { Stanford, S. C. } \\
\text { (1974) and in } \\
T W \mathcal{N} F C \text { xxxix } \\
(1967), 31-9\end{array}$ \\
\hline Kenchester & Herefordshire & Hereford & $\begin{array}{l}2 \text { examples. One } \\
\text { opaque sky blue. } \\
\text { Diam. } 4 \text { mm. Length } \\
3 \mathrm{~cm} \text {. Another } \\
\text { smaller and more } \\
\text { cobalt }\end{array}$ & $\begin{array}{l}\text { Roman town occu- } \\
\text { pied into late } 4^{\text {th }} \text {. } \\
\text { A.D. }\end{array}$ & $\begin{array}{l}T W N F C, 1916 \text { and } \\
1926\end{array}$ \\
\hline
\end{tabular}




\begin{tabular}{|c|c|c|c|c|c|}
\hline $\begin{array}{l}\text { SITE AND } \\
\text { PARISH }\end{array}$ & COUNTY & MUSEUM \& NO. & $\begin{array}{l}\text { DESCRIPTION AND } \\
\text { APPROX. DIMENSIONS }\end{array}$ & $\begin{array}{l}\text { ASSOCIATIONS AND } \\
\text { REMARKS }\end{array}$ & PUBLICATION \\
\hline $\begin{array}{l}\text { Weston- } \\
\text { under- } \\
\text { Penyard, } \\
\text { Bollitree }\end{array}$ & Herefordshire & Gloucester 1772 & $\begin{array}{l}\text { Long green opaque. } \\
\text { Others flatter sections }\end{array}$ & On necklace & $\begin{array}{l}\mathcal{J} B A A \mathrm{xxvii}(187 \mathrm{I}), \\
2 \text { I I }\end{array}$ \\
\hline St. Albans & Hertfordshire & Verulamium & $\begin{array}{l}\text { Light blue opaque. } \\
\text { Diam. } 3 \mathrm{~mm} \text {. Length } \\
5 \mathrm{~mm} .\end{array}$ & $\begin{array}{l}\text { Necklace of prob- } \\
\text { ably } 4^{\text {th }} \text { c. date }\end{array}$ & $V e$, p. 214 , fig. $47 \mathrm{~g}$ \\
\hline $\begin{array}{l}\text { Bardon Mill } \\
\text { (Vindolanda) }\end{array}$ & $\begin{array}{l}\text { Northumber- } \\
\text { land }\end{array}$ & & $\begin{array}{l}\text { Dark opaque tur- } \\
\text { quoise. Diam. } 4 \mathrm{~mm} \text {. } \\
\text { Length } \mathrm{I} \cdot 4 \mathrm{~cm} .\end{array}$ & $\begin{array}{l}\text { Stratified late } 3^{\text {rd }-} \\
4^{\text {th c. A. D. }}\end{array}$ & $\begin{array}{l}\text { Information from } \\
\text { Mr. R. E. Birley }\end{array}$ \\
\hline $\begin{array}{l}\text { Great } \\
\text { Chesters }\end{array}$ & $\begin{array}{l}\text { Northumber- } \\
\text { land }\end{array}$ & $\begin{array}{l}\text { University Museum, } \\
\text { Newcastle-upon- } \\
\text { Tyne }\end{array}$ & $\begin{array}{l}\text { Bright peacock blue } \\
\text { opaque. Diam. } 4 \mathrm{~mm} \text {. } \\
\text { Length } 2 \mathrm{~mm} \text {. } \\
\text { Another longer, blue }\end{array}$ & Roman site & \\
\hline $\begin{array}{l}\text { Lamyatt } \\
\text { Beacon, } \\
\text { Lamyatt }\end{array}$ & Somerset & & $\begin{array}{l}2 \text { small opaque blue } \\
\text { examples }\end{array}$ & $\begin{array}{l}\text { Surface collection } \\
\text { from site of Romano- } \\
\text { Celtic temple fre- } \\
\text { quented from } c . \text { A.D. } \\
3 \text { oo into } 5^{\text {th }} \text { c. }\end{array}$ & $\begin{array}{l}\text { Mr. Jones Colln. } \\
\text { Kindly submitted } \\
\text { by Mr. Roger } \\
\text { Leech }\end{array}$ \\
\hline Whitton & Suffolk & Ipswich & One small example & $\begin{array}{l}\text { Roman villa occu- } \\
\text { pied } c \text {. A.D. I } 3^{\circ}-29^{\circ}\end{array}$ & $\begin{array}{l}\text { PSIA xxi }(193 \mathrm{t}-3) \text {, } \\
24.0 \mathrm{ff} .\end{array}$ \\
\hline $\begin{array}{l}\text { Wick Wood, } \\
\text { Nettleton }\end{array}$ & Wiltshire & $\begin{array}{l}\text { c/o Bath and } \\
\text { Camerton Arch. } \\
\text { Soc. } 288\end{array}$ & $\begin{array}{l}\text { Several very small } \\
\text { examples. Green } \\
\text { opaque }\end{array}$ & $\begin{array}{l}\text { Romano-British } \\
\text { necklace 'Before A.D. } \\
284 \text { ' }\end{array}$ & $\begin{array}{l}\text { Information from } \\
\text { Mr. W.J. Wedlake }\end{array}$ \\
\hline $\begin{array}{l}\text { Stockton } \\
\text { Earthworks }\end{array}$ & Wiltshire & Salisbury & $\begin{array}{l}\text { Pale blue translucent. } \\
\text { Diam. } 2 \mathrm{~mm} \text {. Length } \\
6 \mathrm{~mm} .\end{array}$ & Belgic or Roman & $\begin{array}{l}W A M \text { xliii (1927), } \\
\text { I } 85 \text { and pl. viii }\end{array}$ \\
\hline $\begin{array}{l}\text { Huntcliff, } \\
\text { Saltburn }\end{array}$ & Yorkshire & ? Middlesbrough & $\begin{array}{l}\text { Broken, bright pea- } \\
\text { cock blue. Diam. } \\
4 \mathrm{~mm} \text {. Length } \mathrm{I} \cdot 5 \\
\mathrm{~cm} .\end{array}$ & $\begin{array}{l}\text { Signal station occu- } \\
\text { pied A.D. } 3^{69} \text { to early } \\
5^{\text {th c. }}\end{array}$ & $\begin{array}{l}\mathcal{F} R S \text { ii (I9I2), } 215, \\
\text { and } A r \mathcal{f} \text { lxxxix } \\
(1932), 203\end{array}$ \\
\hline $\begin{array}{l}\text { Templebrough } \\
\text { Roman Fort }\end{array}$ & Yorkshire & Rotherham & Opaque azure & $\begin{array}{l}\text { Excavated subse- } \\
\text { quently to main } \\
\text { excavation. Probably } \\
\text { Ist or } 2 \text { nd c. A.D. }\end{array}$ & May, T. (1922) \\
\hline \multicolumn{6}{|c|}{ I RELAND } \\
\hline Tara & Co. Meath & Dublin & $\begin{array}{l}\text { Small opaque light } \\
\text { blue. Diam. } 3 \mathrm{~mm} \text {. } \\
\text { Length } 5 \mathrm{~mm} \text {. }\end{array}$ & $\begin{array}{l}\text { From the Rath of the } \\
\text { Synods which pro- } \\
\text { duced Roman pottery } \\
\text { of ist-3rd c. A.D. This } \\
\text { bead may be Roman }\end{array}$ & $\begin{array}{l}\text { O Riordáin, S. P. } \\
(1964)\end{array}$ \\
\hline \multicolumn{6}{|c|}{ SGOTLAND } \\
\hline Covesea & Morayshire & N.M.A. HM212 & $\begin{array}{l}\text { Long, battered. Light } \\
\text { blue-green. Diam. } \\
5 \mathrm{~mm} \text {. Length'3 } \mathrm{cm} \text {. }\end{array}$ & $\begin{array}{l}\text { Occupation in } \\
\text { Roman period. Site } \\
\text { included imported } \\
\text { 2nd c. A.D. glass }\end{array}$ & $\begin{array}{l}P S A S 1 \mathrm{xv}(1930-1) \\
177\end{array}$ \\
\hline
\end{tabular}




\begin{tabular}{|c|c|c|c|c|c|}
\hline $\begin{array}{l}\text { SITE AND } \\
\text { PARISH }\end{array}$ & COUNTY & MUSEUM \& NO. & $\begin{array}{l}\text { DESGRIPTION AND } \\
\text { APPROX. DIMENSIONS }\end{array}$ & $\begin{array}{l}\text { ASSOCIATIONS AND } \\
\text { REMARKS }\end{array}$ & PUBLICATION \\
\hline \multicolumn{6}{|c|}{ WALES } \\
\hline $\begin{array}{l}\text { Coygan Camp, } \\
\text { Laugharne }\end{array}$ & $\begin{array}{l}\text { Carmarthen- } \\
\text { shire }\end{array}$ & & $\begin{array}{l}\text { Badly made dark } \\
\text { almost opaque blue. } \\
\text { Diam. } 4 \text { mm. Length } \\
6 \mathrm{~mm} \text {. Half another, } \\
\text { and another } \\
\text { smaller translucent } \\
\text { light blue }\end{array}$ & $\begin{array}{l}\text { Late } 3 \text { rd c. A.D. } \\
\text { stratified. All badly } \\
\text { made and perhaps } \\
\text { local products }\end{array}$ & $\begin{array}{l}\text { Wainwright, G.J. } \\
(1967)\end{array}$ \\
\hline Caerleon & $\begin{array}{l}\text { Monmouth- } \\
\text { shire }\end{array}$ & & $\begin{array}{l}\text { Small opaque } \\
\text { emerald green. } \\
\text { Diam. } 2 \text { mm. Length } \\
5 \mathrm{~mm} \text {. }\end{array}$ & $\begin{array}{l}\text { Stratified } c . \text { A.D. } \\
23^{0}-9^{6} \text { (from } \\
\text { Broadway Drain) }\end{array}$ & Boon, G. C. ( 1972$)$ \\
\hline $\begin{array}{l}\text { Caerwent } \\
\text { (Pound Lane) }\end{array}$ & $\begin{array}{l}\text { Monmouth- } \\
\text { shire }\end{array}$ & & $\begin{array}{l}\text { Bright green. Diam. } \\
4 \mathrm{~mm} \text {. Length } 2 \cdot 1 \\
\mathrm{~cm} \text {. }\end{array}$ & $\begin{array}{l}\text { From late Rornan } \\
\text { stratum }\end{array}$ & $\begin{array}{l}\text { Information from } \\
\text { Dr. G. G. Dunning }\end{array}$ \\
\hline \multicolumn{6}{|c|}{$\begin{array}{c}\text { LONG POLYGONAL BEAD } \\
\text { (opaque emerald green if not stated) } \\
\text { (See Exotic Roman Beads, p. 23I) }\end{array}$} \\
\hline \multicolumn{6}{|c|}{ ENGLAND } \\
\hline $\begin{array}{l}\text { Poundbury } \\
\text { Camp, } \\
\text { Dorchester }\end{array}$ & Dorset & Dorchester & $\begin{array}{l}\text { Translucent bottle } \\
\text { green. Length } 7 \mathrm{~mm} \text {. } \\
\text { Hexagonal }\end{array}$ & 3 rd to 4 th C. A.D. & $\begin{array}{l}\text { Information from } \\
\text { Mr. Christopher } \\
\text { Green }\end{array}$ \\
\hline South Shields & Durham & $\begin{array}{l}\text { University Museum, } \\
\text { Newcastle-upon- } \\
\text { Tyne }\end{array}$ & $\begin{array}{l}\text { One hexagonal } \\
\text { turquoise. Diam. } 6 \mathrm{~mm} \text {. } \\
\text { Length } 2.6 \mathrm{~cm} \text {. } \\
\text { Another, smaller, } \\
\text { green }\end{array}$ & $\begin{array}{l}\text { Fort occupied c. A.D. } \\
\text { I } 22 \text { to } 4^{\text {th }} \text { c. }\end{array}$ & $\begin{array}{l}\text { See Richmond, } \\
\text { I. A. (I954) }\end{array}$ \\
\hline Colchester & Essex & B.M. & $\begin{array}{l}\text { Hexagonal ( } 2 \text { others } \\
\text { in B.M.) }\end{array}$ & $\begin{array}{l}\text { Roman period pre- } \\
\text { A.D. } 6 \text { I }\end{array}$ & $A n \mathcal{F}$ ix $(1929), 3^{8}$ \\
\hline Mount Bures & Essex & & $\begin{array}{l}\text { Octagonal. Large } \\
\text { size shown in illus- } \\
\text { tration may not be } \\
\text { correct. Length } 2 \mathrm{~cm} .\end{array}$ & $\begin{array}{l}\text { Belgic burial with } \\
\text { fire-dogs, etc., } c . \text { Io } \\
\text { B.C.-A.D. } 5^{\circ}\end{array}$ & $\begin{array}{l}\text { Roach Smith, C. } \\
(1852) \text {, ii. For } \\
\text { discussion see } A \text { ci } \\
\text { (1967), Iff. }\end{array}$ \\
\hline $\begin{array}{l}\text { Wickford, } \\
\text { Beauchamps }\end{array}$ & Essex & ? Southend-on-Sea & $\begin{array}{l}\text { Hexagonal. Emerald } \\
\text { green, opaque }\end{array}$ & Roman & $\begin{array}{l}\text { Information from } \\
\text { Mr. W. Rodwell }\end{array}$ \\
\hline Cirencester & $\begin{array}{l}\text { Gloucester- } \\
\text { shire }\end{array}$ & Gloucester $539.4 \mathrm{I}$ & $\begin{array}{l}\text { Several examples. } \\
\text { Green. Rather blur- } \\
\text { red angles. Hex- } \\
\text { agonal. Length } 9 \mathrm{~mm} \text {. }\end{array}$ & $\begin{array}{l}\text { From Watermoor } \\
\text { Cemetery. Roman } \\
\text { period }\end{array}$ & $\begin{array}{l}\text { Anf xlix (1969) } \\
\text { and earlier refs. }\end{array}$ \\
\hline Cirencester & $\begin{array}{l}\text { Gloucester- } \\
\text { shire }\end{array}$ & Cirencester B966 & $\begin{array}{l}\text { Rich translucent } \\
\text { bottle green. Hex- } \\
\text { agonal }\end{array}$ & $\begin{array}{l}\text { Unstratified from } \\
\text { Roman town }\end{array}$ & Anf xlix $(\mathbf{1} 969)$ \\
\hline $\begin{array}{l}\text { Winchester, } \\
\text { Lankhills } \\
\text { Cemetery }\end{array}$ & Hampshire & & $\begin{array}{l}\text { Hexagonal, various } \\
\text { sizes, blue, translu- } \\
\text { cent green, opaque } \\
\text { green }\end{array}$ & $\begin{array}{l}\text { Necklaces } 85, \text { I } 4 \text {, } \\
2 \text { I } 5,363,399,424, \\
\text { and } 436 \text {, all from } \\
\text { graves variously dated } \\
\text { within the period } \\
\text { A.D. } 3 \text { 10-70 }\end{array}$ & $\begin{array}{l}\text { Clarke, G. } \\
\text { (forthcoming) }\end{array}$ \\
\hline
\end{tabular}




\begin{tabular}{|c|c|c|c|c|c|}
\hline $\begin{array}{l}\text { SITE AND } \\
\text { PARISH }\end{array}$ & COUNTY & MUSEUM \& NO. & $\begin{array}{c}\text { DESCRIPTION AND } \\
\text { APPROX. DIMENSIONS }\end{array}$ & $\begin{array}{l}\text { ASSOCIATIONS AND } \\
\text { REMARKS }\end{array}$ & PUBLIGATION \\
\hline St. Albans & Hertfordshire & Verulamium $3^{8.64}$ & $\begin{array}{l}\text { Hexagonal opaque } \\
\text { green. Rather large. } \\
\text { Length } \mathrm{I} \cdot 2 \mathrm{~cm} \text {. } \\
\text { Width } 8 \mathrm{~mm} \text {. }\end{array}$ & $\begin{array}{l}\text { Roman town. Strati- } \\
\text { fied A.D. } 360-70\end{array}$ & $\begin{array}{l}\text { Frere, S. (1972), } \\
\text { fig. } 79, \text { no. } 75\end{array}$ \\
\hline St. Albans & Hertfordshire & $\begin{array}{l}\text { Verulamium } \\
38.64\end{array}$ & $\begin{array}{l}\text { Hexagonal opaque. } \\
\text { Large in diameter. } \\
\text { Length } 9 \mathrm{~mm} \text {. }\end{array}$ & $\begin{array}{l}\text { Roman villa, Park } \\
\text { Street }\end{array}$ & $\begin{array}{l}\text { See refs. in } \\
\text { Anthony, Ilid, } \\
\text { Verulamium (197o) }\end{array}$ \\
\hline Water Newton & $\begin{array}{l}\text { Huntingdon- } \\
\text { shire }\end{array}$ & & One hexagonal & & $\begin{array}{l}\text { Beck's notes in } \\
\text { G.M. }\end{array}$ \\
\hline Richborough & Kent & Richborough 236I & $\begin{array}{l}\text { Translucent green. } \\
\text { Hexagonal }\end{array}$ & $\begin{array}{l}\text { Unstratified from } \\
\text { Roman and Saxon } \\
\text { site }\end{array}$ & Rich iv, 244 \\
\hline Richborough & Kent & Richborough I 359 & $\begin{array}{l}\text { Small opaque green. } \\
\text { Hexagonal. Length } \\
4 \mathrm{~mm} \text {. }\end{array}$ & $3^{\text {rd }}$ or $4^{\text {th }}$ C. A.D. & Rich iv, 254 \\
\hline Richborough & Kent & Richborough 2880 & $\begin{array}{l}\text { Semi-translucent } \\
\text { bright green with } \\
\text { gold iridescence. } \\
\text { Length ro mm. }\end{array}$ & $\begin{array}{l}\text { From inner stone fort } \\
\text { ditch post Carausius }\end{array}$ & Rich iv, 243 \\
\hline Southfleet & Kent & & $\begin{array}{l}\text { A number on gold } \\
\text { chain }\end{array}$ & $3^{\text {rd c. A.D. }}$ & $\begin{array}{l}\text { Beck's notes in } \\
\text { G.M. }\end{array}$ \\
\hline Carrawburgh & $\begin{array}{l}\text { Northumber- } \\
\text { land }\end{array}$ & Chesters 62 & $\begin{array}{l}\text { One opaque green. } \\
\text { Hexagonal. Length } \\
16 \mathrm{~mm} .5 \text { other } \\
\text { examples }\end{array}$ & $\begin{array}{l}\text { Coventina's Well. } \\
\text { Date approx. A.D. } \\
\text { I } 22-3^{8} 3 \text { (John } \\
\text { Clayton excavations) }\end{array}$ & \\
\hline $\begin{array}{l}\text { Chesters } \\
\text { Roman fort }\end{array}$ & $\begin{array}{l}\text { Northumber- } \\
\text { land }\end{array}$ & Chesters 1361 & $\begin{array}{l}\text { Pentagonal. Shiny } \\
\text { opaque dark green. } \\
\text { Length } \mathrm{I} \cdot 2 \mathrm{~cm} \text {. } \\
\text { Slight break 'collar' } \\
\text { at one end }\end{array}$ & $\begin{array}{l}\text { From group: 'chiefly } \\
\text { from Gilurnum' } \\
\text { occupation about } \\
\text { A.D. } 122-3^{8} 3\end{array}$ & \\
\hline Corbridge & $\begin{array}{l}\text { Northumber- } \\
\text { land }\end{array}$ & $\begin{array}{l}\text { Corstopitum I I } 4^{\circ} \\
\text { and } 754\end{array}$ & $\begin{array}{l}2 \text { examples opaque } \\
\text { green }\end{array}$ & $\begin{array}{l}\text { Occupation of the site } \\
\text { from ist to } 5^{\text {th }} \text { c. A.D. }\end{array}$ & \\
\hline $\begin{array}{l}\text { Ilchester } \\
\text { Mead }\end{array}$ & Somerset & $\begin{array}{l}\text { Yeovil Borough } \\
\text { Museum }\end{array}$ & $\begin{array}{l}\text { Bright translucent } \\
\text { green. Broken. } \\
\text { ? Pentagonal or hex- } \\
\text { agonal }\end{array}$ & From Roman villa & $\begin{array}{l}\text { Interim report in } \\
S D \mathcal{N} Q \mathrm{xxvi} \\
\left(195^{1-4}\right), 23^{-15}\end{array}$ \\
\hline $\begin{array}{l}\text { Lamyatt } \\
\text { Beacon }\end{array}$ & Somerset & & $\begin{array}{l}\text { Hexagonal. Green. } \\
\text { Length } 8 \mathrm{~mm} \text {. }\end{array}$ & $\begin{array}{l}\text { From Romano-Celtic } \\
\text { temple begun about } \\
\text { A.D. } 300\end{array}$ & $\begin{array}{l}\text { Information from } \\
\text { Mrs. Crystal } \\
\text { Bennett and Mr. } \\
\text { Roger Leech }\end{array}$ \\
\hline Felixstowe & Suffolk & B.M. & One hexagonal & & $\begin{array}{l}\text { Beck's notes in } \\
\text { G.M. }\end{array}$ \\
\hline Icklingham & Suffolk & Bury St. Edmunds & Hexagonal & $\begin{array}{l}\text { From hoard dated } c \text {. } \\
\text { A.D. } 400\end{array}$ & \\
\hline Whitton & Suffolk & ? Ipswich & Hexagonal & $\begin{array}{l}\text { From Castle Hill } \\
\text { Roman villa, occu- } \\
\text { pied c. A.D. I } 30-290\end{array}$ & $\begin{array}{l}P S I A \times x i(193 \mathrm{I}-3), \\
240 \mathrm{ff} .\end{array}$ \\
\hline
\end{tabular}




\begin{tabular}{|c|c|c|c|c|c|}
\hline $\begin{array}{l}\text { SITE AND } \\
\text { PARISH }\end{array}$ & GOUNTY & MUSEUM \& NO. & $\begin{array}{l}\text { DESGRIPTION AND } \\
\text { APPROX. DIMENSIONS }\end{array}$ & $\begin{array}{l}\text { ASSOCIATIONS AND } \\
\text { REMARKS }\end{array}$ & PUBLICATION \\
\hline Kirkby Thore & Westmorland & & Green. Hexagonal & $\begin{array}{l}\text { Several on a gold } \\
\text { wire necklace found } \\
\text { with dragonesque } \\
\text { brooch, etc. }\end{array}$ & $\begin{array}{l}\text { Way collection of } \\
\text { drawings under } \\
\text { Fibulae in the } \\
\text { S.A.L. Library }\end{array}$ \\
\hline $\begin{array}{l}\text { Overton } \\
\text { Down }\end{array}$ & Wiltshire & & $\begin{array}{l}\text { Small translucent, } \\
\text { pentagonal, bottle } \\
\text { green }\end{array}$ & $\begin{array}{l}\text { From Site XII. Late } \\
\text { Roman }\end{array}$ & $\begin{array}{l}W A M \text { lxii }(\text { I967), } \\
\text { ı } 6 \mathrm{ff} .\end{array}$ \\
\hline $\begin{array}{l}\text { Wick Wood, } \\
\text { Nettleton }\end{array}$ & Wiltshire & $\begin{array}{l}\text { Bath and Camerton } \\
\text { Arch. Soc. } 2009\end{array}$ & $\begin{array}{l}\text { Translucent bottle } \\
\text { green. Hexagonal. } \\
\text { Length } 1 \mathrm{~cm} .\end{array}$ & $\begin{array}{l}\text { From post-Roman } \\
\text { layer perhaps con- } \\
\text { taining Roman } \\
\text { material }\end{array}$ & $\begin{array}{l}\text { Information from } \\
\text { Mr. W.J. } \\
\text { Wedlake }\end{array}$ \\
\hline $\begin{array}{l}\text { Wick Wood, } \\
\text { Nettleton }\end{array}$ & Wiltshire & $\begin{array}{l}\text { Bath and Camerton } \\
\text { Arch. Soc. } 1915\end{array}$ & $\begin{array}{l}\text { Semi-translucent } \\
\text { green. Hexagonal but } \\
\text { flattened. Length } \\
8 \mathrm{~mm} \text {. }\end{array}$ & 'after A.D. $33^{\circ}$ & $\begin{array}{l}\text { Information from } \\
\text { Mr. W.J. } \\
\text { Wedlake }\end{array}$ \\
\hline $\begin{array}{l}\text { Wick Wood, } \\
\text { Nettleton }\end{array}$ & Wiltshire & $\begin{array}{l}\text { Bath and Camerton } \\
\text { Arch. Soc. } 15 \text { Io }\end{array}$ & $\begin{array}{l}\text { Hexagonal. Opaque } \\
\text { green. Length } 7 \mathrm{~mm} \text {. }\end{array}$ & 'pre-Constantinian' & $\begin{array}{l}\text { Information from } \\
\text { Mr. W.J. } \\
\text { Wedlake }\end{array}$ \\
\hline Catterick & Yorkshire & & $\begin{array}{l}\text { Bright emerald green. } \\
\text { Semi-translucent. } \\
\text { Hexagonal. Large. } \\
\text { Length } \mathrm{i} \mathrm{cm} \text {. }\end{array}$ & Roman period & $\begin{array}{l}\text { Information from } \\
\text { Mr. J. Wacher }\end{array}$ \\
\hline Scarborough & Yorkshire & $\begin{array}{l}\text { Scarborough } 1869 . \\
72.3\end{array}$ & $\begin{array}{l}\text { Translucent greenish } \\
\text { blue. Hexagonal. } \\
\text { Length } 9 \mathrm{~mm} \text {. }\end{array}$ & $\begin{array}{l}\text { From Roman signal } \\
\text { station occupied } c . \\
\text { A.D. } 370-400\end{array}$ & \\
\hline \multicolumn{6}{|c|}{ SCOTLAND } \\
\hline $\begin{array}{l}\text { Traprain Law, } \\
\text { Prestonkirk }\end{array}$ & E. Lothian & N.M.A. & $\begin{array}{l}\text { Several, hexagonal, } \\
\text { green or blue-green }\end{array}$ & $\begin{array}{l}\text { From native fort } \\
\text { occupied during } \\
\text { Roman period. From } \\
\text { Level II. Not closely } \\
\text { datable within Roman } \\
\text { times }\end{array}$ & $\begin{array}{l}P S A S \text { lvii (1922- } \\
\text { 3), } 2 \text { I2 }\end{array}$ \\
\hline Covesea & Morayshire & N.M.A. 2 I 3 & $\begin{array}{l}\text { Large. Semi-trans- } \\
\text { lucent. Pentagonal. } \\
\text { Dark green. Length } \\
\text { I } \mathrm{cm} \text {. }\end{array}$ & $\begin{array}{l}\text { From cave occupied } \\
\text { during Roman period. } \\
\text { It produced, inter } \\
\text { alia, a fragment of } \\
\text { 2nd c. A.D. imported } \\
\text { glass }\end{array}$ & $\begin{array}{l}P S A S \mathrm{lxv}\left(\mathrm{I} 93^{\circ}-\mathrm{I}\right), \\
177\end{array}$ \\
\hline $\begin{array}{l}\text { Dun Beag } \\
\text { Broch, } \\
\text { Skye }\end{array}$ & Inverness-shire & $\begin{array}{l}\text { N.M.A. GAi iog, } \\
\text { I I IO }\end{array}$ & $\begin{array}{l}\text { One bright blue } \\
\text { cobalt to opaque. } \\
\text { Hexagonal. Length } \\
4 \text { mm. Another more } \\
\text { globular }\end{array}$ & $\begin{array}{l}\text { From a broch with } \\
\text { Dark Ages occupation }\end{array}$ & $\begin{array}{l}P S A S \operatorname{lv}(\text { I } 920), \\
\text { I I0 }\end{array}$ \\
\hline
\end{tabular}




\begin{tabular}{|c|c|c|c|c|c|}
\hline $\begin{array}{l}\text { SITE AND } \\
\text { PARISH }\end{array}$ & COUNTY & MUSEUM \& NO. & $\begin{array}{l}\text { DESCRIPTION AND } \\
\text { APPROX. DIMENSIONS }\end{array}$ & $\begin{array}{l}\text { ASSOCIATIONS AND } \\
\text { REMARKS }\end{array}$ & PUBLICATION \\
\hline \multicolumn{6}{|c|}{ WALES } \\
\hline $\begin{array}{l}\text { Whitton, nr. } \\
\text { Barry }\end{array}$ & $\begin{array}{l}\text { Glamorgan- } \\
\text { shire }\end{array}$ & & $\begin{array}{l}\text { Pentagonal. Slight } \\
\text { collar at each end } \\
\text { perhaps where } \\
\text { broken off. Bright } \\
\text { opaque yellow core } \\
\text { radiating to each } \\
\text { angle. Covering } \\
\text { translucent green glass } \\
\text { reflecting yellow } \\
\text { through }\end{array}$ & $\begin{array}{l}\text { Unstratified in villa } \\
\text { occupied from } c \text {. Ist c. } \\
\text { B.c. to A.D. } 3^{00}\end{array}$ & $\begin{array}{l}\text { Information from } \\
\text { Dr. Michael } \\
\text { Jarrett }\end{array}$ \\
\hline Caerleon & $\begin{array}{l}\text { Monmouth- } \\
\text { shire }\end{array}$ & $\begin{array}{l}\text { N.M.W.63.228.B, } \\
\text { G7 }\end{array}$ & $\begin{array}{l}\text { Large. Pentagonal. } \\
\text { Translucent emerald } \\
\text { green over opaque } \\
\text { yellow core. Break } \\
\text { 'collar' at one end. } \\
\text { Length } \mathrm{I} \cdot \mathrm{I} \mathrm{cm} \text {. }\end{array}$ & $\begin{array}{l}\text { Antonine. From } \\
\text { Building } \mathrm{X}\end{array}$ & Boon, G. C. (1972) \\
\hline Caerleon & $\begin{array}{l}\text { Monmouth- } \\
\text { shire }\end{array}$ & $\begin{array}{l}\text { N.M.W. } 54 \cdot 3^{89 A} \text {, } \\
\text { Gi Io }\end{array}$ & $\begin{array}{l}\text { Octagonal. Small. } \\
\text { Opaque green. } \\
\text { Length } 8 \mathrm{~mm} .\end{array}$ & $\begin{array}{l}\text { Stratified c. A.D. } \\
\text { I } 30-230\end{array}$ & Boon, G. C. (1972) \\
\hline Caerwent & $\begin{array}{l}\text { Monmouth- } \\
\text { shire }\end{array}$ & Newport & $\begin{array}{l}\text { Pentagonal. Green. } \\
\text { Length I } 1 \mathrm{~cm} \text {. }\end{array}$ & $\begin{array}{l}\text { With pottery of prob- } \\
\text { ably late Ist c. A.D. } \\
\text { (Pound Lane) }\end{array}$ & $\begin{array}{l}\text { Information from } \\
\text { Dr. G. G. Dunning, } \\
\text { see also } A \text { lxxx } \\
\text { (1930), } 239\end{array}$ \\
\hline Caernarvon & $\begin{array}{l}\text { Caernarvon- } \\
\text { shire }\end{array}$ & $\begin{array}{l}\text { Segontium Museum, } \\
\text { Caernarvon }\end{array}$ & $\begin{array}{l}\text { Translucent with } 5 \text { or } \\
6 \text { sides. Badly made }\end{array}$ & $\begin{array}{l}\text { Unstratified in } \\
\text { Roman fort }\end{array}$ & $\begin{array}{l}\text { Unpublished. } \\
\text { Information from } \\
\text { G. C. Boon }\end{array}$ \\
\hline
\end{tabular}

SMALL BICONIGAL BEADS

(I) BLUE

Grove Hill, Tingewick

Porthmeor

Probus

Uplyme,

Holcombe

Badbury

Rings,

Wimborne

Maiden

Castle,

Winterbourne

Monkton
Buckingham- Aylesbury

shire

Cornwall

Cornwall

Devon

Dorset

Dorset Club

Truro

Sidmouth 2-3

Dorchester

\section{ENGLAND}

On chain

West Cornwall Field

Dorchester 1937.57 .
Translucent. Diam. under $5 \mathrm{~mm}$.

Diam. $8 \mathrm{~mm}$. Width $7 \mathrm{~mm}$. Very small perforation

One very small translucent and another, larger

Bright translucent dark cobalt. Diam. c. $4 \mathrm{~mm}$.

Dark blue. Diam. $7 \mathrm{~mm}$.
From RomanoBritish villa

From Hut I 2 in site of long occupation

From RomanoBritish site of Carvossa

Unstratified in

Roman villa

Lent by Mr. W.C.

Wallace

From 'Belgo-Roman' level c. A.D. 25-70
FRIC xxiv (193336)

Information from Mr. H. L. Douch

$P D A S \mathrm{xxxii}$

(I974)

Wheeler, R. E. M. (r943), p. 29r and fig. 98 , no. 5 


\begin{tabular}{|c|c|c|c|c|c|}
\hline $\begin{array}{l}\text { SITE ANL } \\
\text { PARISH }\end{array}$ & GOUNTY & MUSEUM \& No. & $\begin{array}{c}\text { DESCRIPTION AND } \\
\text { APPROX. DIMENSIONS }\end{array}$ & $\begin{array}{l}\text { ASSOCIATIONS AND } \\
\text { REMARKS }\end{array}$ & PUBLICATION \\
\hline Fordington & Dorset & Dorchester I 846.2.I 5 & Small & $\begin{array}{l}\text { From Roman period } \\
\text { cemetery. Possibly } \\
\text { 3rd-4th C. A.D. }\end{array}$ & $\begin{array}{l}\text { Roach Smith, C. } \\
(1852), \text { iii, pl. ix } \\
\text { and p. } 33 \text {, and } \\
\text { R.G.H.M. } \\
\text { Dorset ii }\end{array}$ \\
\hline $\begin{array}{l}\text { Cirencester } \\
\text { (Barnsley } \\
\text { Park) }\end{array}$ & $\begin{array}{l}\text { Gloucester- } \\
\text { shire }\end{array}$ & & $\begin{array}{l}6 \text { examples, diam. } \\
\text { about } 5 \mathrm{~mm} \text {. }\end{array}$ & $\begin{array}{l}\text { From Roman villa, } \\
\text { 'probably } 3 \text { rd }-4^{\text {th c.' }}\end{array}$ & $\begin{array}{l}\text { Information from } \\
\text { Dr. Graham } \\
\text { Webster }\end{array}$ \\
\hline Frocester & $\begin{array}{l}\text { Gloucester- } \\
\text { shire }\end{array}$ & & 4 small examples & $\begin{array}{l}3 \text { from mid- } 4 \text { th c. A.D. } \\
\text { levels of Roman villa }\end{array}$ & $\begin{array}{l}\text { TBGAS lxxxix } \\
(1970)\end{array}$ \\
\hline $\begin{array}{l}\text { Weston- } \\
\text { under- } \\
\text { Penyard, Bollitr }\end{array}$ & $\begin{array}{l}\text { Herefordshire } \\
\text { ree }\end{array}$ & $\begin{array}{l}\text { Gloucester } 1769 \text { and } \\
\text { and } 1771\end{array}$ & $\begin{array}{l}2 \text { examples, one } \\
\text { opaque. Diam. } 6 \mathrm{~mm} \text {. }\end{array}$ & Roman period & $\begin{array}{l}7 B A A \times x v i i(1871), \\
207\end{array}$ \\
\hline $\begin{array}{l}\text { Richborough, } \\
\text { Ash }\end{array}$ & Kent & Richborough 2107 & $\begin{array}{l}\text { Light cobalt trans- } \\
\text { lucent. Diam. } 6 \mathrm{~mm} .\end{array}$ & $\begin{array}{l}\text { From middle layer of } \\
\text { inner stone fort ditch, } \\
\text { probably post- } \\
\text { Carausius }\end{array}$ & Rich iv, 246 \\
\hline $\begin{array}{l}\text { Bardon Mill } \\
\text { (Vindolanda) }\end{array}$ & $\begin{array}{l}\text { Northumber- } \\
\text { land }\end{array}$ & & $\begin{array}{l}\text { Translucent blue. } \\
\text { Larger than usual. } \\
\text { Diam. } 1 \mathrm{~cm} .\end{array}$ & $\begin{array}{l}\text { Stratified late } 3^{\text {rd- }} \\
4^{\text {th C. A.D. }}\end{array}$ & $\begin{array}{l}\text { Information from } \\
\text { Dr. R. E. Birley }\end{array}$ \\
\hline Chesters Fort & $\begin{array}{l}\text { Northumber- } \\
\text { land }\end{array}$ & Chesters $6 I_{4}$ & $\begin{array}{l}\text { About } 5 \text { examples. } \\
\text { One opaque and one } \\
\text { translucent. Diam. } \\
6 \text { mm. and } 2 \text { or } 3 \\
\text { very small examples }\end{array}$ & $\begin{array}{l}\text { Found in } 19 \text { th c. by } \\
\text { John Clayton in } \\
\text { excavations. Prob- } \\
\text { ably date between } \\
\text { A.D. } 122 \text { and } 3^{8} 3\end{array}$ & \\
\hline $\begin{array}{l}\text { Lamyatt } \\
\text { Beacon }\end{array}$ & Somerset & & $\begin{array}{l}\text { Irregular, translu- } \\
\text { cent. Diam. } 9 \mathrm{~mm} \text {. } \\
\text { Two others similar }\end{array}$ & $\begin{array}{l}\text { From Romano- } \\
\text { Celtic temple at } \\
\text { Lamyatt Beacon } \\
\text { begun about A.D. } 300\end{array}$ & $\begin{array}{l}\text { Information from } \\
\text { Mrs. Crystal } \\
\text { Bennett and Mr. } \\
\text { Roger Leech }\end{array}$ \\
\hline $\begin{array}{l}\text { Cold Kitchen } \\
\text { Hill, Brixton } \\
\text { Deverill }\end{array}$ & Wiltshire & Devizes & 2 examples & $\begin{array}{l}\text { Unassociated from hill } \\
\text { which produced large } \\
\text { numbers of Roman } \\
\text { beads }\end{array}$ & $\begin{array}{l}\text { For site see } W A M \\
\text { xliii (r } 926)\end{array}$ \\
\hline $\begin{array}{l}\text { Stockton } \\
\text { Earthworks }\end{array}$ & Wiltshire & Salisbury & $\begin{array}{l}\text { Bright translucent } \\
\text { cobalt. Diam. } 5 \mathrm{~mm} .\end{array}$ & Belgic-Roman site & $\begin{array}{l}W A M \text { xliii }(\mathrm{r} 926), \\
3^{89}\end{array}$ \\
\hline $\begin{array}{l}\text { Larkhill, nr. } \\
\text { Durrington } \\
\text { Walls }\end{array}$ & Wiltshire & & Blue glass & $\begin{array}{l}\text { Probably } 4^{\text {th }} \text { C. A.D. } \\
\text { pit. Feature } 188\end{array}$ & $\begin{array}{l}W A M \text { lxvi (1972), } \\
\text { I 19, fig. } 29.9\end{array}$ \\
\hline Catterick & Yorkshire & & $\begin{array}{l}\text { Bright translucent } \\
\text { cobalt. Diam. } 5 \mathrm{~mm} \text {. }\end{array}$ & Roman & $\begin{array}{l}\text { Information from } \\
\text { Mr.J. Wacher }\end{array}$ \\
\hline \multicolumn{6}{|c|}{ SGOTLAND } \\
\hline $\begin{array}{l}\text { Traprain Law, } \\
\text { Prestonkirk }\end{array}$ & E. Lothian & N.M.A. FR5 I9 & $\begin{array}{l}\text { Translucent bright } \\
\text { greenish blue. Diam. } \\
4 \mathrm{~mm} .\end{array}$ & $\begin{array}{l}\text { Native hill-fort. } \\
\text { Occupied late ist- } \\
\text { 4th c. A.D. }\end{array}$ & $\begin{array}{l}\text { For references see } \\
\text { Rivet,A.L.F.(ed.), } \\
\text { (ıg66) }\end{array}$ \\
\hline
\end{tabular}




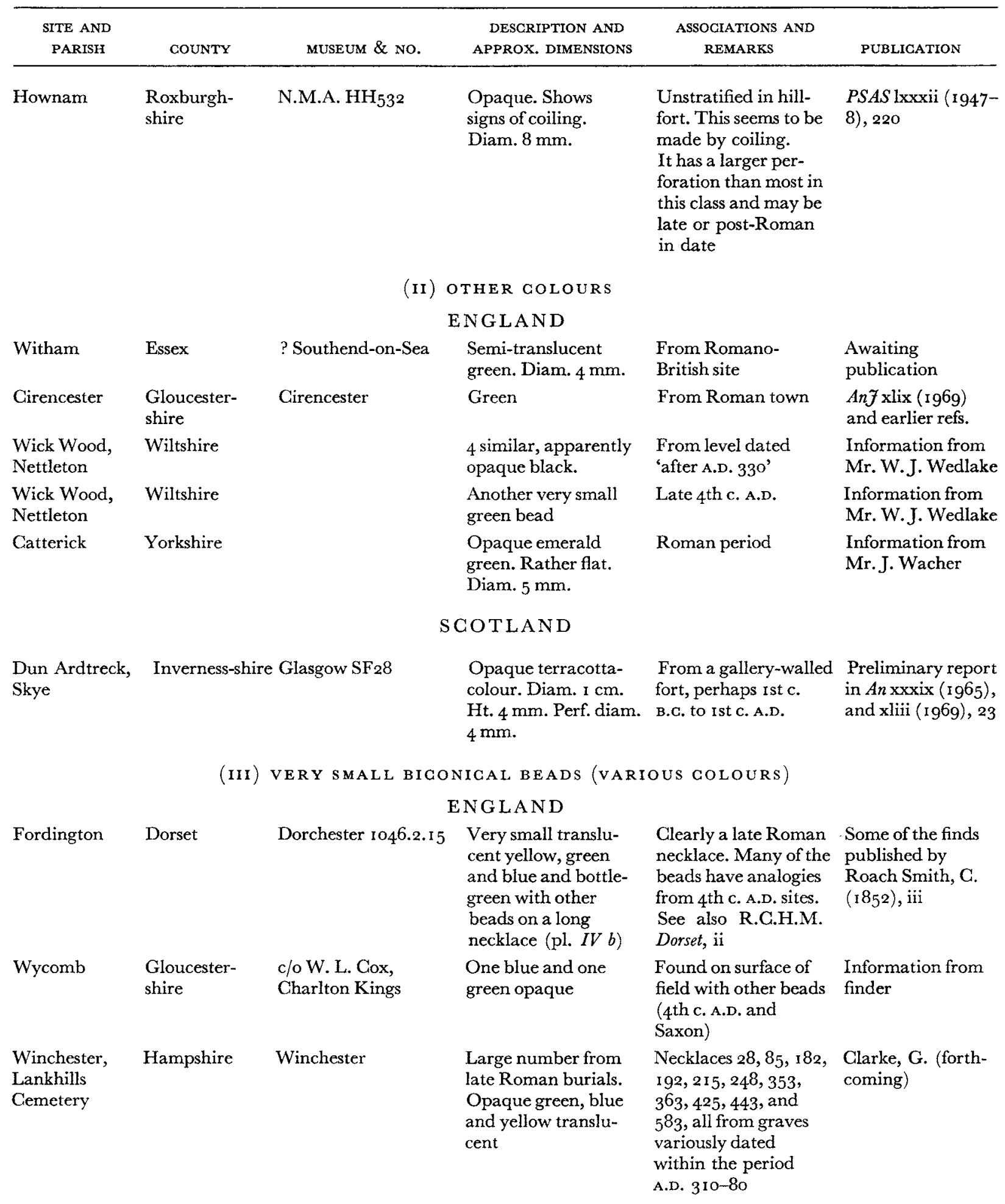




\begin{tabular}{|c|c|c|c|c|c|}
\hline $\begin{array}{l}\text { SITE AND } \\
\text { PARISH }\end{array}$ & COUNTY & MUSEUM \& NO. & $\begin{array}{c}\text { DESCRIPTION AND } \\
\text { APPROX. DIMENSIONS }\end{array}$ & $\begin{array}{l}\text { ASSOCIATIONS AND } \\
\text { REMARKS }\end{array}$ & PUBLICATION \\
\hline Icklingham & Suffolk & A.M. I927.700 & $\begin{array}{l}\text { Necklace with one } \\
\text { translucent yellow, } 7 \\
\text { green translucent } \\
\text { and } 62 \text { blue and a } \\
\text { faceted bead }\end{array}$ & $\begin{array}{l}\text { From Lackford Hills. } \\
\text { Probably } 4 \text { th c. A.D. } \\
\text { Bought. 'Found by a } \\
\text { gravel digger at } \\
\text { Lackford Hills.' The } \\
\text { association as a neck- } \\
\text { lace seems to be } \\
\text { probable }\end{array}$ & $\begin{array}{l}\text { MS. notes of J. } \\
\text { Warren of Ixworth } \\
\text { (1859,9 Feb.) in } \\
\text { A.M. }\end{array}$ \\
\hline $\begin{array}{l}\text { Cold Kitchen } \\
\text { Hill, Brixton } \\
\text { Deverill }\end{array}$ & Wiltshire & Devizes & One blue translucent & $\begin{array}{l}\text { Nearly all late Roman } \\
\text { beads from this } \\
\text { ? sacred site }\end{array}$ & $\begin{array}{l}W A M \text { xliii and xliv } \\
\text { and } U C H \text { Wilts. i }\end{array}$ \\
\hline
\end{tabular}

LONG BICONICAL BEADS

(Various colours, opaque and translucent)

\begin{tabular}{|c|c|c|c|c|c|}
\hline Holcombe & Devon & Sidmouth & $\begin{array}{l}\text { Opaque cobalt blue. } \\
\text { Length I I cm. }\end{array}$ & Unstratified & $P D A S \times x \times \mathrm{ii}$ (1974) \\
\hline Dorchester & Dorset & Dorchester & $\begin{array}{l}\text { Several examples, } \\
\text { blue-green or } \\
\text { colourless }\end{array}$ & $\begin{array}{l}\text { On necklace from } \\
\text { Poundbury Camp. } \\
\text { Late Roman }\end{array}$ & $\begin{array}{l}\text { Information from } \\
\text { excavator } 197 \text { I }\end{array}$ \\
\hline Bagendon & $\begin{array}{l}\text { Gloucester- } \\
\text { shire }\end{array}$ & Cheltenham & $\begin{array}{l}\text { Opaque terracotta- } \\
\text { coloured like Wick } \\
\text { Wood beads below. } \\
\text { Length } 9 \mathrm{~mm} \text {. }\end{array}$ & $\begin{array}{l}\text { Belgic site, probably } \\
\text { Ist C. A.D. }\end{array}$ & $\begin{array}{l}\text { Clifford, E. M. } \\
(\text { I } 96 \text { I })\end{array}$ \\
\hline Cirencester & $\begin{array}{l}\text { Gloucester- } \\
\text { shire }\end{array}$ & Cirencester & $\begin{array}{l}\text { Several blue } \\
\text { examples }\end{array}$ & $\begin{array}{l}\text { Unstratified in } \\
\text { Roman town }\end{array}$ & $\begin{array}{l}\text { Anf xlix (1 } 969 \text { ) } \\
\text { and earlier refs. }\end{array}$ \\
\hline Frocester & $\begin{array}{l}\text { Gloucester- } \\
\text { shire }\end{array}$ & & $\begin{array}{l}\text { Length I } \mathrm{cm} \text {. Almost } \\
\text { opaque turquoise } \\
\text { blue }\end{array}$ & $\begin{array}{l}\text { Probably } 3^{\text {rd }-4^{\text {th }} \mathrm{c} .} \\
\text { A.D. }\end{array}$ & $\begin{array}{l}\text { TBGAS lxxxix } \\
(1970)\end{array}$ \\
\hline Portchester & Hampshire & & $\begin{array}{l}2 \text { dull almost opaque } \\
\text { blue examples. } \\
\text { Length I } \mathrm{cm} \text {. }\end{array}$ & $\begin{array}{l}\text { From late Roman } \\
\text { levels }\end{array}$ & $\begin{array}{l}\text { Information from } \\
\text { Prof. Barry } \\
\text { Cunliffe }\end{array}$ \\
\hline Rockbourne & Hampshire & Fordingbridge & $\begin{array}{l}\text { Almost opaque } \\
\text { cobalt. Length over } \\
\text { Io } \mathrm{mm} \text {. }\end{array}$ & $\begin{array}{l}\text { Unstratified in } \\
\text { Roman villa occupied } \\
\text { throughout Roman } \\
\text { period }\end{array}$ & $\begin{array}{l}\text { Information from } \\
\text { the late Mr. A. T. } \\
\text { Morley Hewitt }\end{array}$ \\
\hline Silchester & Hampshire & Reading & Length $\mathrm{I} \cdot 2 \mathrm{~cm}$ & $\begin{array}{l}\text { Necklace with hex- } \\
\text { agonal beads and } \\
\text { other types from } \\
\text { Roman and pre- } \\
\text { Roman town }\end{array}$ & \\
\hline Kenchester & Herefordshire & Hereford & $\begin{array}{l}\text { Opaque blue. } \\
\text { Length } 1.6 \mathrm{~cm} .\end{array}$ & $\begin{array}{l}\text { Roman site occupied } \\
\text { up to about A.D. } 390\end{array}$ & $\begin{array}{l}T W \mathcal{N} F C, 1916 \text { and } \\
1926\end{array}$ \\
\hline $\begin{array}{l}\text { Weston- } \\
\text { under- } \\
\text { Penyard, }\end{array}$ & Herefordshire & Gloucester $177^{2}$ & $\begin{array}{l}\text { Opaque, atypical and } \\
\text { angular. Length } \mathrm{I} \cdot 5 \\
\mathrm{~cm} \text {. }\end{array}$ & $\begin{array}{l}\text { Necklace with other } \\
\text { Roman beads of } \\
\text { various types }\end{array}$ & $\begin{array}{l}7 B A A \text { xxvii (1 } 87 \text { I), } \\
2 \text { I I ff. }\end{array}$ \\
\hline
\end{tabular}

\section{ENGLAND}

Opaque cobalt blue. Unstratified

Several examples, On necklace from blue-green or Poundbury Camp. colourless pured like Wick

Length $9 \mathrm{~mm}$.

Length I cm. Almost que turquoise

2 dull almost opaque blue examples.

Bollitree $\mathrm{cm}$. 


\begin{tabular}{|c|c|c|c|c|c|}
\hline $\begin{array}{l}\text { SITE AND } \\
\text { PARISH }\end{array}$ & COUNTY & MUSEUM \& NO. & $\begin{array}{l}\text { DESCRIPTION AND } \\
\text { APPROX, DIMENSIONS }\end{array}$ & $\begin{array}{l}\text { ASSOCIATIONS AND } \\
\text { REMARKS }\end{array}$ & PUBLICATION \\
\hline St. Albans & Hertfordshire & $\begin{array}{l}\text { Verulamium } \\
\mathrm{T}_{34: 545}\end{array}$ & $\begin{array}{l}\text { Opaque blue. } \\
\text { Length I } \mathrm{cm} .\end{array}$ & $\begin{array}{l}\text { From the Roman } \\
\text { theatre, mid-2nd - } \\
\text { early } 4^{\text {th }} \text { C. A.D. }\end{array}$ & $A$ lxxxiv (I934) \\
\hline St. Albans & Hertfordshire & Verulamium $3^{\circ}$, I 25 & Blue. Length I $\mathrm{cm}$. & Roman & \\
\hline Ospringe & Kent & $\begin{array}{l}\text { Maison Dieu, } \\
\text { Ospringe }\end{array}$ & Length $\mathrm{I} \cdot 3 \mathrm{~cm}$ & $\begin{array}{l}\text { Group 99, nos. } 339^{-} \\
4^{\circ} . \text { Necklace dated } \\
\text { A.D. } 140-90 \text { from } \\
\text { bulbous beaker }\end{array}$ & $O_{s, \mathrm{pp}} 34-5$ \\
\hline Strood & Kent & $\begin{array}{l}\text { Humphry Wickham } \\
\text { Colln. (perhaps lost) }\end{array}$ & Opaque Samian red & $\begin{array}{l}\text { Roman burial ground } \\
\text { ranging from ist-4th } \\
\text { c. A.D. }\end{array}$ & $\begin{array}{l}\text { Roach Smith, C. } \\
\left(184^{8}\right), \text { p. I } 7 \text {, pl. ii }\end{array}$ \\
\hline $\begin{array}{l}\text { Bardon Mill } \\
\text { (Vindolanda) }\end{array}$ & $\begin{array}{l}\text { Northumber- } \\
\text { land }\end{array}$ & & $\begin{array}{l}4 \text { or } 5 \text { almost opaque } \\
\text { blue beads about } \\
\text { I } 5 \mathrm{~cm} \text {. and } 1.8 \mathrm{~cm} . \\
\text { long but various sizes }\end{array}$ & $\begin{array}{l}\text { Stratified late } 3 \text { rd- } \\
4^{\text {th C. A.D. }}\end{array}$ & $\begin{array}{l}\text { Information from } \\
\text { Mr. R. E. Birley }\end{array}$ \\
\hline Chesters Fort & $\begin{array}{l}\text { Northumber- } \\
\text { land }\end{array}$ & Ghesters 1362 & $\begin{array}{l}\text { Pale blue translucent } \\
\text { and flat. Atypical. } \\
\text { Length } \mathrm{x} \cdot 6 \mathrm{~cm} .\end{array}$ & $\begin{array}{l}\text { Roman. (This could } \\
\text { be classified with } \\
\text { heart-shaped and flat } \\
\text { beads) }\end{array}$ & \\
\hline $\begin{array}{l}\text { Stonham } \\
\text { Aspal }\end{array}$ & Suffolk & Ipswich 965-45 & $\begin{array}{l}\text { Blue. Broken at end. } \\
\text { Length } 1 \cdot 4 \mathrm{~cm} \text {. }\end{array}$ & $\begin{array}{l}\text { From ditch round } \\
\text { early } 3 \text { rd c. A.D. bath } \\
\text { building }\end{array}$ & $\begin{array}{l}P S I A \mathrm{xxx}(1966), \\
24^{\circ}, \text { fig. } 3^{8 \mathrm{e}}\end{array}$ \\
\hline $\begin{array}{l}\text { Lower } \\
\text { Beeding } \\
\text { (Money } \\
\text { Mound) }\end{array}$ & Sussex & & $\begin{array}{l}\text { Blue. Length I } \text { I } \mathrm{cm} \text {. } \\
\text { Wide and flattish. } \\
\text { Badly made }\end{array}$ & $\begin{array}{l}\text { Among Romano- } \\
\text { British objects } \\
\text { deposited in earlier } \\
\text { barrow }\end{array}$ & $\begin{array}{l}S A C \mathrm{cv}(\mathrm{I} 967), \mathrm{I} 8, \\
\text { fig. } 3\end{array}$ \\
\hline $\begin{array}{l}\text { Nr. Rugby } \\
\text { (Tripontium) }\end{array}$ & Warwickshire & & $\begin{array}{l}6 \text { translucent bottle- } \\
\text { green beads, origin- } \\
\text { ally translucent. } \\
\text { Length about } 8 \mathrm{~mm} \text {. }\end{array}$ & $\begin{array}{l}\text { On necklace with red } \\
\text { and white chevron } \\
\text { beads (see below), } \\
\text { bronze bangles and } \\
\text { iron buttons on female } \\
\text { burial }\end{array}$ & $\begin{array}{l}\text { TPBAS } \mathrm{lxxxv} \\
(1972), 13 \mathrm{I}\end{array}$ \\
\hline $\begin{array}{l}\text { Wick Wood, } \\
\text { Nettleton }\end{array}$ & Wiltshire & $\begin{array}{l}\text { c/o Bath and Camer- } \\
\text { ton Arch. Soc. }\end{array}$ & $\begin{array}{l}3 \text { opaque terracotta- } \\
\text { coloured beads with } \\
\text { striated surfaces. All } \\
\text { about } 6-9 \mathrm{~mm} \text {. long }\end{array}$ & $\begin{array}{l}\text { Stratified in Romano- } \\
\text { British site, 'before } \\
\text { A.D. } 284 \text { ' }\end{array}$ & $\begin{array}{l}\text { Information from } \\
\text { Mr. W.J. Wedlake }\end{array}$ \\
\hline
\end{tabular}

\section{LONG BLUE BIGONICAL OR SQUARE-SEGTIONED BEADS WITH RED AND WHITE BAND OR GHEVRON}

\section{ENGLAND}

$\begin{array}{lll}\begin{array}{l}\text { Nor' nour, } \\ \text { Scilly }\end{array} & \text { Cornwall } & \text { St. Mary's, Scilly } \\ \begin{array}{l}\text { Fordington, } \\ \text { Dorchester }\end{array} & \text { Dorset } & \text { Dorchester }\end{array}$
Small with single From Roman site wave in red, bordered unstratified in white
2 possible examples on Necklace probably long necklace. The 3 rd-4th c. A.D. red has quite dis- Probably intrusive appeared

Main report published in Arf cxxiv (1967), $\mathrm{I}$ ff.

R.C.H.M. Dorset 


\begin{tabular}{|c|c|c|c|c|c|}
\hline $\begin{array}{l}\text { SITE AND } \\
\text { PARISH }\end{array}$ & COUNTY & MUSEUM \& NO. & $\begin{array}{l}\text { DESGRIPTION AND } \\
\text { APPROX. DIMENSIONS }\end{array}$ & $\begin{array}{l}\text { ASSOCIATIONS AND } \\
\text { REMARKS }\end{array}$ & PUBLICATION \\
\hline $\begin{array}{l}\text { Tarrant } \\
\text { Hinton }\end{array}$ & Dorset & Wimborne & $\begin{array}{l}\text { Rounded biconical } \\
\text { bead. Length } c .1 \mathrm{~cm} \text {. }\end{array}$ & $\begin{array}{l}\text { Found on Roman } \\
\text { site } 1975^{-76}\end{array}$ & $\begin{array}{l}\text { Excavations in } \\
\text { progress }\end{array}$ \\
\hline Rockbourne & Hampshire & $\begin{array}{l}\text { Roman Villa } \\
\text { Museum, Rock- } \\
\text { bourne }\end{array}$ & $\begin{array}{l}\text { Long, rather biconi- } \\
\text { cal, with single red } \\
\text { wave outlined in } \\
\text { white. Length I } 2 \\
\text { cm. }\end{array}$ & $\begin{array}{l}\text { Unstratified in villa } \\
\text { occupied throughout } \\
\text { Roman period }\end{array}$ & $\begin{array}{l}\text { Information from } \\
\text { the late } \mathrm{Mr}, \mathrm{A} . \mathrm{T} \text {. } \\
\text { Morley Hewitt }\end{array}$ \\
\hline St. Albans & Hertfordshire & Verulamium 232 & & $\begin{array}{l}\text { From woman's grave } \\
\text { near N.W. gate. Late } \\
\text { Roman, probably } \\
4^{\text {th c. A.D. }}\end{array}$ & $\begin{array}{l}V e, \text { p. } 214, \text { fig. } 47 \\
\text { no. } 67 \text { n. }\end{array}$ \\
\hline Ospringe & Kent & $\begin{array}{l}\text { Maison Dieu, } \\
\text { Ospringe }\end{array}$ & $\begin{array}{l}\text { Several small beads } \\
\text { with single red wave } \\
\text { outlined in white }\end{array}$ & $\begin{array}{l}\text { From an unrecorded } \\
\text { grave with } 3 \text { rd- } 4 \text { th c. } \\
\text { A.p. finger ring, } \\
\text { bracelets, etc. }\end{array}$ & \\
\hline $\begin{array}{l}\text { Bardon Mill } \\
\text { (Vindolanda) }\end{array}$ & $\begin{array}{l}\text { Northumber- } \\
\text { land }\end{array}$ & & 2 small examples & $\begin{array}{l}\text { Stratified late } 3^{\text {rd- }} \\
4^{\text {th C. A.D. }}\end{array}$ & $\begin{array}{l}\text { Information from } \\
\text { Mr. R. E. Birley }\end{array}$ \\
\hline $\begin{array}{l}\text { Great } \\
\text { Chesters }\end{array}$ & $\begin{array}{l}\text { Northumber- } \\
\text { land }\end{array}$ & $\begin{array}{l}\text { University Museum, } \\
\text { Newcastle-upon- } \\
\text { Tyne }\end{array}$ & $\begin{array}{l}\text { Length I } \mathrm{I} \mathrm{cm} \text {. with } \\
\text { one red band edged } \\
\text { in white }\end{array}$ & $\begin{array}{l}\text { Unstratified from } \\
\text { Roman site }\end{array}$ & \\
\hline Stouting & Sussex & $\begin{array}{l}\text { C.M., Beck Colln. } \\
{ }_{1704 \mathrm{~b}}\end{array}$ & $\begin{array}{l}\text { Larger than normal } \\
\text { red band bordered in } \\
\text { red. Max. diam. } \\
6 \mathrm{~mm} \text {. Length } \mathrm{I} .5 \mathrm{~cm} \text {. }\end{array}$ & $\begin{array}{l}\text { This came from a } \\
\text { colln. with many } \\
\text { Anglo-Saxon beads }\end{array}$ & \\
\hline $\begin{array}{l}\text { Nr Rugby } \\
\text { (Tripontium) }\end{array}$ & Warwickshire & & $\begin{array}{l}9 \text { examples, all long } \\
\text { biconical with single } \\
\text { chevron. Average } \\
\text { length } 8 \mathrm{~mm} \text {. }\end{array}$ & $\begin{array}{l}\text { With } 6 \text { long biconical } \\
\text { green beads of same } \\
\text { size. With female } \\
\text { burial with bronze } \\
\text { bangles and iron } \\
\text { buttons }\end{array}$ & $\begin{array}{l}T P B A S \mathrm{lxxxv} \\
(1972), \mathrm{I}_{3} \mathrm{r}\end{array}$ \\
\hline $\begin{array}{l}\text { Cold Kitchen } \\
\text { Hill, Brixton } \\
\text { Deverill }\end{array}$ & Wiltshire & Devizes & $\begin{array}{l}\text { Rather biconical. } \\
\text { Length I cm. Single } \\
\text { chevron }\end{array}$ & $\begin{array}{l}\text { Unassociated, from } \\
\text { hill producing large } \\
\text { quantities of Roman } \\
\text { period beads }\end{array}$ & $\begin{array}{l}\text { For site see } W A M \\
\text { xliii }(1926)\end{array}$ \\
\hline $\begin{array}{l}\text { Wick Wood, } \\
\text { Nettleton }\end{array}$ & Wiltshire & $\begin{array}{l}\text { Bath and Camerton } \\
\text { Arch. Soc. }\end{array}$ & $\begin{array}{l}2 \text { small and typical } \\
\text { examples on a neck- } \\
\text { lace }\end{array}$ & $\begin{array}{l}\text { Dated 'before } 284 \text { ' } \\
\text { A.D. }\end{array}$ & $\begin{array}{l}\text { Information from } \\
\text { Mr. W.J. Wedlake }\end{array}$ \\
\hline \multicolumn{6}{|c|}{ SGOTLAND } \\
\hline $\begin{array}{l}\text { Traprain Law, } \\
\text { Prestonkirk }\end{array}$ & E. Lothian & $\begin{array}{l}\text { N.M.A. } 1923.270 \\
\text { small example }\end{array}$ & $\begin{array}{l}\text { One example with } \\
\text { single red wave with } \\
\text { white border. One, } \\
\text { longer, with two } \\
\text { similar waves }\end{array}$ & $\begin{array}{l}\text { Not stratified on site } \\
\text { occupied throughout } \\
\text { Roman period }\end{array}$ & $\begin{array}{l}\text { Larger example, } \\
P S A S \text { lvii }\left(19^{22-3)},\right. \\
225 \text { and fig. } 22, \\
\text { p. } 2 \text { I } 2\end{array}$ \\
\hline
\end{tabular}




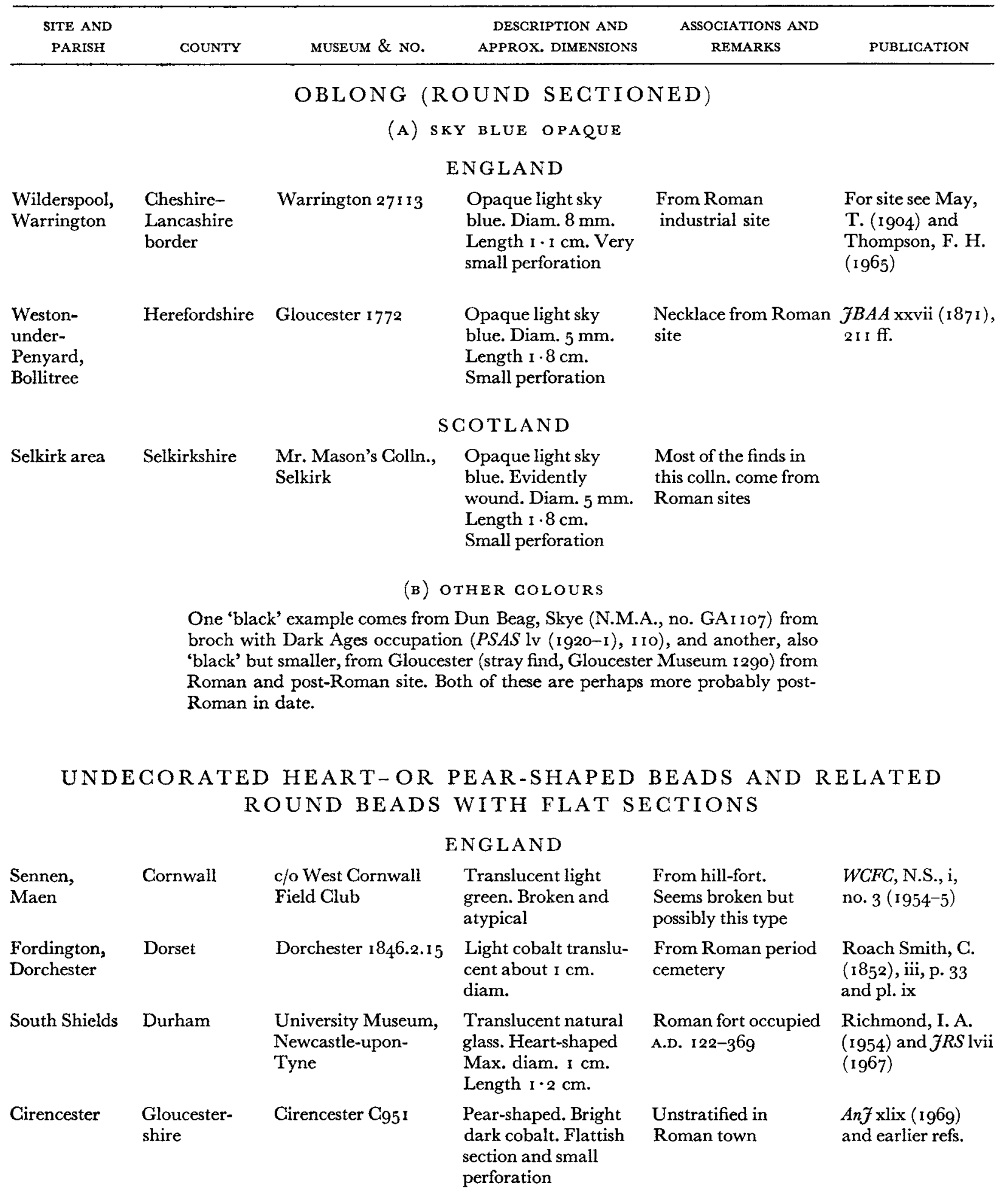




\begin{tabular}{|c|c|c|c|c|c|}
\hline $\begin{array}{l}\text { SITE AND } \\
\text { PARISH }\end{array}$ & COUNTY & MUSEUM \& NO. & $\begin{array}{l}\text { DESGRIPTION AND } \\
\text { APPROX. DIMENSIONS }\end{array}$ & $\begin{array}{l}\text { ASSOCIATIONS AND } \\
\text { REMARKS }\end{array}$ & PUBLICATION \\
\hline Frocester & $\begin{array}{l}\text { Gloucester- } \\
\text { shire }\end{array}$ & & $\begin{array}{l}\text { Pear-shaped, } \\
\text { colourless. Length } \\
\text { I.2 cm. }\end{array}$ & $\begin{array}{l}\text { Not clearly stratified } \\
\text { in villa occupied } \\
\text { from } c \text {. A.D. } 275\end{array}$ & $\begin{array}{l}\text { TBGAS lxxxix } \\
(\mathrm{r} 970)\end{array}$ \\
\hline Frocester & $\begin{array}{l}\text { Gloucester- } \\
\text { shire }\end{array}$ & & $\begin{array}{l}\text { Two small round } \\
\text { beads with flat } \\
\text { sections }\end{array}$ & $\begin{array}{l}\text { Stratified late } 3 \text { rd c. A.D } \\
\text { from Frocester } \\
\text { Court Roman Villa }\end{array}$ & \\
\hline Wolham & $\begin{array}{l}\text { Gloucester- } \\
\text { shire }\end{array}$ & Gloucester $36 / 1942$ & $\begin{array}{l}\text { Triangular green, } \\
\text { translucent. Diam. } \\
2 \cdot 3 \mathrm{~cm} .\end{array}$ & $\begin{array}{l}\text { From Roman and } \\
\text { post-Roman site }\end{array}$ & \\
\hline Owslebury & Hampshire & & $\begin{array}{l}\text { Round, bright, } \\
\text { almost opaque } \\
\text { cobalt with flat sec- } \\
\text { tion. Diam. } 7 \mathrm{~mm} \text {. }\end{array}$ & Probably $4^{\text {th }}$ c. A.D. & $\begin{array}{l}\text { First report in } \\
\text { Anf xlviii ( ( } 968) \text {, } \\
\text { I } 8 \mathrm{ff} .\end{array}$ \\
\hline Portchester & Hampshire & & $\begin{array}{l}\text { Small almost opaque } \\
\text { cobalt heart-shaped } \\
\text { with diamond- } \\
\text { shaped perforation }\end{array}$ & $\begin{array}{l}\text { Late Roman deposit } \\
\text { in Saxon shore-fort } \\
\text { built late 3rd c. A.D. }\end{array}$ & $\begin{array}{l}\text { See } A n f \text { xlix } \\
(1969), 62\end{array}$ \\
\hline Rockbourne & Hampshire & $\begin{array}{l}\text { Roman Villa } \\
\text { Museum, Rock- } \\
\text { bourne }\end{array}$ & $\begin{array}{l}\text { Translucent natural } \\
\text { glass. Pear-shaped. } \\
\text { Length I } 1 \mathrm{~cm} \text {. Flat } \\
\text { section }\end{array}$ & $\begin{array}{l}\text { Villa occupied } \\
\text { throughout Roman } \\
\text { period }\end{array}$ & $\begin{array}{l}\text { Information from } \\
\text { the late Mr. A. T. } \\
\text { Morley Hewitt }\end{array}$ \\
\hline $\begin{array}{l}\text { Winchester, } \\
\text { Lankhills } \\
\text { Cemetery }\end{array}$ & Hampshire & & $\begin{array}{l}\text { Translucent, light } \\
\text { blue glass. Length } \\
0.8 \mathrm{~cm} .\end{array}$ & $\begin{array}{l}\text { Necklace } 363 \text {, from } \\
\text { Grave } 33^{6} \text {, dated } c \text {. } \\
\text { A.D. } 35^{\circ}-70\end{array}$ & $\begin{array}{l}\text { Clarke, G. (forth- } \\
\text { coming) }\end{array}$ \\
\hline Kenchester & Herefordshire & Hereford & $\begin{array}{l}\text { Translucent natural } \\
\text { glass. Wide heart- } \\
\text { shaped. Length I · } 3 \\
\mathrm{~cm} \text {. and flattish } \\
\text { section }\end{array}$ & $\begin{array}{l}\text { From Roman town } \\
\text { occupied till about } \\
\text { A.D. } 39^{\circ}\end{array}$ & $\begin{array}{l}T W \mathcal{N} F C 19 \mathrm{I} 6 \text { and } \\
1926\end{array}$ \\
\hline St. Albans & Hertfordshire & Verulamium & $\begin{array}{l}\text { Translucent pale } \\
\text { green. Oval. Diam. } \\
\mathrm{I} \cdot 4 \mathrm{~cm} .\end{array}$ & $\begin{array}{l}\text { Evidently on a } \\
\text { necklace with other } \\
\text { Roman beads. Prob- } \\
\text { ably } 4 \text { th c. A.D. }\end{array}$ & $\begin{array}{l}V e, \text { not shown in } \\
\text { fig. } 47 \text { where } \\
\text { representative } \\
\text { selection only } \\
\text { illustrated }\end{array}$ \\
\hline $\begin{array}{l}\text { Godman- } \\
\text { chester }\end{array}$ & $\begin{array}{l}\text { Huntingdon- } \\
\text { shire }\end{array}$ & & $\begin{array}{l}\text { Light blue, pear- } \\
\text { shaped with round } \\
\text { section. Length } \\
9 \mathrm{~mm} \text {. }\end{array}$ & $\begin{array}{l}\text { Late ist or early and } \\
\text { C. A.D. Roman }\end{array}$ & $\begin{array}{l}P C A S \text { liv (1960), } \\
57 \text { and } 22\end{array}$ \\
\hline $\begin{array}{l}\text { Manchester } \\
\text { (Castlefields) }\end{array}$ & Lancashire & & $\begin{array}{l}\text { Heart-shaped. } \\
\text { Natural glass. } \\
\text { Approx. diam. I } \cdot \mathrm{I} \\
\mathrm{cm} \text {. Length } \mathrm{I} \cdot 4 \mathrm{~cm} \text {. }\end{array}$ & From Roman fort & $\begin{array}{l}A \text { xxxiv }(1852), \\
\text { pl. v }\end{array}$ \\
\hline $\begin{array}{l}\text { Wilderspool, } \\
\text { Warrington }\end{array}$ & $\begin{array}{l}\text { Lancashire- } \\
\text { Cheshire } \\
\text { border }\end{array}$ & Warrington 386 'o6 & $\begin{array}{l}\text { Wide pear-shaped. } \\
\text { Very fractured. } \\
\text { Translucent bright } \\
\text { clear glass. Max. } \\
\text { diam. I } 3 \mathrm{~mm} \text {. Ht. } \\
\text { I } 5 \mathrm{~mm} \text {. }\end{array}$ & Roman industrial site & $\begin{array}{l}\text { May, T. (1904) } \\
\text { and Thompson, } \\
\text { F. H. (1965) }\end{array}$ \\
\hline
\end{tabular}




\begin{tabular}{|c|c|c|c|c|c|}
\hline $\begin{array}{l}\text { SITE AND } \\
\text { PARISH }\end{array}$ & COUNTY & MUSEUM \& No. & $\begin{array}{l}\text { DESGRIPTION AND } \\
\text { APPROX. DIMENSIONS }\end{array}$ & $\begin{array}{l}\text { ASSOCIATIONS AND } \\
\text { REMARKS }\end{array}$ & PUBLICATION \\
\hline $\begin{array}{l}\text { Chesters } \\
\text { Fort }\end{array}$ & $\begin{array}{l}\text { Northumber- } \\
\text { land }\end{array}$ & $\begin{array}{l}\text { Chesters Museum } \\
6 \mathrm{I} 4\end{array}$ & $\begin{array}{l}\text { Translucent cobalt } \\
\text { blue. Heart-shaped. } \\
\text { Max. diam. } 1 \mathrm{~cm} \text {. } \\
\text { Length } 1.2 \mathrm{~cm} .\end{array}$ & $\begin{array}{l}\text { Probable date A.D. } \\
\text { 1 } 22-3^{8} 3\end{array}$ & \\
\hline $\begin{array}{l}\text { Chesters } \\
\text { Fort }\end{array}$ & $\begin{array}{l}\text { Northumber- } \\
\text { land }\end{array}$ & $\begin{array}{l}\text { Chesters Museum } \\
6 \mathrm{I}_{4}\end{array}$ & $\begin{array}{l}\text { Another smaller } \\
\text { heart-shaped }\end{array}$ & $\begin{array}{l}\text { Probable date A.D. } \\
122-3^{8} 3\end{array}$ & \\
\hline $\begin{array}{l}\text { Great } \\
\text { Chesters }\end{array}$ & $\begin{array}{l}\text { Northumber- } \\
\text { land }\end{array}$ & $\begin{array}{l}\text { Chesters Museum } \\
2508\end{array}$ & $\begin{array}{l}\text { Light blue translu- } \\
\text { cent. Heart-shaped. } \\
\text { Max. diam. I } 3 \mathrm{~cm} \text {. } \\
\text { Length I } 5 \mathrm{~cm} \text {. } \\
\text { Small perforation }\end{array}$ & $\begin{array}{l}\text { Probable date A.D. } \\
\text { I } 22-3^{8} 3\end{array}$ & \\
\hline Bath & Somerset & Bath & $\begin{array}{l}\text { Bright translucent } \\
\text { blue. Irregular and } \\
\text { perhaps accidentally } \\
\text { heart-shaped. } \\
\text { Length } 7 \mathrm{~mm} \text {. }\end{array}$ & $\begin{array}{l}\text { From Roman baths } \\
\text { begun at end of ist c. } \\
\text { A.D. and frequented } \\
\text { through Roman } \\
\text { period }\end{array}$ & $\begin{array}{l}\text { See Cunliffe, B., } \\
\text { Roman Bath } \\
\text { Discovered (1971) } \\
\text { and refs. }\end{array}$ \\
\hline Camerton & Somerset & Bristol F753 & $\begin{array}{l}\text { Circular translucent } \\
\text { natural glass. Flat } \\
\text { section and very } \\
\text { small perforation. } \\
\text { Diam. } 1 \mathrm{~cm} \text {. } \\
\text { Length } \mathrm{I} \cdot 3 \mathrm{~cm} \text {. }\end{array}$ & $\begin{array}{l}\text { Roman and post- } \\
\text { Roman site }\end{array}$ & $\begin{array}{l}\text { Wedlake, W.J } \\
\left(195^{8)}\right.\end{array}$ \\
\hline $\begin{array}{l}\text { Ham Hill, } \\
\text { Montacute }\end{array}$ & Somerset & Taunton & $\begin{array}{l}\text { Bottle glass. Oval. } \\
\text { Length } \mathrm{I} \cdot 3 \mathrm{~cm} . \\
\text { Another }\end{array}$ & $\begin{array}{l}\text { Iron Age hill-fort with } \\
\text { later Roman occu- } \\
\text { pation. Unstratified. } \\
\text { Several with late } \\
\text { Roman beads }\end{array}$ & $\begin{array}{l}\text { For site, see } V C H \\
\text { Somerset i, p. } 295\end{array}$ \\
\hline $\begin{array}{l}\text { Lamyatt } \\
\text { Beacon }\end{array}$ & Somerset & $\begin{array}{l}\text { c/o Mrs. Crystal } \\
\text { Bennett, Bruton, and } \\
\text { Mr. Roger Leech }\end{array}$ & $\begin{array}{l}\text { Small, round, } \\
\text { translucent green } \\
\text { with flat section. } \\
\text { Diam. } 7 \mathrm{~mm} \text {. } \\
\text { Another similar but } \\
\text { oval }\end{array}$ & $\begin{array}{l}\text { From Romano- } \\
\text { Cieltic temple prob- } \\
\text { ably begun } c . \text { A.D. } \\
300 \text { and frequented } \\
\text { into } 5 \text { th } c \text {. }\end{array}$ & $\begin{array}{l}\text { See Lewis, } \\
\text { M.J. T., Temples in } \\
\text { Roman Britain } \\
(1970)\end{array}$ \\
\hline $\begin{array}{l}\text { Castle Hill, } \\
\text { Whitton }\end{array}$ & Suffolk & Ipswich $194^{8 .}$ I 6 & $\begin{array}{l}\text { Translucent bottle } \\
\text { glass. Oval with flat } \\
\text { section. Length } \mathrm{I} \cdot 4 \\
\mathrm{~cm} \text {. Width } 9 \mathrm{~mm} \text {. }\end{array}$ & $\begin{array}{l}\text { Roman villa thought } \\
\text { to be dated } c . \text { A.D. } \\
\text { 130-29o. On neck- } \\
\text { lace with all globular } \\
\text { beads }\end{array}$ & $\begin{array}{l}P S I A \times x i(193 I-3), \\
249 \text { ff. }\end{array}$ \\
\hline Lakenheath & Suffolk & $\begin{array}{l}\text { C.M., Beck Colln. } \\
{ }_{1} 735\end{array}$ & $\begin{array}{l}\text { Translucent green } \\
\text { oval. Length } \mathrm{I} \mathrm{cm} .\end{array}$ & & \\
\hline $\begin{array}{l}\text { Lower Beeding } \\
\text { (Money } \\
\text { Mound) }\end{array}$ & Sussex & & $\begin{array}{l}\text { Glear colourless } \\
\text { glass. Heart-shaped. } \\
\text { Length } 7 \mathrm{~mm} \text {. }\end{array}$ & $\begin{array}{l}\text { Early barrow with } \\
\text { deposit of Romano- } \\
\text { British objects in it }\end{array}$ & $\begin{array}{l}S A C \mathrm{cv}(1967), \mathrm{I} 8 \\
\text { fig. } 3\end{array}$ \\
\hline $\begin{array}{l}\text { Stockton } \\
\text { Earthworks }\end{array}$ & Wiltshire & Salisbury & $\begin{array}{l}\text { Black circular flat } \\
\text { bead. Diam. } 8 \mathrm{~mm} .\end{array}$ & $\begin{array}{l}\text { Probably Roman } \\
\text { period. Belgic- } \\
\text { Roman site }\end{array}$ & $\begin{array}{l}W A M \times \operatorname{xiii}\left(1925^{-}\right. \\
6), 3^{89}\end{array}$ \\
\hline $\begin{array}{l}\text { Stockton } \\
\text { Earthworks }\end{array}$ & Wiltshire & Salisbury & $\begin{array}{l}\text { Translucent bottle } \\
\text { glass. Length } \mathrm{I} \mathrm{cm} \text {. } \\
\text { Width } 7 \mathrm{~mm} \text {. }\end{array}$ & As above & Ibid. \\
\hline
\end{tabular}




\begin{tabular}{|c|c|c|c|c|c|}
\hline $\begin{array}{l}\text { SITE AND } \\
\text { PARISH }\end{array}$ & COUNTY & MUSEUM \& NO. & $\begin{array}{l}\text { DESGRIPTION AND } \\
\text { APPROX. DIMENSIONS }\end{array}$ & $\begin{array}{l}\text { ASSOGIATIONS AND } \\
\text { REMARKS }\end{array}$ & PUBLTCATION \\
\hline \multicolumn{6}{|c|}{ SCOTLAND } \\
\hline Nr. Coulter & $\begin{array}{l}\text { Lanark- } \\
\text { shire }\end{array}$ & $\begin{array}{l}\text { N.M.A., Sim Colln. } \\
\text { FJ32 }\end{array}$ & $\begin{array}{l}\text { Bright green trans- } \\
\text { lucent rather } \\
\text { heart-shaped. Length } \\
\text { I } 2 \mathrm{~cm} \text {. }\end{array}$ & Possibly post-Roman & \\
\hline \multicolumn{6}{|c|}{ WALES } \\
\hline $\begin{array}{l}\text { Whitton, nr. } \\
\text { Barry }\end{array}$ & Glamorgan & N.M.W. & $\begin{array}{l}\text { Irregular, badly } \\
\text { made. Bottle glass. } \\
\text { Round section. } \\
\text { Length } \mathrm{I} \cdot 3 \mathrm{~cm} \text {. }\end{array}$ & $\begin{array}{l}\text { Site occupied } c . \text { ist c. } \\
\text { B.C. to A.D. } 300\end{array}$ & $\begin{array}{l}\text { Information from } \\
\text { Dr. Michael } \\
\text { Jarrett }\end{array}$ \\
\hline \multicolumn{6}{|c|}{$\begin{array}{c}\text { FAGETED BEADS } \\
\text { (Square section with diamond-shaped facets) }\end{array}$} \\
\hline \multicolumn{6}{|c|}{ ENGLAND } \\
\hline Cirencester & $\begin{array}{l}\text { Gloucester- } \\
\text { shire }\end{array}$ & $\begin{array}{l}\text { Corinium Museum, } \\
\text { Cirencester }\end{array}$ & $\begin{array}{l}\text { Bright translucent } \\
\text { blue. Length } 8 \mathrm{~mm} \text {. }\end{array}$ & $\begin{array}{l}4^{\text {th or early }} 5^{\text {th }} \mathrm{c} \text {. } \\
\text { A.D. from burial, } \\
\text { excavated } 1973\end{array}$ & $\begin{array}{l}\text { Awaiting } \\
\text { publication }\end{array}$ \\
\hline Girencester & $\begin{array}{l}\text { Gloucester- } \\
\text { shire }\end{array}$ & $\begin{array}{l}\text { Corinium Museum, } \\
\text { Cirencester }\end{array}$ & $\begin{array}{l}\text { Large bead. Blue. } \\
\text { Length } \mathrm{I} \mathrm{cm} . \mathrm{Ht} \text {. } \\
9 \mathrm{~mm} .\end{array}$ & $\begin{array}{l}\text { On a wire with } 2 \\
\text { melon beads and one } \\
\text { cut green cylinder }\end{array}$ & \\
\hline Wycombe & $\begin{array}{l}\text { Gloucester- } \\
\text { shire }\end{array}$ & $\begin{array}{l}\text { c/o W. L. Cox, } \\
\text { Charlton Kings, } \\
\text { Cheltenham }\end{array}$ & $\begin{array}{l}\text { Length } 7 \mathrm{~mm} . \mathrm{Ht} \text {. } \\
5 \mathrm{~mm} \text {. Blue }\end{array}$ & $\begin{array}{l}\text { Surface find with } \\
\text { other beads ( } 4 \text { th c. } \\
\text { and Saxon) in field }\end{array}$ & $\begin{array}{l}\text { Information from } \\
\text { finder }\end{array}$ \\
\hline $\begin{array}{l}\text { Winchester, } \\
\text { Lankhills } \\
\text { Cemetery }\end{array}$ & Hampshire & Winchester & $\begin{array}{l}\text { Several cube-shaped } \\
\text { blue and green } \\
\text { examples about } \\
6 \mathrm{~mm} \text {. long }\end{array}$ & $\begin{array}{l}\text { Necklace } 140,3^{63} \text {, } \\
424 \text {, and } 436 \text {, all in } \\
\text { graves dated to } \\
\text { A.D. } 35^{\circ-70}\end{array}$ & $\begin{array}{l}\text { Clarke, G. (forth- } \\
\text { coming) }\end{array}$ \\
\hline $\begin{array}{l}\text { Bradley Hill, } \\
\text { Somerton }\end{array}$ & Somerset & & $\begin{array}{l}\text { Translucent blue. } \\
\text { Square. } 5 \mathrm{~mm} \text {. long }\end{array}$ & $\begin{array}{l}\text { With a burial. From } \\
\text { homestead site with } \\
\text { accompanying East- } \\
\text { West graves. } \\
\text { Beginning not later } \\
\text { than A.D. } 370 \text { and } \\
\text { running into the } 5 \text { th } \\
\text { c. }\end{array}$ & $\begin{array}{l}\text { C.B.A. groups XII } \\
\text { and XIII, Arch. } \\
\text { Rev. vii (1972), 39- } \\
4^{1}\end{array}$ \\
\hline Lufton & Somerset & $\begin{array}{l}\text { Yeovil Borough } \\
\text { Museum }\end{array}$ & $\begin{array}{l}\text { Bright translucent } \\
\text { blue }\end{array}$ & $\begin{array}{l}\text { From same horizon as } \\
\text { a coin of Constantine } \\
\text { II as Caesar (A.D. } \\
33^{-}-335 \text { ) }\end{array}$ & $\begin{array}{l}P S A N H S \text { cxvi } \\
(197 \text { I-2), 66, } \\
\text { fig. } 5\end{array}$ \\
\hline Mendip & Somerset & $\begin{array}{l}\text { A. C. Pass Colln., } \\
\text { Bristol F } 2089\end{array}$ & $\begin{array}{l}\text { Long. Translucent } \\
\text { green. Length } 1 \cdot 2 \\
\text { cm. Ht. } 5 \mathrm{~mm} . \text { Perf. } \\
\text { diam. I mm. }\end{array}$ & $\begin{array}{l}\text { From a collection } \\
\text { containing many } \\
\text { Roman beads }\end{array}$ & \\
\hline
\end{tabular}




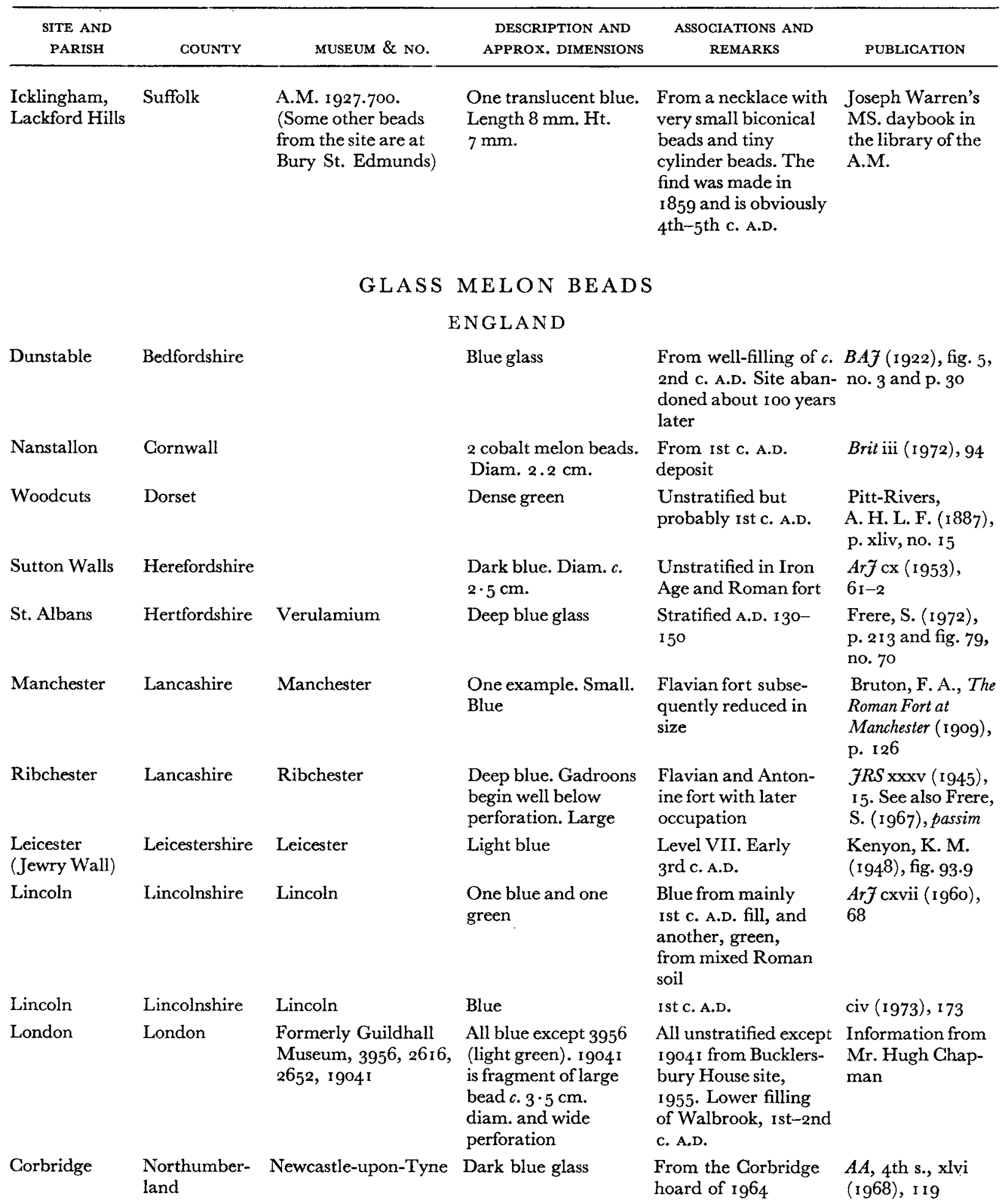




\begin{tabular}{|c|c|c|c|c|c|}
\hline $\begin{array}{l}\text { SITE AND } \\
\text { PARISH }\end{array}$ & GOUNTY & MUSEUM \& No. & $\begin{array}{l}\text { DESCRIPTION AND } \\
\text { APPROX. DIMENSIONS }\end{array}$ & $\begin{array}{l}\text { ASSOCIATIONS AND } \\
\text { REMARKS }\end{array}$ & PUBLICATION \\
\hline Ebchester & $\begin{array}{l}\text { Northumber- } \\
\text { land }\end{array}$ & & $\begin{array}{l}\text { Half a deep blue } \\
\text { glass melon bead }\end{array}$ & Early Roman & $\begin{array}{l}A A, 5^{\text {th }} \text { s., vii } \\
(1975), 78\end{array}$ \\
\hline Great Chesters & $\begin{array}{l}\text { Northumber- } \\
\text { land }\end{array}$ & $\begin{array}{l}\text { Newcastle-upon-Tyne } \\
\text { r } 956.63 \mathrm{~A}\end{array}$ & $\begin{array}{l}\text { Half bead in dark } \\
\text { blue opaque glass }\end{array}$ & & \\
\hline Housesteads & $\begin{array}{l}\text { Northumber- } \\
\text { land }\end{array}$ & $\begin{array}{l}\text { Newcastle-upon-Tyne } \\
\text { 1956.15 } 5.24 . A\end{array}$ & $\begin{array}{l}\text { Fragment of dark } \\
\text { blue bead }\end{array}$ & & \\
\hline $\begin{array}{l}\text { Milking Gap, } \\
\text { High Shield }\end{array}$ & $\begin{array}{l}\text { Northumber- } \\
\text { land }\end{array}$ & $\begin{array}{l}\text { University Museum, } \\
\text { Newcastle-upon- } \\
\text { Tyne }\end{array}$ & $\begin{array}{l}\text { Two fragmentary } \\
\text { translucent blue } \\
\text { beads, } c .3 \mathrm{~cm} \text {. diam. }\end{array}$ & $\begin{array}{l}\text { This site was occu- } \\
\text { pied from about } \\
\text { A.D. } 122-80 \text { at latest }\end{array}$ & $\begin{array}{l}A A, 4^{\text {th s., }} \mathrm{xv} \\
\left(193^{8}\right), 34^{6}\end{array}$ \\
\hline $\begin{array}{l}\text { Wick Wood, } \\
\text { Nettleton }\end{array}$ & Wilts. & $\begin{array}{l}\text { c/o Bath and } \\
\text { Camerton Arch. Soc. }\end{array}$ & $\begin{array}{l}\text { Fragment of large } \\
\text { blue melon bead }\end{array}$ & Romano-British & $\begin{array}{l}\text { Information from } \\
\text { Mr. W.J. Wedlake }\end{array}$ \\
\hline Chiches ter & Sussex & Chichester & Blue & $\begin{array}{l}\text { From Grave } 228 \\
\text { associated with late } \\
\text { Antonine pottery }\end{array}$ & $\begin{array}{l}\text { Down, A. and } \\
\text { Rule, M., } \\
\text { Chichester Excava- } \\
\text { tions, i (1971) }\end{array}$ \\
\hline $\begin{array}{l}\text { Wick Wood, } \\
\text { Nettleton }\end{array}$ & Wiltshire & $\begin{array}{l}\text { c/o Bath and Camer- } \\
\text { ton Arch. Soc. }\end{array}$ & $\begin{array}{l}\text { Fragment. Large. } \\
\text { Blue }\end{array}$ & Cutting A, layer 2 & $\begin{array}{l}\text { Information from } \\
\text { Mr. W.J. Wedlake }\end{array}$ \\
\hline Castleford & Yorkshire & & $\begin{array}{l}\text { At least } 6 \text { blue glass } \\
\text { melon beads and } \\
\text { lumps of the same } \\
\text { glass as waste }\end{array}$ & $\begin{array}{l}\text { A Roman site, perhaps } \\
\text { making beads } \\
\text { among its products }\end{array}$ & $\begin{array}{l}\text { Information from } \\
\text { excavator }\end{array}$ \\
\hline $\begin{array}{l}\text { Edlington } \\
\text { Wood, nr. } \\
\text { Doncaster }\end{array}$ & Yorkshire & & $\begin{array}{l}\text { Fragment, dark blue } \\
\text { glass melon bead, } \\
\text { gadroons start well } \\
\text { below the perfora- } \\
\text { tion }\end{array}$ & $\begin{array}{l}\text { Probably Hadrianic-- } \\
\text { Antonine }\end{array}$ & $\begin{array}{l}\text { Grimes, W. F. } \\
\text { (ed.) (195I) }\end{array}$ \\
\hline $\begin{array}{l}\text { Rotherham } \\
\text { (Temple- } \\
\text { brough) }\end{array}$ & Yorkshire & Rotherham & Several examples & $\begin{array}{l}\text { From excavations of } \\
192 \mathrm{I} \text {. Two forts both } \\
\text { before Hadrian }\end{array}$ & May, T. (I922) \\
\hline \multicolumn{6}{|c|}{ SCOTLAND } \\
\hline \multicolumn{2}{|c|}{ 'Aberdeenshire' } & $\begin{array}{l}\text { N.M.A. (Rae Colln.) } \\
\text { FJ75 }\end{array}$ & $\begin{array}{l}\text { Opaque. Roughly } \\
\text { made. Turquoise } \\
\text { glass }\end{array}$ & No details & \\
\hline $\begin{array}{l}\text { Castle Hill, } \\
\text { Dalry }\end{array}$ & Ayrshire & N.M.A. $\mathrm{HH}_{3}{ }_{5}$ & $\begin{array}{l}\text { Dark blue glass. } \\
\text { Diam. } 2 \cdot 5 \mathrm{~cm} .\end{array}$ & $\begin{array}{l}\text { Fort occupied during } \\
\text { late Ist-early 2nd c. } \\
\text { A.D. and again in } \\
\text { about 8th-9th c. }\end{array}$ & $\begin{array}{l}P S A S \text { liii (19 } 8 \text { ), } \\
\text { I } 23\end{array}$ \\
\hline $\begin{array}{l}\text { Lochlee } \\
\text { Crannog, } \\
\text { Tarbolton }\end{array}$ & Ayrshire & & $\begin{array}{l}\text { No colour specified. } \\
\text { Diam. c. } 1.5 \mathrm{~cm} \text {. }\end{array}$ & $\begin{array}{l}\text { Roman period not } \\
\text { closely dated }\end{array}$ & $\begin{array}{l}P S A S \text { xiii (1874), } \\
239\end{array}$ \\
\hline $\begin{array}{l}\text { Barburgh } \\
\text { Mill, } \\
\text { Nithsdale }\end{array}$ & Dumfriesshire & & $\begin{array}{l}\text { Roughly made, small, } \\
\text { pale blue. } \\
\text { Diam. } c . \mathrm{I} \cdot \mathrm{I} \mathrm{cm} .\end{array}$ & $\begin{array}{l}\text { From Roman fortlet } \\
\text { of Antonine date }\end{array}$ & $\begin{array}{l}\text { Forthcoming in } \\
P S A S \text {. Information } \\
\text { from Roger Miket }\end{array}$ \\
\hline Birrens & Dumfriesshire & & $\begin{array}{l}\text { One dark and one } \\
\text { greenish }\end{array}$ & Roman fort & $\begin{array}{l}P S A S \times x \times(1896), \\
79\end{array}$ \\
\hline
\end{tabular}




\begin{tabular}{|c|c|c|c|c|c|}
\hline $\begin{array}{l}\text { SITE AND } \\
\text { PARISH }\end{array}$ & COUNTY & MUSEUM \& NO. & $\begin{array}{l}\text { DESCRIPTION AND } \\
\text { APPROX. DIMENSIONS }\end{array}$ & $\begin{array}{l}\text { ASSOGIATIONS AND } \\
\text { REMARKS }\end{array}$ & PUBLICATION \\
\hline $\begin{array}{l}\text { Traprain Law, } \\
\text { Prestonkirk }\end{array}$ & E. Lothian & N.M.A. & $\begin{array}{l}\text { Blue melon. Possibly } \\
\text { others not recorded, } \\
\text { and } 2 \text { badly made } \\
\text { green fragments }\end{array}$ & $\begin{array}{l}\text { From Iron Age fort } \\
\text { occupied throughout } \\
\text { Roman period }\end{array}$ & $\begin{array}{l}\text { PSAS lvii ( } 1923), \\
2 \text { I } 2 \text { and fig. I9, } \\
\text { no. } 76 \text { and } i b i d .1 v \\
(1920-1), \text { I } 98\end{array}$ \\
\hline Camphouse & $\begin{array}{l}\text { Roxburgh- } \\
\text { shire }\end{array}$ & & Blue glass & $\begin{array}{l}\text { With finds suggesting } \\
\text { Ist-2nd c. A.D. }\end{array}$ & \\
\hline Newstead & $\begin{array}{l}\text { Roxburgh- } \\
\text { shire }\end{array}$ & N.M.A. & $\begin{array}{l}\text { Several examples in } \\
\text { blue and green }\end{array}$ & $\begin{array}{l}\text { Mainly of Flavian } \\
\text { date }\end{array}$ & $\mathcal{N} e$, p. xci \\
\hline $\begin{array}{l}\text { Blackwood } \\
\text { Hill, Keir Hill, } \\
\text { Gargunnock }\end{array}$ & Stirlingshire & N.M.A. & $\begin{array}{l}\text { Dark blue translu- } \\
\text { cent. Diam. } c .3 \mathrm{~cm} .\end{array}$ & $\begin{array}{l}\text { From homestead of } \\
\text { uncertain date, prob- } \\
\text { ably before A.D. } 80 . \\
\text { Beads exactly like } \\
\text { Newstead ones }\end{array}$ & $\begin{array}{l}P S A S \times c i(1957-8), \\
82\end{array}$ \\
\hline & & & WALES & & \\
\hline Brecon Gaer & Brecknockshire & & & Fort built $c$. A.D. 75 & $\begin{array}{l}\text { YCymmrodor, } \\
\text { xxxvii }(1926), \\
120-1\end{array}$ \\
\hline Caerhun & $\begin{array}{l}\text { Caernarvon- } \\
\text { shire }\end{array}$ & & Various examples & $\begin{array}{l}\text { The fort was dis- } \\
\text { mantled in the } \\
\text { Antonine period }\end{array}$ & $\begin{array}{l}\text { Baillie-Reynolds, } \\
\text { P. K. (I } 93^{8} \text { ), fig. } \\
49\end{array}$ \\
\hline Pen Llystyn & $\begin{array}{l}\text { Caernarvon- } \\
\text { shire }\end{array}$ & & $\begin{array}{l}\text { 'Hand crimped } \\
\text { glass.' Diam. } c \text {. } \\
2 \cdot 2 \mathrm{~cm} .\end{array}$ & $\begin{array}{l}\text { From Roman fort } \\
\text { occupied A.D. } 78-90\end{array}$ & $\begin{array}{l}\operatorname{Arf} \mathrm{cxxv}(1968) \\
\text { I } 80, \mathrm{Gb2} \text { and pl. } \\
\text { xvi c }\end{array}$ \\
\hline Caernarvon & $\begin{array}{l}\text { Caernarvon- } \\
\text { shire }\end{array}$ & $\begin{array}{l}\text { Segontium (Caer- } \\
\text { narvon) }\end{array}$ & $\begin{array}{l}\text { Several examples of } \\
\text { blue paste or glass }\end{array}$ & $\begin{array}{l}\text { Fort built around } \\
\text { A.D. } 75 \text { and later } \\
\text { modified }\end{array}$ & $\begin{array}{l}\text { Wheeler, R. E. M., } \\
\text { Segontium (1926) }\end{array}$ \\
\hline $\begin{array}{l}\text { Whitton, nr. } \\
\text { Barry }\end{array}$ & $\begin{array}{l}\text { Glamorgan- } \\
\text { shire }\end{array}$ & N.M.W. & $\begin{array}{l}\text { Dark olive green. } \\
\text { Diam. } c .2 \mathrm{~cm} .\end{array}$ & $\begin{array}{l}\text { From Roman villa } \\
\text { occupied until about } \\
\text { A.D. } 300 \text {. Unstrati- } \\
\text { fied }\end{array}$ & $\begin{array}{l}\text { Information from } \\
\text { Dr. M. Jarrett }\end{array}$ \\
\hline Tomen-y-mur & $\begin{array}{l}\text { Merioneth- } \\
\text { shire }\end{array}$ & & $\begin{array}{l}\text { Half-bead. Medium } \\
\text { blue, translucent. } \\
\text { Diam. } c .3 \mathrm{~cm} .\end{array}$ & $\begin{array}{l}\text { Fort occupied } c . \\
\text { A.D. } 75^{-1} 40\end{array}$ & $\begin{array}{l}\text { Information from } \\
\text { Dr. M. Jarrett }\end{array}$ \\
\hline Abergavenny & $\begin{array}{l}\text { Monmouth- } \\
\text { shire }\end{array}$ & & & & $\begin{array}{l}M A n \text { ii }(1965-8), \\
\text { fig. Io, no. } 9\end{array}$ \\
\hline Caerleon & $\begin{array}{l}\text { Monmouth- } \\
\text { shire }\end{array}$ & & Several examples & $\begin{array}{l}\text { Timber period of fort } \\
\text { A.D. } 75^{-105}\end{array}$ & $\begin{array}{l}A C \operatorname{lxxxvii}(1932) \\
9^{2}, \text { fig. } 40,1-3\end{array}$ \\
\hline Caerleon & $\begin{array}{l}\text { Monmouth- } \\
\text { shire }\end{array}$ & N.M.W. & $\begin{array}{l}\text { Several more } \\
\text { examples }\end{array}$ & $\begin{array}{l}\text { Dated A.D. } 75^{-100} \\
\text { (2) and one probably } \\
\text { Hadrian or Trajan }\end{array}$ & Boon, G. C. (1972) \\
\hline Caerleon & $\begin{array}{l}\text { Monmouth- } \\
\text { shire }\end{array}$ & N.M.W. & $\begin{array}{l}\text { Black opaque with } \\
\text { irregular concentric } \\
\text { bands round circum- } \\
\text { ference }\end{array}$ & $\begin{array}{l}\text { From main lateral } \\
\text { drain to } \mathrm{S} . \mathrm{W} \text {. of } \\
\text { legionary fortress, } c \text {. } \\
\text { A.D. I } 40\end{array}$ & Boon, G. C. (1972) \\
\hline
\end{tabular}




\section{THE SGHEDULES: ROMAN PERIOD \\ EXOTIC BEADS OF THE ROMAN PERIOD}

\begin{tabular}{|c|c|c|c|c|c|}
\hline $\begin{array}{l}\text { SITE AND } \\
\text { PARISH }\end{array}$ & GOUNTY & MUSEUM \& NO. & $\begin{array}{l}\text { DESCRIPTION AND } \\
\text { APPROX. DIMENSIONS }\end{array}$ & $\begin{array}{l}\text { ASSOGIATIONS AND } \\
\text { REMARKS }\end{array}$ & PUBLICATION \\
\hline \multicolumn{6}{|c|}{ ENGLAND } \\
\hline Bracknell & Berkshire & $\begin{array}{l}\text { C.M., Beck Colln., } \\
2247\end{array}$ & $\begin{array}{l}\text { 'Black' irregular oval } \\
\text { bead with flat section } \\
\text { and band of blue } \\
\text { above the circum- } \\
\text { ference. Diam. } 1 \cdot 3 \\
\mathrm{~cm} \text {. Ht. I } \cdot 2 \mathrm{~cm} \text {. } \\
\text { Small perforation }\end{array}$ & $\begin{array}{l}\text { Comparable to beads } \\
\text { from Kenchester } \\
\text { (Herefordshire) from } \\
\text { Roman context. Both } \\
\text { beads may be imports } \\
\text { from Germanic } \\
\text { contexts. See also } \\
\text { Housesteads } \\
\text { (Northumberland) }\end{array}$ & Not published \\
\hline Pangbourne & Berkshire & $\begin{array}{l}\text { C.M., Beck Colln., } \\
\text { I } 696\end{array}$ & $\begin{array}{l}\text { Long dark blue } \\
\text { bead } 3 \cdot 3 \mathrm{~cm} \text {. by I } 3 \\
\mathrm{~cm} . \text { Central zig-zag } \\
\text { and end bands. } \\
\text { Colour missing }\end{array}$ & $\begin{array}{l}\text { This bead may com- } \\
\text { pare with Lankhills } \\
\text { and Cirencester beads } \\
\text { of } 4 \text { th C. A.D. date }\end{array}$ & Unpublished \\
\hline $\begin{array}{l}\text { Bradwell, nr. } \\
\text { Milton Keynes }\end{array}$ & $\begin{array}{l}\text { Buckingham- } \\
\text { shire }\end{array}$ & & $\begin{array}{l}\text { Square-sectioned } \\
\text { part of translucent } \\
\text { green bead with } \\
\text { irregular opaque red } \\
\text { bands and yellow } \\
\text { spots. Cf. another } \\
\text { somewhat similar } \\
\text { found recently at } \\
\text { Chelmsford (un- } \\
\text { published) }\end{array}$ & $\begin{array}{l}\text { From Roman villa, } \\
\text { probably } 4^{\text {th }} \text { c. A.D. }\end{array}$ & $\begin{array}{l}\text { Green, M., The } \\
\text { Bradwell Roman } \\
\text { Villa (first interim } \\
\text { report). Milton } \\
\text { Keynes Develop- } \\
\text { ment Corpora- } \\
\text { tion }\end{array}$ \\
\hline Willingham & $\begin{array}{l}\text { Cambridge- } \\
\text { shire }\end{array}$ & C.M. $1918-160.9-15$ & $\begin{array}{l}\text { Very like a late La } \\
\text { Tène bead from } \\
\text { Adria, Italy (Grave } \\
\text { I } 904 / 83 \text { ). Illustrated } \\
\text { by Haevernick, T. E. } \\
\text { (1960), Tav. I6. Large } \\
\text { annular opaque blue } \\
\text { black with several } \\
\text { inlaid wavy white } \\
\text { lines round sides. } \\
\text { Diam. } 3.8 \mathrm{~cm} . \mathrm{Ht} \text {. } \\
\mathrm{I} \cdot 4 \mathrm{~cm} . \text { Perf. diam. } \\
\mathrm{I} \cdot \mathrm{I} \mathrm{cm} \text {. }\end{array}$ & $\begin{array}{l}\text { With sceptre-head, } \\
\text { etc., either of } \\
\text { Commodus (A.D. I6I- } \\
\text { 92) or Antoninus Pius } \\
\text { (A.D. I } 3^{8-6 I) . ~ A l m o s t ~} \\
\text { surely a Celtic bead } \\
\text { used in a later context }\end{array}$ & $\begin{array}{l}\text { Anf vi }(1926), \text { I } 78 ; \\
\mathcal{F} R S \text { xxiii (I923), } \\
9 \text { I and xxxix } \\
(1949), \text { I9 }\end{array}$ \\
\hline Chester & Cheshire & Chester & $\begin{array}{l}\text { Azure glass with } \\
\text { white opaque wave } \\
\text { and above it a } \\
\text { painted gold band. } \\
\text { Diam. I } \mathrm{cm} . \mathrm{Ht} \text {. } \\
1 \mathrm{~cm} \text {. Cf. Bromham, } \\
\text { below }\end{array}$ & $\begin{array}{l}\text { Found with coin of } \\
\text { Vespasian in Water } \\
\text { Tower Street, 19I4 }\end{array}$ & \\
\hline
\end{tabular}




\begin{tabular}{|c|c|c|c|c|c|}
\hline $\begin{array}{l}\text { SITE AND } \\
\text { PARISH }\end{array}$ & COUNTY & MUSEUM \& NO. & $\begin{array}{l}\text { DESCRIPTION AND } \\
\text { APPROX. DIMENSIONS }\end{array}$ & $\begin{array}{l}\text { ASSOCIATIONS AND } \\
\text { REMARKS }\end{array}$ & PUBLICATION \\
\hline $\begin{array}{l}\text { Colliton Park, } \\
\text { Dorchester }\end{array}$ & Dorset & Dorchester & $\begin{array}{l}\text { Small globular black } \\
\text { bead with crossing } \\
\text { white swags. Yellow } \\
\text { rings round black } \\
\text { eyes enclosed }\end{array}$ & $\begin{array}{l}\text { From Roman villa. } \\
\text { Possibly } 4^{\text {th }}-5^{\text {th }} \mathrm{c} \text {. } \\
\text { A.D. from German or } \\
\text { N. European source }\end{array}$ & $\begin{array}{l}\text { R.C.H.M. } \\
\text { Dorset ii }\end{array}$ \\
\hline $\begin{array}{l}\text { Poundbury } \\
\text { Camp, } \\
\text { Dorchester }\end{array}$ & Dorset & Dorchester & $\begin{array}{l}\text { Flat hexagonal bead } \\
\text { like Samatian beads } \\
\text { from Richborough } \\
\text { and Chesters, but } \\
\text { blue in colour and } \\
\text { opaque. Length and } \\
\text { height } c .9 .0 \mathrm{~mm} \text {. }\end{array}$ & $\begin{array}{l}\text { From late Roman } \\
\text { graves }\end{array}$ & $\begin{array}{l}\text { Information from } \\
\text { excavator }\end{array}$ \\
\hline South Shields & Durham & South Shields & $\begin{array}{l}\text { Translucent light } \\
\text { greenish bottle-glass } \\
\text { with opaque white } \\
\text { around perforation } \\
\text { and circumferential } \\
\text { bands of finely } \\
\text { twisted white, red } \\
\text { and blue. Diam. } \\
2 \cdot 5 \mathrm{~cm} \text {. Ht. I } \cdot \mathrm{cm} \text {. } \\
\text { Perf. diam. I cm. }\end{array}$ & $\begin{array}{l}\text { From Roman fort } \\
\text { with Spanish, } \\
\text { Palmyrene, and } \\
\text { Tigris area elements. } \\
\text { Occupied } c .122-369\end{array}$ & $\begin{array}{l}\text { The site is pub- } \\
\text { lished in } A A, 4^{\text {th s., }} \\
\text { xi (1934),83-102 }\end{array}$ \\
\hline Colchester & Essex & Colchester, Group 94 & $\begin{array}{l}\text { Biconical bead inlaid } \\
\text { all over with tiny } \\
\text { black, white and } \\
\text { yellow mosaic } \\
\text { tesserae. Max. diam. } \\
\text { I } 2 \mathrm{~cm} \text {. Ht. I } 1 \mathrm{~cm} \text {. } \\
\text { Perf. diam. } 4 \mathrm{~mm} \text {. }\end{array}$ & $\begin{array}{l}\text { Imported from } \\
\text { Egypt? Thought to } \\
\text { have been found } \\
\text { with coin of Nero } \\
\text { (A.D. } 54-68 \text { ) but these } \\
\text { Groups are not } \\
\text { reliable and on the } \\
\text { Continent this type } \\
\text { of mosaic bead is } \\
\text { usually late Roman }\end{array}$ & $\begin{array}{l}\text { May, T. (1930), } \\
\text { p. } 279\end{array}$ \\
\hline Golchester & Essex & Colchester $5^{18}$ & $\begin{array}{l}\text { Bright semi-translu- } \\
\text { cent cobalt with } \\
\text { decoration of opaque } \\
\text { white vertical S- } \\
\text { shaped lines between } \\
\text { pairs of diagonal } \\
\text { lines. Diam. } 2.6 \mathrm{~cm} \text {. } \\
\text { Ht. } 1.1 \mathrm{~cm} \text {. Perf. } \\
\text { diam. } 1 \cdot 2 \mathrm{~cm} \text {. }\end{array}$ & $\begin{array}{l}\text { With remains of box, } \\
\text { rings, mirror, etc., } \\
\text { dated c. A.D. 50-6o. } \\
\text { Joslin Group Io7. } \\
\text { (Not totally reliable) }\end{array}$ & May, T. (1930) \\
\hline Colchester & Essex & Colchester & $\begin{array}{l}\text { Dark brown annular } \\
\text { with badly applied } \\
\text { yellow decoration, } \\
\text { nearly worn away. } \\
\text { Diam. } 2 \cdot 9 \mathrm{~cm} \text {. Ht. } \\
\text { I } \cdot \mathrm{I}^{\prime} \mathrm{cm} \text {. Perf. diam. } \\
\text { I } \cdot 4 \mathrm{~cm} \text {. }\end{array}$ & $\begin{array}{l}\text { Said to be from } \\
\text { Group 94, dated } \\
\text { A.D. 54-68. (These } \\
\text { groups are not } \\
\text { reliable) }\end{array}$ & May, T. (1930) \\
\hline
\end{tabular}




\begin{tabular}{|c|c|c|c|c|c|}
\hline $\begin{array}{l}\text { SITE AND } \\
\text { PARISH }\end{array}$ & COUNTY & MUSEUM \& No. & $\begin{array}{l}\text { DESGRIPTION AND } \\
\text { APPROX. DIMENSIONS }\end{array}$ & $\begin{array}{c}\text { ASSOCIATIONS AND } \\
\text { REMARKS }\end{array}$ & PUBLICATION \\
\hline Barnsley & $\begin{array}{l}\text { Gloucester- } \\
\text { shire }\end{array}$ & $\begin{array}{l}\text { Corinium Museum, } \\
\text { Cirencester, } A_{320}\end{array}$ & $\begin{array}{l}\text { Globular black bead } \\
\text { with white and sky } \\
\text { blue swags and } \\
\text { opaque yellow eyes } \\
\text { with brown centres }\end{array}$ & $\begin{array}{l}\text { From Barnsley } \\
\text { Roman villa. Prob- } \\
\text { ably } 4^{\text {th- }} 5^{\text {th }} \text { c. A.D. } \\
\text { See remarks on Ciren- } \\
\text { cester beads, and on } \\
\text { the bead from } \\
\text { Lankhills, Winchester }\end{array}$ & $\begin{array}{l}\text { TBGAS lxxxvi } \\
\text { (1967) }\end{array}$ \\
\hline Cirencester & $\begin{array}{l}\text { Gloucester- } \\
\text { shire }\end{array}$ & $\begin{array}{l}\text { Corinium Museum, } \\
\text { Cirencester }\end{array}$ & $\begin{array}{l}\text { Long barrel-shaped } \\
\text { black bead with } \\
\text { irregular yellow zig- } \\
\text { zag and stripes. } \\
\text { Another similar, } \\
\text { white decoration }\end{array}$ & $\begin{array}{l}\text { Both these beads must } \\
\text { compare with Lank- } \\
\text { hills, below. Intrusive } \\
\text { elements from Teu- } \\
\text { tonic sources. Late } \\
\text { Roman graves }\end{array}$ & $\begin{array}{l}\text { Publication in } \\
\text { preparation, } 1975\end{array}$ \\
\hline Cirencester & $\begin{array}{l}\text { Gloucester- } \\
\text { shire }\end{array}$ & & $\begin{array}{l}\text { Appears to be part of } \\
\text { a small jug-shaped } \\
\text { bead with broken } \\
\text { neck and handle. } \\
\text { Bluish purple with } \\
\text { white wave. Ht. } c \text {. } \\
I \cdot 2 \mathrm{~cm} \text {. }\end{array}$ & $\begin{array}{l}\text { Gf. Keller, E. (I97I), } \\
\text { Abb. } 27 \text {, no. } 24 \text { (late } \\
\text { Roman from S. } \\
\text { Bavaria) }\end{array}$ & $\begin{array}{l}\text { Buckman and } \\
\text { Newmarch, } \\
\text { Illustrations of the } \\
\text { Remains of Roman } \\
\text { Art in Cirencester } \\
\text { (1850), p. } 97 \text {, fig. a }\end{array}$ \\
\hline Wolham & $\begin{array}{l}\text { Gloucester- } \\
\text { shire }\end{array}$ & Gloucester 36/1942 & $\begin{array}{l}\text { Flat triangular bead, } \\
\text { translucent greenish- } \\
\text { blue. Each side } \\
\text { measures } c .2 .6 \mathrm{~cm} \text {. }\end{array}$ & $\begin{array}{l}\text { Not associated and } \\
\text { may not be Roman }\end{array}$ & $\begin{array}{l}\text { Information from } \\
\text { Dr. O. H. Wild }\end{array}$ \\
\hline $\begin{array}{l}\text { Woolaston, } \\
\text { Chesters } \\
\text { Roman Villa }\end{array}$ & $\begin{array}{l}\text { Gloucester- } \\
\text { shire }\end{array}$ & Lost & $\begin{array}{l}\text { Apparently two } \\
\text { beads, both poly- } \\
\text { chrome with dark } \\
\text { core and 'wedge- } \\
\text { shaped' pieces of red } \\
\text { glass (translucent) } \\
\text { enclosed in oval } \\
\text { yellow glass. Larger } \\
\text { bead } c .2 .5 \mathrm{~cm} \text {. long } \\
\text { and } 1.8 \text { wide }\end{array}$ & $\begin{array}{l}\text { From a Roman villa } \\
\text { occupied into late, } \\
\text { possibly post-Roman } \\
\text { period. Cf. no. } 5 \text { in } \\
\text { Leeds, E. T. and } \\
\text { Harden, D. B., } \\
\text { The Anglo-Saxon } \\
\text { Cemetery at Abingdon, } \\
\text { Berks. (1936), pl. } 6\end{array}$ & $\begin{array}{l}A C \text { xciii (1938), } \\
\text { I } 2 \text { I-2. Fully } \\
\text { described but not } \\
\text { illustrated }\end{array}$ \\
\hline \multirow[t]{2}{*}{$\begin{array}{l}\text { Winchester, } \\
\text { Lankhills } \\
\text { Cemetery }\end{array}$} & \multirow[t]{2}{*}{ Hampshire } & \multirow[t]{2}{*}{ Winchester } & $\begin{array}{l}\text { (i) Large pear- } \\
\text { shaped bead in trans- } \\
\text { lucent dark brown } \\
\text { glass with white } \\
\text { opaque swags enclos- } \\
\text { ing yellow round } \\
\text { brown eyes overlaid } \\
\text { by red opaque trail }\end{array}$ & $\begin{array}{l}\text { From necklace } 43^{6} \text {, } \\
\text { Grave } 323 \text {, a foreign } \\
\text { grave dated c. A.D. } 35^{\circ-}- \\
70 \text {. Widespread } \\
\text { Continental parallels } \\
\text { beyond the Imperial } \\
\text { Frontiers, for which } \\
\text { see Lankhills report }\end{array}$ & $\begin{array}{l}\text { Clarke, G. (forth- } \\
\text { coming), fig. } 8, f\end{array}$ \\
\hline & & & $\begin{array}{l}\text { (ii) } 2 \text { green tapered } \\
\text { beads }\end{array}$ & $\begin{array}{l}\text { From necklaces } 28 \text { and } \\
353 \text {, in Graves } 40 \text { and } \\
336 \text {, two foreign graves } \\
\text { dated within the } \\
\text { period A.D. } 35^{\circ-90 . ~ C f . ~}\end{array}$ & $\begin{array}{l}\text { Ibid. figs. } 69 \text {, } \\
\text { d, } 90, f \\
\text { Bath }\end{array}$ \\
\hline
\end{tabular}




\begin{tabular}{|c|c|c|c|c|c|}
\hline $\begin{array}{l}\text { SITE AND } \\
\text { PARISH }\end{array}$ & GOUNTY & MUSEUM \& NO. & $\begin{array}{c}\text { DESCRIPTION AND } \\
\text { APPROX. DIMENSIONS }\end{array}$ & $\begin{array}{l}\text { ASSOGIATIONS AND } \\
\text { REMARKS }\end{array}$ & PUBLICATION \\
\hline St. Albans & Hertfordshire & & $\begin{array}{l}\text { Green emerald } \\
\text { coloured glass with a } \\
\text { bluish streak. Prism- } \\
\text { shaped, } 2 \cdot 7 \mathrm{~mm} \text {. long } \\
\text { and I } 8 \mathrm{~cm} \text {. wide }\end{array}$ & $\begin{array}{l}\text { Probably Sarmatian. } \\
\text { From } 4^{\text {th }} \text { c. A.D. } \\
\text { necklace }\end{array}$ & $\begin{array}{l}V e, \text { fig. } 47, \text { a and } \\
\text { p. } 2 \text { I } 4\end{array}$ \\
\hline $\begin{array}{l}\text { Leicester } \\
\text { (Jewry Wall) }\end{array}$ & Leicestershire & Leicester & $\begin{array}{l}\text { Dark blue globular } \\
\text { with light thin band } \\
\text { wound once from } \\
\text { perforation around } \\
\text { circumference. Diam. } \\
\text { I } 3 \mathrm{~cm} \text {. Ht. I cm. } \\
\text { Perf. diam. } 2 \mathrm{~mm} \text {. }\end{array}$ & From disturbed level & $\begin{array}{l}\text { Kenyon, K. M. } \\
(1948), \text { p. } 269 \text { and } \\
\text { fig. } 93.5\end{array}$ \\
\hline Chesters Fort & $\begin{array}{l}\text { Northumber- } \\
\text { land }\end{array}$ & Chesters Museum & $\begin{array}{l}\text { Flat hexagonal or } \\
\text { prism-shaped bead } \\
\text { with } 2 \text { long sides } \\
\text { similar to Rich- } \\
\text { borough and Verul- } \\
\text { amiumbeads, above. } \\
\text { Ht. I } 3 \text { cm. Length } 2 \\
\mathrm{~cm} \text {. Small perforation }\end{array}$ & $\begin{array}{l}\text { Opaque and abraded } \\
\text { stone or glass. Per- } \\
\text { haps Sarmatian } \\
\text { (information from } \\
\text { Dr. Grace Simpson) }\end{array}$ & $\begin{array}{l}\text { See for type. } \\
\text { Párduez in } A H \mathrm{xxv} \\
\text { (1941), } 56 \mathrm{ff} \text {. and } \\
\text { Taf. } 24,25\end{array}$ \\
\hline Housesteads & $\begin{array}{l}\text { Northumber- } \\
\text { land }\end{array}$ & $\begin{array}{l}\text { University Museum, } \\
\text { Newcastle-upon- } \\
\text { Tyne }\end{array}$ & $\begin{array}{l}\text { Glossy, 'black', round } \\
\text { with flat section. } \\
\text { White band around } \\
\text { circumference }\end{array}$ & $\begin{array}{l}\text { Unstratified from } \\
\text { Roman site. Early } \\
\text { excavations. Cf. } \\
\text { examples from Ken- } \\
\text { chester and Bracknell, } \\
\text { Berks. }\end{array}$ & \\
\hline $\begin{array}{l}\text { Shakenoak } \\
\text { Farm, Wilcote }\end{array}$ & Oxfordshire & & $\begin{array}{l}\text { Harden described as } \\
\text { follows: 'Fragment of } \\
\text { bead of mosaic glass, } \\
\text { oblate with large hole. } \\
\text { Made from pieces of } \\
\text { blue and white marbled } \\
\text { mosaic and red, green } \\
\text { and white streaky } \\
\text { glass by a native } \\
\text { workman using } \\
\text { waste Roman mosaic } \\
\text { glass fragments' }\end{array}$ & $\begin{array}{l}\text { Probably late } 3 \text { rd c. } \\
\text { A.D. } \\
\text { d }\end{array}$ & $\begin{array}{l}\text { Brodribb, A. C. C. } \\
\text { Hands, A. R. and } \\
\text { Walker, A. D. } \\
\text { Excavations at } \\
\text { Shakenoak Farm } \\
\text { near Wilcote, } \\
\text { Oxfordshire, ii } \\
\text { (1971), I } 66\end{array}$ \\
\hline
\end{tabular}




\begin{tabular}{|c|c|c|c|c|c|}
\hline $\begin{array}{l}\text { SITE AND } \\
\text { PARISH }\end{array}$ & COUNTY & MUSEUM \& No. & $\begin{array}{l}\text { DESCRIPTION AND } \\
\text { APPROX. DIMENSIONS }\end{array}$ & $\begin{array}{l}\text { ASSOCIATIONS AND } \\
\text { REMARKS }\end{array}$ & PUBLICATION \\
\hline Bath & Somerset & $\begin{array}{l}\text { Roman Baths } \\
\text { Museum }\end{array}$ & $\begin{array}{l}\text { Large pear-shaped } \\
\text { bead of brown glass. } \\
\text { Applied opaque blue } \\
\text { swags enclosing yellow } \\
\text { rings round brown eyes }\end{array}$ & $\begin{array}{l}\text { From temple site under } \\
\text { Pump Room.Bead very } \\
\text { like the Lankhills } \\
\text { (Winchester) bead of } \\
\text { foreign origin }\end{array}$ & $\begin{array}{l}\text { Information from } \\
\text { Prof. Barry } \\
\text { Cunliffe (un- } \\
\text { published) }\end{array}$ \\
\hline Wookey Hole & Somerset & Bristol & $\begin{array}{l}\text { Small blackish oval } \\
\text { bead with blue band } \\
\text { around girth at right } \\
\text { angles to perforation. } \\
\text { Diam. } 1.2 \mathrm{~cm} \text {. }\end{array}$ & 'Later 3rd century' & $\begin{array}{l}\text { Information from } \\
\text { G. C. Boon and } \\
\text { Professor Tratman, } \\
\text { I975 }\end{array}$ \\
\hline $\begin{array}{l}\text { Icklingham } \\
\text { (Lackford Hills) }\end{array}$ & Suffolk & A.M. 1927.700 & $\begin{array}{l}\text { 'Black glass ring } \\
\text { about } 1 \frac{7}{8} \text { ' in diameter' } \\
\text { (nearly } 5 \mathrm{~cm} \text {.) }\end{array}$ & $\begin{array}{l}\text { With } 4^{\text {th }} \text { c. A.D. beads } \\
\text { on necklace. Found in } \\
\text { I } 859\end{array}$ & $\begin{array}{l}\text { Joseph Warren's } \\
\text { MS. notebook in } \\
\text { the A.M. }\end{array}$ \\
\hline Bromham & Wiltshire & Devizes $27 \mathrm{C}$ & $\begin{array}{l}\text { Globular, light } \\
\text { opaque with decora- } \\
\text { tive bands in opaque } \\
\text { pink around speckled } \\
\text { gold painted band. Some } \\
\text { mixed glass. Diam. } 1 \cdot 5 \\
\mathrm{~cm} \text {. Ht. } 1 \cdot 4 \mathrm{~cm} \text {. Max. } \\
\text { perf. } 3 \mathrm{~mm} \text {. }\end{array}$ & $\begin{array}{l}\text { From site of Roman } \\
\text { villa, Ig I I. (Cf. } \\
\text { Chester, above) } \\
\text { e }\end{array}$ & \\
\hline Aldborough & Yorkshire & & $\begin{array}{l}\text { Rather large globular } \\
\text { bead. Ground in dark } \\
\text { green covered with } \\
\text { white glass, with } \\
\text { irregular red lines. } \\
\text { Yellow line round } \\
\text { perforation at top } \\
\text { and bottom. Diam. } \\
\mathrm{I} \cdot 5 \mathrm{~cm} . \mathrm{Ht} . \mathrm{I} \cdot 7 \mathrm{~cm} \text {. } \\
\text { Perf. diam. } 3 \mathrm{~mm} \text {. }\end{array}$ & $\begin{array}{l}\text { Found with Roman } \\
\text { coins in } 1843\end{array}$ & $\begin{array}{l}A \text { xxxiv (1852), pl. } \\
\mathrm{v} \text {, no. } 7 . \text { Another } \\
\text { exactly similar and } \\
\text { perhaps the same } \\
\text { bead shown in the } \\
\text { Nightingale Colln. } \\
\text { Drawings in the } \\
\text { S.A.L. }\end{array}$ \\
\hline York & Yorkshire & York & $\begin{array}{l}\text { Decorated with swags } \\
\text { and eyes }\end{array}$ & $\begin{array}{l}\text { Probably an intrusive } \\
\text { bead. Dated } 4^{\text {th }} \text { C. A.D. }\end{array}$ & $\begin{array}{l}\text { Poorly described } \\
\text { in R.C.H.M. York } \\
\mathrm{i}(\mathrm{1} 962 \text { ), fig. } 58 \text {, } \\
\text { p. } 74 \text { and p. } 140 \mathrm{~b}\end{array}$ \\
\hline Dunadd & Argyllshire & Glasgow ? $\mathrm{HPO}_{275}$ & $\begin{array}{l}\text { Long drum-shaped } \\
\text { bead with yellow } \\
\text { collar at each end. } \\
\text { 'Black' ground with } \\
\text { white chevrons. } \\
\text { Length I } 4 \mathrm{~cm} \text {. } \\
\text { Width I cm. }\end{array}$ & $\begin{array}{l}\text { This site is reputed to } \\
\text { have been occupied } \\
\text { from the } 5 \text { th c. A.D. as } \\
\text { a (Scottic) Dalriadic } \\
\text { stronghold. An iden- } \\
\text { tical bead is said to } \\
\text { have come from } \\
\text { Aubigny-en-Artois } \\
\text { (Pas-de-Calais) with } \\
\text { a Roman coin of } c \text {. } \\
\text { A.D. } 300 \text { and another } \\
\text { in a N. French tomb } \\
\text { with a coin of } \\
\text { Gratian (c. A.D. } 380 \text { ) } \\
\text { but with red ground } \\
\text { instead of black }\end{array}$ & $\begin{array}{l}\text { PSAS lxiv (1930), } \\
\text { I } 6 \text {, fig. } 3 \text { and I ig. } \\
\text { See Boulanger, Cl. } \\
\text { (1902-05) }\end{array}$ \\
\hline
\end{tabular}




\begin{tabular}{|c|c|c|c|c|c|}
\hline $\begin{array}{l}\text { STTE AND } \\
\text { PARISH }\end{array}$ & COUNTY & MUSEUM \& NO. & $\begin{array}{l}\text { DESGRIPTION AND } \\
\text { APPROX. DIMENSIONS }\end{array}$ & $\begin{array}{l}\text { ASSOCIATIONS AND } \\
\text { REMARKS }\end{array}$ & PUBLICATION \\
\hline $\begin{array}{l}\text { Newstead, } \\
\text { Melrose }\end{array}$ & $\begin{array}{l}\text { Roxburgh- } \\
\text { shire }\end{array}$ & N.M.A. FRAgO4 & $\begin{array}{l}\text { Opaque bright red } \\
\text { with yellow girth } \\
\text { band decorated with } \\
\text { green herring-bone. } \\
\text { Diam. I } \cdot 3 \mathrm{~cm} \text {. Ht. } \\
\mathrm{I} \cdot \mathrm{I} \mathrm{cm} \text {. Perf. diam. } \\
8 \mathrm{~mm} \text {. }\end{array}$ & $\begin{array}{l}\text { 'Outside the North } \\
\text { Gate of Roman } \\
\text { town.' Occupation } c \text {. } \\
\text { A.D. } 80-200\end{array}$ & \multirow[t]{2}{*}{$\mathcal{N} e$} \\
\hline Newstead & $\begin{array}{l}\text { Roxburgh- } \\
\text { shire }\end{array}$ & $\begin{array}{l}\text { Mr. Mason's Colln., } \\
\text { Selkirk (I954) }\end{array}$ & $\begin{array}{l}\text { Part of long tubular } \\
\text { bead } 10 \mathrm{~mm} \text {. diam. } \\
\text { and broken off at } \mathrm{I} \cdot 5 \\
\mathrm{~cm} \text {. length. Perf. diam. } \\
4 \mathrm{~mm} \text {. Semi-translu- } \\
\text { cent yellow glass with } \\
\text { opaque yellow zig- } \\
\text { zags around it at } \\
\text { right angles to the } \\
\text { perforation }\end{array}$ & $\begin{array}{l}\text { This rather damaged } \\
\text { bead cannot be closely } \\
\text { paralleled but is not } \\
\text { unlike some of the } \\
\text { variants from Meare }\end{array}$ & \\
\hline Newstead & $\begin{array}{l}\text { Roxburgh- } \\
\text { shire }\end{array}$ & $\begin{array}{l}\text { Mr. Mason's Colln., } \\
\text { Selkirk }\end{array}$ & $\begin{array}{l}\text { Bright red globular } \\
\text { with four yellow girth } \\
\text { bands on sides. Each } \\
\text { band has central } \\
\text { black line. Diam. } \\
\text { I } 5 \mathrm{~cm} \text {. Ht. } 1 \cdot 3 \mathrm{~cm} \text {. } \\
\text { Perf. diam. } 3 \mathrm{~mm} \text {. }\end{array}$ & $\begin{array}{l}\text { Surface find in } \\
\text { Roman site }\end{array}$ & \multirow[t]{2}{*}{ Unpublished } \\
\hline & & & WALES & & \\
\hline Caerhun & $\begin{array}{l}\text { Caernarvon- } \\
\text { shire }\end{array}$ & $\begin{array}{l}\text { Segontium Museum, } \\
\text { Caernarvon }\end{array}$ & $\begin{array}{l}\text { Annular green glass } \\
\text { with dark blue wave } \\
\text { edged with red }\end{array}$ & $\begin{array}{l}\text { This fort was dis- } \\
\text { mantled in the } \\
\text { Antonine period }\end{array}$ & $\begin{array}{l}\text { Baillie-Reynolds, } \\
\text { P. K. (r938) }\end{array}$ \\
\hline Caernarvon & $\begin{array}{l}\text { Caernarvon- } \\
\text { shire }\end{array}$ & $\begin{array}{l}\text { Segontium Museum, } \\
\text { Caernarvon }\end{array}$ & $\begin{array}{l}\text { Half a natural green- } \\
\text { ish translucent } \\
\text { annular bead. } \\
\text { Opaque white irregu- } \\
\text { lar trail interspersed } \\
\text { with opaque blue } \\
\text { dots. Diam. } 2 \cdot 2 \mathrm{~cm} \text {. } \\
\text { Ht. I } \mathrm{cm} \text {. Perf. } \\
\text { diam. } 5 \mathrm{~mm} \text {. }\end{array}$ & $\begin{array}{l}\text { Unstratified from } \\
\text { Roman fort }\end{array}$ & $\begin{array}{l}\text { Unpublished. } \\
\text { Information from } \\
\text { G. C. Boon }\end{array}$ \\
\hline Gaernarvon & $\begin{array}{l}\text { Caernarvon- } \\
\text { shire }\end{array}$ & $\begin{array}{l}\text { Segontium Museum, } \\
\text { Caernarvon }\end{array}$ & $\begin{array}{l}\text { Very dark green bead, } \\
\text { seemingly black, with } \\
\text { opaque white and } \\
\text { red irregular swags } \\
\text { and opaque yellow } \\
\text { spots, one containing } \\
\text { opaque green eye. } \\
\text { Irregular globular } \\
\text { about I cm. diam. }\end{array}$ & $\begin{array}{l}\text { Unstratified from } \\
\text { Roman fort (? post- } \\
\text { Roman) }\end{array}$ & $\begin{array}{l}\text { Unpublished. } \\
\text { Information from } \\
\text { G. C. Boon }\end{array}$ \\
\hline
\end{tabular}




\begin{tabular}{|c|c|c|c|c|c|}
\hline $\begin{array}{l}\text { SITE AND } \\
\text { PARISH }\end{array}$ & COUNTY & MUSEUM \& NO. & $\begin{array}{l}\text { DESCRIPTION AND } \\
\text { APPROX. DIMENSIONS }\end{array}$ & $\begin{array}{l}\text { ASSOCIATIONS AND } \\
\text { REMARKS }\end{array}$ & PUBLICATION \\
\hline Caernarvon & $\begin{array}{l}\text { Caernarvon- } \\
\text { shire }\end{array}$ & $\begin{array}{l}\text { Segontium Museum, } \\
\text { Caernarvon }\end{array}$ & $\begin{array}{l}\text { Slightly biconical } \\
\text { dark green almost } \\
\text { black bead with } \\
\text { unmarvered wave } \\
\text { decoration in opaque } \\
\text { red. Diam. I } 4 \mathrm{~cm} \text {. } \\
\text { Ht. } 8 \mathrm{~mm} \text {. Perf. } \\
\text { diam. } 5 \mathrm{~mm} \text {. }\end{array}$ & $\begin{array}{l}\text { Unstratified from } \\
\text { Roman fort (? post- } \\
\text { Roman) }\end{array}$ & $\begin{array}{l}\text { Unpublished. } \\
\text { Information from } \\
\text { G. G. Boon }\end{array}$ \\
\hline Carmarthen & $\begin{array}{l}\text { Carmarthen- } \\
\text { shire }\end{array}$ & N.M.W. & $\begin{array}{l}\text { Half Prussian blue } \\
\text { annular bead with } \\
\text { marvered opaque } \\
\text { white circumferential } \\
\text { bands. Diam. } 2 \cdot 7 \mathrm{~cm} \text {. } \\
\text { Ht. } \cdot 3 \mathrm{~cm} . \text { Perf. } \\
\text { diam. } \mathrm{I} \cdot 3 \mathrm{~cm} \text {. }\end{array}$ & $\begin{array}{l}\text { The earliest material } \\
\text { from this Roman site } \\
\text { is not very early } \\
\text { Flavian, and this bead } \\
\text { may pre-date it }\end{array}$ & $\begin{array}{l}\text { Information from } \\
\text { Mr. G. C. Boon }\end{array}$ \\
\hline $\begin{array}{l}\text { Whitton, nr. } \\
\text { Barry }\end{array}$ & $\begin{array}{l}\text { Glamorgan- } \\
\text { shire }\end{array}$ & Cardiff & $\begin{array}{l}\text { Part of light translu- } \\
\text { cent cobalt annular } \\
\text { bead with glossy } \\
\text { 'black' blob. Original } \\
\text { diam. } 1.5 \mathrm{~cm} \text {. Ht. } \\
4 \mathrm{~mm} \text {. Perf. diam. } \\
6 \mathrm{~mm} \text {. }\end{array}$ & $\begin{array}{l}\text { From Roman villa. } \\
\text { On surface of rubble } \\
\text { roadway }\end{array}$ & $\begin{array}{l}\text { Report forth- } \\
\text { coming }\end{array}$ \\
\hline Caerleon & $\begin{array}{l}\text { Monmouth- } \\
\text { shire }\end{array}$ & $\begin{array}{l}\text { Caerleon 54, } 3894 \\
(\text { Gri } 3)\end{array}$ & $\begin{array}{l}\text { Opaque 'black' gad- } \\
\text { rooned bead with } \\
\text { opaque white } \\
\text { roughly horizontal } \\
\text { lines round it. Diam. } \\
2 \cdot 1 \mathrm{~cm} . \mathrm{Ht} \text {. } \cdot 4 \mathrm{~cm} \text {. } \\
\text { Perf. diam. } 6 \mathrm{~mm} \text {. }\end{array}$ & $\begin{array}{l}\text { 'Near the legionary } \\
\text { fortress' in main } \\
\text { lateral drain of } c \text {. } \\
\text { A.D. I30-230. A } \\
\text { somewhat compar- } \\
\text { able bead came from } \\
\text { a mid-5th c. context } \\
\text { at Krefeld-Gellep } \\
\text { (no. I462). See } \\
\text { Pirling, R. (1966) }\end{array}$ & $\begin{array}{l}\text { Information from } \\
\text { G. G. Boon }\end{array}$ \\
\hline Caerleon & $\begin{array}{l}\text { Monmouth- } \\
\text { shire }\end{array}$ & $\begin{array}{l}\text { Gaerleon } 62,2656 \text {, } \\
\text { G1 } 8\end{array}$ & $\begin{array}{l}\text { Part only of small } \\
\text { translucent blue bead } \\
\text { with remains of } \\
\text { stratified eyes (colour } \\
\text { missing) }\end{array}$ & Late 3 rd c. A.D. & $\begin{array}{l}\text { Boon, G. C. }(1966) \text {, } \\
\text { pp. I04 ff. }\end{array}$ \\
\hline Usk (near) & $\begin{array}{l}\text { Monmouth- } \\
\text { shire }\end{array}$ & & $\begin{array}{l}\text { 'Blue-green glass } \\
\text { coated entirely with } \\
\text { yellow and dull red } \\
\text { lines running diag- } \\
\text { onally, the irregular } \\
\text { series of which is } \\
\text { broken by cracks in } \\
\text { the coating like faults } \\
\text { in geology' }\end{array}$ & $\begin{array}{l}\text { ? From the Roman } \\
\text { site }\end{array}$ & $\begin{array}{l}\text { Lee, J. E., Catalogue } \\
\text { of the Caerleon } \\
\text { Museum (1862), } \\
\text { p. } 55\end{array}$ \\
\hline
\end{tabular}





\section{GENERAL INDEX}

Adabrock (Isle of Lewis), Bronze Age bead from, 22, 24 Aghnaskeagh (Co. Louth), Bronze Age bead from, 2 I Airreoland Grannog (Strathclyde), red vitreous slag from, 37

Aisne (France), beads from, 47, 49, 56, roo

Allen, D. F., cited, 26

Armlets: bronze, snake, I1-12, 34; glass, I0, I1, 12, I 4, I5, $16,3 \circ, 34,36,49,52,64,74,78,79,80$

Austria: beads from: Bronze Age, 24 ; class 4,51 ; group 1, 60 ;

beads distributed from oppida in, 29; see also Dürmberg, the;

Hallstat; St Veit; Vinica

Avery, M., cited, 33, 82, 83

Ballacagen (I. of Man), glass armlet from, 52

Ballinaby, Islay (Hebrides), bead from Viking grave at, 48

Ballymacash (N. Ireland), I oth-I I th-century beads from, 93

Bauxite beads, 89

Beck, H. C., cited, 5, 49

Belfast (N. Ireland), Bell and Grainger collections in, 13

Belgium, Iron Age imports from, 26

Bet Shean (Israel), Arras type beads from, 47

Birka (Sweden): beads from: group 6, 68; melon, roo; reuse of glass at, 31

Birksay (Orkney), Ioo

Bohemia, see Czechoslavakia

Boon, G. C., cited, 93, 94

Boscregan, St. Just-in-Penwith (Cornwall), Wessex Culture bead from, 20, 23

Bowen, E. G., cited, $4 \mathrm{I}$

Brackenbraes, Turrif (Grampian), Roman glass bottle from, 35

Branigan, K., cited, 24, 39

Brecon Gaer (Powys), millefiori glass from, 79

Bř̀n, Prof. J., cited 28, 29

Brigantia, isolation of, 28

Bronsted, J., cited, 24

Bronze Age beads: Britain, 3, 19-22, 23; Europe 23, 24

Bulleid, A., and H. St. George Gray, cited, 33

Burton Fleming (Yorks.), red glass stud from, $15 n$.

Burwell (Cambs.), beads from Anglo-Saxon cemeteries at, 95

Caerhun (Gwynedd), glass canes from, 37

Caerwent (Gwent), glass canes from, 37

Cairnmuir (Borders), torcs from, 55

Caistor-by-Norwich (Norfolk) : Roman glass furnaces at, 30 ;

Anglo-Saxon cemetery at, 39

Caley, Earle R., cited, 9

Callander, J. G., cited, 31, 35
Camelon (Central), bauxite bead from, 89

Carnduff (N. Ireland), bead in Neolithic context at, 2 I

Carnforth at Yealand (Lancs.), Bronze Age bead from, 20

Carniola (Yugoslavia), bead production in, $v, 30$

Carpow (Tayside), bauxite bead from, 89

Carrawburgh (Northumberland), beads as offerings at Coventina's Well, $3^{8}$

Castle Dore (Cornwall), glass armlet from, 52

Castleford (Yorks.), glass slag and raw waste from, 30, 37

Castlehill Fort, Dalry (Strathclyde), glass canes from, 37 , $93^{n}$.

Castle Newe (Grampian): armlets from, 34, 86; torcs from, 55

Celtic resurgence, $4^{\text {th }}-5^{\text {th }}$ centuries A.D., $4^{\text {I }}$

Ghard, South (Somerset), Bronze Age bead from, 21

Charleston, R. J., cited, $3^{\circ}$

Chessel Down (I. of Wight), beads from Jutish cemetery at, 95

Ghewton Mendip (Somerset), Bronze Age bead from, 2 I, 23

Chitty, Miss L. F., cited, 70

Church, Sir A., cited, 30

Girencester (Glos.): Roman burials at, 37, 38; Thracians at, 102

Colchester (Essex) : Thracians at, I02: glass workers from, 30

Cold Kitchen Hill (Wilts.): beads as votive offerings at, $37,3^{8}$; votive offerings probably manufactured at, $3^{8}$

Coles, J. M., cited, 24

Continental imports, 12, I3, 14, I6, I9-20, 25-31, 39, 40, $45-7$ I

Coptic material, 94, 95

Corbridge (Northumberland), bauxite bead from, 89

Gornovii, the, 36

Corseul (Côtes-du-Nord), class 5 beads from, 53

Corsica, class I beads in, 47

Goventina's Well, see Carrawburgh

Govesea Cave (Grampian), glass canes from, 37

Cowlam (Yorks.), bronze brooch and bracelets from, 46, 47

Culbin Sands (Grampian): armlet from, I1-12, 79-80; glass industry at, I I , 16, 28, 31, 34-5,36, 74, 76, 86

Cunliffe, Prof. Barry, cited, 28

Czechoslovakia, Bohemia: beads from: Bronze Age, 24; class I, 47; class 4, 5 I d distributing oppida in, 28, 29; see also Havranck: Staré Hradisko; Stradonitz; Třisov

Dalriada: absence of Irish glass in, 4 I group 6 beads from, 66

Daniel, G., cited, 23

Déchelette, J., cited, $5 \mathrm{I}$

Denmark, Bronze Age beads from, 24

Deskford (Grampian), carnyx-bell from, 34 
Dice, bone, 76

Dinas Powys (Glam.), Teutonic glass at, 31

Dirleton (Lothian), brooch from Craig's Quarry, 55

Dobunni, the, 33

Ducklington (Oxon.), class 5 bead in Saxon grave at, $5^{2}$, 54 .

Dumnonia, isolation of, 28

Dürnberg, the (Hallein) (Austria): distributing oppidum, 29; class 5 beads from, 52

Durotriges, the, 33,34

Dyfed, absence of Irish glass in, $4^{1}$

Eddertoun (Highland), Bronze Age bead from, 22

Egypt: glass, colourless, from, 10; glass factories in, $3^{8-9}$; imports from, 41, IOI, IO2; polygonal bead perhaps from, 96; segmented beads from, 93, 94, ro2; twist decoration used in, 79

Elgin (Grampian), glass furnaces at, 34

Etruria: beads from tombs in, 51 ; colourless glass in, 10

Factories, bead: British: Iron Age (putative) 15, 16, 31; Roman (presumptive) 38-9; Continental, 16, 23, 28-9, 3o, 48-9; Near East, 22-3, 38

Faras (Sudan), beads from, 93, 98n.

Farley Heath (Surrey), beads as votive offerings at, $3^{8}$

Fishbourne (Sussex), armlet from, 78

Fortingall (Tayside), bauxite bead from, 89

Fowler, Elizabeth, cited, 4 I

Fox, Lady (Aileen), cited, 40

Fox, Sir Gyril, cited, 26

France: beads from: Bronze Age, 23-4; class 7, 59; group I, 6o; cylinder, 95; melon, roo; see also Aisne; Corseul; Les Jogasses; Marne district; Presles-et-Bores; Recy Voie Chantereine; Vosges

Frankish beads: 4, 17,64, 93, 95; necklace incorporating class 5 bead, 52

Frattesine (Italy), earliest European glass lumps from, 3 I

Gallo-Roman beads, 4, 42n.

Garryduff (Co. Cork), 7th-8th-century bead from, $93 n$.

Gaulish beads, 4, $5^{n}$.

Germanic beads, $4,17,18 n$.

Germany: beads from: Bronze Age, 24; class 6, $5^{6}$; group I, 60; group 5, 63; see also Heppenheim; HunsrückEifel; Krefeld-Gellep; Manching; Redel; Reinheim; Waldfischbach

Gilchorn, Arbroath (Tayside), Bronze Age bead from, 22, 23

Glass: armlets, see Armlets; beads: see also Table of Contents; post-Roman, 92-3; reuse of 52 , 54; usage, 5, 56 ; as votive offerings, 38 ; canes or rods $37,92,93,96$; furnaces, Roman, 30 ; gaming-pieces, 12; imported, 12 , 1 3, 14, 16, 30, 36; ingots, 66; insets, 1 1-12, 34; lumps, 10, 13, 14, 1 7, 29, 30, 31, 34, 36; millefiori, 42n., 79; reuse of, $11,12,30,31,37,66$; technological data, and manufacturing techniques, 9, 10, 16-17, 91-2, 93, 94; waste, in wrecks, 31 ; see also Factories
Glastonbury (Somerset): possible distribution centre, 35, 36,66 ; glass bead factory at, $33-4,78$

Glenluce Sands (Dumfries and Galloway), possible bead factory at, 35

Glentrool (Dumfries and Galloway), Bronze Age bead from, 22, 24

Gold jewellery trade, Bronze Age, 23

Gortnacargy, Bawnboy (Co. Cavan), Bronze Age bead from, 2 I

Gray, H. St. George, see Bulleid, A.

Greece, colourless glass in, Io

Haevernick, Dr. Thea E., cited, 8, Io, 59

Hallstatt (Austria), class I beads from, 47

Hamworthy (Dorset), glass armlet from, 65

Harden, Dr. D. B., cited, 10, 22-3, 54, 77

Harding, D. W., cited, 3, 47

Harwell (Oxon.), Anglo-Saxon beads from, 66

Havranok (Czechoslovakia), manufacturing oppidum, 28

Hawkes, Prof. C. F. C., cited, 84

Helgö (Sweden), group 6 beads from, 68

Hencken, H. O'Neil, cited, Ioo

Hengistbury Head (Dorset): possible distribution centre, 13, 29, 34; purple glass from, 30

Henry, Françoise, cited, 4I

Heppenheim (W. Germany), class 6 bead as talisman in grave at, 56

Hill-forts: 34,40 ; see also oppida

Hogg, A. H. A., cited, 40

Holland, beads in: Bronze Age, 24; class 4, 5 I

Housesteads (Northumberland), bauxite bead from, 89

Hungary, beads from: class 7,59 ; group $\mathrm{I}, 60$; prisma formiga, 97; biconical, 98 ; diamond faceted, roo

Hunsrück-Eifel (W. Germany), group 5 beads from, $6_{3}$

Iberian influences, 40

Iceni, isolation of, 28

Innes, C., cited, 34

Ireland: beads from: Bronze Age, 21-2; Continental imports, 39-42; class 6,54 ; class $7,58,59$; class 9,77 ; class I I, 84; group 4, 62; twist decoration of, 79 ; insular history of, 4, I1, 39; see also Ballymacash, Carnduff; Garryduff; Gortnacragy; Letterkeen; Mullaghmore; Tara

Iron Age: beads, see Table of Contents; hill-forts, 34, 40; oppida, 28, 29, 3 I

Italy: amphorae from, 49; beads from: class I, 47, class 2 , 49 ; class 4,51 ; class 5,52 ; class 7,59 ; group 1,60 ; lead from, in Tara glass, 30; see also Frattesine

Jarlshof (Shetland), 97

Jersey (Channel Isles), class 7 beads from, 59

Jope, E. M., cited, 40, 55

Keiss Broch (Highland), glass rod from, 96

Keller, E., cited, 98, 99

Kilbride-Jones, H. E., cited, $36,7^{8}$ 
Kingston Deverill (Wilts.), beads in bowl barrow, at, $2 \mathrm{I}$ 23

Kintore (Grampian), glass armlet from, 52

Knackyboy Cairn, St. Martins (Isles of Scilly), Bronze Age beads from, 20, 24

Krefeld-Gellep (W. Germany), boat-shaped beads from, 99

Kunkel, O., cited, 15

Lamyatt Beacon (Somerset): beads as votive offerings at, $3^{8}$; glass cane from, $37,9^{2}$

Landivisian (Finistère), Bronze Age bead from, 23

Lankhills, see Winchester

Lead: used as agent, 17; Italian, in glass from Tara, 30

Leeds, E. T., cited, 37

Leicester (Leics.), Roman glass wasters from, 30

Les Jogasses (France), opaque bead from, I6, 65

Letterkeen (Co. Mayo), post-Roman beads from, 93 .

Llanbabo (Gwynedd), Bronze Age bead from, 22

Lough Crew (Co. Meath), Bronze Age bead from, 2 I

Lough Gur (Co. Limerick), Bronze Age bead from, 2 I, 23

MacKie, Euan, cited, 76

Mancetter (Warwicks.), Roman glass furnaces at, $3^{\circ}$

Manching (W. Germany): beads from: class 5, 52; class 6,56 ; in male grave, 56 ; possible glass factory at, 15,29 Mann, L. McL., cited, 34

Marne District (France), beads from, 26, 47, 49, 51, 52, 56, 62

Marcomanni: entrance into Bohemia of, 29; serving in Britain, 102

Marcus Aurelius, Marcomanni sent to Britain by, 102.

Marksbury (Somerset), Bronze Age bead from, 2 I

Meare (Somerset): possible distribution centre, $10,35,36$, $52,67,75^{-6}$; glass factory at, $15,16,28,3^{1}, 32-3,76,78$ Mecklenburg Collection, v, 5

Megalithic tombs, French, beads from, 23

Minorca, class I beads in, 47

Mons Graupius, Roman victory of, 35,87

Moreau, F., cited, Ioo

Moretonhampstead (Devon), Wessex Culture bead from, 20

Mullaghmore (N. Ireland), Bronze Age bead from, 2 I

Museums: Aberdeen, r94; Abergavenny, r 10; Ashmolean, Oxford, vn., 22, 5I n., 52, 54n., 66, 94, I05, I I0, I I I, I I 2,

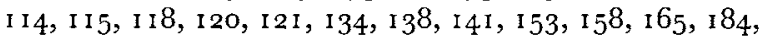
185, 188, 191, 208, 221, 228, 235; Aylesbury, 112, 21 1, 21 8; Banff, 194, 195; Bangor, I45; Bath, I44, I58, I62, 212, 226, 235; Beck Collection, see Cambridge Museum of Archaeology and Ethnology; Belfast, I3, I I 5, I I6, I I 8, 124, 126, 127, 164, I 71, 175, 188, 193, 197; Berlin Antiquarium, 22; Birmingham, I06, I 24, I 57, 180, I83; Bridport, I56; Bristol City Museum, I12, I21, I30, I42, I 49, I 5 I, 158, I68, I 70, 183, 203, 208, 226, 227, 229, 235; British Museum, 47, 52, 53n., 94, 105, 106, 107, 108, I $13,114,116,117,119,122,126,127,129,132,136$, $137,141,152,153,156$, I 71, 180, 188, 189, 193, 197, 215, 216; Bury St. Edmunds, 125, 216; Buxton, 107;
Museums-cont.

Caerleon, I43, I 55, I85, 237; Caernarvon, see Segontium; Caerwent, 189; Cambridge Museum of Archaeology and Ethnology, 21-2, 47, 107, I09, III, II2, I18, I22, 1 25, 1 28, I 30, I 35, I 39, I41, 152, 169, 172, I 73, I 74, 183, 187, 191, 194, 208, 213, 226, 231; Cardiff, see National Museum of Wales; Carlisle, I28, I43, I52, I82; Châlons-sur-Marne, 47, 5 In., 52n., 56; Chedworth Roman Villa, ro8; Chelmsford, I 17 ; Cheltenham, I40, 147, 176, 221 ; Chester, 1 28, 187, 231 ; Chesters, 125, 1 30, $134,137,141,149,170,180,202,206,210,212,216$, 219, 222, 226, 234; Chichester, I15, 229; Christchurch, I 19, 121, 20I; Girencester, III, I27, I29, I40, I47, 153, I 73, I83, 202, 205, 209, 2 I I , $215,220,221,224,227,233$; Glun, I49; Colchester, I I I, I I2, I 20, I21, I40, I66, I 70, 205, 232 ; Copenhagen, 95; Corbridge, see Corstopitum; Cork, I88; Corstopitum, I08, I 39, I41, I49, I51, I53, 164, 216; Coventry, I5 1, 158; Derby, I49, 201, 209, 21 3 ; Devizes, 96, го6, 108, 109, г 31, I35, г 37 , г 38, 142, 149, 154, I58, 159, 171, 177, 192, 203, 204, 219, 22 1, 223, 235; Dorchester (Dorset), I 06, 108, I I I, I I 2, 129, 143, I46, $150,151,153,156,162,168,169$, I 72, I 73, I 76,179 , I $87,201,205,207,209,2 \mathrm{I}$, $213,215,218,219,220,22 \mathrm{I}$, 222, 224, 232; Douglas, 158, 179; Dublin, National Museum of Ireland, I1 2, I 15, I16, $118,120,126,127$, 160, 163, 169, 175, 184, 188, 197, 214; Dumfries, 132; Edinburgh, see National Museum of Antiquities; Elgin, I96; Exeter, I82, I85; Falkirk, I 22; Fishbourne, I58; Fordingbridge, 207, 209, 210, 221; Gillingham, II2; Glasgow, Hunterian, I61, I 72, I81, 197, 199, 200, 220, 235; Glastonbury, I14, I I 7, I 19, 134, 139, 142, 149, 154, 158, 165; Gloucester, 123; 1 29, 140, I41, 144, I5 I, $153,157,164,165,167,168,170,173,174,202,205$, $211,214,215,219,221,224,225,233$; Guildford, 131, 206; Guildhall, see Museum of London; Hambledon Villa, I28, 140; Hereford, I29, I44, I47, 157, 162, 163, I66, I 73, 183, $210,213,221,225,234$, Huddersfield, I3 I ; Hull, I I 2, I 49; Ipswich, I 1 7, I 3 I, I67, I 7 I, 208, 2 I I , 214, 222, 226; Jerusalem, 47; Leicester, 121, 125, 130, 153, I87, 228, 234; Lewes, 108, I1 7, I 37 ; Lincoln, I68, I83, 228; Llandudno, 184; London, see Museum of London; Maidstone, Sir Edward Harrison Collection, I 3 ; Mainz, 52, 97; Manchester, 228; Marquis Mayeda Collection, I05; Monmouth, I72; Museum of London, I13, 114, I $30 ;$ 1 $36,148,151,158$, 168, 1 70, 202, 228; Namur, 95; National Museum of Antiquities, Edinburgh, 34, 99, 109, I 16, I 18, I 19, 120, 122, 1 24, 126, 1 32, 135, 139, 142, $145,150,152,154,155,160,161,164,166,169$, I 7 I, $172,174,175,180,181,182,184,188,189,193,194$, 195, 196, 197, 198, 199, 200, 204, 206, 208, 21 1, 21 2, $214,217,219,220,223,227,229,230,236$; National Museum of Ireland, see Dublin; National Museum of Wales, 107, г10, I19, 120, 126, 133, 136, 167, 174, 182, 185, 206, $218,227,230,237$; Newark, 141, 149; Newbury, I69, I 76; Newcastle-on-Tyne, I I4, 130, 141, 144, I53, I $63,164,167,170,173,179,185,201,202,209,210,212$, $214,215,223,224,228,229,234$; Newham, Passmore 
Museums-cont.

Edwards, 172; Newport, 163, 167, 218; Northampton, I I , I 14, I48, I77; Norwich, I06; Oslo, 95; Ospringe, Maison Dieu, 96, 21 2, 222, 223; Oxford: Pitt-Rivers, 77; see also Ashmolean; Poole, I 21 , 134, 165; Reading, $125,127,129,136,141,144,145,147,153,157,162$, $166,173,179,183$, 185, 207, 211,221 ; Rennes, 47; Ribchester, 228; Richborough, 136, 141, 147, 162, 173, 210, 216, 219, 234; Rochester, 125; Rockbourne Villa, 205, 213, 223, 225; Rome, Villa Giulia, 51 ; Rotherham, 140, I 74, 214, 229; Rothesay, I 50, I60; St. Germain, 95; St. Mary's, Isles of Scilly, I I I, I I 7, I28, 138, 139, I40, $143,156,166,168,169,174,201,207,209,212,222$; Salisbury, I I 1 I I5, I3 I, I44, 154, 158, 166, I 70, I 7 I, 201, 204, 207, 209, 214, 219, 226; Scarborough, I42, I50, 171, 212, 21 7; Scunthorpe, I13, 130, 141, I44, I53, 189, 210; Segontium, 136, 208, 218, 230, 236, 237; Selkirk, 16o, 161, 224, 236; Sheffield, I 15; Shepton Mallet, 154, I68; Shrewsbury, Rowley's House, 130, 142, 180, 206; Sidmouth, I66, 218 , 221; Skipton, I54, 165; South Shields, 182, 188, 209, 213, 232; Speyer, 56; Stranraer, 135, 174, 182; Sussex, see Lewes; Taunton, 21, 33, 106, II I, I14, I1 $8,1_{23}, 1_{30}, 1_{34}, 1_{3}^{8}, 1_{42}, 144$, $149,154,158,163,164,165,170,171,174,177,180$, 183, 188, 189, เ91, 192, 203, 226; Tenby, 145, 162, 166, 167, 172, 175, 189; Truro, I I 1, 1 28, 143, 146, 150, 1 55, 169, 176, 179, 213, 218; Uppark (National Trust), 108; Verulamium, 129, 144, 148, I 51 , 153, 157, 162, I 70, 1 74, 202, 205, 207, 210, 212, 214, 216, 222, 223, 225, 228; Warrington, I 1 3, 1 28, I 55, 165, 1 72, 1 74, 182, 224, 225; Wells, 106, 108, 1 39; Weston-super-Mare, 203; Whitby, 132, 135, 154; Wimborne, 223; Winchester, I13, 122, 1 39, 147, 187, 213, 220, 227, 233; Worms, 53; Worthing, 107, 110, 123; Yeovil, 21 2, 216, 227; York, 105, 106, 135, 235

Myres, Dr. J. N. L., cited, 39

Near East: beads from: faience, 34; glass, group 4, 62; segmented, I I, 94; with twist decoration, 79; factories in, 22-3

Newstead (Borders): bauxite bead from, 89; possible bead factory at, 35,36 ; millefiori from, 79

Newton, Dr. R. G., glass analysis by, 16-17; cited, 30

Oppida, as distribution centres, 28, 29, 3 I

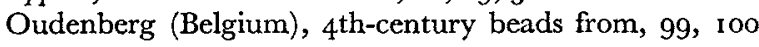

Parc-croc-rioch, Oronsay (Strathclyde), bauxite bead from, 89

Pelynt (Cornwall), imported bronze sword fragment from, 24

Pič, J. L., cited, I 5

Piggott, Prof. S., cited, 23, 26

Pliny, cited, ro

Poland, class 7 , beads from, 59

Pollacorragune (Co. Galway), Bronze Age bead from, 2 I
Portland (Dorset), St. Alban's Head, possible Bronze Age bead from, 20

Poundbury (Dorset), Roman burials at, 37

Presles-et-Bores (Aisne), class 2 beads from, 49

Price, Jennifer, cited, 77

Raftery, Barry, cited, 40

Rainton, Gatehouse-of-Fleet (Dumfries and Galloway), bauxite bead from, 89

Recy Voie Chantereine (Marne), beads from, 49, 52

Redel, Pomerania (E. Germany), biconical beads from, 97

Reinheim, Saarbrücken (W. Germany), group 4 beads from, 62

Renfrew, Prof. Colin, cited, 20

Rhodes, bead factory at, 16, 30, 93

Richborough (Kent), millefiori glass from, 79

Rillaton (Cornwall), Wessex Culture bead from, (lost), 20

Roman: beads, see Table of Contents; furnaces, 30 ; glass, opaque, 9

Rome, Forum, beads in child's grave at, 5

Ross, Dr. Anne, cited, $3^{8}$

Roumania, class 7 beads from, 59

Sacred sites, votive offerings manufactured near, $3^{8}$

St. Veit (Austria): beads from, v; in men's graves, $5^{n}$.

Salina (Lipari Islands), 2nd-millennium beads from La Portella, 24

Sandars, N. K., cited, 81

Sarmatia: beads from: $64,97,98$, 100, 102, 234; used on swords, 56 ; cavalry from, in Britain, 102

Scotti, the, 67

Simpson, Dr. Grace, cited, 97

Sleaford (Lincs.), beads from Anglo-Saxon cemetery at, 95

Snettisham (Norfolk), torcs from, 55

Society of Antiquaries of Scotland, letters in Library of, cited, 34

South Shields (Co. Durham), Gauls serving at, I02

Stanton Harcourt (Oxon.), Anglo-Saxon beads from, 66

Staré Hradisko (Czechoslovakia), manufacturing oppidum, 28, 29

Stead, I. M., cited, 46,49

Stevenson, R. B. K., cited, I4

Stockbridge (Hants), Bronze Age bead from, 20, 23

Stodmarsh (Kent), beads from Anglo-Saxon cemetery at, 95

Stradonitz (Czechoslovakia): beads from: class 5, 5I ; class 6, 52; class 7, 59; possible bead factory at, 29; manufacturing oppidum, 28

Sudan, the, segmented beads from, 93

Sulimirski, T., cited, 65, 97

Switzerland: beads from: class $\mathrm{x}, 46$; class 6,56 ; group I, 60 ; group 5,63 ; see also Yvonand

Swords, beads attached to, $5,5^{6}$

Syria, beads imported from, 39, 102; troops from, serving on Wall, 102

Taexali, the, $34,35,36$ 
Tara (Co. Meath): poor quality beads from, 40 ; red glass lump from, 17, 30;

Teutonic glass: beads, $64,93,171$; broken, 3 I

Thirkel-low (Derbys.), Bronze Age bead from, 20

Thracians, service in Britain of, 102

Tompa, Dr. F., cited, 5

Traprain Law (Lothian): glass armlet from, 37; glass canes from, 37; possible factory at, $28,35-6$

Trebellius Polio, cited, 38

Třisov (Czechoslovakia): manufacturing oppidum, 29; carmine glass from, I 5

Vacomagi, the, 34,36

Vandals, service in Britain of, 102

Van der Sleen, W. G. N., cited, 5, 7

Viking: beads, 48, 68, 92, 93, 100; glass waste, $3^{1}$

Vinica (Austria), beads from, $v, 5$

Viollier, D., cited, 56

Vosges district (France), beads from, 47

Votadini, the, 35, 37

Votive offerings, 37,38
Waldfischbach, Birmisens (W. Germany), class 6 bead from, 56

Warne, G., cited, I5

Welwyn Garden City (Herts.), glass gaming-pieces from, 12

Werner, Joachim, cited, 56

Whitby (Yorks.), jet from, 15

Whitchurch (Avon), glass rod from Lyon Court Farm, 93, 96

Wilderspool (Lancs.): Roman glass furnaces at, 30; possible native factory at, $3^{6}$

Winchester (Hants), Lankhills Roman cemetery, I8n., 37, 38,93

Winterborne St. Martin (Dorset), Bronze Age beads from, 20

Woodeaton (Oxon.): votive objects made at, $3^{8}$;

Woodyates (Dorset), glass canes from, 37

Wookey Hole, Cheddar, (Somerset), Bronze Age bead from, 2 I

Wroxeter (Salop), Roman glass furnaces at, 30

Yugoslavia: class I beads in, 47, 5 I $n$.; see also Carniola

Yvonand (Switzerland), bronze bracelet and brooch from, 46 



\section{INDEX OF SGHEDULES}

(for museums see Museums in General Index)

\section{ENGLAND:}

Abingdon (Oxon.), 94

Alchester (Oxon.), I 53

Aldborough (N. Yorks.), 235

All Cannings Cross (Wilts.), I6, 65, 66, I38, I54, I58, I77

Almondbury (W. Yorks.), 64, I 3 I

Amesbury (Wilts.), 173

Arras (Humberside) : 13, 64, 84, 132; Queen's Barrow, 16, $45,46,47,63,83$, I 05, 106, 135; type site, $26,45-8$

Ashley (Hants), 122

Ashton (Cheshire), 128

Atworth (Wilts.), 108, 203

Avebury (Wilts.), I86

Badbury Rings (Dorset), 218

Badsey (Worcs.), 177

Bagendon(Glos.), 70, 77, 98, 147, 168, I 70, I 76, 183, 185, 221

Baginton (Warwicks.), I 5 I, 158

Bagshot Heath (Surrey), $13^{1}$

Baldock (Herts.), 205

Ballacagen (Isle of Man), 74, I 58, I 79

Barbury Castle, Wroughton (Wilts.), Iog

Barcombe Hill, Ghesterholm (Northumberland), 185

Bardon Mill (Northumberland), see Vindolanda

Barnsley (Glos.), 233

Barnwood (Glos.), I40

Bath (Avon), 12, 77, 144, 158, 162, 187, 21 2, 226, 235

Beckford (Worcs.), $16,54,65,115,138,159$

Beeding, Lower (Sussex), 222, 226

Bersted, North, nr. Felpham (Sussex), i I 7

Bexley Hill, Eastbourne (Sussex), I I 4

Birdlip (Glos.), 147

Bokerly Dyke (Wilts./Dorset), I 3 I

Bottisham (Cambs.), 172

Boxford (Berks.), i 76

Bracknell (Berks.), 23I

Bradwell, Milton Keynes (Bucks.), 23 I

Bredon (Glos./Worcs.), I 2, 70, I5 I, 157, I59, I 70

Breedon-on-the-Hill (Leics.), 66, I 53

Briggswath, Whitby (N. Yorks), 154

Brislington (Somerset), I 70, 203, 208

Broadtown (Wilts.), 142

Bromham (Wilts.), 235

Brough (Humberside), I 49

Brough (Notts.), I 4 I

Broughton Poggs (Oxon.), I I 4

Brough-under-Stainmore (Cumbria), I I 5

Bulbury (Dorset) : 13, 66, 146; type site, 13, 30
Burnt Fen (Cambs.), 54, I 1 2, 152

Burton Fleming (Humberside), 65, I $_{3} 8,{ }_{159}$, I $_{7} 8$

Bury Wood Camp, Colerne (Wilts.), 66, 69, I42, I54, I65

Cadbury Castle (Devon), 146, 156, 201, 207

Cadbury, South (Somerset), 54, 79, I14, I88, 203

Calcot or Henxworth (Beds.), 208

Camerton (Avon), 96, 130, 186, 203, 226

Carrawburgh (Northumberland), 13, 134, 202, 206, 216

Castle Bromwich (West Midlands), I 24

Castle Dore (Cornwall), 18, 70, 74, 1 11, 155, 172, 179

Castleford (W. Yorks.), 37, 229

Catsgore (Somerset), 187

Catterick (N. Yorks.), 142, 145, 171, 204, 211, 217, 219, 220

Caynham (Salop), 82, 189

Chalbury Camp (Dorset), 66, 156

Charterhouse on Mendip (Somerset), 77, 121, 130, 183, 186

Chatham Lines (Kent), 108

Chedworth (Glos.), 108

Chester (Cheshire), 18, 187, 231

Chester, Little (Derbys.), 20 I, 209, 213

Chesterford, Great (Cambs.), 84, I 52, 19 I

Chester-le-Street (Co. Durham), io8

Chesters, Great (Northumberland): 130, 144, 167, 170 , 202, 206, 210, 214, 223, 226, 229; Fort, 61, 65, 97, 125, I $37,141,170,202,210,212,216,219,222,226,234$

Cheverill (Wilts.), I35

Chichester (Sussex), 54, I I 5, 229

Chinnor (Oxon.), 66, 158

Cirencester (Glos.), 37, 38, 62, 77, 92, 94, 95, 97, 99, I I I, I27, I $29,140,147,153,156,166,173,183,202,205$, $207,209,211,215,219,220,221,224,227,233$

Glevedon (Avon), 14, 15, 74, 82, 177, 180, 189

Close-ny-Chollagh, Scarlett (I. of Man), 95, 208

Clungunford (Salop), I 49

Coddenham (Suffolk), I $3^{1}$

Coker, West (Somerset), 2 I 2

Colchester (Essex): 54, 58,69, I 1 1, 1 1 2, 120, 121, 140, 146, I66, I 70, 205, 2 I 5, 232; type site, 54, I 12

Cold Kitchen Hill, Brixton Deverill (Wilts.), 37, 93, 96, I 58, I 7 I, 204, 219, 221, 223

Colerne (Wilts.), see Bury Wood Camp

Conderton Camp, Bredon (Worcs.), 47, 74, 106, 180

Congresbury (Somerset), 66

Cooling (Kent), 56, 6r, 125

Cople (Beds.), 163

Corbridge (Northumberland), 15, 108, 123, 139, 141, 149, I5 I, I $53,164,179,216,228$ 
Cowlam (Humberside), 45, 46, 47,63, I05

Crickley Hill (Glos.), 66, I 57

Croft Ambrey (Herefords.), 68, 157, 163, 213

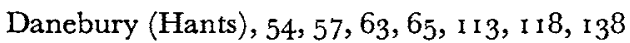

Ditchley (Oxon.), I 4 I

Doncaster (S. Yorks.), I 59

Dorchester (Dorset): 12, 54, I I2, I56, I68, I 72, 20 I, 209, $213,221,232$; see also Fordington and Poundbury

Dowles' Brickyard (Worcs.), 70, I 7 I

Ducklington (Oxon.), I I 4

Dunstable (Beds.), 228,

Ebchester (Northumberland), 229

Edlington Wood (S. Yorks.), 229

Fairford (Glos.), 129

Farley Heath (Surrey), I31, I34, I58, 206

Faversham (Kent), 52, I I I, I 35, 14 I

Felixstowe (Suffolk), 216

Findon (Sussex): 50-I, I IO; type site, 50-I, I Io

Fishbourne (Sussex), 158

Fordham (Cambs.), I85

Fordington, Dorchester (Dorset), 169, 205, 207, 219, 220, 222, 224

Frocester (Glos.) , 92, 140, 202, 207, 21 I, 21 3, 219, 221, 225

Fulwood, nr. Sheffield (S. Yorks.), I 15

Garrow Tor (Cornwall) : 62, I 27; type site, 61-2, 127

Garton Slack, Driffield (Humberside), 47, 107

Glassonby (Cumbria), 128

Glastonbury (Somerset), 54, 57, 58, 66, 69, 77, 82, II4, I $17,119,134,139,142,149,154,158,165,186,190$

Gloucester (Glos.), I40, I 74

Godmanchester (Cambs.), 92, 144, 202, 225

Great Chesterford, see Chesterford, Great

Gussage All Saints (Dorset), 66, 139, г 56

Gussage Down (Dorset), 108

Hales (Staffs.), x 86, 206

Halton (Northumberland), I 79

Hambledon (Bucks.), see Yewden

Ham Hill, Montacute (Somerset), 82, 83, 99, I44, I 54, I 7o, Igo, I9 I, 203, 226

Hampnett, Burn Ground (Glos.), 205

Hamworthy (Dorset), 12, 12 1, 134, I65

Hanging Langford (Wilts.), 52, I I ; type site, 5 I-3, I I I-I 2

Hartfield (Sussex), I44

Harting, South (Sussex); 108; type site, 49-50, 73, 107-10; see also Torberry

Haslingfield (Cambs.), 94, I 12

Hatford (Berks.), ro5

Haughley (Suffolk), I 2 I

Haversham (Bucks.), 2 I I

Hembury Fort, Payhembury (Devon), 77, 182, 185

Hengistbury Head (Dorset), 13, 14, 58, $119,121,122,146$, 201
Henxworth (Beds.), see Calcot

Hepworth (Suffolk), 2 I I

High Rocks, Tunbridge Wells (Sussex), i 2, 63, 173

Hilbre Island (Cheshire), I85

Holcombe, Uplyme (Devon), 97, I66, 218, 22 I

Housesteads (Northumberland), I41, 179, 202, 210,212 , 229,234

Huckoe Fort, Bolham (Northumberland), 74, 179

Hunsbury (Northants.), I 2, 47, 52,6I, 70, 106, III, II4, I $25,148,175$, I 77

Hythe (Kent), I I 3

Icklingham (Suffolk), 61, 125, 216, 221, 228, 235

Ilchester (Somerset), 216

Irchester (Northants.), I3, I $30,4^{8}$

Kelvedon (Essex), 57, I 17

Kenchester (Herefords.), I2, I44, I47, I62, I66, I 73, I 79, I83, $210,213,220,225,234$

Kennet (Wilts.), 13 I

Kimble, Great (Bucks.), i 12

Kingscote (Glos.), 13, 17, 71, 122, 147, 173, 183, 213

Kingsdown Camp (Avon), 142

Kirkby Thore (Cumbria), 217

Kynance Gate (Cornwall), I 55

Lake, see Winterbourne Stoke

Lakenheath (Suffolk), I28, 135, I 73, 226

Lamyatt Beacon (Somerset), 92, 99, 203, $210,214,216,219$, 226

Lankhills, see Winchester

Lansdown, see Bath

Larkhill (Wilts.), 219

Leicester (Leics.), 77, 121, 130, 153, 187, 228, 234

Leighton Buzzard (Beds.), Chamberlain's Barn, 99

Lewes (Sussex), ro8

Lidbury Gamp, Enford (Wilts.), 74, 84, I92

Lincoln (Lincs.), 168, I83, 228

London, 105, I1 $3,130,136,148,15 \mathrm{I}, 158,168,170, \mathrm{I}_{72}$, 173,202

Longbridge Deverill (Wilts.), 63, I31

Lufton (Somerset), 99, 227

Lundy Island, 93

Lydney (Glos.), 205

Lympne (Kent), 202

Madmarston Camp (Oxon.), i38, rg r

Maiden Castle (Dorset), 47, 54, 68, 79, 95, 97, 106, I 12, 146, I $76,179,187,209,218$

Manchester (Greater Manchester), 225, 228

Mancombe Down (Wilts.), I 59

Manton (Lincs.), 2 10

Markham, East (Notts.), 203

Marnhull (Dorset), i i 2

Martlesham Heath (Suffolk), I3 I

Maumbury Rings (Dorset), 52, I I I 
Meare (Somerset), I I, I3, I 5, I6, 17, 31, 32, 52, 54, 57, $63,64,65,66,68,69,70,75,77,79,82,83,84$, го6, I I I, $114,118,123,130,134,13^{8}, 142,149,15^{8}, 163,164$, 165, I 71, I 73, 1 74, I 77, 180, 183, 186, I88, 190, 191, 192; type site, 187,189

Mendip (Somerset), I5I, I68, 208, 227

Micheldever (Hants), I29, I 53

Mildenhall (Wilts.), 65, 131, 135, 137, 149

Milking Gap (Northumberland), I 7, 130,229

Milnthorpe (Cumbria), 206

Monkton Combe (Avon), i 3 I

Monkton Downs (Wilts.), I 37

Mount Bures (Essex), 96, 2 I 5

Nanstallon (Cornwall), 228

Netherby (Cumbria), 87, 1 12, 193

Newark (Notts.), 149

Newcastle Whitcott (Salop), 154

Newton Abbot (Devon), I 50, 201

Normanby (Lincs.), 141

Nor'nour (Isles of Scilly), 52, I I I, I I 7, I $28,138,139$, I 4 o, $143,156,166,168,169,174,201,207,209,212,222$

Norsey Wood Camp (Essex), 57, 117

Northchurch (Herts.), 129

Nyland (Somerset), I 39

Ogbourne St. George (Wilts.), I 59

Oldbury (Kent), 53, 54, I I 3 ; type site, 53-7, I I2, I I 7

Ongar (Essex), I $4^{\circ}$

Ospringe (Kent), 96, 212, 222, 223

Overton Down, West (Wilts.), 17, 83, 191, 211, 212, 217

Owslebury (Hants), I2 I, 143, 225

Pangbourne (Berks.), I 28, 23 I

Penzance (Cornwall) see St. Buryan

Portchester (Hants), 157, 202, 209, 22 1, 225

Porth Gressa, St. Mary's (Isles of Scilly), I 40

Porthmeor (Cornwall), 13, 140, 145, 218

Portland (Dorset), The Verne, I 2, I3, 143, I46, I5 I, 156

Poston Camp, Vowchurch (Herefords.), I 57

Poundbury, Dorchester (Dorset), 92, 95, 98, 209, 211 , 213 , 215,232

Priddy (Somerset), 108

Probus (Cornwall), Carvossa, 128, 143, 2 13, 218

Rainsborough Camp (Northants.), 165

Ribchester (Lancs.), 228

Richborough (Kent), 97, 129, 136, 141, I48, 162, I 73, 210 , 216,219, 234

Richmond (Surrey), I I 4

Risby Warren (Lincs.), 82, 130, 144, I 53, 189

'Rochester and Alnham' (Northumberland), 13, 149, i 80

Rockbourne (Hants), 205, 207, 209, 210, 213, 221, 223, 225

Romney Marsh (Kent), I13

Rotherley (Wilts.), I 44, I 59
Rugby (Warwicks.), see Tripontium

Ryton-on-Dunsmore (Warwicks.), ${ }^{8}$

St. Albans, see Verulamium

St. Buryan (Cornwall), 82, I 91

St. Keverne (Cornwall), I52

St. Mawgan-in-Pyder (Cornwall), 13, 146, 169, I76

Salisbury Plain (Wilts.), I 18, I 74

Salmonsbury (Glos.), 147

Saltburn, Huntcliff (Yorks.), 212, 214

Santon Downham (Suffolk), 95, I 39, I69, 183, 208

Scarborough (N. Yorks.), I42, I50, 212,217

Seamer (N. Yorks.), i 71

Seamills (Avon), 59, 96, 120, 186, 208

Sennen (Cornwall), Maen, 224

Shakenoak (Oxon.), 1 77, 212, 234

Shapwick (Dorset), ij

Shepton Mallet (Somerset), I54, 168

Shields, South, see South ShieJds

Silchester (Hants), I2, I3, 61, 62, 125, 127, 129, 136, 141,

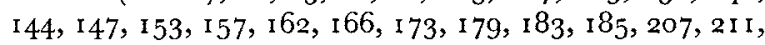
221

Sittingbourne (Kent), 121

Skeffington (Leics.), 6r, I 25

Skipton (N. Yorks.), 69, I54, I65

Somerleigh (Dorset), I53, I 72

Somerton, Bradley Hill (Somerset), 210,227

Southfleet (Kent), 216

South Shields (Co. Durham), 8o, 153, 163, I64, I 73, I 79, 182, 188, 201, 209, $213,215,224,232$

Southwater (Sussex), I 86

Spilsby (Lincs.), 113

Stockton Earthworks (Wilts.), I44, I54, I 7 I, 204, 214, 219 , 226

Stonham Aspall (Suffolk), 222

Stouting (Sussex), 98, 223

Stow, West, Heath (Suffolk), 94

Strood (Kent), 183, 222

Studland (Dorset), 146

Sutton Walls (Herefords.), 228

Swallowcliffe (Wilts.), 13, 47, 66, I06, I 59

Swanage (Dorset), 112

Sydling (Dorset), I 73

Taddington (Derbys.), 107

Tarporley (Cheshire), 6o, 125

Tarrant Hinton (Dorset), 223

Teffont Evias (Wilts.), I 59

Templebrough, Rotherham (Yorks.), 96, 140, 1 74, 214, 229

Thatcham (Berks.), 169

Tingewick (Bucks.), Grove Hill, 2 I8

Torberry, S. Harting (Sussex), I I 5

Trelan Bahow (Cornwall), 152

Trevelgue (Cornwall), 66, г 43, г46, г 5o, i 76

Tripontium (Rugby) (Warwicks.), 131, 184, 222, 223

Tuffley (Glos.), I64, I68

Tunbridge Wells (Kent), 162 
Verulamium (St. Albans) (Herts.), I2, 13, 68, 92, 97, 129, I 44, I 48, I 5 I, I 53, I 57, I62, I 70, I 74, 202, 205, 207, 2 IO, $212,214,216,222,223,225,228,234$

Vindolanda, Bardon Mill (Northumberland), 206, 214, 219, 222, 223

Waddon Hill (Dorset), ${ }_{56}$

Wall (Staffs.), 183

Water Newton (Cambs.), 2 I 6

Weekley, Kettering (Northants.), I 14

Welwyn Garden City (Herts.): 48, 49, 58, ro7, I19; type site, $4^{8-9}$, I07

Westerham (Kent), I I3, I 23

Weston-under-Penyard (Herefords.): 1 2, I 5, I 23, I 29, I4 I, I $44,151,153,157,164,167,170,173,175,202,205$, $214,219,221,224$

Wetton (Staffs.), I 49

Whitby (N. Yorks.), 1 32, 135

Whitchurch (Avon), 203

Whitcombe (Dorset), I2, 129, I62

Whitton (Suffolk), Castle Hill Roman villa, 69, I31, 167, I 7I, 208, 21 4, 216, 226

Wickford (Essex), 201, 215

Wick Wood (Wilts.), 57, I 18, 122, 137, 159, 171, 204, 212, $214,217,220,222,223,229$

Wiggonholt (Pulborough) (Sussex), 48, 96, 107

Wilderspool (Lancs.), I 13, 128, 155, I64, I 72, 174, 182, 224, 226

Willingham (Cambs.), 77, 107, 187, 231

Wimborne (Dorset), 108, 201

Winchester (Hants) : 99, 1 13, 187, 205; Lankills cemetery, $70,92,94,95,96,97,98,99$, го0, I 5 I , 157, I68, г 70, 202, 205, 207, 210, 211, 213, 215, 220, 225, 227, 233

Windmill Hill, Avebury (Wilts.), 77

Winterbourne Stoke (Wilts.), 45, 105

Winteringham, Old (Lincs.), 54, I 13

Witham (Essex), 220

Wolham (Glos.), 225, 233

Wolstonbury Hill (Sussex), I 37

Woodcuts (Dorset), I 54, 1 70, 201, 209, 228

Woodeaton (Oxon.), 50, I I0, I 34,208

Woodyates (Dorset), I66, 207

Wookey Hole (Somerset), 49, 106, 108, 235

Woolaston (Glos.), 233

Woolley Barrow, Morwenstow (Cornwall), 168

Worlebury (Somerset), I 58,203

Worthing (Sussex), 1 23

Worth Matravers (Dorset), r64

Worthy Down (Hants), I 3, 66, I39, 147

Wroxeter (Salop), I30, 142, 180, 206

Wycombe (Glos.), 220, 227

Yeavering (Northumberland), 93, 203

Yewden (Bucks.), Hambledon villa, 54, I 12, 128, 140, 145, 152

Yockleton (Worcs.), I 75

York (N. Yorks.) Ioo, 235
IRELAND:

Carrowmore (Co. Sligo), 82, I90

Cloughwater, Lisnacrogher (N. Ireland), 89, I 18

Denhamstown, Ardcath (Co. Meath), I 20

Donaghadee (N. Ireland), see Loughey

Dun-na-mana (Co. Tyrone), 54, I I6

Dunshaughlin (Co. Meath), 8 in., I6o

Edenderry (Co. Offaly), 58, I I 8

Garryduff (Co. Cork), 8I, I88

Grannagh, Ardrahan (Co. Galway), 69, 167

Hawkhill, Kildare (Co. Offaly), I 20

Lagore, Grannog (Co. Meath), 61, 81, 82, I 26, I 71, 188, I90, 2 I I

Loughey, Donaghadee (N. Ireland), 14, 6I, 70, 74-5, 80, 1 26, I 7 I, I 80, I 88

Muckish Mount (Co. Donegal), I I

Newcastle (N. Ireland), I I 2

Rosapenna Sandhills (Co. Donegal), I88

Sandy Braes (N. Ireland), II 5

Shanganagh (Dublin), I 22

Sheephaven (Co. Donegal), I 88

Tara (Co. Meath), Rath of the Synods, 70, 160, I63, I69, I 71,214

\section{ScOTLAND:}

Aikerness Brock, Evie (Orkney), 184

Airrieoland Crannog (Strathclyde), I 7, 74, I8o

Aitnock Fort, Dalry (Strathclyde), 74, 180

Allasdale, Barra (Western Isles), I8I

Arinabost, Isle of Coll (Strathclyde), I 6

Ballogie (Grampian), I93

Barburgh Mill, Nithsdale (Dumfries and Galloway),229

Bedlam (Grampian), 85, I 93

Birrens (Dumfries and Galloway), I66, г 75, 229

Birse (Grampian), 193

Blelack (Grampian), 193

Bonchester (Borders), I6o

Bowermadden (Highland), 86, 195

Buck of Carbrach (Grampian), I93

Burghead (Grampian), I95

Camelon Fort, Falkirk (Central), Iog

Camphouse (Borders), 230

Castle Haven Fort (Dumfries and Galloway), 132 
Castle Hill (Dalry) (Strathclyde), 66, 76, 150, 229

Castle Island, Mockrum (Dumfries and Galloway), 124, i6 I

Castle Newe (Grampian), 86, I94

Castle O'er (Dumfries and Galloway), 132

Cawdor (Highland), 88, I96, 200

Glerkley Hill (Grampian), 89, 199

Clettraval (North Uist) (Western Isles), 7o, 160

Clickhimin (Shetland), I8 I

Clova (Grampian), I94

Coldstone (Grampian), 86, I94

Coulter (Strathclyde), I60, I 7 I, I 75, 227

Covesea (Grampian), I32, I45, I52, 172, 214,217

Graigsford Mains (Borders), I 66

Gromar (Grampian), 194

Crossmichael (Dumfries and Galloway), 186

Groy (Highland), 87, 195

Culbin Sands (Grampian), 11, 16, 18, 31, 32, 74, 75, 79, $86,88,99,160,161,163,164,169,172,181,188,195$, I96, I99, 204

Cushie (Grampian), I94

Dalmeny (Lothian), 93, 204

Dowalton Loch (Dumfries and Galloway), 200

Drimore, South Uist (Western Isles), I8I

Dunadd (Strathclyde), r6o, 235

Dunagoil Fort, Rothesay (Strathclyde), 66, I50, 160

Dun Ardtreck (Skye) (Highland), 70, 74, 76n., 88, I6I, I 72, I 8I, 200, 220

Dun Beag, Broch of (Skye), 96, I 75, 21 7, 224

Dun Bhuirg (Strathclyde), 18 I

Dun Iardhard, Dunvegan, Skye, (Highland), 86, 88, i 8 г, Ig6, 200

Dun Mor Vaul, Tiree (Strathclyde), 88, 18 1, 199

Dun Troddan Broch, Glenelg (Highland), I 8 I

Dykeside (Orkney), I64

Earlston (Borders), i 16

Eddertoun (Highland), I96

Ellon (Grampian), I 94

Evie (Orkney), I 96

Fendom Sands (Highland), I60

Fetlar (Shetland), i8 8I

Fouhlin, Loch Eriboll (Highland), 86, 197

Freswick Links, Canisbay (Highland), 18 I

Gargunnock (Central), Blackwood Hill, $23^{\circ}$

Gilmerton (Lothian), I 6

Glenluce Sands (Dumfries and Galloway), 74, I35, I61, I $72,174,182,189$, I 90

Glenrinnes, (Grampian 195

Glenskirdie (Grampian), 164

Haughton-Alford (Grampian), I 32

Hownam (Borders), 220

Howrat Castle Rock, Dalry (Strathclyde), 74, 93n., 180
Inverkeilor (Tayside), 74, 180

Keith (Grampian), I 96

Kennethmont (Grampian), 88, I94, 198

Kildonan Fort (Strathclyde), I6o

Kildrummy (Grampian), I94

Kilmany (Fife), I I6

Kinnord (Grampian), r94

Kirkmaiden (Dumfries and Galloway), 59n., I 8

Lickleyhead, Premnay (Grampian), i 98

Lochlee Grannog (Strathclyde), 204, 229

Lochspouts Crannog (Strathclyde), i38, i 8 i

Midmar (Grampian), I94

Monquhitter (Grampian), 88, 198

Mosspebble (Dumfries and Galloway), I 42

Mousewold (Dumfries and Galloway), 63, $15^{2}$

Newstead (Borders), 14, 60, 84, 109, 126, 132, 135, 142, I $55,163,184,186,192,206,211,230,236$

Orkney: 189; see also Aikerness Broch; Birksay; Dykeside; Evie

Orton (Grampian), I 96

Pitchroy, Ballindalloch (Grampian), ig6

Rhynie (Grampian), I95

Selkirk (Borders), I6r, 163, 224

Siccar Point, Cockburnspath (Borders), I6o

Skewalton (Strathclyde), 204

Slains (Grampian), I95

Strathdon (Grampian), 195

Struan, Skye (Highland), 204

Tough (Grampian), I 95

Traprain Law (Lothian): I I, 66, 76, 124, 132, 145, I54, I60, 164, 18I, I84, 204, 208, 21 I, 212, 217, 219, 223, 230

Udney, (Grampian), 175, 198, 199

Ugadale Fort (Strathclyde), 160

Uist, South (Western Isles), 74

Wick (Highland), Io9

Yair (Borders), 160 
WALES :

'Aber-fawr' (Gwynedd), 150

Abergavenny (Gwent), I 10, 230

Brecon Gaer (Powys), $23^{\circ}$

Breiddin, The (Powys), 54, I 16, 152, 182

Bryn-yr-Hen Bobl (Gwynedd), I33

Caerhun (Gwynedd), 135, I84, 230, $23^{6}$

Caerleon (Gwent), 57, 64, 100, I 10, I 19, 126, I33, 136, I $43,155,185,206,215,218,230,237$

Caernarvon, see Segontium

Caerwent (Gwent), 77, 163, 167, 172, 187, 189, 215, 218

Caldey Island (Dyfed), I6 1, I62

Cardiff (Glam.), 185

Garmarthen (Dyfed), 237

Castell Coch Fort (Glam.), 206

Coygan Camp, Laugharne (Dyfed), 66, 69, 76, I45, I6I, I 67, I 69, I 72, I 75, I $82,206,2$ I 5

Cwmyoy see Twyn-y-Gaer

Dinas Powys (Glam.), 95, ז 74, 206

Gronant, nr. Prestatyn (Clwyd), i 16

Llandegai (Gwynedd), I 43

Llanwchllyn (Powys), i io
Merthyr, Mawr Warren (Glam.), I67

Moel Hiraddug, Dyserth (Glwyd), I6r

Moel Trigarn (Dyfed), 66, 79, 145, I62, I66, I67, 189

Moel y Gaer (Glwyd), 184

Nevin (Gwynedd), Iog, I33

Pen Dinas (Dyfed), 79, I89

Pen Llysten (Gwynedd), 77, 184, $23^{\circ}$

Penmaenmawr (Gwynedd), 143

Plas Bach (Gwynedd), I 45

Prestatyn (Clywd), I3, I33, I 50; see also Gronant

St. David's Head (Dyfed), 69, I67, I 72, I 75

Segontium (Caernarvon) (Gwynedd), 64, 136, 208, 218 , 230, 236,237

Sudbrook (Gwent), I55, I6 I

Tomen-y-mur (Gwynedd), 230

Twyn-y-Gaer (Cwmyoy) (Gwent), 74, 16 1, ז82

Tythegston (Glam.), 155

Usk (Gwent), 13, 133, 143, 150, 167, 172, 185, 204, 237

Walesland Rath (Dyfed), 57, I I9

Whitton, Barry (Glam.), 13, 47, 96, 107, I 10, I 26, 1 33, 143, I $45,152,167,218,227,230,237$ 